\title{
Geohydrology and Water Quality of Stratified-Drift Aquifers in the Winnipesaukee River Basin, Central New Hampshire
}

\section{By JOSEPH D. AYOTTE}

\section{U.S. Geological Survey}

Water-Resources Investigations Report 94-4150

Prepared in cooperation with the

NEW HAMPSHIRE DEPARTMENT OF ENVIRONMENTAL SERVICES WATER RESOURCES DIVISION

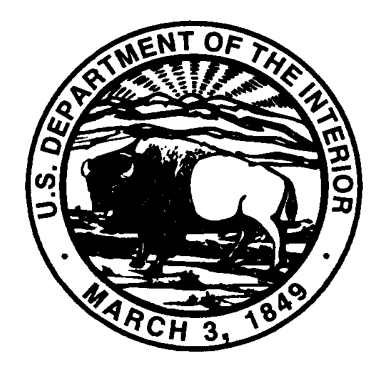

Pembroke, New Hampshire 1997 


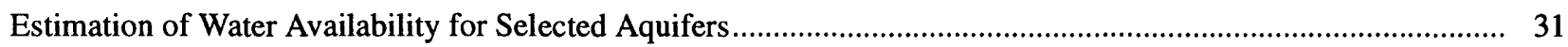

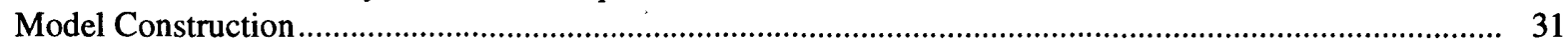

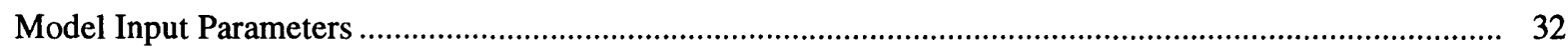

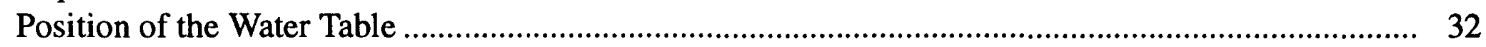

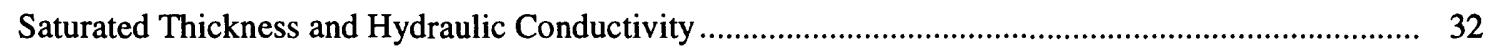

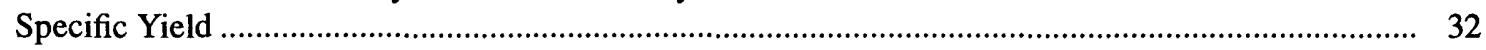

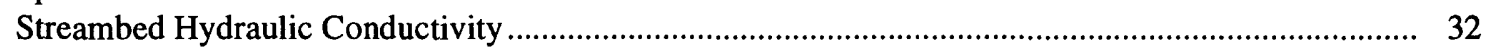

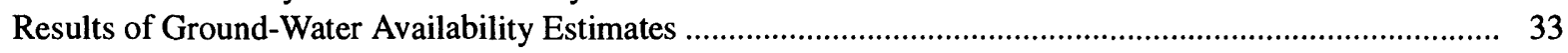

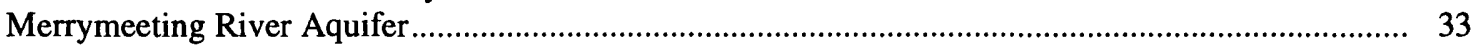

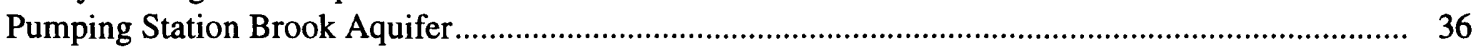

Ground-Water Quality.....

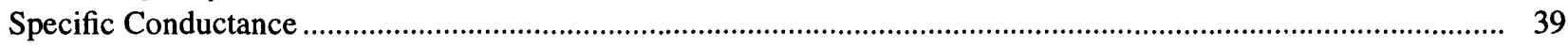

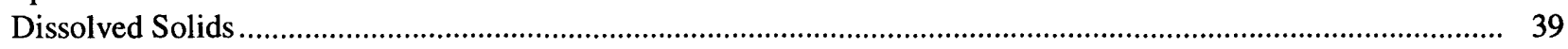

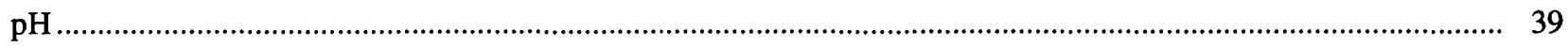

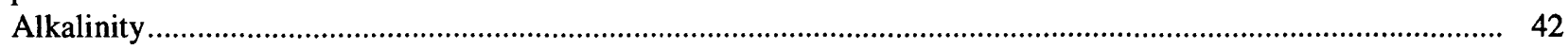

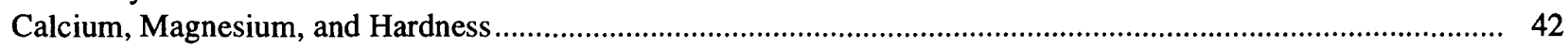

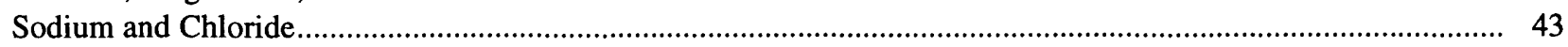

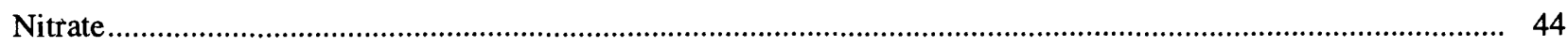

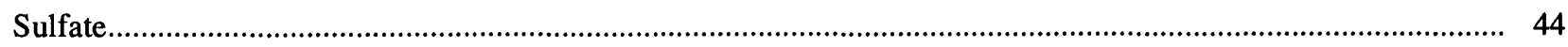

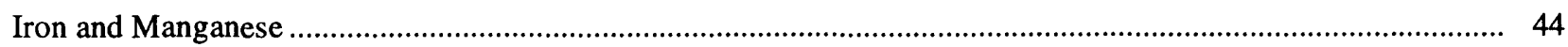

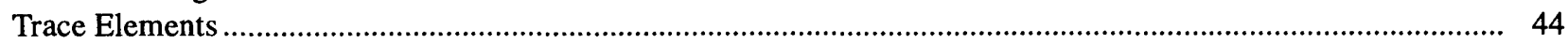

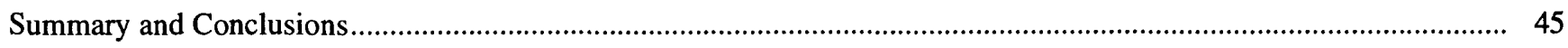

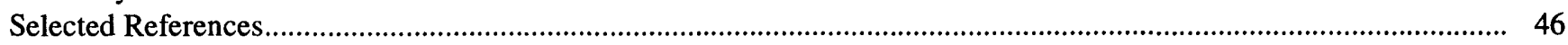

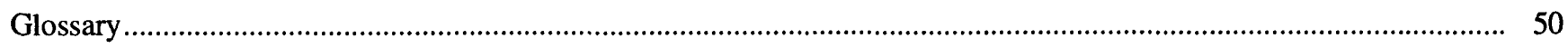

Appendixes

A. Description of selected wells, borings, and springs in the Winnipesaukee River Basin, central New Hampshire ......................................................................................................................... 55

B. Stratigraphic logs of selected wells and borings in the Winnipesaukee River Basin,

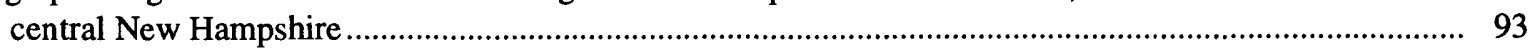

C. Geohydrologic sections interpreted from seismic-refraction data, central New Hampshire............................... 159

D. Low streamflow measurements at miscellaneous sites in central New Hampshire ............................................ 183

E. Monthly water levels at selected wells, central New Hampshire .................................................................. 189

\section{PLATES}

[Plates are in pocket]

1-4. Maps showing aquifer boundaries, data-collection locations, materials, and altitude of water table for stratified-drift aquifers in the Winnipesaukee River Basin, central New Hampshire:

1. Southwestern part

2. Southeastern part

3. Northwestern part

4. Northeastern part

5-8. Maps showing saturated thickness, transmissivity, and materials of stratified-drift aquifers in the Winnipesaukee River Basin, central New Hampshire:

5. Southwestern part

6. Southeastern part

7. Northwestern part

8. Northeastern part 


\section{FIGURES}

1. Map showing location of study area and towns in the Winnipesaukee River Basin, central New Hampshire

2. Sectional diagram of an ice-dammed glaciolacustrine deltaic aquifer

3. Block diagram of the formation of a glaciofluvial deltaic aquifer

4. Map showing maximum extent of glacial-lake environments in the Winnipesaukee River Basin, central New Hampshire

5. Hydrograph showing long-term water levels at observation well FKW-1 in stratified drift, central New Hampshire

6. Map showing locations of selected long-term streamflow-gaging stations in and near the Winnipesaukee River Basin, central New Hampshire

7, 8. Diagrams showing:

7. Ground-water flow and water-level drawdowns at a withdrawal well near an impermeable boundary

8. Ground-water flow and water-level drawdowns at a withdrawal well near a recharge boundary

9. Graph showing relation between estimated hydraulic conductivity, median grain size, and degree of sorting of stratified drift in New Hampshire

10. Map showing general locations of selected aquifers in the Winnipesaukee River Basin, central New Hampshire

11-14. Geohydrologic sections through the:

11. Pumping Station Brook aquifer, Belmont, New Hampshire ….............................................................. 23

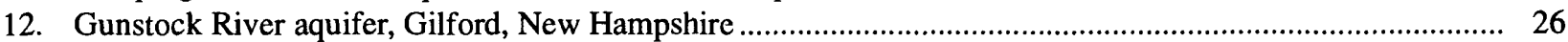

13. Merrymeeting River aquifer, Alton, New Hampshire ............................................................................ 27

14. Hawkins Brook aquifer, Meredith, New Hampshire .................................................................................. 29

15-18. Map showing model boundary, surface-water boundaries, hypothetical wells, and drawdown contours for the;

15. Merrymeeting River aquifer, central New Hampshire with simulation of induced infiltration.

16. Merrymeeting River aquifer, central New Hampshire with simulation of no induced infiltration

17. Pumping Station Brook aquifer, central New Hampshire with simulation of induced infiltration

18. Pumping Station Brook aquifer, central New Hampshire with simulation of no induced infiltration

\section{TABLES}

1. Two-letter town codes used as prefixes in the numbering system for wells, borings, and springs in the Winnipesaukee River Basin, central New Hampshire

2. Percentage of flow duration on July 3, 1991, for selected U.S. Geological Survey streamflow-

gaging stations in and near the Winnipesaukee River Basin, central New Hampshire

3. Relation of mean bulk hydraulic conductivity to median grain size and degree of sorting of stratified drift in New Hampshire

4. Water-availability estimates for two simulations of the Merrymeeting River aquifer, central New Hampshire

5. Water-availability estimates for two simulations of the Pumping Station Brook aquifer, central New Hampshire

6. Chemical analyses of ground-water samples from the Winnipesaukee River Basin, central New Hampshire

7. Classification of hardness of water 


\begin{tabular}{|c|c|c|}
\hline Multiply & By & To obtain \\
\hline \multicolumn{3}{|c|}{ Length } \\
\hline inch (in.) & 25.4 & millimeter \\
\hline foot $(\mathrm{ft})$ & 0.3048 & meter \\
\hline mile (mi) & 1.609 & kilometer \\
\hline \multicolumn{3}{|c|}{ Slope } \\
\hline foot per mile (ft/mi) & 0.1894 & meter per kilometer \\
\hline \multicolumn{3}{|c|}{ Area } \\
\hline square mile $\left(\mathrm{mi}^{2}\right)$ & 2.590 & square kilometer \\
\hline \multicolumn{3}{|c|}{ Volume } \\
\hline gallon (gal) & 3.785 & liter \\
\hline million gallons (Mgal) & 3,785 & cubic meter \\
\hline cubic foot $\left(\mathrm{ft}^{3}\right)$ & 0.02832 & cubic meter \\
\hline \multicolumn{3}{|c|}{ Velocity and Flow } \\
\hline foot per second $(\mathrm{ft} / \mathrm{s})$ & 0.3048 & meter per second \\
\hline cubic foot per second $\left(\mathrm{ft}^{3} / \mathrm{s}\right)$ & 0.02832 & cubic meter per second \\
\hline $\begin{array}{r}\text { cubic foot per second per second per } \\
\left.\text { square mile }\left[\left(\mathrm{ft}^{3} / \mathrm{s}\right) / \mathrm{mi}^{2}\right)\right]\end{array}$ & 0.01093 & cubic meter per per square kilometer \\
\hline gallon per minute ( $\mathrm{gal} / \mathrm{min})$ & 0.06309 & liter per second \\
\hline gallon per day (gal/d) & 3.7854 & liter per day \\
\hline million gallons per day (Mgal/d) & 0.04381 & cubic meter per second \\
\hline $\begin{array}{l}\text { million gallons per day per square mile } \\
\qquad\left(\mathrm{Mgal} / \mathrm{d} / \mathrm{mi}^{2}\right)\end{array}$ & 1,460 & $\begin{array}{l}\text { cubic meter per second per square } \\
\text { kilometer }\end{array}$ \\
\hline \multicolumn{3}{|c|}{ Hydraulic Conductivity } \\
\hline foot per day $(\mathrm{ft} / \mathrm{d})$ & 0.3048 & meter per day \\
\hline \multicolumn{3}{|c|}{ Transmissivity } \\
\hline foot squared per day $\left(\mathrm{ft}^{2} / \mathrm{d}\right)$ & 0.09290 & meter squared per day \\
\hline
\end{tabular}

\section{VERTICAL DATUM}

Sea level: In this report, "sea level" refers to the National Geodetic Vertical Datum of 1929 (NGVD of 1929)-a geodetic datum derived from a general adjustment of the first-order level nets of the United States and Canada, formerly called Sea Level Datum of 1929.

\section{ABBREVIATED WATER-QUALITY UNITS}

In this report, chemical concentration in water is expressed in milligrams per liter $(\mathrm{mg} / \mathrm{L})$ or micrograms per liter $(\mu \mathrm{g} / \mathrm{L})$. Milligrams per liter is a unit expressing the concentration of chemical constituents in solution as weight (milligrams) of solute per unit volume (liter) of water; $1,000 \mu \mathrm{g} / \mathrm{L}$ (micrograms per liter) is equivalent to $1 \mathrm{mg} / \mathrm{L}$ (milligram per liter). Water temperature in degrees Celsius $\left({ }^{\circ} \mathrm{C}\right)$ can be converted to degrees Fahrenheit $\left({ }^{\circ} \mathrm{F}\right)$ by use of the following equation:

$$
{ }^{\circ} \mathrm{F}=1.8\left({ }^{\circ} \mathrm{C}\right)+32 \text {. }
$$

Specific conductance of water is express in microsiemens per centimeter at 25 degrees Celsius $(\mu \mathrm{S} / \mathrm{cm})$. This unit is equivalent to micromhos per centimeter at 25 degrees Celsius, formerly used by the U.S. Geological Survey. 


\title{
Geohydrology and Water Quality of Stratified-Drift Aquifers in the Winnipesaukee River Basin, Central New Hampshire
}

\author{
By Joseph D. Ayotte
}

\section{Abstract}

The Winnipesaukee River Basin drains 484 square miles; 66 square miles is underlain by stratified-drift aquifers. Saturated thickness of stratified drift in the study area is locally greater than 100 feet but generally is less. Transmissivity of stratified-drift aquifers locally exceeds 4,000 square feet per day but is generally less than 1,000 square feet per day. In 1993, in the Winnipesaukee River Basin, ground-water withdrawals from stratified drift totaled about 0.1 million gallons per day for public supply. Many of the stratified-drift aquifers in the study area are not fully developed.

The geohydrologic investigation of stratified-drift aquifers focused on basic aquifer properties including aquifer boundaries; recharge, discharge, and direction of ground-water flow; saturated thickness and storage; and transmissivity. Surficial geologic mapping was used in the determination of aquifer boundaries. Data from more than 860 wells and test borings were used to produce maps of water-table altitude, saturated thickness, and transmissivity of stratified drift. More than 7 miles of seismic-refraction profiling and 10 miles of seismic-reflection profiling also were used to construct the water-table and saturated-thickness maps.

A stratified-drift aquifer in Alton and one in Belmont were analyzed by use of a twodimensional, finite-difference ground-water-flow model to estimate ground-water availability. The available water for the Merrymeeting River aquifer (in Alton) was estimated to be 0.63 to 1.1 million gallons per day, and the available water for the Pumping Station Brook aquifer (in Belmont) was estimated to be 1.6 to 1.8 million gallons per day. Comparison of these estimates with those derived from analytical models for the same areas showed that the estimates are reasonable. Total available water estimates from the analytical models, however, were generally 20 percent greater than estimates from the numerical model.

Results of analysis of water samples from 17 test wells indicate that, with some exceptions, water in the stratified-drift aquifers meets U.S. Environmental Protection Agency primary and secondary drinking-water standards. Sites of known ground-water contamination were not sampled. Elevated concentrations of iron and manganese were the most common water-quality problems. 


\section{INTRODUCTION}

The population of the 16 central New Hampshire towns in the Winnipesaukee River Basin increased by 15 percent from 1980 to 1990 (New Hampshire Office of State Planning, 1985). Economic development has been rapid in south-central New Hampshire, partly because of the area's proximity to metropolitan Boston. This growth has steadily increased demands for water and has stressed the capacity of existing municipal water systems, some of which depend on ground water for part or all of their water supplies. In 1993, the average withdrawal from stratified-drift aquifers for municipal supply was about $0.1 \mathrm{Mgal} / \mathrm{d}$; this amount represents total withdrawal for that year divided by 365 days, as if the total withdrawal was spread out over a full year (New Hampshire Department of Environmental Services, Water Management Bureau, written commun., 1991). Two of the towns use ground water as their sole supply. In addition to concerns raised by population growth, U.S. Environmental Protection Agency (USEPA) primary and secondary drinking-water standards regarding the treatment requirements of surface-water supplies have prompted municipalities to look closely at their ground-water resources.

Stratified-drift aquifers discontinuously underlie $66 \mathrm{mi}^{2}$ of the Winnipesaukee River Basin, which drains an area of $484 \mathrm{mi}^{2}$. Many of the aquifers may be capable of supplying enough water to meet domestic, community, and municipal water needs.

The U.S. Geological Survey (USGS), in cooperation with the New Hampshire Department of Environmental Services, Water Resources Division (NHDES-WRD), has done a series of ground-water studies in New Hampshire to provide detailed geohydrologic information necessary to determine the optimal use of existing water supplies and to make decisions regarding the development of new water supplies. The study described in this report encompasses the Winnipesaukee River Basin and its subbasins, which includes the towns around Lake Winnipesaukee and the Winnipesaukee River downstream to its confluence with the Pemigewasset River in Franklin, N.H. (fig. 1). For most of the studies, major watersheds were selected as study areas because they are the natural subdivision of the hydrologic system; only a few stratified-drift aquifers, in Alton and Franklin, extend across major surfacewater divides. Completed studies and reports in this series include the Nashua Regional Planning Commission area (Toppin, 1987); the Exeter, Lamprey, and Oyster River Basins (Moore, 1990); the Lower Merrimack and coastal river Basins (Stekl and Flanagan, 1992); the Bellamy, Cocheco, and Salmon Falls River Basins (Mack and Lawlor, 1992); the Middle Merrimack River Basin (Ayotte and Toppin, 1995); the Lower Connecticut River Basin (Moore and others, 1994); and the Contoocook River Basin (Harte and Mack, 1995).

\section{Purpose and Scope}

The purpose of this report is to (1) describe the geohydrologic characteristics of the stratified-drift aquifers, including areal extent of stratified-drift aquifers, water-table altitudes, general directions of ground-water flow, saturated thickness, and transmissivity; (2) give estimates of water availability for selected aquifers; and (3) assess the general quality of ground water in stratified-drift aquifers.

The study data and descriptions in this report are limited to the stratified-drift aquifers in the study area. The estimates of water availability from stratified-drift aquifers in Alton and Belmont, currently used by these towns as a sole-source water supply, were derived by use of numerical and analytical models.

\section{Previous Investigations}

Previous investigations include a reconnaissance map at a scale of $1: 125,000$ in which the availability of ground water in the Winnipesaukee River Basin was mapped (Cotton, 1975). Surficial geologic mapping for most of the study area was done by Goldthwait (1968) at a scale of $1: 62,500$. The maps, which include the Winnipesaukee and Wolfeboro 15-minute quadrangles, are accompanied by a text. Goldthwait and others (1951) examined the effects of the enormous erosive capability of meltwater channels at the ice margin and cite a number of examples of erosive features in the Winnipesaukee and Wolfeboro quadrangles. 


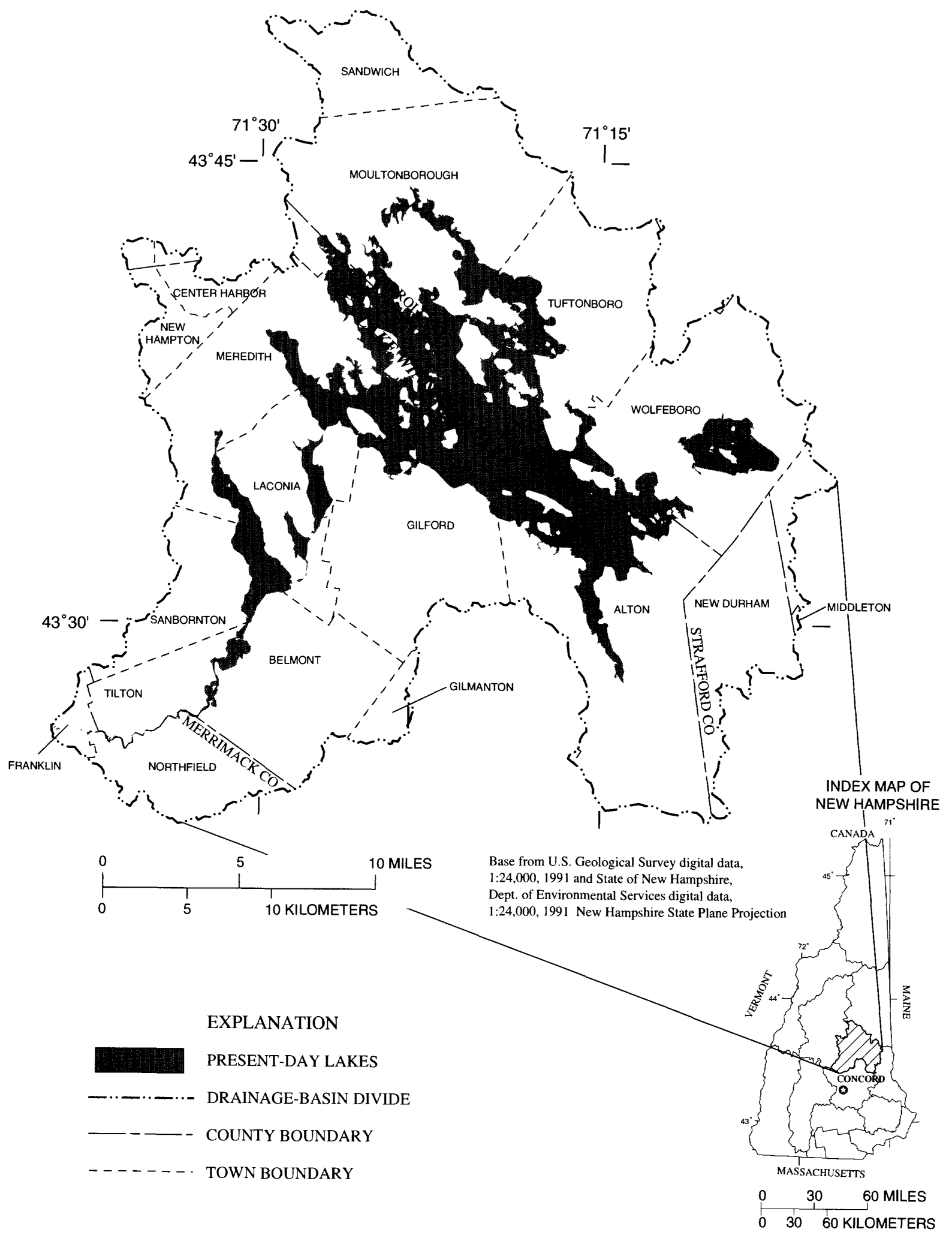

Figure 1. Location of study area and towns in the Winnipesaukee River Basin, central New Hampshire. 
Haselton mapped the surficial geology of the town of Gilford (1991, unpublished map on file at Rust Environment Infrastructure, Concord, N.H.). Morgan (1985) prepared a surficial-aquifer delineation and water-use investigation for the town of Moultonborough. Numerous other studies have been done by private consultants for local concerns.

\section{Methods of Study}

The following methods were used in this study:

1. Areal extent of the stratified-drift aquifers was delineated by use of soils maps from the U.S. Soil Conservation Service, surficial geologic maps, and field mapping done specifically for this project.

2. Published and unpublished data on groundwater levels and the saturated thickness and stratigraphy of the aquifers were compiled from the USGS, NHDES-WRD, NHDESWater Supply and Pollution Control, and the New Hampshire Department of Transportation. Additional data were obtained from municipalities, local residents, welldrilling contractors, and geohydrologic consulting firms. The locations of wells, borings, springs, and seismic lines were plotted on base maps, and pertinent well and bore hole data were added to the GroundWater Site Inventory (GWSI) data base maintained by the USGS. Each data point is cross-referenced to a site-identification number and to any other pertinent information about the site.

3. Seismic-refraction surveying, a surface geophysical technique, was used to determine depths to the water table and depths to the bedrock surface. Locations of these profiles are shown on plates $1-4$. The seismic data were interpreted by use of a time-delay, raytracing computer program developed by Scott and others (1972). Data from nearby wells and test holes were used to verify the interpretations. Actual depths to the bedrock surface are within 10 percent of the estimates from seismic-refraction profiling. Till is not identified in these interpretations because it is generally thin and cannot be distinguished from stratified drift by use of seismicrefraction methods. Where till is present but is not identified in the interpretation, the computed depth to bedrock is slightly less than the actual depth.

4. Seismic-reflection surveying, another surface geophysical method, was used to determine depths to bedrock and to infer the sediment type of the aquifers that lie beneath water bodies. Haeni $(1986,1988$ b) outlines methods for collecting seismic-reflection data.

Seismic-reflection results differ from seismicrefraction results in that information about the texture of the subsurface can sometimes be inferred from the reflection records.

5. Test borings were made at 56 locations to improve definition of the thicknesses and geohydrologic characteristics of the stratifieddrift aquifers. Locations of these test borings and wells are shown on plates $1-4$. Splitspoon samples of the subsurface sediments collected at 5- to 10-foot intervals were used to estimate the horizontal hydraulic conductivity at those depths and to determine the stratigraphic sequence of materials comprising the aquifers. Where test borings indicated that the aquifer would yield sufficient water for municipal supplies, a 2 -inch inside-diameter well with a polyvinyl chloride (PVC) casing and a slotted well screen was installed. Water levels were measured periodically in these wells, and water samples were collected from selected wells.

6. Data collected as described in items $2,3,4$, and 5 were used to construct maps showing the water-table altitude and saturated thickness of the stratified-drift aquifers.

7. Hydraulic conductivities of aquifer materials were estimated from grain-size-distribution data from 454 samples of aquifer material collected during the completion of test borings and wells in southern New Hampshire. Transmissivities were estimated from logs of test borings and wells by assigning horizontal hydraulic conductivities to each interval sampled, multiplying the hydraulic conductivities by the saturated 
thickness of the interval, and summing these results. Additional transmissivity values were obtained from reports by geohydrologic consultants and from analysis of unpublished aquifer-test data. This information was used to prepare maps showing the transmissivity distribution of the stratified-drift aquifers (pls. 5-8).

8. Flow-duration data from eight long-term streamflow-gaging stations within and near the Winnipesaukee River Basin were analyzed and used to correlate miscellaneous low-flow streamflow measurements on ungaged streams. Streamflows measured where the stream flowed into and out of major aquifers in the area during periods of low flow can be used to estimate potential aquifer yields.

9. An aquifer in Alton and one in Belmont were selected to demonstrate a technique for estimating water availability on the basis of a two-dimensional numerical model that simulates ground-water flow. The computer program, developed by McDonald and Harbaugh (1988), is a three-dimensional model that can be used to simulate flow in two dimensions. The model was used to estimate the potential yield and the sources of water to wells in the modeled areas.

10 Samples of ground water from 17 wells constructed during this study were collected and shipped to the USGS National Water Quality Laboratory in Arvada, Colo. for analysis. Selected physical properties (specific conductance, $\mathrm{pH}$, temperature) were measured, and concentrations of inorganic constituents were determined. The data provided by these analyses were used to assess the general quality of water from the stratified-drift aquifers.

\section{Numbering System for Wells, Borings, and Springs}

Local numbers assigned to wells and borings entered into GWSI consist of a two-letter town designation (table 1), a supplemental letter designation (" $\mathrm{A}$ " for borings done for hydrologic
Table 1. Two-letter town codes used as prefixes in the numbering system for wells, borings, and springs in the Winnipesaukee River Basin, central New Hampshire

\begin{tabular}{|c|c|c|c|}
\hline Town & $\begin{array}{l}\text { Two-letter } \\
\text { code }\end{array}$ & Town & $\begin{array}{c}\text { Two-letter } \\
\text { code }\end{array}$ \\
\hline Alton ........ & $\mathrm{AH}$ & New Durham...... & NF \\
\hline Belmont ........................ & BL & New Hampton.... & NH \\
\hline Center Harbor ............. & $\mathrm{CH}$ & Northfield ............ & NR \\
\hline 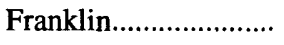 & FK & Sanbornton.......... & SC \\
\hline Gilford …..................... & GF & Sandwich............ & SE \\
\hline Laconia ......................... & LA & Tilton....................... & TS \\
\hline Meredith ...................... & MH & Tuftonboro .......... & $\mathrm{TZ}$ \\
\hline Middleton .................... & ML & Wolfeboro ........... & WR \\
\hline Moultonborough ........ & MM & & \\
\hline
\end{tabular}

investigations, "B" for borings done primarily for construction, " $S$ " for springs, and "W" for all wells in which a casing was set), and a sequential number within each town. For example, the first well listed for the town of Alton is AHW-1.

\section{Acknowledgments}

The author thanks the many State and Federal agencies, municipalities, consulting firms, well-drilling companies, and private companies who provided data for this study. Thanks are also given to the many residents and land owners in the study area who graciously allowed access to their land for purposes of data collection.

\section{GEOHYDROLOGIC SETTING}

Three types of aquifers are present in the study area: (1) stratified drift, which can be a major source of ground water for municipalities; (2) till, which locally can supply minor amounts of water for domestic use; and (3) bedrock, which supplies water to some municipalities and small communities and to most households in the study area that are not connected to a municipal supply.

\section{Stratified Drift and its Depositional Environment}

Coarse-grained stratified drift, the focus of this study, consists of layered, sorted, mostly coarsegrained sediments (sands and gravels) deposited by 
glacial meltwater at the time of deglaciation.

Hydrologic characteristics of these sediments that affect ground-water storage and movement are related to the environment in which the sediments were deposited. Stratified-drift deposits are composed of distinct layers with different grain-size distributions, sorted according to the depositional environment. For example, fast-moving meltwater streams deposit coarse-grained sediments with large pore spaces between grains. If saturated, these sediments store and transmit water readily.

Fine-grained stratified drift (which consists of fine sand, very fine sand, silt, and clay) was deposited in lacustrine environments characterized by slowmoving and ponded glacial meltwater; these finegrained deposits do not transmit water as readily as the coarse-grained sediment does.

The depositional environments associated with deglaciation had a pronounced effect in determining the type of stratified-drift aquifer that was formed. Deglaciation of the study area appears to have been predominantly a systematic process of stagnation-zone retreat (Koteff and Pessl, 1981). Numerous examples of large deltas fed by eskers and by valley-fill deposits support this type of deglaciation. Aquifers deposited by this mechanism are the largest and potentially the most productive. Downwasting of ice (Goldthwait, 1968), although an important mechanism of stratified-drift deposition in the basin, was most likely responsible for thin (less than $20 \mathrm{ft}$ ), discontinuous deposits of sand and gravel. Examples of these are the deposits in and around Center Sandwich. Glacial lakes predominated in the basin during deglaciation, and the largest amounts of stratified drift were deposited in these lakes.

In most of the southern part of the basin where streams presently drain north to Lake Winnipesaukee, southward glacial drainage was obstructed by the highlands to the south and the retreating ice margin to the north. This obstruction resulted in the formation of numerous ice-dammed glacial lakes into which glacial meltwater carried sediment deposited as subaqueous fans or deltas. These deposits are referred to as "icedammed-glacial-lake deposits" (fig. 2). As the ice margin retreated, successively lower drainageways were uncovered to the west and the east. As lake levels declined in response to lower drainageways, fans and deltas formed at the new, lower lake elevations.

In the northern part of the basin, where drainage of glacial meltwater was largely unobstructed by upland areas or glacial ice, the deposits that formed are typical of ice-contact heads of outwash and outwash deltas. These deposits are typically fluvial at the upstream end and grade into deltas where the meltwater streams emptied into a glacial lake; they are referred to as "fluviolacustrine deposits" (fig. 3). Deposits formed in this depositional environment include eskers, kames, kame terraces, and outwash usually in contact with deltaic deposits. These deposits compose stratified-drift aquifers and are referred to here as "fluviodeltaic aquifers."

\section{Ice-Dammed Glacial-Lake Deposits}

Deglaciation of the Winnipesaukee River Basin was complex and included deposition of sediment into glacial lakes that existed at various elevations and times relative to one another. In many places, the retreat of the ice, exposed a new, lower outlet that redirected glacial meltwater, formed new lakes or added to older glacial lakes.

The surfaces defining the previous levels of the glacial lakes in the Winnipesaukee River Basin were uplifted in response to the removal of the glacial ice (isostatic rebound), the uplift being greatest to the

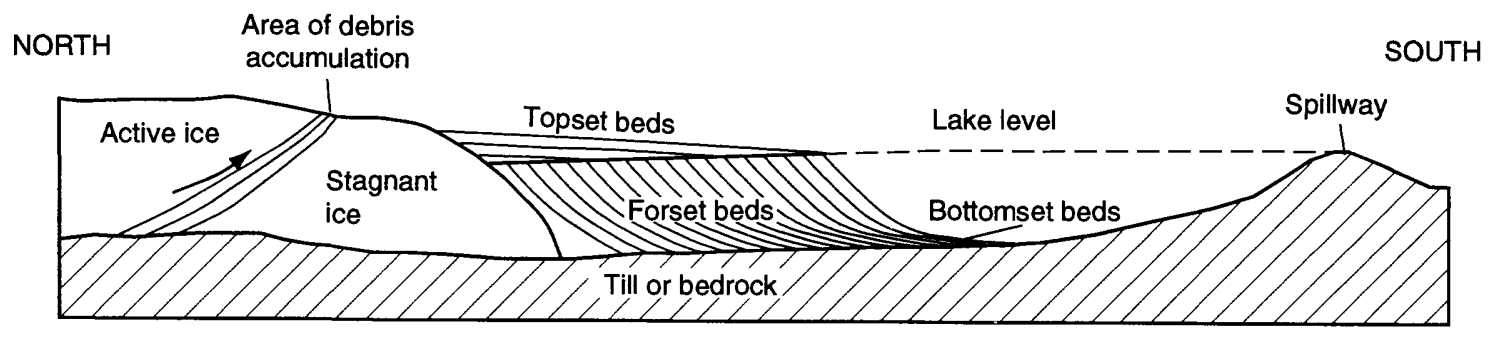

Figure 2. Sectional diagram of an ice-dammed glaciolacustrine deltaic aquifer. 


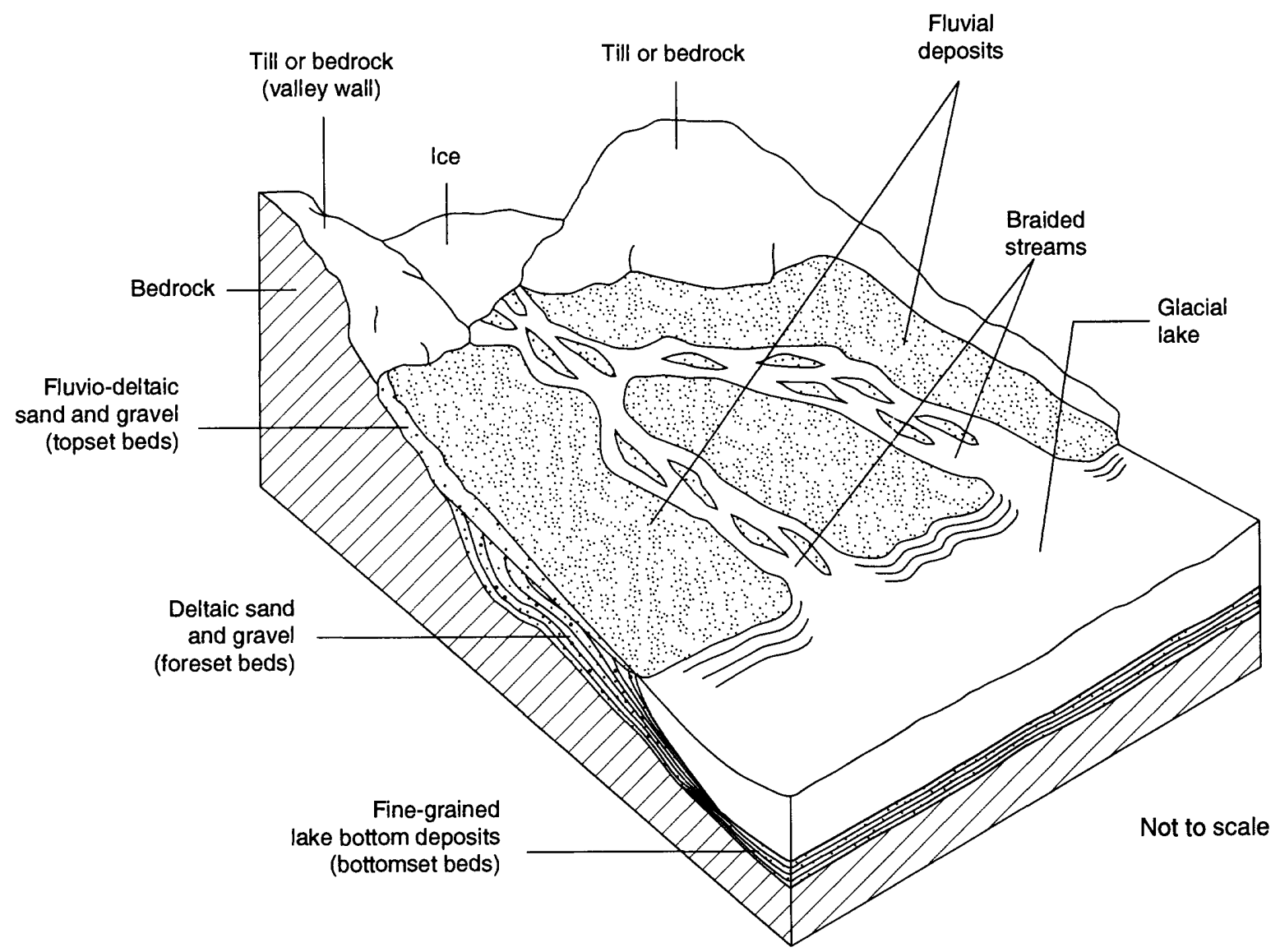

Figure 3. Block diagram of the formation of a glaciofluvial deltaic aquifer.

north-northwest. Projections of these lake surfaces now dip to the south-southeast. No studies have been done in the Winnipesaukee River Basin to determine the exact slope of the projected lake surfaces; however an estimate can be made by examination of deltas in valleys near the study area to the west and south, as well as to the southeast near the coast.

West of the Winnipesaukee River basin, in the Connecticut River Valley, a stabilized level of glacial Lake Hitchcock is indicated by 23 ice-contact deltas and numerous other deltas that have not been modified by collapse and whose topset-foreset contacts fall along a single plane. This stable lake level indicates that the postglacial uplift of New England that resulted from the melting of the continental ice sheet, was delayed by about 5,000 years (Koteff and Larsen, 1989). This plane, after the postglacial uplift, now dips about $4.8 \mathrm{ft} / \mathrm{mi}$ downward in the direction of S. $21^{\circ} \mathrm{E}$. (Koteff and Larsen, 1989). Likewise, the projected lake-level surfaces of glacial lakes to the south, in the Merrimack River Valley (glacial Lakes Tyngsboro, Merrimack, and Hooksett) now slope 4.7 to $4.9 \mathrm{ft} / \mathrm{mi}$ downward to the south-southeast (Koteff and others, 1984). Moore (1995) found that this slope was reasonable for the deltas in the Contoocook River Basin given elevations derived from topographic maps. Similarly, to the southeast, the projected sea-level surface into which numerous glaciomarine deltas were deposited now slopes about $4.5 \mathrm{ft} / \mathrm{mi}$ downward in the direction of S. $28.5^{\circ}$ E. (Koteff and others, 1993). From this information, the plane of previous lake levels of glacial lakes in the Winnipesaukee River Basin is assumed to have a slope of 4.5 to $4.8 \mathrm{ft} / \mathrm{mi}$ downward to the south-southeast. 
Projecting these ice-dammed-glacial-lake surfaces helped to determine the maximum extent of the glacial lakes in the basin and to determine which deposits are related to a given lake stage in the areas where the glacial lake history is complex. The maximum probable extent of glacial lake environments, including glacial Lake Winnipesaukee and numerous other local glacial lake, is shown in figure 4.

The initial drainage of glacial Lake Winnipesaukee during deglaciation was probably across the present-day drainage divide between the Merrymeeting River and the Ela River (pl. 2), and water flowed into the Cocheco River Basin. Before the last glaciation, surface water may have drained in this direction; the elevation of the till and (or) bedrock controlled outlet on the Ela River, below the stratified-drift dam, is approximately $500 \mathrm{ft}$. The elevation of the bedrock controlled outlet at the present-day dam at Lakeport in Laconia is also approximately $500 \mathrm{ft}$. Because both outlets were approximately at the same elevation, the preglacial drainage of the lake was possibly-but not necessarily - out of the Cocheco Basin. The relative elevations of these outlets before glacial erosion and till deposition along the Ela River may have been significantly different.

White (1938) predicted that the depth of the Lake Winnipesaukee Basin due to glacial scour as opposed to stratified-drift damming could be assessed if appropriate data became available. Data collected during this study indicate that the Merrymeeting River valley is filled with more than $100 \mathrm{ft}$ of stratified drift. The actual spillway for the glacial lake, however, was controlled by a till and (or) bedrock high on the Ela River. Bedrock is also the control on the Lakeport outlet. The depth of the Lake Winnipesaukee Basin, therefore, is likely due entirely to scour by glacial ice.

As the ice retreated to the north in the Merrymeeting River Valley from the drainage divide with the Ela River (pl. 2), a thick (at least $100 \mathrm{ft}$ ) sequence of stratified drift filled the now-divided preglacial river valley. Subsequent retreat caused a series of narrow, small glacial lakes to form in the Merrymeeting River Valley, north toward Alton Bay. At successive ice-marginal positions, morphosequences of eskers feeding glaciolacustrine deltas formed. These morphosequences are discussed in detail in the section on "Description of Selected Aquifers."

Subsequent retreat of the ice margin to the north of present-day Lake Wentworth enlarged glacial Lake Winnipesaukee to the north, east, and west (coincident, in part, with present-day Lake Winnipesaukee and Lake Wentworth). Goldthwait $(1968$, p. 30) indicates that some water from the glacial Lake Wentworth area drained out the Merrymeeting River/Ela River outlet, but most drained out to the east of Lake Wentworth. The outlet elevation to the east of Lake Wentworth is approximately $670 \mathrm{ft}$ above sea level; this level is approximately $70 \mathrm{ft}$ higher than the elevation of the delta between Hersey Brook and Harvey Brook. Davis and others (1993, p. EE-9) suggest that water could not drain to the southwest when the Lake Wentworth Basin became ice-free. Nevertheless, deposits in the Lake Wentworth area, as interpreted on the basis of delayed uplift theory (Koteff and others, 1993), appear to be graded to the Merrymeeting River/Ela River outlet, $12 \mathrm{mi}$ to the south. A delta that formed where Harvey Brook and Hersey Brook drain into Lake Wentworth (pl. 4) stands at an elevation of approximately $600 \mathrm{ft}$. The projected water-plane elevation at this area, based on the Merrymeeting River/Ela River outlet, is approximately $585 \mathrm{ft}$. Therefore, drainage appears to have been to the southwest when Lake Wentworth became ice free.

At about the same time that glacial Lake Winnipesaukee began to form, other ice-dammed glacial lakes, such as the glacial lake in Belmont, also were forming. Deglaciation of the south-western part of the Winnipesaukee River Basin formed a glacial lake that occupied much of Belmont. 


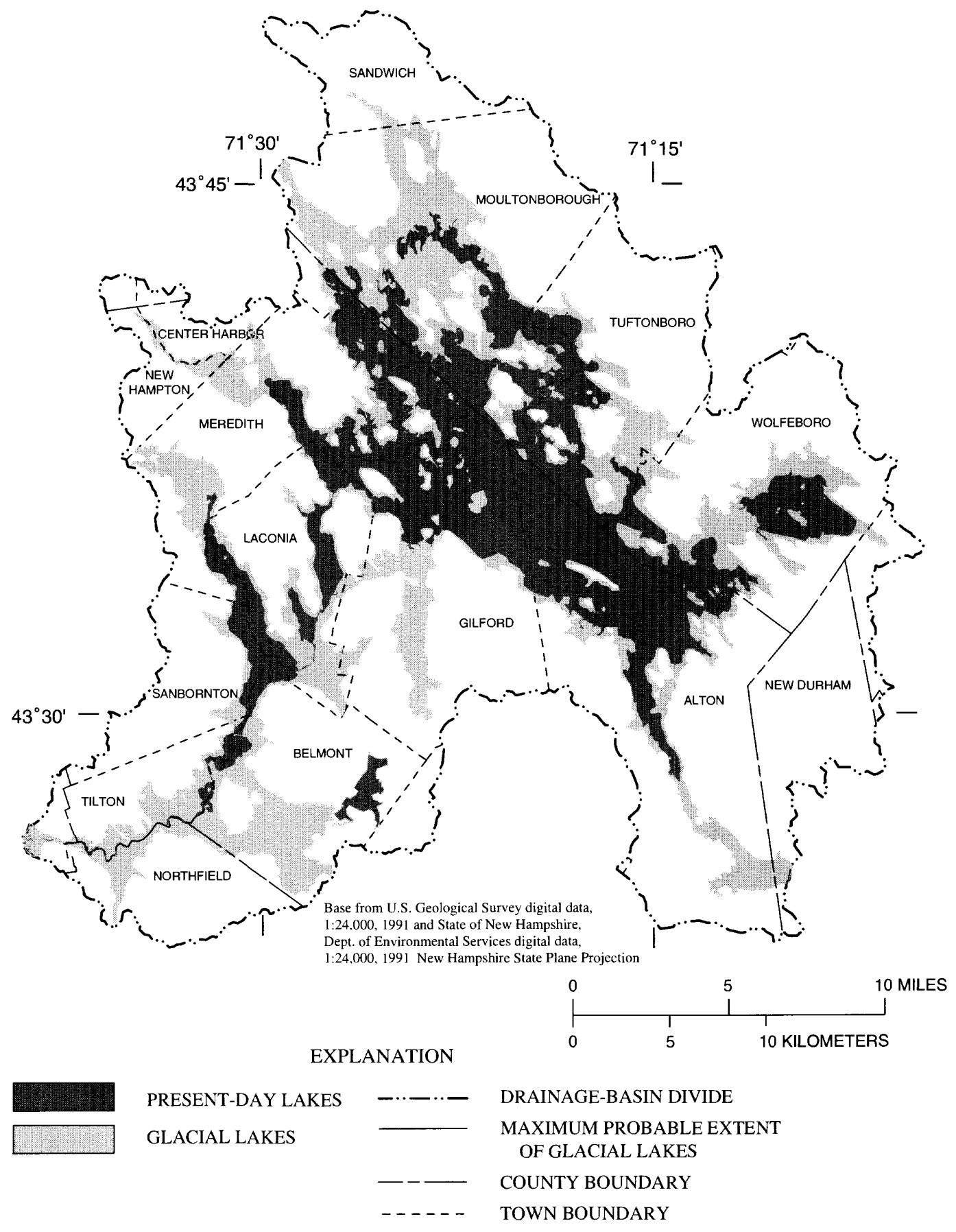

Figure 4. Maximum extent of glacial-lake environments in the Winnipesaukee River Basin, central New Hampshire. 
The level of this glacial lake was controlled by a bedrock spillway $1,000 \mathrm{ft}$ north of the BelmontGilmanton town line along NH Route 106 (pl. 1). The spillway elevation is approximately $640 \mathrm{ft}$ above sea level, and the deposits in the area of Pumping Station Brook in Belmont are graded to this spillway. The most prominent deposit in this area is a delta that is exposed for 60 to $80 \mathrm{ft}$. Deposits below the land surface are greater than $60 \mathrm{ft}$ thick and are composed of materials that are coarser than the exposed delta sediments. An eroded drainage channel originating on the south side of Bean Hill Road, 1,000 ft from the intersection with Union Road leads to an esker trending southeast toward the Belmont delta. this channel indicates that drainage to this area probably came from Winnisquam Lake over a narrow divide near Bean Hill Road. The Tioga River Valley and the Winnipesaukee River Valley below Silver Lake could have been blocked by ice at this point.

Stratified drift along Durkee Brook and Jewett Brook in Laconia (pl. 1) and along the Gunstock River in Gilford (pl. 1) was deposited into smaller, localized glacial lakes that formed against highlands to the south and the ice margin to the north.

Retreating ice from Gardners Grove to Lochmere to Winnisquam (pl. 1) enlarged the glacial lake between Winnisquam Lake and Silver Lake and resulted in the deposition of fine-grained sediment in the Silver Lake and Gardners Grove area.

Subsequently, stratified drift from glacial meltwater flowing along Gulf Brook, which originates near the Tilton-Sanbornton town line (pl. 1), was deposited. The coarse-grained Gulf Brook deposits overlie and may interfinger with the fine-grained deposits south of Silver Lake. A lithologic log for well TSW-80 shows $15 \mathrm{ft}$ of coarse gravel overlying $97 \mathrm{ft}$ of silt and clay; here, coarse gravels from the Gulf Brook spillway must have been deposited after the fine-grained lake-bottom sediment. These deposits appear to be graded to a spillway elevation of $510 \mathrm{ft}$ along Interstate $93,2 \mathrm{mi}$ south of Exit 19 (pl. 1). Much of the very fine grained and fine-grained sediment may have been transported downstream to Northfield and deposited into a glacial lake that existed there at a lower elevation. Test borings
NRW-59 and NRW-61 in Northfield show 75 and $47 \mathrm{ft}$ of very fine sands, respectively, overlying till or bedrock in the Northfield delta.

When the ice retreating to the north-northwest cleared Saunders Bay in Gilford, a lower elevation outlet of glacial Lake Winnipesaukee was exposed through Lily Pond, Black Brook, and Lakeport (pls. 1 and 3). This exposure would have caused the outlet of glacial Lake Winnipesaukee to change from Alton Bay to this new, lower Lakeport outlet at $530 \mathrm{ft}$, dropping the lake level by approximately $65 \mathrm{ft}$. This spillway is controlled by till at Black Brook and by a deep channel cut through till immediately east of the dam at Lakeport. After the ice margin retreated back north of Paugus Bay, glacial Lake Winnipesaukee was lowered by another $30 \mathrm{ft}$ to near its present-day level.

\section{Glaciolacustrine Deposits}

Along the northern shore of present-day Lake Winnipesaukee, stratified-drift deposition probably occurred by stagnation-zone retreat (morphosequence deposition) and by downwasting of stagnant ice. Many of the deposits are associated with ice-marginal drainage near Red Hill and the Ossipee Mountains. Deposits in this part of the basin typically begin as fluvial sequences and are graded to the Lakeport stage (the last stage) of glacial Lake Winnipesaukee. Some of these deposits, however, appear to be graded to the previous level of glacial Lake Winnipesaukee, when the lake drained through Alton Bay. This would be possible if the northeastern side of the ice margin had pulled away from the valley wall enough to allow the formation of a narrow arm of the larger lake to the south. This lake would have extended from the Merrymeeting River spillway up Alton Bay and would have included all of Lake Wentworth. Stratified-drift deposits that may be associated with the possible arm of glacial Lake Winnipesaukee are found near Center Tuftonboro, along the Melvin River, and along Shannon Brook.

As the ice margin retreated north beyond Center Sandwich, Moultonborough, and Center Harbor, glacial Lake Winnipesaukee probably extended northward up narrow valleys that now drain southward into the present-day lake. Glacial Lake Winnipesaukee may have included Squam Lake. The lake-plane elevation at the divide between the two basins (near 
Wakonda Pond), projected from the Lakeport outlet (pl. 4), is approximately $580 \mathrm{ft}$. The elevation of the divide itself, also approximately $580 \mathrm{ft}$, indicates that Squam Lake proper may have been connected to glacial Lake Winnipesaukee by a narrow arm. From similar analysis to the east of Red Hill, former glacial Lake Winnipesaukee would have extended up the Red Hill River for just more than a mile beyond the Moultonborough-Sandwich town line and would have included Berry Pond and the valleys of Halfway Brook. The deposits of the northern part of the basin include stratified-drift deposited in glacial Lake Winnipesaukee and other local glacial-lake environments, as well as stratified drift deposits not associated with glacial lakes. The Moultonborough Airport is probably built on a delta graded to the elevation of glacial Lake Winnipesaukee, as is the large cemetery in Meredith, north of the town park, along Route 25.

In Tuftonboro, to the east, the Melvin River aquifer consists partly of glacial-lake-bottom and deltaic deposits that appear to be graded to the Merrymeeting River outlet of glacial Lake Winnipesaukee. Thick sequences of lacustrine sands can be found in this area. Test boring TZW-3 was drilled to a depth of $103 \mathrm{ft}$ below land surface without reaching the bedrock surface, and it penetrated mostly fine to medium sands. To the east of this area and immediately south of Route 171, an extensive kame field is present in the valley at the base of the Ossipee Mountains. These high deposits are not directly related to glacial Lake Winnipesaukee and are representative of ice-contact deposits.

\section{Till}

Till is an unsorted mixture of clay, silt, sand, gravel, and rock fragments deposited directly by glacial ice. Within the basin, till covers most of the bedrock surface and is overlain locally by stratified drift and Holocene stream deposits. The average thickness of till in the Winnipesaukee River Basin is $35 \mathrm{ft}$, but the thickness can be locally greater than $200 \mathrm{ft}$ (Goldthwait, 1968, p. 19). Koteff (1970) describes two tills in south-central New Hampshire that are thought to represent two separate major glacial advances over the region. Goldthwait (1968, p. 20) describes two tills-ablation till and basal (lodgement) till-but does not relate them to separate glacial advances.

Till is not considered to be a major source of ground water because of its low hydraulic conductivity. Large-diameter wells completed in till can provide modest amounts of water, commonly less than $3 \mathrm{gal} / \mathrm{min}$, for household needs, but water-level fluctuations within till can be large enough to make these wells unreliable during dry seasons.

\section{Bedrock}

Bedrock in the Winnipesaukee River Basin consists of three main groups, as described by Goldthwait (1968, p. 5). The first group consists primarily of metamorphosed sedimentary rocks and includes schists and gneisses of Devonian age known as the Littleton Formation. The second group consists of intrusive igneous rocks known as the New Hampshire Plutonic Series and includes granites and diorites of Middle Devonian age. The third group consists generally of intrusive and extrusive rocks of the White Mountain plutonic-volcanic series of the Late Triassic. Well-known examples of rocks in the third group are Red Hill, the Ossipee Mountains, Copple Crown Mountain, and Belknap Mountain.

\section{GEOHYDROLOGY OF STRATIFIED-DRIFT AQUIFERS}

The geohydrology of stratified-drift aquifers was described by identifying (1) aquifer boundaries, (2) direction of ground-water flow from recharge to discharge areas, (3) aquifer thickness and storage, (4) aquifer transmissivity, and (5) amounts of water potentially available from selected aquifers. Data sources in this investigation included surficial geologic maps, lithologic logs of wells and test borings, and seismic-refraction and seismic-reflection data. Results of the geohydrologic investigation are presented on plates $1-8$ and in the text that follows. 


\section{Delineation of Aquifer Boundaries}

Stratified-drift aquifers in the study area are composed of fine- to coarse-grained sands and gravels deposited by glacial meltwaters; these deposits, in part, are now sufficiently saturated to yield significant quantities of water to wells and springs. Locations of the lateral boundaries of the aquifers are defined as the contacts between the stratified drift and till and (or) bedrock. The position of the contact was determined by use of surficial geologic maps, soil maps, test-boring logs, and field mapping done specifically for this study. The bottom boundary is the contact of the stratified drift with the till and (or) bedrock surface and was determined by use of data from seismic refraction, seismic reflection, test borings, and domestic water wells. The upper boundary is the water table.

\section{Areal Extent of Stratified-Drift Aquifers}

The areal extent of the stratified-drift aquifers is shown on plates $1-8$. Because of the regional scale of this investigation, aquifer boundaries are approximate. Coarse-grained stratified-drift aquifers may be present beneath fine-grained lacustrine deposits but may not have been identified because of the complexity of the stratigraphy and (or) the absence of data. Available data for coarse sediment underlying fine-grained sediment are discussed in the section "Descriptions of Selected Stratified-Drift Aquifers." Although the lacustrine clay, silts, and very fine sands are not capable of supplying adequate amounts of water for domestic and community use, the coarse-grained deposits that may lie below could be productive aquifers.

Aquifer boundaries are shown as solid, dashed, or dotted lines. In the explanation on the plates, solid lines represent "approximately located" boundaries, dashed lines represent "inferred" boundaries, and dotted lines represent "concealed" boundaries. The lateral boundaries of stratified-drift aquifers were delineated from the previously cited published and surficial geologic maps and by interpretation of soil maps of Belknap, Carroll, Merrimack, and Strafford Counties.

\section{Stratigraphy of Geohydrologic Units}

Data for the stratigraphy of geohydrologic units were obtained from available records of subsurface exploration within the study area. Additional test drilling and surface geophysical exploration were done to delineate texturally different geohydrologic units within the stratified drift.

\section{Ground-Water Site Inventory}

Subsurface data from wells and borings were inventoried, and data locations within the stratifieddrift aquifers are plotted on plates 1-4. Geohydrologic data for approximately 2,500 sites were added to the GWSI data base and checked for accuracy. Data for approximately 2,100 of the 2,500 sites were transferred to GWSI from the NHDES-WRD well inventory data base. Approximately 500 of the 2,100 NHDES-WRD sites are within stratifieddrift aquifer areas. Approximately 900 sites of the 2,500 total sites added to the GWSI data base are in the stratified-drift aquifer areas. appendix $A$ contains selected data from the GWSI data base for wells, borings, and springs within the stratifieddrift aquifer areas that were used to construct the accompanying map plates. These data include an identification number for the well, latitude and longitude, depth of the well, water level, and yield of the well. appendix B contains stratigraphic logs of selected wells and borings in stratified drift. These data were used primarily for estimating the transmissivity of the aquifers where no aquifer-test data or grain-size data were available.

\section{Seismic Refraction}

Seismic-refraction profiles, totaling more than $7 \mathrm{mi}$, were completed at 60 locations to determine depths to the water table (pls. 1-4) and depths to the bedrock surface (pls. 5-8). A 12-channel, signalenhancing seismograph was used to record arrival times of compressional wave energy generated by a sound source. The data were collected and interpreted according to methods described by Haeni (1988a). The interpretations, made with the aid of a computer program developed by Scott and others (1972), are shown in appendix C. 
Seismic velocities calculated for the materials under investigation and used in the seismic interpretations range from 500 to $1,500 \mathrm{ft} / \mathrm{s}$ for unsaturated stratified drift, approximately $5,000 \mathrm{ft} / \mathrm{s}$ for saturated stratified drift, and between 10,000 and $20,000 \mathrm{ft} / \mathrm{s}$ for bedrock. Interpreted seismic profiles in this report show (1) the top of the profile, which represents land surface in feet above sea level; (2) an estimate of the altitude of the water table within unconsolidated deposits at the time the seismic data were collected; and (3) an estimate of altitude of the bedrock surface. The relative altitudes of each geophone and shot were determined by leveling if altitude differences greater than $5 \mathrm{ft}$ between geophones were observed. The actual altitudes, relative to sea level, were estimated from USGS topographic maps and are assumed to be accurate to half a contour interval or about $10 \mathrm{ft}$. Till is not accounted for in these interpretations because it is usually thin (less than $10 \mathrm{ft}$ ) and, therefore, cannot be detected with seismic-refraction methods. Where till is present in significant thickness and is not accounted for in the interpretation of seismic data, the computed depth to the bedrock is slightly less than the actual depth. Additional error results if the relief of the bedrock surface differs considerably over distances less than the 50- or 100-foot geophone spacing used in profiling.

Estimated depths to the water table and to the bedrock surface are generally compared with control data, such as nearby well or boring logs and water-table and bedrock-outcrop observations. The accuracy of the depths to water table and bedrock are within 10 percent of the true depth, as determined from test borings made along selected profiles.

\section{Seismic Reflection}

High-resolution, continuous seismic-reflection data were collected according to methods described by Haeni $(1986,1986 \mathrm{~b})$ along approximately $5 \mathrm{mi}$ of the Merrymeeting River within the study area. Data were also collected on navigable reaches of the Winnipesaukee River from near exit 20 on Interstate 93 at Tilton upstream to Silver Lake in Belmont. Parts of Winnisquam Lake also were surveyed. These data were used to map depths to the bedrock surface beneath the water bodies. During data collection, an array of receivers was towed behind a boat that traveled slowly up or down the river. Compressional waves, generated from a sound source, penetrated the river bottom and were reflected back to the surface in response to the physical differences in the geologic strata. The reflected sound waves were received at the water surface, converted to an electrical signal, and displayed on a graphic recorder. Data collection was often affected by the presence of strong reflectors at the water bottom. These strong reflectors cause multiple reflections of the water-bottom to appear on the record and obscure data below.

\section{Altitude of the Water Table}

The approximate altitude of the water table in the stratified drift is shown on plates $1-4$. These maps were constructed from (1) altitudes of streams, ponds, and lakes as shown on 1:24,000-scale USGS topographic maps; (2) water-level data from wells stored in GWSI; and (3) analysis of seismic-refraction data. Groundwater altitudes in fine-grained lacustrine deposits represent the ground-water altitude in those deposits only. Saturated coarse-grained stratified drift may be present below fine-grained material in some areas, and a second, deeper potentiometric surface (in confined aquifers) may be present.

Water-level measurements were made monthly at selected wells in the study area during 1991 and 1992 and were stored in GWSI. A hydrograph showing water levels in well FKW-1 near the study area (near the confluence of the Winnipesaukee and Pemigewasset Rivers) is shown in figure 5. Well FKW-1 represents water-level fluctuations in a stratified-drift aquifer. The data from this well support the conclusion reached for other parts of New Hampshire. Natural water-level fluctuations in coarsegrained stratified drift are usually less than $5 \mathrm{ft}$ but can be as much as $10 \mathrm{ft}$ (Cotton, 1987; Toppin, 1987; Moore, 1990; Mack and Lawlor, 1992; Moore and others, 1994, Harte and Johnson, 1995, Ayotte and Toppin, 1995); therefore, a 20-foot contour interval for water-table altitudes under natural conditions is reasonable for producing a generalized water-table map from water-level measurements made at different times. 


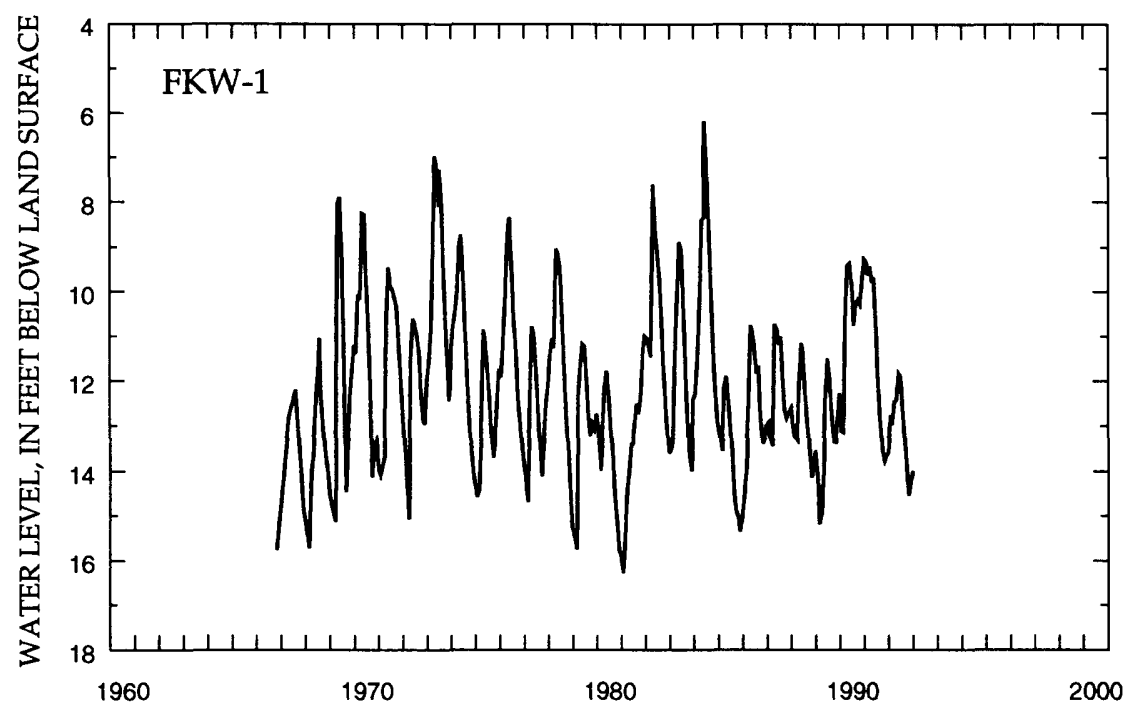

Figure 5. Long-term water levels at observation well FKW-1 in stratified drift, central New Hampshire.

\section{Recharge, Discharge, and Direction of Ground-Water Flow}

Ground-water recharge includes natural recharge from precipitation that falls directly on the aquifer and infiltrates the water table, lateral inflow from adjacent till and bedrock areas, and, in some places, leakage from streams that traverse the aquifer. Natural recharge is the difference between precipitation and the amount of water lost to evapotranspiration and to surface runoff.

Recharge to stratified-drift aquifers can be estimated from stream-discharge measurements made during periods in which there is no change in ground-water storage, as indicated by the position of the water table. Making such estimates requires the assumption that the ground-water discharge consists mostly of ground-water runoff. During periods of low flow and after an extended period without precipitation, this assumption is reasonable. This method probably gives conservative estimates of natural recharge to aquifers.

Estimated ground-water recharge falling directly onto stratified-drift aquifers is approximately half the annual precipitation in glaciated areas of eastern Massachusetts (Knott and Olimpio, 1986) and in southern Maine (Morrissey, 1983). Most of the recharge in the study area occurs in late fall and early spring, when precipitation is greatest and evapotranspiration is lowest.

Recharge to the stratified-drift aquifers occurs in part from adjacent till and (or) bedrock uplands. Lateral inflow from upland areas not drained by perennial streams recharges the stratified-drift aquifer at the till and (or) bedrock contact. Recharge to stratified-drift aquifers from upland areas not drained by streams can be estimated by measuring ground-water discharge from till and (or) bedrock uplands that are drained by streams. Ayotte and Toppin (1995), who examined long-term (1963 to present) streamflow data from Stony Brook Tributary in south-central, New Hampshire, found that the average discharge from till uplands with small drainage areas (3.60 $\mathrm{mi}^{2}$ for Stony Brook) can be as high as $1.95\left[\left(\mathrm{ft}^{3} / \mathrm{s}\right) / \mathrm{mi}^{2}\right]$. For a 23 -square-mile tillcovered drainage in Maine, the estimated average annual lateral inflow of ground water from upland areas to a stratified-drift aquifer was $0.5\left[\left(\mathrm{ft}^{3} / \mathrm{s}\right) / \mathrm{mi}^{2}\right]$. (Morrissey, 1983). Upland areas not drained by streams are generally small but may contribute a significant amount of recharge to aquifers. 
Recharge to stratified-drift aquifers from streams that lose water to the aquifer through permeable streambeds was documented by Randall (1978) and by Morrissey and others (1988). This type of recharge was not observed in any of the baseflow measurements made in this study, although it probably occurs on a small scale within the \pm 5 -percent error associated with base-flow measurements. Such tributary-stream infiltration occurs where the tributary streams flow into aquifers that have a water table below the stream-bottom elevation at the stratified-drift and till and (or) bedrock contact (D.J. Morrissey, U.S. Geological Survey, written commun., 1989).

Ground-water discharge includes natural leakage into streams, lakes, and wetlands; ground-water evapotranspiration; and withdrawal from wells. During periods of low streamflow, usually in late summer and early fall and after extended periods without rainfall, streamflow consists almost entirely of ground-water discharge. Streamflow measurements were made during such a period on July 3, 1991 (appendix D).

Streamflow-gaging stations 01064500 on the Saco River near Conway, 01065500 on the Ossipee River at Cornish, Maine, 01075800 on Stevens Brook near Wentworth, 01076500 on the Pemigewasset River at Plymouth (northwest of the study area), 01078000 on the Smith River near Bristol, 01081000 on the Winnipesaukee River at Tilton, 01081500 on the Merrimack River at Franklin Junction, and 01089100 on the Soucook River at Pembroke Road near Concord were used to monitor flow conditions in and near the basin (fig. 6). Flow duration, in percent, for each of these eight streamflow-gaging stations is given in table 2 . Flow duration indicates how often the average daily streamflow is equaled or exceeded. The average flow duration at the eight sites on July 3, 1991, was 93 percent. Under these conditions, flow within the basin was low, and ground-water discharge was assumed to be natural recharge from ground-water runoff. If this discharge is assumed to be composed entirely of ground-water runoff (a reasonable assumption for these measurements) it can be used as an estimate of recharge to aquifers in the study area. These measurements are discussed further in the section on "Description of Selected Stratified-Drift Aquifers."
Artificial sources of recharge to or discharge from an aquifer complicate the construction of watertable maps that are intended to represent natural conditions. Withdrawals of ground water affect the direction and slope of ground-water flow in an aquifer. Two stratified-drift aquifers in the basin (in Alton and Belmont) are affected by ground-water withdrawals. The amount of drawdown in a withdrawal well is determined in part by the location of the well in relation to the valley wall (stratified drift and till contact) and to potential recharge boundaries (streams, rivers, and surface-water bodies). Ground-water-flow lines and drawdowns due to withdrawal near an impermeable boundary are shown in figure 7 . Drawdown is significantly greater on the impermeable boundary side than on the opposite side where the aquifer is of infinite areal extent. A withdrawal well located near a potential recharge boundary, such as a pond or river (fig. 8), will have significantly less drawdown than a withdrawal well at greater distance from the recharge boundary.

Direction of ground-water flow in an unconfined aquifer is determined by the water-table gradient. Water-table gradients differed throughout the study area because of differences in topography and hydraulic conductivity of the stratified-drift deposits. Water-table gradients in fine-grained stratified drift commonly exceeded 5 percent in areas of high topographic relief. Water-table gradients in coarsegrained stratified drift in areas of low topographic relief were less than 0.1 percent. Potentiometric surfaces within confined aquifers (coarse-grained deposits beneath fine-grained deposits) were not contoured because of insufficient data.

\section{Aquifer Characteristics}

The geohydrology of stratified-drift aquifers shown on plates $5-8$ is based partly on aquifer characteristics that include saturated thickness, storage, and hydraulic conductivity. Estimates of saturated thickness and hydraulic conductivity were used to calculate transmissivity (pls. 5-8). These properties can be used to assess the water-supply potential of stratified-drift aquifers. Values of aquifer storage can be used to provide an estimate of aquifer yield. 


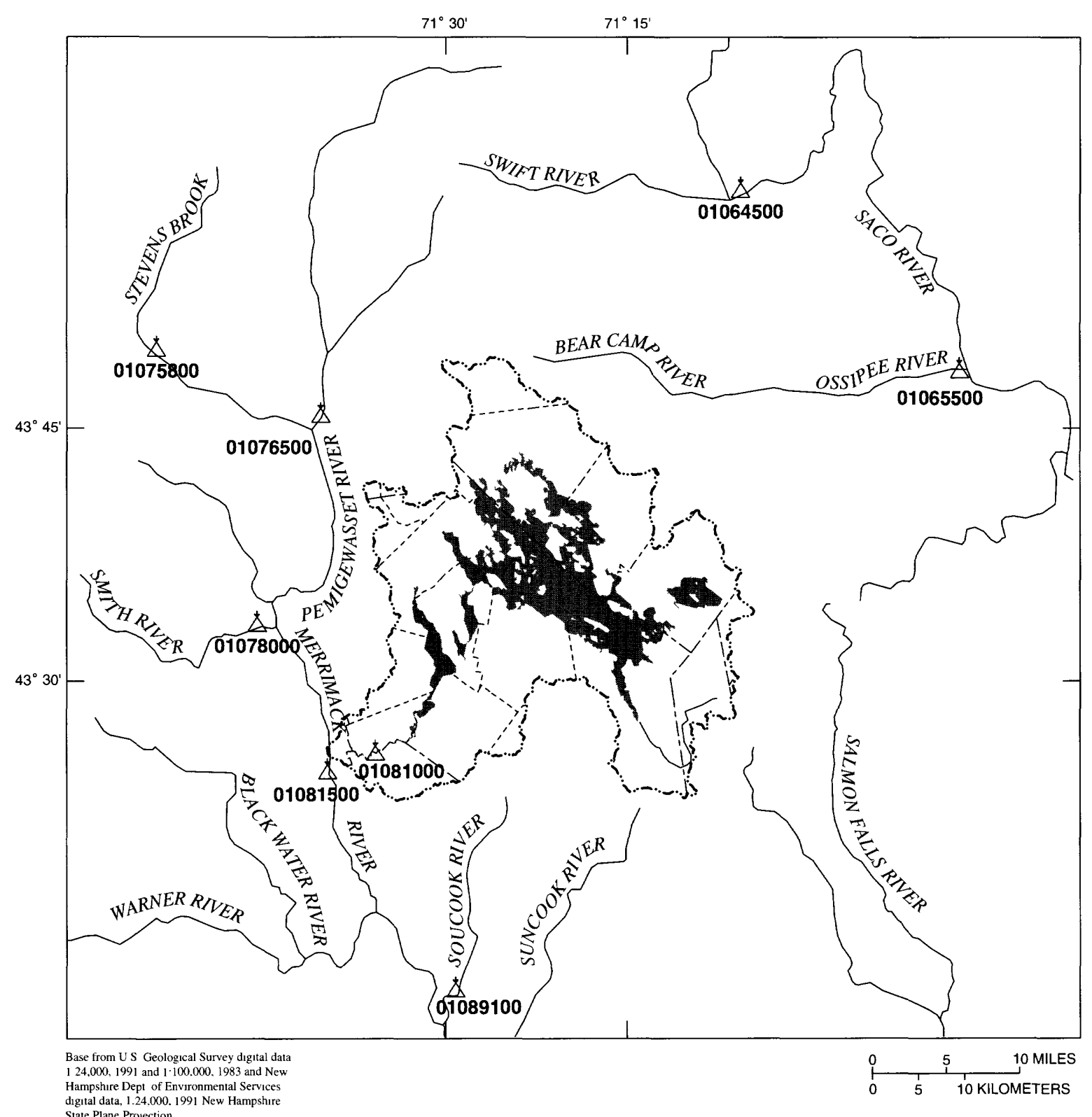

Ste Plane Projection 1991 New Hamphire

EXPLANAT1ON

\begin{tabular}{|c|c|}
\hline & PRESENT-DAY LAKES \\
\hline$-\cdot \cdots-\cdot \cdots-\cdot$ & DRAINAGE-BASIN DIVIDE \\
\hline & COUNTY BOUNDARY \\
\hline & TOWN BOUNDARY \\
\hline & MAJOR RIVERS \\
\hline$\underset{01089100}{\triangle}$ & $\begin{array}{l}\text { LONG-TERM STREAMFLOW-GAGING } \\
\text { STATION--Number is USGS } \\
\text { gaging station identifier. }\end{array}$ \\
\hline
\end{tabular}

Figure 6. Locations of selected long-term streamflow-gaging stations in and near the Winnipesuakee River Basin, central New Hampshire. 
Table 2. Percentage of flow duration on July 3,1991, for selected U.S. Geological Survey streamflow-gaging stations in and near the Winnipesaukee River Basin, central New Hampshire

[USGS, U.S. Geological Survey; $\mathrm{mi}^{2}$, square mile, N.H., New Hampshire]

\begin{tabular}{llcc}
\hline $\begin{array}{c}\text { UsGS gaging } \\
\text { station No. }\end{array}$ & \multicolumn{1}{c}{ Name of site } & $\begin{array}{c}\text { Drainage } \\
\text { area } \\
\left.\text { (mi }^{2}\right)\end{array}$ & $\begin{array}{c}\text { Percentage of } \\
\text { flow duration on } \\
\text { July 3, 1991 }\end{array}$ \\
\hline 01064500 & Saco River near Conway, N.H. & 385 & 93.8 \\
01065500 & Ossipee River at Cornish, Maine & 452 & 92.2 \\
01075800 & Stevens Brook near Wentworth, N.H. & 2.94 & 95.5 \\
01076500 & Pemigewasset River at Plymouth, N.H & 622 & 95.8 \\
01078000 & Smith River near Bristol, N.H. & 85.8 & 93.8 \\
01081000 & Winnipesaukee River at Tilton, N.H & 471 & 90.7 \\
01081500 & Merrimack River at Franklin Junction, N.H. & 143 & 97.8 \\
01089100 & Soucook River at Pembroke Road near Concord, N.H. & 81.9 & 83.3 \\
\hline
\end{tabular}

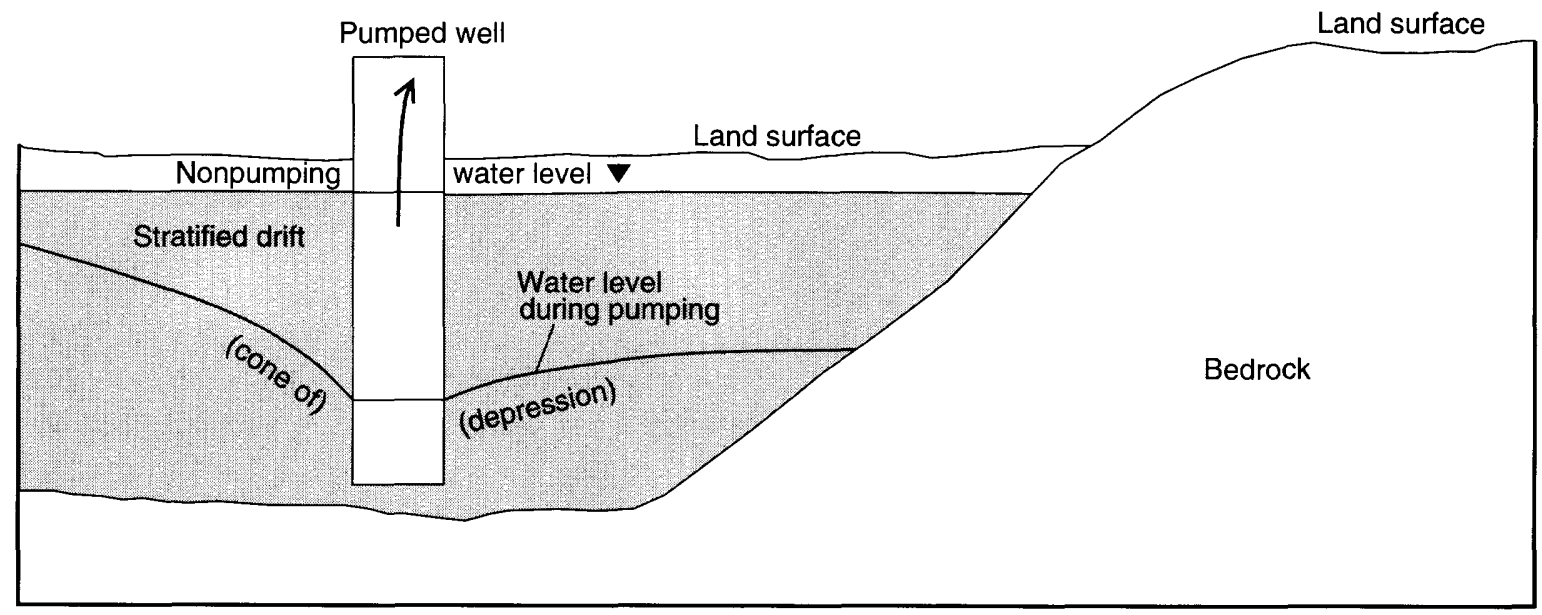

Not to scale

Figure 7. Ground-water flow and water-level drawdowns at a withdrawal well near an impermeable boundary.

\section{Saturated Thickness and Storage}

Saturated thickness of an unconfined stratifieddrift aquifer is the vertical distance between the water table and the base of the aquifer. The base of a stratified-drift aquifer is usually the contact between stratified drift and the till or bedrock surface; for some aquifers, however, the base is the contact between the upper coarse-grained deposits and the underlying finegrained lacustrine deposits. However, saturated thicknesses depicted on plates 5-8 include these finegrained deposits. Saturated thickness contours were constructed from test-boring data, well data, seismic-refraction data, and seismic-reflection data.
The saturated thickness multiplied by the specific yield of an unconfined aquifer determines the amount of ground water that can be released from storage.

The storage coefficient of an aquifer is defined as the volume of water released from or taken into storage per unit surface area of aquifer per unit change in head (Lohman and others, 1972). In unconfined aquifers, the storage coefficient is approximately equal to the specific yield, which is the amount of water released by gravity drainage from a unit volume of aquifer per unit decrease in hydraulic head. A value of 0.2 is commonly used for specific yield for stratified-drift aquifers in New 


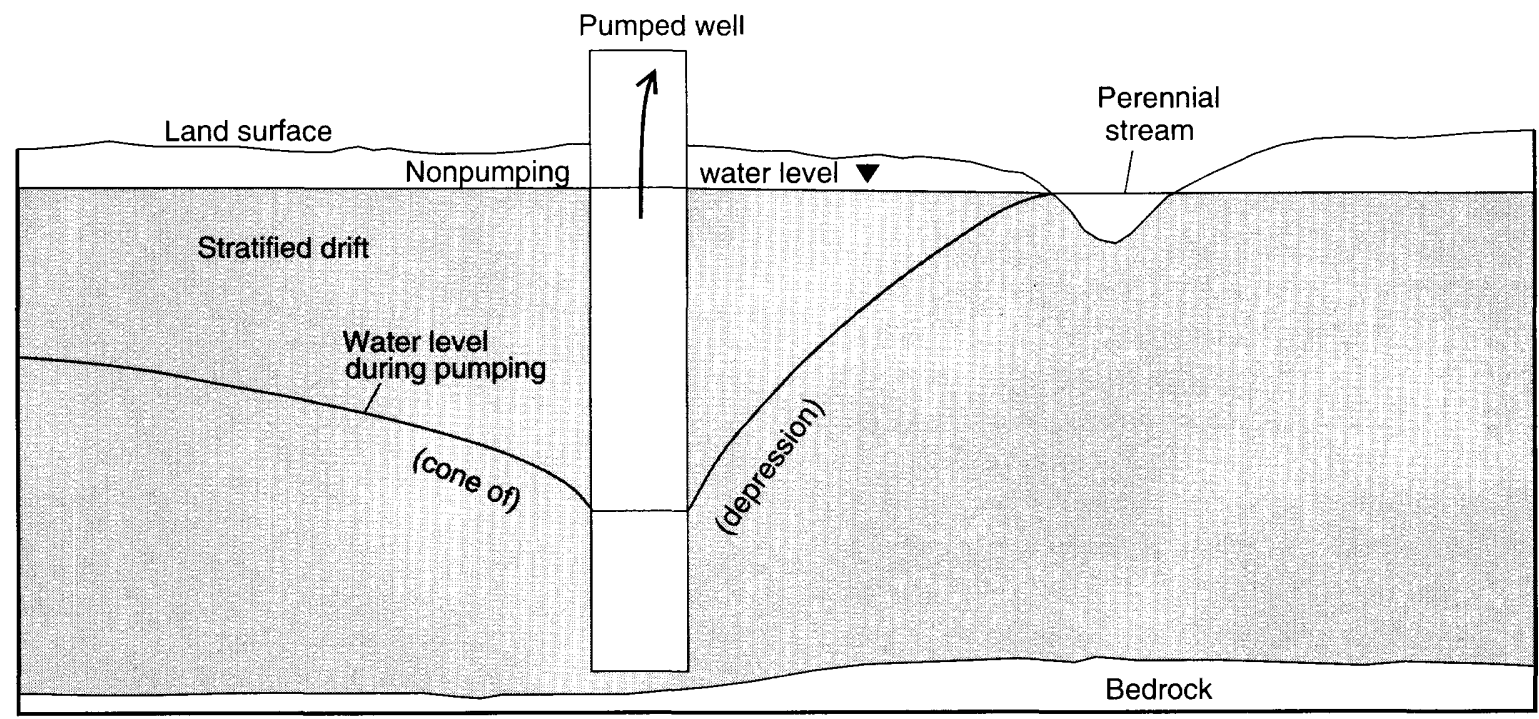

Not to scale

Figure 8. Ground-water flow and water-level drawdowns at a withdrawal well near a recharge boundary.

England (Moore, 1990) and for unconsolidated deposits in other areas (Freeze and Cherry, 1979). Specific yields of 13 samples of stratified drift from southern New Hampshire ranged from 0.14 to 0.34 and averaged 0.26 (Weigle and Kranes, 1966).

Water released from storage in confined aquifers results from expansion of water and compression of the aquifer as hydraulic head declines. Storage coefficients for confined aquifers, which are significantly smaller than specific yields for unconfined aquifers, range from 0.00005 to 0.005 . Smaller storage coefficients associated with confined aquifers indicate that the amount of water derived from expansion and aquifer compression is much less than that from dewatering by gravity drainage.

Saturated-thickness maps can be used to estimate the amount of ground water stored in an aquifer. The saturated volume of an unconfined aquifer is approximately equal to the sum of the products of the areas between successive pairs of saturated-thickness contours multiplied by the average saturated thickness for each area. The actual volume of ground water stored in the aquifer is the product of the saturated volume multiplied by the porosity.

\section{Transmissivity and Hydraulic Conductivity}

Transmissivity is defined as the rate at which water at the prevailing kinematic viscosity can be transmitted through a unit width of an aquifer under a unit hydraulic gradient (Lohman and others, 1972). The transmissivity $(T)$ of an aquifer is equal to the saturated thickness $(b)$, in feet, multiplied by the horizontal hydraulic conductivity ( $K$, a directional measure of the permeability), in $\mathrm{ft} / \mathrm{d}$, and is expressed in feet squared per day $\left(\mathrm{ft}^{2} / \mathrm{d}\right)$; thus,

$$
T=K(b) .
$$

Transmissivity at a specific site was derived from estimates of hydraulic conductivity of lithologic units in the aquifers. Hydraulic conductivity, in turn, was estimated from grain-size distributions of samples of aquifer materials by use of the regression equation developed by Olney (1983). Hydraulic conductivity, however, which has a vertical and a horizontal vector component, is not accounted for by this equation. In this relation, an effective grain size ( $D_{10}$, in phi units) was used to estimate hydraulic conductivity ( $K$, in feet per day) with the following equation:

$$
K=2,100 \times 10^{-0.655\left(D_{10}\right)} \text {. }
$$


The effective grain size $\left(D_{10}\right)$ is a controlling factor for the hydraulic conductivity of stratified drift in New Hampshire and is defined as that grain size where 10 percent of the sample consists of smaller grains and 90 percent of the sample consists of larger grains. Olney (1983) developed this relation from results of permeameter tests of stratified-drift samples from Massachusetts. Moore (1990) found that this relation yielded results that fall within the range of results from other relations that have been developed between grain-size distribution and hydraulic conductivity (Krumbein and Monk, 1942; Bedinger, 1961; and Masch and Denney, 1966). Comparisons with aquifer-test data, however, indicate that equation 2 may not give accurate results for very coarse grained sand and (or) gravel. Estimates of hydraulic conductivity for aquifers with coarse sands and gravels were, in part, based on comparisons to aquifer-test data for similar deposits. Hydraulic conductivity (and transmissivity) based on grain-size relations are only estimates and are vectortless and may differ from results of aquifer-test analyses. Additionally, transmissivities calculated from aquifer-test data may be affected by the presence of hydrologic boundaries such as rivers or valley walls.

Hydraulic conductivity was estimated for 454 samples of stratified drift from southern New Hampshire by means of equation 2 . The samples were collected in the Exeter and Lamprey River Basins (Moore, 1990); in the seacoast area and the Lower Merrimack River Basin (Flanagan and Stekl, 1990); in the Bellamy, Cocheco, Salmon Falls River Basins (Mack and Lawlor, 1992); in the Lower Connecticut River Basin (Moore and others, 1994); in the Contoocook River Basin (Harte and Johnson, 1995), and for this study. The grain-size distribution and the effective grain size $\left(D_{10}\right)$ were determined for these 454 samples.

Hydraulic conductivities calculated from equation 2 were plotted against median grain size in phi groups, and the resulting plot was divided into three categories of degree of sorting (fig. 9). These relative categories are used to describe the types of stratified-drift-aquifer deposits found in New Hampshire. The degree of sorting was based on the standard deviation of each individual sample.

If standard deviations were greater than $1.75 \mathrm{phi}$, the samples were considered poorly sorted; if standard deviations were 1.25 to $1.75 \mathrm{phi}$, the samples were considered moderately sorted; and if standard deviations were less than 1.25 phi, the samples were considered well sorted. A regression equation was developed for each of the three categories to determine the relation between hydraulic conductivity and median grain size (fig. 9). The coefficient of determination $\left(R^{2}\right)$ was 0.93 for the well sorted samples, 0.72 for the moderately sorted samples, and 0.54 for the poorly sorted samples. The calculated hydraulic conductivity, grouped by ranges of median grain size and by ranges of standard deviation (degree of sorting), is shown in table 3 .

Hydraulic conductivities were calculated for each median phi group and were averaged to determine a mean hydraulic conductivity per group. For example, the mean hydraulic conductivity of sediment samples whose median grain size was described as medium sand and well sorted was $38 \mathrm{ft} / \mathrm{d}$ (the average of 25 and $51 \mathrm{ft} / \mathrm{d}$; table 3).

Very fine sand, silt, and clay deposits in the study area were not analyzed for grain-size distribution because their hydraulic conductivities are typically low (less than $4 \mathrm{ft} / \mathrm{d}$ ) and, therefore, considered insignificant in terms of total transmissivity (Todd, 1980).

The values in table 3 were used to estimate hydraulic conductivities from lithologic descriptions given in logs from test borings and wells. For example, for a lithologic description of $10 \mathrm{ft}$ of moderately sorted coarse sand overlying $20 \mathrm{ft}$ of well sorted fine sand overlying bedrock, the hydraulic conductivities assigned would be $39 \mathrm{ft} / \mathrm{d}$ (the average of 30 and $48 \mathrm{ft} / \mathrm{d}$ ) and $9 \mathrm{ft} / \mathrm{d}$ (the average of 12 and $6 \mathrm{ft} / \mathrm{d}$ ), respectively. The estimate of transmissivity, based on the same description, would be $(10 \mathrm{ft} \times 39 \mathrm{ft} / \mathrm{d})+$ $(20 \mathrm{ft} \times 9 \mathrm{ft} / \mathrm{d})$, which equals $570 \mathrm{ft}^{2} / \mathrm{d}$. 


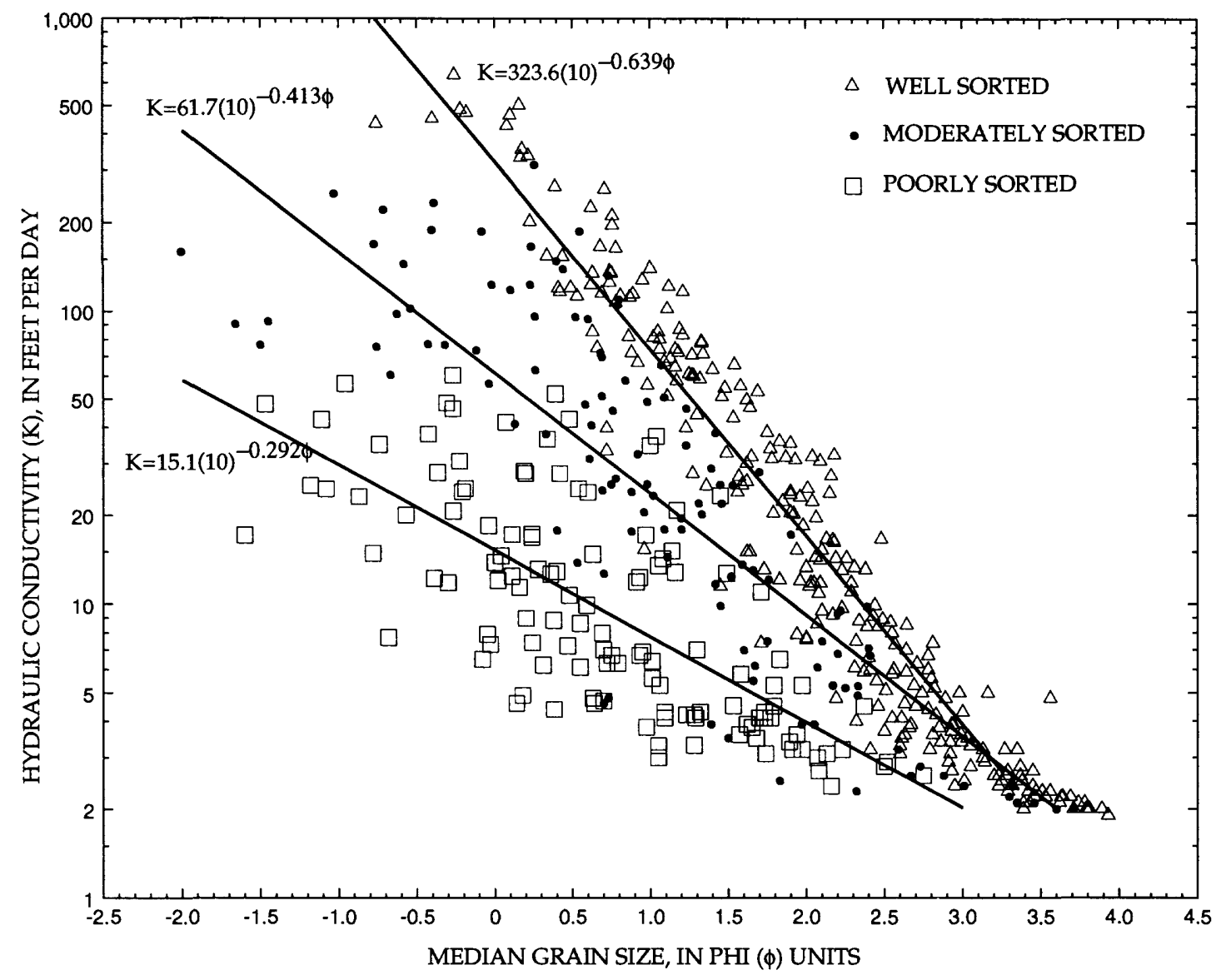

Figure 9. Relation between estimated hydraulic conductivity, median grain size, and degree of sorting of stratified drift in New Hampshire.

Table 3. Relation of mean bulk hydraulic conductivity to median grain size and degree of sorting of stratified drift in New Hampshire

[Mean bulk hydraulic conductivity $(K)$ : vectorless and calculated by use of methods described by Olney (1983). <, actual value less than value shown; $>$, actual value is greater than actual value shown; --, no data. Data from Ayotte and Toppin, 1995]

\begin{tabular}{clccc}
\hline \multirow{2}{*}{$\begin{array}{c}\text { Median } \\
\text { grain size } \\
\text { (phi units) }\end{array}$} & Median grain description & \multicolumn{3}{c}{ Mean bulk hydraulic conductivity (K), in feet per day } \\
\cline { 3 - 5 } & & $\begin{array}{c}\text { Well sorted (standard } \\
\text { deviation <1.25 phi) }\end{array}$ & $\begin{array}{c}\text { Moderately sorted } \\
\text { (standard deviation } \\
\mathbf{1 . 2 5} \text { phi to 1.75 phi) }\end{array}$ & $\begin{array}{c}\text { Poorly sorted } \\
\text { (standard deviation } \\
\text { >1.75 phi) }\end{array}$ \\
\hline-1.75 & Granules & - & 320 & 49 \\
-1.25 & Granules & -- & 200 & 35 \\
-.75 & Very coarse sand & 970 & 120 & 25 \\
-.25 & Very coarse sand & 470 & 78 & 18 \\
.25 & Coarse sand & 220 & 48 & 13 \\
.75 & Coarse sand & 110 & 30 & 9 \\
1.25 & Medium sand & 51 & 19 & 7 \\
1.75 & Medium sand & 25 & 12 & 5 \\
2.25 & Fine sand & 12 & 7 & 3 \\
2.75 & Fine sand & 6 & 4 & 2 \\
3.25 & Very fine sand & 3 & 3 & -- \\
3.75 & Very fine sand & 2 & 2 & - \\
\hline
\end{tabular}




\section{Description of Selected Stratified-Drift Aquifers}

The most extensive and most productive aquifers in the study area are discussed in this section.

Stratified-drift aquifers in the southern part of the basin are typically continuous and are present in the former drainageways of glacial Lake Winnipesaukee and the associated glacial lakes of adjacent upland areas. Aquifers are discussed by plate, starting with plate 5 at the southwestern part of the basin and ending with plate 8 in the northeastern part of the basin (fig. 10).

\section{Gulf Brook Aquifer}

The Gulf Brook aquifer is in the northern part of Tilton, east of Interstate 93. The head of outwash is near the Tilton-Sanbornton town line north of the The Gulf, which is a deeply incised glacial drainageway cut by fast-moving meltwater. The fast-moving water deposited coarse sand to cobble gravel to the south toward the Winnipesaukee River, and this coarse material partially covers the fine-grained sediment below. The saturated thickness of the coarse-grained aquifer is generally less than $20 \mathrm{ft}$ in the northern half but is greater to the south. The log from well TSW-80 shows $15 \mathrm{ft}$ of coarse-grained material below land surface and fine sand and silt from 15 to $112 \mathrm{ft}$. Much of the unsaturated coarse-grained material in this area has been excavated. The transmissivity of the aquifer is less than $1,000 \mathrm{ft}^{2} / \mathrm{d}$ in the northern part but exceeds $1,000 \mathrm{ft}^{2} / \mathrm{d}$ in the southern half, mostly because of the substantial increase in the saturated thickness. This aquifer is hydraulically connected to the Gardners Grove aquifer.

\section{Gardners Grove Aquifer}

The Gardners Grove aquifer is mostly south of Silver Lake in Belmont, although part of it extends to the east up the Tioga River toward the center of Belmont. Glacial meltwater draining from Winnisquam Lake to Silver Lake deposited the fine to medium sands into a glacial lake that once occupied this area. The deposits are graded to the elevation of the glacial-lake outlet, which was the till channel of the Winnipesaukee River near Interstate 93 in the northeastern part of
Tilton. The elevation of the channel is approximately $460 \mathrm{ft}$ above sea level. Test borings BLW-80 and BLW83 (pl. 1) revealed that the saturated thickness of much of this aquifer exceeds $100 \mathrm{ft}$ and is locally greater than $120 \mathrm{ft}$. Hydraulic conductivities estimated from grainsize analyses of aquifer material collected at observation well BLW-80 are $50 \mathrm{ft} / \mathrm{d}$ for the upper $20 \mathrm{ft}$ and approximately $20 \mathrm{ft} / \mathrm{d}$ from 20 to $90 \mathrm{ft}$. The transmissivity of this area is about $1,500 \mathrm{ft}^{2} / \mathrm{d}$. At well BLW-83, the hydraulic conductivity calculated from grain-size analyses was generally less than $30 \mathrm{ft} / \mathrm{d}$. Transmissivity for this part of the aquifer is about $600 \mathrm{ft}^{2} / \mathrm{d}$. Transmissivity for the rest of the aquifer is estimated to exceed $1,000 \mathrm{ft}^{2} / \mathrm{d}$ mostly because of the saturated thickness of the deposit.

\section{Pumping Station Brook Aquifer}

The Pumping Station Brook aquifer in southern Belmont is used by the town for water supply. Two wells near Pout Pond supply approximately $0.08 \mathrm{Mgal} / \mathrm{d}$ to a population of 1,200 (Frank Clairmont, Town of Belmont, oral commun., 1992). These glaciolacustrine deposits are graded to the level of a glacial lake that occupied southern Belmont. The glacial lake drained south, through an outlet at an elevation of $640 \mathrm{ft}, 1,000 \mathrm{ft}$ north of the BelmontGilmanton town line at New Hampshire Route 106. Two coarse-grained eskers lead to the large, flat-topped delta east of Pout Pond, near Pumping Station Brook (pl. 5). Remnants of the eskers are identifiable to the north of Route 140 and trend southeast toward Pout Pond (pl. 5). BLW-28 and BLW-13 (pl. 2) are the municipal wells, and both are within or near an esker. A geologic section through the delta and esker deposits is shown in figure 11. Observation well BLW-84 is drilled through part of an esker that is partially covered by the large delta (fig. 11). In a 4-hour aquifer test at well BLW-13 in June 1967, ground water was withdrawn at a rate of $350 \mathrm{gal} / \mathrm{min}$ with $5 \mathrm{ft}$ of drawdown (pl. 2).

The transmissivity of the aquifer was estimated to be as much as $5,000 \mathrm{ft}^{2} / \mathrm{d}$ (Hydro Group, written commun., 1992). The proximity of this aquifer test to Pout Pond may have limited the total drawdown measured during the test. 


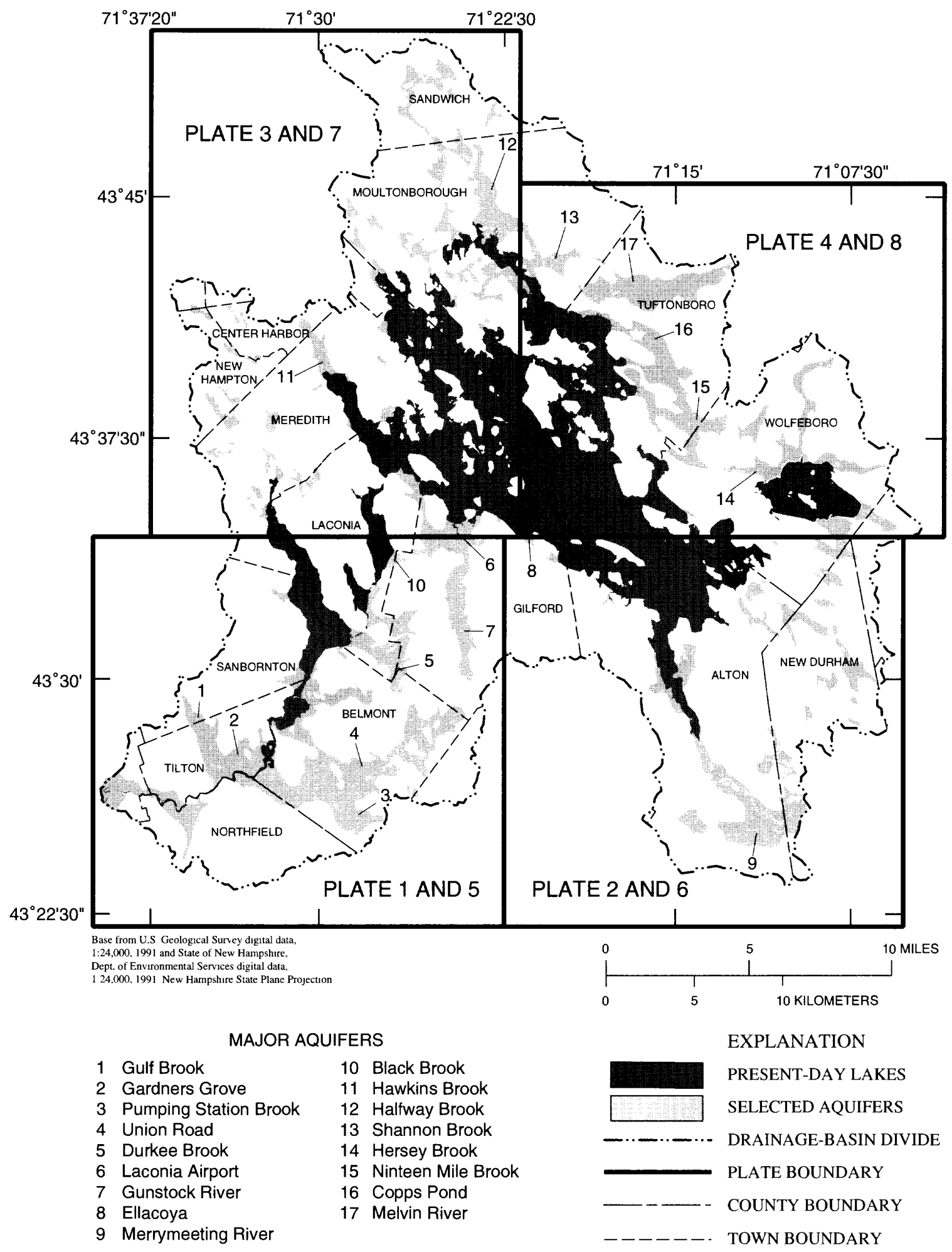

Figure 10. General locations of selected aquifers in the Winnipesaukee River Basin, central New Hampshire. 


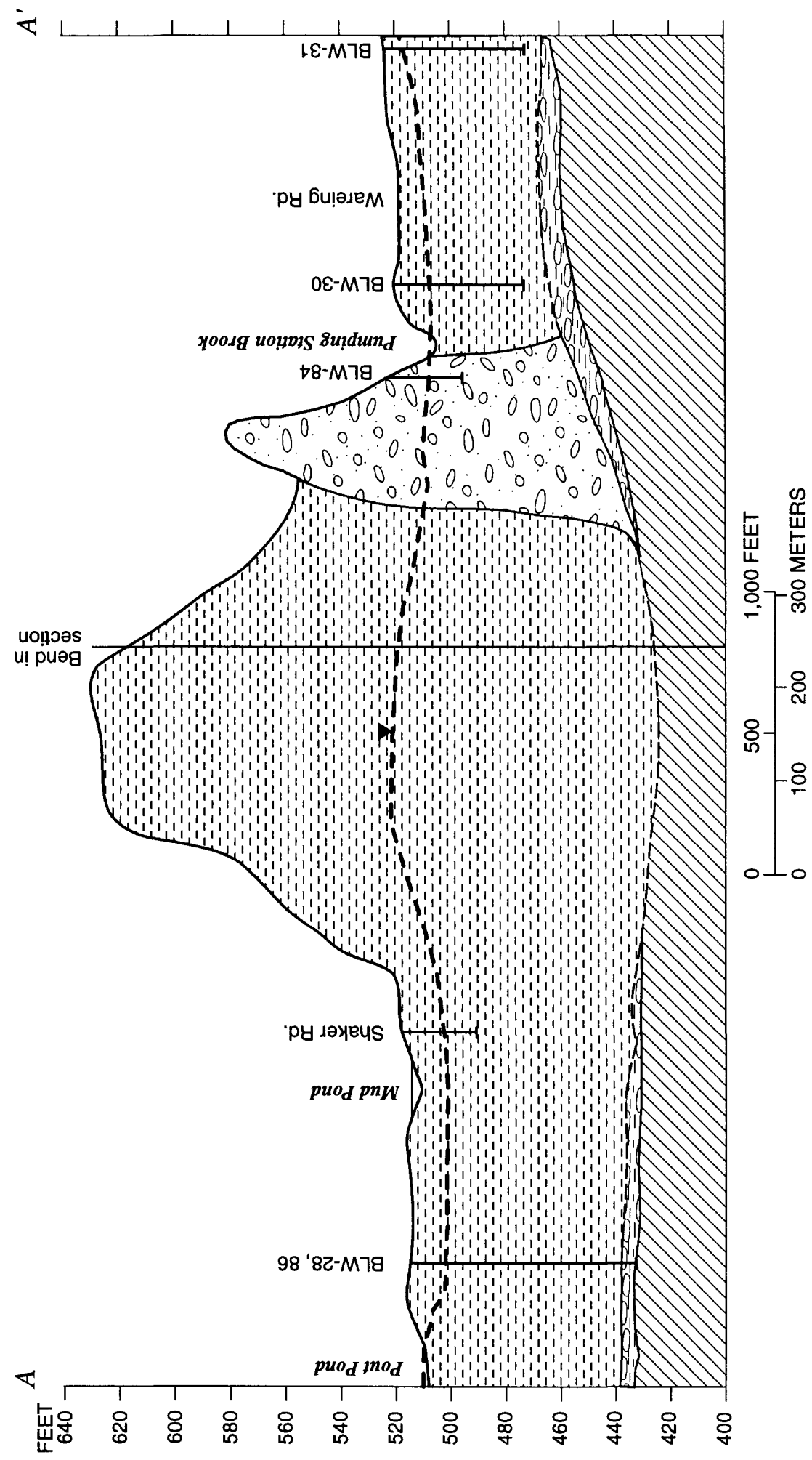

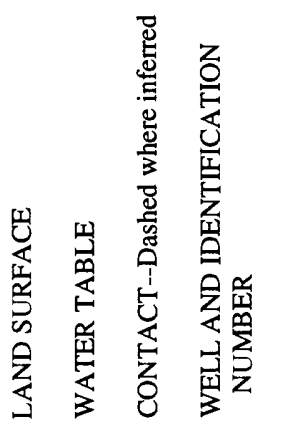

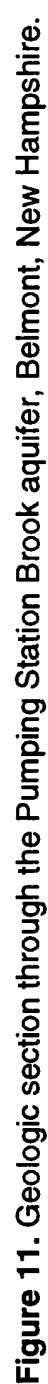

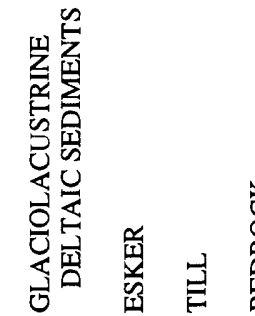

$\left[\begin{array}{ll}1 \\ 1 & 1 \\ 1 & 1 \\ 1 & 1 \\ 1 & 1 \\ 1 & 0 \\ 0 & 0 \\ 0 & 0\end{array}\right.$ 
The estimated transmissivity of this aquifer at observation well BLW-86 (on the southeast side of Pout Pond near well BLW-28) is about $3,000 \mathrm{ft}^{2} / \mathrm{d}$. This estimate is based on the grain-size distribution of aquifer-material samples collected in the field at the time the well was installed. The estimated transmissivity of this part of the aquifer is between 2,000 to $4,000 \mathrm{ft}^{2} / \mathrm{d}$.

Wells BLW-30, BLW-31, and BLW-32 (pl. 1) all show the saturated thickness to be less than $20 \mathrm{ft}$. Additional wells, if installed near the esker, would likely be suitable for municipal supply. North of Belmont center, near Badger Pond, the aquifer becomes thin (less than 20 feet thick). A technique for evaluating water availability and the results of the application of this technique to the Pumping Station Brook aquifer are discussed in the section "Estimation of Water Availability for Selected Aquifers."

\section{Union Road Aquifer}

The Union Road Aquifer is at the southeastern end of Winnisquam Lake, near Lochmere (pl. 7). This aquifer is composed of coarse-grained ice-contact sands. Evidence of fast-moving glacial meltwater can be seen in the numerous channels cut in till uplands on the northeast side of Silver Lake in Belmont and in the deeply incised channel near Bean Hill Road, 1 mi to the west of Silver Lake. A seismic-refraction survey (Belmont $h-h^{\prime}$, pl. 1, appendix (6) showed the saturated thickness of the aquifer to be greater than $40 \mathrm{ft}$ at Union Road and greater than $80 \mathrm{ft}$ at the shore of Winnisquam Lake. This was confirmed during the installation of observation well BLW-81 (pl. 1). Additionally, wells BLW-160, BLW-161, and BLW-162, which are $0.5 \mathrm{mi}$ to the west, are open-ended holes finished in gravel that yield approximately $10 \mathrm{gal} / \mathrm{min}$.

Transmissivity in this area as calculated from the grain-size-distribution analysis of aquifer material collected during test drilling, is greater than $1,700 \mathrm{ft}^{2} / \mathrm{d}$. This aquifer is hydraulically connected to Winnisquam Lake, and ground-water withdrawals could induce flow from the lake to the aquifer. This aquifer would be suitable for high-yielding wells because of the highly transmissive aquifer material present and the potential to induce recharge from Winnisquam Lake.

Across Winnisquam Lake, on a peninsula approximately $1 \mathrm{mi}$ to the northwest between East Tilton and Winnisquam, data for domestic wells indicate coarse-grained ice-contact aquifer materials buried beneath approximately $40 \mathrm{ft}$ of glacial till. Well TSW-61 is an open-ended well finished in the buried gravel deposit. This well reportedly yields $15 \mathrm{gal} / \mathrm{min}$. Logs from other wells in this area indicate that the buried stratifieddrift aquifer may be as much as $50 \mathrm{ft}$ thick. The lateral extent of the deposit and its hydraulic connection to Winnisquam Lake is not well understood; additional data collection would be necessary to define the aquifer spatially and hydraulically.

\section{Durkee Brook Aquifer}

The Durkee Brook aquifer extends from the Laconia-Gilford-Belmont town line northward to Lake Winnipesaukee (pl. 5). Northward drainage of meltwater against the retreating ice margin formed the glacial lake in which this aquifer was deposited. The saturated thickness exceeds $20 \mathrm{ft}$ for most of the aquifer but is generally less than $40 \mathrm{ft}$. The transmissivity of most of the aquifer is less than $1,000 \mathrm{ft}^{2} / \mathrm{d}$ but is slightly greater than $1,000 \mathrm{ft}^{2} / \mathrm{d}$ where the saturated thickness is greatest. At observation well BLW-85 (pl. 1), transmissivity estimated from grainsize distribution data from aquifer samples, is $1,050 \mathrm{ft}^{2} / \mathrm{d}$. Development of this aquifer is limited not by the hydraulic properties of the aquifer but by the amount of water available to potential wells. Low streamflow at measurement site 26 (pl. 1, appendix D) was $0.80 \mathrm{ft}^{3} / \mathrm{s}(0.5 \mathrm{Mgal} / \mathrm{d})$ in Durkee Brook on July 3,1991 . Only some of this water, plus ground water in storage, would potentially be available to wells.

\section{Laconia Airport Aquifer}

The Laconia Airport aquifer underlies all of the airport area and is hydraulically connected to the Gunstock River deposits to the east (pl. 5). Saturated stratified-drift deposits are generally greater than $40 \mathrm{ft}$ thick and locally exceed $80 \mathrm{ft}$ in thickness. 
These deposits are glaciolacustrine fine to very fine sands; test boring GFA-2 penetrated $57 \mathrm{ft}$ of saturated very fine sand and silt before reaching till. The northeastern part of this aquifer contains a zone of coarse-grained ice-contact material, which may be an esker or crevasse filling, and is partially covered by the fine-grained lacustrine deposits. Test borings GFB-6, GFB-7, and GFB-8 (pl. 1) penetrated these coarse deposits and mark the position of the feature. In general, the very fine and fine sands of this aquifer make it unsuitable for large-scale development.

\section{Gunstock River Aquifer}

The Gunstock River aquifer, in a valley to the west of Gunstock and Belknap Mountains (pl. 5), is an example of a multistage glacial-lake deposit resulting from northward drainage of meltwater. Ice retreating to the northwest formed a glacial lake between the ice margin and the uplands to the south. As the ice retreated, it uncovered successively lower meltwater drainageways to the west, toward Laconia. Deposits at the southern end of the aquifer were deposited in glacial lakes at higher elevation than deposits at the northern end. Deposits at the southern end locally exceed 60 feet thick, and their transmissivity exceeds $1,000 \mathrm{ft}^{2} / \mathrm{d}$; however, detailed information about the hydraulic properties of this area is not available.

To the north, the saturated thickness decreases to about $20 \mathrm{ft}$ before increasing to greater than $60 \mathrm{ft}$ near well GFW-11. The saturated thickness at observation well GFW-15 and GFW-11 is $22 \mathrm{ft}$ and $61 \mathrm{ft}$, respectively. Test boring GFA-1, approximately $1 \mathrm{mi}$ to the north, revealed a saturated thickness of less than $20 \mathrm{ft}$ (pl. 5), indicating that the thick deposit near well GFW-11 is not extensive. The transmissivity, however, is estimated to be 2,000 to $4,000 \mathrm{ft}^{2} / \mathrm{d}$.

This aquifer is limited not by the hydraulic properties of the aquifer but by the amount of water available to potential wells. Low streamflow at measurement site 19 (pl. 1, appendix D) was $0.78 \mathrm{ft}^{3} / \mathrm{s}$ $(0.5 \mathrm{Mgal} / \mathrm{d})$ in Gunstock Brook on July 3, 1991. Only some of this water, plus ground water in storage, would potentially be available to wells.

The saturated thickness near test boring GFA-3 is less than $10 \mathrm{ft}$ and remains less than $20 \mathrm{ft}$ thick until the valley widens again approximately $7,500 \mathrm{ft}$ north of
Gilford Center. The saturated thickness at observation well GFW-13 (pl. 1) is $30 \mathrm{ft}$ and increases rapidly to greater than $80 \mathrm{ft}$ at well GFW-12 and $70 \mathrm{ft}$ at well GFW-14. A geologic section through this portion of the aquifer is shown in figure 12 . The transmissivity of this part of the aquifer is greater than $1,000 \mathrm{ft}^{2} / \mathrm{d}$ and locally (near GFW-14) greater than 2,000 $\mathrm{ft}^{2} / \mathrm{d}$. A geologic section through this part of the aquifer is shown in figure 12 . This part of the aquifer is hydraulically connected to the Laconia Airport aquifer that was previously described.

Development of the Gunstock River aquifer is limited by the hydraulic properties of the aquifer, not by the amount of water available to potential wells. Low streamflow at measurement site 22 (pl.1, appendix D) was $1.13 \mathrm{ft}^{3} / \mathrm{s}(0.73 \mathrm{Mgal} / \mathrm{d})$ in Gunstock Brook on July 3, 1991. The sediments in this location are generally too fine to produce high yields.

\section{Ellacoya Aquifer}

Ellacoya State Park overlies a small but potentially productive aquifer along the shore of Lake Winnipesaukee (pls. 2 and 4). This aquifer consists of very coarse grained material in the upper few feet of the subsurface. A seismic-refraction survey (Gilford, line $h-h^{\prime}$, pl. 2, appendix C9) indicates that the saturated thickness of this aquifer may exceed $100 \mathrm{ft}$ locally. Test boring GFB-2 was drilled to a depth of $24 \mathrm{ft}$ in coarse gravel without reaching bedrock. Large cobbles near the surface prevented attempts during this study to confirm seismic-refraction results with test drilling. The transmissivity of this aquifer is greater than $1,000 \mathrm{ft}^{2} / \mathrm{d}$, but may be 2,000 to $4,000 \mathrm{ft}^{2} / \mathrm{d}$ if the aquifer is as thick as seismic-refraction results indicate and the materials are coarse. This small deposit has a potential to be a high yield aquifer because it is hydraulically connected to Lake Winnipesaukee and because withdrawal wells could induce flow from the lake to the aquifer.

\section{Merrymeeting River (Alton) Aquifer}

The Merrymeeting River aquifer extends from the southern tip of Alton Bay south to the drainage divide between the Merrymeeting and Ela Rivers (pl. 2). The Ela River is in part of the Cocheco River Basin that was studied by Mack and Lawlor (1992). 


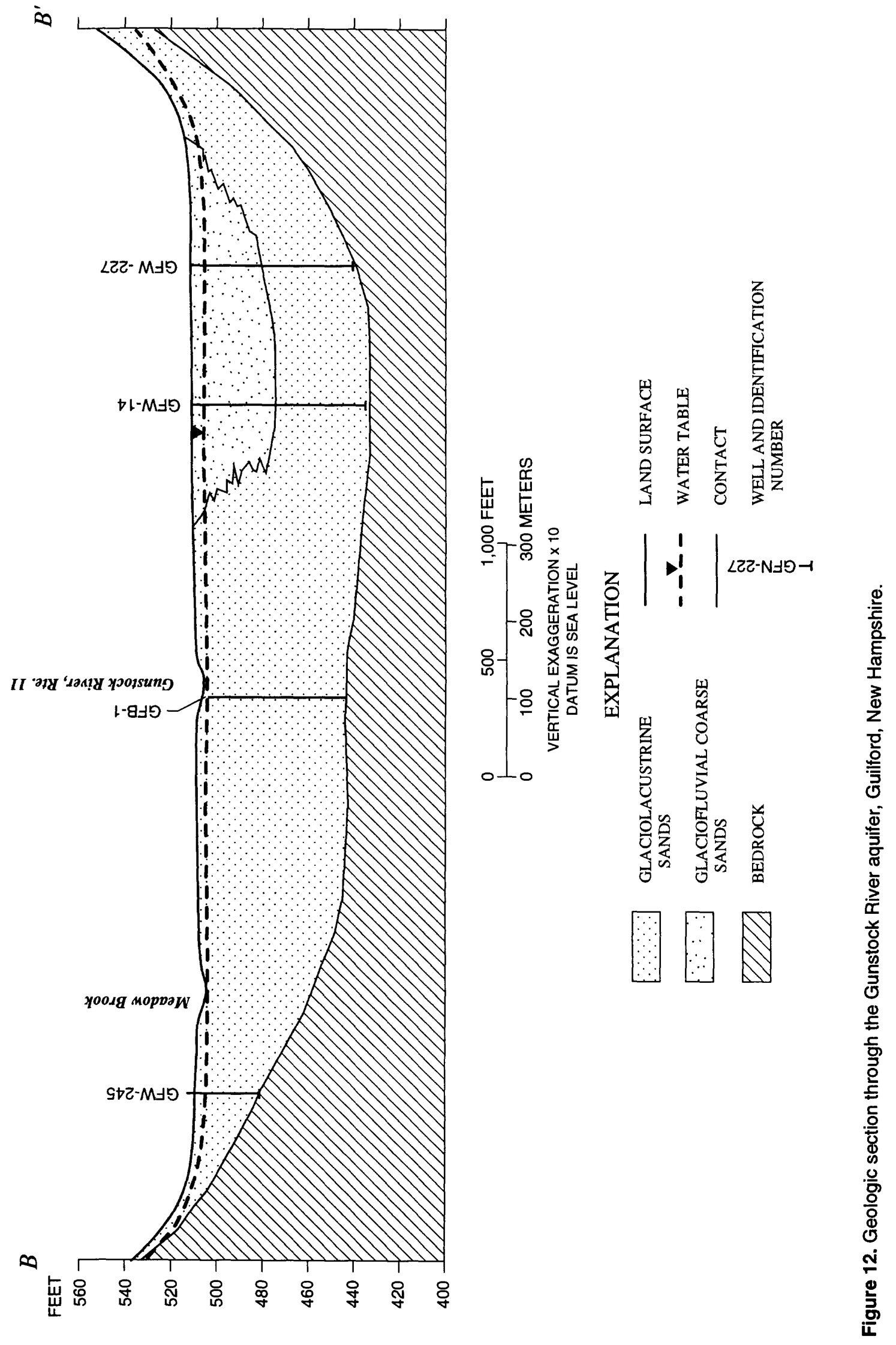


This aquifer was deposited in a glacial lake when meltwater drained south out of the Merrymeeting Valley and down the Ela River in the Cocheco River Basin. This spillway, near the basin divide, probably conveyed water for a long time and was the last easterly draining outlet for glacial Lake Winnipesaukee before the lake began to drain to the west, down the Winnipesaukee River.

From Alton Bay south to the Merrymeeting River Wildlife Management Area, the saturated thickness of the aquifer is typically 20 to $40 \mathrm{ft}$. Several test borings done for this study (AHW-64, AHW-369, AHA-81, and AHW-63, pl. 2) reached refusal or bedrock between 30 and $40 \mathrm{ft}$. Further to the south, near the Alton-New Durham town line, the aquifer becomes thicker and locally as much as $100 \mathrm{ft}$ thick near the drainage divide with the Ela River. Wells
NFW-1 and NFW-54 were drilled to refusal at depths of 96 and $81 \mathrm{ft}$, respectively. The transmissivity of this aquifer is generally greater than $1,000 \mathrm{ft}^{2} / \mathrm{d}$ and is locally 4,000 to $8,000 \mathrm{ft}^{2} / \mathrm{d}$.

The narrow valley segment of the aquifer, in the northern part, is typical of the morphosequence depositional model described by Koteff and Pessl (1981). At least three distinct sequences of deposits are identifiable in this section of the valley. A good example is the esker-delta sequence that begins about $1,000 \mathrm{ft}$ south of Alton Bay, on the west side of the river. The esker is traceable south to New Hampshire Route 140, near where it crosses the Merrymeeting River. A geologic section through this deposit shows the position of the esker (mostly buried), Alton watersupply well AHW-3 (fig. 13), and the delta that formed in the early stages of glacial Lake Winnipesaukee.

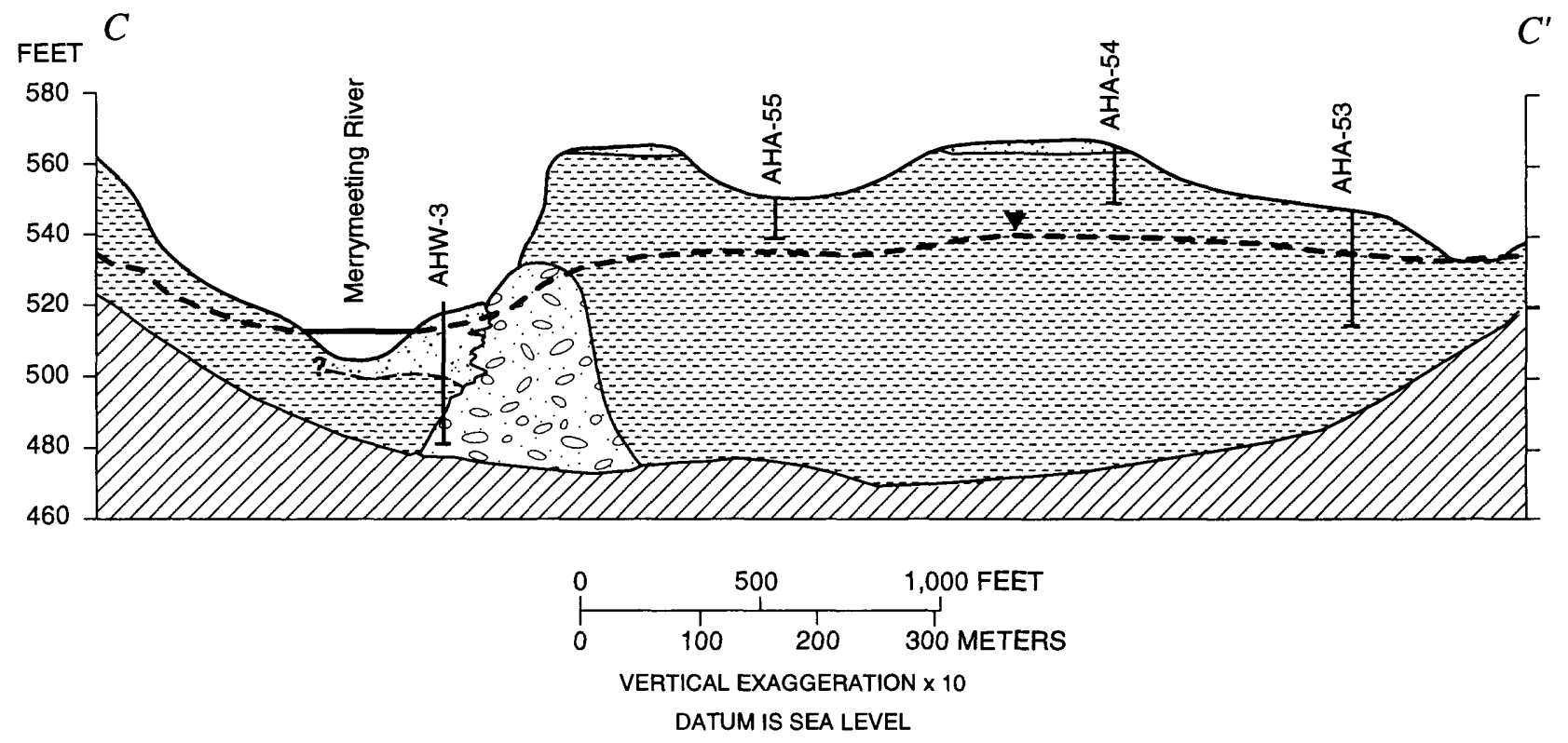

EXPLANATION

\begin{tabular}{|c|c|c|c|}
\hline$\because \because \because$ & FLUVIAL SAND AND GRAVEL & & LAND SURFACE \\
\hline 6.0 .0 & ESKER & & WATER TABLE \\
\hline 政 & $\begin{array}{l}\text { GLACIOLACUSTRINE } \\
\text { DELTAIC SEDIMENT }\end{array}$ & ధి & $\begin{array}{l}\text { CONTACT--Dashed where inferred; } \\
\text { queried where uncertain }\end{array}$ \\
\hline BPA & BEDROCK & $\frac{1}{4}$ & $\begin{array}{l}\text { WELL AND IDENTIFICATION } \\
\text { NUMBER }\end{array}$ \\
\hline
\end{tabular}

Figure 13. Geohydrologic section through the Merrymeeting River aquifer, Alton, New Hampshire. 
The coarse-grained esker formed where fastmoving meltwater flowed in tunnels in the ice, whereas the finer grained delta formed where the fast-moving meltwater slowed as it emptied into the glacial lake. Identification of these sequences of deposits can help in predicting the presence of coarse- or fine-grained stratified-drift aquifers. At least two other similar morphosequences are identifiable in this valley.

The transmissivity of the Merrymeeting River aquifer is variable and is related to the morphology of a deposit in a given sequence of deposits. The transmissivity near well AHW-64 is about $1,800 \mathrm{ft}^{2} / \mathrm{d}$ and near well AHW-3 is about $3,800 \mathrm{ft}^{2} / \mathrm{d}$. Both of these wells are finished in coarse-grained sediments characteristic of an esker. Test borings AHA-52, AHA-53, AHA-56, and AHA-57 (pl. 2) are finished in the associated glaciolacustrine delta. The estimated transmissivity near these wells is less than $1,200 \mathrm{ft}^{2} / \mathrm{d}$. The fairly high transmissivity near AHW-3 is typical of ice-contact coarse-grained stratified drift, whereas the fairly low transmissivity near AHA-53 is typical of fine grained deltaic deposits.

Additional wells, if installed near esker segments, would likely be suitable for municipal supply and would increase the amount of water available from the aquifer. A technique for evaluation of water availability and results of the application of this technique to the Merrymeeting River aquifer are discussed in the section, "Estimation of Water Availability for Selected Aquifers."

\section{Black Brook Aquifer}

The Black Brook aquifer is at the southeastern end of Paugus Bay, immediately west of Lily Pond (pl. 5). Logs from wells drilled into this deposit provide conflicting information regarding the thickness of the stratified-drift aquifer. The saturated thickness of the aquifer is estimated to be greater than $20 \mathrm{ft}$ but may be as much as $100 \mathrm{ft}$. Aquifer transmissivity estimated from logs of domestic wells exceeds $1,000 \mathrm{ft}^{2} / \mathrm{d}$ where the saturated thickness is the greatest.

\section{Hawkins Brook Aquifer}

The Hawkins Brook aquifer is north of the town of Meredith and extends upvalley from Meredith Bay (pl. 7). The aquifer occupies a narrow valley, and the saturated thickness is locally greater than $60 \mathrm{ft}$; for example, the saturated thickness at observation well MHW-1 (pl. 3) is $67 \mathrm{ft}$ and at MHW-2 (pl. 3) is $44 \mathrm{ft}$. The transmissivity is generally less than $1,000 \mathrm{ft}^{2} / \mathrm{d}$ but is 1,000 to $2,000 \mathrm{ft}^{2} / \mathrm{d}$ in the center of the valley where the aquifer is composed of medium to coarse sand. Based on grain-size analysis of sediment samples collected during test drilling, the transmissivity at observation well MHW-1 is about $1,100 \mathrm{ft}^{2} / \mathrm{d}$ and at observation well MHW-2 is about $1,200 \mathrm{ft}^{2} / \mathrm{d}$. This aquifer is hydraulically connected to Meredith Bay; ground-water withdrawals from the aquifer, near the bay, may induce water from the lake to the aquifer.

The upstream end of the aquifer, at the head of the large delta (near MHW-1), has potential for development of a medium-yield well. Coarse sands also were found at observation well MHW-2. A geohydrologic section through the delta and associated deposits is shown on figure 14.

Low streamflow at measurement site 23 (pl. 3 , appendix D) was $0.14 \mathrm{ft}^{3} / \mathrm{s}(0.09 \mathrm{Mgal} / \mathrm{d})$ in Hawkins Brook on July 3, 1991. Some of this water, plus ground water in storage, would potentially be available to withdrawal wells. The aquifer materials in this location are generally too fine to be developed as a high-yield supply, and only a small amount of streamflow is available for induced infiltration.

\section{Halfway Brook Aquifer}

The Halfway Brook aquifer extends along the Halfway Brook drainage from 3,000 ft southeast of Moultonborough (pl. 7). The saturated thickness of the aquifer is locally greater than $40 \mathrm{ft}$. Lithologic logs of holes drilled for domestic wells indicate that the transmissivity in this small zone is 1,000 to $2,000 \mathrm{ft}^{2} / \mathrm{d}$. To the south, toward State Landing, no information was available to determine the saturated thickness or transmissivity; based on data for the vicinity of the Halfway Brook aquifer and the data for the area near State Landing, transmissivity is probably less than $1,000 \mathrm{ft}^{2} / \mathrm{d}$ but may exceed $1,000 \mathrm{ft}^{2} / \mathrm{d}$ in some areas. 


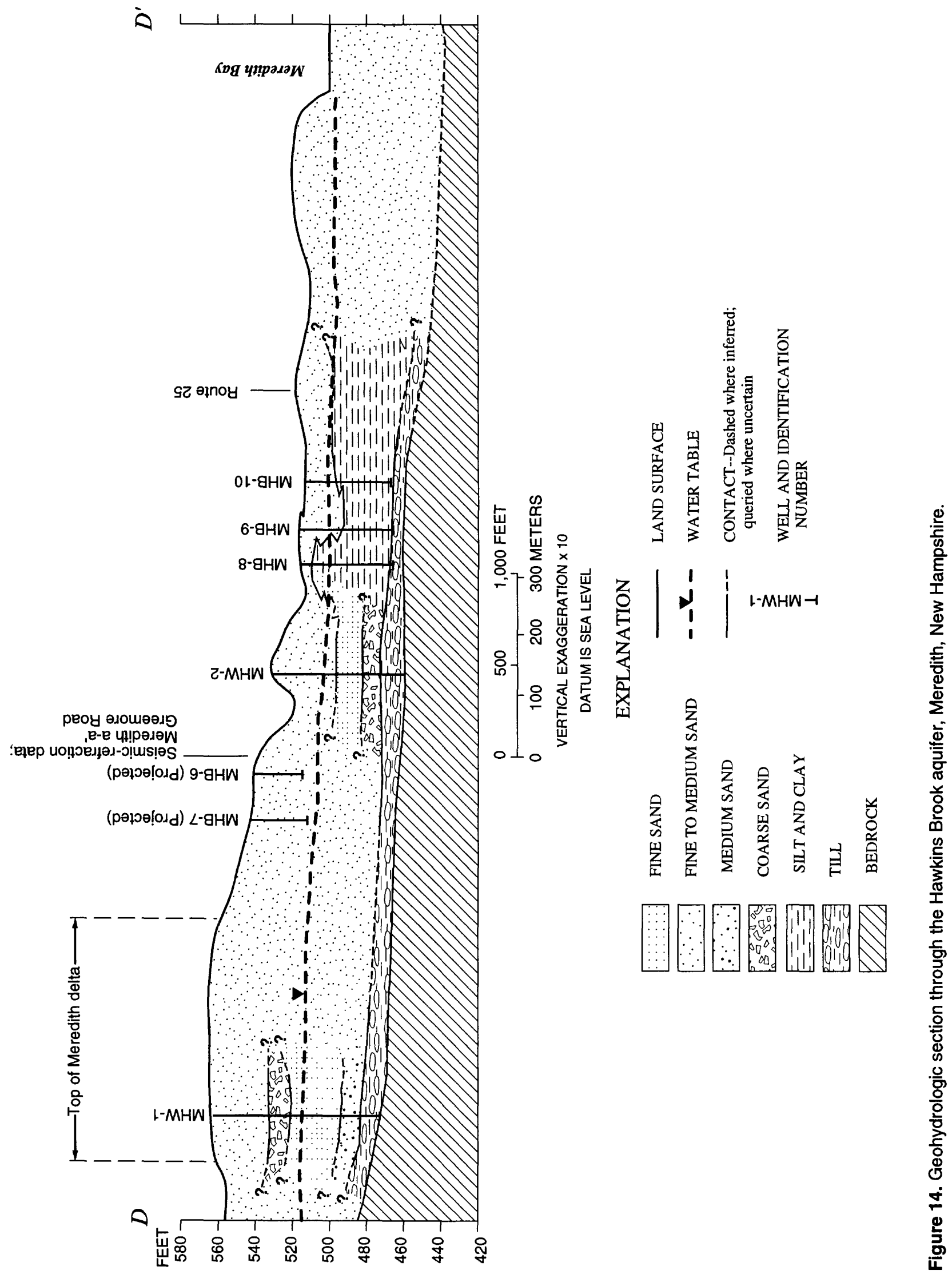


Test borings MWA- 1 and MWA-2 (pl. 3) show the saturated thickness to be 0 and $10 \mathrm{ft}$, respectively. The transmissivity at test boring MWA- 2 is estimated to be approximately $100 \mathrm{ft}^{2} / \mathrm{d}$. Logs from holes drilled for domestic wells indicated that some of the overburden material may be composed of till, so the depth to bedrock minus the depth to the water table may not be an accurate estimate of the saturated thickness of the stratified-drift aquifer in this area. Much of this aquifer may be underlain by a thick till unit.

\section{Shannon Brook Aquifer}

The Shannon Brook aquifer is $2,000 \mathrm{ft}$ northeast of Clark Landing along Shannon Brook (pl. 8). Seismic-refraction profiles for Moultonborough lines $\mathrm{b}-\mathrm{b}^{\prime}$ and $\mathrm{d}-\mathrm{d}^{\prime}$ (pl. 4, appendix C) indicate that the saturated thickness of the aquifer in this area is as much as $60 \mathrm{ft}$. The saturated thickness at observation well MWW-20 is $41 \mathrm{ft}$. The transmissivity of this narrow valley aquifer is locally greater than $1,000 \mathrm{ft}^{2} / \mathrm{d}$. At wells MWW-20 and MWW-275 (pl. 4), the transmissivities are estimated to be 1,250 and $1,425 \mathrm{ft}^{2} / \mathrm{d}$, respectively. To the west of MWW-20, the aquifer thins and, in places, is covered by alluvial fan deposits and (or) till reworked by fluvial processes.

\section{Hersey Brook Aquifer}

The Hersey Brook aquifer is on the northwest shore of Lake Wentworth (pl. 8). The aquifer is generally thin, but saturated thickness exceeds $40 \mathrm{ft}$ locally. The log of test boring WRA-1 indicates that the transmissivity of the aquifer is less than $500 \mathrm{ft}^{2} / \mathrm{d}$. Lithologic logs of holes drilled for domestic wells indicate that the aquifer is coarser to the northwest than near WRA-1; the estimated transmissivity in this area is 1,000 to $2,000 \mathrm{ft}^{2} / \mathrm{d}$.

\section{Nineteen Mile Brook Aquifer}

The Nineteen Mile Brook aquifer is along New Hampshire Route 109A, 3,000 ft from the Moultonborough-Tuftonboro town line (pl. 8). The saturated thickness of this aquifer is as much as $60 \mathrm{ft}$ in the middle of the valley, though most of the adjacent aquifer is less than $20 \mathrm{ft}$ thick. The transmissivity at test boring TZA- 9 is approximately $825 \mathrm{ft}^{2} / \mathrm{d}$, based on grain-size analysis of sediment samples collected during test drilling. The lithologic log of the hole drilled for domestic well TZW-158, however, indicates coarse-grained aquifer material, and the transmissivity near this site is estimated to be 1,000 to $2,000 \mathrm{ft}^{2} / \mathrm{d}$.

\section{Copps Pond Aquifer}

The Copps Pond aquifer is adjacent to and beneath Copps Pond, 5,000 ft east of Melvin Bay (pl. 8). The aquifer is composed of coarse-grained icecontact stratified drift associated with retreating ice and stagnant ice blocks that formed the Copps Pond kettle. Seismic-refraction profiling (Tuftonboro line i-i', pl. 4, appendix $\mathrm{C20}$ ) indicates that the saturated thickness is more than $20 \mathrm{ft}$. The saturated thickness is locally greater than $60 \mathrm{ft}$. The transmissivity is greater than $1,000 \mathrm{ft}^{2} / \mathrm{d}$ for much of the aquifer but probably does not exceed $2,000 \mathrm{ft}^{2} / \mathrm{d}$. The estimated transmissivity at observation well TZW-167 is about $1,300 \mathrm{ft}^{2} / \mathrm{d}$.

\section{Melvin River Aquifer}

The Melvin River aquifer is northwest of Melvin Village, at the base of the Ossipee Mountains (pl. 8). This aquifer is areally extensive and the stratified-drift deposits are generally greater than $20 \mathrm{ft}$ thick. The aquifer is a hummocky mix of ice-contact kames and deltaic deposits. In the western part, fine-grained lacustrine sediment was found during drilling of test borings TZA-7 and TZA-8 (pl. 4). The saturated thickness at both sites is less than $20 \mathrm{ft}$, and the transmissivity is less than $500 \mathrm{ft}^{2} / \mathrm{d}$. In the western part, however, the saturated thickness is locally more than $100 \mathrm{ft}$ (TZW-3). The transmissivity at observation well TZW-3 is estimated to be approximately $2,500 \mathrm{ft}^{2} / \mathrm{d}$. The transmissivity decreases to less than $1,000 \mathrm{ft}^{2} / \mathrm{d}$ eastward, toward the middle of the deposit. At test boring TZA-16, the aquifer is more than $90 \mathrm{ft}$ thick, but the saturated thickness is less than $15 \mathrm{ft}$. At observation well TZW-8, the saturated thickness is only $6 \mathrm{ft}$. Continuing east, the saturated thickness is again locally greater than $20 \mathrm{ft}$ and the transmissivity is 1,000 to $2,000 \mathrm{ft}^{2} / \mathrm{d}$. At observation well $\mathrm{TZW}-2$, the 
saturated thickness is $30 \mathrm{ft}$; transmissivity, based on grain-size analysis of sediment samples collected during test drilling, is approximately $1,500 \mathrm{ft}^{2} / \mathrm{d}$.

The aquifer is hydraulically connected to the Melvin River, but streamflows measured at sites 10, 11, and 12 (pl. 4, appendix D) indicate that available water to wells would come primarily from ground-water storage.

\section{Estimation of Water Availability for Selected Aquifers}

Two aquifers were selected to estimate potential water availability by use of a numerical model that simulates ground-water flow. The aquifers are in Alton and Belmont, and both are ice-contact stratified-drift aquifers that include esker and deltaic deposits. The Merrymeeting River aquifer, in Alton, is fairly thin (less than $45 \mathrm{ft}$ ) and is hydraulically connected to the Merrymeeting River, which may provide recharge as induced infiltration. The Pumping Station Brook aquifer, in Belmont, is locally greater than $60 \mathrm{ft}$ thick and is hydraulically connected to Pumping Station Brook.

\section{Model Construction}

A numerical finite-difference model, MODFLOW (McDonald and Harbaugh, 1988), was used to estimate water availability from the two aquifers. Lapham (1988) cites numerous examples of ground-water availability studies in which analytical models were used to determine rates of combined withdrawal from wells distributed throughout an aquifer. Each of the models used in this study was developed as an aid in estimating water availability and is founded on nearly as many simplifying assumptions as simple analytical models, which do not allow the aquifer system to be discretized. The numerical model enables the user to simulate (1) areal variations of the saturated thickness and hydraulic conductivity of an aquifer, (2) the location of streams overlying the aquifer and variations of the stream characteristics along selected reaches, and (3) drawdown on all sides of a stream boundary. Sources of water to wells was from storage and induced infiltration from surface water bodies. The numerical model was chosen over analytical methods because a numerical model more closely represents the aquifer geometry and hydraulics as mapped on plates 5-8 of this report.

The models were designed to represent the geohydrologic characteristics of ground-water flow in stratified-drift aquifers. The following simplifying assumptions about the ground-water-flow system were made in developing the models:

1. Two-dimensional flow is adequate to represent the flow system. Ground-water flow is predominantly horizontal. Vertical gradients are downward in areas of ground-water recharge and upward in areas of ground-water discharge. Strong vertical gradients are also present near discharging wells, however, the magnitude of the vertical flow gradients diminishes rapidly with distance from the well (Harte and Mack, 1992). The error associated with simulation of water availability by considering only two-dimensional horizontal flow is negligible.

2. Water-supply wells are fully penetrating and 100 percent efficient. Wells used for supply are generally not fully penetrating and are commonly screened in the bottom 25 percent of the aquifer. In addition, these wells are not 100 percent efficient. Increased drawdown in the well results from energy loss between the aquifer and the well, which is a function of well design and construction. The effect of this simplifying assumption is that less drawdown is simulated than would occur in the real system.

3. There is no flow of ground water between till and (or) bedrock and the stratified-drift aquifer. The model areas are stratified-drift aquifers in till-covered bedrock valleys. In an aquifer where horizontal and vertical gradients are found between the stratified drift and the underlying till and (or) bedrock, ground-water flow may occur between the aquifer and the surrounding geologic units but this type of recharge was not simulated. Although lateral flow from uplands adjacent to the edge of the 
stratified drift does occur, it is generally less than $0.1\left(\mathrm{ft}^{3} / \mathrm{s}\right) / \mathrm{mi}^{2}\left(0.05(\mathrm{Mgal} / \mathrm{d}) / \mathrm{mi}^{2}\right)$ (Harte and Mack, 1992, Ayotte and Toppin, 1995) during the summer months and its contribution is considered negligible and was not simulated.

4. Finite-difference approximation of the nonlinear, partial differential equations governing three-dimensional ground-water flow results in reasonable estimates of yield for an aquifer. Flow in the numerical model is described by linear differential equations that are solved by use of a finite-difference approximation. The aquifers are discretized into blocks (cells) in which hydraulic properties are assumed to be constant. For unconfined systems, the linear equations are not strictly applicable because changes in the potentiometric surface (water table) affect the transmissivity, and changes in the transmissivity with time result in a nonlinear aquifer response. The model accounts for this, in part, by readjusting the values of transmissivity due to the declining water table for each of the 20 time steps (specified by the user) in the simulation. Because the changes in transmissivity are small throughout most of the aquifer, inaccuracies that result from this approximation are minimal. Exact solutions to the linear equations are impossible; therefore, the solutions are determined by solving a series of linear equations, through the process of iteration, until the greatest change in the solution is less than some stated limit. A limit of $0.01 \mathrm{ft}$ was used to end the iteration.

\section{Model Input Parameters}

Model input parameters consisted of: (1) the position of the water table, (2) saturated thickness, (3) hydraulic conductivity, (4) specific yield, and (5) the streambed hydraulic conductivity. The model simulated a period of 180 days with no areal recharge to account for extended periods without recharge.
Sources of water to hypothetical wells are from storage and induced infiltration from surface-water bodies such as rivers.

\section{Position of the Water Table}

In both models, the initial water table was assumed to be flat and at an elevation of zero. Resulting declines in the water table were thus negative values. Because the models were designed to estimate water availability - not to be a calibrated representation of the actual ground-water-flow system-a flat initial water table is reasonable.

\section{Saturated Thickness and Hydraulic Conductivity}

The saturated-thickness data for the aquifers were taken directly from plate 1 for the Pumping Station Brook aquifer and from plate 2 for the Merrymeeting River aquifer. The saturated-thickness contours were overlain on the model grid, and the appropriate saturated thickness was assigned to each cell. Hydraulic conductivity $(K)$ is related to saturated thickness, $\mathrm{b}$, and transmissivity, $T$, by $T=K(b)$. These values were taken directly from the saturated thickness and transmissivity maps.

\section{Specific Yield}

The specific yield of the aquifers was not measured for the model areas. Johnson (1967) summarized the results of specific yield for sediments from many studies. He reported that the average specific yield for fine sands was 0.21 ; for coarse sands, 0.27 ; and for gravels, 0.22 . Ayotte and Toppin (1995) found that a shallow, coarse-grained aquifer in southcentral New Hampshire had specific yields ranging from 0.21 to 0.29 . A value of 0.2 was used for both aquifers as a conservative estimate of specific yield.

\section{Streambed Hydraulic Conductivity}

The average vertical hydraulic conductivity of streambed materials in both aquifers was not measured for either aquifer in the model area. 
Rather, a conservative value of $1 \mathrm{ft} / \mathrm{d}$ was used in all cases. This value is somewhat lower than hydraulic conductivities reported for similar areas in New England. Lapham (1988), in a similar water availability study in Massachusetts, used $5 \mathrm{ft} / \mathrm{d}$. Harte and Mack (1992), however, used $3 \mathrm{ft} / \mathrm{d}$ for most reaches but used $1 \mathrm{ft} / \mathrm{d}$ where the channel contained fine-grained sands and organic material. Ayotte and Toppin (1995) used $3 \mathrm{ft} / \mathrm{d}$ on the basis of grain-size analysis of sediment cores collected from the river in the model area. In this study, streams appear to be flowing over a range of sediment types and, in some cases, over organic material.

\section{Results of Ground-Water-Availability Estimates}

For each aquifer, the model was run twiceonce in which the surface-water bodies (streams and rivers) contributed to the total available water and once in which only water from storage contributed to the total available water. This double simulation provides a range of estimated available water from an aquifer over a period of 180 days, both with and without recharge from nearby surface-water sources. Commonly, public-supply wells in stratified drift are near or adjacent to a surface-water body to take advantage of potential induced recharge when the wells are pumped.

\section{Merrymeeting River Aquifer}

For the Merrymeeting River aquifer, the model grid consisted of 84 rows and 45 columns; each cell was 100 by $100 \mathrm{ft}$. Ground-water withdrawals were simulated at five wells in the zones of highest transmissivity. Simulated withdrawals were adjusted so that the total drawdown at the well was no more than 70 percent of the saturated thickness of the aquifer. Calculated drawdown in the cell was the average drawdown for the cell and was less than drawdown at the hypothetical well.
In the simulation of water derived solely from storage, the total water available was $0.63 \mathrm{Mgal} / \mathrm{d}$. In the simulation of water derived from storage and from induced infiltration, the total water available was $1.1 \mathrm{Mgal} / \mathrm{d}$ (table 4). In the latter simulation, $0.09 \mathrm{Mgal} / \mathrm{d}$ came from storage and 1.01 Mgal/d came from induced infiltration.

Induced infiltration calculated by simulation was compared to the amount of water flowing in the stream at a period of low flow (approximately 93-percent flow duration) to determine whether the simulated withdrawals would deplete the available streamflow. The nearest measurement of the Merrymeeting River upstream from or adjacent to the aquifer was near Main Street in New Durham (site 1, pl. 2). Low streamflow measured on July 3,1991 , was $8.6 \mathrm{ft}^{3} / \mathrm{s}(5.5 \mathrm{Mgal} / \mathrm{d})$. Induced infiltration calculated by the model $(1.01 \mathrm{Mgal} / \mathrm{d})$ represents only 18 percent of the streamflow (table 4).

The model boundary, surface-water boundaries, and locations of hypothetical wells are shown in figures 15 and 16 . The drawdown, shown as negative values, as a result of simulated withdrawal with induced infiltration is shown in figure 15 , and drawdown without induced infiltration is shown in figure 16.

Table 4. Water-availability estimates for two simulations of the Merrymeeting River aquifer, central New Hampshire

[Low streamflow measurement on July 3, 1991: site 1, appendix D. Mgal/d, million gallons per day; $\mathrm{ft}^{3} / \mathrm{s}$, cubic foot per second; --, no data]

\begin{tabular}{|c|c|c|c|c|}
\hline $\begin{array}{c}\text { Water- } \\
\text { availability } \\
\text { estimate from: }\end{array}$ & $\begin{array}{c}\text { Ground- } \\
\text { water } \\
\text { storage } \\
\text { (Mgald) }\end{array}$ & $\begin{array}{c}\text { Induced } \\
\text { infiltration } \\
(\text { Mgal/d) }\end{array}$ & $\begin{array}{c}\text { Total } \\
\text { available } \\
\text { water, } \\
\text { numerical } \\
\text { model } \\
\text { (Mgal/d) }\end{array}$ & $\begin{array}{c}\text { Low } \\
\text { streamflow } \\
\text { measure- } \\
\text { ment } \\
\text { on July } 3 \text {, } \\
1991 \\
\left(\mathrm{ft}^{3} / \mathrm{s}\right)\end{array}$ \\
\hline $\begin{array}{l}\text { Ground-water } \\
\quad \text { storage only ...... }\end{array}$ & 0.63 & -- & 0.63 & -- \\
\hline $\begin{array}{l}\text { Ground-water } \\
\text { storage plus } \\
\text { induced } \\
\text { infiltration .......... }\end{array}$ & .09 & 1.01 & 1.1 & 8.6 \\
\hline
\end{tabular}




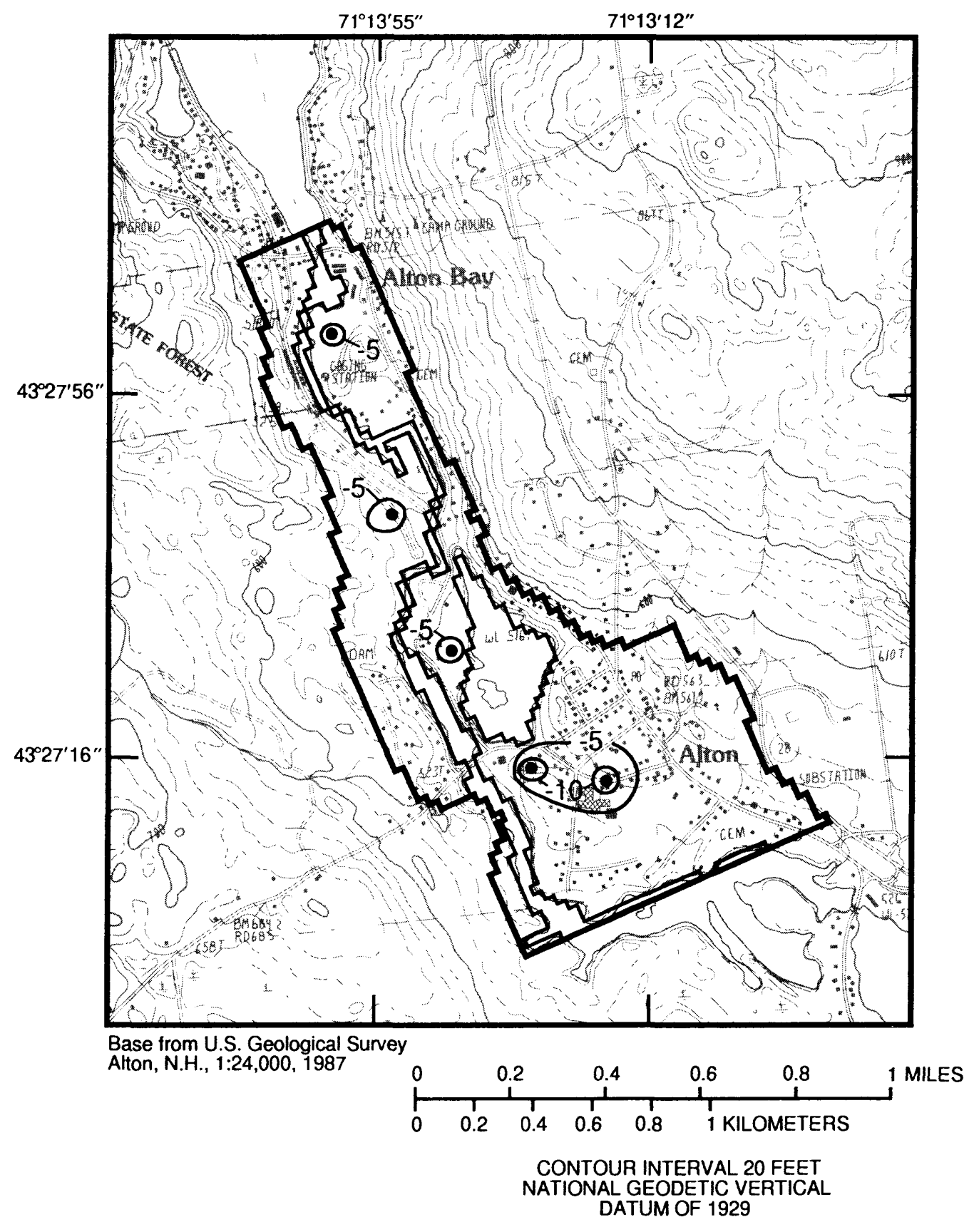

\section{MODEL BOUNDARY \\ ๘ RIVER CELLS \\ - HYPOTHETICAL WELLS}

EXPLANATION

- -5 - DRAWDOWN CONTOUR - Shows drawdown from a flat water table after 180 days of pumping. Contour interval is 5 feet

Figure 15. Model boundary, surface-water boundaries, hypothetical wells, and drawdown contours for the Merrymeeting River aquifer, central New Hampshire with simulation of induced infiltration. 


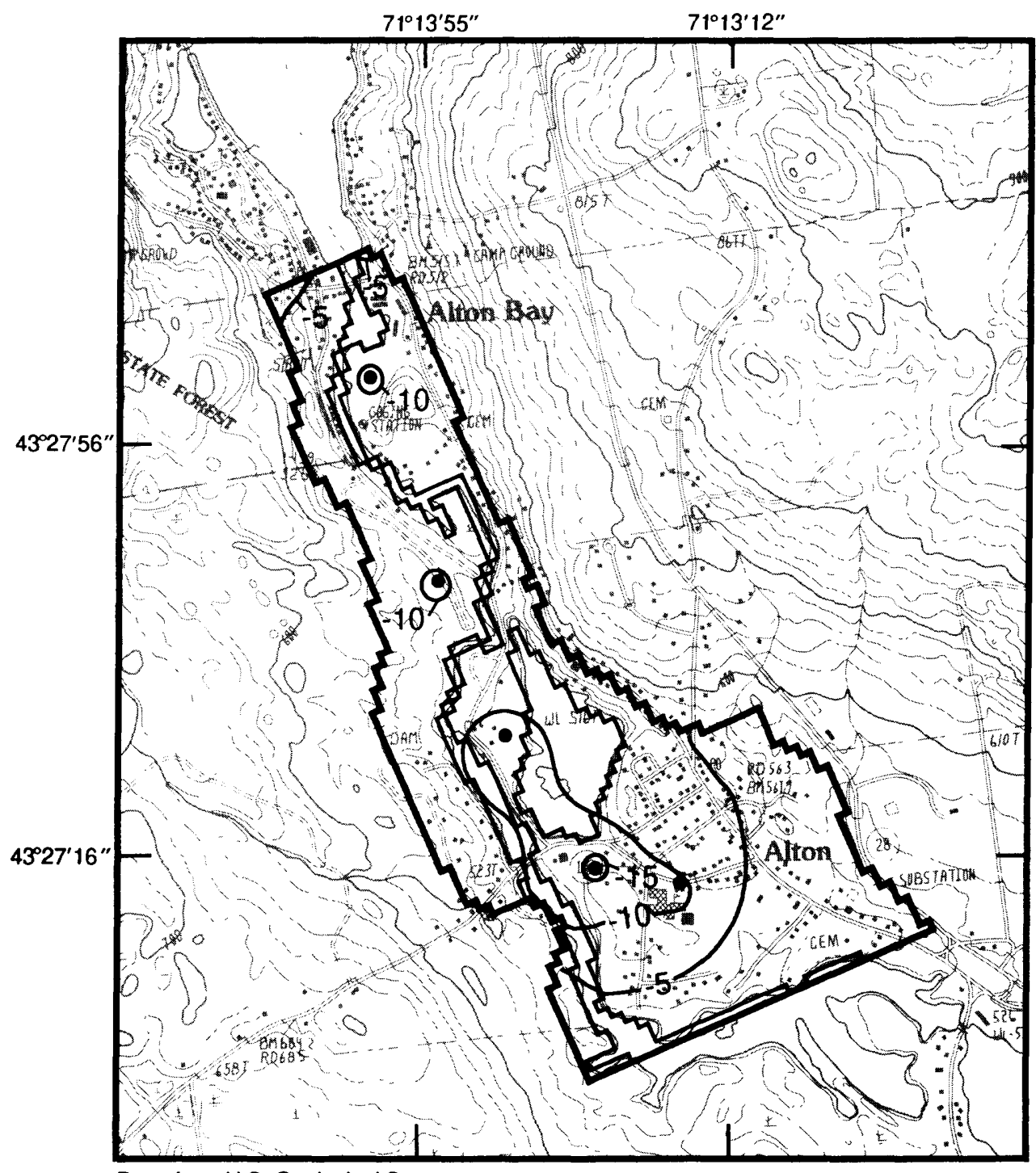

Base from U.S. Geological Survey Alton, N.H., 1:24,000, 1987

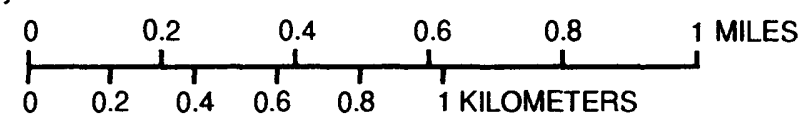

CONTOUR INTERVAL 20 FEET NATIONAL GEODETIC VERTICAL DATUM OF 1929

ل MODEL BOUNDARY

G RIVER CELLS

- HYPOTHETICAL WELLS

- -5 - DRAWDOWN CONTOUR--Shows drawdown from a flat water table after 180 days of pumping. Contour interval is 5 feet

Figure 16. Model boundary, surface-water boundaries, hypothetical wells, and drawdown contours for the Merrymeeting River aquifer, central New Hampshire with simulation of no induced infiltration. 
The area of calculated drawdown is significantly greater for the simulation with no induced infiltration (fig. 16) than for the simulation with induced infiltration from the Merrymeeting River (fig. 15). This comparison indicates that drawdown at withdrawal wells can be reduced and simulated withdrawals can be maximized by locating the wells near the Merrymeeting River. Water availability in this aquifer is limited by available drawdown and not by available recharge. By placing additional wells along the Merrymeeting River, more water could be withdrawn than if wells were placed elsewhere in the aquifer.

\section{Pumping Station Brook Aquifer}

For the Pumping Station Brook aquifer the model grid consisted of 75 rows and 50 columns; each cell was 100 by $100 \mathrm{ft}$. Ground-water withdrawals were simulated at six hypothetical wells in the zones of highest transmissivity. Simulated withdrawals were adjusted so that the total drawdown at the well was not more than 70 percent of the saturated thickness of the aquifer. Calculated drawdown in the cell was the average drawdown for the cell and was less than the drawdown at the hypothetical well.

In the simulation of water derived solely from storage, the total water available was $1.6 \mathrm{Mgal} / \mathrm{d}$. In the simulation of water derived from storage and from induced infiltration, the total water available was $1.8 \mathrm{Mgal} / \mathrm{d}$ (table 5). In the latter simulation, $1.5 \mathrm{Mgal} / \mathrm{d}$ came from storage and $0.3 \mathrm{Mgal} / \mathrm{d}$ from induced infiltration.

Induced infiltration calculated by simulation was compared to the amount of water flowing in the stream at a period of low flow (approximately 93-percent flow duration) to determine whether the
Table 5. Water-availability estimates from two simulations of the Pumping Station Brook aquifer, central New Hampshire

[Low streamflow measurement on July 3, 1991: site 34, appendix D. $\mathrm{Mgal} / \mathrm{d}$, million gallons per day; $\mathrm{ft}^{3} / \mathrm{s}$, cubic foot per second]

\begin{tabular}{ccccc}
\hline $\begin{array}{c}\text { Water- } \\
\text { availability esti- } \\
\text { mate } \\
\text { from: }\end{array}$ & $\begin{array}{c}\text { Ground- } \\
\text { water } \\
\text { storage } \\
\text { (Mgal/d) }\end{array}$ & $\begin{array}{c}\text { Induced } \\
\text { infiltra- } \\
\text { tion } \\
\text { (Mgal/d) }\end{array}$ & $\begin{array}{c}\text { Total } \\
\text { available } \\
\text { water } \\
\text { numerical } \\
\text { model } \\
(\mathrm{Mgal} / \mathrm{d})\end{array}$ & $\begin{array}{c}\text { Low } \\
\text { streamflow } \\
\text { measure- } \\
\text { ment on } \\
\text { July 3, } \\
\mathbf{1 9 9 1} \\
\left(\mathrm{ft}^{3} / \mathrm{s}\right)\end{array}$ \\
\hline $\begin{array}{c}\text { Ground-water } \\
\text { storage only ..... }\end{array}$ & 1.6 & -- & 1.6 & -- \\
$\begin{array}{c}\text { Ground-water } \\
\text { storage plus } \\
\text { induced } \\
\text { infiltration........ }\end{array}$ & 1.5 & 0.3 & & \\
\hline
\end{tabular}

simulated withdrawals would deplete the available streamflow. The nearest measurement of the Tioga River upstream from or adjacent to the aquifer was near Route 140, at the northern end of the model area (site 34, pl. 1). Low streamflow measured on July 3, 1991, was $3.9 \mathrm{ft}^{3} / \mathrm{s}$ ( $2.5 \mathrm{Mgal} / \mathrm{d}$ ) (table 5). Induced infiltration calculated by the model $(0.3 \mathrm{Mgal} / \mathrm{d})$ represents 12 percent of the stream flow (table 5).

The model boundary, surface-water boundaries, and locations of hypothetical wells are shown in figures 17 and 18. The drawdown due to simulated withdrawal with induced infiltration is shown in figure 17, and drawdown without induced infiltration is shown in figure 18. The area of calculated drawdown for the simulation without induced infiltration (fig. 18) is similar to that for the simulation with induced infiltration from the Pumping Station Brook aquifer (fig. 17). This comparison indicates that drawdown at pumped wells cannot be significantly reduced by inducing infiltration and that available water is mainly limited by the amount of water available from storage. 

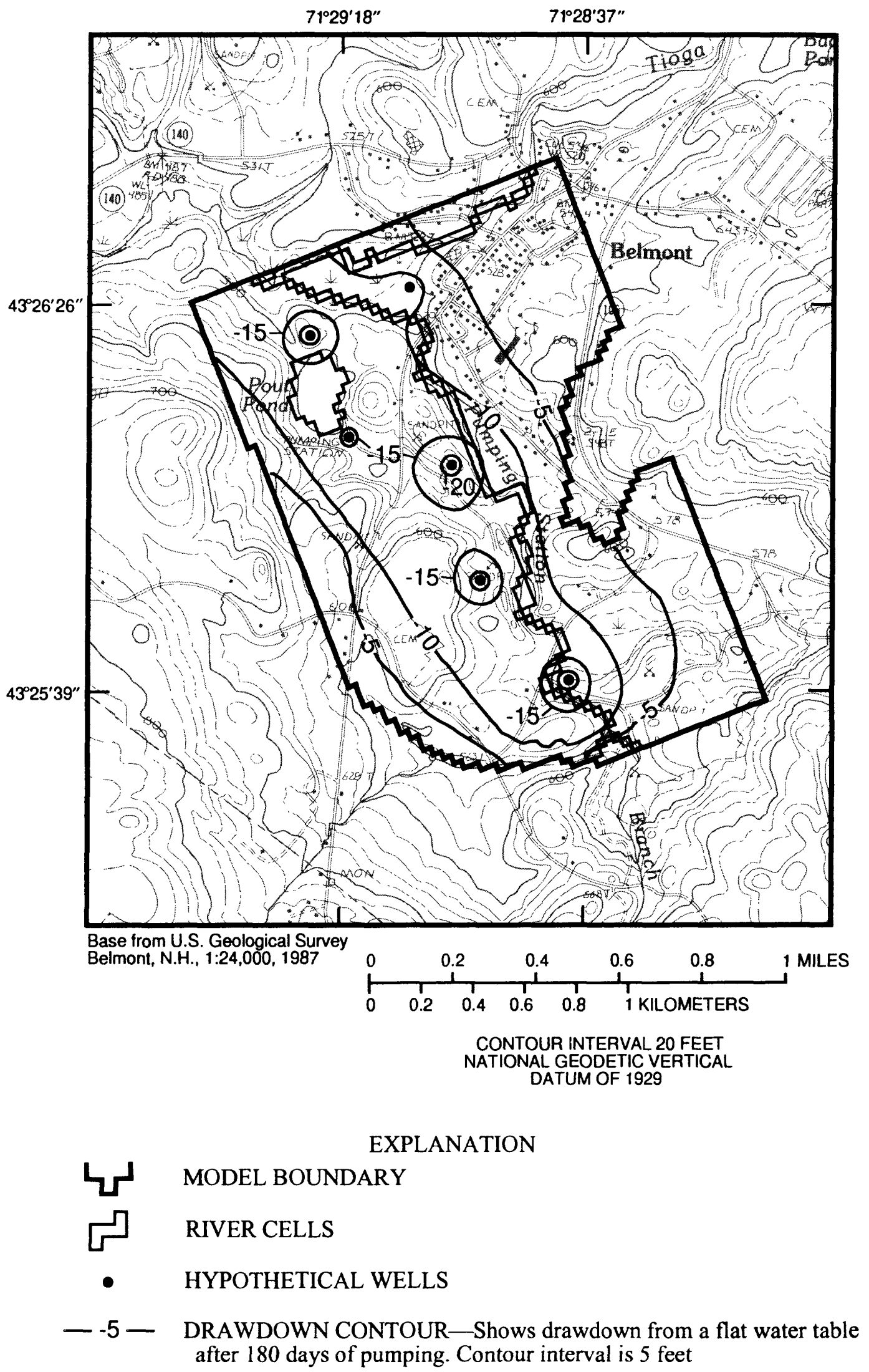

Figure 17. Model boundary, surface-water boundaries, hypothetical wells, and drawdown contours for the Pumping Station Brook aquifer, central New Hampshire with simulation of induced infiltration. 

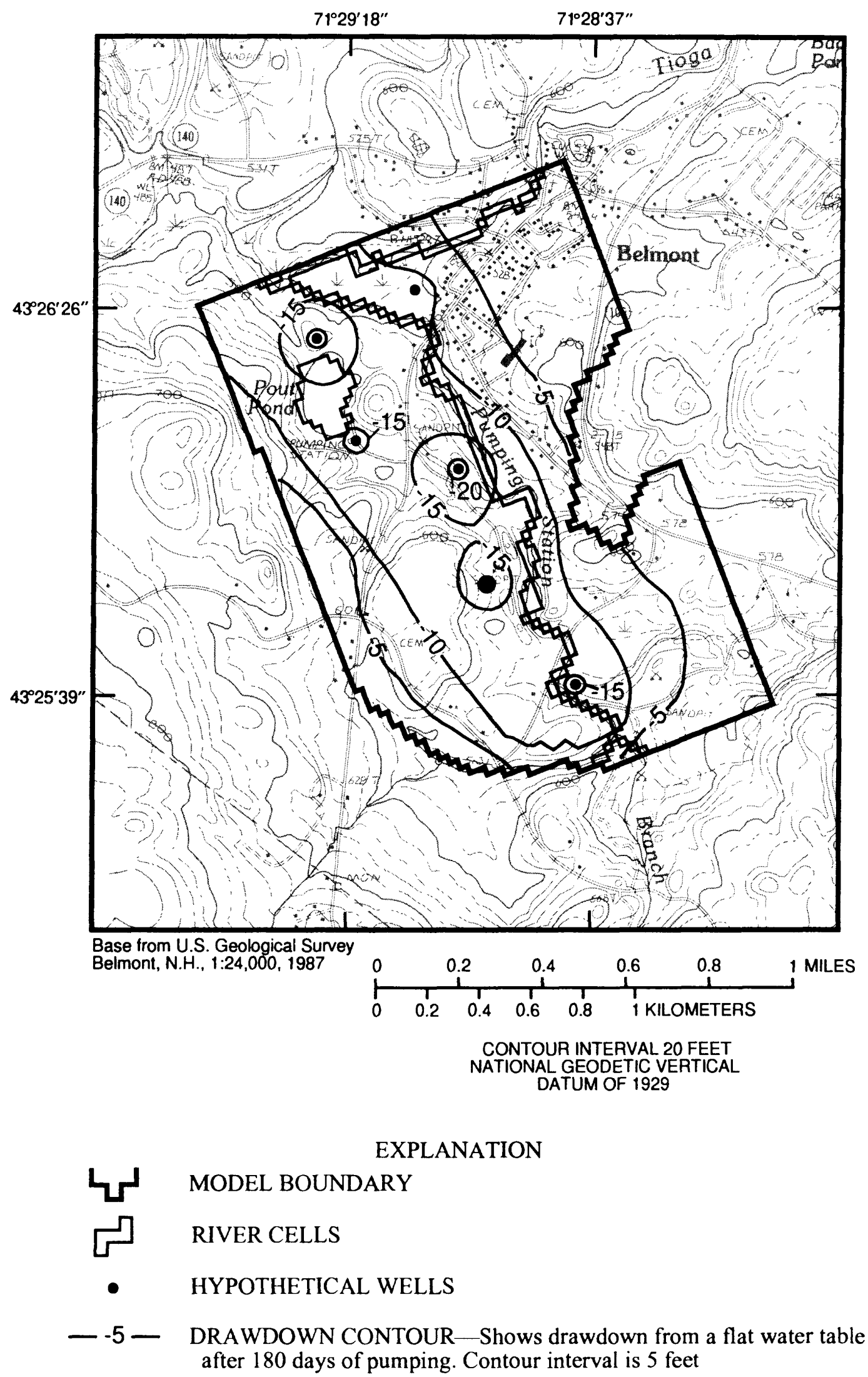

Figure 18. Model boundary, surface-water boundaries, hypothetical wells, and drawdown contours for the Pumping Station Brook aquifer, central New Hampshire with simulation of no induced infiltration. 


\section{GROUND-WATER QUALITY}

Water samples from 17 wells were collected in January and August 1991 and were analyzed for inorganic compounds. The results were used to evaluate the background water quality of the stratified-drift aquifers in the Winnipesaukee River Basin. Results of the analyses indicate that water from the stratified-drift aquifers is generally suitable for drinking and other domestic or municipal uses. During the sampling phase of this study, known areas of ground-water contamination were avoided.

All of the sampled wells were developed either with compressed air or with a centrifugal pump to remove water introduced during drilling, foreign material, and sediment and to improve the hydraulic connection with the aquifer. Wells were allowed to stabilize for at least 1 month before sampling. Just before sampling, the wells were pumped until temperature and specific conductance stabilized and at least three times the volume of water in the well was evacuated. This procedure helped ensure that the sampled water represented water from within the aquifer.

All water samples were analyzed by the USGS National Water Quality Laboratory (NWQL) in Arvada, Colo. Samples were collected and analyzed according to procedures described by Fishman and Friedman (1989).

Results of the chemical analyses are presented and compared with the U.S. Environmental Protection Agency (1991a,b, 1992) primary and secondary drinking-water regulations and the New Hampshire Department of Environmental Services, Water Supply Engineering Bureau drinking-water recommendations (New Hampshire Department of Environmental Services, Water Supply Engineering Bureau, written commun., 1990) in table 6. Naturally occurring constituents that have no recommended limits, but whose concentrations are generally less than a few micrograms per liter, also are included in table 6. Many of the constituents listed in table 6 were not detectable in water samples from the stratified-drift aquifers in the study area. Individual constituents and properties are discussed in the following paragraphs.

\section{Specific Conductance}

Specific conductance-a measure of the ability of water to conduct electrical current-ranged from $49 \mu \mathrm{S} / \mathrm{cm}$ in water from well NRW-59 to $440 \mu \mathrm{S} / \mathrm{cm}$ in water from well WRW-1. The median for all water samples in this study $(112 \mu \mathrm{S} / \mathrm{cm})$ was less than the median for the entire State $(132 \mu \mathrm{S} / \mathrm{cm})$ for publicsupply wells coinpleted in stratified-drift aquifers (Morrissey and Regan, 1987).

\section{Dissolved Solids}

Dissolved-solids (solids residue) concentrations in water include all ionized and un-ionized dissolved solids in solution. The concentrations of all water samples from stratified-drift aquifers ranged from $32 \mathrm{mg} / \mathrm{L}$ (well TZW-3) to $236 \mathrm{mg} / \mathrm{L}$ (well WRW-1) and were less than the maximum recommended limit for drinking water of $500 \mathrm{mg} / \mathrm{L}$ established by the New Hampshire Department of Environmental Services, Water Supply Engineering Bureau (1990). The low concentration of dissolved solids in these stratified-drift aquifers can be attributed to the low solubility of the aquifer matrix and the relatively short time that the water is in contact with the aquifer (Morrissey and Regan, 1987).

\section{pH}

The $\mathrm{pH}$ of water is a measure of the hydrogen ion activity. Water having a $\mathrm{pH}$ of 7.0 is neutral, less than 7.0 is acidic, and greater than 7.0 is alkaline. The $\mathrm{pH}$ of most ground water in the United States ranges from about 6.0 to 8.5 (Hem, 1985, p. 63-64). The $\mathrm{pH}$ of water sampled during this study ranged from 5.4 to 7.2 ; the median was 6.3. The range of $\mathrm{pH}$ in stratified-drift aquifers sampled in previous studies in this series (Moore, 1990; Flanagan and Stekl, 1990; Lawlor and Mack, 1992; Ayotte and Toppin, 1995) in this series was from 5.3 to 8.5 , and the median was 6.4 . The most basic or alkaline ground-water samples came from well BLW-83 (7.2). The most acidic water was from wells AHW-1 (6.4), AHW-63 (6.3), AHW-64 (6.4), BLW-28 (6.3), BLW-80 (5.8), BLW-84 (6.2), BLW-85 (5.5), GFW-11 (5.8), MHW-1 (5.4), MHW-2 (6.3), MWW-20 (5.9), NRW-59 (6.4), TZW-3 (5.9), and TZW-9 (6.3). Each of these samples had a pH less than the SMCL of 6.5 established by the USEPA (U.S. Environmental Protection Agency, 1992). 
Table 6. Chemical analyses of ground-water samples from the Winnipesaukee River Basin, central New Hampshire

[ft, foot; $\mu \mathrm{S} / \mathrm{cm}$, microsiemens per centimeter at 25 degrees Celsius; ${ }^{\circ} \mathrm{C}$, degree Celsius; $\mathrm{mg} / \mathrm{L}$, milligram per liter: $\mu \mathrm{g} / \mathrm{L}$, microgram per liter; <, actual value is less than value shown; --, no data; SMCL, Secondary Maximum Contaminant Level: Contaminants that affect the esthetic quality of drinking water. At high concentrations or values, health implications as well as esthetic degradation may also exist. SMCL's are not Federally enforceable but are intened as guidelines for the States (U.S. Environmental Protection Agency, 1992); MCL, Maximum Contaminant Level: Enforceable, health-based regulation that is to be set as close as is feasible to the level at which no known or anticipated adverse effects on the health of a person occur. The definition of feasible means the use of the best technology, treatment techniques, and other means that the Administrator of the U.S. Environmental Protection Agency finds, after examination for efficacy under field conditions and not solely under laboratory conditions, are generally available (taking cost into consideration) (U.S. Environmental Protection Agency, 1992)]

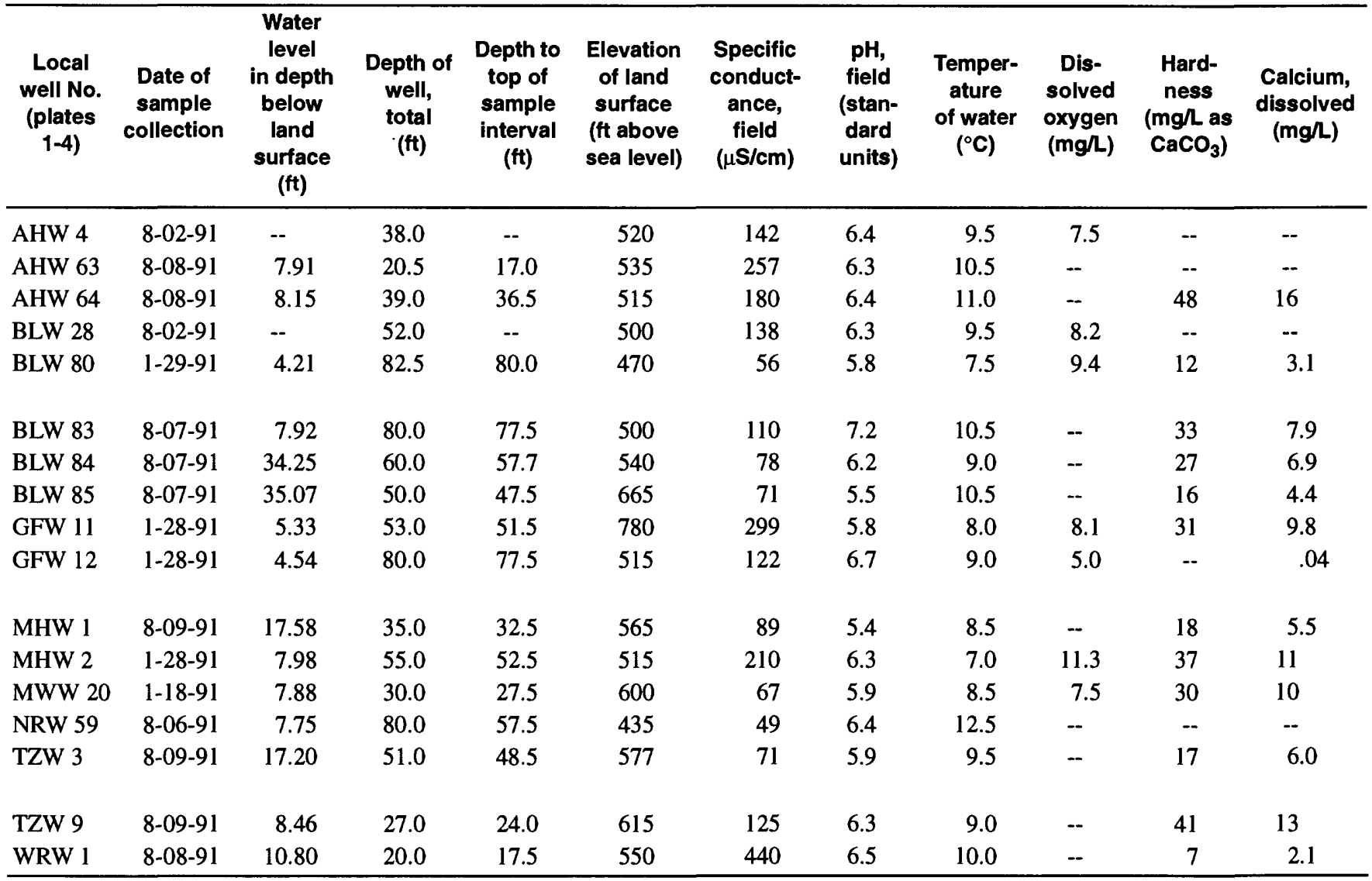

U.S. Environmental Protection Agency drinking-water regulations for listed property or chemical constituent

\begin{tabular}{|c|c|c|c|c|c|c|c|c|c|c|}
\hline SMCL & -- & -- & -- & -- & -- & -- & $6.5-8.0$ & -- & -- & -- \\
\hline MCL & -- & -- & -- & -- & -- & -- & -- & -- & - & -- \\
\hline
\end{tabular}


Table 6. Chemical analyses of ground-water samples from the Winnipesaukee River Basin, central New HampshireContinued

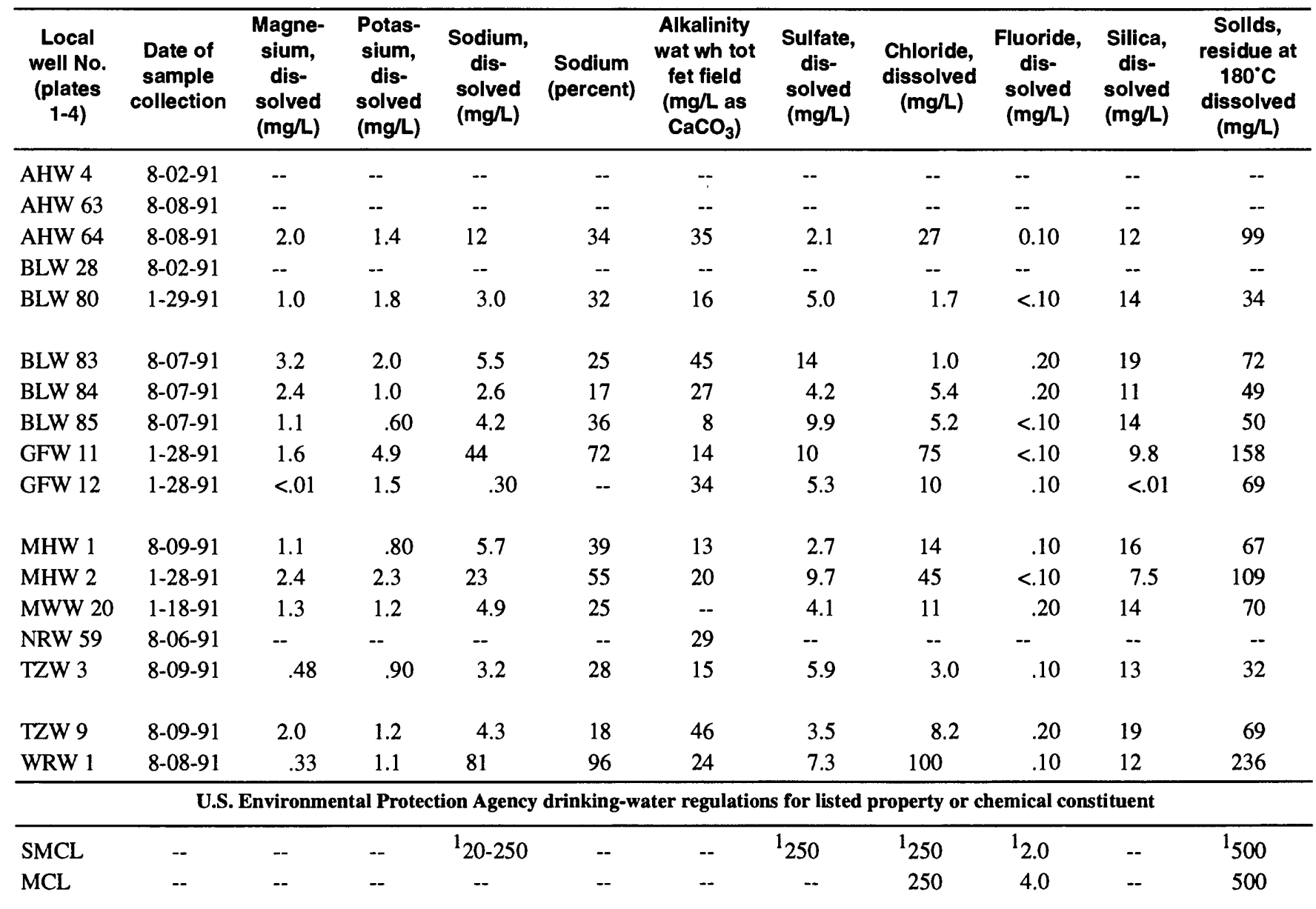


Table 6. Chemical analyses of ground-water samples from the Winnipesaukee River Basin, central New HampshireContinued

\begin{tabular}{|c|c|c|c|c|c|c|c|c|c|c|c|}
\hline $\begin{array}{c}\text { Local } \\
\text { well No. } \\
\text { (plates } \\
1-4)\end{array}$ & $\begin{array}{l}\text { Date of } \\
\text { sample } \\
\text { collection }\end{array}$ & $\begin{array}{l}\text { Solids, } \\
\text { sum of } \\
\text { constit- } \\
\text { uents, } \\
\text { dissolved } \\
\text { (mg/L) }\end{array}$ & $\begin{array}{l}\text { Nitrogen, } \\
\text { nitrite, } \\
\text { dis- } \\
\text { solved } \\
\text { (mg/L } \\
\text { as } \mathrm{N} \text { ) }\end{array}$ & $\begin{array}{l}\text { Nitrogen, } \\
\mathrm{NO}_{2}+\mathrm{NO}_{3} \text {, } \\
\text { dissolved } \\
\text { (mg/L } \\
\text { as } \mathrm{N} \text { ) }\end{array}$ & $\begin{array}{l}\text { Nitrogen, } \\
\text { ammo- } \\
\text { nium, } \\
\text { dissolved } \\
\text { (mgll } \\
\text { as } \mathrm{N} \text { ) }\end{array}$ & $\begin{array}{c}\text { Nitrogen, } \\
\text { ammo- } \\
\text { nium + } \\
\text { organic, } \\
\text { dissolved } \\
\text { (mg/L } \\
\text { as N) }\end{array}$ & $\begin{array}{l}\text { Phos- } \\
\text { phorus, } \\
\text { dis- } \\
\text { solved } \\
\text { (mg/L } \\
\text { as P) }\end{array}$ & $\begin{array}{l}\text { Phos- } \\
\text { phorous } \\
\text { ortho, } \\
\text { dis- } \\
\text { solved } \\
\text { (mg/L } \\
\text { as P) }\end{array}$ & $\begin{array}{l}\text { Barium, } \\
\text { dis- } \\
\text { solved } \\
(\mu g / L)\end{array}$ & $\begin{array}{l}\text { Beryl- } \\
\text { ium, } \\
\text { dis- } \\
\text { solved } \\
(\mu g / L)\end{array}$ & $\begin{array}{l}\text { Cad- } \\
\text { mium, } \\
\text { dis- } \\
\text { solved } \\
(\mu g / L)\end{array}$ \\
\hline AHW 4 & $8-02-91$ & -- & -- & -- & -- & -- & -- & -- & -- & -. & -- \\
\hline AHW 63 & $8-08-91$ & -- & -- & -- & -- & -- & -- & -- & -- & -- & -- \\
\hline AHW 64 & $8-08-91$ & 99 & $<0.010$ & 1.10 & $<0.010$ & $<0.20$ & 0.010 & $<0.010$ & 19 & $<.5$ & $<1.0$ \\
\hline BLW 28 & $8-02-91$ & -- & -- & -- & -- & -- & -- & -- & -- & -- & -- \\
\hline BLW 80 & 1-29-91 & 39 & $<.010$ & $<.100$ & .020 & $<.20$ & $<.010$ & $<.010$ & $<2$ & $<.5$ & $<1.0$ \\
\hline BLW 83 & 8-07-91 & 84 & .010 & $<.050$ & .050 & $<.20$ & .070 & $<.010$ & 27 & .6 & $<1.0$ \\
\hline BLW 84 & $8-07-91$ & 53 & $<.010$ & .780 & .020 & $<.20$ & $<.010$ & $<.010$ & 15 & .9 & $<1.0$ \\
\hline BLW 85 & $8-07-91$ & 46 & $<.010$ & .440 & .020 & $<.20$ & $<.010$ & $<.010$ & 21 & .7 & $<1.0$ \\
\hline GFW 11 & $1-28-91$ & 172 & $<.010$ & 1.70 & $<.010$ & $<.20$ & .030 & $<.010$ & 17 & $<.5$ & $<1.0$ \\
\hline GFW 12 & $1-28-91$ & -- & $<.010$ & $<.100$ & $<.010$ & $<.20$ & .010 & $<.010$ & $<2$ & $<.5$ & $<1.0$ \\
\hline MHW 1 & $8-09-91$ & 56 & $<.010$ & $<.050$ & .460 & .70 & .010 & $<.010$ & 21 & $<.5$ & $<1.0$ \\
\hline MHW 2 & $1-28-91$ & 114 & $<.010$ & .200 & $<.010$ & $<.20$ & $<.010$ & .010 & 9 & $<.5$ & $<1.0$ \\
\hline MWW 20 & $1-18-91$ & 63 & $<.010$ & 1.00 & .010 & .30 & $<.010$ & $<.010$ & $<2$ & $<.5$ & $<1.0$ \\
\hline NRW 59 & 8-06-91 & -- & -- & -- & -- & -- & -- & -- & -- & -- & -- \\
\hline TZW 3 & $8-09-91$ & 44 & $<.010$ & .480 & .020 & $<.20$ & $<.010$ & $<.010$ & 12 & $<.5$ & $<1.0$ \\
\hline TZW 9 & $8-09-91$ & 85 & $<.010$ & $<.050$ & .040 & $<.20$ & $<.010$ & $<.010$ & 17 & $<.5$ & $<1.0$ \\
\hline WRW 1 & 8-08-91 & 222 & $<.010$ & .860 & $<.010$ & $<.20$ & .010 & $<.010$ & 16 & $<.5$ & $<1.0$ \\
\hline
\end{tabular}

U.S. Environmental Protection Agency drinking-water regulations for listed property or chemical constituent

\begin{tabular}{llllllllllll}
\hline SMCL & -- & -- & -- & - & -- & -- & -- & 1250 & -- & -- & - \\
MCL & -- & -- & -- & 10 & -- & -- & -- & 250 & 2,000 & 4 & 5
\end{tabular}

\section{Alkalinity}

The alkalinity of a solution is defined as the capacity for solutes in water to react with and neutralize acid (Hem, 1985, p. 106). It is commonly thought of as an indicator of buffering capacity - the water's ability to resist changes in $\mathrm{pH}$ upon addition of an acid. Almost all of the alkalinity in most natural water can be attributed to carbonate and bicarbonate ions. Because stratified-drift aquifers in New Hampshire consist of sediment derived from bedrock having a low carbonate-mineral content, alkalinity in New Hampshire ground water is generally low. Alkalinity in water samples from this study was determined by incremental titration of unfiltered samples with aliquots of $0.01639 \mathrm{~N}$ sulfuric acid to an endpoint of $\mathrm{pH} 4.5$. For all the water samples, alkalinity ranged from $8 \mathrm{mg} / \mathrm{L}$ as $\mathrm{CaCO}_{3}$ (at well $\mathrm{BLW}-85$ ) to $46 \mathrm{mg} / \mathrm{L}$ as $\mathrm{CaCO}_{3}$ (at well TZW-9). The median alkalinity, $24 \mathrm{mg} / \mathrm{L}$ as $\mathrm{CaCO}_{3}$, indicates that ground water from this area has low alkalinity and, therefore, has low buffering capacity

\section{Calcium, Magnesium, and Hardness}

Calcium and magnesium are common elements of the alkaline-earth minerals. Calcium and magnesium are also the predominant cations in most natural ground water (Hem, 1985). Concentrations of calcium in the samples ranged from 0.04 to $16 \mathrm{mg} / \mathrm{L}$, and the median for the 13 samples was $7.9 \mathrm{mg} / \mathrm{L}$. Concentrations of magnesium in the samples ranged from $<0.01$ to $3.2 \mathrm{mg} / \mathrm{L}$, and the median for the 13 samples was $1.3 \mathrm{mg} / \mathrm{L}$. 
Table 6. Chemical analyses of ground-water samples from the Winnipesaukee River Basin, central New HampshireContinued

\begin{tabular}{|c|c|c|c|c|c|c|c|c|c|c|c|}
\hline $\begin{array}{c}\text { Local } \\
\text { well No. } \\
\text { (plates } \\
1-4 \text { ) }\end{array}$ & $\begin{array}{l}\text { Date of } \\
\text { sample } \\
\text { collection }\end{array}$ & $\begin{array}{c}\text { Cobalt, } \\
\text { dissolved } \\
(\mu g / L)\end{array}$ & $\begin{array}{c}\text { Copper, } \\
\text { dissolved } \\
(\mu g / L)\end{array}$ & $\begin{array}{l}\text { Iron, } \\
\text { dis- } \\
\text { solved } \\
(\mu g / L)\end{array}$ & $\begin{array}{l}\text { Lead, } \\
\text { dis- } \\
\text { solved } \\
(\mu g / L)\end{array}$ & $\begin{array}{l}\text { Lithium, } \\
\text { dissolved } \\
(\mu g / L)\end{array}$ & $\begin{array}{l}\text { Manga- } \\
\text { nese, } \\
\text { dissolved } \\
(\mu g / L)\end{array}$ & $\begin{array}{c}\text { Molyb- } \\
\text { denum, } \\
\text { dissolved } \\
(\mu g / L)\end{array}$ & $\begin{array}{l}\text { Strontium, } \\
\text { dissolved } \\
(\mu g / L)\end{array}$ & $\begin{array}{l}\text { Vanadium, } \\
\text { dissolved } \\
(\mu g / L)\end{array}$ & $\begin{array}{l}\text { Zinc, } \\
\text { dis- } \\
\text { solved } \\
(\mu g / L)\end{array}$ \\
\hline AHW 4 & $8-02-91$ & -. & -- & -- & -- & -- & -- & -- & -- & -- & -- \\
\hline AHW 63 & 8-08-91 & -- & -- & -- & -- & -- & -- & -- & -- & -- & -- \\
\hline AHW 64 & 8-08-91 & $<3$ & $<10$ & 8 & $<10$ & $<4$ & 330 & $<10$ & 140 & $<6$ & 4 \\
\hline BLW 28 & 8-02-91 & -- & -- & -- & -- & -- & -- & -- & -- & -- & -- \\
\hline BLW 80 & $1-29-91$ & $<3$ & $<10$ & 6 & $<10$ & $<4$ & 76 & $<10$ & 28 & $<6$ & 3 \\
\hline BLW 83 & 8-07-91 & $<3$ & $<10$ & 4,000 & $<10$ & 5 & 300 & $<10$ & 60 & $<6$ & 4 \\
\hline BLW 84 & 8-07-91 & $<3$ & $<10$ & 6 & $<10$ & $<4$ & 12 & $<10$ & 64 & $<6$ & $<3$ \\
\hline BLW 85 & 8-07-91 & $<3$ & $<10$ & 72 & $<10$ & $<4$ & 35 & $<10$ & 41 & $<6$ & 6 \\
\hline GFW 11 & $1-28-91$ & $<3$ & $<10$ & 6 & $<10$ & $<4$ & 390 & $<10$ & 200 & $<6$ & $<3$ \\
\hline GFW 12 & $1-28-91$ & $<3$ & $<10$ & $<3$ & $<10$ & 18 & $<1$ & $<10$ & $<1$ & $<6$ & $<3$ \\
\hline MHW 1 & 8-09-91 & $<3$ & $<10$ & 1,900 & $<10$ & $<4$ & 37 & $<10$ & 55 & $<6$ & 5 \\
\hline MHW 2 & $1-28-91$ & $<3$ & $<10$ & 11 & $<10$ & $<4$ & 16 & $<10$ & 100 & $<6$ & 6 \\
\hline MWW 20 & $1-18-91$ & $<3$ & $<10$ & 5 & $<10$ & $<4$ & 16 & $<10$ & 75 & $<6$ & $<3$ \\
\hline NRW 59 & $8-06-91$ & -- & -- & -- & -- & -- & -- & -- & -- & -- & -- \\
\hline TZW 3 & 8-09-91 & $<3$ & $<10$ & 6 & $<10$ & $<4$ & 52 & $<10$ & 51 & $<6$ & 4 \\
\hline TZW 9 & 8-09-91 & $<3$ & $<10$ & 4,400 & $<10$ & $<4$ & 1,200 & $<10$ & 85 & $<6$ & $<3$ \\
\hline WRW 1 & 8-08-91 & $<3$ & $<10$ & 10 & $<10$ & $<4$ & 2 & $<10$ & 79 & $<6$ & 3 \\
\hline \multicolumn{12}{|c|}{ U.S. Environmental Protection Agency drinking-water regulations for listed property or chemical constituent } \\
\hline SMCL & -- & -- & 1,000 & 300 & -- & -- & 50 & -- & - & -- & 5,000 \\
\hline MCL & -- & -- & -- & -- & 50 & -- & -- & -- & -- & -- & 5,000 \\
\hline
\end{tabular}

${ }^{1}$ Secondary level set by the New Hampshire Department of Environmental Services, Water Supply Bureau (New Hampshire Department of Environmental Services, Water Supply Bureau, written commun., 1987)

Hardness of water, expressed in milligrams per liter as $\mathrm{CaCO}_{3}$, is caused by divalent metallic cations dissolved in the water. In freshwater, these cations are primarily calcium and magnesium, but iron, manganese, and strontium also may contribute to hardness. Hardness ranged from $7 \mathrm{mg} / \mathrm{L}$ at well WRW1 to $48 \mathrm{mg} / \mathrm{L}$ at well AHW-64. Hardness in all the 12 samples was less than $60 \mathrm{mg} / \mathrm{L}$; thus, these waters are considered to be soft (table 7).

\section{Sodium and Chloride}

Sodium ( $\mathrm{Na}$ ) and chloride $(\mathrm{Cl})$ can be introduced into ground water from nonindigenous sources (wet or dry deposition, such as sea salt and aerosols) and anthropogenic sources. The major anthropogenic source of sodium and chloride is road salt. On the basis of limited data, it is estimated that New Hampshire towns and cities used about 33,000 tons per year of $\mathrm{NaCl}$ for deicing roads (Hall, 1975). The highest concentration of chloride was $100 \mathrm{mg} / \mathrm{L}$ from well WRW-1, less than one-half of the U.S. Environmental Protection Agency (1992) secondary maximum contaminant level (SMCL ${ }^{1}$ ) for chloride, established as a taste threshold. Water samples from three wells had sodium concentrations that exceeded the $20-\mathrm{mg} / \mathrm{L}$ Health Advisory Level for sodium established by the

\footnotetext{
${ }^{1}$ SMCL, Secondary Maximum Contaminant Level: Contaminants that affect the aesthetic quality of drinking water. At high concentrations or values, health implications as well as aesthetic degradation may also exist. SMCL's are not Federally enforceable but are intended as guidelines for the States.
} 
Table 7. Cassification of hardness of water

$\left[\mathrm{CaCO}_{3}\right.$, calcium carbonate; modified from Durfor and Becker, 1964, p. 27]

\begin{tabular}{lc}
\hline Descriptive rating & $\begin{array}{c}\text { Range of hardness, as } \mathrm{CaCO}_{3} \\
\text { (milligrams per liter) }\end{array}$ \\
\hline Soft & $0-60$ \\
Moderately hard & $61-120$ \\
Hard & $121-180$ \\
Very hard & 181 or greater \\
\hline
\end{tabular}

U.S. Environmental Protection Agency (1992) as a recommended limit for people with heart, hypertension, or kidney problems $(23 \mathrm{mg} / \mathrm{L}$ at well MHW-2, $44 \mathrm{mg} / \mathrm{L}$ at well GFW-11, and $81 \mathrm{mg} / \mathrm{L}$ at well WRW-1). The ratio of $\mathrm{Na}$ to $\mathrm{Cl}$ in water from well WRW-1 was close to 1 to 1 milliequivalents per liter, indicating that $\mathrm{NaCl}$ (probably from road salt) is the source of both constituents.

\section{Nitrate}

The predominant form of inorganic nitrogen in natural water is nitrate, an oxidized, highly soluble compound. Excess nitrate in ground water can originate from fertilizer applications, leachate from sewage systems, or agricultural wastes. Nitrate $\left(\mathrm{NO}_{3}\right.$ as $\left.\mathrm{N}\right)$ in ground water has been linked to methemoglobinemia, or blue-baby syndrome (Lukens, 1987). For all the samples, the concentration of $\mathrm{NO}_{3}$ as $\mathrm{N}$ was at or below the detection limit of $0.010 \mathrm{mg} / \mathrm{L}$. These concentrations are well below the $10-\mathrm{mg} / \mathrm{L}$ maximum contaminant level $\left(\mathrm{MCL}^{2}\right)$ for $\mathrm{NO}_{3}$ as $\mathrm{N}$ established by the USEPA (1992). Inorganic nitrogen also can be present in water as nitrite or ammonium. Among the water sample collected during this study, nitrogen concentrations as ammonium ranged from less than 0.01 to 0.46 $\mathrm{mg} / \mathrm{L}$.

\footnotetext{
${ }^{2}$ MCL, Maximum Contaminant Level: Enforceable, healthbased regulation that is to be set as close as is feasible to the level at which no known or anticipated adverse effects on the health of a person occur. The definition of feasible means the use of the best technology, treatment techniques, and other means that the Administrator of the U.S. Environmental Protection Agency finds, after examination for efficacy under field conditions and not solely under laboratory conditions, are generally available (taking cost into consideration).
}

\section{Sulfate}

The sulfate ion $\left(\mathrm{SO}_{4}^{2-}\right)$ is one of the major anions in natural water. Oxidation of sulfide ores, gypsum, and anhydrite and atmospheric deposition are sources of sulfate, but sulfate-producing minerals generally are not present in stratified-drift aquifers in New Hampshire. Sulfate is reduced by anaerobic bacteria to hydrogen sulfide gas $\left(\mathrm{H}_{2} \mathrm{~S}\right)$, which can be detected by smell at concentrations of only a few tenths of a milligram per liter. The sulfate concentration among all the ground-water samples ranged from 2.1 to $14 \mathrm{mg} / \mathrm{L}$, and the median was $5.3 \mathrm{mg} / \mathrm{L}$. The SMCL for sulfate $\left(\mathrm{SO}_{4}^{2-}\right)$ in drinking water is $250 \mathrm{mg} / \mathrm{L}$.

\section{Iron and Manganese}

Iron and manganese are common elements in minerals in stratified-drift deposits within this study area. Elevated concentrations of manganese, often accompanied by elevated concentrations of iron, were the most common water-quality problem found during this study. Manganese, an abundant metallic element, is an undesirable impurity in water because of its tendency to deposit black oxide stains (Hem, 1985, p. 85). Water from six wells had manganese concentrations that exceeded the SMCL of $50 \mu \mathrm{g} / \mathrm{L}$ (U.S. Environmental Protection Agency, 1991a): $330 \mu \mathrm{g} / \mathrm{L}$ at AHW-64, $76 \mu \mathrm{g} / \mathrm{L}$ at BLW-80, $300 \mu \mathrm{g} / \mathrm{L}$ at BLW-83, $390 \mu \mathrm{g} / \mathrm{L}$ at GFW-11, $52 \mu \mathrm{g} / \mathrm{L}$ at TZW-3, and $1,200 \mu \mathrm{g} / \mathrm{L}$ at $\mathrm{TZW}-9$. Iron, if present in excessive amounts in residential water supplies, forms red oxyhydroxide precipitates that can stain clothes and plumbing fixtures. Concentrations of iron in water from three of the sampled wells $-4,000 \mu \mathrm{g} / \mathrm{L}$ at well BLW-83, 1,900 $\mu \mathrm{g} / \mathrm{L}$ at well MHW-1, and $4,400 \mu \mathrm{g} / \mathrm{L}$ at well TZW-9 exceeded the SMCL of $300 \mu \mathrm{g} / \mathrm{L}$ (U.S. Environmental Protection Agency, 1992).

\section{Trace Elements}

Most trace metals are present in the soil as cations that are strongly adsorbed by oxides and hydroxides (particularly aluminum, iron, and manganese) and complexed by organic ligands at near-neutral $\mathrm{pH}$ (Drever, 1982); the dissolved concentrations are, therefore, usually low. All of the ground-water samples 
analyzed had trace metal concentrations that were below the detection limit for the following metals: cadmium, cobalt, copper, lead, molybdenum, and vanadium. In addition, the concentrations of the following metals were within the range of values commonly found in natural water (Hem, 1985): dissolved barium, lithium, strontium, and zinc. None of the samples exceeded the U.S. Environmental Protection Agency's SMCL for copper of $1,000 \mu \mathrm{g} / \mathrm{L}$ (1991b).

\section{SUMMARY AND CONCLUSIONS}

The Winnipesaukee River Basin in central New Hampshire encompasses an area of $484 \mathrm{mi}^{2}$ and contains approximately $66 \mathrm{mi}^{2}$ of stratified drift. A $15-$ percent increase in population from 1980 to 1990 has increased the demand on the water resources of this area. In 1992, total ground-water withdrawals from stratified drift for public supply within the basin are approximately $0.1 \mathrm{Mgal} / \mathrm{d}$. The towns of Alton and Belmont are the primary users of this ground water. Many of the shallow stratified-drift aquifers within the study area could be valuable sources of domestic and municipal water supplies, but they are not developed to their fullest potential.

Stratified-drift deposits in the basin largely reflect local and regional glacial-lake environments that existed at the time of deposition. Many are deltas deposited directly into glacial lakes or locally ponded meltwater and represent the downstream end of a morphosequence deposit (Koteff and Pessl, 1981). Some are deposits that begin as valley-fill deposits and grade into deltas as the meltwater streams emptied into a glacial lake.

Stratified-drift aquifers in the southern part of the study area are potentially the most productive. Transmissivities are locally greater than $4,000 \mathrm{ft}^{2} / \mathrm{d}$ but are generally less than $1,000 \mathrm{ft}^{2} / \mathrm{d}$. Saturated thicknesses exceed $100 \mathrm{ft}$ locally but are generally less than $40 \mathrm{ft}$. Stratified drift in the southern part of the basin was deposited directly into glacial lakes that formed against the uplands to the south and the active ice margin to the north. Aquifers in this part of the study area are typically composed of kames, eskers, and deltas. Some of these deposits are capable of supplying enough potable water for domestic or small community supplies.
Stratified-drift aquifers in the northern part of the study area are more typical of ice-contact heads of outwash. Stratified drift in this part of the study area was deposited by meltwater streams flowing in valleys that fed into glacial Lake Winnipesaukee. Deposits include kames, kame terraces, eskers, outwash, and outwash deltas. Transmissivities of stratified-drift aquifers are locally greater than $2,000 \mathrm{ft}^{2} / \mathrm{d}$ but are generally less than $1,000 \mathrm{ft}^{2} / \mathrm{d}$. Saturated thicknesses exceed $100 \mathrm{ft}$ locally but are generally less than $40 \mathrm{ft}$.

Twenty-nine of the aquifers in the basin have areas where transmissivities exceed $2,000 \mathrm{ft}^{2} / \mathrm{d}$. Ten of these have areas where transmissivities exceed $4,000 \mathrm{ft}^{2} / \mathrm{d}$. Of the potentially productive aquifers in the Winnipesaukee River Basin, only the Merrymeeting River aquifer and the Pumping Station Brook aquifer are currently (1992) being used for a public water supply. These aquifers may not be developed to their fullest potential. Stratified-drift aquifers with the greatest potential for supply include the Gulf Brook - Gardners Grove aquifer, the Union Road aquifer, the Durkee Brook aquifer, the Gunstock River aquifer, the Ellacoya aquifer, the Hawkins Brook aquifer, the Shannon Brook aquifer, the Hersey Brook aquifer, and the Copps Pond aquifer.

Stratified-drift aquifers in Alton and Belmont were selected for an analysis of water availability. Both are among the most productive aquifers in the study area. The Merrymeeting River aquifer in Alton is hydraulically connected to a river system, and water is available for induced infiltration; the Pumping Station Brook aquifer in Belmont is hydraulically connected to a small brook, but little water is available for induced infiltration. A two-dimensional numerical flow model was used to simulate the aquifer systems. The results showed that the Merrymeeting River aquifer may be capable of supplying 0.63 to $1.1 \mathrm{Mgal} / \mathrm{d}$ and the Pumping Station Brook aquifer may be capable of supplying 1.6 to $1.8 \mathrm{Mgal} / \mathrm{d}$, based on only one of many possible withdrawal scenarios. The analysis indicates that, for the Merrymeeting River aquifer, available drawdown is the limiting factor for water availability; however, installing wells close to the river may increase the amount of available water. For the Pumping Station Brook aquifer, the simulation showed that the available water estimate was limited by induced infiltration from the small stream to the aquifer. 
Ground-water quality in water from 17 wells finished in stratified drift was generally shown to be suitable for drinking and other domestic uses. Sites of known ground-water contamination were not sampled. Water samples from wells MHW-2, GFW-11, and WRW-1 had elevated sodium concentration of 23,44 , and $81 \mathrm{mg} / \mathrm{L}$, respectively. These elevated concentrations may be a result of the proximity of the wells to highways where road salt is applied for deicing.

Water samples from 3 wells had elevated iron concentrations at $4,000 \mu \mathrm{g} / \mathrm{L}, 1,900 \mu \mathrm{g} / \mathrm{L}$, and $4,400 \mu \mathrm{g} / \mathrm{L}$, respectively. Water samples from six wells had manganese concentrations that equaled or exceeded the SMCL of $50 \mu \mathrm{g} / \mathrm{L}$ (U.S. Environmental Protection Agency, 1991a). The pH of water from wells in stratified drift was, in general, less than the SMCL of 6.5 established by USEPA in secondary drinking-water regulations (1992).

\section{SELECTED REFERENCES}

Ayotte J.D.,and Toppin, K.W., 1995, Geohydrology and water quality of stratified-drift aquifers in the middle Merrimack River basin, south-central New Hampshire: U.S. Geological Survey Water-Resources Investigations Report 92-4192, 52 p., 8 pls.

Bates, R.L., and Jackson, J.A., eds., 1980, Glossary of geology ( $2 \mathrm{~d}$ ed.): Falls Church, Va., American Geological Institute, $751 \mathrm{p}$.

Bedinger, M.S., 1961, Relation between median grain size and permeability in the Arkansas River Valley, Arkansas, in Geological Survey Research, 1961, Short papers in the geologic and hydrologic sciences, articles 147-292: U.S. Geological Survey Professional Paper 424-C, p. C31-C32.

Billings, M.P., 1956, The geology of New Hampshire, part II-bedrock geology: Concord, N.H., New Hampshire State Planning and Development Commission, $203 \mathrm{p}$.

Boudette, E.L., Canney, F.C., Cotton, J.E., Davis, R.I., and others, 1985, High levels of arsenic in the ground waters of southeastern New Hampshire-a geochemical reconnaissance: U.S. Geological Survey Open-File Report 85-202, 25 p.

Bradley, Edward, 1964, Geology and ground-water resources of southeastern New Hampshire: U.S. Geological Survey Water-Supply Paper 1695, 80 p.
Chapman, D.H., 1974, New Hampshire's landscape-how it was formed: New Hampshire Profiles, v. 23, no. 1, p. 41-56.

Cotton, J.E., 1975, Availability of ground water in the Pemigewasset and Winnipesaukee River basins, central New Hampshire: U.S. Geological Survey WaterResources Investigation 47-75, scale 1:125,000. 1985, New Hampshire ground-water resources, in U.S. Geological Survey, National water summary 1984: U.S. Geological Survey Water-Supply Paper 2275, p. 303-308.

1987, Ground-water resources of the Lamprey River Basin, southeastern New Hampshire: U.S. Geological Survey Water-Resources Investigations Report 84-4252, 53 p.

Davis, P.T., Thompson, W.B., Stone, B.D., Newton, R.M., Fowler, B.K., 1993, Multiple glaciations and deglaciation along a transect from Boston, Massachusetts, to the White Mountains, New Hampshire, in Cheney, J.T., and Hepburn, J.P.,1993, Field trip guidebook for the Northeastern United States: 1993 Geological Society of America Annual Meeting and 85th Annual Intercollegiate Geological Conference, October 25-28, Boston, Mass, v. 2, p. EE-1-EE-27.

Drever, J.I., 1982, The geochemistry of natural waters: Englewood Cliffs, N.J., Prentice Hall, 388 p.

Durfor, C.N., and Becker, Edith, 1964, Public water supplies of the 100 largest cities in the United States, 1962: U.S. Geological Survey Water-Supply Paper 1812, 364 p.

Ferris, J.G., Knowles, D.B., Brown, R.H., and Stallman, R.W., 1962, Theory of aquifer tests: U.S. Geological Survey Water-Supply Paper 1536-E, p. 69-174.

Fishman, M.J., and Friedman, L.C., 1989, Methods of determination of inorganic substances in water and fluvial sediments (3rd ed.): U.S. Geological Survey Techniques of Water-Resources Investigations, book 5 , chap. A1, 545 p.

Flanagan, S.M., and Stekl, P.J., 1990, Geohydrologic, ground-water-quality, and streamflow data for the stratified-drift aquifers in the lower Merrimack and coastal river basins, southeastern New Hampshire: U.S. Geological Survey Open-File Report 89-390, 130 p., 3 pls.

Folk, R.L., 1974, Petrology of sedimentary rocks: Austin, Tex., Hemphill Publishing Co., 182 p.

Franke, O.L., Reilly, T.E., and Bennett, G.D., 1987, Definition of boundary and initial conditions in the analysis of saturated ground-water flow systems-an introduction: U.S. Geological Survey Techniques of Water-Resources Investigations, book 3, chap. B5, 15 p. 
Freeze, R.A., and Cherry, J.A., 1979, Groundwater: Englewood Cliffs, N.J., Prentice Hall, 604 p.

Goldthwait, J.W., 1925, The geology of New Hampshire: New Hampshire Academy of Science Handbook 1, $86 \mathrm{p}$.

Goldthwait, J.W., Goldthwait, Lawrence, and Goldthwait, R.P., 1951, The geology of New Hampshire, part I, surficial geology: New Hampshire State Planning and Development Commission, 83 p.

Goldthwait, R.P., 1968, Surficial geology of the WolfeboroWinnipesaukee area, New Hampshire: New Hampshire Department of Resources and Economic Development, $60 \mathrm{p}$.

Haeni, F.P., 1986, Application of continuous seismicreflection methods to hydrologic studies: Ground Water, v. 24, no. 1, p. 23-31.

1988a, Application of seismic-refraction techniques to hydrologic studies: U.S. Geological Survey Techniques of Water-Resources Investigations, book 2, chap. D2, $86 \mathrm{p}$.

1988b, Evaluation of the continuous seismic-reflection method for determining the thickness and lithology of stratified drift in the glaciated northeast in Randall, A.D., and Johnson, A.I., eds., Regional aquifer systems of the United States-the northeast glacial aquifers: American Water Resources Association Monograph Series 11, p. 63-82.

Hall, F.R., 1975, Chloride in natural waters of New Hampshire: Durham, N.H., University of New Hampshire, Agricultural Experiment Station, Bulletin 504,25 p.

Hansen, B.P., 1986, Exploration for areas suitable for ground-water development, central Connecticut Valley lowlands, Massachusetts: U.S. Geological Survey Water-Resources Investigations Report 84-4106, 37 p., $1 \mathrm{pl}$.

Harte, P.T., and Johnson, William, 1995, Geohydrology and water quality of stratified-drift aquifers in the Contoocook River Basin, south-central New Hampshire, with a section on Geohydrologic setting, by R.B. Moore: U.S. Geological Survey Water-Resources Investigations Report 92-4154, 72 p., 4 pls.

Harte, P.T., and Mack, T.J., 1992, Geohydrology of, and simulation of ground-water flow in, the MilfordSouhegan glacial-drift aquifer, Milford, New Hampshire: U.S. Geological Survey Water-Resources Investigations Report 91-4177, 75 p.

Heath, R.C., 1983, Basic ground-water hydrology: U.S. Geological Survey Water-Supply Paper 2220, 84 p.
Hem, J.D., 1985, Study and interpretation of the chemical characteristics of natural water ( $3 \mathrm{~d}$ ed.): U.S. Geological Survey Water-Supply Paper 2254, 263 p.

Johnson, A.I., 1967, Specific yield-compilation of specific yields for various materials: U.S. Geological Survey Water-Supply Paper 1662-D, $74 \mathrm{p}$.

Knott, J.F., and Olimpio, J.C., 1986, Estimation of recharge rates to the sand and gravel aquifer using environmental tritium, Nantucket Island, Massachusetts: U.S. Geological Survey Water-Supply Paper 2297, 26 p.

Koteff, Carl, 1970, Surficial geologic map of the Milford quadrangle, Hillsborough County, New Hampshire: U.S. Geological Survey Geologic Quadrangle Map GQ-881, scale 1:62,500.

Koteff, Carl, and Larsen, F.D., 1989, Postglacial uplift in western New England-geologic evidence for delayed rebound, in Gregersen, S., and Basham P.W., eds., Earthquakes at north-Atlantic passive marginsneotectonics and postglacial rebound: Dordrecht, The Netherlands, Kluwer Academic Publishers, p. 105-123.

Koteff, Carl, and Pessl, Fred, Jr., 1981, Systematic ice retreat in New England: U.S. Geological Survey Professional Paper 1179, $20 \mathrm{p}$.

Koteff, Carl; Robinson, G.R.; Goldsmith, Richard; and Thompson, W.B, 1993, Delayed postglacial uplift and synglacial sea levels in coastal central New England: Quaternery Research, v. 40, p. 46-54

Koteff, Carl, Stone, B.D., and Caldwell, D.W., 1984, Deglaciation of the Merrimack River Valley, southern New Hampshire, in Hanson, L.S., ed., Guidebook for the geology of the coastal lowlands, Boston to Kennebunk, Maine: New England Intercollegiate Geological Conference, 76th annual meeting, 1984, p. 381-393.

Krumbein, W.C., and Monk, G.D., 1942, Permeability as a function of the size parameters of unconsolidated sand: Transactions of the American Institute of Mineralogical and Metallurgical Engineers, v. 151, p. 153-163.

Langbein, W.B., and Iseri, K.T., 1960, Manual of hydrology, part 1, general surface-water techniques-general introduction and hydrologic definitions: U.S. Geological Survey Water-Supply Paper 1541-A, 29 p.

Lapham, W.W., 1988, Yield and quality of ground water from stratified-drift aquifers, Taunton River Basin, Massachusetts: U.S. Geological Survey Water Resources Investigations Report 86-4053, 69 p., 2 pl.

Lawlor, Sean, and Mack, T.J., 1992, Geohydrologic, groundwater-quality, and streamflow data for the stratifieddrift aquifers in the Bellamy, Cocheco, and Salmon Falls River Basins, southeastern New Hampshire: U.S. Geological Survey Open-File Report 89-583, 3 pl. 
Lohman, S.W., 1972, Ground-water hydraulics: U.S. Geological Survey Professional Paper 708, 70 p.

Lohman, S.W., and others, 1972, Definitions of selected ground-water terms-revisions and conceptual refinements: U.S. Geological Survey Water-Supply Paper 1988, 21 p.

Lougee, R.J., 1940, Deglaciation of New England: Journal of Geomorphology, v. 3, p. 188-217.

Lyons, J.B., Bothner, W.A., Moench, R.H., and Thompson, J.B., Jr., eds., 1986, Interim geologic map of New Hampshire: New Hampshire Department of Resources and Economic Development, Open-File Report 86-1, map, scale 1:250,000.

Lukens, J.N, 1987, The legacy of well water methemoglobinemia: Journal of American Medical Association, v. 257, no. 20, p. 2793-2795.

Mack, T.J., and Lawlor, Sean, 1992, Geohydrology and water quality of stratified-drift aquifers in the Bellamy, Cocheco, and Salmon Falls River Basins, southeastern New Hampshire: U.S. Geological Survey WaterResources Investigations Report 90-4161, 65 p., 6 pl.

MacNish, R.D., and Randall, A.D., 1982, Stratified-drift aquifers in the Susquehanna River Basin, New York: New York State Department of Environmental Conservation Bulletin 75, 68 p.

Masch F.O., and Denny, K.J., 1966, Grain size distribution and its effect on the permeability of unconsolidated sands: Water Resources Research, v. 2, no. 4, p. 665-677.

Mazzaferro, D.L., Handman, E.H., and Thomas, M.P., 1979, Water-resources inventory of Connecticut, part 8, Quinnipiac River Basin, Connecticut: Connecticut Water Resources Bulletin 27, 88 p., 5 pl.

McDonald, M.G., and Harbaugh, A.W., 1988, A modular three-dimensional finite-difference ground-water flow model: U.S. Geological Survey Techniques of WaterResources Investigations, book 6, chap. A1, 586 p.

Moore, R.B., 1990, Geohydrology and water quality of stratified-drift aquifers in the Exeter, Lamprey, and Oyster River Basins, southeastern New Hampshire: U.S. Geological Survey Water-Resources Investigations Report 88-4128, 61 p., 8 pls.

Moore, R.B., 1995, Geohydrologic setting in Harte, P.T. and Johnson, William, Geohydrology and water quality of stratified-drift aquifers in the Contoocook River Basin, south-central New Hampshire: U.S. Geological Survey Water-Resources Investigations Report 92-4154, p 10-15.
Moore, R.B., Johnson, C.D., and Douglas, E. M., 1994, Geohydrology and water quality of stratified-drift aquifers in the lower Connecticut River Basin, southwestern New Hampshire: U.S. Geological Survey Water-Resources Investigations Report 92-4013, 68 p., 4 pls.

Morgan, Diana, 1985, A surficial aquifer delineation and water use survey for the town of Moultonborough, New Hampshire: Durham, N.H., University of New Hampshire, unpublished Master's thesis, $62 \mathrm{p}$.

Morrissey, D.J., 1983, Hydrology of the Little Androscoggin River Valley aquifer, Oxford County, Maine: U.S. Geological Survey Water-Resources Investigations Report 83-4018, 79 p., 8 pls.

1988, New Hampshire ground-water quality, in U.S. Geological Survey, National water summary 1986: U.S. Geological Survey Water-Supply Paper 2325, p. 363-368.

Morrissey, D.J., Haeni, F.P., and Tepper, D.H., 1985, Continuous seismic-reflection profiling of a glacial-drift deposit on the Saco River, Maine and New Hampshire, in National Water Well Association, Proceedings of the Association of Ground Water Scientists and Engineers, Eastern Regional Ground Water Conference:

Worthington, Ohio, Water Well Journal Publishing Co., p. 277-296.

Morrissey, D.J., Randall, A.D., and Williams, J.H., 1988, Upland runoff as a major source of recharge to stratified drift in the glaciated northeast, in Randall, A.D., and Johnson, A.I., eds., Regional aquifer systems in the United States-the northeast glacial aquifers: American Water Resources Association Monograph series 11, p. 17-36.

Morrissey, D.J., and Regan, J.M., 1987, New Hampshire ground-water quality: U.S. Geological Survey OpenFile Report 87-0739, 8 p.

New Hampshire Department of Environmental Services, Water Supply Engineering Bureau, 1990, Water-quality standards: Chap. Env-WS 310-319, 19 p.

New Hampshire Department of Environmental Services, Water Supply and Pollution Control Commission, 1973, Merrimack River Basin water quality management plan: Staff Report 61, 62 p.

1982a, Inventory of ground water and surface water potential nonpoint pollution sources: $75 \mathrm{p}$.

1982b, Public water supplies, facilities and policy summary 1981: $44 \mathrm{p}$. 1984, Drinking water regulations: Chap. Ws 300, 85 p. 
New Hampshire Department of Environmental Services, Water Supply and Pollution Control Commission and U.S. Environmental Protection Agency, 1971, Waterquality standards summary (New Hampshire): Water Supply and Pollution Control Commission, $91 \mathrm{p}$.

New Hampshire Office of State Planning, 1985, New Hampshire population projections for cities and towns: $19 \mathrm{p}$.

Olimpio, J.C., and de Lima, Virginia, 1984, Ground-water resources of the Mattapoisett River Valley, Plymouth County, Massachusetts: U.S. Geological Survey WaterResources Investigations Report 84-4043, 83 p.

Olney, S.L., 1983, An investigation of the relationship between the coefficient of permeability and effective grain size of unconsolidated sands: Boston, Mass., Boston University, unpublished Master's thesis, $61 \mathrm{p}$.

Pettyjohn, W.A., Studlick, J.R., Bain, R.C., and Lehr, J.H., 1979, A ground-water quality atlas of the United States: National Water Well Association for National Demonstration Water Project, 272 p.

Pluhowski, E.J., and Kantrowitz, I.H., 1964, Hydrology of the Babylon-Islip area, Suffolk County, Long Island, New York: U.S. Geological Survey Water-Supply Paper $1768,119 \mathrm{p}$.

Randall, A.D., 1978, Infiltration from tributary streams in the Susquehanna River Basin, New York: U.S. Geological Survey Journal of Research, v. 6, no. 3, p. 285-297.

Randall, A.D., and Johnson, A.I., eds., 1988, Regional aquifer systems of the United States-the northeast glacial aquifers: American Water Resources Association Monograph Series 11, $156 \mathrm{p}$.

Reynolds, R.J., and Williams, J.H., 1988, Continuous seismic-reflection profiling of glacial drift along the Susquehanna, Chemung, and Chenango Rivers, southcentral New York and north-central Pennsylvania, in Randall, A.D., and Johnson, A.I., eds., Regional aquifer systems of the United States-the northeast glacial aquifers: American Water Resources Association Monograph Series 11, p. 83-103.

Scott, J.H., Tibbetts, B.L., and Burdick, R.G., 1972, Computer analysis of seismic-refraction data: U.S. Bureau of Mines Report of Investigations RI 7595, $95 \mathrm{p}$.

Stekl, P.J., and Flanagan, S.M., 1992, Geohydrology and water quality of stratified-drift aquifers in the lower Merrimack and coastal river basins, southeastern New Hampshire: U.S. Geological Survey Water-Resources Investigations Report 90-4025, 75 p., 7 pls.
Tepper, D.H., Morrissey, D.J., Johnson, C.J., and Maloney, T.J., 1990, Hydrogeology, water quality, and effects of increased municipal pumpage on the Saco River Valley glacial aquifer, Bartlett, New Hampshire to Fryeburg, Maine: U.S. Geological Survey Water-Resources Investigations Report 88-4179, 113 p.

Theis, C.V., 1935, Relation between the lowering of the piezometric surface and the rate and duration of discharge of a well using ground-water storage: American Geophysical Union Transcript, pt. 2, p. 519-524

1938, The significance and nature of the cone of depression in ground-water bodies: Economic Geology, v. 33 , no. 8 , p. $889-902$.

1963, Estimating the transmissibility of a water-table aquifer from the specific capacity of a well, in Bentall, Ray, compiler, Methods of determining permeability, transmissibility, and drawdown: U.S. Geological Survey Water-Supply Paper 1536-I, p. 332-336.

Todd, D.K., 1980, Groundwater hydrology (2d ed.): New York, John Wiley and Sons, $535 \mathrm{p}$.

Toppin, K.W., 1987, Hydrogeology of stratified-drift aquifers and water quality in the Nashua Regional Planning Commission area, south-central New Hampshire: U.S. Geological Survey Water-Resources Investigations Report 86-4358, 45 p., 6 pls.

Toppin, K.W., McKenna, K.E., Cotton, J.C., and Denner, J.C., 1992, Water resources data, New Hampshire and Vermont, water year 1991: U.S. Geological Survey Water-Data Report NH-VT-91-1, 158 p.

Trescott, P.C., Pinder, G.F., and Larson, S.P., 1976, Finitedifference model for aquifer simulation in twodimensions with results of numerical experiments: U.S. Geological Survey Techniques of Water-Resources Investigations, book 7, chap. C1, $116 \mathrm{p}$.

Upham, Warren, 1897, Modified drift in New Hampshire, in Hitchcock, C.H., ed., Geology of New Hampshire: Concord, N.H., v. 3, part II, 740 p.

U.S. Army Corps of Engineers, 1980, Magnitude and frequency of low streamflows in New Hampshire: U.S. Department of the Army, $70 \mathrm{p}$.

U.S. Bureau of the Census, 1990, 1990 census of population and housing, New Hampshire: U.S. Department of Commerce, $\mathrm{CPH}-1-31,65$ p.

U.S. Environmental Protection Agency, 1991a, Final rule, National primary and secondary drinking water regulations-Synthetic organic chemicals and inorganic chemicals (sections 141.11, 141.12, 141.32, $141.50,141.51,141.61$, and 141.62 of part 141 and 143.3 of part 143): U.S. Federal Register, v. 56 , no. 20 , January 30, 1991, p. 3526-3597. 
U.S. Environmental Protection Agency, 1991b, Final rule, Maximum contaminant level goals and national primary drinking water regulations for lead and copper (sections 141.11, 141.32, and 141.51 of part 141): U.S. Federal Register, v. 56, no. 110, June 7, 1991, p. 26,460-26,564.

1992, Final rule, National primary and secondary drinking-water regulations-Synthetic organic chemicals and inorganic chemicals (sections 141.12, $141.32,141.50,141.51,141.61$, and 141.62 of part 141 and 143.3 of part 143): U.S. Federal Register, v. 57, no. 138 , July 17,1992 , p. 31,776-31,849.

U.S. Geological Survey, 1989, Subsurface-water flow and solute transport-Federal glossary of selected terms: Prepared by the Subsurface-Water Glossary Working Subcommittee, Interagency Advisory Committee on Water Data [38 p.].

U.S. Soil Conservation Service, 1968, Soil survey of Belknap County, New Hampshire: U.S. Department of Agriculture, $68 \mathrm{p}$.

1973, Soil survey of Strafford County, New

Hampshire: U.S. Department of Agriculture, 96 p. 1977, Soil survey of Carroll County, New Hampshire:

U.S. Department of Agriculture, 161 p.

1985, Soil survey of Merrimack County, New

Hampshire: U.S. Department of Agriculture, 141 p.

Weigle, J.M., 1968, Ground-water resources of the lower Merrimack River Valley, south-central New Hampshire: U.S. Geological Survey Hydrologic Investigations Atlas HA-277, scale 1:62,500.

Weigle, J.M., and Kranes, Richard, 1966, Records of selected wells, springs, test holes, materials tests, and chemical analyses of water in the lower Merrimack River Valley, New Hampshire: U.S. Geological Survey Open-File Report, New Hampshire Basic-Data Report 2, $44 \mathrm{p}$.

White, G.W., 1938, Geology of the Merrimack Watershed, in Hoover, E.E., Biological survey of the Merrimack Watershed: New Hampshire Fish and Game Survey Report 3, p. 136 - 148.

Wiltshire, D.A., Lyford, F.P., and Cohen, A.J., 1986, Bibliography on ground water in glacial-aquifer systems in the northeastern United States: U.S. Geological Survey Circular 972, 26 p.

\section{GLOSSARY}

Ablation Till: Loosely consolidated rock debris, formerly carried by glacial ice, that accumulated in places as the surface ice was removed by melting, evaporation, or other processes.

Aquifer: A geologic formation, group of formations, or part of a formation that contains sufficient saturated permeable materials to yield significant quantities of water to wells and springs. Where water only partly fills an aquifer, the upper surface of the saturated zone is free to rise and decline.

Aquifer boundary: A geologic or hydrologic feature that limits the extent of an aquifer.

Bedrock: Solid rock, locally called "ledge," that forms the earth's crust. It may be exposed at the surface but more commonly is buried beneath a few inches to more than 100 feet of unconsolidated deposits.

Confined aquifer: An aquifer saturated with water and bounded above and below by material having a distinctly lower hydraulic conductivity than the aquifer itself.

Contact: A plane or irregular surface between two different types or ages of rocks or unconsolidated sediments.

Cubic feet per second $\left(\mathrm{ft}^{3} / \mathrm{s}\right)$ : A unit expressing rate of discharge. One cubic foot per second is equal to the discharge of a stream 1 foot wide and 1 foot deep flowing at an average velocity of 1 foot per second.

Cubic feet per second per square mile $\left[\left(\mathrm{ft}^{3} / \mathrm{s}\right) / \mathrm{mi}^{2}\right]$ : A unit expressing average number of cubic feet of water flowing per second from each square mile of area drained.

Darcy's Law: An equation relating the factors controlling ground-water flow. Darcy's law is $\mathrm{Q}=\mathrm{KA}(\mathrm{dh} / \mathrm{dl})$, where $Q$ is the quantity of water per unit of time; $K$ is the hydraulic conductivity, which depends on the size and arrangement of the water-transmitting openings (pores and fractures) and on the dynamic characteristics of the fluid (water) such as kinematic viscosity, density, and the strength of the gravitational field; $A$ is the cross-sectional area, at a right angle to the flow direction, through which the flow occurs; and $\mathrm{dh} / \mathrm{dl}$ is the hydraulic gradient.

Deposit: Earth material that has accumulated by natural processes. 
Dissolved solids: The residue from a clear sample of water after evaporation and drying for 1 hour at $180^{\circ} \mathrm{C}$; consists primarily of dissolved mineral constituents, but may also contain organic matter and water of crystallization.

Drainage area: The area or tract of land, measured in a horizontal plane, that gathers water and contributes it ultimately to some point on a stream channel, lake, reservoir, or other water body.

Drawdown: The lowering of the water table or potentiometric surface caused by the withdrawal of water from an aquifer by pumping; equal to the difference between the static water level and the pumping water level.

Effective grain size: The grain size at which 10 percent of the sample consists of smaller grains and 90 percent consists of larger grains.

Esker: A long ridge of sand and gravel that was deposited by water flowing in tunnels within or beneath glacial ice.

Flow duration (of a stream): The percentage of time during which specified daily discharges are equaled or exceeded within a given time period.

Fluvial: Pertaining to the flow of liquid water in the natural environment.

Fluviolacustrine: Pertaining to sedimentation partly in lakes and partly in streams or to sediments deposited under alternating or overlapping lacustrine and fluvial conditions

Fracture: A break, crack, or opening in bedrock along which water may move.

Glacial lake: A lake containing water largely from the melting of glaciers. In this study area, it refers to areas where such lake water was dammed by local topographic or geomorphic features.

Glaciofluvial: Pertaining to the flow of meltwater streams from glacial ice and to the deposits associated with streams, including kames, kame terraces, and outwash.

Glaciolacustrine: Deposits in glacial lakes, especially deposits such as deltas and varved sediments, composed of material deposited by meltwater streams flowing into lakes adjacent to and (or) near the glacier.

Gneiss: A coarse-grained metamorphic rock with alternating bands of granular and micaceous minerals.

Granite: A coarse-grained, light colored, igneous rock.
Gravel: Unconsolidated rock debris composed principally of particles larger than 2 millimeters in diameter.

Ground water: Water in the saturated zone that is under pressure equal to or greater than atmospheric pressure.

Ground-water discharge: The discharge of water from the saturated zone by (1) natural processes such as groundwater seepage into stream channels and ground-water evapotranspiration and (2) discharge through wells and other manmade structures.

Ground-water divide: A hypothetical line on a water table on each side of which the water table slopes downward in a direction away from the line. In the vertical dimension, a plane across which ground water does not flow.

Ground-water recharge: Water that is added to the saturated zone of an aquifer.

Ground-Water Site Inventory (GWSI): A computerized file maintained by the U.S. Geological Survey that contains information about wells and springs collected throughout the United States.

Head, static: The height of the surface of a water column above a standard datum that can be supported by the static pressure of a given point.

Hydraulic conductivity $(K)$ : A measure of the ability of a porous medium to transmit a fluid that can be expressed in unit length per unit time. A material has a hydraulic conductivity of 1 foot per day if it will transmit in 1 day, 1 cubic foot of water at the prevailing kinematic viscosity through a 1 foot square cross section of aquifer, measured at right angles to the direction of flow, under a hydraulic gradient of 1 foot change in head over 1 foot length of flow path.

Hydraulic gradient: The change in static head per unit of distance in a given direction. If not specified, the direction is generally understood to be that of the maximum rate of decrease in head.

Hydrograph: A graph showing stage (height), flow velocity, or other property of water with respect to time.

Ice-contact deposits: Stratified drift deposited in contact with melting glacial ice. Landforms include eskers, kames, kame terraces, and grounding-line deltas.

Igneous: Descriptive term for rocks or minerals solidified from molten or partially molten material (that is, from a magma) such as basalt or granite. 
Induced infiltration: The process by which water infiltrates an aquifer from an adjacent surface-water body in response to ground-water withdrawal from that aquifer.

Kame: A ridge, mound, or hummock that may be irregular and is composed of stratified sand and gravel deposited by glacial meltwater; the precise mode of formation is uncertain.

Kame terrace: A ridge consisting of stratified sand and gravel deposited in a glaciofluvial environment between a melting glacier or stagnant ice lobe and a higher valley wall. The deposit has a terrace appearance after the ice has left the area.

Lacustrine: Pertaining to lake environments. In this report, it refers to areas associated with glacial lake environments.

Lodgement till: A firm, compact clay-rich till deposited beneath a moving glacier, containing abraded stones oriented, in general, with their long axes parallel to the direction of ice movement.

Mean (arithmetic): The sum of the individual values of a set, divided by their total number; also referred to as the "average."

Median: The middle value of a set of measurements that are ordered from lowest to highest; 50 percent of the measurements are lower than the median and 50 percent are higher.

Metamorphic: Descriptive term for rocks such as gneiss and schist that have formed, in the solid state, from other rocks.

Micrograms per liter $(\mu \mathrm{g} / \mathbf{L})$ : A unit expressing the concentration of chemical constituents in solution as the mass (micrograms) of a constituent per unit volume (liter) of water. One thousand micrograms per liter is equivalent to one milligram per liter.
Milligrams per liter (mg/L): A unit for expressing the concentration of chemical constituents in solution as the mass (milligrams) of a constituent per unit volume (liter) of water.

Morphosequence: A continuum of time-equivalent landforms composed of meltwater deposits from more collapsed forms as a result of melting of ice blocks at the head or upstream parts of outwash to progressively less collapsed forms downstream. A sequence can thus be viewed as a body of stratified drift laid down, layer upon layer, by meltwater at and beyond the margin of a glacier.

Outwash: Stratified deposits chiefly of sand and gravel removed or "washed out" from a glacier by meltwater streams and deposited beyond the margin of a glacier, usually found in flat or gently sloping outwash plains.

Outwash deltas: Deltas formed beyond the margin of the glacier where glacial meltwater entered a water body.

pH: The negative logarithm of the hydrogen ion concentration. A pH of 7.0 indicates neutrality; values below 7.0 denote acidity, and those above 7.0 denote alkalinity.

Phi grade scale: A logarithmic transformation of the Wentworth grade scale based on the negative logarithm to the base 2 of the particle diameter, in millimeters.

Porosity: The property of a rock or unconsolidated deposit that is a measure of the size and number of internal voids or open spaces; it may be expressed quantitatively as the ratio of the volume of its open spaces to its total volume.

Precipitation: The discharge of water from the atmosphere, either as a liquid or a solid.

Quartzite: A metamorphic rock consisting mainly of quartz and formed by recrystallization of quartz. 
Runoff: That part of the precipitation that appears in streams. It is the same as streamflow unaffected by artificial diversions, storage, or other human activities in or on the stream channels.

Saturated thickness (of stratified drift): Thickness of stratified drift extending down from the water table to the till or bedrock surface.

Saturated zone: The subsurface zone in which all open (interconnected) spaces are filled with water. Water below the water table, the upper limit of the saturated zone, is under pressure greater than atmospheric.

Schist: A metamorphic rock with subparallel orientation of the visible micaceous minerals, which dominate its composition.

Sediment: Fragmental material that originates from weathering of rocks. It can be transported by, suspended in, or deposited by water.

Slate: A compact, fine-grained platey metamorphic rock formed from shale.

Specific capacity (of a well): The rate of discharge of water divided by the corresponding drawdown of the water level in the well; stated in this report in gallons per minute per foot $[(\mathrm{gal} / \mathrm{min}) / \mathrm{ft}]$.

Specific yield: The ratio of the volume of water that a rock or soil will yield, by gravity drainage, after being saturated to the total volume of the rock or soil.

Standard deviation: A measure of the amount of variability within a sample; it is the square root of the average of the squares of the deviations about the arithmetic mean of a set of data.
Storage coefficient: The volume of water an aquifer releases from or takes into storage per unit surface area of the aquifer per unit change in head. In an unconfined aquifer, the storage coefficient is virtually equal to the specific yield.

Stratified drift: Sorted and layered unconsolidated material deposited in meltwater streams flowing from glaciers or settled from suspension in quiet-water bodies fed by meltwater streams.

Surficial geology: The study of or distribution of unconsolidated deposits at or near the land surface.

Till: A predominantly nonsorted, nonstratified sediment deposited directly by a glacier and composed of boulders, gravel, sand, silt, and clay mixed in various proportions.

Transmissivity: The rate at which water is transmitted through a unit width of aquifer under a unit hydraulic gradient. Equal to the average hydraulic conductivity times the saturated thickness.

Unconfined aquifer (water-table aquifer): An aquifer only partly filled with water. In such aquifers, the water table or upper surface of the saturated zone is at atmospheric pressure and is free to rise and fall.

Unsaturated zone: The zone between the water table and the land surface in which the open spaces are not completely filled with water.

Water availability: An amount of water potentially available for water supply; in this report, it refers to water wells.

Water table: The upper surface of the saturated zone. Water at the water table is at atmospheric pressure. 
APPENDIX A. Description of selected wells, borings, and springs in the Winnipesaukee River Basin, central New Hampshire 
Table A-1. Description of selected wells, borings, and springs in the Winnipesaukee River Basin, central New Hampshire

Local site number: First two characters are U.S. Geological Survey town code. Third-character codes are the following: $\mathbf{A}$, auger hole; $\mathbf{B}$, highway bridge boring; $\mathbf{S}$, spring; $\mathbf{W}$, well. The numbers are sequential numbers for each town.

Latitude, longitude: Accurate within 5 seconds.

Owner: NHDOT, New Hampshire Department of Transportation; Indus, Industry; Assoc, Association; Const, Construction; Vill, village; Bldrs, Builders; Corp, corporation; Mtn View Ter, Mountain View Terrace; Co., company; Rte, route; Const Deve, construction developer; Aqu., Aqueduct; ENVDrilling, Environmental Drilling.

Elevation: Elevations are expressed in feet above National Geodetic Vertical Datum of 1929: Those in whole feet are interpolated from U.S. Geological Survey topographic maps and are accurate to plus or minus half the contour interval of the map (5 to 10 feet); those in tenths of feet are instrumentally determined.

Depth to bottom of casing: Depth to the bottom of casing, in feet below land-surface datum (for wells where "Primary aquifer code" is BEDROCK, the depth to the bottom of casing can be used to indicate the depth to the bedrock surface).

Casing-material code: P, Polyvinyl choloride or plastic; $\mathbf{S}$, steel; $\mathbf{R}$, rock or stone.

Type of finish: $\mathbf{G}$, Gravel Pack; $\mathbf{S}$, screen; $\mathbf{W}$; Walled; $\mathbf{X}$, open hole; $\mathbf{Z}$, other.

Type of site: Bor, Boring; BrW, Bedrock well; Cbl, cable tool; Dug, dug; Dvn, Driven; TH, Test hole; Sp, spring

Water level: Water level, in feet below land-surface datum; $\mathrm{mm}$-dd-yy is month-day-year.

Use: Use-of-water codes are the following: $\mathbf{C}$, commercial; $\mathbf{H}$, domestic; $\mathbf{P}$, public; $\mathbf{N}$, industrial; $\mathbf{T}$, institutional; $\mathbf{U}$, unused; $\mathbf{Z}$, other.

Yield: Discharge in gallons per minute (gal/min).

Specific capacity: In gallons per minute.

Pumping period: The length of time, in hours, that the well was pumped prior to the measurements of production.

Name of driller or New Hampshire Water Resources Division driller number: NH HWY DEPT, New Hampshire Highway Department; NHWRD, New Hampshire Water Resources Division; USGS, U.S. Geological Survey, Soil Expl., Soil Exploration. 
Table A-1. Description of selected wells, borings, and springs in the Winnipesaukee River Basin, central New Hampshire $[--$, on data available $]$

\begin{tabular}{|c|c|c|c|c|c|c|c|c|c|c|}
\hline $\begin{array}{l}\text { Local } \\
\text { site } \\
\text { number }\end{array}$ & $\begin{array}{l}\text { Lat- } \\
\text { itude }\end{array}$ & $\begin{array}{l}\text { Long- } \\
\text { itude }\end{array}$ & Owner or user & $\begin{array}{c}\text { Date } \\
\text { of } \\
\text { con- } \\
\text { struction }\end{array}$ & $\begin{array}{l}\text { Ele- } \\
\text { vat- } \\
\text { tion } \\
\text { (feet) }\end{array}$ & $\begin{array}{c}\text { Diameter } \\
\text { of } \\
\text { casing } \\
\text { (inches) }\end{array}$ & $\begin{array}{l}\text { Depth to } \\
\text { bottom } \\
\text { of casing } \\
\text { (feet) }\end{array}$ & $\begin{array}{c}\text { Casing } \\
\text { mater- } \\
\text { ial }\end{array}$ & $\begin{array}{l}\text { Type } \\
\text { of } \\
\text { fin- } \\
\text { ish }\end{array}$ & $\begin{array}{c}\text { Type } \\
\text { of } \\
\text { site }\end{array}$ \\
\hline
\end{tabular}

BELKNAP COUNTY

\begin{tabular}{|c|c|c|c|c|c|c|c|c|c|c|c|}
\hline & & & & & Alton & & & & & & \\
\hline AHA & 52 & 432708 & 0711308 & Alton, Town of & $11-00-67$ & 545 & -- & -- & -- & -- & $\mathrm{TH}$ \\
\hline AHA & 53 & 432712 & 0711302 & Alton, Town of & $11-00-67$ & 545 & -- & -- & -- & -- & $\mathrm{TH}$ \\
\hline AHA & 54 & 432716 & 0711311 & Alton, Town of & $11-00-67$ & 560 & -- & -- & -- & -- & $\mathrm{TH}$ \\
\hline AHA & 55 & 432715 & 0711324 & Alton, Town of & $11-00-67$ & 550 & -- & -- & -- & -- & $\mathrm{TH}$ \\
\hline AHA & 56 & 432705 & 0711325 & Alton, Town of & $11-00-67$ & 550 & -- & -- & -- & -- & $\mathrm{TH}$ \\
\hline AHA & 57 & 432705 & 0711320 & Alton, Town of & $11-00-67$ & 550 & -- & -- & -- & -- & $\mathrm{TH}$ \\
\hline AHA & 58 & 432722 & 0711317 & Alton, Town of & $11-00-67$ & 570 & -- & -- & -- & -- & $\mathrm{TH}$ \\
\hline AHA & 59 & 432721 & 0711322 & Alton, Town of & $11-00-67$ & 570 & -- & -- & -- & -- & $\mathrm{TH}$ \\
\hline AHA & 60 & 432718 & 0711330 & Alton, Town of & $11-00-67$ & 540 & -- & -- & -- & -- & $\mathrm{TH}$ \\
\hline AHA & 61 & 432725 & 0711323 & Alton, Town of & $11-00-67$ & 570 & -- & -- & -- & -- & $\mathrm{TH}$ \\
\hline AHA & 62 & 432725 & 0711327 & Alton, Town of & $11-00-67$ & 565 & -- & -- & -- & -- & $\mathrm{TH}$ \\
\hline AHA & 63 & 432725 & 0711346 & Alton, Town of & $11-00-67$ & 530 & -- & -- & -- & - & $\mathrm{TH}$ \\
\hline AHA & 64 & 432731 & 0711324 & Alton, Town of & $11-00-67$ & 570 & -- & -- & -- & -- & $\mathrm{TH}$ \\
\hline AHA & 65 & 432737 & 0711335 & Alton, Town of & $11-00-67$ & 570 & -- & -- & -- & -- & -- \\
\hline AHA & 66 & 432743 & 0711340 & Alton, Town of & $11-00-67$ & 570 & -- & -- & -- & - & $\mathrm{TH}$ \\
\hline AHA & 67 & 432734 & 0711344 & Alton, Town of & $11-00-67$ & 530 & -- & -- & - & -- & $\mathrm{TH}$ \\
\hline AHA & 68 & 432759 & 0711351 & Alton, Town of & $11-00-67$ & 530 & -- & -- & -- & -- & $\mathrm{TH}$ \\
\hline AHA & 69 & 432810 & 0711356 & Alton, Town of & $11-00-67$ & 520 & -- & -- & -- & -- & $\mathrm{TH}$ \\
\hline AHA & 71 & 432838 & 0711426 & Alton, Town of & $11-00-67$ & 510 & -- & -- & -- & -- & $\mathrm{TH}$ \\
\hline AHA & 72 & 432844 & 0711429 & Alton, Town of & $11-00-67$ & 510 & -- & -- & -- & -- & $\mathrm{TH}$ \\
\hline AHA & 73 & 432854 & 0711433 & Alton, Town of & $11-00-67$ & 530 & -- & -- & -- & -- & -- \\
\hline AHA & 74 & 432854 & 0711434 & Alton, Town of & $11-00-67$ & 530 & - & $\ldots$ & -- & -- & TH \\
\hline AHA & 75 & 432910 & 0711451 & Alton, Town of & $11-00-67$ & 530 & -- & -- & - & -- & -- \\
\hline AHA & 76 & 432750 & 0711345 & Alton, Town of & $11-00-67$ & 530 & -- & -- & -- & -- & $\mathrm{TH}$ \\
\hline AHA & 77 & 432805 & 0711354 & Alton, Town of & $11-00-67$ & 520 & -- & -- & -- & -- & $\mathrm{TH}$ \\
\hline AHA & 78 & 433200 & 0711012 & -- & $10-21-90$ & 735 & -- & -- & - & -- & Bor \\
\hline AHA & 79 & 433213 & 0711212 & -- & $10-19-90$ & 580 & -- & -- & -- & -- & Bor \\
\hline AHA & 80 & 432609 & 0711142 & White, Don & $06-27-91$ & 540 & -- & - & -- & -- & Bor \\
\hline AHA & 81 & 432655 & 0711315 & Alton Sand and Gravel & $10-07-91$ & 530 & -- & -- & -- & -- & Bor \\
\hline AHB & 1 & 433219 & 0711221 & -- & $03-\quad-64$ & 552.3 & -- & -- & -- & -- & Bor \\
\hline AHB & 2 & 432813 & 0711403 & -- & $10-\quad-33$ & 500.5 & -- & -- & -- & -- & Bor \\
\hline AHB & 3 & 432947 & 0711532 & NHDOT & -- & 501 & -- & -- & -- & -- & - \\
\hline AHW & 3 & 432716 & 0711338 & Alton, town of & $05-05-38$ & 520 & 24 & 26 & S & G & $\mathrm{Cbl}$ \\
\hline AHW & 4 & 432804 & 0711357 & Alton, town of & $--\quad-61$ & 520 & 18 & 21 & $\mathrm{~s}$ & G & $\mathrm{Cbl}$ \\
\hline AHW & 51 & 432645 & 0711243 & Alton, Town of & $09-\quad-67$ & 530 & -- & -- & -- & -- & -- \\
\hline AHW & 52 & 432747 & 0711344 & Alton, Town of & $09-\quad-67$ & 530 & -- & -- & -- & -- & -- \\
\hline AHW & 54 & 432801 & 0711408 & Alton, Town of & $09-\quad-67$ & 510 & -- & -- & -- & -- & - \\
\hline AHW & 55 & 432804 & 0711408 & Alton, Town of & $09-\quad-67$ & 510 & -- & -- & -- & -- & -- \\
\hline AHW & 56 & 432813 & 0711413 & Alton, Town of & $09-\quad-67$ & 550 & -- & -- & -- & -- & - \\
\hline AHW & 57 & 432816 & 0711418 & Alton, Town of & $09-\quad-67$ & 540 & -- & -- & -- & -- & -- \\
\hline AHW & 59 & 432826 & 0711433 & Alton, Town of & $09-\quad-67$ & - & -- & -- & -- & -- & -- \\
\hline AHW & 60 & 432834 & 0711430 & Alton, Town of & $09-\quad-67$ & 550 & -- & -- & -- & -- & -- \\
\hline AHW & 61 & 432836 & 0711429 & Alton, Town of & $09-\quad-67$ & 540 & -- & -- & - & -- & -- \\
\hline AHW & 63 & 432638 & 0711221 & Spera, John & $08-01-90$ & 535 & -- & -- & -- & $\mathrm{s}$ & Bor \\
\hline AHW & 64 & 432725 & 0711348 & Alton, Town of & $10-17-90$ & 515 & -- & -- & -- & $\mathrm{s}$ & Bor \\
\hline AHW & 65 & 432513 & 0711232 & Sleeper, David & $10-18-90$ & 550 & -- & -- & -- & $\mathrm{s}$ & Bor \\
\hline AHW & 66 & 432911 & 0711459 & stocker, Ted & $10-26-90$ & 535 & 2 & 30 & - & $s$ & Bor \\
\hline AHW & 68 & 432644 & 0711245 & Carlton, Bob; Water Indus & -- & 535 & -- & -- & -- & w & Dug \\
\hline AHW & 69 & 433158 & 0711200 & Roberts, Irving & -- & 580 & - & -- & -- & $\mathbf{w}$ & Dug \\
\hline AHW & 70 & 432911 & 0711451 & Selesky & $05-03-84$ & 520 & -- & 25.0 & $=-$ & $x$ & $\mathrm{BrW}$ \\
\hline AHW & 72 & 433012 & 0711503 & Giacalone, J. & $06-01-84$ & 550 & -- & 20.0 & -- & $\mathrm{x}$ & Brw \\
\hline AHW & 76 & 432947 & 0711526 & Hanson & $06-13-84$ & 530 & -- & 72.0 & -- & $\mathrm{x}$ & BrW \\
\hline AHW & 77 & 432500 & 0711149 & Coppinding & $08-14-84$ & 600 & -- & 69.0 & -- & $x$ & Brw \\
\hline AHW & 78 & 432623 & 0711229 & Bowman, L.\& B. & $08-27-84$ & 600 & -- & 39.0 & -- & $\mathrm{x}$ & Brw \\
\hline AHW & 79 & 433022 & 0711544 & williams & $09-14-84$ & 520 & -- & 54.0 & -- & $\mathrm{x}$ & Brw \\
\hline
\end{tabular}




\begin{tabular}{|c|c|c|c|c|c|c|c|c|c|c|}
\hline \multirow{2}{*}{$\begin{array}{l}\text { Local } \\
\text { site } \\
\text { number }\end{array}$} & \multicolumn{2}{|c|}{ Water level } & \multirow{2}{*}{$\begin{array}{c}\text { Top of } \\
\text { screen } \\
\text { (feet) }\end{array}$} & \multirow{2}{*}{$\begin{array}{l}\text { Bottom of } \\
\text { screen } \\
\text { (feet) }\end{array}$} & \multirow{2}{*}{$\begin{array}{l}\text { Use } \\
\text { of } \\
\text { water }\end{array}$} & \multirow[b]{2}{*}{$\begin{array}{c}\text { Yield } \\
\text { (gal/min) }\end{array}$} & \multirow[b]{2}{*}{$\begin{array}{l}\text { Drawdown } \\
\text { (feet) }\end{array}$} & \multirow[b]{2}{*}{$\begin{array}{l}\text { Specific } \\
\text { capacity }\end{array}$} & \multirow{2}{*}{$\begin{array}{l}\text { Pumping } \\
\text { period } \\
\text { (hours) }\end{array}$} & \multirow{2}{*}{$\begin{array}{l}\text { Driller } \\
\text { or NHWRD } \\
\text { number }\end{array}$} \\
\hline & $\begin{array}{l}\text { Depth } \\
\text { (feet) }\end{array}$ & $\begin{array}{c}\text { Date } \\
\text { (mm-dd-yy) }\end{array}$ & & & & & & & & \\
\hline
\end{tabular}

BELKNAP COUNTY

\begin{tabular}{|c|c|c|c|c|c|c|c|c|c|c|c|}
\hline & & & & & & & Alton & & & & \\
\hline $\mathrm{AHA}$ & 52 & -- & -- & -- & -- & -- & -- & -- & -- & -- & clattenburg \\
\hline AHA & 53 & -- & -- & -- & -- & -- & -- & -- & -- & -- & Clattenburg \\
\hline AHA & 54 & -- & -- & -- & -- & -- & -- & -- & -- & -- & Clattenburg \\
\hline AHA & 55 & -- & -- & -- & -- & -- & -- & -- & -- & -- & Clattenburg \\
\hline AHA & 56 & -- & -- & -- & -- & -- & -- & -- & -- & -- & Clattenburg \\
\hline AHA & 57 & -- & -- & -- & -- & -- & -- & -- & -- & -- & Clattenburg \\
\hline AHA & 58 & -- & -- & -- & -- & -- & -- & -- & -- & -- & Clattenburg \\
\hline AHA & 59 & -- & -- & -- & -- & -- & -- & -- & -- & -- & Clattenburg \\
\hline AHA & 60 & -- & -- & -- & -- & -- & -- & -- & -- & -- & Clattenburg \\
\hline AHA & 61 & -- & -- & -- & -- & -- & -- & -- & -- & -- & Clattenburg \\
\hline AHA & 62 & -- & -- & -- & -- & -- & -- & -- & -- & -- & Clattenburg \\
\hline AHA & 63 & -- & -- & -- & -- & -- & -- & -- & -- & -- & Clattenburg \\
\hline AHA & 64 & -- & -- & -- & -- & -- & -- & -- & -- & -- & Clattenburg \\
\hline AHA & 65 & -- & -- & -- & -- & -- & -- & -- & -- & -- & clattenburg \\
\hline AHA & 66 & -- & -- & -- & -- & -- & -- & -- & -- & - & Clattenburg \\
\hline AHA & 67 & -- & -- & -- & -- & -- & -- & -- & -- & -- & clattenburg \\
\hline AHA & 68 & -- & -- & -- & -- & -- & -- & -- & -- & -- & Clattenburg \\
\hline AHA & 69 & -- & -- & -- & -- & -- & -- & -- & -- & -- & Clattenburg \\
\hline AHA & 71 & -- & -- & -- & -- & -- & -- & -- & -- & -- & Clattenburg \\
\hline AHA & 72 & -- & -- & -- & -- & -- & -- & -- & -- & -- & Clattenburg \\
\hline AHA & 73 & -- & -- & -- & -- & -- & -- & -- & -- & $\cdots$ & Clattenburg \\
\hline AHA & 74 & -- & -- & -- & -- & -- & -- & -- & -- & -- & clattenburg \\
\hline AHA & 75 & -- & -- & -- & -- & -- & -- & -- & -- & -- & Clattenburg \\
\hline $\mathrm{AHA}$ & 76 & -- & -- & -- & -- & -- & -- & -- & -- & -- & Clattenburg \\
\hline AHA & 77 & -- & -- & -- & -- & -- & -- & -- & -- & -- & Clattenburg \\
\hline AHA & 78 & -- & -- & -- & $-\infty$ & -- & -- & -- & -- & -- & USGS \\
\hline AHA & 79 & -- & -- & -- & -- & -- & -- & -- & -- & -- & USGS \\
\hline AHA & 80 & -- & -- & -- & -- & $\mathrm{U}$ & -- & -- & -- & -- & USGS \\
\hline AHA & 81 & 15 & $10-07-91$ & -- & -- & $\mathrm{U}$ & -- & -- & -- & -- & USGS \\
\hline AHB & 1 & -- & -- & -- & -- & -- & -- & -- & -- & -- & NHDOT \\
\hline AHB & 2 & -- & -- & -- & -- & -- & -- & -- & -- & -- & NHDOT \\
\hline AHB & 3 & -- & -- & -- & -- & -- & -- & -- & -- & -- & -- \\
\hline AHW & 3 & 1.5 & $05-28-38$ & 26 & 36 & $\mathbf{P}$ & 190 & 27 & 7.45 & 72 & Layme-NE \\
\hline AHW & 4 & 8.1 & --61 & 21 & 31 & $\mathbf{P}$ & 388 & 13 & 29.8 & 72 & Layne-NE \\
\hline AHW & 51 & -- & -- & -- & - & $\cdots$ & - & -- & -- & -- & Clattenburg \\
\hline AHW & 52 & 4 & $09-\quad-67$ & -- & -- & -- & - & -- & -- & -- & Clattenburg \\
\hline AHW & 54 & 0 & $09-\quad-67$ & -- & -- & -- & -- & -- & -- & -- & Clattenburg \\
\hline AHW & 55 & 0 & $09-\quad-67$ & -- & -- & -- & -- & -- & -- & -- & Clattenburg \\
\hline AHW & 56 & 0 & $09-\quad-67$ & -- & -- & -- & -- & -- & -- & -- & Clattenburg \\
\hline AHW & 57 & 0 & $09-\quad-67$ & -- & -- & -- & -- & -- & -- & -- & Clattenburg \\
\hline AHW & 59 & 0 & $09-\quad-67$ & -- & -- & -- & -- & - & -- & -- & Clattenburg \\
\hline AHW & 60 & 0 & $09-\quad-67$ & -- & -- & -- & -- & -- & -- & -- & Clattenburg \\
\hline AHW & 61 & 0 & $09-\quad-67$ & - & -- & -- & -- & -- & -- & -- & Clattenburg \\
\hline AHW & 63 & 4.86 & $07-02-91$ & 17 & 20.5 & U & -- & -- & -- & -- & USGS \\
\hline AHW & 64 & 4.7 & $07-02-91$ & 36.5 & 39 & $\mathrm{U}$ & -- & -- & -- & -- & USGS \\
\hline AHW & 65 & 17.9 & $07-02-91$ & 25 & 30 & $\mathrm{U}$ & -- & -- & -- & -- & USGS \\
\hline AHW & 66 & 15.9 & $07-02-91$ & 27.5 & 30 & $\mathrm{U}$ & -- & -- & -- & -- & USGS \\
\hline AHW & 68 & 8.02 & $06-17-91$ & -- & -- & H & -- & -- & -- & -- & CARLTON, B. \\
\hline AHW & 69 & 7.01 & $06-17-91$ & -- & -- & H & -- & -- & -- & -- & -- \\
\hline AHW & 70 & 12.0 & $05-03-84$ & -- & -- & -- & 1.20 & -- & -- & 6.0 & NHWRD 158 \\
\hline AHW & 72 & 10.0 & $06-02-84$ & -- & -- & $\mathbf{H}$ & .75 & -- & -- & 1.0 & NHWRD 90 \\
\hline AHW & 76 & 20.0 & $06-13-84$ & -- & -- & H & 20.0 & -- & -- & 1.0 & NHWRD 192 \\
\hline AHW & 77 & 15.0 & $08-14-84$ & -- & -- & H & 6.00 & -- & -- & -- & NHWRD 541 \\
\hline AHW & 78 & -- & -- & -- & -- & H & 8.50 & -- & -- & 1.0 & NHWRD 90 \\
\hline AHW & 79 & -- & -- & -- & -- & $\mathrm{H}$ & 3.00 & -- & -- & .3 & NHWRD 3 \\
\hline
\end{tabular}


Table A-1. Description of selected wells, borings, and springs in the Winnipesaukee River Basin, central New Hampshire

\begin{tabular}{|c|c|c|c|c|c|c|c|c|c|c|}
\hline $\begin{array}{l}\text { Local } \\
\text { site } \\
\text { number }\end{array}$ & $\begin{array}{l}\text { Lat- } \\
\text { itude }\end{array}$ & $\begin{array}{l}\text { Long- } \\
\text { itude }\end{array}$ & Owner or user & $\begin{array}{c}\text { Date } \\
\text { of } \\
\text { con- } \\
\text { struction }\end{array}$ & $\begin{array}{c}\text { Ele- } \\
\text { vat- } \\
\text { tion } \\
\text { (feet) }\end{array}$ & $\begin{array}{c}\text { Diameter } \\
\text { of } \\
\text { casing } \\
\text { (inches) }\end{array}$ & $\begin{array}{l}\text { Depth to } \\
\text { bottom } \\
\text { of casing } \\
\text { (feet) }\end{array}$ & $\begin{array}{c}\text { Casing } \\
\text { mater- } \\
\text { ial }\end{array}$ & $\begin{array}{c}\text { Type } \\
\text { of } \\
\text { fin- } \\
\text { ish }\end{array}$ & $\begin{array}{c}\text { Type } \\
\text { of } \\
\text { site }\end{array}$ \\
\hline
\end{tabular}

BELKNAP COUNTY

\begin{tabular}{|c|c|c|c|c|c|c|c|c|c|c|c|}
\hline \multirow[b]{2}{*}{ AHW } & \multicolumn{11}{|c|}{ Alton-Continued } \\
\hline & 83 & 432549 & 0711458 & Alden Jr. & $10-29-84$ & 660 & -- & 41.0 & -- & $\mathrm{x}$ & BrW \\
\hline AHW & 92 & 433205 & 0711121 & True, G. & $05-12-84$ & 710 & -- & 74.0 & -- & $\mathrm{x}$ & BrW \\
\hline AHW & 94 & 433018 & 0711506 & Niconchuk, A. & $02-18-84$ & 530 & -- & 20.0 & -- & $\mathrm{x}$ & BrW \\
\hline AHW & 97 & 432536 & 0711233 & Barbarosa, s. & $12-21-84$ & 540 & -- & 30.0 & -- & $\mathrm{x}$ & $\mathrm{BrW}$ \\
\hline AHW & 99 & 433038 & 0711451 & Tanguay, R. & $06-19-84$ & 570 & -- & 11.0 & -- & $\mathrm{x}$ & $\mathrm{BrW}$ \\
\hline AHW & 100 & 432510 & 0711235 & Tuck, J. & $08-07-84$ & 540 & -- & 134 & -- & $\mathrm{x}$ & BrW \\
\hline AHW & 101 & 432512 & 0711219 & Lamper, $\mathrm{F}$. & $01-05-85$ & 560 & -- & 57.0 & -- & -- & -- \\
\hline AHW & 107 & 432628 & 0711231 & Carr, D. & $05-08-85$ & 570 & -- & -- & -- & $\mathrm{x}$ & Brw \\
\hline AHW & 119 & 432513 & 0711239 & Morse, D. & $06-28-85$ & 540 & -- & 1.0 & -- & - & Dug \\
\hline AHW & 123 & 432919 & 0711455 & Sanborn, S. & $07-26-85$ & 550 & -- & 62.0 & -- & $x$ & BrW \\
\hline AHW & 126 & 432537 & 0711449 & Crampoli, A. & $09-11-85$ & 620 & -- & 13.0 & -- & $\mathrm{x}$ & Brw \\
\hline AHW & 131 & 432951 & 0711531 & Bourgault & $03-06-86$ & 520 & -- & 51.0 & -- & $\mathrm{x}$ & BrW \\
\hline AHW & 142 & 433009 & 0711445 & Saunders, R. & $04-20-86$ & 540 & -- & 84.0 & -- & $\mathrm{x}$ & $\mathrm{BrW}$ \\
\hline AHW & 144 & 432558 & 0711227 & Chapman, C. & $05-07-86$ & 570 & -- & 39.0 & -- & $\mathrm{x}$ & $\mathrm{BrW}$ \\
\hline AHW & 175 & 432522 & 0711339 & Barrett, A. & $06-20-87$ & 580 & -- & 45.0 & -- & $\mathrm{x}$ & BrW \\
\hline AHW & 189 & 432835 & 0711402 & Roberts, E. & $11-06-86$ & 520 & -- & 51.0 & -- & $\mathrm{x}$ & BrW \\
\hline AHW & 190 & 432940 & 0711522 & Burke, M. & $08-22-86$ & 560 & -- & 50.0 & -- & $\mathrm{x}$ & $\mathrm{BrW}$ \\
\hline AHW & 196 & 432643 & 0711143 & Moore, $\mathrm{K}$. & $08-14-87$ & 620 & -- & 22.0 & -- & $\mathrm{x}$ & Brw \\
\hline AHW & 206 & 432937 & 0711520 & Bill, K. & $11-08-87$ & 550 & -- & 27.0 & -- & $x$ & BrW \\
\hline AHW & 211 & 432916 & 0711453 & Bristol, D. & $10-19-87$ & 560 & -- & 71.0 & -- & $\mathrm{x}$ & $\mathrm{BrW}$ \\
\hline AHW & 213 & 432509 & 0711224 & Stevens, C. & $05-21-87$ & 540 & -- & 69.0 & -- & $\mathrm{x}$ & $\mathrm{BrW}$ \\
\hline AHW & 228 & 433257 & 0711818 & Benard, R. & $05-07-87$ & 515 & -- & 59.0 & -- & $\mathrm{x}$ & BrW \\
\hline AHW & 243 & 432922 & 0711504 & Young, w. & $06-19-88$ & 520 & -- & 34.0 & -- & $x$ & $\mathrm{BrW}$ \\
\hline AHW & 244 & 433007 & 0711446 & Davis, R. & $06-27-88$ & 520 & -- & 39.0 & -- & $\mathrm{x}$ & $\mathrm{BrW}$ \\
\hline AHW & 245 & 432952 & 0711548 & Bates, B. & $07-01-88$ & 530 & -- & 40.0 & -- & $\mathrm{x}$ & $\mathrm{BrW}$ \\
\hline AHW & 254 & 432644 & 0711224 & Huss, $s$. & $06-17-88$ & 530 & -- & 61.0 & -- & $\mathrm{x}$ & $\mathrm{BrW}$ \\
\hline AHW & 262 & 433242 & 0711203 & Tyler, M. & $08-29-88$ & 640 & -- & 100 & -- & $\mathrm{x}$ & $\mathrm{BrW}$ \\
\hline AHW & 264 & 432909 & 0711508 & Lomband, L. & $09-02-88$ & 580 & -- & 59.0 & -- & $\mathrm{x}$ & $\mathrm{BrW}$ \\
\hline AHW & 265 & 432909 & 0711510 & Nickerson, G. & $09-26-88$ & 590 & -- & 23.0 & -- & $\mathrm{x}$ & $\mathrm{BrW}$ \\
\hline AHW & 266 & 432336 & 0711259 & Miele, J. & $11-29-88$ & 660 & -- & 73.0 & -- & $\mathrm{x}$ & Brw \\
\hline AHW & 277 & 432537 & 0711219 & Northern Land Traders & $12-07-88$ & 540 & -- & 86.0 & -- & $\mathrm{x}$ & BrW \\
\hline AHW & 281 & 432942 & 0711517 & Larsen & $11-20-87$ & 540 & -- & 83.0 & -- & $\mathrm{x}$ & $\mathrm{BrW}$ \\
\hline AHW & 282 & 432939 & 0711513 & TDF Corp & $02-01-88$ & 530 & -- & 69.0 & -- & $\mathrm{x}$ & BrW \\
\hline AHW & 283 & 432937 & 0711514 & Greer & $02-02-88$ & 520 & -- & 66.0 & -- & $\mathrm{x}$ & $\mathrm{BrW}$ \\
\hline AHW & 284 & 432940 & 0711517 & TDF Corp & $01-31-88$ & 540 & -- & 99.0 & -- & $\mathrm{x}$ & BrW \\
\hline AHW & 291 & 433020 & 0711429 & Webb, w. & $04-12-89$ & 590 & -- & 39.0 & -- & $\mathrm{x}$ & BrW \\
\hline AHW & 292 & 433018 & 0711436 & Kidney, $c$. & $04-10-89$ & 580 & -- & 39.0 & -- & $\mathrm{x}$ & BrW \\
\hline AHW & 293 & 433019 & 0711431 & Gray, N. & $04-06-89$ & 590 & -- & 39.0 & -- & $\mathrm{x}$ & BrW \\
\hline AHW & 294 & 432521 & 0711345 & Gussman & $12-14-88$ & 580 & -- & 42.0 & -- & $\mathrm{x}$ & BrW \\
\hline AHW & 295 & 433007 & 0711440 & Lundy, F. & $05-22-89$ & 560 & -- & 66.0 & -- & $\mathrm{x}$ & BrW \\
\hline AHW & 297 & 432916 & 0711459 & Anctil, B. & $06-16-89$ & 540 & -- & 69.0 & -- & $\mathbf{x}$ & BrW \\
\hline AHW & 306 & 433147 & 0711141 & \& L. Clifford, P. & $08-29-89$ & 660 & -- & 39.0 & -- & $\mathbf{x}$ & BrW \\
\hline AHW & 309 & 433021 & 0711439 & Harris, $w$. & $07-24-89$ & 570 & -- & 39.0 & -- & $\mathrm{x}$ & BrW \\
\hline AHW & 311 & 432530 & 0711417 & Portique, $\mathrm{H}$. & $06-04-89$ & 580 & -- & 25.0 & -- & $\mathrm{x}$ & Brw \\
\hline AHW & 313 & 432520 & 0711334 & Zerro, J. & $10-12-89$ & 580 & -- & 34.0 & -- & $\mathrm{x}$ & $\mathrm{BrW}$ \\
\hline AHW & 321 & 432559 & 0711229 & Cornelissen, M. & $12-07-89$ & 580 & -- & 59.0 & -- & $\mathrm{x}$ & BrW \\
\hline AHW & 327 & 432915 & 0711502 & Stark, R. & $03-27-90$ & 530 & -- & 80.0 & -- & $\mathrm{x}$ & $\mathrm{BrW}$ \\
\hline AHW & 334 & 432957 & 0711535 & Morse, F. & $06-07-90$ & 520 & -- & 49.0 & -- & $\mathrm{x}$ & Brw \\
\hline AHW & 340 & 432522 & 0711351 & Hunter, S. & $08-10-90$ & 590 & -- & 19.0 & -- & $\mathrm{x}$ & Brw \\
\hline AHW & 350 & 433030 & 0711553 & Royhall, J. & $06-03-90$ & 540 & -- & 43.0 & -- & $\mathrm{x}$ & BrW \\
\hline AHW & 357 & 432835 & 0711429 & Newton, $\mathrm{H}$. & $10-07-90$ & 530 & -- & 20.0 & -- & $\mathrm{x}$ & $\mathrm{BrW}$ \\
\hline AHW & 361 & 433028 & 0711437 & Jones, B. & $10-04-90$ & 580 & -- & 39.0 & -- & $\mathrm{x}$ & BrW \\
\hline AHW & 362 & 433026 & 0711436 & Boody, L. & $10-08-90$ & 580 & -- & 49.0 & -- & $\mathrm{x}$ & $\mathrm{BrW}$ \\
\hline AHW & 364 & 432452 & 0711218 & Dube, J. & $01-18-91$ & 600 & -- & 124 & -- & $\mathrm{x}$ & $\mathrm{BrW}$ \\
\hline
\end{tabular}




\begin{tabular}{|c|c|c|c|c|c|c|c|c|c|c|}
\hline \multirow{2}{*}{$\begin{array}{l}\text { Local } \\
\text { site } \\
\text { number }\end{array}$} & \multicolumn{2}{|c|}{ Water level } & \multirow{2}{*}{$\begin{array}{l}\text { Top of } \\
\text { screen } \\
\text { (feet) }\end{array}$} & \multirow{2}{*}{$\begin{array}{c}\text { Bottom of } \\
\text { screen } \\
\text { (feet) }\end{array}$} & \multirow{2}{*}{$\begin{array}{c}\text { Use } \\
\text { of } \\
\text { water }\end{array}$} & \multirow[b]{2}{*}{$\begin{array}{c}\text { Yieid } \\
\text { (gal/min) }\end{array}$} & \multirow[b]{2}{*}{$\begin{array}{l}\text { Drawdown } \\
\text { (feet) }\end{array}$} & \multirow[b]{2}{*}{$\begin{array}{l}\text { Specific } \\
\text { capacity }\end{array}$} & \multirow{2}{*}{$\begin{array}{l}\text { Pumping } \\
\text { period } \\
\text { (hours) }\end{array}$} & \multirow{2}{*}{$\begin{array}{l}\text { Driller } \\
\text { or NHWRD } \\
\text { number }\end{array}$} \\
\hline & $\begin{array}{l}\text { Depth } \\
\text { (feet) }\end{array}$ & $\begin{array}{c}\text { Date } \\
\text { (mm-dd-yy) }\end{array}$ & & & & & & & & \\
\hline
\end{tabular}

\section{BELKNAP COUNTY}

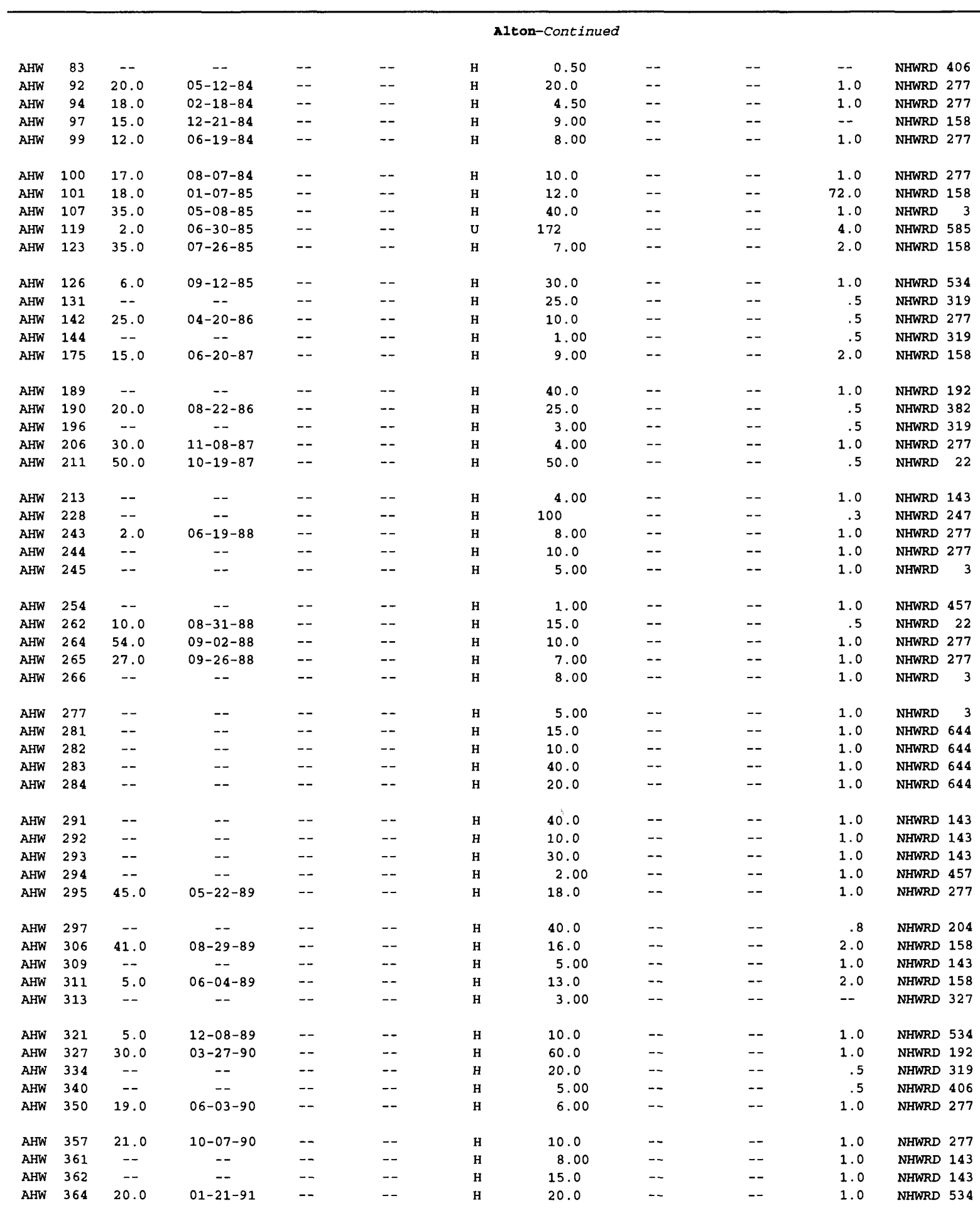


Table A-1. Description of selected wells, borings, and springs in the Winnipesaukee River Basin, central New Hampshire

\begin{tabular}{|c|c|c|c|c|c|c|c|c|c|c|}
\hline $\begin{array}{l}\text { Locai } \\
\text { site } \\
\text { number }\end{array}$ & $\begin{array}{l}\text { Lat- } \\
\text { itude }\end{array}$ & $\begin{array}{l}\text { Long- } \\
\text { itude }\end{array}$ & Owner or user & $\begin{array}{c}\text { Date } \\
\text { of } \\
\text { con- } \\
\text { struction }\end{array}$ & $\begin{array}{c}\text { Eie- } \\
\text { vat- } \\
\text { tion } \\
\text { (feet) }\end{array}$ & $\begin{array}{c}\text { Diameter } \\
\text { of } \\
\text { casing } \\
\text { (inches) }\end{array}$ & $\begin{array}{l}\text { Depth to } \\
\text { bottom } \\
\text { of casing } \\
\text { (feet) }\end{array}$ & $\begin{array}{c}\text { Casing } \\
\text { mater- } \\
\text { iai }\end{array}$ & $\begin{array}{c}\text { Type } \\
\text { of } \\
\text { fin- } \\
\text { ish }\end{array}$ & $\begin{array}{c}\text { Type } \\
\text { of } \\
\text { site }\end{array}$ \\
\hline
\end{tabular}

\section{BELKNAP COUNTY}

\begin{tabular}{|c|c|c|c|c|c|c|c|c|c|c|c|}
\hline \multirow[b]{2}{*}{ AHW } & \multicolumn{11}{|c|}{ alton-Continued } \\
\hline & 369 & 432652 & 0711258 & Alton Sand and Gravel & $10-07-91$ & 525 & 2 & 35 & $\mathbf{P}$ & $\mathrm{s}$ & Bor \\
\hline AHW & 370 & 432600 & 0711105 & Duncan, Rick (contact) & $10-08-91$ & 530 & 2 & 40 & $\mathbf{P}$ & s & Bor \\
\hline \multicolumn{12}{|c|}{ Belmont } \\
\hline BLA & 26 & 432603 & 0712902 & Parent, L. & $03-\quad-88$ & 532.1 & -- & -- & -- & -- & $\mathrm{TH}$ \\
\hline BLAA & 27 & 432601 & 0712900 & Parent, L. & $03-\quad-88$ & 522.2 & -- & -- & -- & -- & $\mathrm{TH}$ \\
\hline BLA & 28 & 432557 & 0712855 & Parent, L. & $03-\quad-88$ & 551.2 & -- & -- & -- & -- & $\mathbf{T H}$ \\
\hline BLA & 29 & 432608 & 0712909 & Parent, L & $11-08-88$ & 516 & -- & -- & -- & -- & Bor \\
\hline BLA & 30 & 432710 & 0712837 & Beapre, Richard & $04-13-92$ & 645 & -- & -- & -- & -- & Bor \\
\hline BLAA & 31 & 432705 & 0712829 & Beapre, Richard & $04-13-92$ & 610 & -- & -- & -- & -- & Bor \\
\hline BLA & 32 & 432725 & 0712724 & New Hampshire, state of & $04-13-92$ & 680 & $\cdots$ & -- & -- & -- & Bor \\
\hline BLB & 26 & 432612 & 0713108 & -- & -- & 512 & -- & -- & -- & -- & Bor \\
\hline BLB & 27 & 432704 & 0712815 & -- & -- & 565 & -- & $\cdots$ & -- & -- & Bor \\
\hline BLB & 28 & 433006 & 0713038 & -- & -- & 482.0 & -- & -- & -- & -- & $\mathrm{TH}$ \\
\hline BLW & 13 & 432611 & 0712912 & Belmont, Town of & $08-\quad-38$ & 520 & -- & -- & -- & $\mathrm{s}$ & -- \\
\hline BLW & 28 & 432611 & 0712920 & Belmont, Town of & $--\quad-71$ & 500 & 12 & 52.7 & $\mathbf{P}$ & $G$ & -- \\
\hline BLW & 29 & 432540 & 0712847 & Nutter & $06-02-67$ & 550 & 8 & 63 & $\mathbf{s}$ & $\mathbf{s}$ & -- \\
\hline BLW & 30 & 432549 & 0712847 & Belmont, Town of & $01-07-69$ & 515 & -- & -- & -- & $\mathrm{s}$ & -- \\
\hline BLW & 31 & 432549 & 0712835 & Belmont, Town of & $01-09-69$ & 510 & -- & -- & -- & $\mathrm{s}$ & -- \\
\hline BLW & 76 & 432739 & 0712949 & -- & -- & 610 & -- & -- & -- & -- & -- \\
\hline BLW & 77 & 432744 & 0712953 & Belmont Landfill & $12-24-86$ & 572 & -- & -- & -- & $\mathrm{s}$ & -- \\
\hline BLW & 78 & 432744 & 0712947 & Belmont Landfill & $12-24-86$ & 573 & -- & -- & -- & $s$ & -- \\
\hline BLW & 79 & 432741 & 0712944 & Belmont Landfill & $12-22-86$ & 573 & -- & -- & -- & $s$ & -- \\
\hline BLW & 80 & 432719 & 0713205 & Bardwel1, Ray & $09-11-90$ & 470 & 2 & 76.5 & $\mathbf{P}$ & $s$ & Bor \\
\hline BLW & 81 & 432836 & 0713104 & Dejaeger, Peter & $08-02-90$ & 500 & 2 & 76.5 & $\mathbf{P}$ & $s$ & Bor \\
\hline BLW & 82 & 432638 & 0712941 & Weeks, Everett & $08-01-90$ & 480 & 2 & 24.5 & $\mathbf{P}$ & $\mathrm{s}$ & Bor \\
\hline BLW & 83 & 432647 & 0713134 & USGS -- NH Route 140 & $09-12-90$ & 500 & 2 & 80 & $\mathbf{P}$ & $\mathbf{s}$ & Bor \\
\hline BLW & 84 & 432556 & 0712851 & Parent Bros. & $10-17-90$ & 540 & 2 & 57.5 & $\mathbf{P}$ & $\mathrm{s}$ & Bor \\
\hline BLW & 85 & 433007 & 0712654 & Mooney, Mark & $09-13-90$ & 665 & 2 & 47.5 & $\mathbf{P}$ & $\mathbf{s}$ & Bor \\
\hline BLW & 86 & 432613 & 0712921 & Belmont, Town of & $05-06-91$ & 510 & 2 & 57.5 & $\mathbf{P}$ & $\mathbf{s}$ & Bor \\
\hline BLW & 87 & 432608 & 0712910 & Parent, L. & $11-08-88$ & 509 & 2 & 18.9 & $\mathbf{P}$ & $\mathbf{s}$ & Bor \\
\hline BLW & 88 & 432609 & 0712909 & Parent, L. & $11-08-88$ & 516 & 2 & 21.2 & $\mathbf{P}$ & $\mathrm{s}$ & Bor \\
\hline BLW & 89 & 432610 & 0712909 & Parent, L. & $11-08-88$ & 517 & 2 & 25.6 & $\mathbf{P}$ & $\mathbf{s}$ & Bor \\
\hline BLW & 90 & 432608 & 0712908 & Parent, L. & $11-08-88$ & 517 & 2 & 25.9 & $\mathbf{P}$ & $\mathrm{s}$ & Bor \\
\hline BLW & 91 & 432553 & 0712804 & Wilson, Leo & -- & 555 & -- & -- & -- & w & Dug \\
\hline BLW & 92 & 432655 & 0712808 & Clairmont, Lawrence & -- & 625 & -- & -- & -- & W & Dug \\
\hline BLW & 93 & 432733 & 0712957 & Duggan Construction & $07-23-91$ & 590 & 2 & 40 & $\mathbf{P}$ & $\mathbf{s}$ & Bor \\
\hline BLW & 94 & 432933 & 0713023 & Dionne, $\mathrm{R}$ & $07-18-84$ & 500 & -- & 79.0 & -- & -- & -- \\
\hline BLW & 95 & 433013 & 0713029 & Parkinson & $02-17-84$ & 490 & -- & 154 & -- & $\mathrm{x}$ & BrW \\
\hline BLW & 96 & 432834 & 0713039 & Drouin Bldrs & $02-29-84$ & 500 & -- & 73.0 & -- & $\mathrm{x}$ & BrW \\
\hline BLW & 99 & 433019 & 0713015 & Gallant & $05-24-84$ & 520 & -- & 100 & -- & $\mathrm{x}$ & BrW \\
\hline BLW & 100 & 432725 & 0712808 & Fullerton & $04-17-84$ & 600 & -- & 29.0 & -- & $\mathrm{x}$ & $\mathrm{BrW}$ \\
\hline BLW & 103 & 432815 & 0712529 & Drouin Bldrs & $06-12-84$ & 820 & -- & 59.0 & -- & $\mathrm{x}$ & $\mathrm{BrW}$ \\
\hline$B L W$ & 104 & 432735 & 0712721 & Lauriel & $07-25-84$ & 660 & -- & 51.0 & -- & $\mathrm{x}$ & Brw \\
\hline BLW & 105 & 432933 & 0713019 & Letourneau & $07-20-84$ & 500 & -- & 99.0 & -- & $\mathrm{x}$ & $\mathrm{BrW}$ \\
\hline BLW & 106 & 432933 & 0713017 & $O^{\prime}$ Keefe & $07-12-84$ & 500 & -- & 64.0 & -- & $\mathrm{x}$ & $\mathrm{BrW}$ \\
\hline BLW & 107 & 432754 & 0713013 & Gilman & $07-14-84$ & 660 & -- & 29.0 & -- & $\mathrm{x}$ & $\mathrm{BrW}$ \\
\hline BLW & 110 & 432933 & 0713021 & Drouin Bldrs & $11-21-84$ & 500 & -- & 99.0 & -- & $\mathrm{x}$ & $\mathrm{BrW}$ \\
\hline BLW & 112 & 432742 & 0712836 & Stewart, A. & $08-28-84$ & 680 & -- & 39.0 & -- & $\mathrm{x}$ & $\mathrm{BrW}$ \\
\hline BLW & 113 & 432857 & 0712502 & Reynolds, T. & $03-26-85$ & 820 & -- & 19.0 & -- & $\mathrm{x}$ & BrW \\
\hline BLW & 114 & 432735 & 0712756 & Jezak, W. & $04-15-85$ & 640 & -- & 39.0 & -- & $\mathrm{x}$ & BrW \\
\hline BLW & 116 & 432739 & 0712753 & Jusczak, W. & $09-25-85$ & 670 & -- & 61.0 & -- & $\mathrm{x}$ & BrW \\
\hline
\end{tabular}




\begin{tabular}{|c|c|c|c|c|c|c|c|c|c|c|}
\hline \multirow{2}{*}{$\begin{array}{l}\text { Locai } \\
\text { site } \\
\text { number }\end{array}$} & \multicolumn{2}{|c|}{ Water levei } & \multirow{2}{*}{$\begin{array}{l}\text { Top of } \\
\text { screen } \\
\text { (feet) }\end{array}$} & \multirow{2}{*}{$\begin{array}{c}\text { Bottom of } \\
\text { screen } \\
\text { (feet) }\end{array}$} & \multirow{2}{*}{$\begin{array}{c}\text { Use } \\
\text { of } \\
\text { water }\end{array}$} & \multirow[b]{2}{*}{$\begin{array}{c}\text { Yieid } \\
\text { (gal/min) }\end{array}$} & \multirow[b]{2}{*}{$\begin{array}{l}\text { Drawdown } \\
\text { (feet) }\end{array}$} & \multirow[b]{2}{*}{$\begin{array}{l}\text { Specific } \\
\text { capacity }\end{array}$} & \multirow{2}{*}{$\begin{array}{l}\text { Pumping } \\
\text { period } \\
\text { (hours) }\end{array}$} & \multirow{2}{*}{$\begin{array}{l}\text { Driiier } \\
\text { or NHWRD } \\
\text { number }\end{array}$} \\
\hline & $\begin{array}{l}\text { Depth } \\
\text { (feet) }\end{array}$ & $\begin{array}{c}\text { Date } \\
\text { (mm-dd-yy) }\end{array}$ & & & & & & & & \\
\hline
\end{tabular}

BELKNAP COUNTY

\begin{tabular}{|c|c|c|c|c|c|c|c|c|c|c|c|c|}
\hline \multirow[b]{2}{*}{ AHW } & \multirow[b]{2}{*}{369} & \multicolumn{11}{|c|}{ A1ton-Continued } \\
\hline & & 3.1 & $10-07-91$ & 32.5 & 35 & $\mathrm{U}$ & -- & -- & -- & -- & USGS & \\
\hline AHW & 370 & 6 & $10-17-91$ & 37.5 & 40 & $\mathrm{u}$ & -- & -- & -- & -- & USGS & \\
\hline \multicolumn{13}{|c|}{ Belmont } \\
\hline BLA & 26 & 24.2 & $03-\quad-88$ & -- & - & -- & -- & -- & -- & -- & -- & \\
\hline BLA & 27 & 19.1 & $03-\quad-88$ & -- & -- & -- & -- & -- & -- & -- & -- & \\
\hline BLA & 28 & -- & -- & - & -- & -- & -- & -- & -- & -- & -- & \\
\hline BLA & 29 & -- & -- & -- & -- & $\mathbf{u}$ & -- & -- & -- & -- & Aries & Engineer \\
\hline BLA & 30 & 13 & $04-13-92$ & -- & -- & $\mathbf{u}$ & -- & -- & -- & -- & USGS & \\
\hline BLA & 31 & 3 & $04-13-92$ & -- & -- & $\mathbf{u}$ & -- & -- & -- & -- & USGS & \\
\hline BLA & 32 & 6 & $04-13-92$ & -- & -- & $\mathbf{u}$ & -- & -- & -- & -- & USGS & \\
\hline BLB & 26 & -- & -- & -- & -- & -- & -- & -- & -- & -- & NHDOT & \\
\hline BLB & 27 & -- & -- & -- & -- & -- & -- & -- & - & -- & NHDOT & \\
\hline BLB & 28 & -- & -- & -- & -- & $\mathbf{U}$ & -- & -- & -- & -- & -- & \\
\hline BLW & 13 & 14 & $10-23-49$ & -- & -- & $P$ & 350 & 5 & -- & 4 & Layme-1 & -Bowler \\
\hline BLW & 28 & 8.1 & $--\quad-71$ & 53 & 68 & $\mathbf{P}$ & -- & -- & -- & -- & Lauman & $\mathrm{co}$ \\
\hline BLW & 29 & 8 & $06-02-67$ & 63 & 73 & $\mathbf{u}$ & 440 & 38 & -- & 84 & LAYNE & N.E. \\
\hline BLW & 30 & 15.1 & $01-07-69$ & 41 & 46 & U & 40 & 2.3 & -- & 3 & Layne 1 & N.E. \\
\hline BLW & 31 & 6 & $01-09-69$ & 41 & 46 & $\mathrm{U}$ & 20 & 7 & -- & 1 & Layme 1 & N.E. \\
\hline BLW & 76 & 51.8 & $01-20-87$ & -- & - & -- & -- & -- & -- & -- & -- & \\
\hline BLW & 77 & .4 & $01-27-87$ & -- & -- & -- & -- & -- & -- & -- & Maine & Test \\
\hline BLW & 78 & .49 & $01-27-87$ & -- & -- & -- & -- & -- & -- & -- & Maine & Test \\
\hline BLW & 79 & 1.42 & $01-27-87$ & -- & -- & -- & -- & -- & -- & -- & Maine & Test \\
\hline BLW & 80 & 3.54 & $01-01-93$ & 80 & 82.5 & U & -- & -- & -- & -- & USGS & \\
\hline BLW & 81 & 12.8 & $07-02-91$ & 76.5 & 79.0 & $\mathrm{u}$ & -- & -- & -- & -- & USGS & \\
\hline BLW & 82 & 6.04 & $07-02-91$ & 24.5 & 27 & $\mathrm{U}$ & -- & -- & -- & -- & USGS & \\
\hline BLW & 83 & 5.25 & $07-02-91$ & 77.5 & 80 & $\mathrm{u}$ & -- & -- & -- & -- & USGS & \\
\hline BLW & 84 & 30.1 & $07-02-91$ & 57.5 & 60 & $\mathrm{U}$ & - & -- & -- & -- & USGS & \\
\hline BLW & 85 & 31.2 & $07-02-91$ & 47.5 & 50 & $\mathrm{U}$ & -- & -- & -- & -- & USGS & \\
\hline BLW & 86 & 12.2 & $08-21-91$ & 55.0 & 57.5 & $\mathrm{U}$ & -- & -- & -- & -- & USGS & \\
\hline BLW & 87 & 10.9 & $11-10-88$ & 8.9 & 18.9 & $\mathrm{U}$ & -- & -- & -- & -- & Aries & Engineer \\
\hline BLW & 88 & 16.2 & $11-10-88$ & 11.2 & 21.2 & $\mathrm{U}$ & -- & -- & -- & -- & Aries & Engineer \\
\hline BLW & 89 & 18 & $11-10-88$ & 15.6 & 25.6 & $\mathrm{U}$ & -- & -- & -- & -- & Aries & Engineer \\
\hline BLW & 90 & 17.8 & $11-10-88$ & 15.9 & 25.9 & $\mathrm{U}$ & -- & -- & -- & -- & Aries & Engineer \\
\hline BLW & 91 & 17.3 & $06-12-91$ & -- & -- & $\mathrm{H}$ & -- & -- & -- & -- & Nutter & \\
\hline BLW & 92 & 9.8 & $06-12-91$ & -- & -- & $\mathrm{H}$ & -- & -- & - & -- & -- & \\
\hline BLW & 93 & 15 & $07-23-91$ & 37 & 40 & $\mathbf{u}$ & -- & -- & -- & -- & USGS & \\
\hline BLW & 94 & -- & -- & - & $\cdots$ & $\mathrm{H}$ & 50.0 & -- & -- & .5 & NHWRD & 319 \\
\hline BLW & 95 & 10.0 & $02-17-84$ & -- & -- & $\mathrm{H}$ & 7.00 & -- & -- & 2.0 & NHWRD & 192 \\
\hline BLW & 96 & -- & -- & -- & -- & $\mathrm{H}$ & 4.00 & -- & -- & 1.0 & NHWRD & 319 \\
\hline BLW & 99 & -- & -- & -- & -- & $\mathrm{H}$ & 1.00 & -- & -- & 1.0 & NHWRD & 3 \\
\hline BLW & 100 & 6.0 & $04-17-84$ & -- & -- & $\mathrm{H}$ & 7.00 & -- & -- & .3 & NHWRD & 13 \\
\hline BLW & 103 & -- & -- & -- & -- & $\mathrm{H}$ & -- & -- & -- & -- & NHWRD & 319 \\
\hline BLW & 104 & -- & -- & -- & -- & $\mathrm{H}$ & 7.00 & -- & -- & .5 & NHWRD & 319 \\
\hline BLW & 105 & -- & -- & -- & -- & $\mathrm{H}$ & 3.00 & -- & -- & .5 & NHWRD & 319 \\
\hline BLW & 106 & -- & -- & -- & -- & $\mathrm{H}$ & 3.00 & -- & -- & .5 & NHWRD & 319 \\
\hline BLW & 107 & -- & -- & -- & -- & $\mathrm{H}$ & 2.00 & -- & -- & .5 & NHWRD & 319 \\
\hline BLW & 110 & -- & -- & -- & -- & $\mathrm{H}$ & 50.0 & -- & -- & .5 & NHWRD & 319 \\
\hline BLW & 112 & -- & -- & -- & -- & $\mathrm{H}$ & 20.0 & -- & -- & .5 & NHWRD & 247 \\
\hline BLW & 113 & - & -- & -- & -- & $\mathrm{H}$ & 8.00 & -- & -- & -- & NHWRD & 319 \\
\hline BLW & 114 & -- & -- & -- & -- & $\mathrm{H}$ & 25.0 & -- & -- & .5 & NHWRD & 319 \\
\hline BLW & 116 & -- & -- & - & -- & $\mathrm{H}$ & 6.00 & -- & -- & .5 & NHWRD & 319 \\
\hline
\end{tabular}


Table A-1. Description of selected wells, borings, and springs in the Winnipesaukee River Basin, central New Hampshire

\begin{tabular}{|c|c|c|c|c|c|c|c|c|c|c|}
\hline $\begin{array}{l}\text { Local } \\
\text { site } \\
\text { number }\end{array}$ & $\begin{array}{l}\text { Lat- } \\
\text { itude }\end{array}$ & $\begin{array}{l}\text { Long- } \\
\text { itude }\end{array}$ & Owner or user & $\begin{array}{c}\text { Date } \\
\text { of } \\
\text { con- } \\
\text { struction }\end{array}$ & $\begin{array}{l}\text { Ele- } \\
\text { vat- } \\
\text { tion } \\
\text { (feet) }\end{array}$ & $\begin{array}{c}\text { Diameter } \\
\text { of } \\
\text { casing } \\
\text { (inches) }\end{array}$ & $\begin{array}{l}\text { Depth to } \\
\text { bottom } \\
\text { of casing } \\
\text { (feet) }\end{array}$ & $\begin{array}{c}\text { Casing } \\
\text { mater- } \\
\text { ial }\end{array}$ & $\begin{array}{c}\text { Type } \\
\text { of } \\
\text { fin- } \\
\text { ish }\end{array}$ & $\begin{array}{c}\text { Type } \\
\text { of } \\
\text { site }\end{array}$ \\
\hline
\end{tabular}

BELKNAP COUNTY

\begin{tabular}{|c|c|c|c|c|c|c|c|c|c|c|c|}
\hline \multirow[b]{2}{*}{ BLW } & \multicolumn{11}{|c|}{ Belmont-Cont inued } \\
\hline & 120 & 432938 & 0713001 & Sutton, J. & $10-22-85$ & 540 & -- & 20.0 & -- & $\mathrm{x}$ & BrW \\
\hline BLW & 122 & 432735 & 0712734 & Fortin, $\mathrm{J}$. & $08-06-85$ & 640 & -- & 39.0 & -- & $\mathrm{x}$ & $\mathrm{BrW}$ \\
\hline BLW & 123 & 432932 & 0713023 & Drouin Bldrs & $08-15-85$ & 500 & -- & 79.0 & -- & $\mathrm{x}$ & BrW \\
\hline BLW & 124 & 432653 & 0713050 & Weeks & $08-16-85$ & 520 & -- & 67.0 & -- & $\mathrm{x}$ & $\mathrm{BrW}$ \\
\hline BLW & 125 & 432922 & 0713021 & Mallards Landing Assoc & $07-18-85$ & 500 & -- & 119 & -- & $\mathrm{x}$ & $\mathrm{BrW}$ \\
\hline BLW & 126 & 432923 & 0713021 & Mallards Landing Assoc & $07-16-85$ & 500 & -- & 140 & -- & $\mathrm{x}$ & $\mathrm{BrW}$ \\
\hline BLW & 127 & 432738 & 0713216 & Poulin, R. & $10-03-85$ & 470 & -- & 19.0 & -- & $\mathrm{x}$ & $\mathrm{BrW}$ \\
\hline BLW & 130 & 432556 & 0712919 & Dalton, F. & $09-19-85$ & 580 & -- & 29.0 & -- & $\mathrm{x}$ & $\mathrm{BrW}$ \\
\hline BLW & 131 & 432932 & 0713017 & Drouin Bldrs & $05-10-85$ & 500 & -- & 94.0 & -- & $\mathrm{x}$ & $\mathrm{BrW}$ \\
\hline BLW & 132 & 432931 & 0713019 & Drouin Bldrs & $05-14-85$ & 500 & -- & 99.0 & -- & $\mathrm{x}$ & $\mathrm{BrW}$ \\
\hline BLW & 135 & 432904 & 0713037 & Northland Devel & $06-27-85$ & 520 & -- & 26.0 & -- & $\mathrm{x}$ & BrW \\
\hline BLW & 138 & 432734 & 0712753 & Lakewood Devel Corp & $07-24-85$ & 630 & -- & 40.0 & -- & $\mathrm{x}$ & $\mathrm{BrW}$ \\
\hline BLW & 139 & 432731 & 0712705 & Salta, B. & $07-15-85$ & 720 & -- & 30.0 & -- & $\mathrm{x}$ & BrW \\
\hline BLW & 140 & 432732 & 0712708 & Brough, N. & $08-12-85$ & 710 & -- & 40.0 & -- & $\mathrm{x}$ & $\mathrm{BrW}$ \\
\hline BLW & 141 & 432730 & 0712658 & GN Const & $01-03-86$ & 750 & -- & 20.0 & -- & $\mathrm{x}$ & BrW \\
\hline BLW & 146 & 432733 & 0712701 & Zielski, D. & $04-10-86$ & 740 & -- & 29.0 & -- & $\mathrm{x}$ & BrW \\
\hline BLW & 147 & 432947 & 0713048 & Parris, E. & $12-01-85$ & 485 & -- & 117 & -- & $\mathrm{x}$ & $\mathrm{BrW}$ \\
\hline BLW & 150 & 432711 & 0712843 & Woundy, B. & $12-01-85$ & 640 & -- & 51.0 & -- & $\mathrm{x}$ & $\mathrm{BrW}$ \\
\hline BLW & 151 & 432731 & 0712815 & Audet, P. & $12-01-85$ & 640 & -- & 63.0 & -- & $\mathrm{x}$ & $\mathrm{BrW}$ \\
\hline BLW & 157 & 432719 & 0712829 & Seigel, R. & $11-26-85$ & 620 & -- & 30.0 & -- & $\mathrm{x}$ & BrW \\
\hline BLW & 158 & 432630 & 0712837 & Lewandoski, C. & $01-01-85$ & 600 & -- & 20.0 & -- & $\mathrm{x}$ & $\mathrm{BrW}$ \\
\hline BLW & 159 & 432744 & 0712747 & Jusczak，W. & $09-24-85$ & 710 & -- & -- & -- & $\mathrm{x}$ & $\mathrm{BrW}$ \\
\hline BLW & 160 & 432835 & 0713136 & Morway, $\mathrm{R}$. & $04-03-86$ & 490 & -- & 94.0 & -- & -- & -- \\
\hline BLW & 161 & 432836 & 0713132 & Morway, $\mathrm{R}$. & $04-08-86$ & 490 & -- & 84.0 & -- & -- & -- \\
\hline BLW & 162 & 432835 & 0713134 & Morway, $\mathrm{R}$. & $04-08-86$ & 490 & -- & 79.0 & -- & -- & -- \\
\hline BLW & 165 & 432947 & 0713015 & Northland Devel & $06-25-86$ & 490 & -- & 39.0 & -- & $\mathrm{x}$ & $\mathrm{BrW}$ \\
\hline BLW & 167 & 432921 & 0713033 & Reed, $\mathbf{R}$. & $06-28-86$ & 490 & -- & 13.0 & -- & $\mathbf{s}$ & -- \\
\hline BLW & 168 & 432741 & 0712743 & Ekberg, W. & $07-10-86$ & 660 & -- & 64.0 & -- & $\mathrm{x}$ & $\mathrm{BrW}$ \\
\hline BLW & 170 & 432812 & 0712534 & Plummer, $\mathrm{C}$. & $03-06-86$ & 790 & -- & 59.0 & -- & $\mathrm{x}$ & $\mathrm{BrW}$ \\
\hline BLW & 171 & 432809 & 0712525 & Lurvey, $\mathrm{C}$. & $12-28-86$ & 820 & -- & 25.0 & -- & $\mathrm{x}$ & $\mathrm{BrW}$ \\
\hline BLW & 172 & 432821 & 0713102 & Drouin Bldrs & $09-18-86$ & 560 & -- & 79.0 & -- & $\mathrm{x}$ & $\mathrm{BrW}$ \\
\hline BLW & 173 & 432821 & 0713100 & Drouin Bldrs & $09-15-86$ & 560 & -- & 79.0 & -- & $\mathrm{x}$ & $\mathrm{BrW}$ \\
\hline BLW & 174 & 432823 & 0713101 & Drouin Bldrs & $09-12-86$ & 560 & -- & 82.0 & -- & $\mathrm{x}$ & BrW \\
\hline BLW & 176 & 432911 & 0713036 & Corbishley, H. & $11-08-86$ & 490 & -- & 104 & -- & $\mathrm{x}$ & BrW \\
\hline BLW & 179 & 432731 & 0712701 & Peterson, w. & $05-11-87$ & 740 & -- & 40.0 & -- & $\mathrm{x}$ & Brw \\
\hline BLW & 181 & 432923 & 0712612 & Eber, c. & $03-12-87$ & 860 & -- & 20.0 & -- & $\mathrm{x}$ & $\mathrm{BrW}$ \\
\hline BLW & 183 & 432655 & 0712623 & Gilbert, $D$. & $06-24-87$ & 770 & -- & 20.0 & -- & $\mathrm{x}$ & BrW \\
\hline BLW & 184 & 432718 & 0712830 & Dutile & $07-02-87$ & 630 & -- & 40.0 & -- & $\mathrm{x}$ & BrW \\
\hline BLW & 185 & 432844 & 0713051 & Croes, B. & $08-03-87$ & 510 & -- & 29.0 & -- & $\mathrm{x}$ & $\mathrm{BrW}$ \\
\hline BLW & 186 & 432847 & 0713055 & Guyer, D. & $08-05-87$ & 500 & -- & 32.0 & -- & $\mathrm{x}$ & $\mathrm{BrW}$ \\
\hline BLW & 188 & 432855 & 0713105 & Chao, F. & $09-09-86$ & 500 & -- & 84.0 & -- & $\mathrm{x}$ & $\mathrm{BrW}$ \\
\hline BLW & 189 & 432947 & 0712752 & Sewall, P. & $11-03-86$ & 740 & -- & 20.0 & -- & $\mathrm{x}$ & $\mathrm{BrW}$ \\
\hline BLW & 190 & 432722 & 0712839 & Lakeland Const & $03-26-87$ & 620 & -- & 19.0 & -- & $\mathrm{x}$ & $\mathrm{BrW}$ \\
\hline BLW & 191 & 433003 & 0713034 & McCormick, s. & $06-23-86$ & 500 & -- & 154 & -- & $\mathrm{x}$ & BrW \\
\hline BLW & 198 & 433052 & 0712854 & Searls, W. & $09-11-86$ & 640 & -- & 81.0 & -- & $\mathrm{x}$ & BrW \\
\hline BLW & 199 & 432930 & 0712754 & Scott, R. & $07-03-86$ & 740 & -- & 37.0 & -- & $\mathrm{x}$ & $\mathrm{BrW}$ \\
\hline BLW & 200 & 432943 & 0712858 & Kitching, G. & $07-03-86$ & 660 & -- & 120 & -- & $\mathrm{x}$ & $\mathrm{BrW}$ \\
\hline BLW & 201 & 432712 & 0712906 & Gammon, $\mathrm{G}$ & $06-19-86$ & 610 & -- & 20.0 & -- & $\mathrm{x}$ & $\mathrm{BrW}$ \\
\hline BLW & 202 & 433047 & 0712903 & Ladd & $11-20-87$ & 680 & -- & 83.0 & -- & $\mathrm{x}$ & $\mathrm{BrW}$ \\
\hline BLW & 206 & 432937 & 0712910 & Drouin, $\mathrm{w}$. & $04-11-86$ & 630 & -- & 61.0 & -- & $\mathrm{x}$ & $\mathrm{BrW}$ \\
\hline BLW & 207 & 432939 & 0712903 & Farrar, K. & $07-28-86$ & 660 & -- & 74.0 & -- & $\mathrm{x}$ & $\mathrm{BrW}$ \\
\hline BLW & 209 & 432715 & 0712906 & Wood \& Clay Bldrs & $08-20-87$ & 610 & -- & 19.0 & -- & $\mathrm{x}$ & $\mathrm{BrW}$ \\
\hline BLW & 210 & 432855 & 0712506 & Wilking, E. & $09-11-87$ & 810 & -- & 21.0 & -- & $\mathrm{x}$ & $\mathrm{BrW}$ \\
\hline BLW & 211 & 432650 & 0712600 & Lamothe, $\mathrm{R}$. & $09-09-87$ & 800 & -- & 19.0 & -- & $\mathrm{x}$ & $\mathrm{BrW}$ \\
\hline BLW & 212 & 432916 & 0712606 & Davis, C. & $09-29-87$ & 840 & -- & 39.0 & -- & $\mathrm{x}$ & $\mathrm{BrW}$ \\
\hline
\end{tabular}




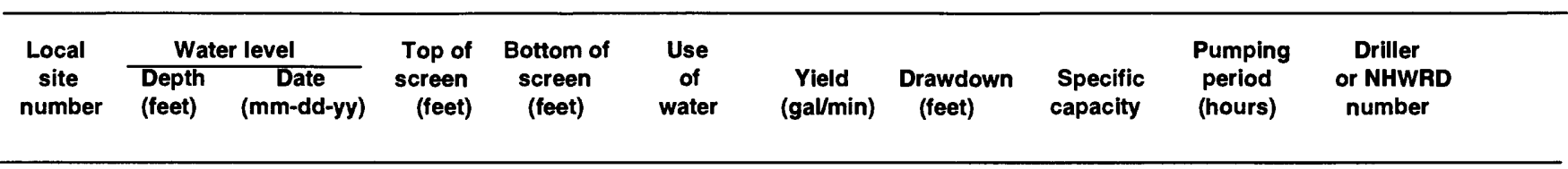

\section{BELKNAP COUNTY}

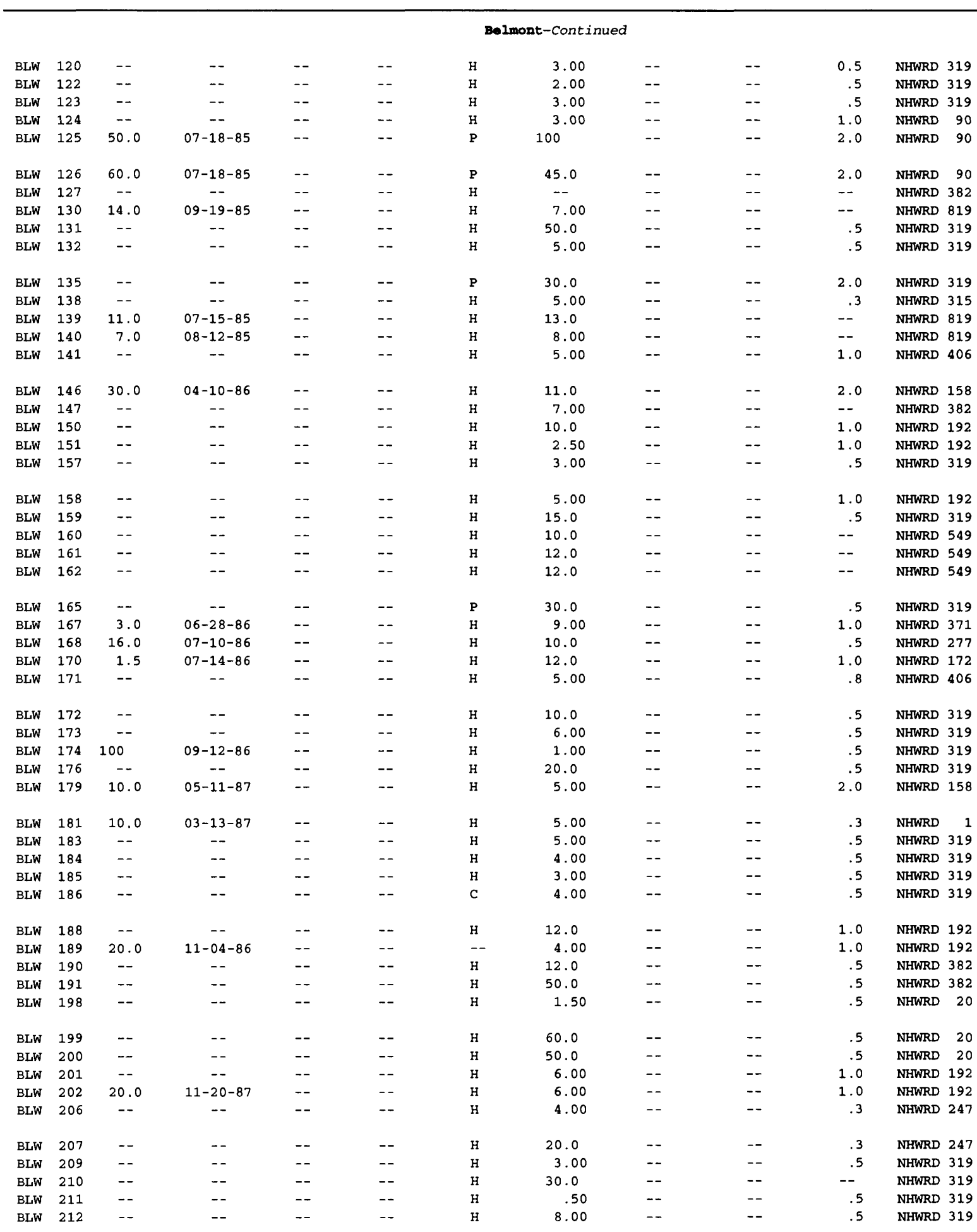


Table A-1. Description of selected wells, borings, and springs in the Winnipesaukee River Basin, central New Hampshire

\begin{tabular}{|c|c|c|c|c|c|c|c|c|c|c|}
\hline $\begin{array}{l}\text { Local } \\
\text { site } \\
\text { number }\end{array}$ & $\begin{array}{l}\text { Lat- } \\
\text { itude }\end{array}$ & $\begin{array}{l}\text { Long- } \\
\text { itude }\end{array}$ & Owner or user & $\begin{array}{c}\text { Date } \\
\text { of } \\
\text { con- } \\
\text { struction }\end{array}$ & $\begin{array}{c}\text { Ele- } \\
\text { vat- } \\
\text { tlon } \\
\text { (feet) }\end{array}$ & $\begin{array}{c}\text { Diameter } \\
\text { of } \\
\text { casing } \\
\text { (inches) }\end{array}$ & $\begin{array}{l}\text { Depth to } \\
\text { bottom } \\
\text { of casing } \\
\text { (feet) }\end{array}$ & $\begin{array}{c}\text { Casing } \\
\text { mater- } \\
\text { ial }\end{array}$ & $\begin{array}{l}\text { Type } \\
\text { of } \\
\text { fin- } \\
\text { ish }\end{array}$ & $\begin{array}{c}\text { Type } \\
\text { of } \\
\text { site }\end{array}$ \\
\hline
\end{tabular}

\section{BELKNAP COUNTY}

\begin{tabular}{|c|c|c|c|c|c|c|c|c|c|c|c|}
\hline \multirow[b]{2}{*}{ BLW } & \multicolumn{11}{|c|}{ Belmont-Continued } \\
\hline & 213 & 432932 & 0712923 & Laurent, c. & $10-19-87$ & 640 & -- & 72.0 & -- & $\mathrm{x}$ & Brw \\
\hline BLW & 215 & 433048 & 0712902 & Duggan, $\mathrm{J}$. & $09-22-86$ & 580 & -- & 80.0 & -- & $x$ & BrW \\
\hline BLW & 216 & 433050 & 0712901 & Duggan, $\mathrm{R}$. & $09-24-86$ & 580 & -- & 100 & -- & $\mathrm{x}$ & BrW \\
\hline BLW & 217 & 432735 & 0712700 & Powel & $12-22-87$ & 740 & -- & 32.0 & -- & $\mathrm{x}$ & BrW \\
\hline BLW & 219 & 432943 & 0712856 & Gouveau, M. & $10-19-87$ & 660 & -- & 69.0 & -- & -- & -- \\
\hline BLW & 220 & 432553 & 0712809 & Dindo, J. & $01-25-88$ & 560 & -- & 72.0 & -- & $\mathrm{x}$ & BrW \\
\hline BLW & 221 & 432917 & 0712933 & Collins & $11-02-87$ & 540 & -- & 19.0 & -- & $\mathrm{x}$ & Brw \\
\hline BLW & 222 & 432843 & 0713049 & McMenaman, J. & $11-12-87$ & 520 & -- & 29.0 & -- & $\mathrm{x}$ & Brw \\
\hline BLW & 224 & 432716 & 0712809 & Drouin, $\mathrm{M}$. & $01-15-88$ & 600 & -- & 20.0 & -- & $\mathrm{x}$ & BrW \\
\hline$B L W$ & 226 & 432834 & 0713149 & Rogers, A. & $05-30-87$ & 500 & -- & 130 & -- & $x$ & $\mathrm{BrW}$ \\
\hline BLW & 227 & 432942 & 0712703 & Rotonnelli, J. & $02-02-88$ & 960 & -- & 39.0 & -- & $x$ & Brw \\
\hline BLW & 230 & 432959 & 0712648 & MacIntosh, E. & $03-30-88$ & 750 & -- & 28.0 & -- & $\mathbf{x}$ & BrW \\
\hline BLW & 231 & 432710 & 0712840 & AE Mitchell & $05-02-88$ & 640 & -- & 37.0 & -- & $\mathrm{x}$ & Brw \\
\hline BLW & 234 & 432822 & 0713136 & Marock, T. & $03-29-88$ & 530 & -- & 63.0 & -- & $\mathrm{x}$ & BrW \\
\hline BLW & 235 & 432720 & 0712839 & deJagger, P. & $02-01-88$ & 630 & -- & 19.0 & -- & $x$ & $\mathrm{BrW}$ \\
\hline BLW & 238 & 432715 & 0712841 & Aubut, $\mathrm{R}$. & $05-07-87$ & 640 & -- & 59.0 & -- & $\mathrm{x}$ & BrW \\
\hline BLW & 240 & 432819 & 0713114 & Bjelt, $R$. & $12-07-87$ & 560 & -- & 59.0 & -- & $\mathrm{x}$ & BrW \\
\hline BLW & 243 & 432905 & 0713045 & Pickering, G. & $11-03-87$ & 510 & -- & 89.0 & -- & $\mathbf{x}$ & Brw \\
\hline BLW & 244 & 432720 & 0712834 & deJagger, P. & $04-05-88$ & 630 & -- & 19.0 & -- & $\mathrm{x}$ & BrW \\
\hline BLW & 248 & 432717 & 0712808 & Drouin, $M$ & $04-04-88$ & 610 & -- & 19.0 & -- & $x$ & BrW \\
\hline BLW & 253 & 432732 & 0712705 & Carignon, R. & $03-24-88$ & 720 & -- & 39.0 & -- & $\mathrm{x}$ & BrW \\
\hline BLW & 255 & 432743 & 0712632 & Bossey, $\mathrm{T}$. & $07-15-88$ & 730 & -- & 41.0 & -- & $\mathrm{x}$ & BrW \\
\hline BLW & 257 & 432951 & 0713045 & Smart, $R$. & $09-18-88$ & 485 & -- & 147 & -- & $x$ & $\mathrm{BrW}$ \\
\hline BLW & 258 & 432904 & 0712442 & Grant, s. & $07-09-88$ & 860 & -- & 37.0 & -- & $\mathrm{x}$ & $\mathrm{BrW}$ \\
\hline BLW & 262 & 432550 & 0712920 & Booth, P. & $06-17-88$ & 510 & -- & 29.0 & -- & $x$ & $\mathrm{BrW}$ \\
\hline BLW & 263 & 432554 & 0712920 & Booth, P. & $06-17-88$ & 500 & -- & 19.0 & -- & $\mathrm{x}$ & BrW \\
\hline BLW & 264 & 432739 & 0712838 & Smock & $06-17-88$ & 660 & -- & 49.0 & -- & $\mathrm{x}$ & $\mathrm{BrW}$ \\
\hline BLW & 271 & 432718 & 0712806 & Drouin Bldrs & $09-19-88$ & 610 & -- & 19.0 & -- & $\mathrm{x}$ & BrW \\
\hline BLW & 275 & 432911 & 0712504 & Caldwell, J. & $10-20-88$ & 860 & -- & 26.0 & -- & $\mathrm{x}$ & BrW \\
\hline BLW & 276 & 432658 & 0712620 & Kierman, D. & $06-09-88$ & 765 & -- & 39.0 & -- & $\mathrm{x}$ & BrW \\
\hline BLW & 277 & 432659 & 0712620 & Donavan, L. & $05-19-88$ & 765 & -- & 40.0 & -- & $\mathrm{x}$ & Brw \\
\hline BLW & 278 & 432943 & 0712647 & Reilly, D. & $05-27-88$ & 900 & -- & 19.0 & -- & $x$ & BrW \\
\hline BLW & 286 & 432848 & 0713051 & Clement, $R$. & $12-06-88$ & 510 & -- & 19.0 & -- & $\mathrm{x}$ & Brw \\
\hline BLW & 287 & 432852 & 0713041 & Piper, R. & $03-10-89$ & 580 & -- & 79.0 & -- & $\mathrm{x}$ & Brw \\
\hline BLW & 288 & 432810 & 0713051 & Kathcort, R. & $12-20-88$ & 660 & -- & 40.0 & -- & $x$ & Brw \\
\hline BLW & 290 & 432817 & 0713112 & Rogacki & $10-24-88$ & 580 & -- & 60.0 & -- & $\mathrm{x}$ & Brw \\
\hline BLW & 291 & 432817 & 0713110 & Duggan & $10-25-88$ & 570 & -- & 60.0 & -- & $\mathrm{x}$ & Brw \\
\hline BLW & 292 & 432933 & 0713037 & Scott, R. & $02-27-89$ & 490 & -- & 119 & -- & $\mathbf{x}$ & $\mathrm{BrW}$ \\
\hline BLW & 293 & 432934 & 0713045 & Doyon, A. & $04-15-89$ & 490 & -- & 139 & -- & $x$ & $\mathrm{BrW}$ \\
\hline BLW & 294 & 432825 & 0713039 & Creteau, $\mathrm{R}$. & $10-07-88$ & 510 & -- & 99.0 & -- & $\mathrm{x}$ & $\mathrm{BrW}$ \\
\hline BLW & 296 & 432703 & 0712913 & Wincox, D. & $06-17-89$ & 580 & -- & 24.0 & -- & $\mathrm{x}$ & Brw \\
\hline BLW & 297 & 432848 & 0713157 & Walton, $\mathrm{R}$. & $06-11-89$ & 500 & -- & 154 & -- & $x$ & Brw \\
\hline BLW & 303 & 432852 & 0713045 & Treh Blars Inc & $09-13-89$ & 580 & -- & 62.0 & -- & $\mathrm{x}$ & BrW \\
\hline BLW & 306 & 432945 & 0713046 & Bohlin Property & $11-01-89$ & 490 & -- & 125 & -- & $\mathrm{x}$ & BrW \\
\hline BLW & 308 & 432745 & 0713206 & Jackson, s. & $11-27-89$ & 470 & -- & 110 & -- & $\mathrm{x}$ & Brw \\
\hline BLW & 309 & 432741 & 0712636 & Senechal, N. & $09-29-89$ & 740 & -- & 49.0 & -- & $\mathrm{x}$ & BrW \\
\hline BLW & 315 & 432904 & 0712445 & Jausqak, w. & $03-08-89$ & 860 & -- & 40.0 & -- & $\mathrm{x}$ & $\mathrm{Brw}$ \\
\hline BLW & 316 & 432849 & 0713038 & Shulze & $04-26-89$ & 600 & -- & 61.0 & -- & $\mathrm{x}$ & Brw \\
\hline BLW & 318 & 432906 & 0713042 & Robinson, J. & $07-17-90$ & 490 & -- & 79.0 & -- & $x$ & BrW \\
\hline BLW & 321 & 432836 & 0713048 & Clive, $\mathrm{T}$. & $06-15-90$ & 500 & -- & 89.0 & -- & $x$ & Brw \\
\hline BLW & 322 & 432933 & 0713041 & Conant, $\mathrm{R}$. & $06-20-90$ & 490 & -- & 130 & -- & $x$ & $\mathrm{BrW}$ \\
\hline BLW & 323 & 432946 & 0713045 & Fletcher, R. & $07-12-90$ & 490 & -- & 131 & -- & $x$ & $\mathrm{BrW}$ \\
\hline BLW & 325 & 432737 & 0712621 & Jusczak, w. & $09-14-89$ & 750 & -- & 40.0 & -- & $\mathrm{x}$ & $\mathrm{BrW}$ \\
\hline BLW & 327 & 432651 & 0713128 & Yellow Freight Terminal & $10-16-90$ & 520 & -- & 59.4 & -- & $\mathrm{x}$ & BrW \\
\hline BLW & 329 & 432708 & 0712623 & Wilder, $\mathrm{D}$. & $08-15-90$ & 770 & -- & 19.0 & -- & $\mathbf{x}$ & BrW \\
\hline
\end{tabular}




\begin{tabular}{|c|c|c|c|c|c|c|c|c|c|c|}
\hline \multirow{2}{*}{$\begin{array}{l}\text { Local } \\
\text { site } \\
\text { number }\end{array}$} & \multicolumn{2}{|c|}{ Water level } & \multirow{2}{*}{$\begin{array}{l}\text { Top of } \\
\text { screen } \\
\text { (feet) }\end{array}$} & \multirow{2}{*}{$\begin{array}{l}\text { Bottom of } \\
\text { screen } \\
\text { (feet) }\end{array}$} & \multirow{2}{*}{$\begin{array}{c}\text { Use } \\
\text { of } \\
\text { water }\end{array}$} & \multirow[b]{2}{*}{$\begin{array}{c}\text { Yield } \\
\text { (gal/min) }\end{array}$} & \multirow[b]{2}{*}{$\begin{array}{l}\text { Drawdown } \\
\text { (feet) }\end{array}$} & \multirow[b]{2}{*}{$\begin{array}{l}\text { Specific } \\
\text { capacity }\end{array}$} & \multirow{2}{*}{$\begin{array}{l}\text { Pumplng } \\
\text { period } \\
\text { (hours) }\end{array}$} & \multirow{2}{*}{$\begin{array}{l}\text { Driller } \\
\text { or NHWRD } \\
\text { number }\end{array}$} \\
\hline & $\begin{array}{l}\text { Depth } \\
\text { (feet) }\end{array}$ & $\begin{array}{c}\text { Date } \\
\text { (mm-dd-yy) }\end{array}$ & & & & & & & & \\
\hline
\end{tabular}

BELKNAP COUNTY

\begin{tabular}{|c|c|c|c|c|c|c|c|c|c|c|c|c|}
\hline \multirow[b]{2}{*}{ BLW } & \multirow[b]{2}{*}{213} & \multicolumn{11}{|c|}{ Balmont-Cont inued } \\
\hline & & -- & -- & -- & -- & $\mathrm{H}$ & 25.0 & -- & -- & 0.5 & NHWRD & 319 \\
\hline BLW & 215 & 25.0 & $09-23-86$ & -- & -- & $\mathrm{H}$ & 3.00 & -- & -- & .5 & NHWRD & 302 \\
\hline BLW & 216 & 20.0 & $09-24-86$ & -- & -- & $\mathrm{H}$ & 20.0 & -- & -- & .5 & NHWRD & 302 \\
\hline BLW & 217 & -- & -- & -- & -- & $\mathrm{H}$ & 10.0 & -- & -- & -- & NHWRD & 126 \\
\hline BLW & 219 & -- & -- & -- & -- & $\mathrm{H}$ & 20.0 & -- & -- & .8 & NHWRD & 204 \\
\hline BLW & 220 & -- & -- & -- & -- & $\mathrm{H}$ & 12.0 & -- & -- & .5 & NHWRD & 319 \\
\hline BLW & 221 & -- & -- & -- & -- & $\mathrm{H}$ & 1.00 & -- & -- & .5 & NHWRD & 319 \\
\hline BLW & 222 & -- & -- & -- & -- & $\mathrm{H}$ & 3.00 & -- & -- & .5 & NHWRD & 319 \\
\hline BLW & 224 & -- & -- & -- & +- & H & 20.0 & -- & -- & .5 & NHWRD & 319 \\
\hline BLW & 226 & -- & -- & -- & -- & H & 1.00 & -- & -- & .5 & NHWRD & 225 \\
\hline BLW & 227 & 30.0 & $02-02-88$ & -- & -- & $\mathrm{H}$ & 8.00 & -- & -- & -- & NHWRD & 819 \\
\hline BLW & 230 & -- & -- & -- & -- & $\mathrm{H}$ & 6.00 & -- & -- & -- & NHWRD & 819 \\
\hline BLW & 231 & -- & -- & - & -- & $\mathrm{H}$ & 6.00 & -- & -- & 1.0 & NHWRD & 192 \\
\hline BLW & 234 & -- & -- & -- & -- & $\mathrm{H}$ & 3.00 & -- & -- & 1.0 & NHWRD & 192 \\
\hline BLW & 235 & 20.0 & $02-06-88$ & -- & -- & $\mathrm{H}$ & 15.0 & -- & -- & .5 & NHWRD & 382 \\
\hline BLW & 238 & -- & -- & -- & -- & H & 20.0 & -- & -- & .3 & NHWRD & 247 \\
\hline BLW & 240 & -- & -- & -- & -- & H & 5.00 & -- & - & .3 & NHWRD & 247 \\
\hline BLW & 243 & -- & -- & -- & -- & H & 3.00 & -- & -- & .3 & NHWRD & 247 \\
\hline BLW & 244 & 15.0 & $04-05-88$ & -- & -- & H & 50.0 & -- & -- & .5 & NHWRD & 382 \\
\hline BLW & 248 & -- & -- & -- & -- & $\mathrm{H}$ & 3.00 & -- & -- & .5 & NHWRD & 319 \\
\hline BLW & 253 & 15.0 & $03-25-88$ & -- & -- & $\mathbf{H}$ & 7.50 & -- & -- & .5 & NHWRD & 142 \\
\hline BLW & 255 & -- & -- & -- & -- & $\mathrm{H}$ & 6.00 & -- & -- & 1.0 & NHWRD & 192 \\
\hline BLW & 257 & -- & -- & -- & -- & $\mathrm{H}$ & 12.0 & - & - & 1.0 & NHWRD & 192 \\
\hline BLW & 258 & 3.0 & $07-09-88$ & -- & -- & $\mathrm{H}$ & 15.0 & -- & -- & 2.0 & NHWRD & 158 \\
\hline BLW & 262 & 20.0 & $06-17-88$ & -- & -- & $\mathrm{H}$ & - & -- & -- & -- & NHWRD & 382 \\
\hline BLW & 263 & 20.0 & $06-18-88$ & -- & -- & $\mathrm{H}$ & .50 & -- & -- & .5 & NHWRD & 382 \\
\hline BLW & 264 & -- & -- & -- & -- & $\mathrm{H}$ & 5.00 & -- & -- & .3 & NHWRD & 247 \\
\hline BLW & 271 & -- & -- & -- & -- & $\mathrm{H}$ & 11.0 & -- & -- & .5 & NHWRD & 319 \\
\hline BLW & 275 & 11.0 & $10-20-88$ & -- & -- & $\mathrm{H}$ & 10.0 & -- & -- & -- & NHWRD & 819 \\
\hline BLW & 276 & -- & -- & -- & -- & $\mathbf{H}$ & 10.0 & -- & -- & .5 & NHWRD & 225 \\
\hline BLW & 277 & -- & -- & -- & -- & $\mathrm{H}$ & 3.00 & -- & -- & 1.0 & NHWRD & 225 \\
\hline BLW & 278 & -- & -- & -- & -. & $\mathrm{H}$ & .50 & -- & -- & 1.0 & NHWRD & 143 \\
\hline BLW & 286 & -- & -- & -- & -- & $\mathrm{H}$ & 15.0 & -- & -- & .5 & NHWRD & 319 \\
\hline BLW & 287 & -- & -- & -- & -- & $\mathrm{H}$ & 9.00 & -- & -- & .3 & NHWRD & 247 \\
\hline BLW & 288 & 5.0 & $12-21-88$ & -- & -- & $\mathrm{H}$ & 1.50 & -- & -- & .5 & NHWRD & 142 \\
\hline BLW & 290 & 10.0 & $10-25-88$ & -- & -- & $\mathrm{H}$ & 3.00 & -- & -- & .5 & NHWRD & 142 \\
\hline BLW & 291 & 20.0 & $10-26-88$ & -- & -- & $\mathrm{H}$ & 10.0 & $\ldots$ & -- & .5 & NHWRD & 142 \\
\hline BLW & 292 & -- & -- & -- & -- & $\mathrm{H}$ & 25.0 & -- & -- & .5 & NHWRD & 319 \\
\hline BLW & 293 & -- & -- & -- & -- & $\mathrm{H}$ & 7.00 & -- & -- & .5 & NHWRD & 319 \\
\hline BLW & 294 & -- & -- & -- & -- & $\mathrm{H}$ & 20.0 & -- & -- & 1.0 & NHWRD & 192 \\
\hline$B L W$ & 296 & -- & -- & -- & -- & $\mathrm{H}$ & 5.00 & -- & -- & .3 & NHWRD & 90 \\
\hline BLW & 297 & -- & -- & -- & -- & $\mathrm{H}$ & 1.50 & -- & -- & .8 & NHWRD & 90 \\
\hline BLW & 303 & -- & -- & -- & -- & $\mathrm{H}$ & 8.00 & -- & -- & .2 & NHWRD & 238 \\
\hline BLW & 306 & -- & -- & - & -- & $\mathrm{H}$ & 30.0 & -- & -- & 1.0 & NHWRD & 192 \\
\hline BLW & 308 & 10.0 & $11-27-89$ & -- & -- & $\mathrm{H}$ & 5.00 & -- & -- & 1.0 & NHWRD & 192 \\
\hline BLW & 309 & -- & -- & -- & -- & $\mathrm{H}$ & 7.00 & -- & -- & 1.0 & NHWRD & 143 \\
\hline BLW & 315 & 10.0 & $03-09-89$ & -- & -- & $\mathrm{H}$ & 2.00 & -- & -- & .5 & NHWRD & 142 \\
\hline BLW & 316 & 20.0 & $04-27-89$ & -- & -- & $\mathrm{H}$ & 25.0 & -- & -- & .5 & NHWRD & 142 \\
\hline BLW & 318 & -- & - & -- & -- & $\mathrm{H}$ & 6.00 & -- & -- & .5 & NHWRD & 319 \\
\hline BLW & 321 & -- & -- & -- & -- & $\mathrm{H}$ & 10.0 & -- & -- & 1.0 & NHWRD & 123 \\
\hline BLW & 322 & 3.0 & $06-20-90$ & -- & -- & H & 4.00 & -- & -- & -- & NHWRD & 819 \\
\hline BLW & 323 & -- & -- & -- & -- & $\mathbf{H}$ & 3.00 & -- & -- & 1.0 & NHWRD & 192 \\
\hline BLW & 325 & 15.0 & $09-14-89$ & -- & -- & $\mathbf{H}$ & 7.00 & -- & -- & 10.0 & NHWRD & 302 \\
\hline BLW & 327 & -- & -- & -- & -- & H & 10.0 & -- & -- & -- & NHWRD & 192 \\
\hline BLW & 329 & -- & -- & -- & -- & $\mathrm{H}$ & 6.00 & -- & -- & .3 & NHWRD & 247 \\
\hline
\end{tabular}


Table A-1. Description of selected wells, borings, and springs in the Winnipesaukee River Basin, central New Hampshire

\begin{tabular}{|c|c|c|c|c|c|c|c|c|c|c|}
\hline $\begin{array}{l}\text { Local } \\
\text { site } \\
\text { number }\end{array}$ & $\begin{array}{l}\text { Lat- } \\
\text { itude }\end{array}$ & $\begin{array}{l}\text { Long- } \\
\text { itude }\end{array}$ & Owner or user & $\begin{array}{c}\text { Date } \\
\text { of } \\
\text { con- } \\
\text { struction }\end{array}$ & $\begin{array}{c}\text { Ele- } \\
\text { vat- } \\
\text { tion } \\
\text { (feet) }\end{array}$ & $\begin{array}{c}\text { Diameter } \\
\text { of } \\
\text { casing } \\
\text { (inches) }\end{array}$ & $\begin{array}{l}\text { Depth to } \\
\text { bottom } \\
\text { of casing } \\
\text { (feet) }\end{array}$ & $\begin{array}{c}\text { Casing } \\
\text { mater- } \\
\text { ial }\end{array}$ & $\begin{array}{l}\text { Type } \\
\text { of } \\
\text { fin- } \\
\text { ish }\end{array}$ & $\begin{array}{c}\text { Type } \\
\text { of } \\
\text { site }\end{array}$ \\
\hline
\end{tabular}

BELKNAP COUNTY

\begin{tabular}{|c|c|c|c|c|c|c|c|c|c|c|c|}
\hline \multirow[b]{2}{*}{ BLW } & \multicolumn{11}{|c|}{ Belmont-Continued } \\
\hline & 331 & 432708 & 0712617 & Pease & $11-15-89$ & 780 & -- & 19.0 & -- & $\mathrm{x}$ & BrW \\
\hline BLW & 332 & 432646 & 0713051 & Jusczak, w. & $07-10-90$ & 515 & -- & 83.0 & -- & $\mathrm{x}$ & BrW \\
\hline BLW & 334 & 432858 & 0713051 & Lenardis, $\mathrm{J}$. & $09-08-90$ & 500 & -- & 54.0 & -- & $\mathrm{x}$ & BrW \\
\hline BLW & 335 & 432857 & 0713057 & Gobeille, L. & $08-29-90$ & 500 & -- & 74.0 & -- & $\mathrm{x}$ & $\mathrm{BrW}$ \\
\hline BLW & 336 & 432905 & 0713051 & Dawkins, E. & $07-27-90$ & 500 & -- & 89.0 & -- & $\mathrm{x}$ & BrW \\
\hline BLW & 341 & 432945 & 0712649 & Small, R. & $10-01-90$ & 900 & -- & 17.0 & -- & $\mathrm{x}$ & BrW \\
\hline BLW & 342 & 432818 & 0712558 & Gilbert, A. & $11-01-90$ & 740 & -- & 28.0 & -- & $\mathrm{x}$ & BrW \\
\hline BLW & 346 & 432817 & 0713103 & $R \& A$ Assoc & $07-31-89$ & 560 & -- & 51.0 & -- & $\mathrm{x}$ & Brw \\
\hline BLW & 347 & 432906 & 0712458 & Durocher, $M$. & $05-25-91$ & 840 & -- & 22.0 & -- & $\mathrm{x}$ & Brw \\
\hline BLW & 349 & 432845 & 0713156 & Nordel, L. & $07-02-91$ & -- & -- & 139 & -- & $x$ & Brw \\
\hline BLW & 350 & 432741 & 0712615 & Jusczah，w. & $06-17-91$ & -- & -- & 36.0 & -- & $\mathrm{x}$ & Brw \\
\hline BLW & 353 & 432816 & 0713159 & Lochmere Vill. District & $04-\quad-92$ & 470 & 1.25 & 11 & $\mathbf{P}$ & $s$ & Dug \\
\hline BLW & 354 & 432650 & 0713207 & Tilton-Northfield Aqua. & $12-06-94$ & 485 & 2.5 & 20 & $\mathrm{~s}$ & $s$ & BOR \\
\hline \multirow[t]{2}{*}{ BLW } & 355 & 432625 & 0713122 & Tilton-Northfield Aqua. & $12-08-94$ & 520 & - & -- & -- & -- & BOR \\
\hline & \multicolumn{11}{|c|}{ Center Harbor } \\
\hline $\mathrm{CHW}$ & 1 & 434225 & 0712748 & Finn & $05-29-84$ & 540 & -- & 47.0 & -- & $\mathrm{x}$ & BrW \\
\hline CHW & 2 & 434229 & 0712759 & Allard, M. & $08-13-84$ & 600 & -- & 24.0 & -- & $\mathrm{x}$ & BrW \\
\hline CHW & 3 & 434230 & 0712804 & Kneeland, w. & $08-05-84$ & 640 & -- & 19.0 & -- & $\mathrm{x}$ & BrW \\
\hline CHW & 5 & 434231 & 0712744 & Parker, G. & $10-10-84$ & 540 & -- & -- & -- & $\mathrm{x}$ & BrW \\
\hline $\mathrm{CHW}$ & 6 & 434242 & 0712753 & Heath & $08-26-85$ & 560 & -- & 19.0 & -- & $\mathrm{x}$ & BrW \\
\hline CHW & 7 & 434223 & 0712749 & Dole, J. & $08-10-85$ & 540 & -- & 69.0 & -- & $\mathrm{x}$ & BrW \\
\hline CHW & 11 & 434053 & 0713042 & Skawinski, W. & $11-27-84$ & 620 & -- & 20.0 & -- & $x$ & BrW \\
\hline CHW & 14 & 434230 & 0712801 & Poff, H. & $07-20-84$ & 600 & -- & 55.0 & -- & $\mathrm{x}$ & BrW \\
\hline CHW & 23 & 434041 & 0713035 & LaBraney, J . & $03-31-86$ & 620 & -- & 20.0 & -- & $\mathrm{x}$ & BrW \\
\hline CHW & 25 & 434103 & 0713315 & Fisher, D. & $06-06-86$ & 780 & -- & 20.0 & -- & $\mathrm{x}$ & BrW \\
\hline \multirow[t]{2}{*}{ CHW } & 29 & 434232 & 0712753 & -- & -- & 570 & -- & -- & -- & -- & BrW \\
\hline & \multicolumn{11}{|c|}{ Gilford } \\
\hline GFA & 1 & 433212 & 0712421 & Gilford, Town of & $10-16-90$ & 760 & -- & -- & -- & -- & Bor \\
\hline GFA & 2 & 433416 & 0712507 & Laconia Airport Authority & $06-25-91$ & 518 & -- & -- & -- & -- & Bor \\
\hline GFA & 3 & 433242 & 0712419 & Gilford, Town of & $06-26-91$ & 750 & -- & -- & -- & -- & Bor \\
\hline GFB & 1 & 433443 & 0712416 & -- & -- & 509 & -- & -- & -- & -- & Bor \\
\hline GFB & 2 & 433422 & 0712121 & -- & -- & 517 & -- & -- & -- & -- & Bor \\
\hline GFB & 3 & 433614 & 0712547 & NHDOT & -- & 506 & -- & -- & -- & -- & Bor \\
\hline GFB & 4 & 433158 & 0712624 & Lemays Garage & $03-08-88$ & 610 & -- & -- & -- & -- & Bor \\
\hline GFB & 5 & 433201 & 0712621 & Lemays Garage & $03-18-88$ & 610 & -- & -- & -- & -- & Bor \\
\hline GFB & 6 & 433447 & 0712531 & Gilford Landfill & $09-12-86$ & 550 & -- & -- & -- & -- & Bor \\
\hline GFB & 7 & 433434 & 0712508 & Gilford Landfill & $09-08-86$ & 520 & -- & -- & -- & -- & Bor \\
\hline GFB & 8 & 433435 & 0712518 & Gilford Landfill & $09-10-86$ & 510 & -- & - & -- & -- & Bor \\
\hline GFB & 9 & 433442 & 0712524 & Gilford Landfill & $09-04-86$ & 530 & -- & -- & -- & -- & Bor \\
\hline GFB & 10 & 433443 & 0712515 & Gilford Landfill & $09-10-86$ & 570 & -- & -- & -- & -- & Bor \\
\hline GFB & 11 & 433446 & 0712523 & Gilford Landfill & $09-10-86$ & 550 & -- & -- & -- & -- & Bor \\
\hline GFB & 12 & 433159 & 0712619 & Lemays Garage & $07-06-88$ & 610 & -- & -- & -- & -- & $\mathrm{TH}$ \\
\hline GFB & 13 & 433157 & 0712624 & Lemays Garage & $03-08-88$ & 610 & -- & -- & -- & -- & Bor \\
\hline GFW & 7 & 433445 & 0712539 & Gilford Landfill & -- & 548.22 & -- & -. & -- & $\ldots$ & - \\
\hline GFW & 9 & 433349 & 0712625 & Getty Petroleum & -- & 530 & -- & -- & -- & -- & -- \\
\hline GFW & 11 & 433145 & 0712414 & Gilford, Town of & $10-15-90$ & 780 & 2 & 51.5 & $P$ & $\mathrm{~s}$ & Bor \\
\hline GFW & 12 & 433423 & 0712404 & Roberts, Steven & $11-01-90$ & 515 & 2 & 77.5 & $\mathbf{P}$ & s & Bor \\
\hline GFW & 13 & 433358 & 0712359 & Howe, P. D. & $09-14-90$ & 540 & 2 & 32.5 & $P$ & $\mathrm{~s}$ & Bor \\
\hline GFW & 14 & 433445 & 0712359 & Gilford, Town of & $06-25-91$ & 510 & 2 & 68 & $P$ & $s$ & Bor \\
\hline GFW & 15 & 433125 & 0712403 & Lyman, John & $06-26-91$ & 800 & 2 & 42 & $P$ & $s$ & Bor \\
\hline GFW & 16 & 433110 & 0712340 & Piche & -- & 980 & -- & -- & -- & $w$ & Dug \\
\hline GFW & 17 & 433021 & 0712349 & Liptak & $05-14-84$ & 1080 & -- & 170 & -- & $x$ & BrW \\
\hline
\end{tabular}




\begin{tabular}{|c|c|c|c|c|c|c|c|c|c|c|}
\hline \multirow{2}{*}{$\begin{array}{l}\text { Local } \\
\text { site } \\
\text { number }\end{array}$} & \multicolumn{2}{|c|}{ Water level } & \multirow{2}{*}{$\begin{array}{r}\text { Top of } \\
\text { screen } \\
\text { (feet) }\end{array}$} & \multirow{2}{*}{$\begin{array}{l}\text { Bottom of } \\
\text { screen } \\
\text { (feet) }\end{array}$} & \multirow{2}{*}{$\begin{array}{c}\text { Use } \\
\text { of } \\
\text { water }\end{array}$} & \multirow[b]{2}{*}{$\begin{array}{l}\text { Yield } \\
\text { (gal/min) }\end{array}$} & \multirow[b]{2}{*}{$\begin{array}{l}\text { Drawdown } \\
\text { (feet) }\end{array}$} & \multirow[b]{2}{*}{$\begin{array}{l}\text { Specific } \\
\text { capacity }\end{array}$} & \multirow{2}{*}{$\begin{array}{l}\text { Pumping } \\
\text { period } \\
\text { (hours) }\end{array}$} & \multirow{2}{*}{$\begin{array}{l}\text { Drlller } \\
\text { or NHWRD } \\
\text { number }\end{array}$} \\
\hline & $\begin{array}{l}\text { Depth } \\
\text { (feet) }\end{array}$ & $\begin{array}{c}\text { Date } \\
\text { (mm-dd-yy) }\end{array}$ & & & & & & & & \\
\hline
\end{tabular}

\section{BELKNAP COUNTY}

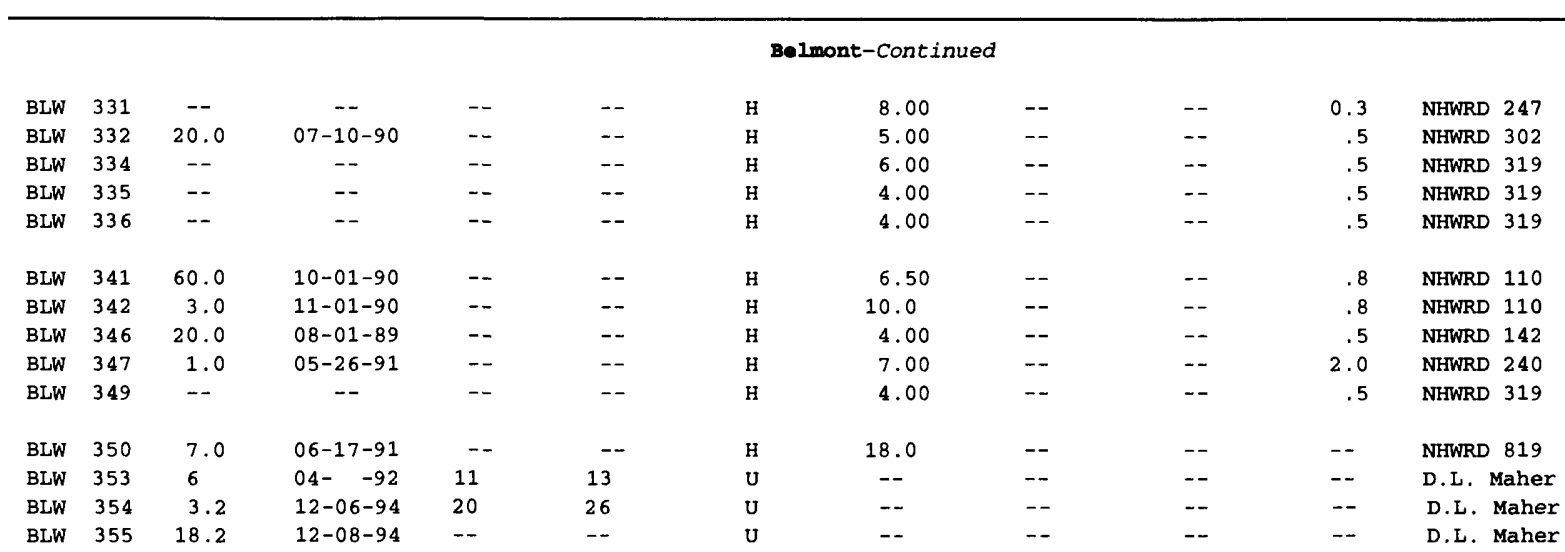

Center Earbor

\begin{tabular}{|c|c|c|c|c|c|c|c|c|c|c|c|c|}
\hline $\mathrm{CHW}$ & 1 & -- & - & -- & -- & H & 6.00 & -- & -- & 1.5 & 90 & \\
\hline $\mathrm{CHW}$ & 2 & -- & -- & -- & - & $\mathrm{H}$ & 10.0 & -- & -- & 2.0 & 90 & \\
\hline $\mathrm{CHW}$ & 3 & -- & -- & -- & -- & H & 4.50 & -- & -- & 1.0 & 90 & \\
\hline $\mathrm{CHW}$ & 5 & -- & -- & -- & -- & H & 3.00 & -- & -- & .5 & 247 & \\
\hline $\mathrm{CHW}$ & 6 & -- & -- & -- & -- & H & 20.0 & -- & -- & 1.0 & 90 & \\
\hline CHW & 7 & - & -- & -- & -- & H & .75 & -- & -- & 1.0 & 90 & \\
\hline CHW & 11 & -- & -- & -- & -- & H & 4.00 & -- & -- & .5 & NHWRD & 20 \\
\hline CHW & 14 & -- & -- & -- & -- & H & 4.50 & -- & -- & .5 & NHWRD & 20 \\
\hline CHW & 23 & -- & -- & -- & -- & H & 2.00 & -- & -- & .5 & NHWRD & 20 \\
\hline $\mathrm{CHW}$ & 25 & -- & -- & -- & -- & H & 1.50 & -- & -- & .5 & NHWRD & 20 \\
\hline
\end{tabular}

CHW $29 \quad 60 \quad 08-10-89 \quad \ldots-\ldots$

allford

\begin{tabular}{|c|c|c|c|c|c|c|c|c|c|c|c|}
\hline GFA & 1 & -- & -- & -- & -- & $\mathrm{U}$ & -- & -- & -- & -- & USGS \\
\hline GFA & 2 & -- & -- & -- & -- & $\mathrm{U}$ & -- & -- & -- & -- & USGS \\
\hline GFA & 3 & -- & -- & -- & -- & U & -- & -- & -- & -- & USGS \\
\hline GFB & 1 & 4 & $-\quad-70$ & -- & -- & -- & -- & -- & -- & -- & NHDOT \\
\hline GFB & 2 & -- & -- & -- & -- & -- & -- & -- & -- & -- & NHDOT \\
\hline GFB & 3 & -- & -- & - & -- & -- & -- & -- & -- & -- & NHDOT \\
\hline GFB & 4 & 4.52 & $07-12-88$ & -- & -- & $\mathbf{U}$ & -- & -- & -- & -- & Kennedy \\
\hline GFB & 5 & 7.73 & $07-12-88$ & -- & -- & $\mathrm{U}$ & -- & -- & -- & -- & Kennedy \\
\hline GFB & 6 & 3 & $09-12-86$ & -- & -- & U & -- & -- & -- & -- & Con-Tec, Inc \\
\hline GFB & 7 & 1.3 & $09-09-86$ & -- & -- & $\mathrm{U}$ & -- & -- & -- & -- & Con-Tec, Inc \\
\hline GFB & 8 & 1.3 & $09-10-86$ & -- & -- & U & -- & -- & -- & -- & Con-Tec, Inc \\
\hline GFB & 9 & 1.6 & $09-04-86$ & -- & -- & $\mathrm{U}$ & -- & -- & -- & -- & Con-Tec, Inc \\
\hline GFB & 10 & 12 & $09-10-86$ & -- & -- & $\mathrm{U}$ & -- & -- & -- & -- & Con-Tec, Inc \\
\hline GFB & 11 & 21 & $09-10-86$ & -- & -- & $\mathrm{U}$ & -- & -- & -- & -- & Con-Tec, Inc \\
\hline GFB & 12 & -- & -- & - & -- & $\mathrm{U}$ & -- & -- & -- & -- & Kennedy \\
\hline GFB & 13 & 8.95 & $07-18-88$ & -- & -- & $\mathrm{U}$ & -- & -- & -- & -- & Kennedy \\
\hline GFW & 7 & -- & -- & -- & -- & $U$ & -- & -- & -- & -- & -- \\
\hline GFW & 9 & -- & -- & -- & -- & $\mathrm{U}$ & -- & -- & -- & - & -- \\
\hline GFW & 11 & 6.56 & $07-02-91$ & 51.5 & 53 & $U$ & -- & -- & -- & -- & USGS \\
\hline GFW & 12 & 5.79 & $07-02-91$ & 77.5 & 80 & $\mathrm{U}$ & -- & -- & -- & -- & USGS \\
\hline GFW & 13 & 13.6 & $07-02-91$ & 32.5 & 35 & U & -- & -- & -- & -- & USGS \\
\hline GFW & 14 & 5.24 & $07-02-91$ & 68 & 70.5 & U & -- & -- & -- & -- & USGS \\
\hline GFW & 15 & 21.0 & $07-02-91$ & 39.5 & 42 & U & -- & -- & -- & -- & USGS \\
\hline GFW & 16 & 8.65 & $06-17-91$ & -- & -- & $\mathrm{H}$ & -- & -- & -- & -- & -- \\
\hline GFW & 17 & -- & -- & -- & -- & $\mathrm{H}$ & .50 & -- & -- & .5 & NHWRD 319 \\
\hline
\end{tabular}


Table A-1. Description of selected wells, borings, and springs in the Winnipesaukee River Basin, central New Hampshire

\begin{tabular}{|c|c|c|c|c|c|c|c|c|c|c|}
\hline $\begin{array}{l}\text { Local } \\
\text { site } \\
\text { number }\end{array}$ & $\begin{array}{l}\text { Lat- } \\
\text { itude }\end{array}$ & $\begin{array}{l}\text { Long- } \\
\text { itude }\end{array}$ & Owner or user & $\begin{array}{c}\text { Date } \\
\text { of } \\
\text { con- } \\
\text { struction }\end{array}$ & $\begin{array}{c}\text { Ele- } \\
\text { vat- } \\
\text { tion } \\
\text { (feet) }\end{array}$ & $\begin{array}{c}\text { Diameter } \\
\text { of } \\
\text { casing } \\
\text { (inches) }\end{array}$ & $\begin{array}{l}\text { Depth to } \\
\text { bottom } \\
\text { of casing } \\
\text { (feet) }\end{array}$ & $\begin{array}{c}\text { Casing } \\
\text { mater- } \\
\text { iai }\end{array}$ & $\begin{array}{c}\text { Type } \\
\text { of } \\
\text { fin- } \\
\text { ish }\end{array}$ & $\begin{array}{c}\text { Type } \\
\text { of } \\
\text { site }\end{array}$ \\
\hline
\end{tabular}

BELKNAP COUNTY

\begin{tabular}{|c|c|c|c|c|c|c|c|c|c|c|c|}
\hline \multirow[b]{2}{*}{ GFW } & \multicolumn{11}{|c|}{ G1lford-Continued } \\
\hline & 18 & 433344 & 0712635 & Johnson & $05-25-84$ & 520 & -- & 59.0 & -- & $\mathbf{x}$ & BrW \\
\hline GFW & 19 & 433147 & 0712354 & Hutchins & $01-01-84$ & 860 & -- & 115 & -- & $x$ & $\mathrm{BrW}$ \\
\hline GFW & 21 & 433402 & 0712403 & Ritson & $03-16-84$ & 540 & -- & 60.0 & -- & $\mathrm{x}$ & BrW \\
\hline GFW & 22 & 433405 & 0712030 & Olsen & $04-18-84$ & 620 & -- & 39.0 & -- & $x$ & BrW \\
\hline GFW & 23 & 433102 & 0712334 & Dickinson, $\mathrm{G}$. & $08-06-84$ & 960 & -- & 39.0 & -- & $\mathbf{x}$ & Brw \\
\hline GFW & 24 & 433349 & 0712642 & Bilodeau, A. & $07-25-84$ & 520 & -- & 141 & -- & $\mathrm{x}$ & BrW \\
\hline GFW & 31 & 433030 & 0712404 & Haley, $\mathrm{s}$ & $01-09-84$ & 1020 & -- & 99.0 & -- & $\mathrm{x}$ & BrW \\
\hline GFW & 32 & 433401 & 0712040 & Mooney & $07-17-84$ & 620 & -- & 29.0 & -- & $\mathrm{x}$ & $\mathrm{BrW}$ \\
\hline GFW & 33 & 433349 & 0712640 & King, $\mathrm{s}$. & $08-10-84$ & 520 & -- & 21.0 & -- & $\mathrm{s}$ & -- \\
\hline GFW & 35 & 433406 & 0712540 & Moody, F. & $03-15-85$ & 530 & -- & 154 & -- & $\mathrm{x}$ & BrW \\
\hline GFW & 37 & 433438 & 0712414 & Gilford Square & $12-23-85$ & 510 & -- & 121 & -- & $\mathbf{x}$ & BrW \\
\hline GFW & 38 & 433348 & 0712644 & Sargent Mobile Home Park & $12-05-84$ & 520 & -- & 15.5 & -- & $\mathrm{s}$ & -- \\
\hline GFW & 39 & 433143 & 0712621 & Page, L. & $04-23-85$ & 680 & -- & 114 & -- & $x$ & BrW \\
\hline GFW & 40 & 433107 & 0712335 & Ginter, E. & $05-02-85$ & 1020 & -- & 119 & -- & $\mathrm{x}$ & BrW \\
\hline GFW & 43 & 433029 & 0712404 & Sanborn, J. & $07-26-85$ & 1010 & -- & 83.0 & -- & $\mathrm{x}$ & BrW \\
\hline GFW & 44 & 433416 & 0712027 & Gamble, v. & $09-12-85$ & 560 & -- & 125 & -- & $\mathrm{x}$ & $\mathrm{Brw}$ \\
\hline GFW & 52 & 433059 & 0712643 & Flanders, $\mathrm{K}$. & $09-03-85$ & 740 & -- & 90.0 & -- & $\mathrm{x}$ & Brw \\
\hline GFW & 58 & 433354 & 0712546 & Elliott, S. & $11-12-85$ & 570 & - & 134 & -- & $\mathrm{x}$ & BrW \\
\hline GFW & 63 & 433033 & 0712402 & McCabe, D. & $05-01-85$ & 1020 & -- & 128 & -- & $\mathrm{x}$ & Brw \\
\hline GFW & 66 & 433453 & 0712419 & McGrath, P. & $02-01-85$ & 510 & -- & 84.0 & -- & $\mathbf{x}$ & $\mathrm{Brw}$ \\
\hline GFW & 67 & 433346 & 0712540 & Realty Resources & $02-01-85$ & 640 & -- & 104 & -- & $\mathrm{x}$ & BrW \\
\hline GFW & 70 & 433150 & 0712350 & $S \cot t, D$ & $02-01-85$ & 900 & -- & 104 & -- & $x$ & BrW \\
\hline GFW & 74 & 433412 & 0712038 & Gen Inc \& Devel Corp & $09-01-85$ & 620 & -- & 55.0 & -- & $\mathbf{x}$ & BrW \\
\hline GFW & 75 & 433044 & 0712624 & April, J. & $07-12-84$ & 860 & -- & 20.0 & -- & $\mathrm{x}$ & BrW \\
\hline GFW & 78 & 433413 & 0712019 & Egan, D. & $11-01-86$ & 560 & -- & 104 & -- & $\mathrm{x}$ & Brw \\
\hline GFW & 81 & 433402 & 0712357 & Droin Bldrs & $05-10-86$ & 520 & -- & 99.0 & -- & $\mathrm{x}$ & BrW \\
\hline GFW & 82 & 433400 & 0712531 & Shep Brown's Boat Basin & $04-24-86$ & 540 & -- & 24.0 & -- & $\mathbf{x}$ & BrW \\
\hline GFW & 88 & 433452 & 0712338 & watts, $\mathrm{G}$ & $05-30-86$ & 510 & -- & 85.0 & -- & $\mathrm{x}$ & $\mathrm{BrW}$ \\
\hline GFW & 89 & 433119 & 0712342 & Wright, $\mathrm{H}$. & $07-28-86$ & 970 & -- & 39.0 & -- & $x$ & $\mathrm{BrW}$ \\
\hline GFW & 91 & 433142 & 0712426 & Smith, D. & $09-08-86$ & 820 & -- & 39.0 & -- & $\mathbf{x}$ & $\mathrm{BrW}$ \\
\hline GFW & 92 & 433342 & 0712536 & Realty Resources & $09-01-86$ & 670 & -- & 122 & -- & $\mathbf{x}$ & BrW \\
\hline GFW & 98 & 433349 & 0712552 & Boulleard, $P$. & $02-10-87$ & 580 & -- & 101 & -- & $\mathrm{x}$ & $\mathrm{BrW}$ \\
\hline GFW & 100 & 433258 & 0712415 & Gilford village water Dis & $01-01-86$ & 720 & -- & 59.0 & -- & $\mathbf{x}$ & BrW \\
\hline GFW & 101 & 433302 & 0712415 & Town of Gilford & $02-13-87$ & 690 & -- & 84.0 & -- & $\mathbf{x}$ & $\mathrm{BrW}$ \\
\hline GFW & 112 & 433140 & 0712626 & Village West II & $10-21-86$ & 640 & -- & 109 & -- & $x$ & $\mathrm{BrW}$ \\
\hline GFW & 114 & 433132 & 0712610 & Audet, L. & $08-27-87$ & 780 & -- & 174 & -- & $\mathrm{x}$ & Brw \\
\hline GFW & 118 & 433404 & 0712403 & Hoyt-Dupont, $\mathrm{K}$. & $09-16-87$ & 530 & -- & 99.0 & -- & $x$ & BrW \\
\hline GFW & 120 & 433417 & 0712028 & Persons, w. & $10-30-87$ & 560 & -- & 159 & -- & $\mathrm{x}$ & BrW \\
\hline GFW & 121 & 433301 & 0712444 & Parisi, C. & $04-26-86$ & 840 & -- & 41.0 & -- & $\mathrm{x}$ & BrW \\
\hline GFW & 123 & 433500 & 0712327 & Hoffman, J. & $04-03-87$ & 510 & -- & 102 & -- & $\mathrm{x}$ & BrW \\
\hline GFW & 124 & 433401 & 0712538 & Reed Elwell Realtor & $03-27-87$ & 530 & -- & 63.0 & -- & $x$ & BrW \\
\hline GFW & 126 & 433319 & 0712400 & Harter Brook House & $10-04-87$ & 630 & -- & 64.0 & -- & $\mathrm{x}$ & $\mathrm{BrW}$ \\
\hline GFW & 134 & 433538 & 0712537 & Robertson, $C$ & $12-03-86$ & 550 & -- & 41.0 & -- & $\mathrm{x}$ & BrW \\
\hline GFW & 136 & 433453 & 0712413 & Englehardt, L. & $06-06-86$ & 510 & -- & 94.0 & -- & $x$ & BrW \\
\hline GFW & 139 & 433417 & 0712425 & Silven, $P$ & $11-25-87$ & 520 & -- & 126 & -- & $\mathrm{x}$ & BrW \\
\hline GFW & 147 & 433503 & 0712233 & Broadview Condo Assoc & $04-20-88$ & 510 & -- & 113 & -- & $\mathbf{x}$ & BrW \\
\hline GFW & 148 & 433420 & 0712549 & Vernitron Corp & $03-11-88$ & 540 & -- & 70.0 & -- & $x$ & Brw \\
\hline GFW & 151 & 433420 & 0712551 & Trapper Brown Corp & $02-25-88$ & 540 & -- & 84.0 & -- & $\mathbf{x}$ & BrW \\
\hline GFW & 153 & 433415 & 0712410 & Gokey, B. & $04-28-88$ & 520 & -- & 114 & -- & $\mathbf{x}$ & Brw \\
\hline GFW & 159 & 433505 & 0712324 & crocker, J. & $09-09-88$ & 520 & -- & 60.0 & -- & $\mathbf{x}$ & BrW \\
\hline GFW & 162 & 433413 & 0712024 & Noel, $\mathrm{D}$. & $09-22-88$ & 570 & -- & 126 & -- & $\mathrm{x}$ & BrW \\
\hline GFW & 167 & 433129 & 0712418 & Cesati, R. & $08-17-88$ & 800 & -- & 45.0 & -- & $\mathbf{x}$ & BrW \\
\hline GFW & 169 & 433412 & 0712519 & Sky Bright Hangers & $11-10-88$ & 530 & -- & 179 & -- & $\mathbf{x}$ & BrW \\
\hline GFW & 178 & 433400 & 0712405 & A. Fletcher Const, R. & $11-03-88$ & 540 & -- & 41.0 & -- & $\mathrm{x}$ & BrW \\
\hline GFW & 182 & 433020 & 0712359 & Murphy, L. & $12-08-88$ & 1060 & -- & 132 & -- & $\mathbf{x}$ & $\mathrm{BrW}$ \\
\hline
\end{tabular}




\begin{tabular}{|c|c|c|c|c|c|c|c|c|c|c|}
\hline \multirow{2}{*}{$\begin{array}{l}\text { Local } \\
\text { site } \\
\text { number }\end{array}$} & \multicolumn{2}{|c|}{ Water level } & \multirow{2}{*}{$\begin{array}{l}\text { Top of } \\
\text { screen } \\
\text { (feet) }\end{array}$} & \multirow{2}{*}{$\begin{array}{l}\text { Bottom of } \\
\text { screen } \\
\text { (feet) }\end{array}$} & \multirow{2}{*}{$\begin{array}{c}\text { Use } \\
\text { of } \\
\text { water }\end{array}$} & \multirow[b]{2}{*}{$\begin{array}{l}\text { Yield } \\
\text { (gal/min) }\end{array}$} & \multirow[b]{2}{*}{$\begin{array}{l}\text { Drawdown } \\
\text { (feet) }\end{array}$} & \multirow[b]{2}{*}{$\begin{array}{l}\text { Specific } \\
\text { capacity }\end{array}$} & \multirow{2}{*}{$\begin{array}{l}\text { Pumping } \\
\text { period } \\
\text { (hours) }\end{array}$} & \multirow{2}{*}{$\begin{array}{l}\text { Driller } \\
\text { or NHWRD } \\
\text { number }\end{array}$} \\
\hline & $\begin{array}{l}\text { Depth } \\
\text { (feet) }\end{array}$ & $\begin{array}{c}\text { Date } \\
\text { (mm-dd-yy) }\end{array}$ & & & & & & & & \\
\hline
\end{tabular}

\section{BELKNAP COUNTY}

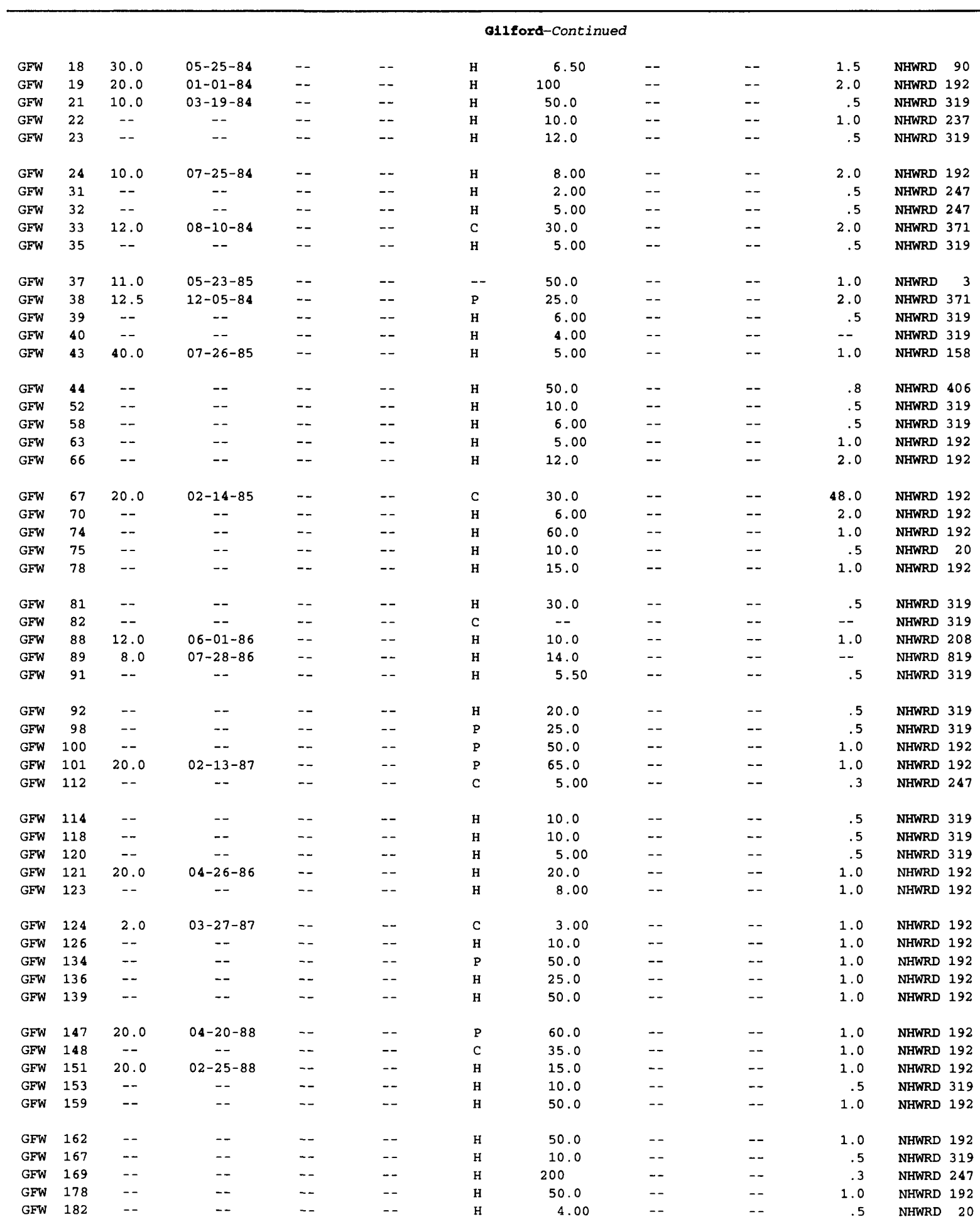


Tabie A-1. Description of selected wells, borings, and springs in the Winnipesaukee River Basin, central New Hampshire

\begin{tabular}{|c|c|c|c|c|c|c|c|c|c|c|}
\hline $\begin{array}{l}\text { Local } \\
\text { site } \\
\text { number }\end{array}$ & $\begin{array}{l}\text { Lat- } \\
\text { itude }\end{array}$ & $\begin{array}{l}\text { Long- } \\
\text { itude }\end{array}$ & Owner or user & $\begin{array}{c}\text { Date } \\
\text { of } \\
\text { con- } \\
\text { struction }\end{array}$ & $\begin{array}{c}\text { Ele- } \\
\text { vat- } \\
\text { tion } \\
\text { (feet) }\end{array}$ & $\begin{array}{c}\text { Diameter } \\
\text { of } \\
\text { casing } \\
\text { (inches) }\end{array}$ & $\begin{array}{l}\text { Depth to } \\
\text { bottom } \\
\text { of casing } \\
\text { (feet) }\end{array}$ & $\begin{array}{c}\text { Casing } \\
\text { mater- } \\
\text { ial }\end{array}$ & $\begin{array}{c}\text { Type } \\
\text { of } \\
\text { fin- } \\
\text { ish }\end{array}$ & $\begin{array}{c}\text { Type } \\
\text { of } \\
\text { site }\end{array}$ \\
\hline
\end{tabular}

BELKNAP COUNTY

\begin{tabular}{|c|c|c|c|c|c|c|c|c|c|c|c|}
\hline \multirow[b]{2}{*}{ GFW } & \multirow[b]{2}{*}{183} & \multicolumn{10}{|c|}{ Ollford-Continued } \\
\hline & & 433505 & 0712318 & Dept of Safety Services & $01-25-89$ & 510 & -- & -- & -- & $\mathbf{s}$ & -- \\
\hline GFW & 187 & 433452 & 0712335 & Cupples, A. & $11-26-89$ & 510 & -- & 92.0 & -- & $\mathrm{x}$ & $\mathrm{BrW}$ \\
\hline GFW & 188 & 433414 & 0712020 & w. Flaler, c. & $10-19-88$ & 540 & -- & 105 & -- & $\mathrm{x}$ & BrW \\
\hline GFW & 190 & 433412 & 0712014 & Ouellette, $\mathrm{R}$. & $03-30-89$ & 520 & -- & 20.0 & -- & $\mathrm{x}$ & BrW \\
\hline GFW & 194 & 433450 & 0712416 & Mountain View Yacht club & $05-05-89$ & 510 & -- & 121 & -- & $\mathrm{x}$ & $\mathrm{BrW}$ \\
\hline GFW & 200 & 433452 & 0712416 & Smith, c. & $06-19-89$ & 510 & -- & 89.0 & -- & $\mathrm{x}$ & $\mathrm{BrW}$ \\
\hline GFW & 204 & 433035 & 0712404 & Ross, E. & $11-09-89$ & 1000 & -- & 134 & -- & $\mathrm{x}$ & BrW \\
\hline GFW & 205 & 433335 & 0712659 & Walter, $\mathbf{R}$. & $09-08-89$ & 520 & -- & 92.0 & -- & $\mathrm{x}$ & $\mathrm{BrW}$ \\
\hline GFW & 213 & 433424 & 0712410 & Mawson & $10-04-89$ & 510 & -- & 124 & -- & $\mathrm{x}$ & -- \\
\hline GFW & 219 & 433545 & 0712548 & Blixt, $C$. & $06-02-88$ & 510 & -- & 99.0 & -- & $\mathrm{x}$ & $\mathrm{BrW}$ \\
\hline GFW & 223 & 433419 & 0712547 & ES Johnson Const & $08-23-90$ & 540 & -- & 100 & -- & $\mathrm{x}$ & $\mathrm{BrW}$ \\
\hline GFW & 224 & 433424 & 0712412 & Lucas & $07-20-90$ & 510 & -- & 124 & -- & $\mathrm{x}$ & -- \\
\hline GFW & 225 & 433153 & 0712624 & McGinley & $09-07-89$ & 620 & -- & 81.0 & -- & $\mathrm{x}$ & $\mathrm{BrW}$ \\
\hline GFW & 227 & 433446 & 0712351 & Lockes Hill Marine \& Spor & $08-13-90$ & 510 & -- & 80.0 & -- & $\mathrm{x}$ & BrW \\
\hline GFW & 234 & 433348 & 0712549 & Plante, A. & $12-18-90$ & 600 & -- & 120 & -- & $\mathrm{x}$ & Brw \\
\hline GFW & 235 & 433208 & 0712423 & Patterson, J. & $01-15-91$ & 790 & -- & 74.0 & -- & -- & -- \\
\hline GFW & 237 & 433501 & 0712327 & Sheldon, E. & $01-10-91$ & 510 & -- & 99.0 & -- & $\mathrm{x}$ & $\mathrm{BrW}$ \\
\hline GFW & 243 & 433225 & 0712415 & Godbout, A. & $07-18-91$ & 760 & -- & 85.0 & -- & $s$ & BrW \\
\hline GFW & 244 & 433122 & 0712417 & Bobotas, J. & $09-17-91$ & -- & -- & 31.0 & -- & $\mathrm{x}$ & Brw \\
\hline GFW & 245 & 433448 & 0712440 & Misty Harbour & $07-12-91$ & 520 & -- & 49.0 & -- & $\mathrm{x}$ & BrW \\
\hline GFW & 246 & 433501 & 0712321 & Ekholm, L. & $07-19-91$ & 520 & -- & 100 & -- & $\mathrm{x}$ & BrW \\
\hline GFW & 250 & 433423 & 0712539 & TBC Corp & $08-26-87$ & -- & -- & 106 & -- & $\mathrm{x}$ & BrW \\
\hline GFW & 251 & 433424 & 0712534 & Sugarloaf Mountain Bldrs & $01-01-86$ & -- & -- & 109 & -- & $\mathrm{x}$ & BrW \\
\hline GFW & 252 & 433420 & 0712524 & Laconia Water Dept & $11-10-67$ & 530 & -- & -- & -- & -- & Bor \\
\hline GFW & 253 & 433425 & 0712527 & Laconia Water Dept. & $11-14-67$ & 540 & -- & -- & -- & $-\cdots$ & Bor \\
\hline GFW & 254 & 433425 & 0712514 & Laconia Water Dept. & $11-14-67$ & 530 & -- & -- & - & -- & Wsh \\
\hline GFW & 255 & 433435 & 0712539 & Laconia Water Dept. & $11-17-67$ & 530 & -- & - & -- & -- & Wsh \\
\hline GFW & 256 & 433423 & 0712451 & Laconia Water Dept. & $11-20-67$ & 520 & -- & -- & -- & $\mathbf{s}$ & Wsh \\
\hline \multirow[t]{2}{*}{ GFW } & 257 & 433425 & 0712446 & Laconia Water Dept. & $11-22-67$ & 520 & -- & -- & -- & $\mathbf{s}$ & Wsh \\
\hline & \multicolumn{11}{|c|}{ Laconla } \\
\hline LAA & 1 & 433106 & 0712703 & State of $\mathrm{NH}--$ USGS & $10-16-90$ & 680 & -- & -- & -- & -- & Bor \\
\hline LAB & 1 & 433045 & 0712716 & -- & -- & 597 & -- & -- & -- & -- & Bor \\
\hline LAB & 2 & 433609 & 0712551 & -- & -- & 502 & -- & -- & -- & -- & Bor \\
\hline $\mathrm{LAB}$ & 3 & 433128 & 0712834 & -- & -- & 481 & -- & -- & -- & -- & Bor \\
\hline LAB & 4 & 433211 & 0712806 & -- & - & 499 & -- & -- & -- & -- & Bor \\
\hline $\mathrm{LAB}$ & 5 & 433205 & 0712809 & -- & -- & 498 & -- & -- & -- & -- & Bor \\
\hline $\mathrm{LAB}$ & 6 & 433209 & 0712810 & -- & -- & 500 & -- & -- & -- & -- & Bor \\
\hline LAW & 1 & 433133 & 0712843 & Winconia (Boston) Inc. & -- & 486.95 & -- & -- & -- & -- & -- \\
\hline LAW & 5 & 433014 & 0712701 & Wright, Eugene & -- & 660 & -- & -- & -- & $w$ & Dug \\
\hline LAW & 7 & 433058 & 0712659 & Champoux & $01-01-84$ & 700 & -- & 89.0 & -- & $\mathrm{x}$ & Brw \\
\hline LAW & 9 & 433541 & 0713056 & Weeks, J. & $08-10-84$ & 680 & -- & 19.0 & -- & $\mathrm{x}$ & $\mathrm{BrW}$ \\
\hline LAW & 12 & 433541 & 0713037 & Giguere, M. & $09-01-84$ & 670 & -- & 99.0 & -- & $\mathrm{x}$ & $\mathrm{BrW}$ \\
\hline LAW & 16 & 433624 & 0712624 & Salta, B. & $10-01-84$ & 510 & -- & 29.0 & -- & $\mathrm{x}$ & $\mathrm{BrW}$ \\
\hline LAW & 17 & 433550 & 0713025 & Lovely, M. & $06-23-84$ & 640 & -- & 29.0 & -- & $\mathrm{x}$ & BrW \\
\hline LAW & 41 & 433340 & 0712701 & Rudzinski， J . & $03-03-87$ & 510 & -- & 159 & -- & $\mathrm{x}$ & Brw \\
\hline LAW & 43 & 433610 & 0712558 & Lermer, $\mathrm{w}$. & $08-22-87$ & 510 & -- & 80.0 & -- & $\mathrm{x}$ & BrW \\
\hline LAW & 47 & 433240 & 0712745 & Rudzinski, P. & $01-02-88$ & 580 & -- & 79.0 & -- & $\mathrm{x}$ & BrW \\
\hline LAW & 54 & 433049 & 0712742 & Henry, J. & $04-01-88$ & 560 & -- & 60.0 & -- & $\mathrm{x}$ & Brw \\
\hline LAW & 59 & 433133 & 0712848 & Winconia Inc & $12-14-88$ & 490 & -- & -- & -- & $\mathbf{s}$ & -- \\
\hline LAW & 70 & 433636 & 0713005 & Brown, A. & $01-16-90$ & 650 & -- & 88.0 & -- & $x$ & BrW \\
\hline LAW & 71 & 433109 & 0712843 & Sanborn's Mobil Station & $04-02-90$ & 490 & -- & 4.0 & -- & G & -- \\
\hline LAW & 75 & 433606 & 0712629 & Fresta Sr, S. & $11-07-90$ & 560 & -- & 21.0 & -- & $\mathrm{x}$ & Brw \\
\hline
\end{tabular}




\begin{tabular}{|c|c|c|c|c|c|c|c|c|c|c|}
\hline $\begin{array}{l}\text { Local } \\
\text { site } \\
\text { number }\end{array}$ & $\begin{array}{l}\text { Depth } \\
\text { (feet) }\end{array}$ & $\begin{array}{c}\text { Date } \\
\text { (mm-dd-yy) }\end{array}$ & $\begin{array}{l}\text { Top of } \\
\text { screen } \\
\text { (feet) }\end{array}$ & $\begin{array}{l}\text { Bottom of } \\
\text { screen } \\
\text { (feet) }\end{array}$ & $\begin{array}{l}\text { Use } \\
\text { of } \\
\text { water }\end{array}$ & $\begin{array}{c}\text { Yield } \\
\text { (gal/min) }\end{array}$ & $\begin{array}{l}\text { Drawdown } \\
\text { (feet) }\end{array}$ & $\begin{array}{l}\text { Specific } \\
\text { capacity }\end{array}$ & $\begin{array}{l}\text { Pumplng } \\
\text { perlod } \\
\text { (hours) }\end{array}$ & $\begin{array}{l}\text { Driller } \\
\text { or NHWRD } \\
\text { number }\end{array}$ \\
\hline
\end{tabular}

\section{BELKNAP COUNTY}

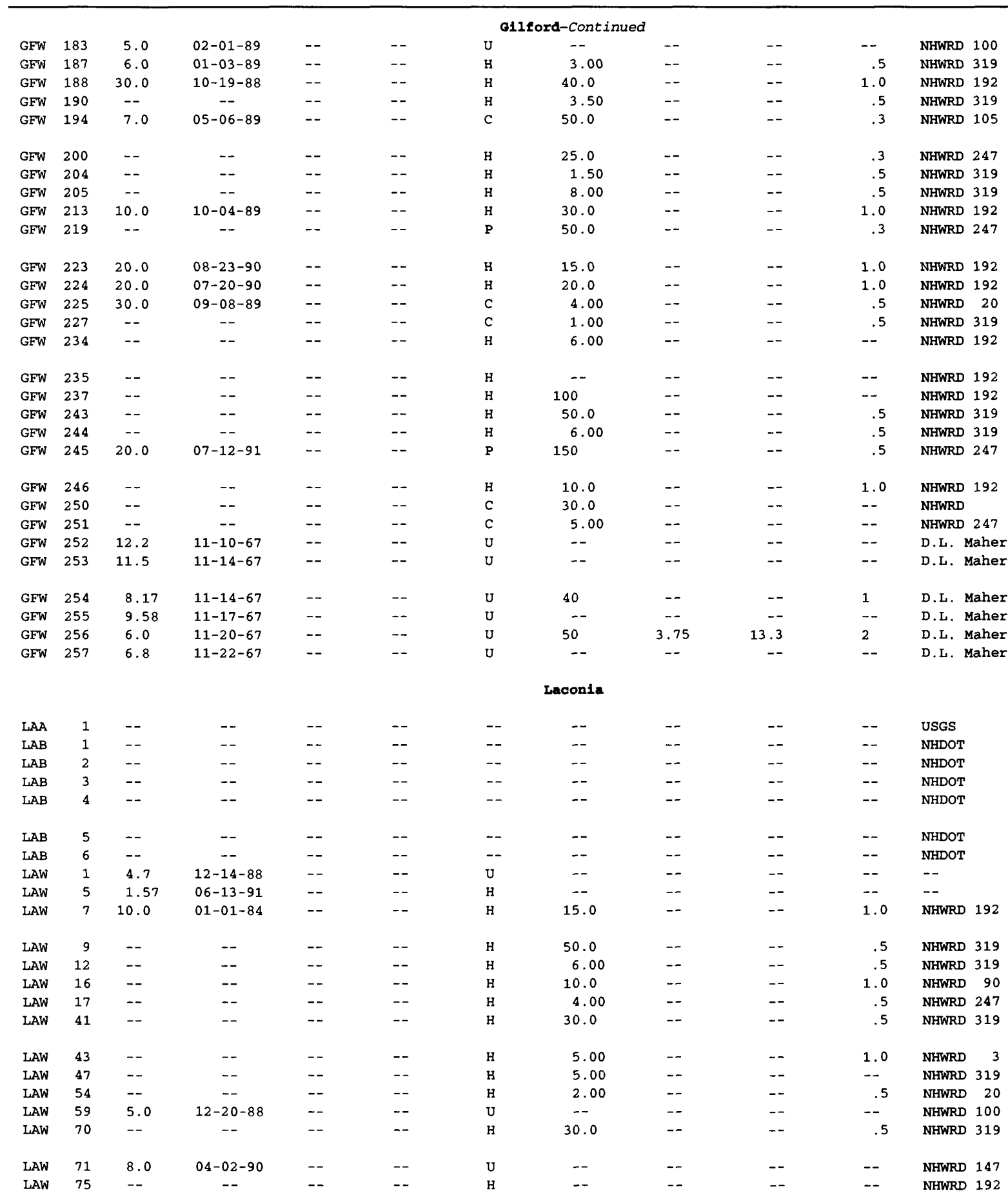


Table A-1. Description of selected wells, borings, and springs in the Winnipesaukee River Basin, central New Hampshire

\begin{tabular}{|c|c|c|c|c|c|c|c|c|c|c|}
\hline $\begin{array}{l}\text { Local } \\
\text { site } \\
\text { number }\end{array}$ & $\begin{array}{l}\text { Lat- } \\
\text { itude }\end{array}$ & $\begin{array}{l}\text { Long- } \\
\text { itude }\end{array}$ & Owner or user & $\begin{array}{c}\text { Date } \\
\text { of } \\
\text { con- } \\
\text { struction }\end{array}$ & $\begin{array}{c}\text { Ele- } \\
\text { vat- } \\
\text { tion } \\
\text { (feet) }\end{array}$ & $\begin{array}{c}\text { Diameter } \\
\text { of } \\
\text { casing } \\
\text { (inches) }\end{array}$ & $\begin{array}{l}\text { Depth to } \\
\text { bottom } \\
\text { of casing } \\
\text { (feet) }\end{array}$ & $\begin{array}{c}\text { Casing } \\
\text { mater- } \\
\text { |al }\end{array}$ & $\begin{array}{c}\text { Type } \\
\text { of } \\
\text { fin- } \\
\text { ish }\end{array}$ & $\begin{array}{c}\text { Type } \\
\text { of } \\
\text { site }\end{array}$ \\
\hline
\end{tabular}

BELKNAP COUNTY

\begin{tabular}{|c|c|c|c|c|c|c|c|c|c|c|c|}
\hline \multicolumn{12}{|c|}{ Meredith } \\
\hline MHB & 1 & 433902 & 0712954 & -- & -- & 555 & -- & -- & -- & -- & Bor \\
\hline MHB & 2 & 433908 & 0713001 & - & -- & 506 & -- & -- & -- & -- & Bor \\
\hline MHB & 3 & 434026 & 0712953 & Meredith, Town of & $11-12-70$ & 570 & -- & -- & -- & -- & $\mathrm{TH}$ \\
\hline MHB & 4 & 434029 & 0712955 & Meredith, Town of & $11-12-70$ & 570 & -- & -- & -- & -- & $\mathrm{TH}$ \\
\hline MHB & 6 & 434001 & 0712951 & Meredith, Town of & $11-12-70$ & 540 & -- & -- & -- & -- & Bor \\
\hline MHB & 7 & 434003 & 0712952 & Meredith, Town of & $11-12-70$ & 540 & -- & -- & -- & -- & $\mathrm{TH}$ \\
\hline MHB & 8 & 433951 & 0712945 & Meredith, Town of & $11-18-70$ & 530 & -- & -- & -- & -- & $\mathrm{TH}$ \\
\hline MHB & 9 & 433949 & 0712945 & Meredith, Town of & $11-16-70$ & 530 & -- & -- & -- & -- & $\mathrm{TH}$ \\
\hline MHB & 10 & 433947 & 0712942 & Meredith, Town of & $11-17-70$ & 520 & -- & -- & -- & -- & $\mathrm{TH}$ \\
\hline MHB & 11 & 433950 & 0712958 & Meredith, Town of & $11-17-70$ & 510 & -- & -- & -- & -- & $\mathrm{TH}$ \\
\hline MHB & 12 & 434014 & 0712951 & Meredith, Town of & $11-18-70$ & 560 & -- & -- & -- & -- & $\mathrm{TH}$ \\
\hline MHB & 13 & 434021 & 0712953 & Meredith, Town of & $11-10-70$ & 575 & -- & -- & -- & -- & $\mathrm{TH}$ \\
\hline MHB & 14 & 434024 & 0712954 & Meredith, Town of & $11-12-70$ & 570 & -- & -- & -- & -- & $\mathrm{TH}$ \\
\hline MHW & 1 & 434017 & 0713006 & Meredith, Town of & $11-01-90$ & 565 & -- & -- & -- & $s$ & Bor \\
\hline MHW & 2 & 433956 & 0712951 & Meredith, Town of & $10-31-90$ & 515 & -- & -- & -- & $\mathrm{s}$ & Bor \\
\hline MHW & 13 & 433610 & 0713059 & Trombetta, L. & $12-11-84$ & 650 & -- & 22.0 & -- & $\mathrm{x}$ & BrW \\
\hline MHW & 24 & 433926 & 0712856 & Zis, S. & $09-25-85$ & 530 & -- & 79.0 & -- & $\mathrm{x}$ & BrW \\
\hline MHW & 28 & 433924 & 0712854 & McGrath & $06-20-85$ & 540 & -- & 39.0 & -- & $\mathbf{x}$ & BrW \\
\hline MHW & 29 & 434046 & 0712715 & Tiege, P. & $06-02-85$ & 510 & -- & 59.0 & -- & $x$ & $\mathrm{BrW}$ \\
\hline MHW & 33 & 434011 & 0712953 & Crosby Peck & $02-05-85$ & 540 & -- & 79.0 & -- & $\mathbf{x}$ & BrW \\
\hline MHW & 58 & 433801 & 0712737 & Grimes, $P$. & $09-28-85$ & 520 & - & 29.0 & -- & $\mathrm{x}$ & BrW \\
\hline MHW & 61 & 434043 & 0712715 & Lee, J. & $12-14-85$ & 510 & -- & 60.0 & -- & $\mathbf{x}$ & \\
\hline MHW & 85 & 433537 & 0713212 & Hoyler, $\mathrm{R}$. & $05-14-86$ & 510 & -- & 19.0 & -- & $x$ & BrW \\
\hline MHW & 90 & 433621 & 0713047 & Cook & $06-19-87$ & 660 & -- & 20.0 & -- & $x$ & $\mathrm{BrW}$ \\
\hline MHW & 91 & 433753 & 0712848 & Stevens, $\mathrm{R}$. & $06-24-87$ & 520 & -- & 42.0 & -- & $\mathrm{x}$ & Brw \\
\hline MHW & 95 & 433758 & 0712849 & Boyer, N. & $06-17-87$ & 520 & -- & 33.0 & -- & $\mathrm{x}$ & BrW \\
\hline MHW & 101 & 433539 & 0713215 & Rist, $\mathrm{R}$ & $12-08-86$ & 600 & -- & 40.0 & -- & $\mathrm{x}$ & $\mathrm{BrW}$ \\
\hline MHW & 111 & 433522 & 0713219 & Kessler, G. & $12-22-87$ & 490 & -- & 34.0 & -- & $\mathrm{x}$ & Brw \\
\hline MHW & 125 & $434-43$ & 0712731 & Crognale, G. & $5-17-88$ & 540 & -- & 39.0 & -- & $\mathrm{x}$ & BrW \\
\hline MHW & 136 & 433946 & 0713113 & Rousseau, J. & $09-12-88$ & 550 & -- & 10.0 & -- & $x$ & Brw \\
\hline MHW & 143 & 433635 & 0713159 & $\&$ R. Dawson, D. & $07-15-88$ & 535 & -- & 40.0 & -- & $\mathrm{x}$ & BrW \\
\hline MHW & 147 & 433957 & 0713021 & Brady, D. & $04-20-88$ & 560 & -- & 58.0 & -- & $\mathrm{x}$ & BrW \\
\hline MHW & 162 & 433534 & 0713214 & Sheridan, J. & $05-13-87$ & 500 & -- & 27.0 & -- & $\mathrm{x}$ & BrW \\
\hline MHW & 164 & 433624 & 0713106 & Russell & $03-06-87$ & 660 & -- & 20.0 & -- & $\mathrm{x}$ & Brw \\
\hline MHW & 167 & 433807 & 0712727 & Estano, B. & $01-26-87$ & 550 & -- & 60.0 & -- & $\mathrm{x}$ & $\mathrm{BrW}$ \\
\hline MHW & 185 & 433923 & 0712854 & The Timbers & $10-26-88$ & 540 & -- & 60.0 & -- & $\mathrm{x}$ & BrW \\
\hline MHW & 203 & 433510 & 0713219 & Gallagar, T. & $06-28-88$ & 490 & -- & 66.0 & -- & $x$ & $\mathrm{BrW}$ \\
\hline MHW & 212 & 433618 & 0713045 & Lerner, $\mathrm{J}$. & $07-06-89$ & 640 & -- & 18.0 & -- & $x$ & BrW \\
\hline MHW & 216 & 433758 & 0712749 & Dwyer, $T$. & $03-20-89$ & 510 & -- & 31.0 & -- & $\mathrm{x}$ & BrW \\
\hline MHW & 223 & 434009 & 0712952 & Interlakes Mobile Park & $03-03-89$ & 560 & -- & 79.0 & -- & $\mathrm{x}$ & BrW \\
\hline MHW & 228 & 434105 & 0712722 & Milette, A. & $12-11-89$ & 510 & -- & 69.0 & -- & $\mathrm{x}$ & BrW \\
\hline MHW & 236 & 433657 & 0713218 & Plunkett, $M$. & $04-25-89$ & 510 & -- & 51.0 & -- & $\mathrm{x}$ & BrW \\
\hline MHW & 237 & 433639 & 0713159 & Forton, s. & $04-27-89$ & 520 & -- & 40.0 & -- & $\mathrm{x}$ & Brw \\
\hline MHW & 242 & 433507 & 0713217 & Tamposi, S. & $05-11-89$ & 490 & -- & 29.0 & -- & $\mathrm{x}$ & BrW \\
\hline MHW & 258 & 433711 & 0713235 & Golden, W. & $09-22-90$ & 530 & -- & 39.0 & -- & $\mathrm{x}$ & BrW \\
\hline MHW & 262 & 433753 & 0712852 & Settele, J. & $07-23-91$ & 530 & -- & 60.0 & -- & -- & -- \\
\hline \multicolumn{12}{|c|}{ New Eampton } \\
\hline NHS & 1 & 434123 & 0713457 & -- & -- & 590 & -- & -- & -- & -- & $\mathrm{sp}$ \\
\hline NHW & 33 & 434047 & 0713421 & Dawber, william & -- & 555 & -- & -- & -- & -- & Brw \\
\hline NHW & 34 & 434120 & 0713542 & Saunders, John and Kriste & -- & 700 & -- & - & -- & -- & BrW \\
\hline \multicolumn{12}{|c|}{ Sanbornton } \\
\hline $\mathrm{SCB}$ & 3 & 433008 & 0713045 & -- & -- & 482 & -- & - & -- & -- & $\mathrm{TH}$ \\
\hline SCW & 45 & 433007 & 0713129 & Gilman, $M$. & $04-\quad-56$ & 505 & -- & $-\cdots$ & -- & -- & BrW \\
\hline
\end{tabular}




\begin{tabular}{|c|c|c|c|c|c|c|c|c|c|c|}
\hline $\begin{array}{l}\text { Local } \\
\text { site } \\
\text { number }\end{array}$ & $\begin{array}{l}\text { Depth } \\
\text { (feet) }\end{array}$ & $\frac{\text { Date }}{\text { (mm-dd-yy) }}$ & $\begin{array}{l}\text { Top of } \\
\text { screen } \\
\text { (feet) }\end{array}$ & $\begin{array}{l}\text { Bottom of } \\
\text { screen } \\
\text { (feet) }\end{array}$ & $\begin{array}{c}\text { Use } \\
\text { of } \\
\text { water }\end{array}$ & $\begin{array}{c}\text { Yield } \\
\text { (gal/min) }\end{array}$ & $\begin{array}{l}\text { Drawdown } \\
\text { (feet) }\end{array}$ & $\begin{array}{l}\text { Specific } \\
\text { capacity }\end{array}$ & $\begin{array}{l}\text { Pumplng } \\
\text { period } \\
\text { (hours) }\end{array}$ & $\begin{array}{l}\text { Driller } \\
\text { or NHWRD } \\
\text { number }\end{array}$ \\
\hline
\end{tabular}

BELKNAP COUNTY

\begin{tabular}{|c|c|c|c|c|c|c|c|c|c|c|c|}
\hline \multirow[b]{2}{*}{ MHB } & \multirow[b]{2}{*}{1} & \multicolumn{10}{|c|}{ woredith } \\
\hline & & -- & -- & -- & -- & -- & -- & -- & -- & - & NHDOT \\
\hline MHB & 2 & -- & -- & -- & -- & -- & -- & -- & -- & -- & NHDOT \\
\hline MHB & 3 & -- & -- & -- & -- & $u$ & -- & -- & -- & -- & R.E. Chapman \\
\hline MHB & 4 & -- & -- & -- & $\cdots$ & $\mathrm{U}$ & $\cdots$ & -- & -- & -- & R.E. Chapman \\
\hline MHB & 6 & -- & -- & -- & -- & $\mathbf{U}$ & -- & -- & -- & -- & R.E. Chapman \\
\hline MHB & 7 & -- & -- & -- & -- & U & -- & -- & -- & -- & R.E. Chapman \\
\hline MHB & 8 & -- & -- & -- & -- & $\mathrm{u}$ & -- & -- & -- & -- & R.E. Chapman \\
\hline MHB & 9 & -- & -- & -- & -- & $u$ & -- & -- & - & -- & R.E. Chapman \\
\hline MHB & 10 & -- & -- & -- & -- & $U$ & -- & -- & -- & -- & R.E. Chapman \\
\hline MHB & 11 & -- & -- & -- & -- & $\mathbf{U}$ & -- & -- & $\cdots$ & -- & R.E. Chapman \\
\hline MHB & 12 & 3.2 & $11-18-70$ & $\rightarrow$ & -- & $\mathrm{U}$ & -- & -- & -- & -- & R.E. Chapman \\
\hline MHB & 13 & -- & -- & - & -- & $\mathbf{U}$ & -- & -- & -- & -- & R.E. Chapman \\
\hline MHB & 14 & -- & -- & -- & -- & $\mathrm{U}$ & -- & -- & + & -- & R.E. Chapman \\
\hline MHW & 1 & 17.2 & $07-25-91$ & 32.5 & 35 & U & -- & - & -- & $\cdots$ & USGS \\
\hline MHW & 2 & 9.01 & $07-02-91$ & 52.5 & 55 & $\mathrm{U}$ & -- & -- & $\rightarrow$ & -- & USGS \\
\hline MHW & 13 & 20.0 & $12-11-84$ & -- & -- & H & 6.00 & -- & -- & 1.0 & NHWRD 90 \\
\hline MHW & 24 & -- & -- & -- & -- & $\mathrm{H}$ & 70.0 & -- & -- & 1.0 & NHWRD 90 \\
\hline MHW & 28 & -- & -- & -- & -- & H & 4.00 & -- & -- & 1.0 & NHWRD 90 \\
\hline MHW & 29 & 5.0 & $06-02-85$ & -- & $\cdots$ & H & & & & & NHWRD 90 \\
\hline MHW & 33 & 24.0 & $02-18-85$ & -- & -- & $\mathbf{P}$ & 30.0 & -- & + & 48.0 & NHWRD 90 \\
\hline MHW & 58 & 20.0 & $09-29-85$ & -- & -- & $\mathrm{H}$ & 2.75 & -- & -- & .5 & NHWRD 20 \\
\hline MHW & 61 & 60.0 & $06-02-85$ & -- & -- & $\mathbf{H}$ & & & & & NHWRD 61 \\
\hline MHW & 85 & -- & -- & -- & -- & $\mathbf{H}$ & 50.0 & -- & -- & .3 & NHWRD 247 \\
\hline MHW & 90 & -- & -- & -- & -- & H & 30.0 & -- & -- & 1.0 & NHWRD 192 \\
\hline MHW & 91 & -- & - & -- & -- & $\mathbf{H}$ & 10.0 & -- & -- & 1.0 & NHWRD 192 \\
\hline MHW & 95 & 15.0 & $06-17-87$ & -- & -- & H & 100 & -- & -- & 1.0 & NHWRD 59 \\
\hline MHW & 101 & -- & -- & -- & -- & H & 8.00 & -- & -- & .5 & NHWRD 20 \\
\hline MHW & 111 & 8.0 & $12-22-87$ & -- & -- & H & 10.0 & -- & -- & -- & NHWRD 819 \\
\hline MHW & 125 & 20.0 & $5-17-88$ & -- & -- & H & & & & & NHWRD 382 \\
\hline MHW & 136 & -- & -- & $\rightarrow$ & -- & H & 1.00 & -- & -- & .3 & NHWRD 247 \\
\hline MHW & 143 & 50.0 & $07-16-88$ & -- & -- & H & 30.0 & -- & -- & .5 & NHWRD 20 \\
\hline MHW & 147 & 50.0 & $04-21-88$ & - & -- & H & 60.0 & -- & -- & .5 & NHWRD 20 \\
\hline MHW & 162 & 15.0 & $05-14-87$ & -- & -- & H & 2.50 & -- & -- & .5 & NHWRD 20 \\
\hline MHW & 164 & 25.0 & $03-07-87$ & -- & -- & H & 1.50 & -- & -- & .5 & NHWRD 20 \\
\hline MHW & 167 & 20.0 & $01-27-87$ & -- & -- & $\mathbf{H}$ & 5.00 & -- & -- & .5 & NHWRD 20 \\
\hline MHW & 185 & -- & -- & -- & -- & $\mathbf{P}$ & 50.0 & -- & -- & .5 & NHWRD 20 \\
\hline MHW & 203 & 15.0 & $06-29-88$ & -- & -- & $\mathbf{H}$ & 15.0 & -- & -- & .5 & NHWRD 142 \\
\hline MHW & 212 & -- & -- & -- & -- & $\mathbf{H}$ & 10.0 & -- & -- & .5 & NHWRD 90 \\
\hline MHW & 216 & -- & -- & -- & -- & $\mathbf{H}$ & 7.00 & -- & -- & .3 & NHWRD 90 \\
\hline MHW & 223 & 38.0 & $03-03-89$ & -- & -- & $\mathbf{P}$ & 35.0 & -- & -- & 48.0 & NHWRD 90 \\
\hline MHW & 228 & 6.0 & $12-14-89$ & -- & -- & - & & & & & NHWRD 90 \\
\hline MHW & 236 & 10.0 & $04-26-89$ & -- & -- & $\mathrm{H}$ & 10.0 & -- & -- & .5 & NHWRD 142 \\
\hline MHW & 237 & 15.0 & $04-28-89$ & - & -- & $\mathrm{H}$ & 7.50 & -- & -- & .5 & NHWRD 142 \\
\hline MHW & 242 & 8.0 & $05-12-89$ & -- & -- & H & 100 & -- & -- & .5 & NHWRD 20 \\
\hline MHW & 258 & -- & -- & -- & -- & $\mathrm{H}$ & 30.0 & -- & -- & .5 & NHWRD 319 \\
\hline \multirow[t]{2}{*}{ MHW } & 262 & 20.0 & $07-23-91$ & -- & -- & $\mathbf{H}$ & 30.0 & -- & -- & 1.0 & NHWRD 192 \\
\hline & & \multicolumn{10}{|c|}{ New Bampton } \\
\hline NHS & 1 & -- & -- & -- & -- & -- & -- & -- & -- & -- & -- \\
\hline NHW & 33 & -- & -- & -- & -- & H & -- & -- & -- & -- & -- \\
\hline \multirow[t]{2}{*}{ NHW } & 34 & 20 & $11-08-84$ & -- & -- & H & -- & -- & -- & -- & -- \\
\hline & & \multicolumn{10}{|c|}{ sanbornton } \\
\hline $\mathrm{SCB}$ & 3 & -- & -- & -- & -- & $\mathrm{u}$ & -- & -- & -- & -- & -- \\
\hline SCW & 45 & -- & -- & -- & -- & -- & -- & -- & -- & -- & Daniels \\
\hline
\end{tabular}


Table A-1. Description of selected wells, borings, and springs in the Winnipesaukee River Basin, central New Hampshire

\begin{tabular}{|c|c|c|c|c|c|c|c|c|c|c|}
\hline $\begin{array}{l}\text { Local } \\
\text { site } \\
\text { number }\end{array}$ & $\begin{array}{l}\text { Lat- } \\
\text { itude }\end{array}$ & $\begin{array}{l}\text { Long- } \\
\text { itude }\end{array}$ & Owner or user & $\begin{array}{c}\text { Date } \\
\text { of } \\
\text { con- } \\
\text { struction }\end{array}$ & $\begin{array}{l}\text { Ele- } \\
\text { vat- } \\
\text { tion } \\
\text { (feet) }\end{array}$ & $\begin{array}{c}\text { Diameter } \\
\text { of } \\
\text { casing } \\
\text { (inches) }\end{array}$ & $\begin{array}{l}\text { Depth to } \\
\text { bottom } \\
\text { of casing } \\
\text { (feet) }\end{array}$ & $\begin{array}{c}\text { Casing } \\
\text { mater- } \\
\text { ial }\end{array}$ & $\begin{array}{c}\text { Type } \\
\text { of } \\
\text { fin- } \\
\text { ish }\end{array}$ & $\begin{array}{c}\text { Type } \\
\text { of } \\
\text { site }\end{array}$ \\
\hline
\end{tabular}

\section{BELKNAP COUNTY}

\begin{tabular}{|c|c|c|c|c|c|c|c|c|c|c|c|}
\hline \multirow[b]{2}{*}{ SCW } & \multicolumn{11}{|c|}{ sanbornton-Continued } \\
\hline & 49 & 433002 & 0713158 & Nelson & $07-\quad-60$ & 585 & -- & -- & -- & -- & BrW \\
\hline SCW & 69 & 433250 & 0713215 & LaFond, $T$. & $07-30-84$ & 540 & -- & 39.0 & -- & $\mathrm{x}$ & Brw \\
\hline SCW & 81 & 433309 & 0713158 & Taylor, s. & $01-01-85$ & 640 & -- & 20.0 & -- & $\mathrm{x}$ & Brw \\
\hline SCW & 88 & 433230 & 0713121 & Rosenberg & $05-13-86$ & 500 & -- & 69.0 & -- & $\mathrm{x}$ & BrW \\
\hline SCW & 94 & 433037 & 0713059 & Drouin, L. & $11-17-86$ & 500 & -- & 49.0 & -- & $\mathrm{x}$ & BrW \\
\hline $\mathrm{SCW}$ & 97 & 432910 & 0713512 & Kent, $\mathrm{D}$. & $04-22-87$ & 720 & -- & 15.0 & -- & $\mathrm{x}$ & BrW \\
\hline SCW & 110 & 433017 & 0713048 & Garside, J. & $09-16-86$ & 500 & -- & 79.0 & -- & $\mathrm{x}$ & BrW \\
\hline scW & 130 & 433010 & 0713051 & Teco Corp. & $04-08-86$ & 485 & 2 & 75 & $\mathbf{P}$ & $s$ & Bor \\
\hline SCW & 131 & 433007 & 0713050 & Teco Corp. & $04-18-86$ & 485 & 2 & 80 & $\mathbf{P}$ & $\mathrm{s}$ & Bor \\
\hline SCW & 132 & 433006 & 0713054 & Teco Corp. & $04-16-86$ & 485 & 2 & 85 & $\mathbf{P}$ & $s$ & Bor \\
\hline SCW & 133 & 433004 & 0713053 & Sylvestros Tires & $10-10-89$ & 499.62 & 2 & 10 & $\mathbf{P}$ & $s$ & Bor \\
\hline \multirow[t]{2}{*}{$\mathrm{SCW}$} & 134 & 433005 & 0713051 & Sylvestros Tires & $10-10-89$ & 499.77 & 2 & 10 & $P$ & $s$ & Bor \\
\hline & \multicolumn{11}{|c|}{ T11ton } \\
\hline TSB & 1 & 432706 & 0713347 & -- & -- & 469 & -- & -- & -- & -- & Bor \\
\hline TSB & 3 & 432819 & 0713159 & -- & -- & 450 & -- & -- & -- & -- & Bor \\
\hline TSB & 4 & 432822 & 0713230 & Aries Eng. & -- & 500 & -- & -- & -- & -- & $\mathrm{TH}$ \\
\hline TSB & 5 & 432816 & 0713228 & Aries Eng. & -- & 480 & -- & -- & -- & -- & $\mathrm{TH}$ \\
\hline TSW & 1 & 432635 & 0713515 & Layne, NE & $08-15-68$ & 440 & -- & -- & -- & -- & Bor \\
\hline TSW & 2 & 432617 & 0713550 & Layne, NE & $12-10-68$ & 420 & -- & -- & -- & -- & Bor \\
\hline TSW & 4 & 432712 & 0713251 & Quinn-T Corp. & $02-20-86$ & 479.33 & 2 & 15 & $\mathbf{P}$ & $s$ & Bor \\
\hline TSW & 5 & 432717 & 0713302 & Quinn-T Corp. & $02-18-86$ & 485.5 & 2 & 45 & $\mathbf{P}$ & $s$ & Bor \\
\hline TSW & 6 & 432714 & 0713302 & Quinn-T Corp. & $02-20-86$ & 479 & 2 & 15 & $\mathbf{P}$ & $s$ & Bor \\
\hline TSW & 7 & 432712 & 0713258 & Quinn-T Corp. & $03-03-86$ & 475 & 2 & 41 & $\mathbf{P}$ & $\mathbf{s}$ & Bor \\
\hline TSW & 8 & 432721 & 0713246 & Quinn-T Corp. & $03-21-86$ & 485 & 2 & 15 & $\mathbf{P}$ & $\mathrm{s}$ & Bor \\
\hline TSW & 9 & 432726 & 0713241 & Quinn-T Corp. & $03-19-86$ & 485 & 2 & 15 & $\mathbf{P}$ & $\mathrm{s}$ & Bor \\
\hline TSW & 10 & 432730 & 0713255 & Quinn-T Corp. & $03-30-86$ & 485 & 2 & 3 & $\mathbf{P}$ & $\mathbf{s}$ & Bor \\
\hline TSW & 11 & 432733 & 0713313 & Quin-T Corp. & $02-24-89$ & 489.43 & 2 & 16 & $P$ & $\mathrm{~s}$ & Bor \\
\hline TSW & 12 & 432730 & 0713316 & Quin-T Corp. & $02-24-89$ & 491.64 & 2 & 20 & $\mathbf{P}$ & $\mathrm{s}$ & Bor \\
\hline TSW & 13 & 432729 & 0713317 & Quin-T Corp. & $03-01-89$ & 489.35 & 2 & 65 & $\mathbf{P}$ & $\mathrm{s}$ & Bor \\
\hline TSW & 14 & 432729 & 0713315 & Quin-T Corp. & $02-27-89$ & 489.72 & 2 & 20 & $\mathbf{P}$ & $\mathbf{s}$ & Bor \\
\hline TSW & 15 & 433004 & 0713052 & Sylvestros Tires & $10-10-89$ & 499.5 & 2 & 5 & $\mathbf{P}$ & $s$ & Bor \\
\hline Tsw & 16 & 432720 & 0713358 & Pike Industries, Inc & $01-24-90$ & 475 & 2 & 15 & $\mathbf{P}$ & $s$ & Bor \\
\hline TSW & 17 & 432718 & 0713358 & Pike Industries, Inc. & $01-24-90$ & 472 & 2 & 15 & $\mathbf{P}$ & $s$ & Bor \\
\hline TSW & 18 & 432719 & 0713357 & Pike Industries, Inc. & $01-24-90$ & 473 & 2 & 15 & $\mathbf{P}$ & $s$ & Bor \\
\hline TSW & 19 & 432717 & 0713358 & Pike Industries, Inc. & $01-24-90$ & 469 & 2 & 15 & $\mathbf{P}$ & $\mathbf{s}$ & Bor \\
\hline TSW & 20 & 432721 & 0713356 & Pike Industries, Inc. & $01-24-90$ & 474 & 2 & 15 & $\mathbf{P}$ & $\mathrm{s}$ & Bor \\
\hline TSW & 21 & 432722 & 0713357 & Pike Industries, Inc. & $01-24-90$ & 477 & 2 & 15 & $\mathbf{P}$ & $\mathrm{s}$ & Bor \\
\hline TSW & 22 & 432724 & 0713351 & Pike Industries, Inc. & $01-25-90$ & 478 & 2 & 15 & P & $s$ & Bor \\
\hline TSW & 23 & 432720 & 0713353 & Pike Industries, Inc. & $01-25-90$ & 471 & 2 & 15 & $\mathbf{p}$ & $\mathrm{s}$ & Bor \\
\hline TSW & 24 & 432736 & 0713240 & Jackson & -- & 470 & -- & -- & -- & $w$ & Dug \\
\hline TSW & 25 & 432827 & 0713236 & Tilton Nursery & $06-07-84$ & 500 & -- & 64.0 & $\cdots$ & $\mathrm{x}$ & BrW \\
\hline TSW & 26 & 432714 & 0713409 & McDonald's Corp & $11-02-84$ & 480 & -- & 167 & -- & $\mathrm{x}$ & BrW \\
\hline TSW & 28 & 432845 & 0713221 & Goodsell, D. & $10-15-84$ & 520 & -- & 146 & -- & $\mathrm{x}$ & BrW \\
\hline TSW & 33 & 432828 & 0713210 & Lodge, G. & $06-18-85$ & 500 & -- & 1.0 & -- & -- & Dug \\
\hline TSW & 34 & 432900 & 0713157 & Crawford, J. & $01-15-87$ & 490 & -- & 101 & -- & $\mathrm{x}$ & BrW \\
\hline TSW & 35 & 432958 & 0713108 & Tioga Realty & $12-11-86$ & 495 & -- & 59.0 & -- & $\mathrm{x}$ & Brw \\
\hline TSW & 36 & 432925 & 0713135 & Garofalo, v. & $11-21-86$ & 490 & -- & 94.0 & -- & $\mathrm{x}$ & BrW \\
\hline TSW & 40 & 432755 & 0713257 & Trapper Brown Corp & $10-26-87$ & 480 & -- & 83.0 & -- & $\mathrm{x}$ & BrW \\
\hline TSW & 41 & 432903 & 0713156 & Donavon, $\mathrm{T}$. & $10-08-87$ & 500 & -- & 99.0 & -- & $\mathrm{x}$ & BrW \\
\hline TSW & 42 & 432905 & 0713158 & Mears, R. & $09-24-87$ & 510 & -- & 119 & -- & $\mathrm{x}$ & BrW \\
\hline TSW & 43 & 432722 & 0713353 & Pike Industries Inc & $07-26-86$ & 470 & -- & 146 & -- & $\mathrm{x}$ & BrW \\
\hline TSW & 44 & 432957 & 0713106 & Tioga Realty & $01-13-88$ & 500 & -- & 94.0 & -- & $\mathrm{x}$ & Brw \\
\hline TSW & 45 & 432901 & 0713153 & Internicola, $\mathrm{J}$. & $11-06-87$ & 485 & -- & 99.0 & -- & $\mathrm{x}$ & Brw \\
\hline
\end{tabular}




\begin{tabular}{|c|c|c|c|c|c|c|c|c|c|c|}
\hline \multirow{2}{*}{$\begin{array}{l}\text { Local } \\
\text { site } \\
\text { number }\end{array}$} & \multicolumn{2}{|c|}{ Water level } & \multirow{2}{*}{$\begin{array}{l}\text { Top of } \\
\text { screen } \\
\text { (feet) }\end{array}$} & \multirow{2}{*}{$\begin{array}{c}\text { Bottom of } \\
\text { screen } \\
\text { (feet) }\end{array}$} & \multirow{2}{*}{$\begin{array}{c}\text { Use } \\
\text { of } \\
\text { water }\end{array}$} & \multirow[b]{2}{*}{$\begin{array}{l}\text { Yield } \\
\text { (gal/min) }\end{array}$} & \multirow[b]{2}{*}{$\begin{array}{l}\text { Drawdown } \\
\text { (feet) }\end{array}$} & \multirow[b]{2}{*}{$\begin{array}{l}\text { Specific } \\
\text { capacity }\end{array}$} & \multirow{2}{*}{$\begin{array}{l}\text { Pumping } \\
\text { period } \\
\text { (hours) }\end{array}$} & \multirow{2}{*}{$\begin{array}{l}\text { Driller } \\
\text { or NHWRD } \\
\text { number }\end{array}$} \\
\hline & $\begin{array}{l}\text { Depth } \\
\text { (feet) }\end{array}$ & $\begin{array}{c}\text { Date } \\
\text { (mm-dd-yy) }\end{array}$ & & & & & & & & \\
\hline
\end{tabular}

BELKNAP COUNTY

\begin{tabular}{lccccc}
\hline & & & & & \\
SCW & 49 & -- & -- & -- & -- \\
SCW & 69 & -- & -- & -- & -- \\
SCW & 81 & -- & -- & -- & -- \\
& & & & & \\
SCW & 88 & 10.0 & $05-01-86$ & -- & -- \\
SCW & 94 & -- & -- & -- & -- \\
SCW & 97 & 20.0 & $04-23-87$ & -- & -- \\
SCW & 110 & -- & -- & -- & -- \\
SCW & 130 & 6.8 & $04-08-86$ & 75 & 80 \\
& & & & & \\
SCW & 131 & 6.3 & $04-18-86$ & 80 & 83 \\
SCW & 132 & 9.5 & $04-16-86$ & 85 & 91 \\
SCW & 133 & 13.9 & $10-26-89$ & 10 & 20 \\
SCW & 134 & 13.3 & $10-10-89$ & 10 & 20 \\
& & & & &
\end{tabular}

Sanbornton-Continued

\begin{tabular}{|c|c|c|c|c|c|c|c|c|c|c|}
\hline TSB & -- & -- & -- & -- & -- & -- & - & -- & -- & NHDOT \\
\hline TSB & -- & -- & -- & -- & -- & -- & -- & -- & -- & NHDOT \\
\hline TSB & .3 & $05-18-88$ & -- & -- & $\mathrm{U}$ & -- & -- & -- & -- & -- \\
\hline TSB & .6 & $05-19-88$ & -- & -- & $\mathrm{U}$ & -- & -- & -- & -- & -- \\
\hline TSW & 12 & $08-15-68$ & -- & -- & -- & -- & -- & -- & -- & Layne \\
\hline TSW & 9 & $12-10-68$ & -- & -- & -- & -- & -- & -- & - & Layne \\
\hline TSW & 14.1 & $02-20-86$ & 15 & 25 & $\mathrm{U}$ & -- & -- & -- & -- & Con-Tec, Inc \\
\hline TSW & 19.7 & $02-18-86$ & 45 & 50 & $\mathrm{U}$ & -- & -- & -- & -- & Con-Tec, Inc \\
\hline TSW & 14.1 & $02-20-86$ & 15 & 25 & $\mathrm{U}$ & -- & -- & -- & -- & Con-Tec, Inc \\
\hline TSW & 1.02 & $03-03-86$ & 41 & 46 & $\mathrm{U}$ & -- & -- & -- & - & Con-Tec, Inc \\
\hline TSW & 14 & $03-21-86$ & 15 & 30 & $\mathrm{u}$ & -- & -- & -- & - & Con-Tec, Inc \\
\hline TSW & 14 & $03-19-86$ & 15 & 30 & $\mathrm{U}$ & -- & -- & -- & - & Con-Tec, Inc \\
\hline TSW & 6.5 & $03-30-86$ & 3 & 13 & $U$ & -- & - & -- & - & Con-Tec, Inc \\
\hline TSW & 17.4 & $02-28-89$ & 16 & 26 & $\mathrm{U}$ & -- & -- & -- & -- & Soil Expl. \\
\hline TSW & 22.5 & $02-28-89$ & 20 & 30 & $\mathrm{U}$ & - & -- & -- & -- & Soil Expl. \\
\hline TSW & 13 & -- & 65 & 75 & $\mathrm{u}$ & -- & -- & -- & -- & Soil Expl. \\
\hline TSW & 21.1 & $02-28-89$ & 20 & 30 & $\mathrm{U}$ & -- & -- & -- & - & Soil Expl. \\
\hline TSW & 12.9 & $10-26-89$ & 5 & 15 & $U$ & -- & -- & -- & -- & Kennedy \\
\hline TSW & 6.76 & $01-29-90$ & 5 & 15 & $\mathrm{U}$ & -- & -- & -- & -- & Aries Engineer \\
\hline TSW & 4.52 & $01-29-90$ & 5 & 15 & $\mathrm{U}$ & -- & -- & -- & -- & Aries Engineer. \\
\hline TSW & 5.23 & $01-29-90$ & 5 & 15 & $\mathrm{U}$ & -- & -- & -- & -- & Aries Engineer \\
\hline TSW & 1.84 & $01-29-90$ & 5 & 15 & $\mathrm{U}$ & -- & -- & -- & - & Aries Engineer. \\
\hline TSW & 5.63 & $01-29-90$ & 5 & 15 & $U$ & -- & -- & -- & -- & Aries Engineer \\
\hline TSW & 8.92 & $01-29-90$ & 5 & 15 & $U$ & -- & -- & -- & -- & Aries Engineer \\
\hline TSW & 9.23 & $01-29-90$ & 5 & 15 & U & -- & -- & -- & -- & Aries Engineer. \\
\hline TSW & 4.28 & $01-29-90$ & 5 & 15 & U & -- & -- & -- & -- & Aries Engineer \\
\hline TSW & 7.41 & $06-13-91$ & -- & -- & $\mathrm{H}$ & -- & -- & -- & -- & Gilbert, L. \\
\hline TSW & 20.0 & $06-07-84$ & -- & -- & $\mathbf{z}$ & 20.0 & -- & -- & 1.0 & NHWRD 280 \\
\hline TSW & 20.0 & $11-02-84$ & - & -- & $\mathrm{c}$ & 10.0 & -- & -- & 2.0 & NHWRD 427 \\
\hline TSW & 28 & -- & -- & -- & H & 10.0 & -- & -- & .5 & $\begin{array}{ll}\text { NHWRD } & 1\end{array}$ \\
\hline TSW & 5.0 & $06-20-85$ & -- & -- & H & -- & -- & -- & -- & NHWRD 536 \\
\hline TSW & 34 & -- & -- & -- & $\mathrm{H}$ & 2.00 & -- & -- & .5 & NHWRD 319 \\
\hline TSW & 35 & -- & -- & -- & $\mathrm{H}$ & 6.00 & -- & -- & .5 & NHWRD 319 \\
\hline TSW & 36 & -- & -- & - & $\mathrm{H}$ & 5.00 & - & -- & .5 & NHWRD 319 \\
\hline TSW & 10.0 & $10-26-87$ & -- & -- & $\mathrm{H}$ & 4.00 & -- & -- & 1.0 & NHWRD 192 \\
\hline TSW & 41 & -- & -- & -- & $\mathrm{H}$ & 6.00 & -- & -- & .5 & NHWRD 319 \\
\hline TSW & 42 & -- & - & -- & $\mathrm{H}$ & 15.0 & -- & -- & .5 & NHWRD 319 \\
\hline TSW & 43 & -- & -- & -- & H & 30.0 & -- & -- & 1.0 & NHWRD 192 \\
\hline TSW & 44 & -- & -- & -- & C & 1.00 & -- & -- & -- & NHWRD 319 \\
\hline TSW & 45 & -- & -- & -- & $\mathrm{H}$ & 2.00 & -- & -- & .5 & NHWRD 319 \\
\hline
\end{tabular}


Tabie A-1. Description of selected wells, borings, and springs in the Winnipesaukee River Basin, central New Hampshire

\begin{tabular}{|c|c|c|c|c|c|c|c|c|c|c|}
\hline $\begin{array}{l}\text { Local } \\
\text { site } \\
\text { number }\end{array}$ & $\begin{array}{l}\text { Lat- } \\
\text { itude }\end{array}$ & $\begin{array}{l}\text { Long- } \\
\text { itude }\end{array}$ & Owner or user & $\begin{array}{c}\text { Date } \\
\text { of } \\
\text { con- } \\
\text { struction }\end{array}$ & $\begin{array}{l}\text { Ele- } \\
\text { vat- } \\
\text { tion } \\
\text { (feet) }\end{array}$ & $\begin{array}{c}\text { Diameter } \\
\text { of } \\
\text { casing } \\
\text { (inches) }\end{array}$ & $\begin{array}{l}\text { Depth to } \\
\text { bottom } \\
\text { of casing } \\
\text { (feet) }\end{array}$ & $\begin{array}{c}\text { Casing } \\
\text { mater- } \\
\text { lal }\end{array}$ & $\begin{array}{l}\text { Type } \\
\text { of } \\
\text { fin- } \\
\text { ish }\end{array}$ & $\begin{array}{c}\text { Type } \\
\text { of } \\
\text { site }\end{array}$ \\
\hline
\end{tabular}

BELKNAP COUNTY

\begin{tabular}{|c|c|c|c|c|c|c|c|c|c|c|c|}
\hline \multicolumn{12}{|c|}{ Tilton-Continued } \\
\hline TSW & 49 & 432920 & 0713145 & Lyons, s. & $02-26-88$ & 520 & -- & 99.0 & -- & $\mathrm{x}$ & Brw \\
\hline TSW & 50 & 432902 & 0713202 & Dion, R. & $07-11-88$ & 500 & -- & 149 & -- & $\mathbf{x}$ & BrW \\
\hline TSW & 52 & 432736 & 0713229 & Champagne, $w$. & $08-22-88$ & 480 & -- & 139 & -- & $\mathrm{x}$ & BrW \\
\hline TSW & 55 & 433004 & 0713050 & Bayside Landing & $11-07-88$ & 485 & -- & 119 & -- & $\mathrm{x}$ & BrW \\
\hline TSW & 57 & 432901 & 0713155 & Blakeslee & $11-10-88$ & 500 & -- & 114 & -- & $\mathbf{x}$ & BrW \\
\hline TSW & 58 & 432901 & 0713156 & Nielson, C. & $11-07-88$ & 495 & -- & 109 & -- & $\mathbf{x}$ & BrW \\
\hline TSW & 59 & 432905 & 0713154 & Lynch, B. & $11-03-88$ & 500 & -- & 111 & -- & $\mathrm{x}$ & BrW \\
\hline TSW & 60 & 432900 & 0713154 & Nielson, $P$. & $11-02-88$ & 490 & -- & 104 & -- & $\mathbf{x}$ & BrW \\
\hline TSW & 61 & 432909 & 0713155 & Thompson, $\mathrm{M}$. & $11-01-88$ & 520 & -- & 56.0 & -- & -- & -- \\
\hline TSW & 65 & 432735 & 0713236 & Ritarick, J. & $11-23-88$ & 480 & -- & 154 & -- & $\mathbf{x}$ & BrW \\
\hline TSW & 67 & 432713 & 0713410 & Super 8 Hotel & $01-18-89$ & 480 & -- & 144 & -- & $\mathrm{x}$ & BrW \\
\hline TSW & 69 & 432846 & 0713228 & DES-Lochmere Xtra Mart & $03-20-89$ & 540 & -- & 76.0 & -- & G & -- \\
\hline TSW & 80 & 432730 & 0713343 & Fisher Management Co. & $10-29-92$ & 490 & 8 & 133 & $s$ & 0 & -- \\
\hline
\end{tabular}

CARROLL COUNTY

\begin{tabular}{|c|c|c|c|c|c|c|c|c|c|c|c|}
\hline \multirow[b]{2}{*}{ MWA } & \multirow[b]{2}{*}{1} & \multicolumn{10}{|c|}{ Moultonborough } \\
\hline & & 434403 & 0712152 & unknown & $04-21-92$ & 550 & -- & -- & -- & -- & Bor \\
\hline MWA & 2 & 434402 & 0712155 & unknown & $04-21-92$ & 550 & -- & -- & -- & -- & Bor \\
\hline MWW & 1 & 434420 & 0712416 & Fowler & $04-19-84$ & 580 & -- & 19.0 & -- & $\mathrm{x}$ & Brw \\
\hline MWW & 2 & 434423 & 0712422 & Buoniello & $03-23-84$ & 520 & -- & 20.0 & -- & $\mathrm{x}$ & BrW \\
\hline MWW & 3 & 434423 & 0712420 & Buoniello & $03-26-84$ & 520 & -- & 19.0 & -- & $\mathrm{x}$ & BrW \\
\hline MWW & 4 & 434501 & 0712316 & Harkins, G. & $08-10-84$ & 560 & -- & 113 & -- & $\mathrm{x}$ & BrW \\
\hline MWW & 5 & 434421 & 0712900 & Schultz, w. & $11-06-84$ & 600 & -- & 19.0 & -- & $\mathrm{x}$ & BrW \\
\hline MWW & 6 & 434613 & 0712206 & Werien, R. & $10-18-84$ & 580 & -- & 19.0 & -- & $\mathrm{x}$ & BrW \\
\hline MWW & 7 & 434407 & 0712837 & Allen, $D$. & $07-20-85$ & 580 & -- & 20.0 & -- & $\mathrm{x}$ & BrW \\
\hline MWW & 9 & 434508 & 0712321 & Kelly, W. & $07-01-85$ & 570 & -- & 64.0 & -- & $\mathrm{x}$ & BrW \\
\hline MWW & 10 & 434456 & 0712257 & MacPhail, L. & $08-06-84$ & 580 & -- & 80.0 & -- & $\mathrm{x}$ & BrW \\
\hline MWW & 11 & 434531 & 0712326 & Richardson, V. & $09-19-85$ & 580 & -- & 57.0 & -- & $\mathbf{x}$ & BrW \\
\hline MWW & 12 & 434409 & 0712838 & Mills, L. & $08-15-85$ & 580 & -- & 20.0 & -- & $\mathrm{x}$ & BrW \\
\hline MWW & 15 & 434522 & 0712338 & Covel1, E. & $04-03-87$ & 600 & -- & 140 & -- & $\mathbf{x}$ & BrW \\
\hline MWW & 16 & 434518 & 0712346 & Holden, $\mathrm{S}$. & $07-16-87$ & 600 & -- & 49.0 & -- & $\mathrm{x}$ & BrW \\
\hline MWW & 18 & 434422 & 0712830 & Mardis, s. & $05-08-86$ & 560 & -- & 20.0 & -- & $\mathrm{x}$ & BrW \\
\hline MWW & 19 & 434521 & 0712257 & White, Jeff & $10-30-90$ & 575 & 2 & 29.5 & $\mathbf{P}$ & $S$ & Bor \\
\hline MWW & 20 & 434253 & 0712009 & Vappi, Frank & $10-29-90$ & 600 & 2 & 27.5 & $\mathbf{P}$ & $\mathbf{s}$ & Bor \\
\hline MWW & 21 & 434540 & 0712248 & Rush, Everett & -- & 620 & -- & -- & -- & -- & Dug \\
\hline MWW & 23 & 434329 & 0712635 & Ramage & $04-24-84$ & 530 & -- & 39.0 & -- & $\mathrm{x}$ & BrW \\
\hline MWW & 30 & 434359 & 0712816 & Frustino, G. & $08-14-84$ & 540 & -- & 24.0 & -. & $\mathbf{x}$ & BrW \\
\hline MWW & 31 & 434321 & 0712624 & Sullivan, D. & $08-24-84$ & 560 & -- & 59.0 & -- & $\mathrm{x}$ & $\mathrm{BrW}$ \\
\hline MWW & 33 & 434323 & 0712628 & Bonnell, $\mathrm{H}$. & $11-09-84$ & 540 & - & 109 & -- & $\mathrm{x}$ & BrW \\
\hline MWW & 35 & 434203 & 0712141 & Mitra & $10-25-84$ & 510 & -- & 64.0 & -- & $\mathrm{x}$ & BrW \\
\hline MWW & 36 & 434233 & 0712102 & Woodworth, R. & $11-25-84$ & 530 & -- & 43.0 & -- & $\mathrm{x}$ & Bral \\
\hline MWW & 52 & 434233 & 0712149 & Curtis & $12-14-84$ & 540 & -- & 39.0 & -- & $\mathbf{x}$ & BrW \\
\hline MWW & 53 & 434206 & 0712115 & Cobham, w. & $12-18-84$ & 515 & -- & 39.0 & -- & $\mathrm{x}$ & BrW \\
\hline MWW & 54 & 434132 & 0712413 & Richards, R. & $11-15-85$ & 520 & -- & 40.0 & -- & $\mathrm{x}$ & BrW \\
\hline MWW & 55 & 434205 & 0712139 & Anagnos & $11-15-85$ & 610 & -- & 80.0 & -- & $\mathrm{x}$ & BrW \\
\hline MWW & 64 & 434442 & 0712307 & Keyser, D. & $03-23-84$ & 540 & -- & 50.0 & -- & $\mathrm{x}$ & BrW \\
\hline MWW & 66 & 434402 & 0712806 & Passamonti, J. & $06-07-84$ & 540 & -- & 20.0 & -- & $\mathrm{x}$ & BrW \\
\hline MWW & 68 & 434311 & 0712617 & Wheeler, R. & $09-08-84$ & 520 & -- & 21.0 & -- & $\mathrm{x}$ & BrW \\
\hline MWW & 70 & 434325 & 0712553 & Abbott, $\mathrm{H}$. & $10-25-84$ & 560 & -- & 22.0 & -- & $\mathrm{x}$ & BrW \\
\hline MWW & 71 & 434211 & 0712203 & Caplis & $11-27-84$ & 600 & -- & 20.0 & -- & $\mathrm{x}$ & BrW \\
\hline MWW & 72 & 434233 & 0712222 & Snuffer, $C$. & $03-21-84$ & 530 & -- & 131 & -- & $\mathrm{x}$ & BrW \\
\hline
\end{tabular}




\begin{tabular}{|c|c|c|c|c|c|c|c|c|c|c|}
\hline \multirow{2}{*}{$\begin{array}{l}\text { Local } \\
\text { site } \\
\text { number }\end{array}$} & \multicolumn{2}{|c|}{ Water level } & \multirow{2}{*}{$\begin{array}{r}\text { Top of } \\
\text { screen } \\
\text { (feet) }\end{array}$} & \multirow{2}{*}{$\begin{array}{l}\text { Bottom of } \\
\text { screen } \\
\text { (feet) }\end{array}$} & \multirow{2}{*}{$\begin{array}{c}\text { Use } \\
\text { of } \\
\text { water }\end{array}$} & \multirow[b]{2}{*}{$\begin{array}{c}\text { Yield } \\
\text { (gal/min) }\end{array}$} & \multirow[b]{2}{*}{$\begin{array}{l}\text { Drawdown } \\
\text { (feet) }\end{array}$} & \multirow[b]{2}{*}{$\begin{array}{l}\text { Specific } \\
\text { capacity }\end{array}$} & \multirow{2}{*}{$\begin{array}{l}\text { Pumplng } \\
\text { period } \\
\text { (hours) }\end{array}$} & \multirow{2}{*}{$\begin{array}{l}\text { Driller } \\
\text { or NHWRD } \\
\text { number }\end{array}$} \\
\hline & $\begin{array}{l}\text { Depth } \\
\text { (feet) }\end{array}$ & $\begin{array}{c}\text { Date } \\
\text { (mm-dd-yy) }\end{array}$ & & & & & & & & \\
\hline
\end{tabular}

\section{BELKNAP COUNTY}

\begin{tabular}{|c|c|c|c|c|c|c|c|c|c|c|c|}
\hline \multicolumn{12}{|c|}{ T11ton-Continued } \\
\hline TSW & 49 & -- & -- & -- & -- & $\mathbf{P}$ & 8.00 & -- & -- & 0.3 & NHWRD 247 \\
\hline TSW & 50 & -- & -- & -- & -- & $\mathrm{H}$ & 7.00 & -- & -- & .3 & NHWRD 247 \\
\hline TSW & 52 & -- & -- & - & -- & $\mathrm{H}$ & 20.0 & -- & -- & .3 & NHWRD 247 \\
\hline TSW & 55 & -- & -- & -- & -- & $\mathbf{H}$ & 10.0 & -- & -- & .8 & NHWRD 406 \\
\hline TSW & 57 & 15.0 & $11-11-88$ & -- & -- & $\mathrm{H}$ & 2.00 & -- & - & .5 & NHWRD 126 \\
\hline TSW & 58 & 40.0 & $11-08-88$ & -- & -- & H & 2.00 & - & -- & .5 & NHWRD 126 \\
\hline TSW & 59 & 30.0 & $11-05-88$ & -- & -- & $\mathrm{H}$ & 12.0 & -- & -- & .5 & NHWRD 123 \\
\hline TSW & 60 & 30.0 & $11-04-88$ & -- & -- & $\mathrm{H}$ & 4.00 & -- & -- & .5 & NHWRD 126 \\
\hline TSW & 61 & 25.0 & $11-01-88$ & -- & -- & $\mathrm{H}$ & 15.0 & -- & -- & 1.0 & NHWRD 126 \\
\hline TSW & 65 & 20.0 & $11-25-88$ & -- & -- & $\mathrm{H}$ & 6.00 & -- & -- & .5 & NHWRD 142 \\
\hline TSW & 67 & -- & -- & -- & -- & $\mathrm{C}$ & 50.0 & -- & -- & .3 & NHWRD 247 \\
\hline TSW & 69 & 19.0 & $03-02-89$ & -- & -- & $\mathrm{U}$ & -- & -- & -- & -- & NHWRD 141 \\
\hline TSW & 80 & -- & -- & -- & -- & $\mathrm{C}$ & -- & -- & - & -- & L. Cushing \\
\hline
\end{tabular}

\section{CARROLLL COUNTY}

\section{Moult onborough}

\begin{tabular}{|c|c|c|c|c|c|c|c|c|c|c|c|c|}
\hline MWA & 1 & -- & $04-21-92$ & -- & -- & -- & -- & -- & -- & -- & USGS & \\
\hline MWA & 2 & 8.2 & $04-21-92$ & -- & -- & -- & -- & -- & -- & -- & USGS & \\
\hline MWW & 1 & -- & - & -- & -- & $\mathrm{H}$ & 11.0 & -- & -- & .5 & NHWRD & 319 \\
\hline MWW & 2 & -- & -- & -- & -- & $\mathrm{H}$ & 2.00 & -- & -- & .5 & NHWRD & 319 \\
\hline MWW & 3 & -- & -- & -- & -- & $\mathrm{H}$ & 3.00 & -- & -- & .5 & NHWRD & 319 \\
\hline MWW & 4 & 23.0 & $08-10-84$ & -- & -- & H & -- & -- & -- & -- & NHWRD & 22 \\
\hline MWW & 5 & 33.0 & $11-07-84$ & -- & -- & $\mathrm{H}$ & 1.50 & -- & -- & 1.0 & NHWRD & 3 \\
\hline MWW & 6 & 20.0 & $10-30-84$ & -- & -- & $\mathrm{H}$ & 7.00 & -- & -- & 1.0 & NHWRD & 90 \\
\hline MWW & 7 & -- & -- & -- & -- & $\mathrm{H}$ & 1.50 & -- & -- & .5 & NHWRD & 315 \\
\hline MWW & 9 & -- & -- & -- & -- & $\mathrm{H}$ & 20.0 & -- & -- & 1.0 & NHWRD & 192 \\
\hline MWW & 10 & -- & -- & -- & -- & $\mathrm{H}$ & 20.0 & -- & -- & .5 & NHWRD & 175 \\
\hline MWW & 11 & -- & -- & -- & -- & $\mathrm{H}$ & 20.0 & -- & -- & .5 & NHWRD & 175 \\
\hline MWW & 12 & 5.0 & $08-20-85$ & -- & -- & $\mathrm{H}$ & 6.00 & -- & -- & .5 & NHWRD & 175 \\
\hline MWW & 15 & -- & -- & -- & -- & $\mathrm{H}$ & .25 & -- & -- & .5 & NHWRD & 22 \\
\hline MWW & 16 & 15.0 & $07-16-87$ & -- & -- & $\mathrm{H}$ & 2.00 & -- & -- & .5 & NHWRD & 22 \\
\hline MWW & 18 & -- & -- & -- & -- & $\mathrm{H}$ & 2.00 & -- & -- & .5 & NHWRD & 175 \\
\hline MWW & 19 & 8.23 & $07-02-91$ & 29.5 & 32 & $\mathrm{U}$ & -- & -- & -- & -- & USGS & \\
\hline MWW & 20 & 10.6 & $07-02-91$ & 27.5 & 30 & $\mathrm{U}$ & -- & -- & -- & -- & USGS & \\
\hline MWW & 21 & 2.68 & $06-18-91$ & -- & -- & U & -- & -- & -- & -- & -- & \\
\hline MWW & 23 & 7.0 & $04-26-84$ & -- & -- & $\mathrm{H}$ & 2.50 & -- & -- & 1.0 & NHWRD & 3 \\
\hline MWW & 30 & -- & -- & -- & -- & $\mathrm{H}$ & 2.00 & -- & -- & 1.0 & NHWRD & 90 \\
\hline MWW & 31 & -- & -- & -- & -- & $\mathrm{H}$ & 3.00 & -- & -- & 1.0 & NHWRD & 90 \\
\hline MWW & 33 & 25.0 & $11-13-84$ & -- & -- & $\mathrm{H}$ & 1.50 & -- & -- & .5 & NHWRD & 22 \\
\hline MWW & 35 & 15.0 & $10-29-84$ & -- & -- & $\mathrm{H}$ & 1.50 & -- & -- & 1.0 & NHWRD & 90 \\
\hline MWW & 36 & 25.0 & $11-26-84$ & -- & -- & $\mathrm{H}$ & 2.00 & -- & -- & 1.0 & NHWRD & 397 \\
\hline MWW & 52 & -- & -- & -- & -- & $\mathrm{H}$ & 2.25 & -- & -- & 1.0 & NHWRD & 90 \\
\hline MWW & 53 & -- & -- & -- & -- & $\mathrm{H}$ & 4.00 & -- & -- & 1.0 & NHWRD & 90 \\
\hline MWW & 54 & 3.0 & $11-15-85$ & -- & -- & $\mathrm{H}$ & 6.00 & -- & -- & -- & NHWRD & 819 \\
\hline MWW & 55 & -- & -- & -- & -- & $\mathrm{H}$ & 1.00 & -- & -- & .5 & NHWRD & 319 \\
\hline MWW & 64 & -- & -- & -- & -- & $\mathrm{H}$ & 13.0 & -- & -- & .5 & NHWRD & 20 \\
\hline MWW & 66 & -- & -- & -- & -- & $\mathrm{H}$ & 1.75 & -- & -- & .5 & NHWRD & 20 \\
\hline MWW & 68 & -- & -- & -- & -- & $\mathrm{H}$ & 4.00 & -- & -- & .5 & NHWRD & 20 \\
\hline MWW & 70 & -- & -- & -- & -- & $\mathrm{H}$ & 1.00 & -- & -- & .5 & NHWRD & 20 \\
\hline MWW & 71 & -- & -- & -- & - & $\mathrm{H}$ & 30.0 & -- & -- & .5 & NHWRD & 20 \\
\hline MWW & 72 & -- & -- & -- & -- & $\mathrm{H}$ & 6.00 & -- & -- & .5 & NHWRD & 20 \\
\hline
\end{tabular}


Table A-1. Description of selected wells, borings, and springs in the Winnipesaukee River Basin, central New Hampshire

\begin{tabular}{|c|c|c|c|c|c|c|c|c|c|c|}
\hline $\begin{array}{l}\text { Local } \\
\text { site } \\
\text { number }\end{array}$ & $\begin{array}{l}\text { Lat- } \\
\text { itude }\end{array}$ & $\begin{array}{l}\text { Long- } \\
\text { itude }\end{array}$ & Owner or user & $\begin{array}{c}\text { Date } \\
\text { of } \\
\text { con- } \\
\text { struction }\end{array}$ & $\begin{array}{c}\text { Ele- } \\
\text { vat- } \\
\text { tion } \\
\text { (feet) }\end{array}$ & $\begin{array}{c}\text { Diameter } \\
\text { of } \\
\text { casing } \\
\text { (inches) }\end{array}$ & $\begin{array}{l}\text { Depth to } \\
\text { bottom } \\
\text { of casing } \\
\text { (feet) }\end{array}$ & $\begin{array}{c}\text { Casing } \\
\text { mater- } \\
\text { ial }\end{array}$ & $\begin{array}{c}\text { Type } \\
\text { of } \\
\text { fin- } \\
\text { ish }\end{array}$ & $\begin{array}{c}\text { Type } \\
\text { of } \\
\text { site }\end{array}$ \\
\hline
\end{tabular}

CARROLL COUNTY

\begin{tabular}{|c|c|c|c|c|c|c|c|c|c|c|c|}
\hline \multirow[b]{2}{*}{ MWW } & \multicolumn{11}{|c|}{ Moultonborough-Continued } \\
\hline & 81 & 434226 & 0712342 & Merryfield Nelson & $08-27-85$ & 540 & -- & 20.0 & -- & $\mathrm{x}$ & BrW \\
\hline MWW & 84 & 434316 & 0712229 & Difazio, R. & $10-24-85$ & 520 & -- & 40.0 & -- & $\mathrm{x}$ & BrW \\
\hline MWW & 88 & 434340 & 0712213 & \& E. MCGuigan, D. & $06-04-86$ & 550 & -- & 80.0 & -- & $\mathrm{x}$ & $\mathrm{BrW}$ \\
\hline MWW & 96 & 434233 & 0712338 & Smalley, R. & $05-05-87$ & 540 & -- & 20.0 & -- & $\mathrm{x}$ & BrW \\
\hline MWW & 101 & 434342 & 0712215 & Hesseltine & $06-13-87$ & 560 & -- & 79.0 & -- & $x$ & BrW \\
\hline MWW & 103 & 434349 & 0712239 & Lundari, $\mathrm{J}$. & $06-29-87$ & 510 & -- & 36.0 & -- & $\mathrm{x}$ & Brw \\
\hline MWW & 106 & 434254 & 0712242 & $T \& C B l d r s$ & $08-08-87$ & 520 & -- & 20.0 & -- & $\mathrm{x}$ & $\mathrm{BrW}$ \\
\hline MWW & 111 & 434353 & 0712215 & Duclos, R. & $10-20-86$ & 540 & -- & 59.0 & -- & $\mathrm{x}$ & BrW \\
\hline MWW & 114 & 434236 & 0712724 & Straffordshire Condo & $07-23-86$ & 520 & -- & 30.0 & -- & $\mathrm{x}$ & BrW \\
\hline MWW & 116 & 434230 & 0712524 & Levesque, $\mathrm{F}$. & $07-25-86$ & 515 & -- & 20.0 & -- & $\mathrm{x}$ & $\mathrm{BrW}$ \\
\hline MWW & 120 & 434230 & 0712521 & \& C. Rix, C. & $09-19-86$ & 510 & -- & 40.0 & -- & $\mathrm{x}$ & BrW \\
\hline MWW & 132 & 434320 & 0712552 & Blackadar, $w$. & $06-23-86$ & 570 & -- & 20.0 & -- & $\mathrm{x}$ & $\mathrm{BrW}$ \\
\hline MWW & 153 & 434347 & 0712219 & MacDonald, A. & $03-31-88$ & 540 & -- & 72.0 & -- & $\mathrm{x}$ & BrW \\
\hline MWW & 155 & 434402 & 0712811 & \& J. McKinnon, J. & $09-05-85$ & 535 & -- & 19.0 & -- & $\mathrm{x}$ & BrW \\
\hline MWW & 165 & 434344 & 0712231 & Chen, M. & $04-15-88$ & 520 & -- & 110 & -- & $\mathrm{x}$ & BrW \\
\hline MWW & 171 & 434543 & 0712147 & Rice, M. & $07-01-88$ & 860 & - & 40.0 & -- & $\mathrm{x}$ & BrW \\
\hline MWW & 177 & 434550 & 0712257 & Poole, D. & $07-08-87$ & 640 & -- & 40.0 & -- & $\mathrm{x}$ & BrW \\
\hline MWW & 179 & 434155 & 0712025 & Broadbent & $07-14-87$ & 600 & -- & 140 & -- & $\mathrm{x}$ & $\mathrm{BrW}$ \\
\hline MWW & 180 & 434146 & 0712134 & Jannson, B. & $06-02-87$ & 520 & -- & 40.0 & -- & $\mathrm{x}$ & BrW \\
\hline MWW & 181 & 434241 & 0712228 & Sampson, J. & $06-01-87$ & 520 & -- & 29.0 & -- & $\mathrm{x}$ & $\mathrm{BrW}$ \\
\hline MWW & 183 & 434455 & 0712308 & Gravelle, $\mathrm{K}$. & $02-11-87$ & 560 & -- & 100 & -- & $\mathrm{x}$ & BrW \\
\hline MWW & 187 & 434524 & 0712256 & \& L. White, w. & $11-19-87$ & 590 & -- & 40.0 & -- & $\mathrm{x}$ & BrW \\
\hline MWW & 194 & 434521 & 0712348 & Town of Moultonborough & $08-13-87$ & 620 & -- & 40.0 & -- & $\mathrm{x}$ & $\mathrm{BrW}$ \\
\hline MWW & 197 & 434522 & 0712346 & Town of Moultonborough & $07-08-87$ & 580 & -- & 60.0 & -- & $\mathrm{x}$ & BrW \\
\hline MWW & 198 & 434400 & 0712808 & Rose, J. & $07-01-88$ & 540 & -- & 20.0 & -- & $\mathrm{x}$ & $\mathrm{BrW}$ \\
\hline MWW & 199 & 434359 & 0712806 & Welch & $02-24-88$ & 540 & -- & 40.0 & -- & $\mathrm{x}$ & BrW \\
\hline MWW & 201 & 434252 & 0712238 & Richard Murphy Const & $05-26-88$ & 510 & -- & 40.0 & -- & $\mathrm{x}$ & BrW \\
\hline MWW & 203 & 434541 & 0712313 & Peaslee, E. & $05-20-88$ & 580 & -- & 40.0 & -- & $\mathrm{x}$ & BrW \\
\hline MWW & 206 & 434338 & 0712221 & Nelson, J. & $09-14-88$ & 520 & -- & 54.0 & -- & $\mathrm{x}$ & BrW \\
\hline MWW & 207 & 434147 & 0712135 & Zimmer, $\mathrm{V}$. & $09-28-88$ & 520 & -- & 29.0 & -- & $\mathrm{x}$ & BrW \\
\hline MWW & 210 & 434551 & 0712540 & Knu, D. & $10-20-88$ & 670 & -- & 61.0 & -- & $\mathrm{x}$ & BrW \\
\hline MWW & 214 & 434421 & 0712822 & Lessard, R. & $10-28-88$ & 560 & -- & 20.0 & -- & $\mathrm{x}$ & $\mathrm{BrW}$ \\
\hline MWW & 217 & 434242 & 0712253 & Richard Murphy Const & $01-13-89$ & 540 & -- & 40.0 & -- & $\mathrm{x}$ & BrW \\
\hline MWW & 218 & 434242 & 0712249 & Richard Murphy Const & $01-10-89$ & 530 & - & 40.0 & -- & $\mathrm{x}$ & BrW \\
\hline MWW & 219 & 434242 & 0712252 & Richard Murphy Const & $01-07-89$ & 540 & -- & 40.0 & -- & $\mathrm{x}$ & BrW \\
\hline MWW & 220 & 434500 & 0712311 & Moreau & $12-05-88$ & 560 & -- & 163 & -- & $\mathrm{x}$ & BrW \\
\hline MWW & 221 & 434323 & 0712557 & Autenzio, R. & $01-31-88$ & 570 & -- & 19.0 & -- & $\mathrm{x}$ & $\mathrm{BrW}$ \\
\hline MWW & 222 & 434544 & 0712203 & Allan, D. & $01-13-89$ & 800 & -- & 99.0 & -- & $\mathrm{x}$ & BrW \\
\hline MWW & 225 & 434607 & 0712212 & Wheely, P. & $10-05-88$ & 810 & -- & 87.0 & -- & $\mathrm{x}$ & BrW \\
\hline MWW & 227 & 434313 & 0712620 & \& M. Vitas, T. & $12-17-88$ & 520 & -- & 377 & -- & $\mathrm{x}$ & $\mathrm{BrW}$ \\
\hline MWW & 228 & 434232 & 0712225 & Puntonio, J. & $11-17-88$ & 540 & -- & 60.0 & -- & $\mathrm{x}$ & BrW \\
\hline MWW & 232 & 434242 & 0712323 & Chapman, D. & $06-09-89$ & 525 & -- & 19.0 & -- & $\mathrm{x}$ & BrW \\
\hline MWW & 234 & 434521 & 0712246 & Shaw, $D$ & $07-15-89$ & 600 & -- & 67.0 & -- & $\mathrm{x}$ & BrW \\
\hline MWW & 238 & 434234 & 0712230 & Cordel10, J. & $05-24-89$ & 540 & -- & 19.0 & -- & $\mathrm{x}$ & BrW \\
\hline MWW & 257 & 434401 & 0712802 & Casella, R. & $09-27-88$ & 540 & -- & 26.0 & -- & $\mathrm{x}$ & BrW \\
\hline MWW & 258 & 434219 & 0712342 & Salvati, I. & $10-06-88$ & 540 & -- & 19.0 & -- & $\mathrm{x}$ & BrW \\
\hline MWW & 265 & 434213 & 0712353 & Ahne, J. & $07-01-88$ & 540 & -- & 19.0 & -- & $\mathrm{x}$ & BrW \\
\hline MWW & 275 & 434251 & 0712104 & Anderson, A. & $12-18-89$ & 560 & -- & 80.0 & -- & $\mathrm{x}$ & $\mathrm{BrW}$ \\
\hline MWW & 287 & 434129 & 0712422 & Middlebrook, B. & $06-27-90$ & 510 & -- & 38.0 & - & $\mathrm{x}$ & $\mathrm{BrW}$ \\
\hline MWW & 295 & 434230 & 0712236 & Mover, L. & $03-02-89$ & 560 & -- & 40.0 & -- & $\mathrm{x}$ & BIW \\
\hline MWW & 301 & 434537 & 0712303 & Hoyt, F. & $07-13-89$ & 600 & -- & 25.0 & -- & $\mathrm{x}$ & BrW \\
\hline MWW & 303 & 434128 & 0712425 & Hazel, $R$. & $11-01-89$ & 510 & -- & 40.0 & -- & $\mathrm{x}$ & BrW \\
\hline MWW & 304 & 434200 & 0712111 & Young, $R$. & $05-15-90$ & 510 & -- & -- & -- & -- & Dug \\
\hline MWW & 307 & 434213 & 0712136 & Smith, B. & $10-05-90$ & 540 & -- & 34.0 & -- & $\mathrm{x}$ & BrW \\
\hline MWW & 309 & 434225 & 0712309 & Morril, s. & $01-23-90$ & 520 & -- & 40.0 & -- & $\mathrm{x}$ & BrW \\
\hline
\end{tabular}




\begin{tabular}{|c|c|c|c|c|c|c|c|c|c|c|}
\hline $\begin{array}{l}\text { Local } \\
\text { site } \\
\text { number }\end{array}$ & $\begin{array}{l}\text { Depth } \\
\text { (feet) }\end{array}$ & $\begin{array}{c}\text { Date } \\
\text { (mm-dd-yy) }\end{array}$ & $\begin{array}{l}\text { Top of } \\
\text { screen } \\
\text { (feet) }\end{array}$ & $\begin{array}{l}\text { Bottom of } \\
\text { screen } \\
\text { (feet) }\end{array}$ & $\begin{array}{c}\text { Use } \\
\text { of } \\
\text { water }\end{array}$ & $\begin{array}{l}\text { Yield } \\
\text { (gal/min) }\end{array}$ & $\begin{array}{l}\text { Drawdown } \\
\text { (feet) }\end{array}$ & $\begin{array}{l}\text { Specific } \\
\text { capacity }\end{array}$ & $\begin{array}{l}\text { Pumping } \\
\text { period } \\
\text { (hours) }\end{array}$ & $\begin{array}{l}\text { Driller } \\
\text { or NHWRD } \\
\text { number }\end{array}$ \\
\hline
\end{tabular}

\section{CARROLL COUNTY}

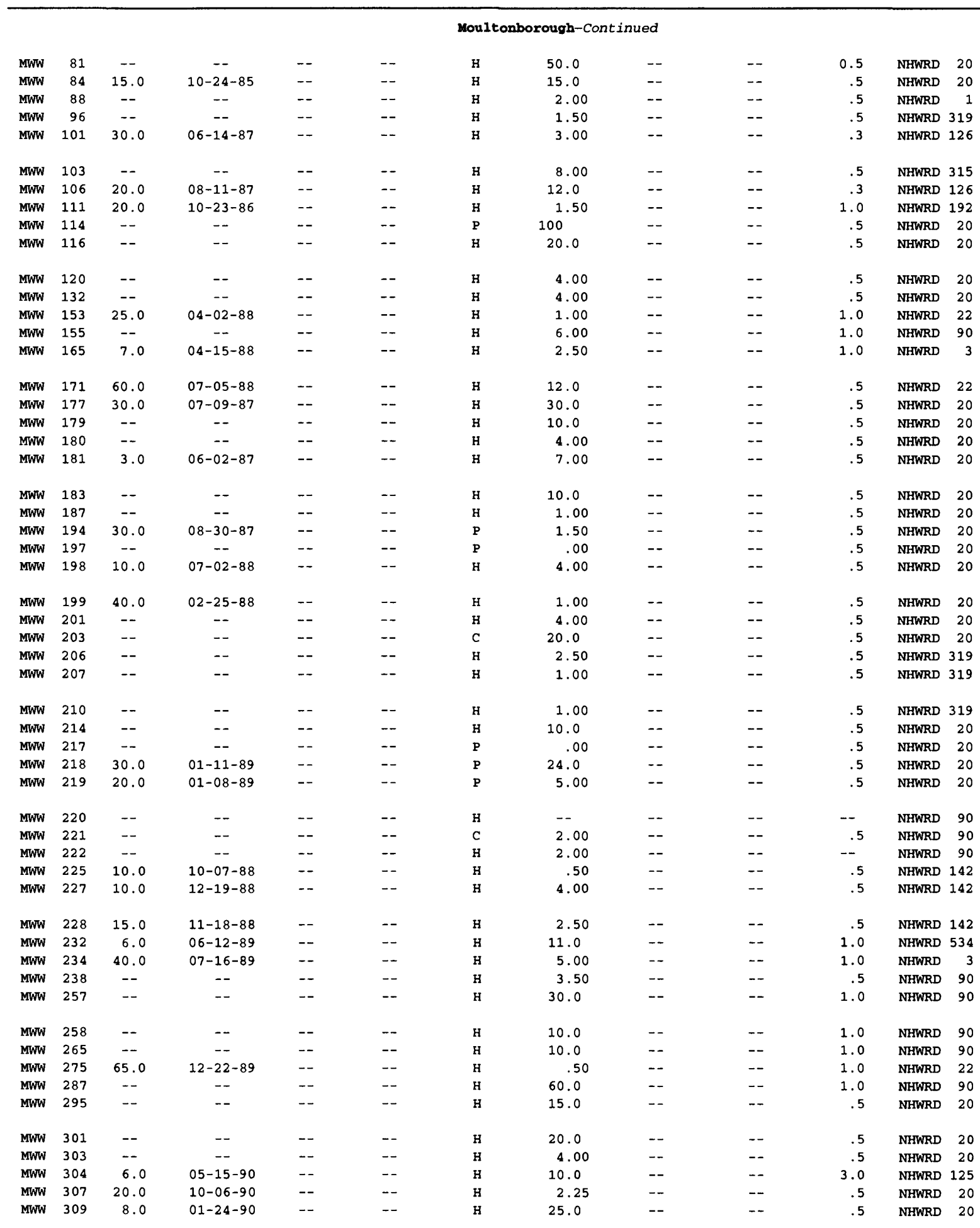


Table A-1. Description of selected wells, borings, and springs in the Winnipesaukee River Basin, central New Hampshire

\begin{tabular}{|c|c|c|c|c|c|c|c|c|c|c|}
\hline $\begin{array}{l}\text { Locai } \\
\text { site } \\
\text { number }\end{array}$ & $\begin{array}{l}\text { Lat- } \\
\text { itude }\end{array}$ & $\begin{array}{l}\text { Long- } \\
\text { Itude }\end{array}$ & Owner or user & $\begin{array}{c}\text { Date } \\
\text { of } \\
\text { con- } \\
\text { struction }\end{array}$ & $\begin{array}{l}\text { Eie- } \\
\text { vat- } \\
\text { tion } \\
\text { (feet) }\end{array}$ & $\begin{array}{c}\text { Dlameter } \\
\text { of } \\
\text { casing } \\
\text { (inches) }\end{array}$ & $\begin{array}{l}\text { Depth to } \\
\text { bottom } \\
\text { of casing } \\
\text { (feet) }\end{array}$ & $\begin{array}{c}\text { Casing } \\
\text { mater- } \\
\text { lai }\end{array}$ & $\begin{array}{c}\text { Type } \\
\text { of } \\
\text { fin- } \\
\text { ish }\end{array}$ & $\begin{array}{c}\text { Type } \\
\text { of } \\
\text { site }\end{array}$ \\
\hline
\end{tabular}

CARROLL COUNTY

\begin{tabular}{|c|c|c|c|c|c|c|c|c|c|c|c|}
\hline \multirow[b]{2}{*}{ MWW } & \multicolumn{11}{|c|}{ Moultonborough-Continued } \\
\hline & 310 & 434150 & 0712025 & Terry, J. & $01-26-90$ & 560 & - & 100 & -- & $\mathrm{x}$ & BrW \\
\hline MWW & 316 & 434221 & 0712315 & McTwigan, G. & $09-27-90$ & 540 & -- & 30.0 & -- & $\mathrm{x}$ & BrW \\
\hline MWW & 321 & 434534 & 0712316 & Murphy, K. & $09-03-90$ & 580 & -- & 29.0 & -- & $\mathrm{x}$ & BrW \\
\hline MWW & 323 & 434407 & 0712156 & Mason, $T$. & $10-20-90$ & 550 & -- & -- & -- & $\mathrm{x}$ & BrW \\
\hline MWW & 324 & 434408 & 0712158 & Mason, $\mathbf{T}$. & $10-25-90$ & 550 & -- & 50.0 & -- & $\mathrm{x}$ & BrW \\
\hline MWW & 326 & 434335 & 0712643 & Wood \& Clay & $12-15-90$ & 520 & -- & 33.0 & -- & $\mathrm{x}$ & Brw \\
\hline MWW & 330 & 434535 & 0712153 & Cameron, D. & $12-26-89$ & 840 & -- & 31.0 & -- & $\mathrm{x}$ & BrW \\
\hline MWW & 331 & 434306 & 0712556 & Viccard, N. & $12-19-89$ & 590 & -- & 40.0 & $-\infty$ & $\mathrm{x}$ & BrW \\
\hline MWW & 332 & 434624 & 0712419 & Hume, $D$. & $11-09-89$ & 580 & -- & 40.0 & -- & $\mathrm{x}$ & BrW \\
\hline MWW & 334 & 434341 & 0712229 & Roach, E. & $10-04-89$ & 510 & -- & 105 & -- & $\mathrm{x}$ & Brw \\
\hline MWW & 335 & 434359 & 0712834 & Soltis & $10-11-89$ & 550 & -- & 45.0 & -- & $\mathrm{x}$ & BrW \\
\hline MWW & 339 & 434359 & 0712207 & Economo, L. & $08-31-90$ & 540 & -- & 88.0 & -- & $\mathrm{x}$ & BrW \\
\hline MWW & 340 & 434331 & 0712833 & McAntire, F. & $03-22-90$ & 580 & -- & 60.0 & -- & $\mathrm{x}$ & BrW \\
\hline MWW & 343 & 434243 & 0712231 & Landrine, J. & $06-12-90$ & 520 & -- & 40.0 & -- & $\mathrm{x}$ & BrW \\
\hline \multirow[t]{2}{*}{ MWW } & 355 & 434522 & 0712311 & Carson, c. & $05-14-91$ & 580 & -- & 29.0 & -- & $\mathrm{x}$ & Brw \\
\hline & \multicolumn{11}{|c|}{ Sandwich } \\
\hline SEW & 10 & 434821 & 0712634 & Pohl, P. & $03-26-87$ & 650 & -- & 40.0 & -- & $\mathrm{x}$ & BrW \\
\hline SEW & 15 & 434842 & 0712610 & Gabriel Jr, R. & $07-03-86$ & 660 & -- & 43.0 & -- & $\mathbf{x}$ & Brw \\
\hline SEW & 21 & 434925 & 0712520 & Quimby, L. & $06-07-85$ & 760 & -- & 39.0 & -- & $x$ & BrW \\
\hline SEW & 31 & 434900 & 0712453 & Paterno, B. & $08-20-86$ & 640 & -- & 1.0 & -- & -- & Dug \\
\hline SEW & 49 & 434905 & 0712446 & Seeley, $M$ & $03-21-88$ & 670 & -- & 40.0 & -- & $\mathrm{x}$ & BrW \\
\hline SEW & 50 & 434734 & 0712652 & Toby Eaton Bldrs & $03-09-88$ & 620 & -- & 94.0 & -- & $\mathbf{x}$ & Brw \\
\hline SEW & 53 & 434829 & 0712629 & Hadley, $T$. & $05-13-88$ & 680 & -- & 40.0 & -- & $\mathrm{x}$ & Brw \\
\hline SEW & 60 & 434822 & 0712615 & Sandwich Home Ind & $07-06-88$ & 650 & -- & 40.0 & -- & $x$ & Brw \\
\hline SEW & 61 & 434826 & 0712630 & Kimbal1, G. & $05-23-88$ & 680 & -- & 40.0 & -- & $\mathbf{x}$ & Brw \\
\hline SEW & 105 & 434825 & 0712624 & Houston, A. & $03-01-89$ & 660 & -- & 40.0 & -- & $\mathrm{x}$ & BrW \\
\hline SEW & 108 & 434738 & 0712655 & Rawson, $\mathrm{J}$. & $08-06-90$ & 630 & -- & 39.0 & -- & $\mathbf{x}$ & BrW \\
\hline SEW & 150 & 434847 & 0712557 & Nolan & $09-18-85$ & 660 & -- & 34.0 & -- & $x$ & BrW \\
\hline \multirow[t]{2}{*}{ SEW } & 151 & 434824 & 0712630 & Piper, D. & $06-11-85$ & 660 & -- & 139 & -- & $\mathrm{x}$ & BrW \\
\hline & \multicolumn{11}{|c|}{ Tuftonboro } \\
\hline TZA & 1 & 434208 & 0711507 & Tuftonboro Landfill & $08-\quad-74$ & 700 & -- & -- & -- & -- & Bor \\
\hline TZA & 2 & 434159 & 0711506 & Tuftonboro Landfill & $08-\quad-74$ & 700 & -- & -- & -- & -- & Bor \\
\hline TZA & 3 & 434155 & 0711510 & Tuftonboro Landfill & $08-\quad-74$ & 680 & -- & -- & -- & -- & Bor \\
\hline TZA & 4 & 434158 & 0711514 & Tuftonboro Landfill & $08-\quad-74$ & 680 & - & -- & -- & -- & Bor \\
\hline TZA & 5 & 434205 & 0711514 & Tuftonboro Landfill & $08-\quad-74$ & 700 & - & -- & -- & -- & Bor \\
\hline TZA & 6 & 434211 & 0711511 & Tuftonboro Landfill & $08-\quad-74$ & 700 & -- & -- & -- & -- & Bor \\
\hline TZA & 7 & 434213 & 0711807 & Berry, $T$ & $07-31-90$ & 585 & -- & -- & -- & -- & Bor \\
\hline TZA & 8 & 434159 & 0711807 & Berry， T & $07-31-90$ & 575 & -- & -- & -- & -- & Bor \\
\hline TZA & 9 & 433814 & 0711517 & Hunter, S. & $10-25-90$ & 535 & -- & -- & -- & -- & Bor \\
\hline TZA & 10 & 433854 & 0711640 & Tuftonboro, Town of & $06-27-91$ & 510 & -- & -- & -- & -- & Bor \\
\hline TZA & 12 & 434051 & 0711721 & Nash Comp. & $09-09-87$ & 520 & -- & -- & -- & -- & Bor \\
\hline TZA & 13 & 434052 & 0711723 & Nash Comp. & $09-10-87$ & 520 & -- & -- & -- & -- & Bor \\
\hline TZA & 14 & 434053 & 0711727 & Nash Comp. & $09-11-87$ & 515 & -- & -- & -- & -- & Bor \\
\hline TZA & 15 & 433931 & 0711558 & McWhirter, George & $07-23-91$ & 535 & -- & -- & -- & -- & Bor \\
\hline TZA & 16 & 434158 & 0711557 & Sargent, Fred & $07-26-91$ & 640 & -- & -- & -- & -- & Bor \\
\hline TZA & 17 & 433811 & 0711438 & State Rte. 190A & $10-23-90$ & 560 & -- & -- & -- & -- & Bor \\
\hline TZA & 18 & 434006 & 0711547 & Bill Stockman & $10-13-92$ & 595 & -- & -- & -- & -- & Bor \\
\hline TZW & 1 & 434210 & 0711509 & Hunter, Steven & -- & 690 & -- & -- & -- & -- & -- \\
\hline TZW & 2 & 434211 & 0711437 & State Rte. 171 & $10-29-90$ & 690 & -- & -- & -- & $\mathbf{S}$ & Bor \\
\hline TZW & 3 & 434203 & 0711727 & Detwiler & $06-28-91$ & 577 & 2 & 51 & $\mathrm{P}$ & $S$ & Bor \\
\hline TZW & 4 & 434002 & 0711523 & Unknown & -- & 640 & -- & -- & - & w & Dug \\
\hline TZW & 5 & 434043 & 0711600 & Williams, Barbara & -- & 585 & -- & - & -- & w & Dug \\
\hline TZW & 6 & 434221 & 0711507 & Smith, Doris & -- & 760 & -- & -- & -- & $\mathbf{w}$ & Dug \\
\hline
\end{tabular}




\begin{tabular}{|c|c|c|c|c|c|c|c|c|c|c|}
\hline \multirow{2}{*}{$\begin{array}{l}\text { Local } \\
\text { site } \\
\text { number }\end{array}$} & \multicolumn{2}{|c|}{ Water level } & \multirow{2}{*}{$\begin{array}{l}\text { Top of } \\
\text { screen } \\
\text { (feet) }\end{array}$} & \multirow{2}{*}{$\begin{array}{l}\text { Bottom of } \\
\text { screen } \\
\text { (feet) }\end{array}$} & \multirow{2}{*}{$\begin{array}{c}\text { Use } \\
\text { of } \\
\text { water }\end{array}$} & \multirow[b]{2}{*}{$\begin{array}{l}\text { Yield } \\
\text { (gal/min) }\end{array}$} & \multirow[b]{2}{*}{$\begin{array}{l}\text { Drawdown } \\
\text { (feet) }\end{array}$} & \multirow[b]{2}{*}{$\begin{array}{l}\text { Specific } \\
\text { capacity }\end{array}$} & \multirow{2}{*}{$\begin{array}{l}\text { Pumping } \\
\text { period } \\
\text { (hours) }\end{array}$} & \multirow{2}{*}{$\begin{array}{l}\text { Driller } \\
\text { or NHWRD } \\
\text { number }\end{array}$} \\
\hline & $\begin{array}{l}\text { Depth } \\
\text { (feet) }\end{array}$ & $\begin{array}{c}\text { Date } \\
\text { (mm-dd-yy) }\end{array}$ & & & & & & & & \\
\hline
\end{tabular}

\section{CARROLL COUNTY}

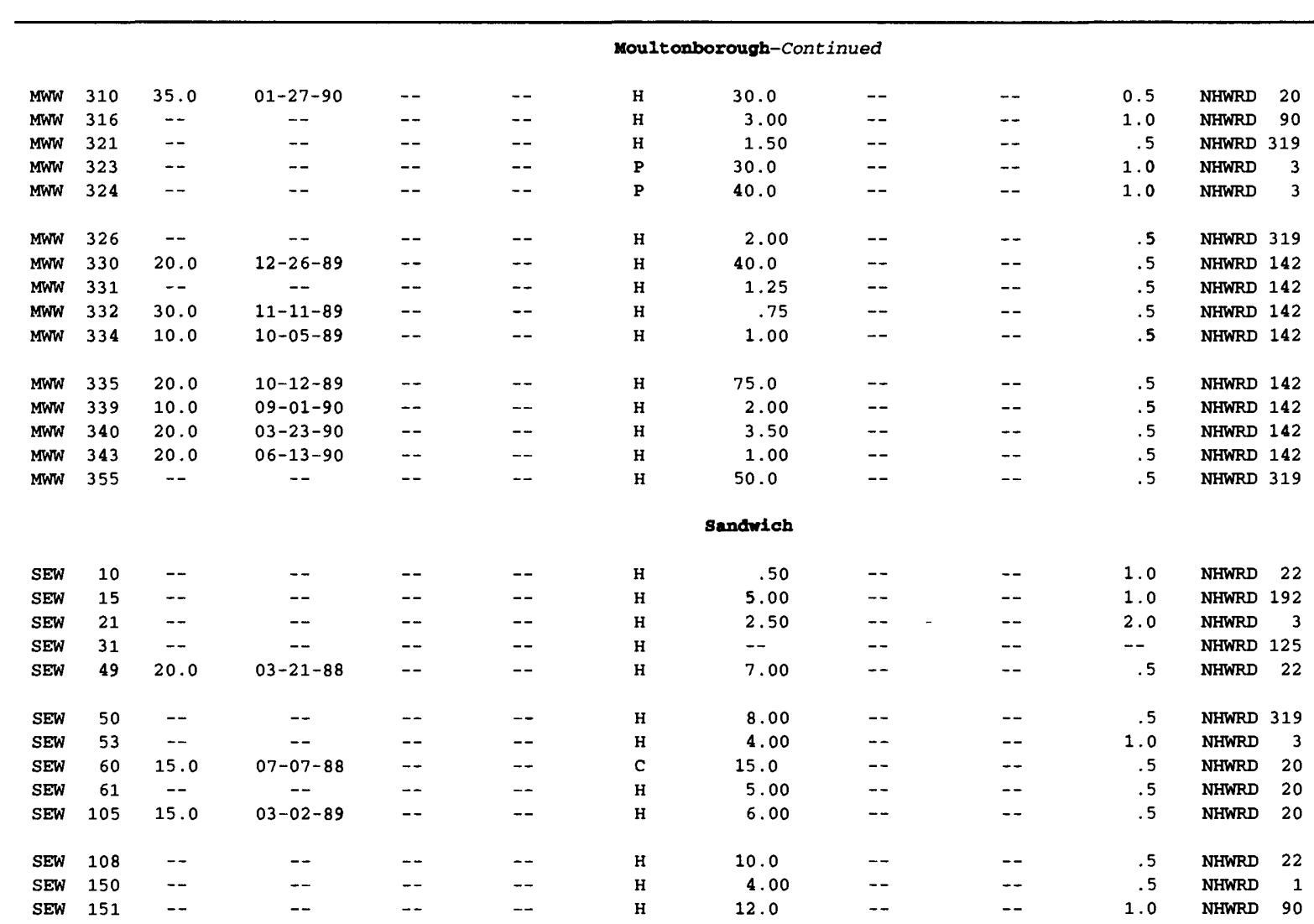

Tuftonboro

\begin{tabular}{|c|c|c|c|c|c|c|c|c|c|c|c|}
\hline TZA & 1 & 38 & $08-\quad-74$ & -- & -- & $\mathrm{U}$ & -- & -- & -- & -- & Clattenburg \\
\hline TZA & 2 & 40 & $08-\quad-74$ & -- & -- & $\mathrm{U}$ & -- & -- & -- & - & clattenburg \\
\hline TZA & 3 & -- & -- & - & -- & $\mathrm{U}$ & -- & -- & - & -- & clattenburg \\
\hline TZA & 4 & -- & -- & -- & -- & $\mathrm{U}$ & -- & -- & -- & -- & Clattenburg \\
\hline TZA & 5 & -- & -- & -- & -- & $\mathrm{U}$ & -- & -- & -- & -- & Clattenburg \\
\hline TZA & 6 & -- & -- & -- & -- & $\mathrm{u}$ & -- & -- & -- & -- & clattenburg \\
\hline TZA & 7 & -- & -- & -- & -- & -- & -- & -- & -- & -- & USGS \\
\hline TZA & 8 & -- & -- & -- & -- & $\mathrm{U}$ & -- & -- & -- & -- & USGS \\
\hline TZA & 9 & -- & -- & -- & -- & -- & -- & -- & -- & -- & USGS \\
\hline TZA & 10 & -- & -- & -- & -- & $\mathrm{U}$ & -- & -- & -- & -- & USGS \\
\hline TZA & 12 & 15.2 & $09-09-87$ & -- & -- & $\mathbf{P}$ & 16.0 & -- & -- & 48.0 & D.L. Maher Co \\
\hline TZA & 13 & 11.2 & $09-10-87$ & - & -- & $\mathrm{U}$ & -- & -- & -- & -- & D.L. Maher CO \\
\hline TZA & 14 & 3.7 & $09-11-87$ & -- & -- & $\mathrm{u}$ & -- & -- & -- & -- & D.L. Maher CO \\
\hline TZA & 15 & 10 & $07-23-91$ & -- & -- & $\mathrm{U}$ & -- & -- & -- & -- & USGS \\
\hline TZA & 16 & 77 & $07-26-91$ & -- & -- & $\mathrm{U}$ & -- & -- & -- & -- & USGS \\
\hline TZA & 17 & -- & -. & -- & -- & - & - & -- & -- & -- & USGS \\
\hline TZA & 18 & -- & -- & -- & -- & $\mathrm{U}$ & -- & -- & -- & -- & USGS \\
\hline TZW & 1 & -- & - & -- & - & $\mathrm{U}$ & -- & -- & - & - & -- \\
\hline TZW & 2 & 4.74 & $07-02-91$ & 21.5 & 23 & $\mathrm{u}$ & -- & -- & -- & -- & USGS \\
\hline TZW & 3 & 14.7 & $07-02-91$ & 48.5 & 51 & $\mathrm{U}$ & -- & -- & -- & -- & USGS \\
\hline TZW & 4 & 4.86 & $06-17-91$ & -- & - & $\mathrm{H}$ & -- & -- & -- & -- & -- \\
\hline TZW & 5 & 7.0 & $06-18-91$ & -- & -- & $\mathrm{H}$ & -- & -- & -- & $\ldots$ & Owner \\
\hline TZW & 6 & 8.35 & $06-18-91$ & -- & -- & $\mathrm{H}$ & -- & -- & -- & -- & Smith \\
\hline
\end{tabular}


Table A-1. Description of selected wells, borings, and springs in the Winnipesaukee River Basin, central New Hampshire

\begin{tabular}{|c|c|c|c|c|c|c|c|c|c|c|}
\hline $\begin{array}{l}\text { Local } \\
\text { site } \\
\text { number }\end{array}$ & $\begin{array}{l}\text { Lat- } \\
\text { itude }\end{array}$ & $\begin{array}{l}\text { Long- } \\
\text { itude }\end{array}$ & Owner or user & $\begin{array}{c}\text { Date } \\
\text { of } \\
\text { con- } \\
\text { struction }\end{array}$ & $\begin{array}{l}\text { Ele- } \\
\text { vat- } \\
\text { tion } \\
\text { (feet) }\end{array}$ & $\begin{array}{c}\text { Diameter } \\
\text { of } \\
\text { casing } \\
\text { (inches) }\end{array}$ & $\begin{array}{l}\text { Depth to } \\
\text { bottom } \\
\text { of casing } \\
\text { (feet) }\end{array}$ & $\begin{array}{c}\text { Casing } \\
\text { mater- } \\
\text { ial }\end{array}$ & $\begin{array}{c}\text { Type } \\
\text { of } \\
\text { fin- } \\
\text { ish }\end{array}$ & $\begin{array}{c}\text { Type } \\
\text { of } \\
\text { site }\end{array}$ \\
\hline
\end{tabular}

\section{CARROLL COUNTY}

\begin{tabular}{|c|c|c|c|c|c|c|c|c|c|c|c|}
\hline \multirow{3}{*}{$\begin{array}{l}\text { TZW } \\
\text { TZW }\end{array}$} & & \multicolumn{10}{|c|}{ Tuftonboro-Continued } \\
\hline & 8 & 434201 & 0711634 & Bean, Edward & $07-24-91$ & 600 & 2 & 20 & $\mathbf{P}$ & $\mathrm{s}$ & Bor \\
\hline & 9 & 434221 & 0711658 & Thompson, Lester & $07-25-91$ & 615 & 2 & 27 & $\mathbf{P}$ & $s$ & Bor \\
\hline TZW & 11 & 434110 & 0711753 & Mason & $04-19-84$ & 510 & -- & 52.0 & -- & $x$ & $B r W$ \\
\hline TZW & 16 & 434213 & 0711445 & Bolton, $\mathrm{J}$. & $12-20-84$ & 700 & -- & 169 & -- & $\mathrm{x}$ & BrW \\
\hline TZW & 18 & 434123 & 0711844 & Ladd Const & $11-27-84$ & 540 & -- & 56.0 & -- & $\mathrm{x}$ & BrW \\
\hline TZW & 26 & 433816 & 0711438 & Morgan, E. & $12-20-85$ & 570 & -- & 41.0 & -- & $x$ & BrW \\
\hline TZW & 27 & 434117 & 0711832 & Hanson, N. & $08-27-85$ & 515 & -- & 84.0 & -- & $x$ & BrW \\
\hline TZW & 29 & 434110 & 0711748 & Swift, $c$. & $11-01-85$ & 530 & -- & 49.0 & -- & $\mathrm{x}$ & $\mathrm{BrW}$ \\
\hline TZW & 35 & 433941 & 0711735 & Johnson, B. & $02-14-84$ & 510 & -- & 112 & -- & $\mathrm{x}$ & $\mathrm{BrW}$ \\
\hline TZW & 39 & 433957 & 0711712 & Sawyer, N. & $05-08-86$ & 530 & -- & 249 & -- & $x$ & Brw \\
\hline TZW & 43 & 433919 & 0711706 & Red Gate Cottage Colony & $04-30-86$ & 530 & -- & 41.0 & -- & $\mathrm{x}$ & BrW \\
\hline TZW & 44 & 433745 & 0711555 & McGrath, J. & $04-24-86$ & 520 & -- & 20.0 & -- & $\mathrm{x}$ & $\mathrm{BrW}$ \\
\hline TZW & 47 & 434110 & 0711332 & Leroux, A. & $08-11-86$ & 1080 & -- & 20.0 & -- & $\mathrm{x}$ & $\mathrm{BrW}$ \\
\hline TZW & 48 & 434118 & 0711843 & Hodges, B. & $06-11-86$ & 510 & -- & 100 & -- & $\mathrm{x}$ & BrW \\
\hline TZW & 63 & 433915 & 0711651 & Edge-O-Lakes Trailers & $12-18-86$ & 550 & -- & 30.0 & -- & $\mathrm{x}$ & $\mathrm{BrW}$ \\
\hline TZW & 71 & 434017 & 0711526 & Healy, B. & $07-15-87$ & 650 & -- & 79.0 & -- & $x$ & $\mathrm{BrW}$ \\
\hline TZW & 88 & 434217 & 0711723 & Hunter, P. & $10-22-87$ & 660 & -- & 29.0 & -- & $\mathrm{x}$ & $\mathrm{BrW}$ \\
\hline TZW & 95 & 433821 & 0711444 & Roseen, E. & $09-16-87$ & 580 & -- & 80.0 & -- & $\mathrm{x}$ & $\mathrm{BrW}$ \\
\hline TZW & 99 & 433958 & 0711709 & Triolo, A. & $04-07-88$ & 520 & -- & 202 & -- & $\mathrm{x}$ & $\mathrm{BrW}$ \\
\hline TZW & 102 & 433839 & 0711455 & Haeger, M. & $03-25-88$ & 600 & -- & 39.0 & -- & $\mathrm{x}$ & $\mathrm{BrW}$ \\
\hline TZW & 104 & 434044 & 0711604 & Rudolph, G. & $07-13-88$ & 580 & -- & 93.0 & -- & $\mathrm{x}$ & $\mathrm{BrW}$ \\
\hline TZW & 107 & 433918 & 0711647 & Berry, s. & $07-25-88$ & 580 & -- & 20.0 & -- & $\mathrm{x}$ & BrW \\
\hline TZW & 108 & 433924 & 0711523 & North Country vil & $06-02-88$ & 590 & -- & 41.0 & -- & $x$ & Brw \\
\hline TZW & 109 & 433924 & 0711521 & North Country vil & $05-26-88$ & 590 & -- & 46.0 & -- & $\mathrm{x}$ & $\mathrm{BrW}$ \\
\hline TZW & 111 & 434208 & 0711803 & Berry, $c$ & $09-10-88$ & 580 & -- & 35.0 & -- & $\mathbf{s}$ & -- \\
\hline TZW & 114 & 434018 & 0711524 & $\& \mathrm{~K}$. DuBrino, $\mathrm{F}$ & $11-17-87$ & 650 & -- & 80.0 & -- & $\mathrm{x}$ & BrW \\
\hline TZW & 116 & 433910 & 0711701 & Cravotta, T. & $09-14-88$ & 510 & -- & 40.0 & -- & $\mathrm{x}$ & BrW \\
\hline $\mathrm{TZW}$ & 128 & 434204 & 0711353 & Stockman, G. & $05-30-89$ & 800 & -- & 80.0 & -- & $\mathrm{x}$ & BrW \\
\hline $\mathrm{TZW}$ & 130 & 434236 & 0711719 & Gribbell, J. & $04-04-89$ & 670 & -- & 123 & -- & $\mathrm{x}$ & BrW \\
\hline TZW & 132 & 434153 & 0711802 & Hersey, $\mathbf{H}$. & $06-14-89$ & 560 & -- & 60.0 & -- & $\mathrm{x}$ & BrW \\
\hline TZW & 133 & 434137 & 0711831 & Beldings & $04-29-89$ & 570 & -- & 123 & -- & $\mathrm{x}$ & BrW \\
\hline TZW & 137 & 433951 & 0711703 & Feeley, J. & $09-09-89$ & 510 & -- & 141 & -- & $\mathrm{x}$ & BrW \\
\hline TZW & 139 & 433923 & 0711518 & North County village & $05-04-88$ & 600 & -- & 45.0 & -- & $\mathrm{x}$ & $\mathrm{BrW}$ \\
\hline TZW & 142 & 434055 & 0711731 & Bob Baker Ent & $05-25-88$ & 510 & -- & 70.0 & -- & $\mathrm{x}$ & BrW \\
\hline TZW & 144 & 434050 & 0711634 & O. T. Patrol Shed, D. & $05-01-89$ & 580 & -- & 120 & -- & $\mathrm{x}$ & Brw \\
\hline TZW & 145 & 434119 & 0711907 & Mazerka, E. & $10-31-89$ & 520 & -- & 137 & -- & $\mathrm{x}$ & BrW \\
\hline TZW & 148 & 433939 & 0711718 & onufrak, $\mathrm{M}$. & $11-30-89$ & 510 & -- & 59.0 & -- & $\mathrm{x}$ & BrW \\
\hline TZW & 158 & 433759 & 0711430 & Meehan, M. & $07-09-90$ & 580 & -- & 89.0 & -- & $\mathrm{x}$ & BrW \\
\hline TZW & 163 & 433904 & 0711638 & Hughes, $\mathrm{S}$. & $10-26-90$ & 520 & -- & 79.0 & -- & $\mathrm{x}$ & BrW \\
\hline TZW & 167 & 434015 & 0711550 & Bill stockman & $10-13-92$ & 585 & 2 & 17.5 & $\mathbf{P}$ & $\mathbf{s}$ & Bor \\
\hline \multirow[t]{2}{*}{ TZW } & 168 & 434015 & 0711551 & Bill Stockman & -- & 583 & -- & -- & -- & C & Dug \\
\hline & \multicolumn{11}{|c|}{ Wolfeboro } \\
\hline WRA & 1 & 433627 & 0711119 & Albee Constr. & $10-26-90$ & 600 & -- & -- & -- & -- & Bor \\
\hline WRA & 3 & 433826 & 0710924 & State Rte. 28 & -- & 630 & -- & -- & -- & -- & $\mathrm{TH}$ \\
\hline WRS & 1 & 433748 & 0711356 & -- & -- & 650 & -- & -- & -- & -- & $\mathrm{Sp}$ \\
\hline WRW & 1 & 433657 & 0710957 & Fernald Sta. & $10-21-90$ & 550 & 2 & 17.5 & $\mathrm{P}$ & $\mathbf{s}$ & Bor \\
\hline WRW & 2 & 433444 & 0710824 & Devylder, Denis & -- & 590 & -- & -- & -- & W & Dug \\
\hline WRW & 3 & 433718 & 0710903 & Jewell & $02-22-84$ & 580 & -- & 37.0 & -- & $x$ & $\mathrm{BrW}$ \\
\hline WRW & 4 & 433726 & 0711047 & Diprizio, T. & $04-02-84$ & 680 & -- & 37.0 & -- & $x$ & BrW \\
\hline WRW & 6 & 433646 & 0711032 & Wol feboro Full Gospel & $07-24-84$ & 570 & -- & 44.0 & -- & $\mathrm{x}$ & $\mathrm{BrW}$ \\
\hline WRW & 11 & 433642 & 0710904 & Bickford & $08-11-84$ & 540 & -- & 40.0 & -- & $\mathrm{x}$ & BrW \\
\hline WRW & 12 & 433635 & 0711129 & Hersey, R. & $11-27-84$ & 600 & -- & 99.0 & - & $\mathrm{x}$ & BrW \\
\hline
\end{tabular}




\begin{tabular}{|c|c|c|c|c|c|c|c|c|c|c|}
\hline $\begin{array}{l}\text { Local } \\
\text { site } \\
\text { number }\end{array}$ & $\begin{array}{l}\text { Depth } \\
\text { (feet) }\end{array}$ & $\begin{array}{c}\text { Date } \\
\text { (mm-dd-yy) }\end{array}$ & $\begin{array}{c}\text { Top of } \\
\text { screen } \\
\text { (feet) }\end{array}$ & $\begin{array}{c}\text { Bottom of } \\
\text { screen } \\
\text { (feet) }\end{array}$ & $\begin{array}{c}\text { Use } \\
\text { of } \\
\text { water }\end{array}$ & $\begin{array}{l}\text { Yield } \\
\text { (gal/min) }\end{array}$ & $\begin{array}{l}\text { Drawdown } \\
\text { (feet) }\end{array}$ & $\begin{array}{r}\text { Specific } \\
\text { capacity }\end{array}$ & $\begin{array}{l}\text { Pumping } \\
\text { period } \\
\text { (hours) }\end{array}$ & $\begin{array}{l}\text { Driller } \\
\text { or NHWRD } \\
\text { number }\end{array}$ \\
\hline
\end{tabular}

CARROLL COUNTY

\begin{tabular}{|c|c|c|c|c|c|}
\hline TZW & 8 & 17 & $07-24-91$ & 17 & 20 \\
\hline TZW & 9 & 3 & $07-25-91$ & 24 & 27 \\
\hline TZW & 11 & 20.0 & $04-20-84$ & -- & -- \\
\hline TZW & 16 & 50.0 & $12-20-84$ & -- & -- \\
\hline TZW & 18 & 20.0 & $11-27-84$ & -- & -- \\
\hline TZW & 26 & -- & -- & -- & -- \\
\hline TZW & 27 & -- & -- & -- & -- \\
\hline TZW & 29 & 15.0 & $11-02-85$ & -- & -- \\
\hline TZW & 35 & -- & -- & -- & -- \\
\hline TZW & 39 & 50.0 & $05-10-86$ & -- & -- \\
\hline TZW & 43 & 10.0 & $04-30-86$ & -- & -- \\
\hline TZW & 44 & -- & -- & -- & - \\
\hline TZW & 47 & -- & -- & -- & -- \\
\hline TZW & 48 & 18.0 & $06-12-86$ & -- & -- \\
\hline TZW & 63 & 20.0 & $12-18-86$ & -- & -- \\
\hline TZW & 71 & -- & -- & - & - \\
\hline TZW & 88 & 9.0 & $12-07-87$ & -- & -- \\
\hline TZW & 95 & 25.0 & $09-16-87$ & -- & - \\
\hline TZW & 99 & 30.0 & $04-11-88$ & -- & -- \\
\hline TZW & 102 & -- & -- & -- & -- \\
\hline TZW & 104 & 25.0 & $07-14-88$ & -- & -- \\
\hline TZW & 107 & 9.0 & $07-26-88$ & -- & -- \\
\hline TZW & 108 & -- & -- & - & - \\
\hline TZW & 109 & -- & -- & -- & -- \\
\hline TZW & 111 & 16.0 & $09-10-88$ & -- & -- \\
\hline TZW & 114 & 20.0 & $11-18-87$ & -- & -- \\
\hline TZW & 116 & 4.0 & $09-16-88$ & -- & -. \\
\hline TZW & 128 & 40.0 & $06-02-89$ & -- & -- \\
\hline TZW & 130 & -- & -- & -- & -- \\
\hline TZW & 132 & -- & -- & -- & -- \\
\hline TZW & 133 & -- & -- & -- & -- \\
\hline TZW & 137 & -- & -- & -- & -- \\
\hline TZW & 139 & -- & -- & -- & - \\
\hline TZW & 142 & -- & -- & -- & - \\
\hline TZW & 144 & -- & -- & -- & -- \\
\hline TZW & 145 & -- & -- & -- & -- \\
\hline
\end{tabular}

Tuftonboro-Continued 
Table A-1. Description of selected wells, borings, and springs in the Winnipesaukee River Basin, central New Hampshire

\begin{tabular}{|c|c|c|c|c|c|c|c|c|c|c|}
\hline $\begin{array}{l}\text { Local } \\
\text { site } \\
\text { number }\end{array}$ & $\begin{array}{l}\text { Lat- } \\
\text { itude }\end{array}$ & $\begin{array}{l}\text { Long- } \\
\text { itude }\end{array}$ & Owner or user & $\begin{array}{c}\text { Date } \\
\text { of } \\
\text { con- } \\
\text { struction }\end{array}$ & $\begin{array}{l}\text { Ele- } \\
\text { vat- } \\
\text { tion } \\
\text { (feet) }\end{array}$ & $\begin{array}{c}\text { Diameter } \\
\text { of } \\
\text { casing } \\
\text { (inches) }\end{array}$ & $\begin{array}{l}\text { Depth to } \\
\text { bottom } \\
\text { of casing } \\
\text { (feet) }\end{array}$ & $\begin{array}{c}\text { Casing } \\
\text { mater- } \\
\text { ial }\end{array}$ & $\begin{array}{l}\text { Type } \\
\text { of } \\
\text { fin- } \\
\text { ish }\end{array}$ & $\begin{array}{c}\text { Type } \\
\text { of } \\
\text { site }\end{array}$ \\
\hline
\end{tabular}

CARROLL COUNTY

\begin{tabular}{|c|c|c|c|c|c|c|c|c|c|c|c|}
\hline \multicolumn{12}{|c|}{ Wolfeboro-Continued } \\
\hline WRW & 19 & 433630 & 0711137 & Runnals, C. & $07-22-85$ & 600 & -- & 100 & -- & $\mathrm{x}$ & Brw \\
\hline WRW & 20 & 433615 & 0711100 & Gamero & $06-27-85$ & 540 & -- & 60.0 & -- & $\mathrm{x}$ & Brw \\
\hline WRW & 29 & 433618 & 0711038 & McKechnie, w. & $02-25-86$ & 540 & -- & 39.0 & -- & $\mathrm{x}$ & Brw \\
\hline WRW & 32 & 433720 & 0710907 & Moran, L. & $04-19-86$ & 590 & -- & 31.0 & -- & $\mathbf{x}$ & $B r W$ \\
\hline WRW & 33 & 433700 & 0710942 & Ort, $F$ & $05-14-86$ & 540 & -- & 21.0 & -- & $\mathbf{x}$ & BrW \\
\hline WRW & 34 & 433626 & 0711137 & Matte, $\mathrm{T}$. & $02-27-86$ & 600 & -- & 80.0 & -- & $\mathrm{x}$ & $\mathrm{BrW}$ \\
\hline WRW & 37 & 433650 & 0711011 & Pfeifer, W. & $06-21-86$ & 540 & -- & 104 & -- & $\mathrm{x}$ & Brw \\
\hline WRW & 43 & 433641 & 0710828 & Griffin, B. & $05-06-87$ & 540 & -- & 62.0 & -- & $\mathrm{x}$ & Brw \\
\hline WRW & 44 & 433640 & 0710827 & Clark, D. & $08-21-86$ & 540 & -- & 41.0 & -- & $\mathrm{x}$ & BrW \\
\hline WRW & 45 & 433619 & 0710753 & Giroux, E. & $08-19-86$ & 580 & -- & 86.0 & -- & $\mathrm{x}$ & Brw \\
\hline WRW & 59 & 433736 & 0711208 & Sullivan, R. & $05-18-87$ & 730 & -- & 41.0 & -- & $\mathrm{x}$ & Brw \\
\hline WRW & 71 & 433623 & 0710753 & Mtn View Ter Partnership & $09-19-87$ & 580 & -- & 102 & -- & $\mathrm{x}$ & Brw \\
\hline WRW & 72 & 433624 & 0710752 & Mtn View Ter Partnership & $08-20-87$ & 580 & -- & 108 & -- & $\mathrm{x}$ & Brw \\
\hline WRW & 73 & 433624 & 0710752 & Mtn View Ter Partnership & $09-21-87$ & 590 & -- & 102 & -- & $\mathrm{x}$ & Brw \\
\hline WRW & 74 & 433624 & 0710751 & Mtn View Ter Partnership & $09-22-87$ & 590 & -- & 94.0 & -- & $x$ & BrW \\
\hline WRW & 75 & 433623 & 0710750 & Mtn View Ter Partnership & $09-23-87$ & 590 & -- & 102 & -- & $\mathrm{x}$ & Brw \\
\hline WRW & 76 & 433623 & 0710749 & Mtn View Ter Partnership & $09-25-87$ & 590 & -- & 102 & -- & $\mathrm{x}$ & Brw \\
\hline WRW & 78 & 433816 & 0710909 & Foss, D. & $10-12-87$ & 700 & -- & 39.0 & -- & $\mathrm{x}$ & Brw \\
\hline WRW & 80 & 433734 & 0711102 & Papps, P. & $06-29-87$ & 700 & -- & 41.0 & -- & $\mathrm{x}$ & BrW \\
\hline WRW & 81 & 433735 & 0711106 & Quimby, $\mathrm{k}$. & $06-20-87$ & 700 & -- & 41.0 & -- & $\mathrm{x}$ & BrW \\
\hline WRW & 82 & 433656 & 0711030 & Your Xtra Room Inc & $01-06-86$ & 580 & -- & 40.0 & -- & $\mathrm{x}$ & Brw \\
\hline WRW & 87 & 433645 & 0711019 & Wichroski & $10-01-87$ & 540 & -- & 42.0 & -- & $\mathrm{x}$ & BrW \\
\hline WRW & 89 & 433516 & 0711441 & Bunting, D. & $05-06-88$ & 540 & -- & 39.0 & -- & $\mathrm{x}$ & Brw \\
\hline WRW & 92 & 433430 & 0710827 & Buckingham, E. & $05-26-88$ & 620 & -- & 39.0 & -- & $\mathrm{x}$ & Brw \\
\hline WRW & 94 & 433637 & 0710635 & Bean, B. & $02-01-88$ & 660 & -- & 42.0 & -- & $\mathrm{x}$ & BrW \\
\hline WRW & 102 & 433446 & 0710836 & Baehrend, J. & $08-05-88$ & 590 & -- & 93.0 & -- & $\mathrm{x}$ & Brw \\
\hline WRW & 104 & 433821 & 0710901 & Crowther, B. & $01-06-87$ & 750 & -- & 60.0 & -. & $\mathrm{x}$ & BrW \\
\hline WRW & 108 & 433431 & 0710829 & Calligandes Const & $11-07-88$ & 620 & -- & 59.0 & -- & $\mathrm{x}$ & Brw \\
\hline WRW & 110 & 433618 & 0710751 & Hertling, $M$. & $01-11-89$ & 580 & -- & 79.0 & -- & $\mathbf{x}$ & BrW \\
\hline WRW & 111 & 433510 & 0711433 & Hess, G. & $11-01-88$ & 530 & -- & 40.0 & -- & $\mathrm{x}$ & $\mathrm{BrW}$ \\
\hline WRW & 115 & 433642 & 0711025 & Fernald, c. & $05-19-89$ & 540 & -- & 40.0 & -- & $\mathbf{x}$ & BrW \\
\hline WRW & 116 & 433634 & 0711222 & Streeter, E. & $06-26-89$ & 620 & -- & 29.0 & -- & $\mathrm{x}$ & BrW \\
\hline WRW & 123 & 433624 & 0710804 & Baldwin, $\mathrm{H}$. & $08-21-89$ & 570 & -- & 79.0 & -- & $\mathbf{x}$ & BrW \\
\hline WRW & 125 & 433435 & 0710834 & Garnsey, F. & $10-19-89$ & 620 & -- & 59.0 & -- & $\mathrm{x}$ & BrW \\
\hline WRW & 129 & 433631 & 0711141 & Warren Devel Corp & $11-19-90$ & 600 & -- & 86.0 & -- & $\mathrm{x}$ & BrW \\
\hline WRW & 130 & 433759 & 0710925 & Bartlett, $\mathrm{K}$. & $05-09-90$ & 620 & -- & 42.0 & -- & $\mathbf{x}$ & BrW \\
\hline WRW & 132 & 433643 & 0710918 & Hill, $\mathrm{C}$. & $04-17-90$ & 540 & -- & 31.0 & -- & $\mathrm{x}$ & BrW \\
\hline WRW & 138 & 433634 & 0711316 & Spencer Hughes Const Deve & $11-01-89$ & 620 & -- & 49.0 & -- & $\mathbf{x}$ & BrW \\
\hline WRW & 143 & 433732 & 0711059 & Lin-Ho & $06-27-90$ & 680 & -- & 40.0 & -- & $\mathbf{x}$ & BrW \\
\hline WRW & 145 & 433444 & 0710825 & Devylder, D. & $06-18-90$ & 590 & -- & 80.0 & -- & $\mathbf{x}$ & BrW \\
\hline WRW & 146 & 433813 & 0710927 & Armour, $\mathrm{C}$. & $07-24-90$ & 620 & -- & 49.0 & -- & $\mathrm{x}$ & $\mathrm{BrW}$ \\
\hline WRW & 149 & 433647 & 0711008 & Baldwin, $\mathrm{P}$. & $11-17-90$ & 540 & -- & 32.0 & -- & $\mathbf{x}$ & Brw \\
\hline WRW & 152 & 433512 & 0711435 & \&. M. Fischer, W. & $12-03-90$ & 520 & -- & 37.0 & -- & $\mathbf{x}$ & Brw \\
\hline WRW & 154 & 433618 & 0710747 & Stocton, $\mathrm{R}$ & $03-18-91$ & 600 & -- & 104 & -- & $\mathrm{x}$ & BrW \\
\hline
\end{tabular}

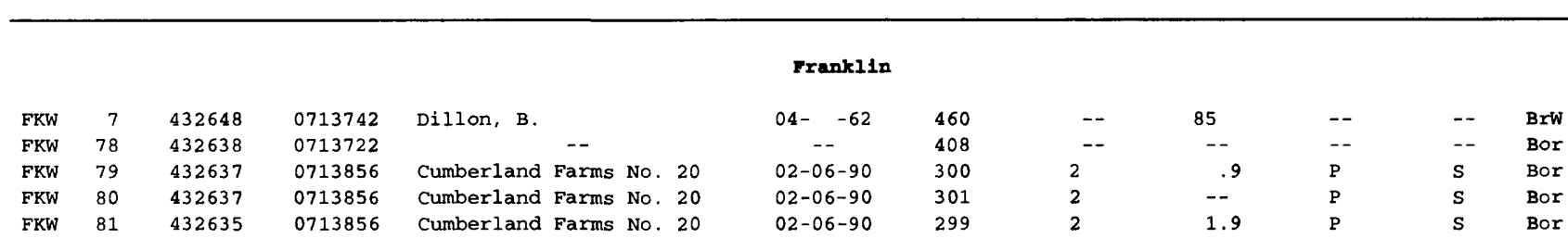




\begin{tabular}{|c|c|c|c|c|c|c|c|c|c|c|}
\hline $\begin{array}{l}\text { Local } \\
\text { site } \\
\text { number }\end{array}$ & $\begin{array}{l}\text { Depth } \\
\text { (feet) }\end{array}$ & $\begin{array}{c}\text { Date } \\
\text { (mm-dd-yy) }\end{array}$ & $\begin{array}{l}\text { Top of } \\
\text { screen } \\
\text { (feet) }\end{array}$ & $\begin{array}{l}\text { Bottom of } \\
\text { screen } \\
\text { (feet) }\end{array}$ & $\begin{array}{c}\text { Use } \\
\text { of } \\
\text { water }\end{array}$ & $\begin{array}{c}\text { Yieid } \\
\text { (gal/min) }\end{array}$ & $\begin{array}{l}\text { Drawdown } \\
\text { (feet) }\end{array}$ & $\begin{array}{l}\text { Specific } \\
\text { capacity }\end{array}$ & $\begin{array}{l}\text { Pumping } \\
\text { period } \\
\text { (hours) }\end{array}$ & $\begin{array}{l}\text { Driller } \\
\text { or NHWRD } \\
\text { number }\end{array}$ \\
\hline
\end{tabular}

\section{CARROLL COUNTY}

\begin{tabular}{|c|c|c|c|c|c|c|c|c|c|c|c|c|}
\hline \multicolumn{13}{|c|}{ wolfeboro-Continued } \\
\hline WRW & 19 & -- & -- & -- & -- & $\mathrm{H}$ & 12.0 & -- & -- & 1.0 & NHWRD & 3 \\
\hline WRW & 20 & 15.0 & $06-27-85$ & -- & -- & $\mathrm{H}$ & 5.00 & -- & -- & .5 & NHWRD & 22 \\
\hline WRW & 29 & 6.0 & $02-26-86$ & -- & -- & $\mathrm{H}$ & 2.00 & -- & -- & 1.0 & NHWRD & 3 \\
\hline WRW & 32 & 3.0 & $04-20-86$ & -- & -- & $\mathrm{H}$ & 12.0 & -- & -- & 1.0 & NHWRD & 3 \\
\hline WRW & 33 & -- & -- & -- & -- & $\mathrm{H}$ & 3.00 & -- & -- & 1.5 & NHWRD & 406 \\
\hline WRW & 34 & 45.0 & $02-28-86$ & -- & -- & $\mathrm{H}$ & 3.50 & -. & -- & .5 & NHWRD & 22 \\
\hline WRW & 37 & -- & -- & -- & -- & $\mathrm{H}$ & .25 & -- & -- & 1.5 & NHWRD & 406 \\
\hline WRW & 43 & -- & -- & -- & -- & $\mathrm{H}$ & .75 & -- & -- & 1.0 & NHWRD & 406 \\
\hline WRW & 44 & -- & -- & -- & -- & $\mathrm{H}$ & 9.00 & -- & -- & .8 & NHWRD & 406 \\
\hline WRW & 45 & 15.0 & $08-19-86$ & -- & -- & $\mathrm{H}$ & 2.00 & -- & -- & 1.0 & NHWRD & 3 \\
\hline WRW & 59 & 5.0 & $05-19-87$ & -- & -- & $\mathrm{H}$ & 4.50 & -- & -- & .5 & NHWRD & 22 \\
\hline WRW & 71 & 21.0 & $09-19-87$ & -- & -- & $\mathrm{H}$ & 1.00 & -- & -- & 1.0 & NHWRD & 123 \\
\hline WRW & 72 & 20.0 & $09-22-87$ & -- & -- & $\mathrm{H}$ & 1.00 & -- & -- & 1.0 & NHWRD & 123 \\
\hline WRW & 73 & -- & -- & -- & -- & $\mathrm{H}$ & .75 & -- & - & 1.0 & NHWRD & 123 \\
\hline WRW & 74 & -- & -- & -- & -- & $\mathrm{H}$ & .50 & -- & -- & 1.0 & NHWRD & 123 \\
\hline WRW & 75 & -- & -- & -- & -- & $\mathrm{H}$ & .75 & -- & -- & 1.0 & NHWRD & 123 \\
\hline WRW & 76 & 22.0 & $09-25-87$ & -- & -- & $\mathrm{H}$ & .75 & -- & -- & 1.0 & NHWRD & 123 \\
\hline WRW & 78 & 30.0 & $10-13-87$ & -- & -- & $\mathrm{H}$ & 15.0 & -- & -- & 1.0 & NHWRD & 3 \\
\hline WRW & 80 & -- & -- & -- & -- & $\mathrm{H}$ & 1.00 & -- & -- & 1.0 & NHWRD & 644 \\
\hline WRW & 81 & -- & -- & -- & -- & H & 2.50 & -- & -- & 1.0 & NHWRD & 644 \\
\hline WRW & 82 & -- & -- & -- & -- & $\mathrm{C}$ & 4.50 & -- & -- & .5 & NHWRD & 20 \\
\hline WRW & 87 & 60.0 & $10-01-87$ & -- & -- & $\mathrm{H}$ & 2.0 & -- & -- & 1.0 & NHWRD & 22 \\
\hline WRW & 89 & -- & -- & -- & -- & $\mathbf{H}$ & 12.0 & -- & -- & 1.0 & NHWRD & 3 \\
\hline WRW & 92 & 10.0 & $05-31-88$ & -- & -- & $\mathrm{H}$ & 1.50 & -- & -- & .5 & NHWRD & 138 \\
\hline WRW & 94 & -- & -- & -- & -- & H & 18.0 & -- & -- & 36.0 & NHWRD & 158 \\
\hline WRW & 102 & 40.0 & $08-05-88$ & -- & -- & $\mathbf{H}$ & 4.50 & -- & -- & 1.0 & NHWRD & 3 \\
\hline WRW & 104 & 20.0 & $01-07-87$ & -- & -- & $\mathrm{H}$ & 2.00 & -- & -- & .5 & NHWRD & 20 \\
\hline WRW & 108 & -- & -- & -- & -- & $\mathrm{H}$ & .50 & -- & -- & 2.0 & NHWRD & 644 \\
\hline WRW & 110 & -- & -- & -- & -- & $\mathrm{H}$ & .50 & -- & -- & 1.0 & NHWRD & 143 \\
\hline WRW & 111 & -- & -- & -- & -- & $\mathrm{H}$ & 15.0 & -- & -- & 1.0 & NHWRD & 457 \\
\hline WRW & 115 & 2.0 & $06-01-89$ & -- & -- & $\mathrm{H}$ & 2.75 & -- & -- & .5 & NHWRD & 22 \\
\hline WRW & 116 & -- & -- & -- & -- & $\mathrm{H}$ & 2.00 & -- & -- & .3 & NHWRD & 247 \\
\hline WRW & 123 & 18.0 & $08-22-89$ & -- & -- & $\mathrm{H}$ & 1.00 & -- & -- & 1.0 & NHWRD & 123 \\
\hline WRW & 125 & 25.0 & $10-19-89$ & -- & -- & $\mathrm{H}$ & 12.0 & -- & -- & 1.0 & NHWRD & 277 \\
\hline WRW & 129 & -- & -- & -- & - & $\mathrm{H}$ & 1.50 & -- & -- & .8 & NHWRD & 406 \\
\hline WRW & 130 & -- & -- & -- & -- & $\mathrm{H}$ & 3.00 & -- & -- & 1.0 & NHWRD & 534 \\
\hline WRW & 132 & 8.0 & $04-19-90$ & -- & -- & $\mathrm{H}$ & 1.50 & -- & -- & 1.0 & NHWRD & 534 \\
\hline WRW & 138 & -- & -- & -- & -- & $\mathrm{H}$ & 5.00 & -- & -- & .3 & NHWRD & 247 \\
\hline WRW & 143 & -- & -- & -- & -- & $\mathbf{H}$ & 5.00 & -- & -- & 1.0 & NHWRD & 3 \\
\hline WRW & 145 & -- & -- & -- & -- & $\mathrm{H}$ & 100 & -- & -- & .5 & NHWRD & 22 \\
\hline WRW & 146 & -- & -- & -- & -- & H & 17.0 & -- & -- & .3 & NHWRD & 406 \\
\hline WRW & 149 & 14.0 & $11-17-90$ & -- & -- & $\mathbf{H}$ & 2.00 & -- & -- & 1.0 & NHWRD & 277 \\
\hline WRW & 152 & 10.0 & $12-03-90$ & -- & -- & -- & 15.0 & -- & -- & 36.0 & NHWRD & 158 \\
\hline WRW & 154 & 60.0 & $03-25-91$ & -- & -- & $\mathrm{H}$ & .33 & -- & -- & 1.0 & NHWRD & 22 \\
\hline
\end{tabular}

Frank11n

\begin{tabular}{|c|c|c|c|c|c|c|c|c|c|c|c|}
\hline FKW & 7 & -- & -- & -- & -- & -- & -- & -- & -- & -- & Thomas, \\
\hline FKW & 78 & -- & -- & -- & -- & -- & -- & -- & $\cdots$ & -- & NHDOT \\
\hline FKW & 79 & 5.15 & $02-06-90$ & .9 & 10.9 & $\mathrm{U}$ & -- & -- & -- & -- & Capital \\
\hline FKW & 80 & 5.74 & $02-06-90$ & 4 & 14 & $\mathrm{U}$ & -- & -- & -- & -- & CAPITAI \\
\hline FKW & 81 & 5.34 & $02-06-90$ & 1.9 & 11.9 & $\mathrm{U}$ & -- & -- & -- & -- & Capital \\
\hline
\end{tabular}


Table A-1. Description of selected wells, borings, and springs in the Winnipesaukee River Basin, central New Hampshire

\begin{tabular}{|c|c|c|c|c|c|c|c|c|c|c|}
\hline $\begin{array}{l}\text { Local } \\
\text { site } \\
\text { number }\end{array}$ & $\begin{array}{l}\text { Lat- } \\
\text { itude }\end{array}$ & $\begin{array}{l}\text { Long- } \\
\text { itude }\end{array}$ & Owner or user & $\begin{array}{c}\text { Date } \\
\text { of } \\
\text { con- } \\
\text { struction }\end{array}$ & $\begin{array}{c}\text { Ele- } \\
\text { vat- } \\
\text { tion } \\
\text { (feet) }\end{array}$ & $\begin{array}{c}\text { Diameter } \\
\text { of } \\
\text { casing } \\
\text { (inches) }\end{array}$ & $\begin{array}{l}\text { Depth to } \\
\text { bottom } \\
\text { of casing } \\
\text { (feet) }\end{array}$ & $\begin{array}{c}\text { Casing } \\
\text { mater- } \\
\text { ial }\end{array}$ & $\begin{array}{c}\text { Type } \\
\text { of } \\
\text { fin- } \\
\text { ish }\end{array}$ & $\begin{array}{c}\text { Type } \\
\text { of } \\
\text { site }\end{array}$ \\
\hline
\end{tabular}

MERRIMACK COUNTY

\begin{tabular}{|c|c|c|c|c|c|c|c|c|c|c|c|}
\hline \multirow[b]{2}{*}{ FKW } & \multicolumn{11}{|c|}{ Frankl1n-Continued } \\
\hline & 82 & 432637 & 0713856 & Cumberland Farms No. 20 & $02-07-90$ & 301 & 2 & 3.3 & $\mathrm{P}$ & $\mathrm{s}$ & Bor \\
\hline FKW & 83 & 432637 & 0713856 & Cumberland Farms No. 20 & $02-07-90$ & 303 & 2 & 3.9 & P & $\mathrm{s}$ & Bor \\
\hline FKW & 84 & 432637 & 0713856 & Cumberland Farms No. 20 & $03-26-90$ & 302 & 2 & 3.3 & P & s & Bor \\
\hline FKW & 85 & 432637 & 0713856 & Cumberland Farms No. 20 & $03-26-90$ & 300 & 2 & 3.5 & P & $s$ & Bor \\
\hline FKW & 86 & 432637 & 0713856 & Cumberland Farms No. 20 & $03-26-90$ & 300 & 2 & 1 & P & $s$ & Bor \\
\hline FKW & 87 & 432635 & 0713856 & Cumberland Farms No. 20 & $03-26-90$ & 300 & 2 & 2.8 & $P$ & $s$ & Bor \\
\hline FKW & 88 & 432635 & 0713856 & Cumberland Farms No. 20 & $03-26-90$ & 299 & 2 & 3.4 & $P$ & $\mathrm{~s}$ & Bor \\
\hline FKW & 89 & 432632 & 0713857 & Cumberland Farms No. 20 & $07-17-90$ & 297 & 2 & 3.3 & $\mathrm{P}$ & $\mathrm{s}$ & Bor \\
\hline FKW & 90 & 432633 & 0713856 & Cumberland Farms No. 20 & $07-17-90$ & 298 & 2 & 4.1 & $\mathbf{P}$ & $\mathrm{s}$ & Bor \\
\hline FKW & 91 & 432634 & 0713856 & Cumberland Farms No. 20 & $07-17-90$ & 297 & 2 & 4.5 & $\mathbf{P}$ & s & Bor \\
\hline FKW & 92 & 432634 & 0713856 & Cumberland Farms No. 20 & $07-17-90$ & 299 & 2 & 2.9 & $\mathrm{P}$ & $\mathrm{s}$ & Bor \\
\hline FKW & 93 & 432635 & 0713856 & Cumberland Farms No. 20 & $07-17-90$ & 300 & 2 & 2.5 & $\mathrm{P}$ & $\mathrm{s}$ & Bor \\
\hline FKW & 94 & 432635 & 0713858 & Cumber land Farms No. 20 & $07-17-90$ & 297 & 2 & 2.2 & $P$ & 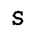 & Bor \\
\hline FKW & 95 & 432631 & 0713856 & Cumberland Farms No. 20 & $09-27-90$ & 296 & 2 & 7.6 & $\mathrm{P}$ & $\mathrm{s}$ & Bor \\
\hline FKW & 96 & 432633 & 0713856 & Cumberland Farms No. 20 & $09-27-90$ & 299 & 2 & 9.5 & $\mathrm{P}$ & S & Bor \\
\hline FKW & 97 & 432635 & 0713856 & Cumberland Farms No. 20 & $09-27-90$ & 301 & 2 & 4.6 & $\mathrm{P}$ & $s$ & Bor \\
\hline FKW & 98 & 432634 & 0713856 & Cumberland Farms No. 20 & $09-27-90$ & 299 & 2 & 8.5 & $\mathrm{P}$ & $\mathrm{s}$ & Bor \\
\hline FKW & 99 & 432632 & 0713857 & Cumberland Farms No. 20 & $09-27-90$ & 299 & 2 & 8.0 & $P$ & $\mathrm{~s}$ & Bor \\
\hline FKW & 100 & 432634 & 0713856 & Cumberland Farms No. 20 & $09-27-90$ & 300 & 2 & 7 & $P$ & S & Bor \\
\hline FKW & 101 & 432634 & 0713858 & Cumberland Farms No. 20 & $09-28-90$ & 298 & 2 & 5.9 & $\mathrm{P}$ & $\mathrm{S}$ & Bor \\
\hline FKW & 102 & 432634 & 0713858 & Cumberland Farms No. 20 & $09-28-90$ & 297 & 2 & 6.8 & $\mathrm{P}$ & $\mathbf{s}$ & Bor \\
\hline \multirow[t]{2}{*}{ FKW } & 103 & 432634 & 0713856 & Cumberland Farms No. 20 & $09-28-90$ & 300 & 2 & 5.2 & P & $\mathbf{s}$ & Bor \\
\hline & \multicolumn{11}{|c|}{ Northfield } \\
\hline NRB & 1 & 432645 & 0713214 & -- & -- & 469 & -- & -- & -- & -- & Bor \\
\hline NRB & 26 & 432635 & 0713721 & -- & -- & 405 & -- & -- & -- & -- & Bor \\
\hline NRB & 27 & 432548 & 0713519 & -- & -- & 449 & -- & -- & -- & -- & $\mathrm{TH}$ \\
\hline NRB & 28 & 432548 & 0713522 & -- & -- & 433 & -- & -- & -- & -- & Bor \\
\hline NRB & 29 & 432515 & 0713535 & -- & -- & 435 & - & -- & -- & -- & Bor \\
\hline NRB & 30 & 432516 & 0713531 & -- & -- & 449 & -- & -- & -- & -- & Bor \\
\hline NRB & 31 & 432707 & 0713414 & -- & -- & 456 & -- & -- & -- & -- & Bor \\
\hline NRB & 32 & 432707 & 0713412 & -- & -- & 454 & -- & -- & -- & -- & Bor \\
\hline NRW & 51 & 432603 & 0713556 & Tilton-Northfield Aqu. & $08-14-68$ & 420 & -- & -- & - & -- & -- \\
\hline NRW & 52 & 432602 & 0713531 & Tilton-Northfield Aqu. & $08-14-68$ & 441 & -- & -- & -- & -- & Bor \\
\hline NRW & 53 & 432556 & 0713542 & Tilton-Northfield Aqu. & -- & 420 & -- & -- & -- & -- & Bor \\
\hline NRW & 54 & 432613 & 0713554 & Tilton-Northfield Aqu. & $12-11-68$ & 415 & - & -- & -- & -- & Bor \\
\hline NRW & 55 & 432713 & 0713321 & - & $05-22-85$ & 468 & 2 & 54 & $\mathrm{P}$ & $\mathrm{s}$ & Bor \\
\hline NRW & 56 & 432714 & 0713336 & -- & $05-29-85$ & 470 & 1.5 & 69 & $\mathrm{P}$ & $\mathrm{s}$ & Bor \\
\hline NRW & 57 & 432710 & 0713335 & -- & $05-30-85$ & 480 & 1.5 & 38 & $P$ & s & Bor \\
\hline NRW & 58 & 432709 & 0713325 & -- & $06-03-85$ & 500 & 1.5 & 82 & $P$ & $\mathrm{~s}$ & Bor \\
\hline NRW & 59 & 432555 & 0713529 & Northfield, Town of & $09-10-90$ & 435 & 2 & 57.5 & $\mathrm{P}$ & $s$ & Bor \\
\hline NRW & 60 & 432555 & 0713529 & Northfield, Town of & $09-10-90$ & 435 & 2 & 20.0 & $\mathbf{P}$ & s & Bor \\
\hline NRW & 61 & 432614 & 0713624 & Partridge, Ken & $06-24-91$ & 410 & 2 & 37.7 & $P$ & $\mathrm{~s}$ & Bor \\
\hline NRW & 62 & 432613 & 0713508 & Jenks, Joanne & -- & 480 & -- & -- & -- & W & Dug \\
\hline NRW & 89 & 432534 & 0713539 & Brown, B. & $09-19-85$ & 440 & -- & 89.0 & -- & $\mathrm{x}$ & BrW \\
\hline NRW & 118 & 432634 & 0713442 & Dunlop, R. & $09-22-87$ & 510 & -- & -- & -- & -- & Dug \\
\hline NRW & 119 & 432554 & 0713605 & Simpson, H. & $10-31-87$ & 420 & -- & -- & -- & -- & Dug \\
\hline NRW & 142 & 432531 & 0713541 & Curtis, $\mathrm{J}$. & $10-21-87$ & 420 & -- & 49.0 & -- & $\mathrm{x}$ & Brw \\
\hline NRW & 146 & 432654 & 0713334 & Gilbert, $R$. & $05-31-88$ & 500 & -- & 150 & -- & $\mathrm{x}$ & BrW \\
\hline NRW & 171 & 432556 & 0713613 & -- & -- & 440 & -- & 74.0 & -- & $\mathrm{x}$ & BrW \\
\hline NRW & 172 & 432700 & 0713314 & Beede Electric & $10-11-88$ & 480 & -- & 139.0 & -- & $\mathrm{x}$ & BrW \\
\hline NRW & 174 & 432553 & 0713620 & Durand, L. & $12-16-88$ & 560 & -- & 89.0 & -- & $\mathrm{x}$ & BrW \\
\hline $\begin{array}{l}\text { NRW } \\
\text { NRW }\end{array}$ & $\begin{array}{l}197 \\
198\end{array}$ & 432655 & 0713239 & Tilton-Northfield Aqu. & $11-30-94$ & 480 & 2.5 & 20.0 & $S$ & $\mathrm{~S}$ & Bor \\
\hline
\end{tabular}




\begin{tabular}{|c|c|c|c|c|c|c|c|c|c|c|}
\hline \multirow{2}{*}{$\begin{array}{l}\text { Local } \\
\text { site } \\
\text { number }\end{array}$} & \multicolumn{2}{|c|}{ Water level } & \multirow{2}{*}{$\begin{array}{l}\text { Top of } \\
\text { screen } \\
\text { (feet) }\end{array}$} & \multirow{2}{*}{$\begin{array}{l}\text { Bottom of } \\
\text { screen } \\
\text { (feet) }\end{array}$} & \multirow{2}{*}{$\begin{array}{c}\text { Use } \\
\text { of } \\
\text { water }\end{array}$} & \multirow[b]{2}{*}{$\begin{array}{c}\text { Yield } \\
\text { (gal/min) }\end{array}$} & \multirow[b]{2}{*}{$\begin{array}{l}\text { Drawdown } \\
\text { (feet) }\end{array}$} & \multirow[b]{2}{*}{$\begin{array}{l}\text { Specific } \\
\text { capacity }\end{array}$} & \multirow{2}{*}{$\begin{array}{l}\text { Pumping } \\
\text { period } \\
\text { (hours) }\end{array}$} & \multirow{2}{*}{$\begin{array}{l}\text { Driller } \\
\text { or NHWRD } \\
\text { number }\end{array}$} \\
\hline & $\begin{array}{l}\text { Depth } \\
\text { (feet) }\end{array}$ & $\begin{array}{c}\text { Date } \\
\text { (mm-dd-yy) }\end{array}$ & & & & & & & & \\
\hline
\end{tabular}

\section{CARROLL COUNTY}

\begin{tabular}{|c|c|c|c|c|c|c|c|c|c|c|c|}
\hline \multirow[b]{2}{*}{ FKW } & \multirow[b]{2}{*}{82} & \multicolumn{10}{|c|}{ Frank11n-Continued } \\
\hline & & 5.52 & $02-07-90$ & 3.3 & 13.3 & $\mathrm{U}$ & -- & -- & -- & -- & Capital Env \\
\hline FKW & 83 & 7.57 & $02-07-90$ & 3.9 & 13.9 & $\mathrm{U}$ & -- & -- & -- & -- & Capital Env \\
\hline FKW & 84 & 6.80 & $03-28-90$ & 3.3 & 13.3 & $\mathrm{U}$ & - & -- & -- & -- & Env Drilling \\
\hline FKW & 85 & 5.53 & $03-28-90$ & 3.5 & 13.5 & $\mathrm{U}$ & $\ldots$ & -- & -- & -- & Env Drilling \\
\hline FKW & 86 & 5.08 & $03-28-90$ & 1 & 11 & $\mathrm{U}$ & -- & -- & -- & -- & Env Drilling \\
\hline FKW & 87 & 6.38 & $03-28-90$ & 2.8 & 12.8 & $\mathrm{u}$ & -- & -- & -- & -- & Env Drilling \\
\hline FKW & 88 & 7.03 & $03-28-90$ & 3.4 & 13.4 & $\mathrm{U}$ & -- & -- & -- & -- & Env Drilling \\
\hline FKW & 89 & 7.03 & $08-14-90$ & 3.3 & 8.3 & $\mathrm{U}$ & -- & -- & -- & -- & Env Drilling \\
\hline FKW & 90 & 8.71 & $07-17-90$ & 4.1 & 14.1 & $\mathrm{U}$ & -- & -- & -- & -- & Env Drilling \\
\hline FKW & 91 & 8.08 & $07-17-90$ & 4.5 & 14.5 & $\mathrm{U}$ & -- & -- & -- & -- & Env Drilling \\
\hline FKW & 92 & 8.09 & $07-17-90$ & 2.9 & 12.9 & $\mathrm{U}$ & -- & -- & $=-$ & -- & Env Drilling \\
\hline FKW & 93 & 7.58 & $07-17-90$ & 2.5 & 12.5 & $\mathrm{U}$ & -- & -- & -- & -- & Env Drilling \\
\hline FKW & 94 & 3.08 & $07-17-90$ & 2.2 & 7.2 & $\mathrm{U}$ & -- & -- & -- & -- & Env Drilling \\
\hline FKW & 95 & 8.70 & $10-01-90$ & 7.6 & 17.6 & $\mathrm{U}$ & -- & -- & -- & -- & Env Drilling \\
\hline FKW & 96 & 7.9 & $10-01-90$ & 9.5 & 19.5 & $\mathrm{U}$ & -- & -- & -- & -- & Env Drilling \\
\hline FKW & 97 & 7.35 & $10-01-90$ & 4.6 & 14.6 & $\mathrm{U}$ & -- & -- & -- & -- & Env Drilling \\
\hline FKW & 98 & 8.43 & $10-01-90$ & 8.5 & 18.5 & $\mathrm{U}$ & -- & -- & -- & -- & Env Drilling \\
\hline FKW & 99 & 9 & $10-01-90$ & 8 & 18.0 & $\mathrm{U}$ & -- & -- & -- & -- & Env Drilling \\
\hline FKW & 100 & 9.85 & $10-01-90$ & 7 & 17 & $\mathrm{U}$ & -- & -- & -- & -- & Env Drilling \\
\hline FKW & 101 & 9.79 & $10-01-90$ & 5.9 & 15.9 & $\mathrm{u}$ & -- & -- & -- & - & Env Drilling \\
\hline FKW & 102 & 11.5 & $10-01-90$ & 6.8 & 16.8 & $\mathrm{U}$ & -- & -- & -- & -- & Env Drilling \\
\hline \multirow[t]{2}{*}{ FKW } & 103 & 10.1 & $10-01-90$ & 5.2 & 15.2 & $\mathrm{U}$ & -- & -- & -- & -- & Env Drilling \\
\hline & & \multicolumn{10}{|c|}{ Northfield } \\
\hline NRB & 1 & -- & -- & -- & -- & -- & -- & -- & -- & - & NHDOT \\
\hline NRB & 26 & -- & -- & -- & -- & -- & -- & -- & -- & -- & NHDOT \\
\hline NRB & 27 & -- & -- & -- & -- & -- & $\ldots$ & -- & -- & -- & - \\
\hline NRB & 28 & -- & -- & -- & -- & -- & -- & -- & -- & -- & NHDOT \\
\hline NRB & 29 & -- & -- & -- & -- & -- & -- & -- & -- & -- & NHDOT \\
\hline NRB & 30 & -- & -- & -- & -- & -- & -- & -- & -- & -- & NHDOT \\
\hline NRB & 31 & -- & -- & -- & -- & -- & -- & -- & -- & -- & NHDOT \\
\hline NRB & 32 & -- & -- & -- & -- & -- & -- & -- & -- & -- & NHDOT \\
\hline NRW & 51 & 14 & $08-14-68$ & -- & -- & -- & -- & -- & -- & -- & Layne \\
\hline NRW & 52 & -- & -- & -- & -- & -- & -- & -- & -- & -- & Layne \\
\hline NRW & 53 & 12.1 & $08-15-68$ & -- & -- & -- & -- & -- & -- & -- & Layne \\
\hline NRW & 54 & 11.4 & $12-11-68$ & -- & -- & -- & -- & -- & -- & -- & Layne \\
\hline NRW & 55 & 10.2 & $05-22-85$ & 54 & 59 & $\mathrm{U}$ & -- & -- & -- & -- & Con-Tec, Inc \\
\hline NRW & 56 & 10.5 & $05-29-85$ & 69 & 73 & $\mathrm{U}$ & -- & -- & -- & -- & Con-Tec, Inc \\
\hline NRW & 57 & 19.8 & $05-30-85$ & 38 & 43 & $\mathrm{U}$ & -- & -- & -- & -- & Con-Tec, Inc \\
\hline NRW & 58 & 28.8 & $06-03-85$ & 82 & 85 & $\mathrm{U}$ & -- & -- & -- & -- & Con-Tec, Inc \\
\hline NRW & 59 & .39 & $07-02-91$ & 57.5 & 80 & $\mathrm{U}$ & -- & -- & -- & -- & USGS \\
\hline NRW & 60 & 5.2 & $07-02-91$ & 20 & 30 & -- & -- & -- & -- & -- & USGS \\
\hline NRW & 61 & 5.47 & $07-02-91$ & 37.5 & 40 & $\mathrm{U}$ & -- & -- & -- & -- & USGS \\
\hline NRW & 62 & 20.8 & $06-13-91$ & -- & -- & U & -- & -- & -- & -- & -- \\
\hline NRW & 89 & -- & -- & -- & -- & $\mathrm{H}$ & -- & -- & -- & -- & NHWRD 382 \\
\hline NRW & 118 & 8.0 & $09-24-87$ & -- & -- & $\mathrm{H}$ & -- & -- & -- & -- & NHWRD 536 \\
\hline NRW & 119 & 6.0 & $11-02-87$ & -- & -- & $\mathbf{H}$ & -- & -- & -- & -- & NHWRD 536 \\
\hline NRW & 142 & -- & -- & -- & -- & $\mathrm{H}$ & 15.0 & -- & -- & .3 & NHWRD 247 \\
\hline NRW & 146 & 25.0 & $06-01-88$ & -- & -- & $\mathrm{H}$ & 2.00 & -- & -- & .5 & NHWRD 382 \\
\hline NRW & 171 & -- & $-\infty$ & -- & -- & $\mathbf{H}$ & -- & -- & -- & -- & NHWRD 239 \\
\hline NRW & 172 & -- & -- & -- & - & H & 20.0 & -- & -- & 1.0 & NHWRD 192 \\
\hline NRW & 174 & -- & -- & -- & -- & $\mathbf{H}$ & 25.0 & -- & -- & .3 & NHWRD 274 \\
\hline NRW & 197 & 16 & $11-30-94$ & 38 & 44 & U & -- & -- & -- & -- & D.L. Maher \\
\hline NRW & 198 & 7.3 & $12-01-94$ & 20 & 26 & $\mathrm{U}$ & -- & -- & -- & -- & D.L.Maher \\
\hline
\end{tabular}


Table A-1. Description of selected wells, borings, and springs in the Winnipesaukee River Basin, central New Hampshire

\begin{tabular}{|c|c|c|c|c|c|c|c|c|c|c|}
\hline $\begin{array}{l}\text { Local } \\
\text { site } \\
\text { number }\end{array}$ & $\begin{array}{l}\text { Lat- } \\
\text { itude }\end{array}$ & $\begin{array}{l}\text { Long- } \\
\text { itude }\end{array}$ & Owner or user & $\begin{array}{c}\text { Date } \\
\text { of } \\
\text { con- } \\
\text { struction }\end{array}$ & $\begin{array}{c}\text { Ele- } \\
\text { vat- } \\
\text { tion } \\
\text { (feet) }\end{array}$ & $\begin{array}{c}\text { Diameter } \\
\text { of } \\
\text { casing } \\
\text { (inches) }\end{array}$ & $\begin{array}{l}\text { Depth to } \\
\text { bottom } \\
\text { of casing } \\
\text { (feet) }\end{array}$ & $\begin{array}{c}\text { Casing } \\
\text { mater- } \\
\text { ial }\end{array}$ & $\begin{array}{c}\text { Type } \\
\text { of } \\
\text { fin- } \\
\text { ish }\end{array}$ & $\begin{array}{c}\text { Type } \\
\text { of } \\
\text { site }\end{array}$ \\
\hline
\end{tabular}

MERRIMACK COUNTY

\begin{tabular}{|c|c|c|c|c|c|c|c|c|c|c|c|}
\hline \multicolumn{12}{|c|}{ Northfield-Continued } \\
\hline NRW & 199 & 432641 & 0713218 & Tilton-Northfield Aqu. & $12-02-94$ & 500 & 2.5 & 61.0 & $s$ & s & Bor \\
\hline NRW & 200 & 432637 & 0713212 & Tilton-Northfield Aqu. & $12-05-94$ & 480 & 2.5 & 68.0 & $\mathrm{~s}$ & $\mathbf{s}$ & Bor \\
\hline NRW & 201 & 432641 & 0713219 & Tilton-Northfield Aqu. & $12-09-94$ & 500 & 2.5 & 62.0 & $s$ & -- & Bor \\
\hline NRW & 202 & 432637 & 0713212 & -- & $12-16-94$ & 480 & -- & -- & -- & $\mathbf{s}$ & Bor \\
\hline NRW & 203 & 432637 & 0713214 & Tilton-Northfield Aqu. & $12-15-94$ & 480 & 2.5 & 61.0 & $s$ & $\mathbf{s}$ & Bor \\
\hline NRW & 204 & 432641 & 0713218 & Tilton-Northfield Aqu. & $01-23-96$ & 500 & -- & -- & -- & $\mathbf{s}$ & Bor \\
\hline NRW & 205 & 432637 & 0713212 & -- & $02-23-96$ & 480 & 1.5 & 54.0 & $s$ & $s$ & Bor \\
\hline
\end{tabular}

\section{STRAFFORD COUNTY}

\begin{tabular}{|c|c|c|c|c|c|c|c|c|c|c|c|}
\hline \multicolumn{12}{|c|}{ Middleton } \\
\hline MLW & 11 & 432955 & 0710636 & Libby, G. & $08-12-85$ & 900 & -- & 20.0 & -- & $\mathrm{x}$ & $\mathrm{BrW}$ \\
\hline \multicolumn{12}{|c|}{ Now Durham } \\
\hline NFA & 1 & 432556 & 0711006 & New Hampshire, state of & $08-15-86$ & 510 & -- & -- & -- & -- & Bor \\
\hline NFA & 2 & 432601 & 0711015 & -- & -- & 520 & -- & -- & - & -- & $\mathrm{TH}$ \\
\hline NFB & 3 & 431001 & 0711014 & -- & -- & 521.5 & -- & -- & -- & -- & TH \\
\hline NFB & 26 & 432601 & 0711014 & -- & -- & 521 & -- & -- & -- & -- & Bor \\
\hline NFB & 27 & 432732 & 0711039 & -- & -- & -- & -- & -- & -- & - & Bor \\
\hline NFW & 1 & 432557 & 0710958 & Larrabee, Erwin $\mathrm{H}$. & $00-00-73$ & 530 & -- & -- & -- & -- & $\mathrm{Cbl}$ \\
\hline NFW & 2 & 432552 & 0710952 & Parsons, Frank & $00-00-80$ & 524 & 36 & 14.0 & $\mathrm{R}$ & -- & - \\
\hline NFW & 3 & 432542 & 0710956 & Swett, Fred & -- & 522 & 36 & 6.5 & $\mathbf{T}$ & -- & Dug \\
\hline NFW & 4 & 432540 & 0710957 & Swett, Fred & -- & 525 & -- & -- & -- & -- & -- \\
\hline NFW & 5 & 432539 & 0710953 & Hersam, Richard & -- & 522 & 30 & 11.4 & $\mathbf{T}$ & -- & Dug \\
\hline NFW & 6 & 432544 & 0710954 & Rollins, Doris & -- & 535 & 36 & 12.2 & $\mathbf{T}$ & -- & Dug \\
\hline NFW & 7 & 432534 & 0710955 & Hockady, Frank & -- & 528 & -- & -- & -- & $\mathbf{T}$ & Dvn \\
\hline NFW & 8 & 432530 & 0710954 & Barnes, Leonard & $00-00-74$ & 517 & 36 & 7.7 & $\mathbf{T}$ & -- & Dug \\
\hline NFW & 16 & 432559 & 0710941 & Hunter, Virginia & -- & 546 & 48 & 11.9 & $\mathbf{R}$ & - & Dug \\
\hline NFW & 19 & 432527 & 0710958 & Clarke, Robert & $00-00-78$ & 540 & -- & -- & -- & -- & Dvn \\
\hline NFW & 21 & 432531 & 0710855 & Coleman, Sandy & $00-00-78$ & 535 & 36 & 5.0 & $\mathbf{T}$ & $\mathbf{T}$ & Dug \\
\hline NFW & 21 & 432531 & 0710855 & new well inside 36 -inch well & -- & & 2 & 15.0 & $\mathbf{s}$ & -- & -- \\
\hline NFW & 27 & 432556 & 0710941 & Gault, John & -- & 545 & -- & -- & -- & $\mathbf{T}$ & Dvn \\
\hline NFW & 28 & 432559 & 0710946 & School, New Durham & $00-00-66$ & 547 & -- & -- & -- & $\mathrm{x}$ & -- \\
\hline NFW & 29 & 432601 & 0710945 & Lapointe, Richard & -- & 546 & 24 & 13.9 & $\mathbf{T}$ & $\mathrm{x}$ & Dug \\
\hline NFW & 30 & 432602 & 0710949 & Dadura, Edward & -- & 547 & 36 & 13.2 & $\mathbf{R}$ & $\mathrm{x}$ & Dug \\
\hline NFW & 53 & 432536 & 0710955 & -- & $08-13-86$ & 545 & -- & -- & -- & $\mathbf{P}$ & Bor \\
\hline NFW & 54 & 432604 & 0710950 & Stuart & $08-14-86$ & 542 & 2 & 18.0 & $\mathbf{P}$ & $\mathbf{P}$ & Bor \\
\hline NFW & 55 & 432551 & 0710959 & New Hampshire, state of & $08-15-86$ & 537 & 2 & 41.0 & $\mathbf{P}$ & $\mathbf{P}$ & -- \\
\hline NFW & 56 & 432546 & 0710951 & New Durham, Town of, & $09-25-86$ & 538 & 2 & 18.0 & $\mathbf{P}$ & $\mathbf{P}$ & Bor \\
\hline NFW & 59 & 432941 & 0710740 & Peterson & $08-08-84$ & 650 & -- & 11.0 & -- & -- & BrW \\
\hline NFW & 61 & 432943 & 0710740 & Morine, $\mathrm{R}$ & $12-10-84$ & 650 & -- & 19.0 & -- & -- & $\mathrm{BrW}$ \\
\hline NFW & 62 & 432724 & 0711007 & Arsenault, B. & $09-19-84$ & 640 & -- & 100 & -- & -- & $\mathrm{BrW}$ \\
\hline NFW & 63 & 432453 & 0710953 & Ellison, S. & $04-11-84$ & 660 & -- & 47.0 & -- & $\mathrm{x}$ & $\mathrm{BrW}$ \\
\hline NFW & 67 & 432854 & 0710935 & Silva, w. & $09-25-85$ & 700 & -- & 82.0 & -- & -- & BrW \\
\hline NFW & 69 & 432458 & 0710954 & Crothers, $\mathrm{M}$. & $09-17-85$ & 660 & -- & 49.0 & -- & -- & BrW \\
\hline NFW & 71 & 432746 & 0711023 & Parsons, F. & $11-05-85$ & 660 & -- & 25.0 & -- & -- & BrW \\
\hline NFW & 72 & 433023 & 0710706 & crosby, c. & $11-08-85$ & 860 & -- & 62.0 & - & -- & Brw \\
\hline NFW & 76 & 432956 & 0710910 & Deorio, W. & $11-19-85$ & 640 & -- & 25.0 & -- & -- & BrW \\
\hline NFW & 77 & 432626 & 0711025 & Mohr, D. & $04-21-86$ & 540 & -- & 20.0 & -- & -- & BrW \\
\hline NFW & 80 & 432612 & 0710952 & Cornellisen, R. & $03-28-86$ & 540 & -- & 39.0 & -- & -- & $\mathrm{BrW}$ \\
\hline NFW & 81 & 432616 & 0710947 & Heoer, S. & $03-28-86$ & 540 & -- & 32.0 & -- & -- & $\mathrm{BrW}$ \\
\hline NFW & 86 & 432615 & 0711010 & Bickford, David & $--\quad-90$ & 545 & -- & -- & -- & $w$ & Dug \\
\hline NFW & 87 & 432603 & 0710953 & US Post office, New Durham & -- & 545 & -- & -- & -- & w & Dug \\
\hline
\end{tabular}




\begin{tabular}{|c|c|c|c|c|c|c|c|c|c|c|}
\hline $\begin{array}{l}\text { Local } \\
\text { site } \\
\text { number }\end{array}$ & $\begin{array}{l}\text { Depth } \\
\text { (feet) }\end{array}$ & $\begin{array}{c}\text { Date } \\
\text { (mm-dd-yy) }\end{array}$ & $\begin{array}{l}\text { Top of } \\
\text { screen } \\
\text { (feet) }\end{array}$ & $\begin{array}{c}\text { Bottom of } \\
\text { screen } \\
\text { (feet) }\end{array}$ & $\begin{array}{c}\text { Use } \\
\text { of } \\
\text { water }\end{array}$ & $\begin{array}{c}\text { Yield } \\
\text { (gal/min) }\end{array}$ & $\begin{array}{l}\text { Drawdown } \\
\text { (feet) }\end{array}$ & $\begin{array}{l}\text { Specific } \\
\text { capacity }\end{array}$ & $\begin{array}{l}\text { Pumping } \\
\text { period } \\
\text { (hours) }\end{array}$ & $\begin{array}{l}\text { Driller } \\
\text { or NHWRD } \\
\text { number }\end{array}$ \\
\hline
\end{tabular}

\section{MERRIMACK COUNTY}

\begin{tabular}{|c|c|c|c|c|c|c|c|c|c|c|c|}
\hline \multicolumn{12}{|c|}{ Northeleld-Continued } \\
\hline NRW & 199 & 2.0 & $12-02-94$ & 61 & 67 & $\mathrm{U}$ & -- & -- & -- & -- & D.L. Maher \\
\hline NRW & 200 & 6.9 & $12-05-94$ & 70 & 76 & $\mathrm{U}$ & -- & -- & -- & -- & D.L. Maher \\
\hline NRW & 201 & 11 & $12-09-94$ & 60 & 69 & $\mathrm{U}$ & 70 & 1.44 & 49 & 2 & D.L. Maher \\
\hline NRW & 202 & 4.6 & $12-16-94$ & 62 & 68 & $\mathrm{U}$ & 75 & .93 & 81 & 3 & D.L. Maher \\
\hline NRW & 203 & 10.2 & $12-15-94$ & 61 & 67 & $\mathrm{U}$ & 65 & 2.0 & 32.5 & 2 & D.L. Maher \\
\hline NRW & 204 & 7.31 & $01-23-96$ & 52 & 69 & $\mathbf{P}$ & 800 & 16.4 & 48.8 & -- & D.L. Maher \\
\hline NRW & 205 & 13.4 & $02-23-96$ & 54 & 69 & $\mathbf{P}$ & 500 & 18.6 & 26.8 & -- & D.L. Maher \\
\hline
\end{tabular}

STRAFFORD COUNTY

\begin{tabular}{|c|c|c|c|c|c|c|c|c|c|c|c|}
\hline \multicolumn{12}{|c|}{ xiddieton } \\
\hline MLW & 11 & -- & -- & $\cdots$ & -- & $\mathrm{H}$ & 10.0 & -- & -- & - & $\# 177$ \\
\hline \multicolumn{12}{|c|}{ Now Durham } \\
\hline NFA & 1 & -- & -- & -- & -- & $\mathrm{U}$ & -- & -- & -- & -- & USGS \\
\hline NFA & 2 & -- & -- & -- & -- & $\mathrm{U}$ & -- & -- & -- & -- & -- \\
\hline NFB & 3 & -- & -- & - & -- & $\mathrm{U}$ & -- & -- & $\cdots$ & -- & -- \\
\hline NFB & 26 & -- & -- & -- & -- & -- & -- & -- & -- & -- & NHDOT \\
\hline NFB & 27 & -- & -- & -- & -- & -- & -- & -- & -- & -- & NHDOT \\
\hline NFW & 1 & 15 & $00-00-73$ & -- & -- & $\mathrm{H}$ & 40 & -- & -- & -- & Bob Carr \\
\hline NFW & 2 & 11.6 & $12-30-80$ & -- & -- & H & -- & -- & -- & -- & -- \\
\hline NFW & 3 & 2.9 & $12-30-80$ & -- & -- & $\mathrm{H}$ & -- & -- & -- & -- & -- \\
\hline NFW & 4 & 12.8 & $12-30-80$ & -- & -- & $\mathrm{U}$ & -- & -- & -- & -- & -- \\
\hline NFW & 5 & 8.05 & $12-30-80$ & -- & -- & $\mathrm{H}$ & -- & -- & -- & -- & -- \\
\hline NFW & 6 & 7.75 & $12-30-80$ & -- & -- & $\mathrm{H}$ & - & -- & -- & -- & -- \\
\hline NFW & 7 & -- & -- & -- & -- & $\mathrm{H}$ & -- & -- & -- & -- & -- \\
\hline NFW & 8 & 5.2 & $01-02-81$ & $\cdots$ & -- & $\mathrm{H}$ & -- & -- & -- & -- & W Hayes \\
\hline NFW & 16 & 10.1 & $01-07-81$ & -- & -- & $\mathrm{H}$ & -- & -- & -- & -- & -- \\
\hline NFW & 19 & -- & -- & -- & -- & $\mathrm{H}$ & -- & -- & -- & -- & Smith \\
\hline NFW & 21 & -- & -- & 12 & 15 & $\mathrm{H}$ & -- & -- & -- & -- & Owner's Roomate \\
\hline NFW & 21 & -- & - & - & -- & & -- & -- & -- & -- & -- \\
\hline NFW & 27 & -- & -- & -- & -- & $\mathrm{H}$ & -- & - & -- & -- & -- \\
\hline NFW & 28 & -- & -- & -- & -- & $\mathrm{H}$ & -- & -- & -- & -- & Bob Carr \\
\hline NFW & 29 & 10.5 & $01-07-81$ & -- & -- & $\mathrm{H}$ & -- & -- & -- & -- & -- \\
\hline NFW & 30 & 10.5 & $01-07-81$ & -- & -- & $\mathrm{H}$ & -- & -- & -- & -- & -- \\
\hline NFW & 53 & 19.7 & $12-02-86$ & 57.5 & 60.0 & $\mathrm{U}$ & -- & -- & -- & -- & USGS \\
\hline NFW & 54 & 7.95 & $12-02-86$ & 18 & 23 & $\mathrm{U}$ & -- & -- & -- & -- & USGS \\
\hline NFW & 55 & 10.4 & $12-02-86$ & 41 & 46 & $\mathrm{U}$ & -- & -- & -- & -- & USGS \\
\hline NFW & 56 & 10.5 & $12-02-86$ & 18 & 23 & $\mathrm{U}$ & -- & -- & -- & -- & USGS \\
\hline NFW & 59 & - & -- & -- & -- & $\mathrm{H}$ & -- & -- & -- & -- & NHWRD 406 \\
\hline NFW & 61 & 30 & $12-12-84$ & -- & -- & $\mathrm{H}$ & 30.0 & -- & -- & 1.0 & NHWRD 90 \\
\hline NFW & 62 & 45 & $09-19-84$ & -- & -- & $\mathbf{H}$ & 15.0 & -- & -- & .5 & NHWRD 22 \\
\hline NFW & 63 & -- & -- & -- & -- & $\mathbf{H}$ & 15.0 & -- & -- & .5 & NHWRD 3 \\
\hline NFW & 67 & -- & -- & -- & -- & H & 3.0 & -- & -- & 2.0 & NHWRD 406 \\
\hline NFW & 69 & -- & -- & -- & -- & $\mathrm{H}$ & 4.00 & -- & -- & -- & NHWRD 177 \\
\hline NFW & 71 & 15 & $11-05-85$ & -- & -- & $\mathrm{H}$ & 4.00 & -- & -- & 1.0 & NHWRD 158 \\
\hline NFW & 72 & -- & - & -- & - & $\mathrm{H}$ & 7.50 & -- & -- & 1.2 & NHWRD 406 \\
\hline NFW & 76 & -- & -- & -- & -- & $\mathrm{H}$ & 10.0 & -- & -- & -- & NHWRD 177 \\
\hline NFW & 77 & -- & -- & -- & - & $\mathrm{H}$ & 3.00 & -- & -- & .7 & NHWRD 406 \\
\hline NFW & 80 & -- & -- & -- & -- & $\mathrm{H}$ & 3.00 & -- & -- & .5 & NHWRD 319 \\
\hline NFW & 81 & 20 & -- & -- & $\cdots$ & $\mathrm{H}$ & 11.0 & -- & -- & 2.0 & NHWRD 158 \\
\hline NFW & 86 & 15.4 & $06-17-91$ & -- & -- & $\mathrm{H}$ & -- & -- & -- & -- & -- \\
\hline NFW & 87 & 6.27 & $06-17-91$ & -- & -- & $\mathrm{H}$ & -- & -- & -- & -- & -- \\
\hline
\end{tabular}

Appendix A 91 


\section{APPENDIX B. Stratigraphic logs of selected wells and borings in the Winnipesaukee River Basin, central New Hampshire}


Table B-1. Stratigraphic Logs of Selected Wells and Borings in the Winnipesaukee River Basin, central New Hampshire

Local Site Number: First two characters are U.S. Geological Survey town code. Third-character codes are the following: A, auger hole; B, highway bridge boring; $\mathbf{W}$, well. The numbers are sequential numbers for each town.

Depth of well: Depth of well, in feet below land-surface datum.

Depth to refusal: Depth to refusal on bedrock, in till, or on large boulders.

Depth to top: Depth to top of unit, in feet below land-surface datum.

Primary aquifer code: Primary aquifer code of well or boring; codes for geologic ages and materials are listed below.

$\begin{array}{ll}\text { 110SDMN } & \text { Quaternary sediment, undifferentiated } \\ \text { 111ALVM } & \text { Holocene alluvium } \\ \text { 111SWMP } & \text { Holocene swamp deposits } \\ \text { 111FILL } & \text { Holocene fill (artificial fill) } \\ \text { 112OTSH } & \text { Pleistocene outwash } \\ \text { 112LCSR } & \text { Pleistocene lacustrine deposits } \\ \text { 112SRFD } & \text { Pleistocene stratified drift } \\ 112 \text { TILL } & \text { Pleistocene till } \\ \text { BEDROCK } & \text { bedrock }\end{array}$


Table B-1. Stratigraphic logs of selected wells and borings in the Winnipesaukee River Basin, central New Hampshire

\begin{tabular}{|c|c|c|c|c|c|c|}
\hline $\begin{array}{l}\text { Local } \\
\text { site } \\
\text { number }\end{array}$ & $\begin{array}{l}\text { Depth } \\
\text { drilled } \\
\text { (feet) }\end{array}$ & $\begin{array}{c}\text { Depth } \\
\text { of } \\
\text { well } \\
\text { (feet) }\end{array}$ & $\begin{array}{l}\text { Depth } \\
\text { to } \\
\text { refusal } \\
\text { (feet) }\end{array}$ & $\begin{array}{l}\text { Depth } \\
\text { to } \\
\text { top } \\
\text { (feet) }\end{array}$ & $\begin{array}{l}\text { Aquifer } \\
\text { code }\end{array}$ & $\begin{array}{c}\text { Lithologic description } \\
\text { of } \\
\text { material }\end{array}$ \\
\hline
\end{tabular}

\section{BELKNAP COUNTY}

\begin{tabular}{|c|c|c|c|c|c|c|c|c|}
\hline \multirow[b]{2}{*}{ AHA } & \multirow[b]{2}{*}{52} & \multirow[b]{2}{*}{10.0} & \multirow[b]{2}{*}{--} & \multicolumn{5}{|c|}{ alton } \\
\hline & & & & -- & $\begin{array}{l}0 \\
10.0\end{array}$ & $\begin{array}{l}112 \text { SRFD } \\
112 \text { SRFD }\end{array}$ & $\begin{array}{l}\text { SAND } \\
\text { SAND }\end{array}$ & $\begin{array}{l}\text { Sand, fine } \\
\text { End of hole }\end{array}$ \\
\hline AHA & 53 & 25.0 & -- & -- & $\begin{array}{c}0 \\
25.0\end{array}$ & $\begin{array}{l}112 \text { SRFD } \\
112 \text { SRFD }\end{array}$ & $\begin{array}{l}\text { SAND } \\
\text { SAND }\end{array}$ & $\begin{array}{l}\text { Sand, fine } \\
\text { End of hole }\end{array}$ \\
\hline AHA & 54 & 14.0 & -- & -- & $\begin{array}{r}0 \\
2.0 \\
14.0\end{array}$ & $\begin{array}{l}112 \text { SRFD } \\
112 S R F D \\
112 S R F D\end{array}$ & $\begin{array}{l}\text { GRVL } \\
\text { SAND } \\
\text { SAND }\end{array}$ & $\begin{array}{l}\text { Gravel } \\
\text { Sand, fine } \\
\text { End of hole }\end{array}$ \\
\hline AHA & 55 & 10.0 & -- & $\sim$ & $\begin{array}{r}0 \\
2.0 \\
10.0\end{array}$ & $\begin{array}{l}112 \text { SRFD } \\
112 \text { SRFD } \\
112 \text { SRFD }\end{array}$ & $\begin{array}{l}\text { GRVL } \\
\text { SAND } \\
\text { SAND }\end{array}$ & $\begin{array}{l}\text { Gravel } \\
\text { Sand, medium to coarse } \\
\text { End of hole }\end{array}$ \\
\hline AHA & 56 & 10.0 & -- & -- & $\begin{array}{r}0 \\
5.0 \\
10.0\end{array}$ & $\begin{array}{l}112 \text { SRFD } \\
112 \text { SRFD } \\
112 \text { SRFD }\end{array}$ & $\begin{array}{l}\text { GRVL } \\
\text { SAND } \\
\text { SAND }\end{array}$ & $\begin{array}{l}\text { Gravel } \\
\text { Sand, fine } \\
\text { End of hole }\end{array}$ \\
\hline AHA & 57 & 10.0 & -- & -- & $\begin{array}{l}0 \\
10.0\end{array}$ & $\begin{array}{l}112 \text { SRFD } \\
112 \text { SRFD }\end{array}$ & $\begin{array}{l}\text { SAND } \\
\text { SAND }\end{array}$ & $\begin{array}{l}\text { Sand, medium } \\
\text { End of hole }\end{array}$ \\
\hline AHA & 58 & 14.0 & -- & -- & $\begin{array}{r}0 \\
5.0 \\
14.0\end{array}$ & $\begin{array}{l}112 \text { SRFD } \\
112 \text { SRFD } \\
112 \text { SRFD }\end{array}$ & $\begin{array}{l}\text { GRVL } \\
\text { SAND } \\
\text { SAND }\end{array}$ & $\begin{array}{l}\text { Gravel } \\
\text { Sand, fine } \\
\text { End of hole }\end{array}$ \\
\hline AHA & 59 & 10.0 & -- & -- & $\begin{array}{r}0 \\
4.0 \\
10.0\end{array}$ & $\begin{array}{l}112 \text { SRFD } \\
112 \text { SRFD } \\
112 \text { SRFD }\end{array}$ & $\begin{array}{l}\text { SDGL } \\
\text { SAND } \\
\text { SAND }\end{array}$ & $\begin{array}{l}\text { Gravel } \\
\text { Sand, fine } \\
\text { End of hole }\end{array}$ \\
\hline $\mathrm{AHA}$ & 60 & 10.0 & -- & -- & $\begin{array}{r}0 \\
4.0 \\
8.0 \\
10.0\end{array}$ & $\begin{array}{l}112 \text { SRFD } \\
112 \text { SRFD } \\
112 \text { SRFD } \\
112 \text { SRFD }\end{array}$ & $\begin{array}{l}\text { SDGL } \\
\text { GRVL } \\
\text { SAND } \\
\text { SAND }\end{array}$ & $\begin{array}{l}\text { Sand and gravel } \\
\text { Gravel } \\
\text { Sand, medium, wet } \\
\text { End of hole }\end{array}$ \\
\hline $\mathrm{AHA}$ & 61 & 10.0 & -- & -- & $\begin{array}{r}0 \\
4.0 \\
10.0\end{array}$ & $\begin{array}{l}112 \text { SRFD } \\
112 \text { SRFD } \\
112 \text { SRFD }\end{array}$ & $\begin{array}{l}\text { SDGL } \\
\text { SAND } \\
\text { SAND }\end{array}$ & $\begin{array}{l}\text { Sand and gravel } \\
\text { Sand, fine } \\
\text { End of hole }\end{array}$ \\
\hline AHA & 62 & 10.0 & -- & -- & $\begin{array}{r}0 \\
5.0 \\
10.0\end{array}$ & $\begin{array}{l}112 \text { SRFD } \\
112 \text { SRFD } \\
112 \text { SRFD }\end{array}$ & $\begin{array}{l}\text { GRVL } \\
\text { SAND } \\
\text { SAND }\end{array}$ & $\begin{array}{l}\text { Gravel } \\
\text { Sand, fine } \\
\text { End of hole }\end{array}$ \\
\hline AHA & 63 & 20.0 & -- & -- & $\begin{array}{r}0 \\
4.0 \\
10.0 \\
20.0\end{array}$ & $\begin{array}{l}112 \text { SRFD } \\
112 \text { SRFD } \\
112 \text { SRFD } \\
112 \text { SRFD }\end{array}$ & $\begin{array}{l}\text { SAND } \\
\text { SDGL } \\
\text { SAND } \\
\text { SAND }\end{array}$ & $\begin{array}{l}\text { Sand, coarse } \\
\text { Gravel } \\
\text { Sand, fine } \\
\text { End of hole }\end{array}$ \\
\hline AHA & 64 & 7.0 & -- & -- & $\begin{array}{l}0 \\
7.0\end{array}$ & $\begin{array}{l}\text { 112TILL } \\
\text { BEDROCK }\end{array}$ & $\begin{array}{l}\text { TILL } \\
\text { ROCK }\end{array}$ & $\begin{array}{l}\text { Till, gravelly } \\
\text { Bedrock }\end{array}$ \\
\hline AHA & 65 & 6.0 & -- & -- & $\begin{array}{l}0 \\
6.0\end{array}$ & $\begin{array}{l}\text { 112TILL } \\
\text { BEDROCK }\end{array}$ & $\begin{array}{l}\text { TILL } \\
\text { ROCK }\end{array}$ & $\begin{array}{l}\text { Till } \\
\text { Bedrock }\end{array}$ \\
\hline AHA & 66 & 4.0 & -- & -- & $\begin{array}{l}0 \\
4.0\end{array}$ & $\begin{array}{l}\text { 112TILL } \\
\text { BEDROCK }\end{array}$ & $\begin{array}{l}\text { TILL } \\
\text { ROCK }\end{array}$ & $\begin{array}{l}\text { Till, gravelly } \\
\text { Bedrock }\end{array}$ \\
\hline
\end{tabular}


Table B-1. Stratigraphic logs of selected wells and borings in the Winnipesaukee River Basin, central New Hampshire-Continued

\begin{tabular}{|c|c|c|c|c|c|c|}
\hline $\begin{array}{l}\text { Local } \\
\text { site } \\
\text { number }\end{array}$ & $\begin{array}{l}\text { Depth } \\
\text { drilled } \\
\text { (feet) }\end{array}$ & $\begin{array}{l}\text { Depth } \\
\text { of } \\
\text { well } \\
\text { (feet) }\end{array}$ & $\begin{array}{l}\text { Depth } \\
\text { to } \\
\text { refusal } \\
\text { (feet) }\end{array}$ & $\begin{array}{l}\text { Depth } \\
\text { to } \\
\text { top } \\
\text { (feet) }\end{array}$ & $\begin{array}{l}\text { Aquifer } \\
\text { code }\end{array}$ & $\begin{array}{c}\text { Lithologic description } \\
\text { of } \\
\text { material }\end{array}$ \\
\hline
\end{tabular}

\section{BELKNAP COUNTY}

\begin{tabular}{|c|c|c|c|c|c|c|c|}
\hline \multicolumn{8}{|c|}{ Mlton-Continued } \\
\hline AHA & 67 & 10.0 & -- & -- & $\begin{array}{l}0 \\
10.0\end{array}$ & $\begin{array}{l}\text { 112SRFD } \\
112 \text { SRFD }\end{array}$ & $\begin{array}{l}\text { SDGL Sand, gravelly } \\
\text { SDGL End of hole }\end{array}$ \\
\hline AHA & 68 & 10.0 & -- & -- & $\begin{array}{l}0 \\
10.0\end{array}$ & $\begin{array}{l}\text { 112SRFD } \\
112 \text { SRFD }\end{array}$ & $\begin{array}{l}\text { SAND Sand, fine } \\
\text { SAND End of hole }\end{array}$ \\
\hline AHA & 69 & 10.0 & -- & -- & $\begin{array}{l}0 \\
10.0\end{array}$ & $\begin{array}{l}\text { 112SRFD } \\
112 \text { SRFD }\end{array}$ & $\begin{array}{l}\text { SDGL Sand, gravelly } \\
\text { SDGL End of hole }\end{array}$ \\
\hline $\mathrm{AHA}$ & 71 & 8.0 & -- & -- & $\begin{array}{l}0 \\
2.0 \\
8.0\end{array}$ & $\begin{array}{l}\text { 112SRFD } \\
\text { 112SRFD } \\
\text { BEDROCK }\end{array}$ & $\begin{array}{l}\text { GRVL Gravel } \\
\text { SAND Sand, fine } \\
\text { ROCK Bedrock }\end{array}$ \\
\hline AHA & 72 & 15.0 & -- & -- & $\begin{array}{c}0 \\
3.0 \\
12.0 \\
15.0\end{array}$ & $\begin{array}{l}\text { 112SRFD } \\
112 \text { SRFD } \\
112 \text { TILL } \\
\text { BEDROCK }\end{array}$ & $\begin{array}{l}\text { GRVL Gravel } \\
\text { SAND Sand, fine } \\
\text { TILL Till, sandy } \\
\text { ROCK Bedrock }\end{array}$ \\
\hline AHA & 73 & 20.0 & -- & $\cdots$ & $\begin{array}{c}0 \\
20.0\end{array}$ & $\begin{array}{l}\text { 112SRFD } \\
112 \text { SRFD }\end{array}$ & $\begin{array}{l}\text { SAND Sand, fine } \\
\text { SAND End of hole }\end{array}$ \\
\hline AHA & 74 & 11.0 & -- & -- & $\begin{array}{r}0 \\
3.0 \\
7.0 \\
11.0\end{array}$ & $\begin{array}{l}\text { 112SRFD } \\
112 \text { SRFD } \\
\text { 112TILL } \\
\text { BEDROCK }\end{array}$ & $\begin{array}{l}\text { GRVL Gravel } \\
\text { SAND Sand, fine } \\
\text { TILL Till } \\
\text { ROCK Bedrock }\end{array}$ \\
\hline AHA & 75 & 10.0 & - & -- & $\begin{array}{r}0 \\
6.0 \\
10.0\end{array}$ & $\begin{array}{l}111 \text { FILL } \\
112 \text { SRFD } \\
112 \text { SRFD }\end{array}$ & $\begin{array}{l}\text { GRVL Fill, gravel } \\
\text { SAND Sand, fine } \\
\text { SAND End of hole }\end{array}$ \\
\hline AHA & 76 & 5.0 & -- & -- & $\begin{array}{l}0 \\
5.0\end{array}$ & $\begin{array}{l}112 \text { TILL } \\
\text { BEDROCK }\end{array}$ & $\begin{array}{l}\text { TILL Till, gravelly } \\
\text { ROCK Bedrock }\end{array}$ \\
\hline AHA & 77 & 30.0 & - & -- & $\begin{array}{l}0 \\
30.0\end{array}$ & $\begin{array}{l}\text { 112SRFD } \\
112 \text { SRFD }\end{array}$ & $\begin{array}{l}\text { SAND Sand, fine } \\
\text { SAND End of hole }\end{array}$ \\
\hline AHA & 78 & 24.0 & -- & 24.0 & $\begin{array}{c}0 \\
10.0 \\
24.0\end{array}$ & $\begin{array}{l}110 \text { SDMN } \\
110 \text { SDMN } \\
\text { BEDROCK }\end{array}$ & $\begin{array}{l}\text { SAND Sand, medium } \\
\text { SAND Sand, medium to fine } \\
\text { ROCK Refusal ( } 3 \text { times, probably rock) }\end{array}$ \\
\hline AHA & 79 & 52.0 & -- & 52.0 & $\begin{array}{c}0 \\
45.0 \\
50.0 \\
52.0\end{array}$ & $\begin{array}{l}110 \text { SDMN } \\
110 \text { SDMN } \\
112 \text { TILL } \\
112 \text { TILL }\end{array}$ & $\begin{array}{l}\text { SDST Sand, very fine, some silt } \\
\text { CLSD Clay, varved; thin medium sand layer } \\
\text { TILL Till } \\
\text { TILL Refusal; till or rock }\end{array}$ \\
\hline AHA & 80 & 15.0 & -- & 15.0 & $\begin{array}{c}0 \\
15.0\end{array}$ & $\begin{array}{l}110 \text { SDMN } \\
110 \text { SDMN }\end{array}$ & $\begin{array}{l}\text { SDGL Sand, very coarse, with pebbles and cobbles } \\
\text { ROCK End of hole; refusal; boulders }\end{array}$ \\
\hline AHA & 81 & 45.0 & -- & 45.0 & $\begin{array}{l}0 \\
19.0 \\
24.0 \\
34.0 \\
45.0\end{array}$ & $\begin{array}{l}110 \text { SDMN } \\
110 \text { SDMN } \\
110 \text { SDMN } \\
112 \text { TILL } \\
112 \text { TILL }\end{array}$ & $\begin{array}{l}\text { SAND Sand, medium to coarse, well sorted; some fine } \\
\text { with coarse layers } \\
\text { SDGL Sand, coarse to very coarse and gravel, fine to } \\
\text { coarse; well sorted } \\
\text { SAND Sand, medium, with coarse and fine } \\
\text { sand layers; iron stained } \\
\text { TILL Till with rock } \\
\text { TILL Refusal; rock/till }\end{array}$ \\
\hline
\end{tabular}


Table B-1. Stratigraphic logs of selected wells and borings in the Winnipesaukee River Basin, central New Hampshire-Continued

\begin{tabular}{|c|c|c|c|c|c|c|}
\hline $\begin{array}{l}\text { Local } \\
\text { site } \\
\text { number }\end{array}$ & $\begin{array}{l}\text { Depth } \\
\text { drilled } \\
\text { (feet) }\end{array}$ & $\begin{array}{c}\text { Depth } \\
\text { of } \\
\text { well } \\
\text { (feet) }\end{array}$ & $\begin{array}{l}\text { Depth } \\
\text { to } \\
\text { refusal } \\
\text { (feet) }\end{array}$ & $\begin{array}{l}\text { Depth } \\
\text { to } \\
\text { top } \\
\text { (feet) }\end{array}$ & $\begin{array}{l}\text { Aquifer } \\
\text { code }\end{array}$ & $\begin{array}{c}\text { Lithologic description } \\
\text { of } \\
\text { materlal }\end{array}$ \\
\hline
\end{tabular}

BELKNAP COUNTY

\begin{tabular}{|c|c|c|c|c|c|c|c|}
\hline & & & \multicolumn{5}{|c|}{ alton-Continued } \\
\hline AHB & 1 & 18.0 & -- & -- & $\begin{array}{r}0 \\
1.0 \\
4.0 \\
14.0 \\
18.0\end{array}$ & $\begin{array}{l}110 \text { SOIL } \\
110 \text { SDMN } \\
110 \text { SDMN } \\
112 \text { TILL } \\
112 \text { TILL }\end{array}$ & $\begin{array}{l}\text { SOIL Topsoil } \\
\text { SAND Sand, fine } \\
\text { SDGL Gravel, sandy } \\
\text { TILL Till, silty } \\
\text { TILL End of hole }\end{array}$ \\
\hline AHB & 2 & 55.0 &,-- & -- & $\begin{array}{l}0 \\
15.0 \\
27.0 \\
38.0 \\
52.0 \\
55.0\end{array}$ & $\begin{array}{l}110 \text { SDMN } \\
110 \text { SDMN } \\
110 \text { SDMN } \\
110 \text { SDMN } \\
110 \text { SDMN } \\
110 \text { SDMN }\end{array}$ & $\begin{array}{l}\text { SAND Sand, coarse } \\
\text { SAND Sand, coarse } \\
\text { SDGL Gravel and sand, coarse } \\
\text { SAND Sand, coarse } \\
\text { SDGL Gravel and sand, coarse } \\
\text { SAND End of hole at } 55 \text { feet }\end{array}$ \\
\hline AHB & 3 & 26.0 & -- & 26.0 & $\begin{array}{r}0 \\
7.5 \\
17.5\end{array}$ & $\begin{array}{l}111 \text { SWMP } \\
112 \text { SRFD } \\
112 \text { TILL }\end{array}$ & $\begin{array}{l}\text { MUCK Muck } \\
\text { SAND } \\
\text { TILL Till, sandy; refusal at } 26 \text { feet }\end{array}$ \\
\hline AHW & 3 & 36.0 & 36.0 & -- & $\begin{array}{l}0 \\
18.0 \\
27.0 \\
36.0\end{array}$ & $\begin{array}{l}110 \text { SDMN } \\
110 \text { SDMN } \\
110 \text { SDMN } \\
400 \text { CRSL }\end{array}$ & $\begin{array}{l}\text { GRVL Gravel } \\
\text { SDCL Sand, fine, and clay } \\
\text { GRVL Gravel } \\
\text { ROCK Refusal, ledge; End of hole }\end{array}$ \\
\hline AHW & 4 & -- & 31.0 & -- & $\begin{array}{r}0 \\
6.0 \\
20.0 \\
26.0 \\
32.0\end{array}$ & $\begin{array}{l}110 \text { SDMN } \\
110 \text { SDMN } \\
110 \text { SDMN } \\
110 \text { SDMN } \\
110 \text { SDMN }\end{array}$ & $\begin{array}{l}\text { SDCL Sand, brown, fine; and clay } \\
\text { SDGL Sand, fine; some gravel } \\
\text { SDGL Sand, fine to medium; and gravel } \\
\text { BLSD Sand, brown; tight, boulders } \\
\text { End of hole }\end{array}$ \\
\hline AHW & 51 & 8.0 & 8.0 & -- & $\begin{array}{r}0 \\
8.0 \\
10.0\end{array}$ & $\begin{array}{l}112 T I L L \\
112 T I L L \\
112 \text { SRFD }\end{array}$ & $\begin{array}{l}\text { TILL Till, boulders } \\
\text { TILL End of hole } \\
\text { SAND End of hole }\end{array}$ \\
\hline AHW & 52 & 8.0 & 8.0 & -- & $\begin{array}{l}0 \\
8.0\end{array}$ & $\begin{array}{l}\text { 112SRFD } \\
112 \text { SRFD }\end{array}$ & $\begin{array}{l}\text { SAND Sand, gravelly } \\
\text { SAND End of hole }\end{array}$ \\
\hline AHW & 54 & 8.0 & 8.0 & -- & $\begin{array}{l}0 \\
3.0 \\
8.0\end{array}$ & $\begin{array}{l}112 \text { SRFD } \\
112 \text { SRFD } \\
112 \text { SRFD }\end{array}$ & $\begin{array}{l}\text { SDGL Sand and gravel } \\
\text { SDST Sand and silt } \\
\text { SDST End of hole }\end{array}$ \\
\hline AHW & 55 & 8.0 & 8.0 & -- & $\begin{array}{l}0 \\
4.0 \\
8.0\end{array}$ & $\begin{array}{l}112 \text { SRFD } \\
112 \text { SRFD } \\
112 \text { SRFD }\end{array}$ & $\begin{array}{l}\text { SDGL Sand and gravel } \\
\text { SDST Sand and silt } \\
\text { SDST End of hole }\end{array}$ \\
\hline AHW & 56 & 8.0 & 8.0 & -- & $\begin{array}{l}0 \\
8.0\end{array}$ & $\begin{array}{l}\text { 112SRFD } \\
112 \text { SRFD }\end{array}$ & $\begin{array}{l}\text { SDGL Sand and gravel } \\
\text { SDGL End of hole }\end{array}$ \\
\hline AHW & 57 & 7.0 & 7.0 & -- & $\begin{array}{l}0 \\
7.0\end{array}$ & $\begin{array}{l}\text { 112SRFD } \\
\text { BEDROCK }\end{array}$ & $\begin{array}{l}\text { SAND Sand and boulders } \\
\text { ROCK Bedrock }\end{array}$ \\
\hline AHW & 59 & 8.0 & 8.0 & -- & $\begin{array}{l}0 \\
8.0\end{array}$ & $\begin{array}{l}\text { 112SRFD } \\
112 \text { SRFD }\end{array}$ & $\begin{array}{l}\text { SDGL Sand and gravel } \\
\text { SDGL End of hole }\end{array}$ \\
\hline AHW & 60 & 6.0 & 6.0 & -- & $\begin{array}{l}0 \\
6.0\end{array}$ & $\begin{array}{l}112 \text { TILL } \\
\text { BEDROCK }\end{array}$ & $\begin{array}{l}\text { TILL Till, silty } \\
\text { ROCK Bedrock }\end{array}$ \\
\hline AHW & 61 & 4.0 & 4.0 & -- & $\begin{array}{l}0 \\
4.0\end{array}$ & $\begin{array}{l}\text { 112TILL } \\
\text { BEDROCK }\end{array}$ & $\begin{array}{l}\text { TILL Till, sandy } \\
\text { ROCK Bedrock }\end{array}$ \\
\hline
\end{tabular}


Table B-1. Stratigraphic logs of selected wells and borings in the Winnipesaukee River Basin, central New Hampshire-Continued

\begin{tabular}{cccccccc}
\hline $\begin{array}{c}\text { Local } \\
\text { site }\end{array}$ & $\begin{array}{c}\text { Depth } \\
\text { drilled } \\
\text { number }\end{array}$ & $\begin{array}{c}\text { Depth } \\
\text { of }\end{array}$ & $\begin{array}{c}\text { Depth } \\
\text { well } \\
\text { (feet) }\end{array}$ & $\begin{array}{c}\text { Depth } \\
\text { refusal } \\
\text { (feet) }\end{array}$ & $\begin{array}{c}\text { to } \\
\text { top }\end{array}$ & $\begin{array}{c}\text { Aquifer } \\
\text { (feet) }\end{array}$ & $\begin{array}{c}\text { code } \\
\text { Lithologic description } \\
\text { of } \\
\text { material }\end{array}$ \\
\hline
\end{tabular}

\section{BELKNAP COUNTY}

\begin{tabular}{|c|c|c|c|c|c|c|c|}
\hline \multicolumn{8}{|c|}{ alton-Continued } \\
\hline AHW & 63 & 41.5 & 20.5 & 41.5 & $\begin{array}{l}0 \\
10.0 \\
35.0 \\
41.5\end{array}$ & $\begin{array}{l}112 \text { SRFD } \\
112 \text { SRFD } \\
112 \text { TILL } \\
\text { BEDROCK }\end{array}$ & $\begin{array}{l}\text { SAND Sand, fine to medium } \\
\text { SDGL Sand, very coarse to fine gravel } \\
\text { TILL Till } \\
\text { ROCK Bedrock }\end{array}$ \\
\hline AHW & 64 & 45.0 & 39.0 & 45.0 & $\begin{array}{l}0 \\
43.0 \\
45.0\end{array}$ & $\begin{array}{l}112 \text { SRFD } \\
112 \text { TILL } \\
\text { BEDROCK }\end{array}$ & $\begin{array}{l}\text { SDGL Sand, coarse, variable coarse and finer layers } \\
\text { TILL Till } \\
\text { ROCK Refusal; bedrock }\end{array}$ \\
\hline AHW & 65 & 69.0 & 30.0 & 69.0 & $\begin{array}{l}0 \\
25.0 \\
48.0 \\
69.0\end{array}$ & $\begin{array}{l}112 \text { SRFD } \\
112 \text { SRFD } \\
112 \text { TILL } \\
\text { BEDROCK }\end{array}$ & $\begin{array}{l}\text { SDGL Sand, very coarse; and medium sand to pebbles } \\
\text { SAND Sand, very fine; range very fine to fine } \\
\text { TILL Til1, sandy } \\
\text { ROCK Refusal; bedrock }\end{array}$ \\
\hline AHW & 66 & 41.0 & 30.0 & 41.0 & $\begin{array}{l}0 \\
30.0 \\
37.0 \\
41.0\end{array}$ & $\begin{array}{l}\text { 112SRFD } \\
112 \text { SRFD } \\
112 \text { TILL } \\
\text { BEDROCK }\end{array}$ & $\begin{array}{l}\text { SDGL Sand, fine; some coarser grains } \\
\text { SDGL Sand, fine to coarse, dirty } \\
\text { TILL Till } \\
\text { ROCK Refusal; bedrock }\end{array}$ \\
\hline AHW & 68 & -- & 12.5 & -- & 0 & & - \\
\hline AHW & 69 & -- & 9.9 & -- & 0 & & \\
\hline AHW & 70 & -- & 86.0 & -- & $\begin{array}{c}0 \\
11.0\end{array}$ & $\begin{array}{l}110 \text { SDMN } \\
\text { BEDROCK }\end{array}$ & $\begin{array}{l}\text { SAND } \\
\text { ROCK }\end{array}$ \\
\hline AHW & 72 & -- & 705.0 & -- & $\begin{array}{l}0 \\
--\end{array}$ & $\begin{array}{l}112 T I L L \\
\text { BEDROCK }\end{array}$ & $\begin{array}{l}\text { TILL } \\
\text { ROCK }\end{array}$ \\
\hline AHW & 76 & -- & 250.0 & -- & $\begin{array}{c}0 \\
63.0\end{array}$ & $\begin{array}{l}110 \text { SDMN } \\
\text { BEDROCK }\end{array}$ & $\begin{array}{l}\text { SDGL } \\
\text { ROCK }\end{array}$ \\
\hline AHW & 77 & -- & 135.0 & -- & $\begin{array}{c}0 \\
10.0 \\
35.0\end{array}$ & $\begin{array}{l}110 \text { SDMN } \\
110 \text { SDMN } \\
\text { BEDROCK }\end{array}$ & $\begin{array}{l}\text { SAND } \\
\text { SDGL } \\
\text { ROCK }\end{array}$ \\
\hline AHW & 78 & -- & 205.0 & -- & $\begin{array}{c}0 \\
30.0\end{array}$ & $\begin{array}{l}110 \text { SDMN } \\
\text { BEDROCK }\end{array}$ & $\begin{array}{l}\text { SDGL } \\
\text { ROCK }\end{array}$ \\
\hline AHW & 79 & -- & 421.0 & -- & $\begin{array}{c}0 \\
45.0\end{array}$ & $\begin{array}{l}\text { 112TILL } \\
\text { BEDROCK }\end{array}$ & $\begin{array}{l}\text { TILL Sand, hardpan } \\
\text { ROCK }\end{array}$ \\
\hline AHW & 83 & -- & 300.0 & -- & $\begin{array}{c}0 \\
33.0\end{array}$ & $\begin{array}{l}110 \text { SDMN } \\
\text { BEDROCK }\end{array}$ & $\begin{array}{l}\text { SAND } \\
\text { ROCK }\end{array}$ \\
\hline AHW & 92 & -- & 150.0 & -- & $\begin{array}{c}0 \\
60.0\end{array}$ & $\begin{array}{l}\text { 112TILL } \\
\text { BEDROCK }\end{array}$ & $\begin{array}{l}\text { TILL } \\
\text { ROCK }\end{array}$ \\
\hline AHW & 94 & -- & 175.0 & -- & $\begin{array}{c}0 \\
10.0\end{array}$ & $\begin{array}{l}\text { 112TILL } \\
\text { BEDROCK }\end{array}$ & $\begin{array}{l}\text { TILL Gravel, hardpan } \\
\text { ROCK }\end{array}$ \\
\hline AHW & 97 & -- & 156.0 & -- & $\begin{array}{l}0 \\
15.0\end{array}$ & $\begin{array}{l}112 \text { TILL } \\
\text { BEDROCK }\end{array}$ & $\begin{array}{l}\text { TILL } \\
\text { ROCK }\end{array}$ \\
\hline AHW & 99 & -- & 145.0 & -- & $\begin{array}{l}0 \\
9.0\end{array}$ & $\begin{array}{l}\text { 110SDMN } \\
\text { BEDROCK }\end{array}$ & $\begin{array}{l}\text { CLAY } \\
\text { ROCK }\end{array}$ \\
\hline
\end{tabular}


Table B-1. Stratigraphic logs of selected wells and borings in the Winnipesaukee River Basin, central New Hampshire-Continued

\begin{tabular}{|c|c|c|c|c|c|c|}
\hline $\begin{array}{l}\text { Local } \\
\text { site } \\
\text { number }\end{array}$ & $\begin{array}{l}\text { Depth } \\
\text { drilled } \\
\text { (feet) }\end{array}$ & $\begin{array}{c}\text { Depth } \\
\text { of } \\
\text { well } \\
\text { (feet) }\end{array}$ & $\begin{array}{l}\text { Depth } \\
\text { to } \\
\text { refusal } \\
\text { (feet) }\end{array}$ & $\begin{array}{l}\text { Depth } \\
\text { to } \\
\text { top } \\
\text { (feet) }\end{array}$ & $\begin{array}{l}\text { Aquifer } \\
\text { code }\end{array}$ & $\begin{array}{c}\text { Lithologic description } \\
\text { of } \\
\text { material }\end{array}$ \\
\hline
\end{tabular}

BELKNAP COUNTY

\begin{tabular}{|c|c|c|c|c|c|c|c|}
\hline & & & & & & alton- & Continued \\
\hline AHW & 100 & -- & 160.0 & -- & $\begin{array}{c}0 \\
-- \\
125.0\end{array}$ & $\begin{array}{l}110 \text { SDMN } \\
110 S D M N \\
\text { BEDROCK }\end{array}$ & $\begin{array}{l}\text { SAND } \\
\text { CLAY } \\
\text { ROCK }\end{array}$ \\
\hline AHW & 101 & -- & 63.0 & -- & 0 & $110 \mathrm{SDMN}$ & OTHR \\
\hline AHW & 107 & -- & 244.0 & -- & 0 & & \\
\hline AHW & 119 & -- & 10.0 & -- & 0 & $110 \mathrm{SDMN}$ & SDCL \\
\hline AHW & 123 & -- & 130.0 & -- & $\begin{array}{c}0 \\
53.0\end{array}$ & $\begin{array}{l}\text { 110SDMN } \\
\text { BEDROCK }\end{array}$ & $\begin{array}{l}\text { SAND } \\
\text { ROCK }\end{array}$ \\
\hline AHW & 126 & -- & 138.0 & -- & 1.0 & BEDROCK & ROCK \\
\hline AHW & 131 & -- & 210.0 & -- & $\begin{array}{c}0 \\
40.0\end{array}$ & $\begin{array}{l}\text { 112TILL } \\
\text { BEDROCK }\end{array}$ & $\begin{array}{l}\text { TILL } \\
\text { ROCK }\end{array}$ \\
\hline AHW & 142 & -- & 145.0 & -- & $\begin{array}{c}0 \\
10.0 \\
78.0\end{array}$ & $\begin{array}{l}112 \mathrm{TILL} \\
110 \mathrm{SDMN} \\
\text { BEDROCK }\end{array}$ & $\begin{array}{l}\text { TILL } \\
\text { SAND } \\
\text { ROCK }\end{array}$ \\
\hline AHW & 144 & -- & 400.0 & -- & $\begin{array}{c}0 \\
20.0\end{array}$ & $\begin{array}{l}\text { 112TILL } \\
\text { BEDROCK }\end{array}$ & $\begin{array}{l}\text { TILL } \\
\text { ROCK }\end{array}$ \\
\hline AHW & 175 & -- & 174.0 & -- & $\begin{array}{c}0 \\
24.0\end{array}$ & $\begin{array}{l}\text { 112TILL } \\
\text { BEDROCK }\end{array}$ & $\begin{array}{l}\text { TILL } \\
\text { ROCK }\end{array}$ \\
\hline AHW & 189 & -- & 275.0 & -- & $\begin{array}{c}0 \\
35.0\end{array}$ & $\begin{array}{l}110 \text { SDMN } \\
\text { BEDROCK }\end{array}$ & $\begin{array}{l}\text { SDGL } \\
\text { ROCK }\end{array}$ \\
\hline AHW & 190 & -- & 105.0 & -- & $\begin{array}{c}0 \\
30.0\end{array}$ & $\begin{array}{l}110 \text { SDMN } \\
\text { BEDROCK }\end{array}$ & $\begin{array}{l}\text { SDGL } \\
\text { ROCK }\end{array}$ \\
\hline AHW & 196 & -- & 310.0 & - & $\begin{array}{l}0 \\
9.0\end{array}$ & $\begin{array}{l}\text { 112TILL } \\
\text { BEDROCK }\end{array}$ & $\begin{array}{l}\text { TILL } \\
\text { ROCK }\end{array}$ \\
\hline AHW & 206 & -- & 200.0 & -- & $\begin{array}{c}0 \\
19.0\end{array}$ & $\begin{array}{l}110 \text { SDMN } \\
\text { BEDROCK }\end{array}$ & $\begin{array}{l}\text { SDGL } \\
\text { ROCK }\end{array}$ \\
\hline AHW & 211 & -- & 222.0 & -- & $\begin{array}{c}0 \\
60.0\end{array}$ & $\begin{array}{l}110 \text { SDMN } \\
\text { BEDROCK }\end{array}$ & $\begin{array}{l}\text { SDCL } \\
\text { ROCK }\end{array}$ \\
\hline AHW & 213 & -- & 460.0 & -- & $\begin{array}{c}0 \\
58.0\end{array}$ & $\begin{array}{l}\text { 112TILL } \\
\text { BEDROCK }\end{array}$ & $\begin{array}{l}\text { TILL } \\
\text { ROCK }\end{array}$ \\
\hline AHW & 228 & -- & 205.0 & -- & 0 & & \\
\hline AHW & 243 & -- & 100.0 & -- & $\begin{array}{c}0 \\
25.0\end{array}$ & $\begin{array}{l}\text { 112TILL } \\
\text { BEDROCK }\end{array}$ & $\begin{array}{l}\text { TILL } \\
\text { ROCK }\end{array}$ \\
\hline AHW & 244 & -- & 130.0 & -- & $\begin{array}{c}0 \\
29.0\end{array}$ & $\begin{array}{l}110 \text { SDMN } \\
\text { BEDROCK }\end{array}$ & $\begin{array}{l}\text { SAND } \\
\text { ROCK }\end{array}$ \\
\hline AHW & 245 & -- & 304.0 & -- & $\begin{array}{c}0 \\
12.0\end{array}$ & $\begin{array}{l}\text { 112TILL } \\
\text { BEDROCK }\end{array}$ & $\begin{array}{l}\text { TILL } \\
\text { ROCK }\end{array}$ \\
\hline
\end{tabular}


Table B-1. Stratigraphic logs of selected wells and borings in the Winnipesaukee River Basin, central New Hampshire-Continued

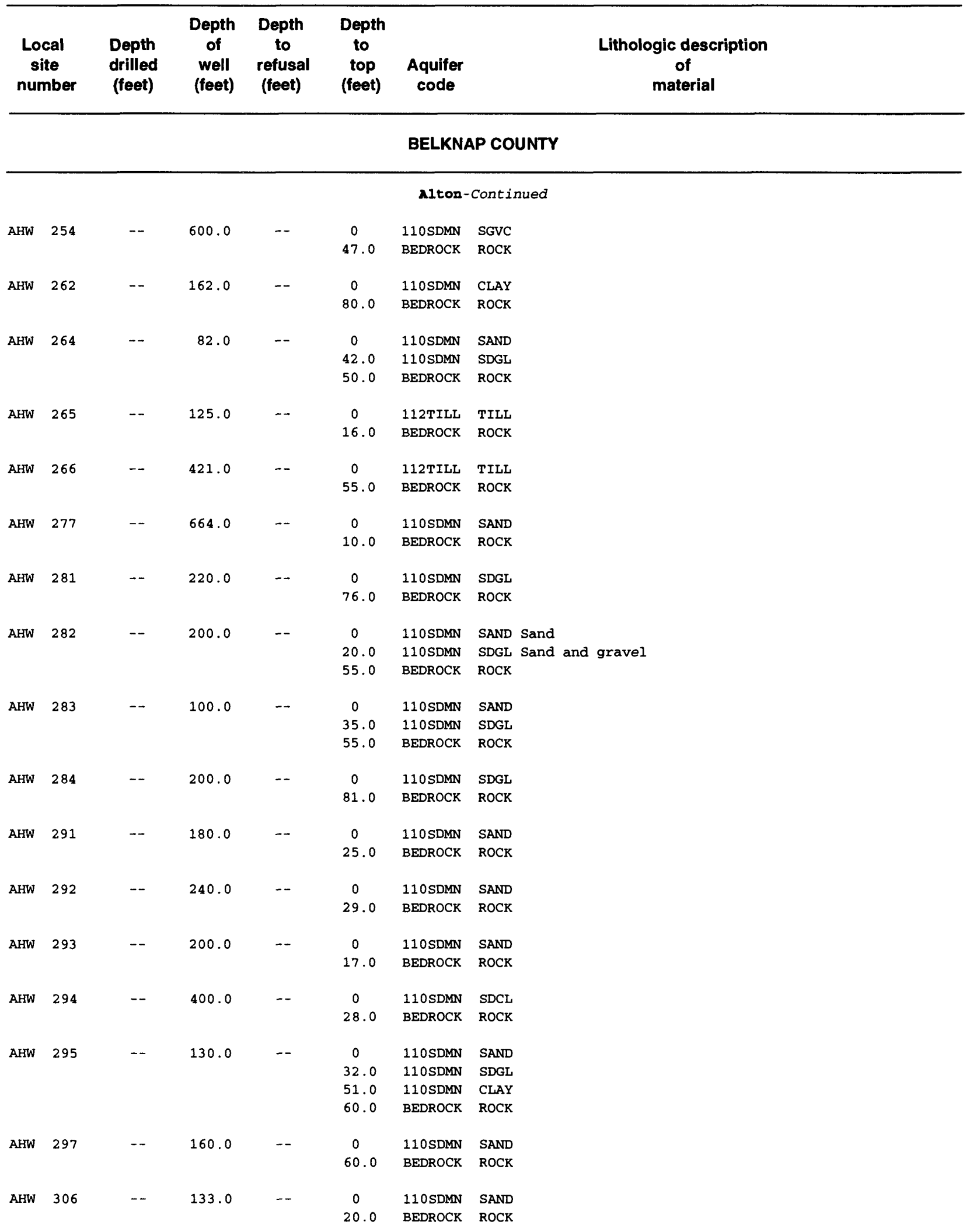


Table B-1. Stratigraphic logs of selected wells and borings in the Winnipesaukee River Basin, central New Hampshire-Continued

\begin{tabular}{|c|c|c|c|c|c|c|}
\hline $\begin{array}{l}\text { Local } \\
\text { site } \\
\text { number }\end{array}$ & $\begin{array}{l}\text { Depth } \\
\text { drilled } \\
\text { (feet) }\end{array}$ & $\begin{array}{l}\text { Depth } \\
\text { of } \\
\text { well } \\
\text { (feet) }\end{array}$ & $\begin{array}{l}\text { Depth } \\
\text { to } \\
\text { refusal } \\
\text { (feet) }\end{array}$ & $\begin{array}{l}\text { Depth } \\
\text { to } \\
\text { top } \\
\text { (feet) }\end{array}$ & $\begin{array}{l}\text { Aquifer } \\
\text { code }\end{array}$ & $\begin{array}{c}\text { Lithologic descriptlon } \\
\text { of } \\
\text { material }\end{array}$ \\
\hline
\end{tabular}

\section{BELKNAP COUNTY}

\begin{tabular}{|c|c|c|c|c|c|c|c|}
\hline \multicolumn{8}{|c|}{ alton-Continued } \\
\hline AHW & 309 & -- & 260.0 & -- & $\begin{array}{c}0 \\
26.0\end{array}$ & $\begin{array}{l}\text { 110SDMN } \\
\text { BEDROCK }\end{array}$ & $\begin{array}{l}\text { SAND } \\
\text { ROCK }\end{array}$ \\
\hline AHW & 311 & -- & 136.0 & -- & $\begin{array}{c}0 \\
10.0\end{array}$ & $\begin{array}{l}\text { 112TILL } \\
\text { BEDROCK }\end{array}$ & $\begin{array}{l}\text { TILL Gravel, hardpan } \\
\text { ROCK }\end{array}$ \\
\hline AHW & 313 & -- & 400.0 & -- & $\begin{array}{c}0 \\
24.0\end{array}$ & $\begin{array}{l}\text { 110SDMN } \\
\text { BEDROCK }\end{array}$ & $\begin{array}{l}\text { SDGL } \\
\text { ROCK }\end{array}$ \\
\hline AHW & 321 & -- & 87.0 & -- & $\begin{array}{c}0 \\
38.0\end{array}$ & $\begin{array}{l}\text { 112TILL } \\
\text { BEDROCK }\end{array}$ & $\begin{array}{l}\text { TILL } \\
\text { ROCK }\end{array}$ \\
\hline AHW & 327 & -- & 250.0 & -- & $\begin{array}{l}0 \\
69.0\end{array}$ & $\begin{array}{l}\text { 110SDMN } \\
\text { BEDROCK }\end{array}$ & $\begin{array}{l}\text { SDGL } \\
\text { ROCK }\end{array}$ \\
\hline AHW & 334 & -- & 250.0 & -- & $\begin{array}{c}0 \\
35.0\end{array}$ & $\begin{array}{l}\text { 112TILL } \\
\text { BEDROCK }\end{array}$ & $\begin{array}{l}\text { TILL } \\
\text { ROCK }\end{array}$ \\
\hline AHW & 340 & -- & 310.0 & -- & $\begin{array}{l}0 \\
8.0\end{array}$ & $\begin{array}{l}\text { 112TILL } \\
\text { BEDROCK }\end{array}$ & $\begin{array}{l}\text { TILL } \\
\text { ROCK }\end{array}$ \\
\hline AHW & 350 & -- & 185.0 & $\cdots$ & $\begin{array}{c}0 \\
12.0 \\
38.0\end{array}$ & $\begin{array}{l}110 S D M N \\
112 \text { TILL } \\
\text { BEDROCK }\end{array}$ & $\begin{array}{l}\text { SDGL } \\
\text { TILL } \\
\text { ROCK }\end{array}$ \\
\hline AHW & 357 & -- & 160.0 & - & $\begin{array}{l}0 \\
8.0\end{array}$ & $\begin{array}{l}\text { 112TILL } \\
\text { BEDROCK }\end{array}$ & $\begin{array}{l}\text { TILL } \\
\text { ROCK }\end{array}$ \\
\hline AHW & 361 & -- & 780.0 & -- & $\begin{array}{c}0 \\
12.0 \\
26.0\end{array}$ & $\begin{array}{l}110 S D M N \\
110 S D M N \\
\text { BEDROCK }\end{array}$ & $\begin{array}{l}\text { SAND } \\
\text { CLAY } \\
\text { ROCK }\end{array}$ \\
\hline AHW & 362 & -- & 220.0 & -- & $\begin{array}{c}0 \\
15.0 \\
35.0\end{array}$ & $\begin{array}{l}110 S D M N \\
110 S D M N \\
\text { BEDROCK }\end{array}$ & $\begin{array}{l}\text { SAND } \\
\text { CLAY } \\
\text { ROCK }\end{array}$ \\
\hline AHW & 364 & -- & 166.0 & -- & $\begin{array}{c}0 \\
124.0\end{array}$ & $\begin{array}{l}\text { 112TILL } \\
\text { BEDROCK }\end{array}$ & $\begin{array}{l}\text { TILL Sand, hardpan } \\
\text { ROCK }\end{array}$ \\
\hline AHW & 369 & 38.0 & 35.0 & 38.0 & $\begin{array}{c}0 \\
12.0 \\
24.0 \\
29.0 \\
34.0 \\
38.0\end{array}$ & $\begin{array}{l}110 \text { SDMN } \\
110 \text { SDMN } \\
110 \text { SDMN } \\
110 \text { SDMN } \\
112 \text { TILL } \\
\text { BEDROCK }\end{array}$ & $\begin{array}{l}\text { SAND Sand, coarse to very coarse and pebbles; light } \\
\text { brown } \\
\text { SAND Sand, very coarse to coarse; some silt } \\
\text { SAND Sand, coarse, ranges from medium to very } \\
\text { coarse; some pebbles and cobbles; clean } \\
\text { SAND Sand, very coarse, well sorted, clean } \\
\text { TILL Till, with silt, pebbles and cobbles } \\
\text { ROCK Refusal; bedrock }\end{array}$ \\
\hline AHW & 370 & 83.0 & 40.0 & 83.0 & $\begin{array}{c}0 \\
34.0 \\
43.0 \\
49.0\end{array}$ & $\begin{array}{l}110 \text { SDMN } \\
110 \text { SDMN } \\
110 \text { SDMN } \\
110 \text { SDMN }\end{array}$ & $\begin{array}{l}\text { SAND Sand, medium, tan; interlayered with } \\
\text { fine, coarse, and very coarse sand } \\
\text { SAND Sand, coarse, tan; some fine gravel, } \\
\text { well sorted } \\
\text { SAND Sand, fine; some medium, with zones } \\
\text { of coarse to very coarse } \\
\text { SAND Sand, medium to coarse, iron } \\
\text { stained, poorly sorted; some medium to fine }\end{array}$ \\
\hline
\end{tabular}


Table B-1. Stratigraphic logs of selected wells and borings in the Winnipesaukee River Basin, central New Hampshire-Continued

\begin{tabular}{|c|c|c|c|c|c|c|}
\hline $\begin{array}{l}\text { Local } \\
\text { site } \\
\text { number }\end{array}$ & $\begin{array}{l}\text { Depth } \\
\text { drilled } \\
\text { (feet) }\end{array}$ & $\begin{array}{l}\text { Depth } \\
\text { of } \\
\text { well } \\
\text { (feet) }\end{array}$ & $\begin{array}{l}\text { Depth } \\
\text { to } \\
\text { refusal } \\
\text { (feet) }\end{array}$ & $\begin{array}{l}\text { Depth } \\
\text { to } \\
\text { top } \\
\text { (feet) }\end{array}$ & $\begin{array}{l}\text { Aquifer } \\
\text { code }\end{array}$ & $\begin{array}{c}\text { Lithologic description } \\
\text { of } \\
\text { material }\end{array}$ \\
\hline
\end{tabular}

\section{BELKNAP COUNTY}

AHW 370-Continued

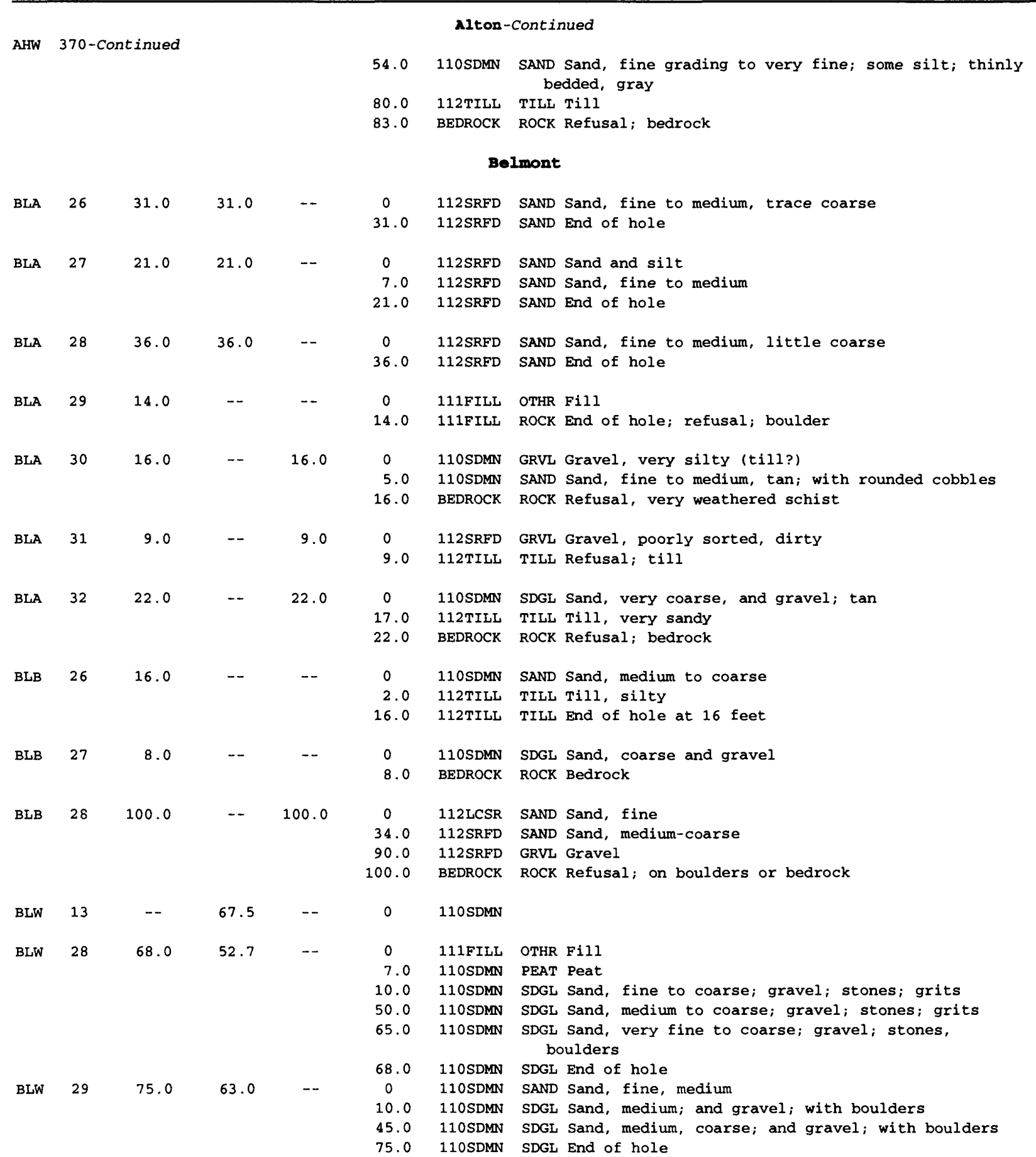

\section{alton-Continued}


Table B-1. Stratigraphic logs of selected wells and borings in the Winnipesaukee River Basin, central New Hampshire-Continued

\begin{tabular}{|c|c|c|c|c|c|c|}
\hline $\begin{array}{l}\text { Local } \\
\text { site } \\
\text { number }\end{array}$ & $\begin{array}{l}\text { Depth } \\
\text { drilled } \\
\text { (feet) }\end{array}$ & $\begin{array}{l}\text { Depth } \\
\text { of } \\
\text { well } \\
\text { (feet) }\end{array}$ & $\begin{array}{l}\text { Depth } \\
\text { to } \\
\text { refusal } \\
\text { (feet) }\end{array}$ & $\begin{array}{l}\text { Depth } \\
\text { to } \\
\text { top } \\
\text { (feet) }\end{array}$ & $\begin{array}{l}\text { Aquifer } \\
\text { code }\end{array}$ & $\begin{array}{c}\text { Lithologic description } \\
\text { of } \\
\text { material }\end{array}$ \\
\hline
\end{tabular}

\section{BELKNAP COUNTY}

\begin{tabular}{|c|c|c|c|c|c|c|c|c|}
\hline & & & & & & Belmont & $=-$ Cont & inued \\
\hline BLW & 30 & 46.0 & 42.0 & -- & $\begin{array}{r}0 \\
8.0 \\
35.0 \\
46.0\end{array}$ & $\begin{array}{l}110 \text { SDMN } \\
110 \text { SDMN } \\
110 \text { SDMN } \\
110 \text { SDMN }\end{array}$ & $\begin{array}{l}\text { SOIL } \\
\text { SAND } \\
\text { SAND } \\
\text { SAND }\end{array}$ & $\begin{array}{l}\text { Topsoil } \\
\text { Sand, light brown, fine } \\
\text { Sand, brown, fine to medium, with fine gravel } \\
\text { End of hole }\end{array}$ \\
\hline BLW & 31 & 50.0 & -- & -- & $\begin{array}{r}0 \\
5.0 \\
37.0 \\
50.0\end{array}$ & $\begin{array}{l}110 \text { SDMN } \\
110 \text { SDMN } \\
110 \text { SDMN } \\
110 \text { SDMN }\end{array}$ & $\begin{array}{l}\text { SOIL } \\
\text { SAND } \\
\text { SDGL } \\
\text { with } \\
\text { SDGL }\end{array}$ & $\begin{array}{l}\text { Topsoil } \\
\text { Sand, light brown, fine, silty, with clay } \\
\text { Sand and gravel, reddish brown, fine to medium, } \\
\text { silt } \\
\text { End of hole }\end{array}$ \\
\hline$B L W$ & 76 & 73.5 & 73.5 & -- & $\begin{array}{l}0 \\
28.0 \\
32.0 \\
60.5 \\
67.2\end{array}$ & $\begin{array}{l}112 \text { SRFD } \\
112 \text { SRFD } \\
112 \text { SRFD } \\
110 \text { SDMN } \\
\text { BEDROCK }\end{array}$ & $\begin{array}{l}\text { SAND } \\
\text { GRVL } \\
\text { SAND } \\
\text { SDST } \\
\text { ROCK }\end{array}$ & $\begin{array}{l}\text { Sand, medium to coarse, brown } \\
\text { Gravel, fine, with medium to coarse sand } \\
\text { Sand, fine, brown, trace silt } \\
\text { Sand, silty with boulders } \\
\text { End of hole at } 73 \text { feet in bedrock }\end{array}$ \\
\hline BLW & 77 & 40.0 & 40.0 & -- & $\begin{array}{c}0 \\
15.0 \\
25.0 \\
27.0 \\
29.0 \\
35.0\end{array}$ & $\begin{array}{l}110 \text { SDMN } \\
112 \text { SRFD } \\
110 \text { SDMN } \\
112 \text { SRFD } \\
112 \text { SRFD } \\
\text { BEDROCK }\end{array}$ & $\begin{array}{l}\text { PEAT } \\
\text { SILT } \\
\text { SAND } \\
\text { SAND } \\
\text { SDGL } \\
\text { ROCK }\end{array}$ & $\begin{array}{l}\text { Peat } \\
\text { Silt, brown } \\
\text { Sand, medium to fine, silty } \\
\text { Sand, medium to coarse } \\
\text { Sand and gravel } \\
\text { End of hole at } 40 \text { feet }\end{array}$ \\
\hline BLW & 78 & 35.0 & 35.0 & -- & $\begin{array}{r}0 \\
9.0 \\
11.0 \\
16.0 \\
30.0\end{array}$ & $\begin{array}{l}110 \text { SDMN } \\
112 \text { SRFD } \\
112 \text { SRFD } \\
112 \text { SRFD } \\
\text { BEDROCK }\end{array}$ & $\begin{array}{l}\text { PEAT } \\
\text { SAND } \\
\text { SAND } \\
\text { GRVL } \\
\text { ROCK }\end{array}$ & $\begin{array}{l}\text { Peat } \\
\text { Sand, fine to coarse } \\
\text { Sand, fine to medium, gray } \\
\text { Gravel, fine to coarse, trace silt } \\
\text { End of hole at } 35 \text { feet }\end{array}$ \\
\hline BLW & 79 & 52.5 & 52.5 & -- & $\begin{array}{c}0 \\
15.5 \\
16.4 \\
37.0 \\
42.5 \\
48.0\end{array}$ & $\begin{array}{l}110 \text { SDMN } \\
112 \text { SRFD } \\
112 \text { SRFD } \\
112 \text { SRFD } \\
112 \text { SRFD } \\
\text { BEDROCK }\end{array}$ & $\begin{array}{l}\text { PEAT } \\
\text { SILT } \\
\text { SAND } \\
\text { SAND } \\
\text { SILT } \\
\text { ROCK }\end{array}$ & $\begin{array}{l}\text { Peat } \\
\text { Silt, brown } \\
\text { Sand, medium to coarse, trace fine gravel } \\
\text { Sand, fine to coarse with gravel, gray } \\
\text { Silt, sandy with gravel, gray } \\
\text { End of hole at } 52.5 \text { feet in bedrock }\end{array}$ \\
\hline BLW & 80 & 90.0 & 82.5 & 90.0 & $\begin{array}{l}0 \\
20.0 \\
60.0 \\
89.0 \\
90.0\end{array}$ & $\begin{array}{l}110 \text { SDMN } \\
110 \text { SDMN } \\
110 \text { SDMN } \\
112 \text { TILL } \\
\text { BEDROCK }\end{array}$ & $\begin{array}{l}\text { SAND } \\
\text { STCL } \\
\text { SAND } \\
\text { TILL } \\
\text { ROCK }\end{array}$ & $\begin{array}{l}\text { Sand, medium, tan } \\
\text { Silt and clay } \\
\text { Sand, medium } \\
\text { Till } \\
\text { Bedrock }\end{array}$ \\
\hline BLW & 81 & 93.0 & 79.0 & 93.0 & $\begin{array}{c}0 \\
30.0 \\
89.0 \\
93.0\end{array}$ & $\begin{array}{l}110 \mathrm{SDMN} \\
110 \mathrm{SDMN} \\
112 \mathrm{TILL} \\
112 \mathrm{TILL}\end{array}$ & $\begin{array}{l}\text { SAND } \\
\text { SAND } \\
\text { TILL } \\
\text { TILL }\end{array}$ & $\begin{array}{l}\text { Sand, fine, tan } \\
\text { Sand, coarse, intervals of medium to fine sand } \\
\text { Till } \\
\text { Refusal; till }\end{array}$ \\
\hline BLW & 82 & 68.0 & 27.0 & 68.0 & $\begin{array}{l}0 \\
10.0 \\
30.0 \\
68.0\end{array}$ & $\begin{array}{l}112 \text { SRFD } \\
112 \text { SRFD } \\
112 \text { SRFD } \\
\text { BEDROCK }\end{array}$ & $\begin{array}{l}\text { SAND } \\
\text { SAND } \\
\text { SAND } \\
\text { ROCK }\end{array}$ & $\begin{array}{l}\text { Sand, fine } \\
\text { Sand, coarse } \\
\text { Sand, fine } \\
\text { Refusal; bedrock }\end{array}$ \\
\hline BLW & 83 & 114.0 & 80.0 & 114.0 & $\begin{array}{r}0 \\
5.0 \\
55.0 \\
80.0\end{array}$ & $\begin{array}{l}112 \text { SRFD } \\
112 \text { SRFD } \\
112 \text { SRFD } \\
112 \text { SRFD }\end{array}$ & $\begin{array}{l}\text { SDGL } \\
\text { SAND } \\
\text { SAND } \\
\text { SAND }\end{array}$ & $\begin{array}{l}\text { Sand, coarse and gravel, fine; tan } \\
\text { Sand, very fine, variable; gray } \\
\text { Sand, medium; gray } \\
\text { Sand, very fine, uniform }\end{array}$ \\
\hline
\end{tabular}


Table B-1. Stratigraphic logs of selected wells and borings in the Winnipesaukee River Basin, central New Hampshire-Continued

\begin{tabular}{|c|c|c|c|c|c|c|}
\hline $\begin{array}{l}\text { Local } \\
\text { site } \\
\text { number }\end{array}$ & $\begin{array}{l}\text { Depth } \\
\text { drilled } \\
\text { (feet) }\end{array}$ & $\begin{array}{c}\text { Depth } \\
\text { of } \\
\text { well } \\
\text { (feet) }\end{array}$ & $\begin{array}{l}\text { Depth } \\
\text { to } \\
\text { refusal } \\
\text { (feet) }\end{array}$ & $\begin{array}{l}\text { Depth } \\
\text { to } \\
\text { top } \\
\text { (feet) }\end{array}$ & $\begin{array}{l}\text { Aquifer } \\
\text { code }\end{array}$ & $\begin{array}{c}\text { Lithologic description } \\
\text { of } \\
\text { material }\end{array}$ \\
\hline
\end{tabular}

\section{BELKNAP COUNTY}

\begin{tabular}{|c|c|c|c|c|c|c|c|}
\hline \multirow{3}{*}{ BLW } & \multicolumn{7}{|c|}{ Belmont-Continued } \\
\hline & \multicolumn{4}{|c|}{$83-$ Cont inued } & \multirow{3}{*}{$\begin{array}{l}110.0 \\
114.0\end{array}$} & \multirow{3}{*}{$\begin{array}{l}\text { 112TILL } \\
\text { BEDROCK }\end{array}$} & \multirow{3}{*}{$\begin{array}{l}\text { TILL Till } \\
\text { ROCK Bedrock }\end{array}$} \\
\hline & & & & & & & \\
\hline & & & & & & & \\
\hline \multirow[t]{6}{*}{ BLW } & 84 & 78.0 & 60.0 & 78.0 & 0 & 112SRFD & SAND Sand, coarse to fine gravel \\
\hline & & & & & 25.0 & 112SRFD & SDGL Sand, coarse to fine gravel \\
\hline & & & & & 40.0 & 112SRFD & SAND Sand, medium \\
\hline & & & & & 50.0 & 112SRFD & SAND Sand, coarse \\
\hline & & & & & 65.0 & 112TILL & TILL Till \\
\hline & & & & & 78.0 & BEDROCK & ROCK Refusal; bedrock \\
\hline \multirow[t]{4}{*}{ BLW } & 85 & 58.0 & 50.0 & 58.0 & 0 & 112 SRFD & SAND Sand, very fine to medium \\
\hline & & & & & 38.0 & 112SRFD & SAND Sand, coarse \\
\hline & & & & & 52.0 & 112TILL & TILL Till \\
\hline & & & & & 58.0 & 112TILL & TILL Refusal in till at 58 feet \\
\hline \multirow[t]{7}{*}{ BLW } & 86 & 82.0 & 57.5 & 82.0 & 0 & 110 SDMN & SAND Sand, coarse; and gravel \\
\hline & & & & & 17.0 & 110 SDMN & $\begin{array}{l}\text { SDST Sand, coarse; and silt/clay; alternating 2-inch } \\
\text { layers }\end{array}$ \\
\hline & & & & & 19.0 & 110 SDMN & SAND Sand, coarse \\
\hline & & & & & 49.0 & 110 SDMN & SAND Sand, fine with some medium and coarse \\
\hline & & & & & 69.0 & 110 SDMN & SAND Sand, fine to coarse alternating layers \\
\hline & & & & & 78.0 & 112TILL & TILL Till \\
\hline & & & & & 82.0 & BEDROCK & ROCK Refusal; bedrock \\
\hline \multirow[t]{4}{*}{ BLW } & 87 & 19.5 & 18.9 & -- & 0 & 111FILL & OTHR Fill \\
\hline & & & & & 10.0 & 110SDMN & PEAT Peat \\
\hline & & & & & 10.5 & $110 \mathrm{SDMN}$ & $\begin{array}{l}\text { SAND Sand, medium to fine, poorly graded; trace } \\
\text { silt, orange-brown, some oxidation }\end{array}$ \\
\hline & & & & & 19.5 & $110 \mathrm{SDMN}$ & SAND End of hole \\
\hline \multirow[t]{4}{*}{ BLW } & 88 & 22.0 & 21.2 & -- & 0 & 111FILL & OTHR Fill \\
\hline & & & & & 15.0 & 110SDMN & PEAT Peat \\
\hline & & & & & 15.3 & $110 \mathrm{SDMN}$ & $\begin{array}{l}\text { SAND Sand, medium to fine, poorly graded; trace } \\
\text { silt, brown }\end{array}$ \\
\hline & & & & & 22.0 & $110 \mathrm{SDMN}$ & SAND End of hole \\
\hline \multirow[t]{3}{*}{ BLW } & 89 & 26.5 & 25.6 & -- & 0 & $110 \mathrm{SDMN}$ & $\begin{array}{l}\text { SAND Sand, medium to fine, poorly graded; trace } \\
\text { silt, brown }\end{array}$ \\
\hline & & & & & 18.0 & $110 \mathrm{SDMN}$ & $\begin{array}{l}\text { SAND Sand, fine to coarse, well graded; trace silt, } \\
\text { brown }\end{array}$ \\
\hline & & & & & 26.5 & $110 \mathrm{SDMN}$ & SAND End of hole \\
\hline \multirow[t]{4}{*}{ BLW } & 90 & 26.5 & 25.9 & -- & 0 & 111FILL & OTHR Fill \\
\hline & & & & & 10.0 & 110 SDMN & SAND Sand, medium to fine, poorly graded; some silt \\
\hline & & & & & 18.0 & 110 SDMN & $\begin{array}{l}\text { SAND Sand, fine to coarse, mod. graded; some silt, } \\
\text { brown, oxidation }\end{array}$ \\
\hline & & & & & 26.5 & $110 S D M N$ & SAND End of hole \\
\hline BLW & 91 & -- & -- & -- & 0 & 112SRFD & -- \\
\hline$B L W$ & 92 & - & -- & -- & 0 & 112SRFD & -- \\
\hline BLW & 93 & 49.0 & 40.0 & 49.0 & $\begin{array}{r}0 \\
7.0 \\
17.0\end{array}$ & $\begin{array}{l}110 \text { SDMN } \\
110 \text { SDMN } \\
110 \text { SDMN }\end{array}$ & $\begin{array}{l}\text { SAND Sand, fine, tan } \\
\text { SAND Sand, medium coarse, orange-brown } \\
\text { SAND Sand, fine, orange-brown }\end{array}$ \\
\hline
\end{tabular}


Table B-1. Stratigraphic logs of selected wells and borings in the Winnipesaukee River Basin, central New Hampshire-Continued

\begin{tabular}{|c|c|c|c|c|c|c|}
\hline $\begin{array}{l}\text { Local } \\
\text { site } \\
\text { number }\end{array}$ & $\begin{array}{l}\text { Depth } \\
\text { drilled } \\
\text { (feet) }\end{array}$ & $\begin{array}{c}\text { Depth } \\
\text { of } \\
\text { well } \\
\text { (feet) }\end{array}$ & $\begin{array}{l}\text { Depth } \\
\text { to } \\
\text { refusal } \\
\text { (feet) }\end{array}$ & $\begin{array}{l}\text { Depth } \\
\text { to } \\
\text { top } \\
\text { (feet) }\end{array}$ & $\begin{array}{l}\text { Aquifer } \\
\text { code }\end{array}$ & $\begin{array}{c}\text { Lithologic description } \\
\text { of } \\
\text { material }\end{array}$ \\
\hline
\end{tabular}

\section{BELKNAP COUNTY}

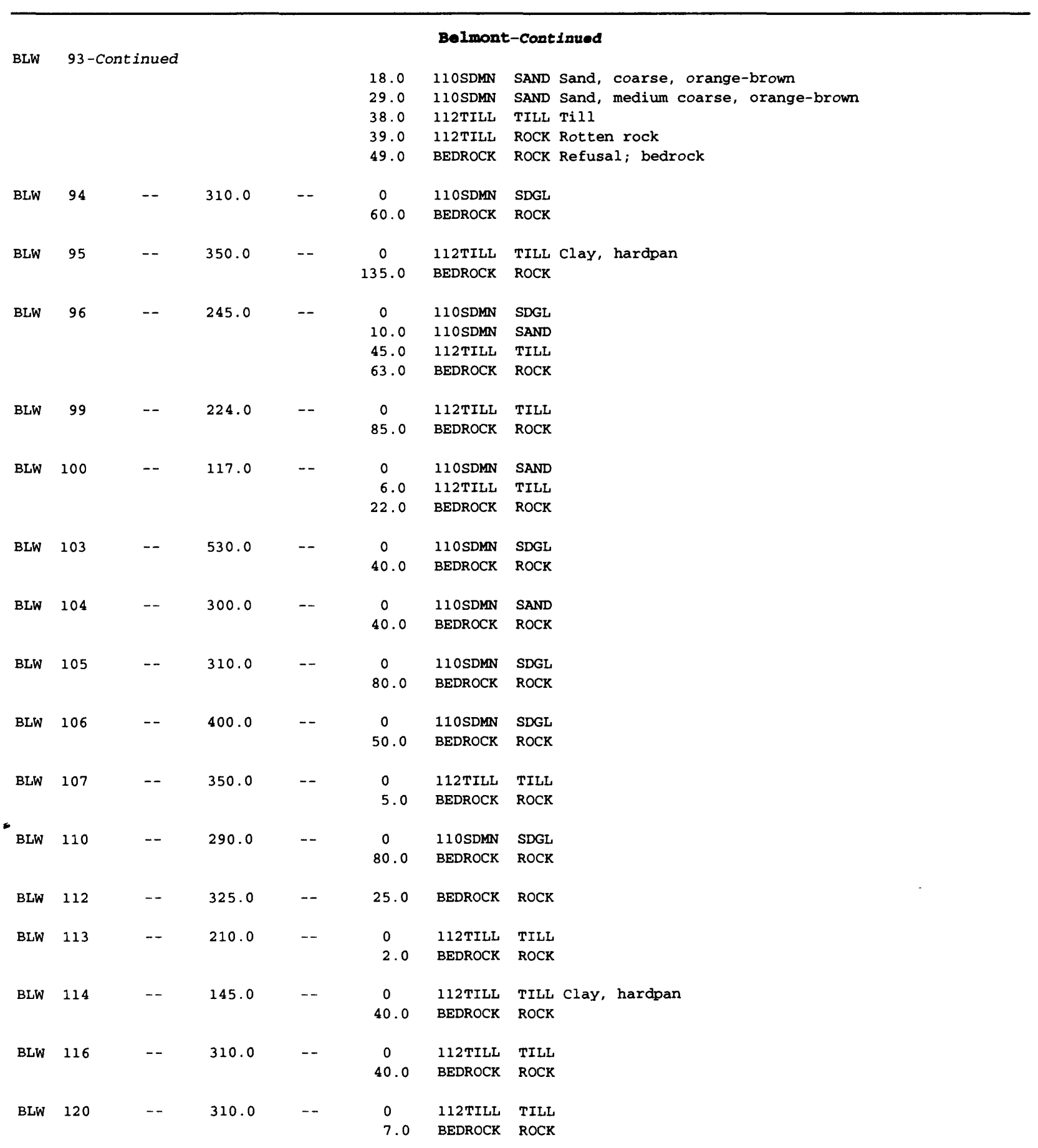


Table B-1. Stratigraphic logs of selected wells and borings in the Winnipesaukee River Basin, central New Hampshire-Continued

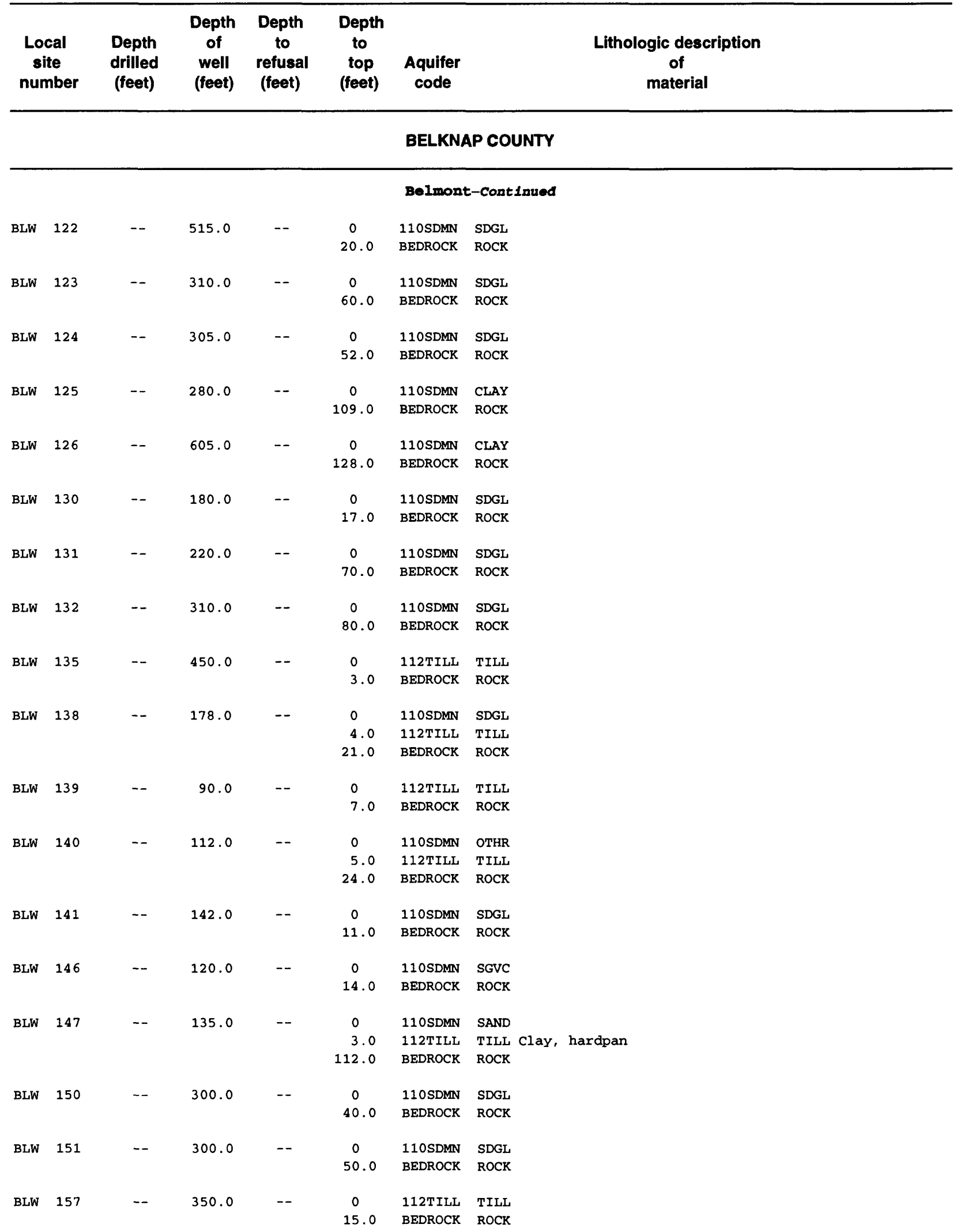


Table B-1. Stratigraphic logs of selected wells and borings in the Winnipesaukee River Basin, central New Hampshire-Continued

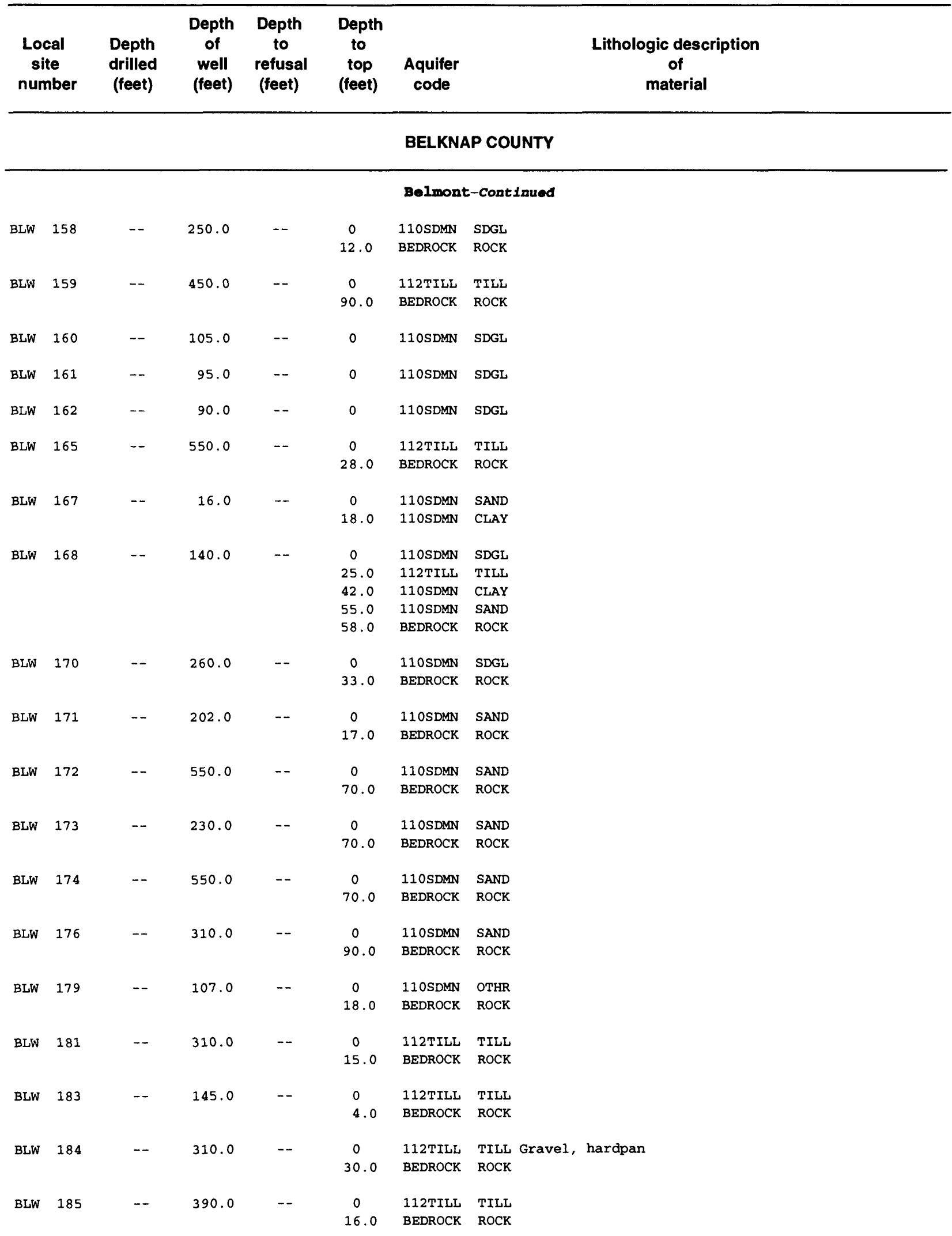


Table B-1. Stratigraphic logs of selected wells and borings in the Winnipesaukee River Basin, central New Hampshire-Continued

\begin{tabular}{|c|c|c|c|c|c|c|c|}
\hline \multicolumn{2}{|c|}{$\begin{array}{l}\text { Local } \\
\text { site } \\
\text { number }\end{array}$} & \multirow[t]{2}{*}{$\begin{array}{l}\text { Depth } \\
\text { drilled } \\
\text { (feet) }\end{array}$} & \multirow[t]{2}{*}{$\begin{array}{l}\text { Depth } \\
\text { of } \\
\text { well } \\
\text { (feet) }\end{array}$} & \multirow[t]{2}{*}{$\begin{array}{l}\text { Depth } \\
\text { to } \\
\text { refusal } \\
\text { (feet) }\end{array}$} & \multirow[t]{2}{*}{$\begin{array}{l}\text { Depth } \\
\text { to } \\
\text { top } \\
\text { (feet) }\end{array}$} & \multicolumn{2}{|r|}{$\begin{array}{c}\text { Lithologic description } \\
\text { of } \\
\text { material }\end{array}$} \\
\hline \multicolumn{4}{|c|}{ BELKNAP COUNTY } & & & & \\
\hline & & & & & & Belmont & $=-$ Continued \\
\hline BLW & 186 & -- & 370.0 & -- & $\begin{array}{c}0 \\
22.0\end{array}$ & $\begin{array}{l}110 S D M N \\
\text { BEDROCK }\end{array}$ & $\begin{array}{l}\text { SDGL } \\
\text { ROCK }\end{array}$ \\
\hline BLW & 188 & -- & 300.0 & -- & $\begin{array}{c}0 \\
70.0\end{array}$ & $\begin{array}{l}110 \text { SDMN } \\
\text { BEDROCK }\end{array}$ & $\begin{array}{l}\text { SDGL } \\
\text { ROCK }\end{array}$ \\
\hline BLW & 189 & -- & 300.0 & -- & $\begin{array}{c}0 \\
15.0\end{array}$ & $\begin{array}{l}\text { 110SDMN } \\
\text { BEDROCK }\end{array}$ & $\begin{array}{l}\text { SDGL } \\
\text { ROCK }\end{array}$ \\
\hline BLW & 190 & -- & 280.0 & -- & $\begin{array}{l}0 \\
10.0\end{array}$ & $\begin{array}{l}110 \text { SDMN } \\
\text { BEDROCK }\end{array}$ & $\begin{array}{l}\text { SDGL } \\
\text { ROCK }\end{array}$ \\
\hline BLW & 191 & -- & 160.0 & -- & 0 & $110 \mathrm{SDMN}$ & SDGL \\
\hline BLW & 198 & -- & 433.0 & -- & $\begin{array}{c}0 \\
62.0\end{array}$ & $\begin{array}{l}\text { 112TILL } \\
\text { BEDROCK }\end{array}$ & $\begin{array}{l}\text { TILL } \\
\text { ROCK }\end{array}$ \\
\hline BLW & 199 & -- & 230.0 & -- & $\begin{array}{c}0 \\
20.0\end{array}$ & $\begin{array}{l}\text { 112TILL } \\
\text { BEDROCK }\end{array}$ & $\begin{array}{l}\text { TILL Sand, gravel, hardpan } \\
\text { ROCK }\end{array}$ \\
\hline BLW & 200 & -- & 272.0 & -- & $\begin{array}{c}0 \\
103.0\end{array}$ & $\begin{array}{l}\text { 112TILL } \\
\text { BEDROCK }\end{array}$ & $\begin{array}{l}\text { TILL } \\
\text { ROCK }\end{array}$ \\
\hline BLW & 201 & -- & 300.0 & -- & 8.0 & BEDROCK & ROCK \\
\hline BLW & 202 & -- & 200.0 & -- & $\begin{array}{l}0 \\
69.0\end{array}$ & $\begin{array}{l}110 \text { SDMN } \\
\text { BEDROCK }\end{array}$ & $\begin{array}{l}\text { SDGL } \\
\text { ROCK }\end{array}$ \\
\hline BLW & 206 & -- & 325.0 & -- & $\begin{array}{c}0 \\
50.0\end{array}$ & $\begin{array}{l}110 \text { SDMN } \\
\text { BEDROCK }\end{array}$ & $\begin{array}{l}\text { OTHR } \\
\text { ROCK }\end{array}$ \\
\hline BLW & 207 & -- & 265.0 & -- & $\begin{array}{l}0 \\
65.0\end{array}$ & $\begin{array}{l}\text { 11OSDMN } \\
\text { BEDROCK }\end{array}$ & $\begin{array}{l}\text { OTHR } \\
\text { ROCK }\end{array}$ \\
\hline BLW & 209 & -- & 430.0 & -- & $\begin{array}{l}0 \\
8.0\end{array}$ & $\begin{array}{l}\text { 112TILL } \\
\text { BEDROCK }\end{array}$ & $\begin{array}{l}\text { TILL } \\
\text { ROCK }\end{array}$ \\
\hline BLW & 210 & -- & 145.0 & -- & $\begin{array}{c}0 \\
12.0\end{array}$ & $\begin{array}{l}\text { 112TILL } \\
\text { BEDROCK }\end{array}$ & $\begin{array}{l}\text { TILL } \\
\text { ROCK }\end{array}$ \\
\hline BLW & 211 & -- & 590.0 & -- & $\begin{array}{l}0 \\
8.0\end{array}$ & $\begin{array}{l}\text { 112TILL } \\
\text { BEDROCK }\end{array}$ & $\begin{array}{l}\text { TILL } \\
\text { ROCK }\end{array}$ \\
\hline BLW & 212 & -- & 125.0 & -. & $\begin{array}{c}0 \\
30.0\end{array}$ & $\begin{array}{l}\text { 110SDMN } \\
\text { BEDROCK }\end{array}$ & $\begin{array}{l}\text { SDGL } \\
\text { ROCK }\end{array}$ \\
\hline BLW & 213 & -- & 270.0 & -- & $\begin{array}{c}0 \\
40.0\end{array}$ & $\begin{array}{l}\text { 112TILL } \\
\text { BEDROCK }\end{array}$ & $\begin{array}{l}\text { TILL } \\
\text { ROCK }\end{array}$ \\
\hline BLW & 215 & -- & 220.0 & -- & $\begin{array}{c}0 \\
70.0\end{array}$ & $\begin{array}{l}\text { 112TILL } \\
\text { BEDROCK }\end{array}$ & $\begin{array}{l}\text { TILL } \\
\text { ROCK }\end{array}$ \\
\hline BLW & 216 & -- & 280.0 & -- & $\begin{array}{c}0 \\
85.0\end{array}$ & $\begin{array}{l}\text { 112TILL } \\
\text { BEDROCK }\end{array}$ & $\begin{array}{l}\text { TILL } \\
\text { ROCK }\end{array}$ \\
\hline
\end{tabular}


Table B-1. Stratigraphic logs of selected wells and borings in the Winnipesaukee River Basin, central New Hampshire-Continued

\begin{tabular}{|c|c|c|c|c|c|c|}
\hline $\begin{array}{l}\text { Local } \\
\text { site } \\
\text { number }\end{array}$ & $\begin{array}{l}\text { Depth } \\
\text { drilled } \\
\text { (feet) }\end{array}$ & $\begin{array}{l}\text { Depth } \\
\text { of } \\
\text { well } \\
\text { (feet) }\end{array}$ & $\begin{array}{l}\text { Depth } \\
\text { to } \\
\text { refusal } \\
\text { (feet) }\end{array}$ & $\begin{array}{l}\text { Depth } \\
\text { to } \\
\text { top } \\
\text { (feet) }\end{array}$ & $\begin{array}{l}\text { Aquifer } \\
\text { code }\end{array}$ & $\begin{array}{c}\text { Lithologic description } \\
\text { of } \\
\text { material }\end{array}$ \\
\hline
\end{tabular}

BELKNAP COUNTY

\begin{tabular}{|c|c|c|c|c|c|c|c|}
\hline \multirow{2}{*}{ BLW } & \multicolumn{7}{|c|}{ Belmont-Cont Inued } \\
\hline & 217 & -- & 250.0 & -- & $\begin{array}{c}0 \\
21.0\end{array}$ & $\begin{array}{l}110 S D M N \\
\text { BEDROCK }\end{array}$ & $\begin{array}{l}\text { SDGL } \\
\text { ROCK }\end{array}$ \\
\hline BLW & 219 & -- & 70.0 & -- & $\begin{array}{l}0 \\
70.0\end{array}$ & $\begin{array}{l}11 \text { OSDMN } \\
\text { BEDROCK }\end{array}$ & $\begin{array}{l}\text { SDGL } \\
\text { ROCK }\end{array}$ \\
\hline BLW & 220 & -- & 290.0 & -- & $\begin{array}{c}0 \\
50.0\end{array}$ & $\begin{array}{l}11 \text { OSDMN } \\
\text { BEDROCK }\end{array}$ & $\begin{array}{l}\text { SAND } \\
\text { ROCK }\end{array}$ \\
\hline BLW & 221 & -- & 310.0 & -- & $\begin{array}{l}0 \\
6.0\end{array}$ & $\begin{array}{l}\text { 112TILL } \\
\text { BEDROCK }\end{array}$ & $\begin{array}{l}\text { TILL } \\
\text { ROCK }\end{array}$ \\
\hline BLW & 222 & -- & 560.0 & $-\infty$ & $\begin{array}{c}0 \\
10.0\end{array}$ & $\begin{array}{l}\text { 11OSDMN } \\
\text { BEDROCK }\end{array}$ & $\begin{array}{l}\text { SDGL } \\
\text { ROCK }\end{array}$ \\
\hline $\mathrm{BLW}$ & 224 & -- & 125.0 & -- & $\begin{array}{l}0 \\
8.0\end{array}$ & $\begin{array}{l}\text { 112TILL } \\
\text { BEDROCK }\end{array}$ & $\begin{array}{l}\text { TILL } \\
\text { ROCK }\end{array}$ \\
\hline BLW & 226 & -- & 510.0 & -- & $\begin{array}{c}0 \\
60.0 \\
112.0\end{array}$ & $\begin{array}{l}110 \text { SDMN } \\
112 \text { TILL } \\
\text { BEDROCK }\end{array}$ & $\begin{array}{l}\text { SAND } \\
\text { TILL } \\
\text { ROCK }\end{array}$ \\
\hline BLW & 227 & -- & 140.0 & -- & $\begin{array}{c}0 \\
15.0 \\
24.0\end{array}$ & $\begin{array}{l}112 \text { TILL } \\
110 \text { SDMN } \\
\text { BEDROCK }\end{array}$ & $\begin{array}{l}\text { TILL } \\
\text { CLAY } \\
\text { ROCK }\end{array}$ \\
\hline$B L W$ & 230 & -- & 75.0 & -- & $\begin{array}{l}0 \\
10.0\end{array}$ & $\begin{array}{l}110 S D M N \\
\text { BEDROCK }\end{array}$ & $\begin{array}{l}\text { SAND } \\
\text { ROCK }\end{array}$ \\
\hline BLW & 231 & -- & 300.0 & -- & $\begin{array}{c}0 \\
26.0\end{array}$ & $\begin{array}{l}110 \text { SDMN } \\
\text { BEDROCK }\end{array}$ & $\begin{array}{l}\text { SDGL } \\
\text { ROCK }\end{array}$ \\
\hline BLW & 234 & -- & 300.0 & -- & $\begin{array}{l}0 \\
56.0\end{array}$ & $\begin{array}{l}110 \text { SDMN } \\
\text { BEDROCK }\end{array}$ & $\begin{array}{l}\text { SDGL } \\
\text { ROCK }\end{array}$ \\
\hline BLW & 235 & -- & 305.0 & -- & $\begin{array}{c}0 \\
14.0\end{array}$ & $\begin{array}{l}112 \text { TILL } \\
\text { BEDROCK }\end{array}$ & $\begin{array}{l}\text { TILL Gravel, hardpan } \\
\text { ROCK }\end{array}$ \\
\hline BLW & 238 & -- & 305.0 & -- & 0 & & \\
\hline$B L W$ & 240 & -- & 305.0 & -- & 0 & & \\
\hline BLW & 243 & -- & 385.0 & -- & 0 & & \\
\hline$B L W$ & 244 & -- & 230.0 & -- & $\begin{array}{c}0 \\
14.0\end{array}$ & $\begin{array}{l}\text { 112TILL } \\
\text { BEDROCK }\end{array}$ & $\begin{array}{l}\text { TILL } \\
\text { ROCK }\end{array}$ \\
\hline$B L W$ & 248 & -- & 310.0 & -- & $\begin{array}{l}0 \\
5.0\end{array}$ & $\begin{array}{l}110 \text { SDMN } \\
\text { BEDROCK }\end{array}$ & $\begin{array}{l}\text { SAND } \\
\text { ROCK }\end{array}$ \\
\hline BLW & 253 & -- & 226.0 & -- & $\begin{array}{c}0 \\
10.0\end{array}$ & $\begin{array}{l}\text { 112TILL } \\
\text { BEDROCK }\end{array}$ & $\begin{array}{l}\text { TILL } \\
\text { ROCK }\end{array}$ \\
\hline$B L W$ & 255 & -- & 325.0 & -- & $\begin{array}{c}0 \\
30.0\end{array}$ & $\begin{array}{l}110 S D M N \\
\text { BEDROCK }\end{array}$ & $\begin{array}{l}\text { SDGL } \\
\text { ROCK }\end{array}$ \\
\hline
\end{tabular}


Table B-1. Stratigraphic logs of selected wells and borings in the Winnipesaukee River Basin, central New Hampshire-Continued

\begin{tabular}{|c|c|c|c|c|c|c|c|}
\hline \multicolumn{2}{|c|}{$\begin{array}{l}\text { Local } \\
\text { site } \\
\text { number }\end{array}$} & \multirow[t]{2}{*}{$\begin{array}{l}\text { Depth } \\
\text { drilled } \\
\text { (feet) }\end{array}$} & \multirow[t]{2}{*}{$\begin{array}{l}\text { Depth } \\
\text { of } \\
\text { well } \\
\text { (feet) }\end{array}$} & \multirow[t]{2}{*}{$\begin{array}{l}\text { Depth } \\
\text { to } \\
\text { refusal } \\
\text { (feet) }\end{array}$} & \multirow[t]{2}{*}{$\begin{array}{l}\text { Depth } \\
\text { to } \\
\text { top } \\
\text { (feet) }\end{array}$} & \multicolumn{2}{|r|}{$\begin{array}{c}\text { Lithologic description } \\
\text { of } \\
\text { material }\end{array}$} \\
\hline \multicolumn{4}{|c|}{ BELKNAP COUNTY } & & & & \\
\hline \multicolumn{8}{|c|}{ Belmont-Continued } \\
\hline BLW & 257 & -- & 300.0 & -- & $\begin{array}{c}0 \\
131.0\end{array}$ & $\begin{array}{l}\text { 11OSDMN } \\
\text { BEDROCK }\end{array}$ & $\begin{array}{l}\text { OTHR } \\
\text { ROCK }\end{array}$ \\
\hline BLW & 258 & -- & 119.0 & -- & $\begin{array}{l}0 \\
10.0\end{array}$ & $\begin{array}{l}\text { 110SDMN } \\
\text { BEDROCK }\end{array}$ & $\begin{array}{l}\text { SDGL } \\
\text { ROCK }\end{array}$ \\
\hline BLW & 262 & -- & 255.0 & -- & $\begin{array}{c}0 \\
24.0\end{array}$ & $\begin{array}{l}\text { 110SDMN } \\
\text { BEDROCK }\end{array}$ & $\begin{array}{l}\text { SDCL } \\
\text { ROCK }\end{array}$ \\
\hline BLW & 263 & -- & 255.0 & -- & $\begin{array}{l}0 \\
11.0\end{array}$ & $\begin{array}{l}\text { 112TILL } \\
\text { BEDROCK }\end{array}$ & $\begin{array}{l}\text { TILL } \\
\text { ROCK }\end{array}$ \\
\hline BLW & 264 & -- & 325.0 & -- & 40.0 & BEDROCK & ROCK \\
\hline BLW & 271 & -- & 210.0 & -- & $\begin{array}{l}0 \\
8.0\end{array}$ & $\begin{array}{l}\text { 112TILL } \\
\text { BEDROCK }\end{array}$ & $\begin{array}{l}\text { TILL } \\
\text { ROCK }\end{array}$ \\
\hline BLW & 275 & -- & 120.0 & -- & $\begin{array}{l}0 \\
10.0\end{array}$ & $\begin{array}{l}\text { 110SDMN } \\
\text { BEDROCK }\end{array}$ & $\begin{array}{l}\text { CLAY } \\
\text { ROCK }\end{array}$ \\
\hline BLW & 276 & -- & 300.0 & -- & $\begin{array}{l}0 \\
4.0\end{array}$ & $\begin{array}{l}110 \text { SDMN } \\
\text { BEDROCK }\end{array}$ & $\begin{array}{l}\text { SAND } \\
\text { ROCK }\end{array}$ \\
\hline BLW & 277 & -- & 340.0 & -- & $\begin{array}{l}0 \\
4.0\end{array}$ & $\begin{array}{l}110 \text { SDMN } \\
\text { BEDROCK }\end{array}$ & $\begin{array}{l}\text { SAND } \\
\text { ROCK }\end{array}$ \\
\hline BLW & 278 & -- & 640.0 & -- & $\begin{array}{l}0 \\
6.0\end{array}$ & $\begin{array}{l}\text { 110SDMN } \\
\text { BEDROCK }\end{array}$ & $\begin{array}{l}\text { CLAYY } \\
\text { ROCK }\end{array}$ \\
\hline BLW & 286 & -- & 170.0 & -- & $\begin{array}{l}0 \\
7.0\end{array}$ & $\begin{array}{l}\text { 112TILL } \\
\text { BEDROCK }\end{array}$ & $\begin{array}{l}\text { TILL } \\
\text { ROCK }\end{array}$ \\
\hline $\mathrm{BLW}$ & 287 & -- & 365.0 & -- & $\begin{array}{l}0 \\
65.0\end{array}$ & $\begin{array}{l}\text { 112TILL } \\
\text { BEDROCK }\end{array}$ & $\begin{array}{l}\text { TILL Gravel, hardpan } \\
\text { ROCK }\end{array}$ \\
\hline BLW & 288 & -- & 428.0 & -- & $\begin{array}{l}0 \\
9.0\end{array}$ & $\begin{array}{l}\text { 110SDMN } \\
\text { BEDROCK }\end{array}$ & $\begin{array}{l}\text { SDGL } \\
\text { ROCK }\end{array}$ \\
\hline BLW & 290 & -- & 405.0 & -- & $\begin{array}{l}0 \\
30.0\end{array}$ & $\begin{array}{l}\text { 112TILL } \\
\text { BEDROCK }\end{array}$ & $\begin{array}{l}\text { TILL Gravel, hardpan } \\
\text { ROCK }\end{array}$ \\
\hline BLW & 291 & -- & 452.0 & -- & $\begin{array}{l}0 \\
30.0\end{array}$ & $\begin{array}{l}\text { 112TILL } \\
\text { BEDROCK }\end{array}$ & $\begin{array}{l}\text { TILL Gravel, hardpan } \\
\text { ROCK }\end{array}$ \\
\hline BLW & 292 & -- & 270.0 & -- & $\begin{array}{l}0 \\
80.0\end{array}$ & $\begin{array}{l}\text { 110SDMN } \\
\text { BEDROCK }\end{array}$ & $\begin{array}{l}\text { SAND } \\
\text { ROCK }\end{array}$ \\
\hline BLW & 293 & -- & 270.0 & -- & $\begin{array}{c}0 \\
90.0\end{array}$ & $\begin{array}{l}110 S D M N \\
\text { BEDROCK }\end{array}$ & $\begin{array}{l}\text { SAND } \\
\text { ROCK }\end{array}$ \\
\hline BLW & 294 & -- & 450.0 & -- & $\begin{array}{l}0 \\
82.0\end{array}$ & $\begin{array}{l}\text { 11OSDMN } \\
\text { BEDROCK }\end{array}$ & $\begin{array}{l}\text { SGVC } \\
\text { ROCK }\end{array}$ \\
\hline BLW & 296 & -- & 405.0 & -- & $\begin{array}{l}0 \\
10.0\end{array}$ & $\begin{array}{l}\text { 112TILL } \\
\text { BEDROCK }\end{array}$ & $\begin{array}{l}\text { TILL Sand, gravel, hardpan } \\
\text { ROCK }\end{array}$ \\
\hline
\end{tabular}


Table B-1. Stratigraphic logs of selected wells and borings in the Winnipesaukee River Basin, central New Hampshire-Continued

\begin{tabular}{|c|c|c|c|c|c|c|}
\hline $\begin{array}{l}\text { Local } \\
\text { site } \\
\text { number }\end{array}$ & $\begin{array}{l}\text { Depth } \\
\text { drilled } \\
\text { (feet) }\end{array}$ & $\begin{array}{l}\text { Depth } \\
\text { of } \\
\text { well } \\
\text { (feet) }\end{array}$ & $\begin{array}{l}\text { Depth } \\
\text { to } \\
\text { refusal } \\
\text { (feet) }\end{array}$ & $\begin{array}{l}\text { Depth } \\
\text { to } \\
\text { top } \\
\text { (feet) }\end{array}$ & $\begin{array}{l}\text { Aquifer } \\
\text { code }\end{array}$ & $\begin{array}{c}\text { Lithologic description } \\
\text { of } \\
\text { material }\end{array}$ \\
\hline
\end{tabular}

\section{BELKNAP COUNTY}

\begin{tabular}{|c|c|c|c|c|c|c|c|}
\hline \multicolumn{8}{|c|}{ Belmont-Continued } \\
\hline BLW & 297 & -- & 430.0 & -- & $\begin{array}{c}0 \\
140.0\end{array}$ & $\begin{array}{l}110 \text { SDMN } \\
\text { BEDROCK }\end{array}$ & $\begin{array}{l}\text { SGVC } \\
\text { ROCK }\end{array}$ \\
\hline BLW & 303 & -- & 220.0 & -- & $\begin{array}{c}0 \\
40.0\end{array}$ & $\begin{array}{l}110 \text { SDMN } \\
\text { BEDROCK }\end{array}$ & $\begin{array}{l}\text { CLAY } \\
\text { ROCK }\end{array}$ \\
\hline BLW & 306 & -- & 300.0 & -- & $\begin{array}{c}0 \\
112.0\end{array}$ & $\begin{array}{l}110 \text { SDMN } \\
\text { BEDROCK }\end{array}$ & $\begin{array}{l}\text { CLAY } \\
\text { ROCK }\end{array}$ \\
\hline BLW & 308 & -- & 400.0 & -- & $\begin{array}{l}0 \\
97.0\end{array}$ & $\begin{array}{l}110 \mathrm{SDMN} \\
\text { BEDROCK }\end{array}$ & $\begin{array}{l}\text { SGVC } \\
\text { ROCK }\end{array}$ \\
\hline BLW & 309 & -- & 220.0 & -- & $\begin{array}{c}0 \\
35.0\end{array}$ & $\begin{array}{l}112 \text { TILL } \\
\text { BEDROCK }\end{array}$ & $\begin{array}{l}\text { TILL Clay, hardpan } \\
\text { ROCK }\end{array}$ \\
\hline BLW & 315 & -- & 430.0 & -- & $\begin{array}{l}0 \\
14.0\end{array}$ & $\begin{array}{l}110 \text { SDMN } \\
\text { BEDROCK }\end{array}$ & $\begin{array}{l}\text { SDGL } \\
\text { ROCK }\end{array}$ \\
\hline BLW & 316 & -- & 230.0 & -- & $\begin{array}{c}0 \\
33.0\end{array}$ & $\begin{array}{l}112 \text { TILL } \\
\text { BEDROCK }\end{array}$ & $\begin{array}{l}\text { TILL Sand, hardpan } \\
\text { ROCK }\end{array}$ \\
\hline BLW & 318 & -- & 210.0 & -- & $\begin{array}{l}0 \\
60.0\end{array}$ & $\begin{array}{l}110 \text { SDMN } \\
\text { BEDROCK }\end{array}$ & $\begin{array}{l}\text { SAND } \\
\text { ROCK }\end{array}$ \\
\hline BLW & 321 & -- & 165.0 & -- & $\begin{array}{c}0 \\
20.0 \\
80.0\end{array}$ & $\begin{array}{l}110 \mathrm{SDMN} \\
110 \mathrm{SDMN} \\
\text { BEDROCK }\end{array}$ & $\begin{array}{l}\text { SAND } \\
\text { CLAY } \\
\text { ROCK }\end{array}$ \\
\hline BLW & 322 & -- & 155.0 & -- & $\begin{array}{c}0 \\
80.0 \\
117.0\end{array}$ & $\begin{array}{l}110 \text { SDMN } \\
110 \text { SDMN } \\
\text { BEDROCK }\end{array}$ & $\begin{array}{l}\text { SAND } \\
\text { CLAY } \\
\text { ROCK }\end{array}$ \\
\hline BLW & 323 & -- & 475.0 & -- & $\begin{array}{c}0 \\
119.0\end{array}$ & $\begin{array}{l}110 \text { SDMN } \\
\text { BEDROCK }\end{array}$ & $\begin{array}{l}\text { SDCL } \\
\text { ROCK }\end{array}$ \\
\hline BLW & 325 & -- & 175.0 & -- & $\begin{array}{l}0 \\
30.0\end{array}$ & $\begin{array}{l}112 \text { TILL } \\
\text { BEDROCK }\end{array}$ & $\begin{array}{l}\text { TILL } \\
\text { ROCK }\end{array}$ \\
\hline BLW & 327 & -- & 300.0 & -- & $\begin{array}{l}0 \\
47.0\end{array}$ & $\begin{array}{l}110 \text { SDMN } \\
\text { BEDROCK }\end{array}$ & $\begin{array}{l}\text { SAND } \\
\text { ROCK }\end{array}$ \\
\hline$B L W$ & 329 & -- & 325.0 & -- & $\begin{array}{l}0 \\
5.0\end{array}$ & $\begin{array}{l}\text { 112TILL } \\
\text { BEDROCK }\end{array}$ & $\begin{array}{l}\text { TILL } \\
\text { ROCK }\end{array}$ \\
\hline $\mathrm{BLW}$ & 331 & -- & 245.0 & -- & $\begin{array}{l}0 \\
10.0\end{array}$ & $\begin{array}{l}110 \text { SDMN } \\
\text { BEDROCK }\end{array}$ & $\begin{array}{l}\text { SDGL } \\
\text { ROCK }\end{array}$ \\
\hline BLW & 332 & -- & 220.0 & -- & $\begin{array}{l}0 \\
65.0\end{array}$ & $\begin{array}{l}110 \text { SDMN } \\
\text { BEDROCK }\end{array}$ & $\begin{array}{l}\text { SAND } \\
\text { ROCK }\end{array}$ \\
\hline BLW & 334 & -- & 290.0 & -- & $\begin{array}{c}0 \\
40.0\end{array}$ & $\begin{array}{l}112 \text { TILL } \\
\text { BEDROCK }\end{array}$ & $\begin{array}{l}\text { TILL Clay, hardpan } \\
\text { ROCK }\end{array}$ \\
\hline$B L W$ & 335 & - & 250.0 & -. & $\begin{array}{c}0 \\
50.0\end{array}$ & $\begin{array}{l}110 \text { SDMN } \\
\text { BEDROCK }\end{array}$ & $\begin{array}{l}\text { SAND } \\
\text { ROCK }\end{array}$ \\
\hline
\end{tabular}


Table B-1. Stratigraphic logs of selected wells and borings in the Winnipesaukee River Basin, central New Hampshire-Continued

\begin{tabular}{|c|c|c|c|c|c|c|}
\hline $\begin{array}{l}\text { Local } \\
\text { site } \\
\text { number }\end{array}$ & $\begin{array}{l}\text { Depth } \\
\text { drilled } \\
\text { (feet) }\end{array}$ & $\begin{array}{c}\text { Depth } \\
\text { of } \\
\text { well } \\
\text { (feet) }\end{array}$ & $\begin{array}{l}\text { Depth } \\
\text { to } \\
\text { refusal } \\
\text { (feet) }\end{array}$ & $\begin{array}{l}\text { Depth } \\
\text { to } \\
\text { top } \\
\text { (feet) }\end{array}$ & $\begin{array}{c}\text { Aquifer } \\
\text { code }\end{array}$ & $\begin{array}{c}\text { Lithologic description } \\
\text { of } \\
\text { material }\end{array}$ \\
\hline
\end{tabular}

BELKNAP COUNTY

\begin{tabular}{|c|c|c|c|c|c|c|c|}
\hline \multirow[b]{2}{*}{ BLW } & \multirow[b]{2}{*}{336} & \multicolumn{6}{|c|}{ Belmont-Continued } \\
\hline & & -- & 360.0 & -- & $\begin{array}{c}0 \\
78.0\end{array}$ & $\begin{array}{l}110 \text { SDMN } \\
\text { BEDROCK }\end{array}$ & $\begin{array}{l}\text { SAND } \\
\text { ROCK }\end{array}$ \\
\hline BLW & 341 & -- & 190.0 & -- & $\begin{array}{c}0 \\
12.0\end{array}$ & $\begin{array}{l}110 \text { SDMN } \\
\text { BEDROCK }\end{array}$ & $\begin{array}{l}\text { SAND } \\
\text { ROCK }\end{array}$ \\
\hline BLW & 342 & -- & 100.0 & -- & $\begin{array}{c}0 \\
10.0\end{array}$ & $\begin{array}{l}110 \text { SDMN } \\
\text { BEDROCK }\end{array}$ & $\begin{array}{l}\text { SDGL } \\
\text { ROCK }\end{array}$ \\
\hline BLW & 346 & -- & 305.0 & - & $\begin{array}{c}0 \\
25.0\end{array}$ & $\begin{array}{l}11 \text { OSDMN } \\
\text { BEDROCK }\end{array}$ & $\begin{array}{l}\text { SAND } \\
\text { ROCK }\end{array}$ \\
\hline BLW & 347 & -- & 160.0 & -- & $\begin{array}{c}0 \\
10.0\end{array}$ & $\begin{array}{l}\text { 11̣2TILL } \\
\text { BEDROCK }\end{array}$ & $\begin{array}{l}\text { TILL } \\
\text { ROCK }\end{array}$ \\
\hline BLW & 349 & -- & 310.0 & -- & $\begin{array}{c}0 \\
128.0\end{array}$ & $\begin{array}{l}110 \text { SDMN } \\
\text { BEDROCK }\end{array}$ & $\begin{array}{l}\text { SAND } \\
\text { ROCK }\end{array}$ \\
\hline BLW & 350 & -- & 100.0 & -- & $\begin{array}{r}0 \\
3.0 \\
10.0 \\
19.5\end{array}$ & $\begin{array}{l}110 \text { SDMN } \\
112 \text { TILL } \\
110 \text { SDMN } \\
\text { BEDROCK }\end{array}$ & $\begin{array}{l}\text { SDGL } \\
\text { TILL } \\
\text { CLAY } \\
\text { ROCK }\end{array}$ \\
\hline BLW & 353 & 13.0 & 13.0 & -- & $\begin{array}{l}0 \\
10.0 \\
11.0 \\
12.0 \\
13.0\end{array}$ & $\begin{array}{l}112 \text { SRFD } \\
112 T I L L \\
112 T I L L \\
112 T I L L \\
112 T I L L\end{array}$ & $\begin{array}{l}\text { SDGL Sand, fine to coarse; gravel } \\
\text { TILL Till, loose; sandy } \\
\text { TILL Till; medium-dense; sandy; yellow } \\
\text { TILL Till, loose; sandy; orange } \\
\text { TILL End of hole at } 13 \text { feet }\end{array}$ \\
\hline BLW & 354 & 121 & 26 & -- & $\begin{array}{r}0.0 \\
10.0 \\
45.0 \\
52.0 \\
121.0\end{array}$ & $\begin{array}{l}112 \text { SRFD } \\
112 \text { SRFD } \\
112 \text { SRFD } \\
112 \text { SRFD } \\
112 \text { SRFD }\end{array}$ & $\begin{array}{l}\text { SDGL Sand, fine to coarse; some gravel, silt } \\
\text { STCL Clay, gray } \\
\text { SDCL Sand, fine, gray; clay } \\
\text { SAND Sand, fine, gray } \\
\text { SAND Refusal at } 121 \text { feet }\end{array}$ \\
\hline BLW & 355 & 90 & -- & -- & $\begin{array}{r}0 \\
5.0 \\
30.0 \\
48.0 \\
52.0 \\
65.0\end{array}$ & $\begin{array}{l}112 \text { SRFD } \\
112 \text { SRFD } \\
112 \text { SRFD } \\
112 \text { SRFD } \\
112 \text { SRFD } \\
112 \text { SRFD } \\
\text { Cente }\end{array}$ & $\begin{array}{l}\text { SDGL Sand, fine to coarse; gravel; some silt } \\
\text { SAND Sand, fine; trace silt } \\
\text { SDCL Sand and clay } \\
\text { SDCL Sand, fine with clay } \\
\text { CLAY Clay, gray } \\
\text { SAND Sand, fine; trace silt } \\
\text { Harbor }\end{array}$ \\
\hline CHW & 1 & -- & 380.0 & -- & $\begin{array}{c}0 \\
20.0 \\
-- \\
37.0\end{array}$ & $\begin{array}{l}110 \text { SDMN } \\
112 \text { TILL } \\
112 \text { TILL } \\
\text { BEDROCK }\end{array}$ & $\begin{array}{l}\text { SDGL } \\
\text { TILL } \\
\text { TILL } \\
\text { ROCK }\end{array}$ \\
\hline CHW & 2 & -- & 130.0 & -- & $\begin{array}{c}0 \\
15.0\end{array}$ & $\begin{array}{l}110 \mathrm{SDMN} \\
\text { BEDROCK }\end{array}$ & $\begin{array}{l}\text { SDGL } \\
\text { ROCK }\end{array}$ \\
\hline CHW & 3 & -- & 305.0 & -- & $\begin{array}{l}0 \\
7.0\end{array}$ & $\begin{array}{l}\text { 112TILL } \\
\text { BEDROCK }\end{array}$ & $\begin{array}{l}\text { TILL } \\
\text { ROCK }\end{array}$ \\
\hline $\mathrm{CHW}$ & 5 & -- & 605.0 & - & 90.0 & BEDROCK & ROCK \\
\hline
\end{tabular}


Table B-1. Stratigraphic logs of selected wells and borings in the Winnipesaukee River Basin, central New Hampshire-Continued

\begin{tabular}{|c|c|c|c|c|c|c|}
\hline $\begin{array}{l}\text { Local } \\
\text { site } \\
\text { number }\end{array}$ & $\begin{array}{l}\text { Depth } \\
\text { drilled } \\
\text { (feet) }\end{array}$ & $\begin{array}{l}\text { Depth } \\
\text { of } \\
\text { well } \\
\text { (feet) }\end{array}$ & $\begin{array}{l}\text { Depth } \\
\text { to } \\
\text { refusal } \\
\text { (feet) }\end{array}$ & $\begin{array}{l}\text { Depth } \\
\text { to } \\
\text { top } \\
\text { (feet) }\end{array}$ & $\begin{array}{l}\text { Aquifer } \\
\text { code }\end{array}$ & $\begin{array}{c}\text { Lithologic description } \\
\text { of } \\
\text { material }\end{array}$ \\
\hline
\end{tabular}

\section{BELKNAP COUNTY}

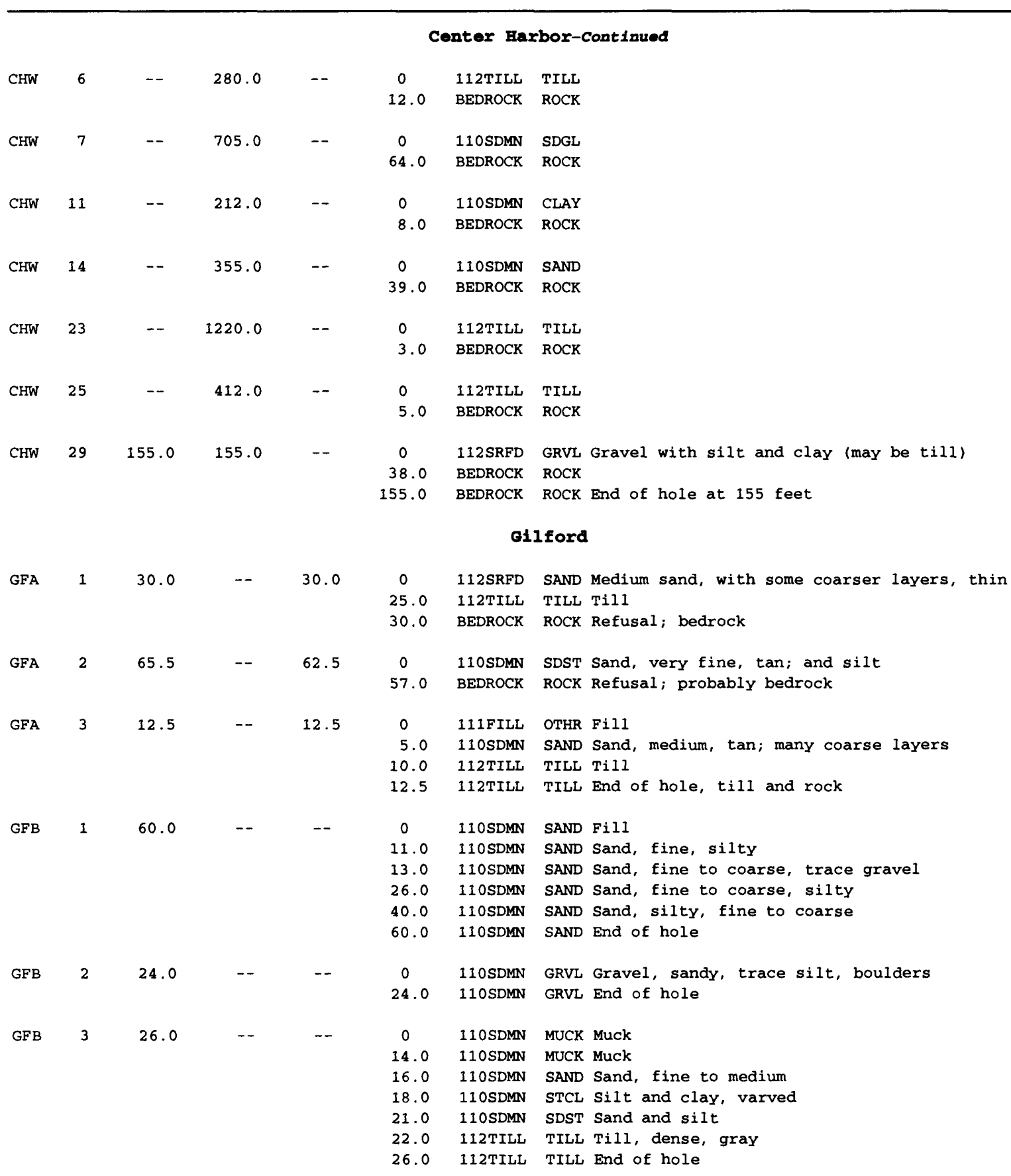


Table B-1. Stratigraphic logs of selected wells and borings in the Winnipesaukee River Basin, central New Hampshire-Continued

\begin{tabular}{|c|c|c|c|c|c|c|}
\hline $\begin{array}{l}\text { Local } \\
\text { site } \\
\text { number }\end{array}$ & $\begin{array}{l}\text { Depth } \\
\text { drilled } \\
\text { (feet) }\end{array}$ & $\begin{array}{l}\text { Depth } \\
\text { of } \\
\text { well } \\
\text { (feet) }\end{array}$ & $\begin{array}{l}\text { Depth } \\
\text { to } \\
\text { refusal } \\
\text { (feet) }\end{array}$ & $\begin{array}{l}\text { Depth } \\
\text { to } \\
\text { top } \\
\text { (feet) }\end{array}$ & $\begin{array}{l}\text { Aqulfer } \\
\text { code }\end{array}$ & $\begin{array}{c}\text { Lithologic description } \\
\text { of } \\
\text { materlal }\end{array}$ \\
\hline
\end{tabular}

\section{BELKNAP COUNTY}

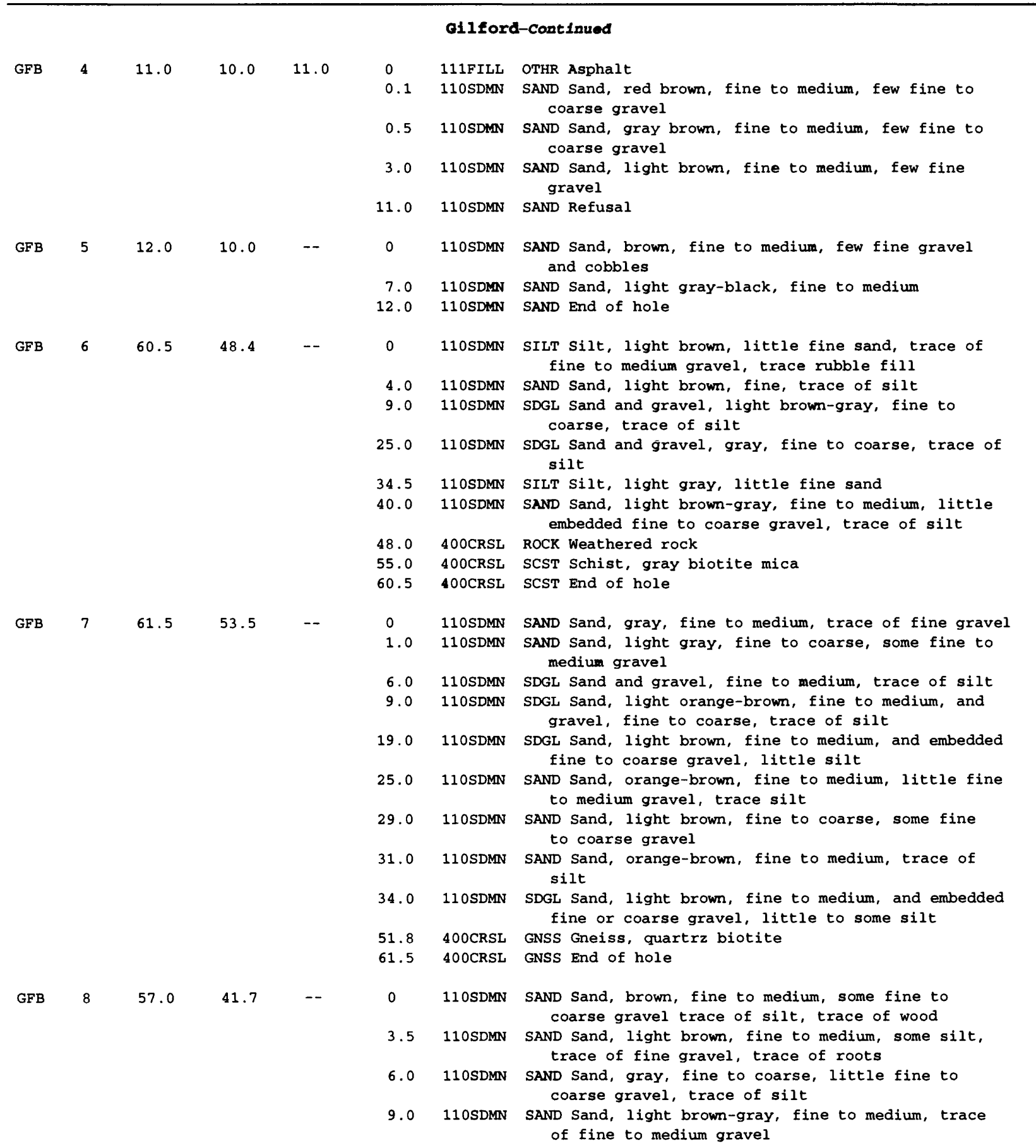


Table B-1. Stratigraphic logs of selected wells and borings in the Winnipesaukee River Basin, central New Hampshire-Continued

\begin{tabular}{|c|c|c|c|c|c|c|}
\hline $\begin{array}{l}\text { Local } \\
\text { site } \\
\text { number }\end{array}$ & $\begin{array}{l}\text { Depth } \\
\text { drilled } \\
\text { (feet) }\end{array}$ & $\begin{array}{c}\text { Depth } \\
\text { of } \\
\text { well } \\
\text { (feet) }\end{array}$ & $\begin{array}{l}\text { Depth } \\
\text { to } \\
\text { refusal } \\
\text { (feet) }\end{array}$ & $\begin{array}{l}\text { Depth } \\
\text { to } \\
\text { top } \\
\text { (feet) }\end{array}$ & $\begin{array}{l}\text { Aquifer } \\
\text { code }\end{array}$ & $\begin{array}{c}\text { Lithologic description } \\
\text { of } \\
\text { material }\end{array}$ \\
\hline
\end{tabular}

\section{BELKNAP COUNTY}

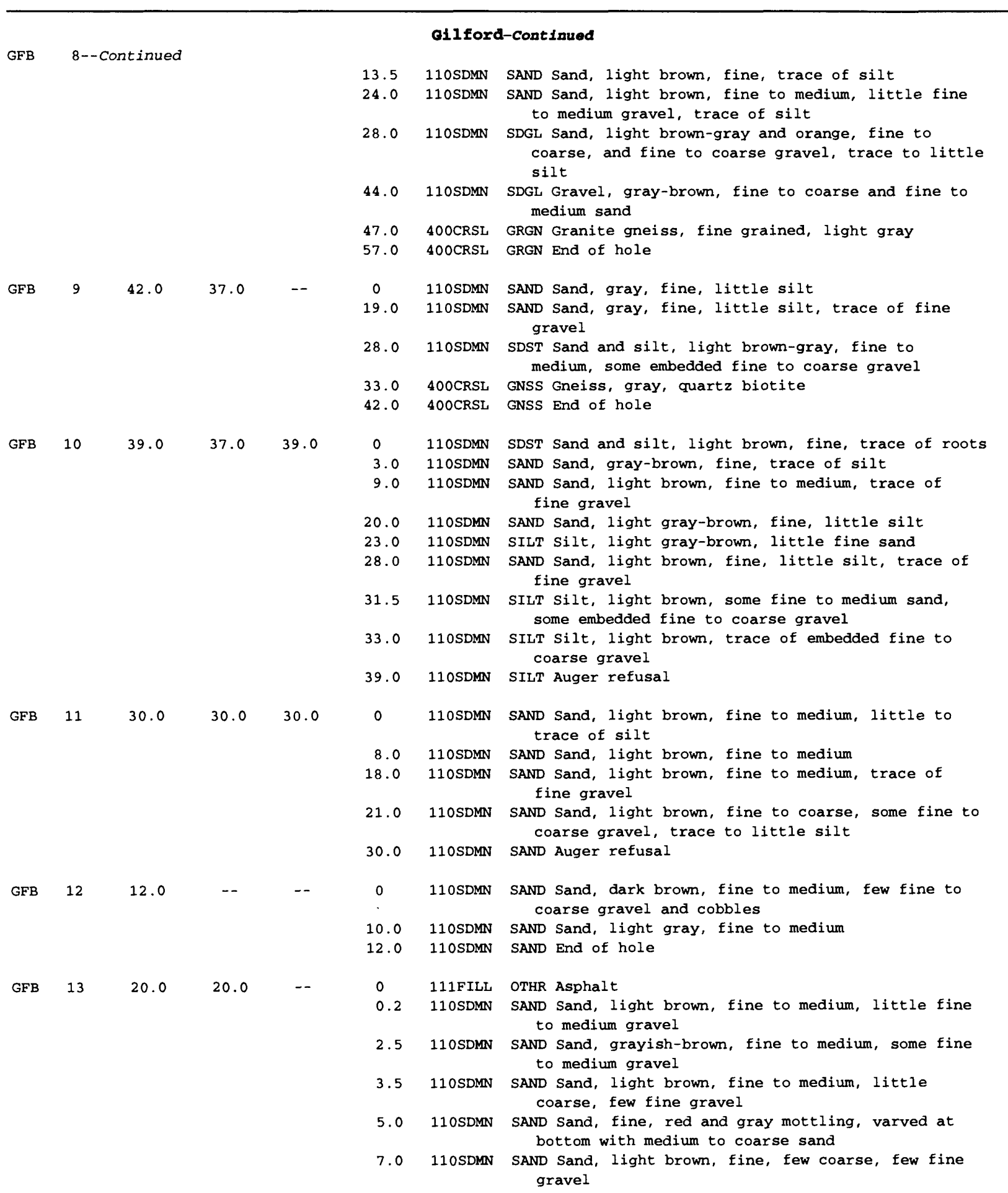


Table B-1. Stratigraphic logs of selected wells and borings in the Winnipesaukee River Basin, central New Hampshire-Continued

\begin{tabular}{|c|c|c|c|c|c|c|c|}
\hline \multicolumn{2}{|c|}{$\begin{array}{l}\text { Local } \\
\text { site } \\
\text { number }\end{array}$} & \multirow[t]{2}{*}{$\begin{array}{l}\text { Depth } \\
\text { drilled } \\
\text { (feet) }\end{array}$} & \multirow[t]{2}{*}{$\begin{array}{c}\text { Depth } \\
\text { of } \\
\text { well } \\
\text { (feet) }\end{array}$} & \multirow[t]{2}{*}{$\begin{array}{l}\text { Depth } \\
\text { to } \\
\text { refusal } \\
\text { (feet) }\end{array}$} & \multirow[t]{2}{*}{$\begin{array}{c}\text { Depth } \\
\text { to } \\
\text { top } \\
\text { (feet) }\end{array}$} & \multicolumn{2}{|r|}{$\begin{array}{c}\text { Lithologic description } \\
\text { of } \\
\text { material }\end{array}$} \\
\hline & & & & & & \multicolumn{2}{|c|}{ BELKNAP COUNTY } \\
\hline \multicolumn{8}{|c|}{ Gilford-Continued } \\
\hline \multirow[t]{4}{*}{ GFB } & \multicolumn{2}{|c|}{$13--$ Contiued } & & & & & \\
\hline & & & & & 13.0 & 110 SDMN & COBB Auger grinding on cobbles \\
\hline & & & & & 15.0 & 110 SDMN & SAND Sand, light gray-brown, fine \\
\hline & & & & & 17.0 & 110 SDMN & SAND End of hole \\
\hline \multirow[t]{6}{*}{ GFW } & 7 & 30.0 & 15.0 & -- & 0 & 110 SDMN & $\begin{array}{l}\text { SILT Silt, black organic, with peat, trace medium to } \\
\text { fine sand, trace of gravel }\end{array}$ \\
\hline & & & & & 2.5 & $110 \mathrm{SDMN}$ & $\begin{array}{l}\text { SDGL Gravel, brown, fine to coarse to medium, and } \\
\text { medium to coarse sand, occasional cobbles }\end{array}$ \\
\hline & & & & & 6.5 & $110 S D M N$ & $\begin{array}{l}\text { SDGL Sand, tan, medium to coarse, and fine to medium } \\
\text { gravel }\end{array}$ \\
\hline & & & & & 10.0 & $110 \mathrm{SDMN}$ & $\begin{array}{l}\text { SAND Sand, tan, medium to coarse, some fine to } \\
\text { medium gravel }\end{array}$ \\
\hline & & & & & 12.0 & $110 \mathrm{SDMN}$ & $\begin{array}{l}\text { SAND Sand, tan, fine, trace of orange medium sand in } \\
\text { occasoinal layers }\end{array}$ \\
\hline & & & & & 30.0 & $110 \mathrm{SDMN}$ & SAND End of hole \\
\hline \multirow[t]{7}{*}{ GFW } & 9 & 16.5 & 14.5 & -- & 0 & 110 SDMN & $\begin{array}{l}\text { SAND Sand, brown, medium to coarse, some gravel, } \\
\text { little fine sand }\end{array}$ \\
\hline & & & & & 3.0 & $110 \mathrm{SDMN}$ & $\begin{array}{l}\text { SAND Sand, gray, medium to coarse, some gravel, } \\
\text { little fine sand }\end{array}$ \\
\hline & & & & & 5.0 & 110 SDMN & $\begin{array}{l}\text { SAND Sand, gray, fine to medium, little coarse, } \\
\text { little gravel (fill, petroleum odor) }\end{array}$ \\
\hline & & & & & 10.0 & $110 \mathrm{SDMN}$ & $\begin{array}{l}\text { SAND Sand, gray, graded very coarse to medium, } \\
\text { little gravel }\end{array}$ \\
\hline & & & & & 11.0 & $110 \mathrm{SDMN}$ & SDST Sand and silt, gray, fine, laminated \\
\hline & & & & & 12.5 & $110 \mathrm{SDMN}$ & $\begin{array}{l}\text { SAND Sand, brown, medium to coarse, little fine, } \\
\text { trace of gravel }\end{array}$ \\
\hline & & & & & 16.5 & 110 SDMN & SAND End of hole \\
\hline \multirow[t]{4}{*}{ GFW } & 11 & 67.0 & 53.0 & 67.0 & 0 & 112SRFD & SAND Sand, coarse \\
\hline & & & & & 15.0 & 112SRFD & SAND Sand, medium \\
\hline & & & & & 55.0 & 112SRFD & SAND Sand, coarse \\
\hline & & & & & 66.0 & 112 TILL & TILL Refusal; till \\
\hline \multirow[t]{4}{*}{ GFW } & 12 & 90.0 & 80.0 & 90.0 & 0 & 112SRFD & SAND Sand, fine; some coarser thin layers \\
\hline & & & & & 75.0 & 112SRFD & SDGL Sand, very coarse \\
\hline & & & & & 85.0 & 112 TILL & TILL Till \\
\hline & & & & & 90.0 & 112 TILL & TILL Refusal in till at 90 feet \\
\hline \multirow[t]{4}{*}{ GFW } & 13 & 49.0 & 35.0 & 49.0 & 0 & 112SRFD & SAND Sand, coarse; some thin finer layers \\
\hline & & & & & 38.0 & 112SRFD & SAND Sand, very fine; silt \\
\hline & & & & & 41.0 & 112TILL & TILL Till \\
\hline & & & & & 49.0 & 112 TILL & TILL Refusal in till at 49 feet \\
\hline \multirow[t]{4}{*}{ GFW } & 14 & 75.0 & 70.5 & 75.0 & $\begin{array}{c}0 \\
37.0\end{array}$ & $\begin{array}{l}110 \text { SDMN } \\
110 \text { SDMN }\end{array}$ & $\begin{array}{l}\text { SAND Sand, coarse, gray; some pebbles } \\
\text { SDST Sand, fine; some silt layers }\end{array}$ \\
\hline & & & & & 57.0 & 110SDMN & SAND Sand, fine to medium \\
\hline & & & & & 67.0 & 110SDMN & SDST Sand, medium; some very fine, and silt \\
\hline & & & & & 75.0 & BEDROCK & ROCK Refusal; probably bedrock \\
\hline \multirow[t]{4}{*}{ GFW } & 15 & 44.0 & 42.0 & 44.0 & 0 & 110 SDMN & SAND Sand, very fine, tan; some silt and medium sand \\
\hline & & & & & 37.0 & 110 SDMN & SAND Sand, medium \\
\hline & & & & & 43.0 & 112TILL & TILL Till \\
\hline & & & & & 44.0 & BEDROCK & ROCK Refusal; probably bedrock \\
\hline
\end{tabular}


Table B-1. Stratigraphic logs of selected wells and borings in the Winnipesaukee River Basin, central New Hampshire-Continued

\begin{tabular}{|c|c|c|c|c|c|c|c|}
\hline $\begin{array}{r}\text { Loc } \\
\text { si } \\
\text { num }\end{array}$ & & $\begin{array}{l}\text { Depth } \\
\text { drilled } \\
\text { (feet) }\end{array}$ & $\begin{array}{l}\text { Depth } \\
\text { of } \\
\text { well } \\
\text { (feet) }\end{array}$ & $\begin{array}{l}\text { Depth } \\
\text { to } \\
\text { refusal } \\
\text { (feet) }\end{array}$ & $\begin{array}{l}\text { Depth } \\
\text { to } \\
\text { top } \\
\text { (feet) }\end{array}$ & $\begin{array}{l}\text { Aquifer } \\
\text { code }\end{array}$ & $\begin{array}{c}\text { Lithologlc description } \\
\text { of } \\
\text { material }\end{array}$ \\
\hline & & & & & & BELKNA & P COUNTY \\
\hline & & & & & & Gilford & -Cont Inued \\
\hline GFW & 16 & -- & 14.4 & -- & 0 & 112SRFD & -- \\
\hline GFW & 17 & -- & 450.0 & -- & $\begin{array}{c}0 \\
125.0 \\
150.0\end{array}$ & $\begin{array}{l}110 \text { SDMN } \\
110 \text { SDMN } \\
\text { BEDROCK }\end{array}$ & $\begin{array}{l}\text { SDGL } \\
\text { CLAY } \\
\text { ROCK }\end{array}$ \\
\hline GFW & 18 & -- & 305.0 & -- & $\begin{array}{c}0 \\
31.0\end{array}$ & $\begin{array}{l}\text { 112TILL } \\
\text { BEDROCK }\end{array}$ & $\begin{array}{l}\text { TILL Sand, hardpan } \\
\text { ROCK }\end{array}$ \\
\hline GFW & 19 & -- & 265.0 & -- & $\begin{array}{c}0 \\
101.0\end{array}$ & $\begin{array}{l}\text { 112TILL } \\
\text { BEDROCK }\end{array}$ & $\begin{array}{l}\text { TILL Gravel, hardpan } \\
\text { ROCK }\end{array}$ \\
\hline GFW & 21 & -- & 185.0 & - & $\begin{array}{c}0 \\
50.0\end{array}$ & $\begin{array}{l}110 \text { SDMN } \\
\text { BEDROCK }\end{array}$ & $\begin{array}{l}\text { SAND } \\
\text { ROCK }\end{array}$ \\
\hline GFW & 22 & -- & 165.0 & -- & $\begin{array}{l}0 \\
10.0\end{array}$ & $\begin{array}{l}110 \text { SDMN } \\
\text { BEDROCK }\end{array}$ & $\begin{array}{l}\text { SGVC } \\
\text { ROCK }\end{array}$ \\
\hline GFW & 23 & -- & 145.0 & -- & $\begin{array}{c}0 \\
28.0\end{array}$ & $\begin{array}{l}112 \text { TILL } \\
\text { BEDROCK }\end{array}$ & $\begin{array}{l}\text { TILL Gravel, hardpan } \\
\text { ROCK }\end{array}$ \\
\hline GFW & 24 & -- & 550.0 & -- & $\begin{array}{c}0 \\
132.0\end{array}$ & $\begin{array}{l}110 S D M N \\
\text { BEDROCK }\end{array}$ & $\begin{array}{l}\text { SDGL } \\
\text { ROCK }\end{array}$ \\
\hline GFW & 31 & -- & 385.0 & -- & 80.0 & BEDROCK & ROCK \\
\hline GFW & 32 & - & 205.0 & -- & 15.0 & BEDROCK & ROCK \\
\hline GFW & 33 & -- & 24.5 & -- & $\begin{array}{l}0 \\
30.0\end{array}$ & $\begin{array}{l}110 \mathrm{SDMN} \\
112 \mathrm{TILL}\end{array}$ & $\begin{array}{l}\text { SDGL } \\
\text { TILL }\end{array}$ \\
\hline GFW & 35 & -- & 300.0 & -- & $\begin{array}{c}0 \\
130.0\end{array}$ & $\begin{array}{l}110 \mathrm{SDMN} \\
\text { BEDROCK }\end{array}$ & $\begin{array}{l}\text { SAND } \\
\text { ROCK }\end{array}$ \\
\hline GFW & 37 & -- & 444.0 & -- & $\begin{array}{l}0 \\
63.0 \\
85.0\end{array}$ & $\begin{array}{l}110 \text { SDMN } \\
110 \text { SDMN } \\
\text { BEDROCK }\end{array}$ & $\begin{array}{l}\text { SDCL } \\
\text { SDGL } \\
\text { ROCK }\end{array}$ \\
\hline GFW & 38 & -- & 19.5 & -- & $\begin{array}{c}0 \\
20.0\end{array}$ & $\begin{array}{l}110 \mathrm{SDMN} \\
110 \mathrm{SDMN}\end{array}$ & $\begin{array}{l}\text { SDGL } \\
\text { SAND }\end{array}$ \\
\hline GFW & 39 & -- & 535.0 & -- & $\begin{array}{l}0 \\
90.0\end{array}$ & $\begin{array}{l}112 \text { TILI } \\
\text { BEDROCK }\end{array}$ & $\begin{array}{l}\text { TILL } \\
\text { ROCK }\end{array}$ \\
\hline GEW & 40 & - & 250.0 & -- & $\begin{array}{c}0 \\
100.0\end{array}$ & $\begin{array}{l}\text { 112TILL } \\
\text { BEDROCK }\end{array}$ & $\begin{array}{l}\text { TILL } \\
\text { ROCK }\end{array}$ \\
\hline GFW & 43 & -- & 182.0 & -- & $\begin{array}{c}0 \\
75.0\end{array}$ & $\begin{array}{l}112 T I L L \\
\text { BEDROCK }\end{array}$ & $\begin{array}{l}\text { TILL } \\
\text { ROCK }\end{array}$ \\
\hline GFW & 44 & -- & 139.0 & -- & $\begin{array}{c}0 \\
116.0\end{array}$ & $\begin{array}{l}110 \text { SDMN } \\
\text { BEDROCR }\end{array}$ & $\begin{array}{l}\text { SDGL } \\
\text { ROCK }\end{array}$ \\
\hline GFW & 52 & -- & 310.0 & -- & $\begin{array}{c}0 \\
75.0\end{array}$ & $\begin{array}{l}110 \text { SDMN } \\
\text { BEDROCK }\end{array}$ & $\begin{array}{l}\text { SAND } \\
\text { ROCK }\end{array}$ \\
\hline
\end{tabular}


Table B-1. Stratigraphic logs of selected wells and borings in the Winnipesaukee River Basin, central New Hampshire-Continued

\begin{tabular}{|c|c|c|c|c|c|c|c|}
\hline $\begin{array}{r}\text { Lo } \\
\text { si } \\
\text { nur }\end{array}$ & & $\begin{array}{l}\text { Depth } \\
\text { drilled } \\
\text { (feet) }\end{array}$ & $\begin{array}{l}\text { Depth } \\
\text { of } \\
\text { well } \\
\text { (feet) }\end{array}$ & $\begin{array}{l}\text { Depth } \\
\text { to } \\
\text { refusal } \\
\text { (feet) }\end{array}$ & $\begin{array}{l}\text { Depth } \\
\text { to } \\
\text { top } \\
\text { (feet) }\end{array}$ & $\begin{array}{l}\text { Aquifer } \\
\text { code }\end{array}$ & $\begin{array}{c}\text { Lithologic description } \\
\text { of } \\
\text { material }\end{array}$ \\
\hline & & & & & & BELKNA & P COUNTY \\
\hline & & & & & & Gilford & -Continued \\
\hline GFW & 58 & -- & 290.0 & -- & $\begin{array}{c}0 \\
105.0\end{array}$ & $\begin{array}{l}110 \mathrm{SDMN} \\
\text { BEDROCK }\end{array}$ & $\begin{array}{l}\text { SAND } \\
\text { ROCK }\end{array}$ \\
\hline GFW & 63 & -- & 300.0 & -- & 0 & $110 \mathrm{SDMN}$ & SDGL \\
\hline & & & & & 105.0 & BEDROCK & ROCK \\
\hline GFW & 66 & -- & 375.0 & -- & 0 & $110 \mathrm{SDMN}$ & SAND \\
\hline & & & & & 70.0 & BEDROCK & ROCK \\
\hline GFW & 67 & -- & 400.0 & -- & 0 & $110 \mathrm{SDMN}$ & OTHR \\
\hline & & & & & 95.0 & BEDROCK & ROCK \\
\hline GFW & 70 & -- & 325.0 & -- & 0 & $110 \mathrm{SDMN}$ & SDGL \\
\hline & & & & & 90.0 & BEDROCK & ROCK \\
\hline GFW & 74 & -- & 310.0 & -- & 0 & $110 \mathrm{SDMN}$ & SDGL \\
\hline & & & & & 45.0 & BEDROCK & ROCK \\
\hline GFW & 75 & -- & 195.0 & -- & 0 & 112 TILL & TILL \\
\hline & & & & & 3.0 & BEDROCK & ROCK \\
\hline GFW & 78 & -- & 225.0 & -- & 0 & 112TILL & TILL \\
\hline & & & & & 90.0 & BEDROCK & ROCK \\
\hline GFW & 81 & -- & 180.0 & -- & 0 & 110 SDMN & SAND \\
\hline & & & & & 80.0 & BEDROCK & ROCK \\
\hline GFW & 82 & -- & 430.0 & -- & 0 & $112 \mathrm{TILL}$ & TILL \\
\hline & & & & & 12.0 & BEDROCK & ROCK \\
\hline GFW & 88 & -- & 305.0 & -- & 0 & $110 \mathrm{SDMN}$ & CLAY \\
\hline & & & & & 60.0 & BEDROCK & ROCK \\
\hline GFW & 89 & -- & 75.0 & -- & 0 & $112 \mathrm{TILL}$ & TILL \\
\hline & & & & & 16.0 & BEDROCK & ROCK \\
\hline GFW & 91 & -- & 390.0 & -- & 0 & $112 \mathrm{TILL}$ & TILL Gravel, hardpan \\
\hline & & & & & 30.0 & BEDROCK & ROCK \\
\hline GFW & 92 & -- & 560.0 & -- & 0 & 112TILL & TILL \\
\hline & & & & & 100.0 & BEDROCK & ROCK \\
\hline GFW & 98 & -- & 310.0 & -- & 0 & $110 \mathrm{SDMN}$ & SAND \\
\hline & & & & & 80.0 & BEDROCK & ROCK \\
\hline GFW & 100 & - & 650.0 & - & 0 & 112 TILL & TILL \\
\hline & & & & & 50.0 & BEDROCK & ROCK \\
\hline GFW & 101 & -- & 277.0 & -- & 0 & 112 TILL & TILL Clay, hardpan \\
\hline & & & & & 75.0 & BEDROCK & ROCK \\
\hline GFW & 112 & -- & 265.0 & -- & 0 & $110 \mathrm{SDMN}$ & OTHR \\
\hline & & & & & 100.0 & BEDROCK & ROCK \\
\hline GFW & 114 & - & 310.0 & -- & 0 & $110 \mathrm{SDMN}$ & CLAY \\
\hline & & & & & 150.0 & BEDROCK & ROCK \\
\hline
\end{tabular}


Table B-1. Stratigraphic logs of selected wells and borings in the Winnipesaukee River Basin, central New Hampshire-Continued

\begin{tabular}{|c|c|c|c|c|c|c|}
\hline $\begin{array}{l}\text { Local } \\
\text { site } \\
\text { number }\end{array}$ & $\begin{array}{l}\text { Depth } \\
\text { drilled } \\
\text { (feet) }\end{array}$ & $\begin{array}{l}\text { Depth } \\
\text { of } \\
\text { well } \\
\text { (feet) }\end{array}$ & $\begin{array}{l}\text { Depth } \\
\text { to } \\
\text { refusal } \\
\text { (feet) }\end{array}$ & $\begin{array}{l}\text { Depth } \\
\text { to } \\
\text { top } \\
\text { (feet) }\end{array}$ & $\begin{array}{l}\text { Aquifer } \\
\text { code }\end{array}$ & $\begin{array}{c}\text { Lithologic description } \\
\text { of } \\
\text { material }\end{array}$ \\
\hline
\end{tabular}

\section{BELKNAP COUNTY}

\begin{tabular}{|c|c|c|c|c|c|c|c|}
\hline \multicolumn{8}{|c|}{ Gilford-Continued } \\
\hline GFW & 118 & -- & 200.0 & -- & $\begin{array}{c}0 \\
80.0\end{array}$ & $\begin{array}{l}\text { 112TILL } \\
\text { BEDROCK }\end{array}$ & $\begin{array}{l}\text { TILI } \\
\text { ROCK }\end{array}$ \\
\hline GFW & 120 & -- & 230.0 & -- & $\begin{array}{c}0 \\
120.0\end{array}$ & $\begin{array}{l}110 S D M N \\
\text { BEDROCK }\end{array}$ & $\begin{array}{l}\text { CLAY } \\
\text { ROCK }\end{array}$ \\
\hline GFW & 121 & -- & 300.0 & -- & $\begin{array}{c}0 \\
30.0\end{array}$ & $\begin{array}{l}110 \text { SDMN } \\
\text { BEDROCK }\end{array}$ & $\begin{array}{l}\text { SDGL } \\
\text { ROCK }\end{array}$ \\
\hline GFW & 123 & -- & 300.0 & -- & $\begin{array}{c}0 \\
87.0\end{array}$ & $\begin{array}{l}110 \text { SDMN } \\
\text { BEDROCK }\end{array}$ & $\begin{array}{l}\text { SDGL } \\
\text { ROCK }\end{array}$ \\
\hline GFW & 124 & -- & 325.0 & -- & $\begin{array}{c}0 \\
50.0\end{array}$ & $\begin{array}{l}110 \text { SDMN } \\
\text { BEDROCK }\end{array}$ & $\begin{array}{l}\text { SAND } \\
\text { ROCK }\end{array}$ \\
\hline GFW & 126 & -- & 225.0 & -- & $\begin{array}{c}0 \\
63.0\end{array}$ & $\begin{array}{l}110 \text { SDMN } \\
\text { BEDROCK }\end{array}$ & $\begin{array}{l}\text { SAND } \\
\text { ROCK }\end{array}$ \\
\hline GFW & 134 & -- & 295.0 & -- & $\begin{array}{c}0 \\
27.0\end{array}$ & $\begin{array}{l}\text { 112TILL } \\
\text { BEDROCK }\end{array}$ & $\begin{array}{l}\text { TILL Gravel, hardpan } \\
\text { ROCK }\end{array}$ \\
\hline GFW & 136 & -- & 375.0 & -- & 83.0 & BEDROCK & ROCK \\
\hline GFW & 139 & -- & 300.0 & -- & $\begin{array}{c}0 \\
100.0 \\
120.0\end{array}$ & $\begin{array}{l}110 \text { SDMN } \\
110 \text { SDMN } \\
\text { BEDROCK }\end{array}$ & $\begin{array}{l}\text { SAND } \\
\text { SDGL } \\
\text { ROCK }\end{array}$ \\
\hline GFW & 147 & -- & 475.0 & -- & $\begin{array}{l}0 \\
91.0\end{array}$ & $\begin{array}{l}110 \text { SDMN } \\
\text { BEDROCK }\end{array}$ & $\begin{array}{l}\text { SGVC } \\
\text { ROCK }\end{array}$ \\
\hline GFW & 148 & - & 700.0 & -- & $\begin{array}{c}0 \\
10.0 \\
58.0\end{array}$ & $\begin{array}{l}110 \text { SDMN } \\
110 \text { SDMN } \\
\text { BEDROCK }\end{array}$ & $\begin{array}{l}\text { SDGL } \\
\text { CLAY } \\
\text { ROCK }\end{array}$ \\
\hline GFW & 151 & -- & 900.0 & -- & $\begin{array}{c}0 \\
70.0\end{array}$ & $\begin{array}{l}110 S D M N \\
\text { BEDROCK }\end{array}$ & $\begin{array}{l}\text { SDGL } \\
\text { ROCK }\end{array}$ \\
\hline GFW & 159 & -- & 325.0 & -- & $\begin{array}{c}0 \\
47.0\end{array}$ & $\begin{array}{l}112 \text { TILL } \\
\text { BEDROCK }\end{array}$ & $\begin{array}{l}\text { TILL Sand, gravel, hardpan } \\
\text { ROCK }\end{array}$ \\
\hline GFW & 162 & -- & 230.0 & -- & $\begin{array}{c}0 \\
102.0\end{array}$ & $\begin{array}{l}112 \text { TILL } \\
\text { BEDROCK }\end{array}$ & $\begin{array}{l}\text { TILL Gravel, clay, hardpan } \\
\text { ROCK }\end{array}$ \\
\hline GFW & 167 & -- & 510.0 & -- & $\begin{array}{c}0 \\
33.0\end{array}$ & $\begin{array}{l}112 \text { TILL } \\
\text { BEDROCK }\end{array}$ & $\begin{array}{l}\text { TILI } \\
\text { ROCK }\end{array}$ \\
\hline GFW & 169 & -- & 325.0 & -- & 170.0 & BEDROCK & ROCK \\
\hline GFW & 178 & -- & 150.0 & -- & $\begin{array}{c}0 \\
29.0\end{array}$ & $\begin{array}{l}110 \text { SDMN } \\
\text { BEDROCK }\end{array}$ & $\begin{array}{l}\text { SDGL } \\
\text { ROCK }\end{array}$ \\
\hline GFW & 182 & -- & 460.0 & -- & $\begin{array}{c}0 \\
95.0\end{array}$ & $\begin{array}{l}110 \text { SDMN } \\
\text { BEDROCK }\end{array}$ & $\begin{array}{l}\text { SDGL } \\
\text { ROCK }\end{array}$ \\
\hline GFW & 183 & -- & 15.0 & - & 0 & 110 SDMN & SAND \\
\hline
\end{tabular}


Table B-1. Stratigraphic logs of selected wells and borings in the Winnipesaukee River Basin, central New Hampshire-Continued

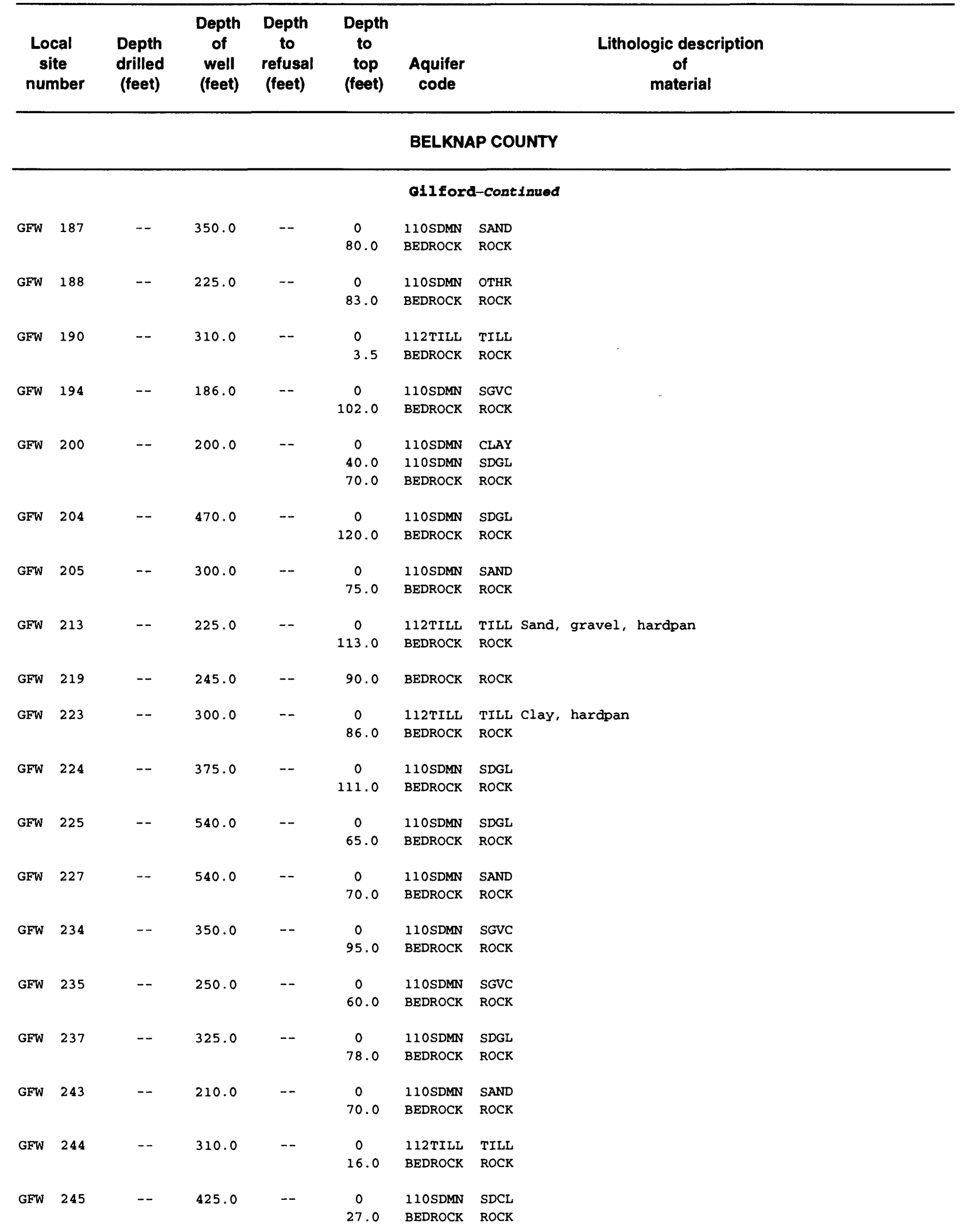


Table B-1. Stratigraphic logs of selected wells and borings in the Winnipesaukee River Basin, central New Hampshire-Continued

\begin{tabular}{|c|c|c|c|c|c|c|}
\hline $\begin{array}{l}\text { Local } \\
\text { site } \\
\text { number }\end{array}$ & $\begin{array}{l}\text { Depth } \\
\text { drified } \\
\text { (feet) }\end{array}$ & $\begin{array}{l}\text { Depth } \\
\text { of } \\
\text { weil } \\
\text { (feet) }\end{array}$ & $\begin{array}{l}\text { Depth } \\
\text { to } \\
\text { refusal } \\
\text { (feet) }\end{array}$ & $\begin{array}{l}\text { Depth } \\
\text { to } \\
\text { top } \\
\text { (feet) }\end{array}$ & $\begin{array}{c}\text { Aquifer } \\
\text { code }\end{array}$ & $\begin{array}{c}\text { Lithologlc description } \\
\text { of } \\
\text { material }\end{array}$ \\
\hline
\end{tabular}

\section{BELKNAP COUNTY}

\begin{tabular}{|c|c|c|c|c|c|c|c|}
\hline \multicolumn{8}{|c|}{ Gilford-Continued } \\
\hline GFW & 246 & -- & 300.0 & -- & $\begin{array}{l}0 \\
88.0\end{array}$ & $\begin{array}{l}\text { 110SDMN } \\
\text { BEDROCK }\end{array}$ & $\begin{array}{l}\text { SGVC } \\
\text { ROCK }\end{array}$ \\
\hline GFW & 252 & 55.3 & 55.3 & -- & $\begin{array}{c}0 \\
43.0\end{array}$ & $\begin{array}{l}112 \mathrm{LCSR} \\
112 \mathrm{LCSR}\end{array}$ & $\begin{array}{l}\text { SAND Sand, fine, tan; small gravel; and clay } \\
\text { SAND Sand, fine, gray; gravel, large, sharp; and } \\
\text { clay; End of hole at } 55.33 \text { feet }\end{array}$ \\
\hline GFW & 253 & 53.9 & 53.9 & -- & $\begin{array}{c}0 \\
41.0\end{array}$ & $\begin{array}{l}112 \mathrm{LCSR} \\
112 \mathrm{LCSR}\end{array}$ & $\begin{array}{l}\text { SAND Sand, fine, gray; and clay } \\
\text { SAND Sand, fine to medium, gray; gravel, large, } \\
\text { broken; specks of clay; refusal at } 53.91 \text { feet }\end{array}$ \\
\hline GFW & 254 & 52.2 & -- & 52.2 & $\begin{array}{l}0 \\
21.0 \\
36.0\end{array}$ & $\begin{array}{l}112 \text { SRFD } \\
112 \text { SRFD } \\
112 \text { SRFD }\end{array}$ & $\begin{array}{l}\text { SDGL Sand, fine to medium, large broken gravel } \\
\text { SAND Fine brown sand and some gravel } \\
\text { SAND Sand, fine to medium, brown, trace of clay }\end{array}$ \\
\hline GFW & 255 & 42.5 & -- & 42.5 & $\begin{array}{c}0 \\
23.0\end{array}$ & $\begin{array}{l}112 \mathrm{LCSR} \\
112 \mathrm{LCSR}\end{array}$ & $\begin{array}{l}\text { SAND Sand, fine to medium, specks of clay, tight } \\
\text { SAND Sand, fine, gray, tight, some clay; refusal at } \\
\quad 42.5 \text { feet }\end{array}$ \\
\hline GFW & 256 & 58.7 & 49.0 & 58.7 & $\begin{array}{l}0 \\
33.0 \\
38.0 \\
49.0\end{array}$ & $\begin{array}{l}112 \mathrm{LCSR} \\
112 \mathrm{LCSR} \\
112 \mathrm{LCSR} \\
112 \mathrm{LCSR}\end{array}$ & $\begin{array}{l}\text { SAND Sand and gravel, fine to medium } \\
\text { SAND Sand, fine to medium, brown } \\
\text { SAND Sand, fine to medium, brown-gray, some gravel } \\
\text { SAND Sand, fine to medium, gray; some gravel; specks } \\
\text { of clay }\end{array}$ \\
\hline GFW & 257 & 61.6 & 61.6 & 61.6 & $\begin{array}{l}0 \\
27.0 \\
33.0 \\
53.0\end{array}$ & $\begin{array}{l}112 \mathrm{LCSR} \\
112 \mathrm{LCSR} \\
112 \mathrm{LCSR} \\
112 \mathrm{LCSR}\end{array}$ & $\begin{array}{l}\text { SAND Sand and gravel, fine to medium; specks of clay } \\
\text { SAND Sand and gravel, fine; specks of clay } \\
\text { SDCL Sand, fine and clay; tight } \\
\text { SAND Sand, fine; brown and gray }\end{array}$ \\
\hline \multicolumn{8}{|c|}{ Laconia } \\
\hline LAA & 1 & 5.0 & -- & -- & $\begin{array}{l}0 \\
5.0\end{array}$ & $\begin{array}{l}112 \text { SRFD } \\
110 \text { SDMN }\end{array}$ & $\begin{array}{l}\text { SAND Sand, medium, brown } \\
\text { SAND Refusal }\end{array}$ \\
\hline LAB & 1 & 37.5 & -- & 37.5 & $\begin{array}{r}0 \\
5.0 \\
10.0 \\
15.0 \\
28.0 \\
31.0 \\
37.5\end{array}$ & $\begin{array}{l}110 \text { SDMN } \\
110 \text { SDMN } \\
110 \text { SDMN } \\
110 \text { SDMN } \\
110 \text { SDMN } \\
110 \text { SDMN } \\
\text { BEDROCK }\end{array}$ & $\begin{array}{l}\text { SDGL Sand and gravel } \\
\text { SAND Sand, coarse } \\
\text { SILT Silt } \\
\text { CLAY Clay } \\
\text { SAND Sand, silty } \\
\text { SAND Sand, silty with stones } \\
\text { ROCK Refusal; bedrock or boulders }\end{array}$ \\
\hline LAB & 2 & 60.0 & -- & -- & $\begin{array}{r}0 \\
9.0 \\
15.0 \\
22.0 \\
30.0 \\
50.0 \\
60.0\end{array}$ & $\begin{array}{l}110 \text { SDMN } \\
110 \text { SDMN } \\
110 \text { SDMN } \\
110 \text { SDMN } \\
110 \text { SDMN } \\
112 \mathrm{TILL} \\
112 \mathrm{TILL}\end{array}$ & $\begin{array}{l}\text { SAND Sand, fine to coarse } \\
\text { MUCK Muck, fibrous } \\
\text { SAND Sand, fine, silty } \\
\text { SILT Silt, varved, little fine sand } \\
\text { SAND Sand, silty } \\
\text { TILL Till, dense, silty } \\
\text { TILL End of hole }\end{array}$ \\
\hline $\mathrm{LAB}$ & 3 & 75.0 & -- & -- & $\begin{array}{r}0 \\
6.0 \\
62.0 \\
75.0\end{array}$ & $\begin{array}{l}110 \text { SDMN } \\
110 \text { SDMN } \\
112 \text { TILL } \\
112 \text { TILL }\end{array}$ & $\begin{array}{l}\text { SAND Sand and muck } \\
\text { SAND Sand, fine, trace of silt } \\
\text { TILL Till, sandy with boulders } \\
\text { TILL End of hole }\end{array}$ \\
\hline
\end{tabular}


Table B-1. Stratigraphic logs of selected wells and borings in the Winnipesaukee River Basin, central New Hampshire-Continued

\begin{tabular}{|c|c|c|c|c|c|c|}
\hline $\begin{array}{l}\text { Local } \\
\text { site } \\
\text { number }\end{array}$ & $\begin{array}{l}\text { Depth } \\
\text { drilled } \\
\text { (feet) }\end{array}$ & $\begin{array}{l}\text { Depth } \\
\text { of } \\
\text { well } \\
\text { (feet) }\end{array}$ & $\begin{array}{l}\text { Depth } \\
\text { to } \\
\text { refusal } \\
\text { (feet) }\end{array}$ & $\begin{array}{l}\text { Depth } \\
\text { to } \\
\text { top } \\
\text { (feet) }\end{array}$ & $\begin{array}{l}\text { Aquifer } \\
\text { code }\end{array}$ & $\begin{array}{c}\text { Lithologic description } \\
\text { of } \\
\text { material }\end{array}$ \\
\hline
\end{tabular}

\section{BELKNAP COUNTY}

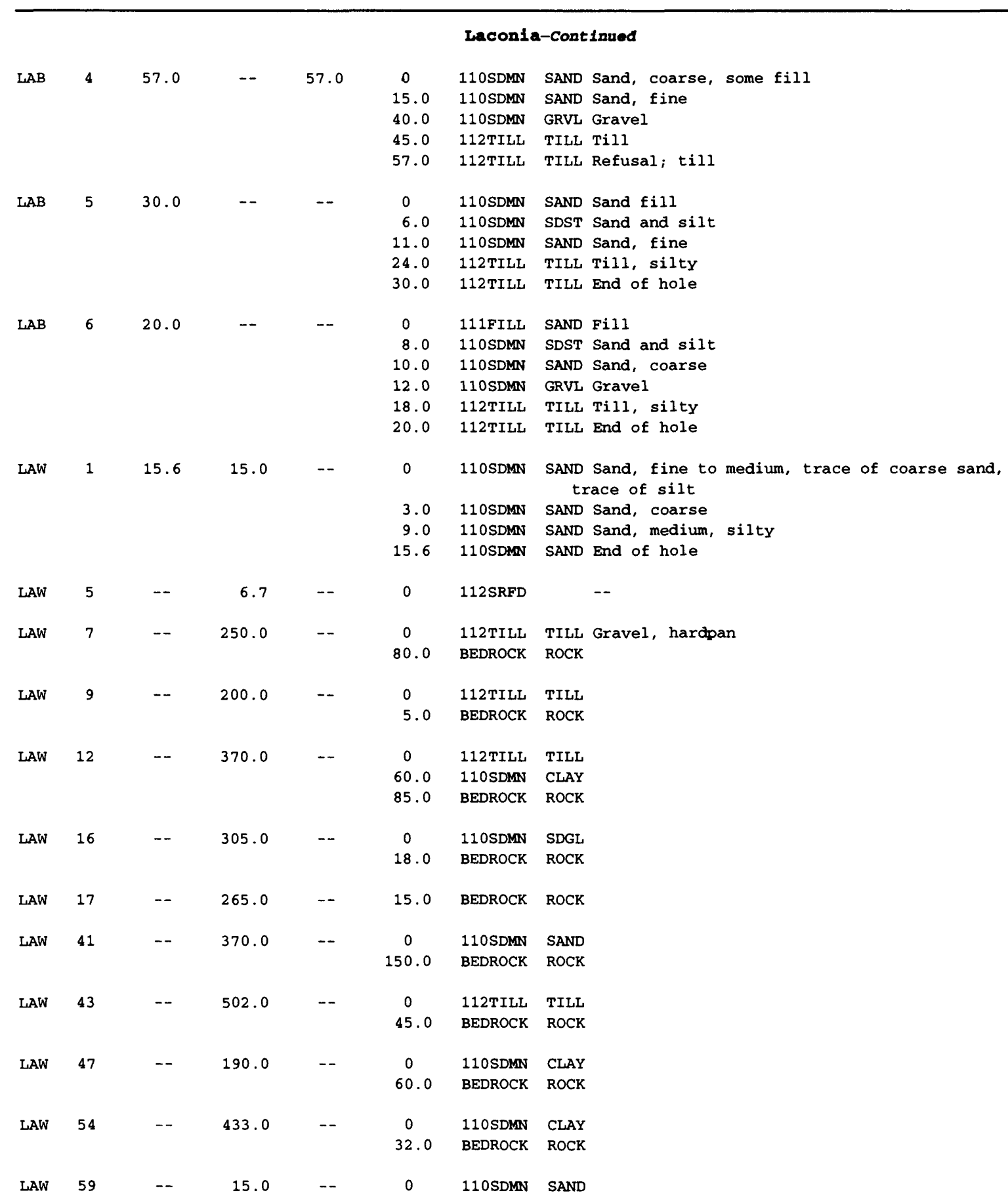


Table B-1. Stratigraphic logs of selected wells and borings in the Winnipesaukee River Basin, central New Hampshire-Continued

\begin{tabular}{|c|c|c|c|c|c|c|}
\hline $\begin{array}{l}\text { Local } \\
\text { site } \\
\text { number }\end{array}$ & $\begin{array}{l}\text { Depth } \\
\text { drilled } \\
\text { (feet) }\end{array}$ & $\begin{array}{l}\text { Depth } \\
\text { of } \\
\text { well } \\
\text { (feet) }\end{array}$ & $\begin{array}{l}\text { Depth } \\
\text { to } \\
\text { refusal } \\
\text { (feet) }\end{array}$ & $\begin{array}{l}\text { Depth } \\
\text { to } \\
\text { top } \\
\text { (feet) }\end{array}$ & $\begin{array}{l}\text { Aquifer } \\
\text { code }\end{array}$ & $\begin{array}{c}\text { Lithologic description } \\
\text { of } \\
\text { material }\end{array}$ \\
\hline
\end{tabular}

\section{BELKNAP COUNTY}

\begin{tabular}{|c|c|c|c|c|c|c|c|c|}
\hline \multicolumn{9}{|c|}{ Laconia-continued } \\
\hline LAW & 70 & -- & 145.0 & -- & $\begin{array}{c}0 \\
70.0\end{array}$ & $\begin{array}{l}\text { 112TILL } \\
\text { BEDROCK }\end{array}$ & $\begin{array}{l}\text { TILL } \\
\text { ROCK }\end{array}$ & . \\
\hline LAW & 71 & -- & 20.0 & -- & $\begin{array}{l}0 \\
8.0\end{array}$ & $\begin{array}{l}110 \text { SDMN } \\
110 \text { SDMN }\end{array}$ & $\begin{array}{l}\text { SAND } \\
\text { SDCL }\end{array}$ & \\
\hline LAW & 75 & -- & 400.0 & -- & $\begin{array}{l}0 \\
6.0\end{array}$ & $\begin{array}{l}110 \text { SDMN } \\
\text { BEDROCK }\end{array}$ & $\begin{array}{l}\text { SDGL } \\
\text { ROCK }\end{array}$ & \\
\hline \multicolumn{9}{|c|}{ Meredith } \\
\hline MHB & 1 & 9.0 & -- & 9.0 & $\begin{array}{l}0 \\
4.0 \\
9.0\end{array}$ & $\begin{array}{l}\text { 110SDMN } \\
112 \text { TILL } \\
\text { BEDROCK }\end{array}$ & $\begin{array}{l}\text { CLAY } \\
\text { TILL } \\
\text { ROCK }\end{array}$ & $\begin{array}{l}\text { Clay } \\
\text { Till } \\
\text { Bedrock }\end{array}$ \\
\hline MHB & 2 & 35.0 & -- & -- & $\begin{array}{c}0 \\
14.0 \\
22.0 \\
27.0 \\
35.0\end{array}$ & $\begin{array}{l}110 \text { SDMN } \\
110 \text { SDMN } \\
110 \text { SDMN } \\
112 \text { TILL } \\
112 \text { TILL }\end{array}$ & $\begin{array}{l}\text { SDST } \\
\text { SILT } \\
\text { SAND } \\
\text { TILL } \\
\text { TILL }\end{array}$ & $\begin{array}{l}\text { Sand, fine and silty } \\
\text { Silt, varved, gray } \\
\text { Sand, fine } \\
\text { Till, dense and sandy } \\
\text { End of hole }\end{array}$ \\
\hline MHB & 3 & 28.0 & -- & 28.0 & $\begin{array}{c}0 \\
10.0 \\
20.0 \\
25.0 \\
28.0\end{array}$ & $\begin{array}{l}110 \text { SDMN } \\
110 \text { SDMN } \\
110 \text { SDMN } \\
110 \text { SDMN } \\
110 \text { SDMN }\end{array}$ & $\begin{array}{l}\text { SAND } \\
\text { SAND } \\
\text { SDCL } \\
\text { OTHR } \\
\text { OTHR }\end{array}$ & $\begin{array}{l}\text { Sand, medium; brown, fine } \\
\text { Sand, fine, clay boulders } \\
\text { Sand, silty, fine, and clay } \\
\text { Silt and hardpan } \\
\text { Refusal }\end{array}$ \\
\hline MHB & 4 & 27.0 & -- & 27.0 & $\begin{array}{c}0 \\
10.0 \\
20.0 \\
24.0 \\
27.0\end{array}$ & $\begin{array}{l}110 \text { SDMN } \\
110 \text { SDMN } \\
110 \text { SDMN } \\
110 \text { SDMN } \\
110 \text { SDMN }\end{array}$ & $\begin{array}{l}\text { SAND } \\
\text { SAND } \\
\text { SAND } \\
\text { HRDP } \\
\text { HRDP }\end{array}$ & $\begin{array}{l}\text { Sand, medium; brown, fine } \\
\text { Sand, fine, silty, boulders } \\
\text { Sand, fine, silty } \\
\text { Hardpan } \\
\text { Refusal }\end{array}$ \\
\hline MHB & 6 & 25.0 & -- & 25.0 & $\begin{array}{r}0 \\
5.0 \\
10.0 \\
20.0 \\
24.0 \\
25.0\end{array}$ & $\begin{array}{l}110 \text { SDMN } \\
110 \text { SDMN } \\
110 \text { SDMN } \\
110 \text { SDMN } \\
110 \text { SDMN } \\
110 \text { SDMN }\end{array}$ & $\begin{array}{l}\text { SAND } \\
\text { SAND } \\
\text { SAND } \\
\text { SAND } \\
\text { HRDP } \\
\text { HRDP }\end{array}$ & $\begin{array}{l}\text { Sand, brown, fine } \\
\text { Sand, brown, medium, trace of clay } \\
\text { Sand, dark brown } \\
\text { Sand, brown, fine, trace of clay } \\
\text { Hardpan } \\
\text { Refusal }\end{array}$ \\
\hline MHB & 7 & 29.0 & -- & 29.0 & $\begin{array}{r}0 \\
5.0 \\
10.0 \\
15.0 \\
20.0 \\
25.0 \\
29.0\end{array}$ & $\begin{array}{l}110 \text { SDMN } \\
110 \text { SDMN } \\
110 \text { SDMN } \\
110 \text { SDMN } \\
110 \text { SDMN } \\
110 \text { SDMN } \\
110 \text { SDMN }\end{array}$ & $\begin{array}{l}\text { SAND } \\
\text { SAND } \\
\text { SAND } \\
\text { SAND } \\
\text { SAND } \\
\text { HRDP } \\
\text { HRDP }\end{array}$ & $\begin{array}{l}\text { Sand, brown, fine } \\
\text { Sand, brown, medium } \\
\text { Sand, brown, medium, trace of clay } \\
\text { Sand, brown, medium, clay } \\
\text { Sand, brown, fine, clay } \\
\text { Hardpan } \\
\text { Refusal }\end{array}$ \\
\hline MHB & 8 & 51.0 & -- & 51.0 & $\begin{array}{r}0 \\
5.0 \\
35.0 \\
45.0 \\
51.0\end{array}$ & $\begin{array}{l}110 \text { SDMN } \\
110 \text { SDMN } \\
110 \text { SDMN } \\
110 S D M N \\
110 S D M N\end{array}$ & $\begin{array}{l}\text { SAND } \\
\text { CLAY } \\
\text { SDCL } \\
\text { SDST } \\
\text { SDST }\end{array}$ & $\begin{array}{l}\text { Sand, brown, medium } \\
\text { Clay, sandy } \\
\text { Sand, fine, and clay } \\
\text { Silt, fine, and sand } \\
\text { Refusal }\end{array}$ \\
\hline
\end{tabular}


Table B-1. Stratigraphic logs of selected wells and borings in the Winnipesaukee River Basin, central New Hampshire-Continued

\begin{tabular}{|c|c|c|c|c|c|c|}
\hline $\begin{array}{l}\text { Local } \\
\text { site } \\
\text { number }\end{array}$ & $\begin{array}{l}\text { Depth } \\
\text { drilled } \\
\text { (feet) }\end{array}$ & $\begin{array}{l}\text { Depth } \\
\text { of } \\
\text { well } \\
\text { (feet) }\end{array}$ & $\begin{array}{l}\text { Depth } \\
\text { to } \\
\text { refusal } \\
\text { (feet) }\end{array}$ & $\begin{array}{l}\text { Depth } \\
\text { to } \\
\text { top } \\
\text { (feet) }\end{array}$ & $\begin{array}{l}\text { Aquifer } \\
\text { code }\end{array}$ & $\begin{array}{c}\text { Lithologic description } \\
\text { of } \\
\text { material }\end{array}$ \\
\hline
\end{tabular}

\section{BELKNAP COUNTY}

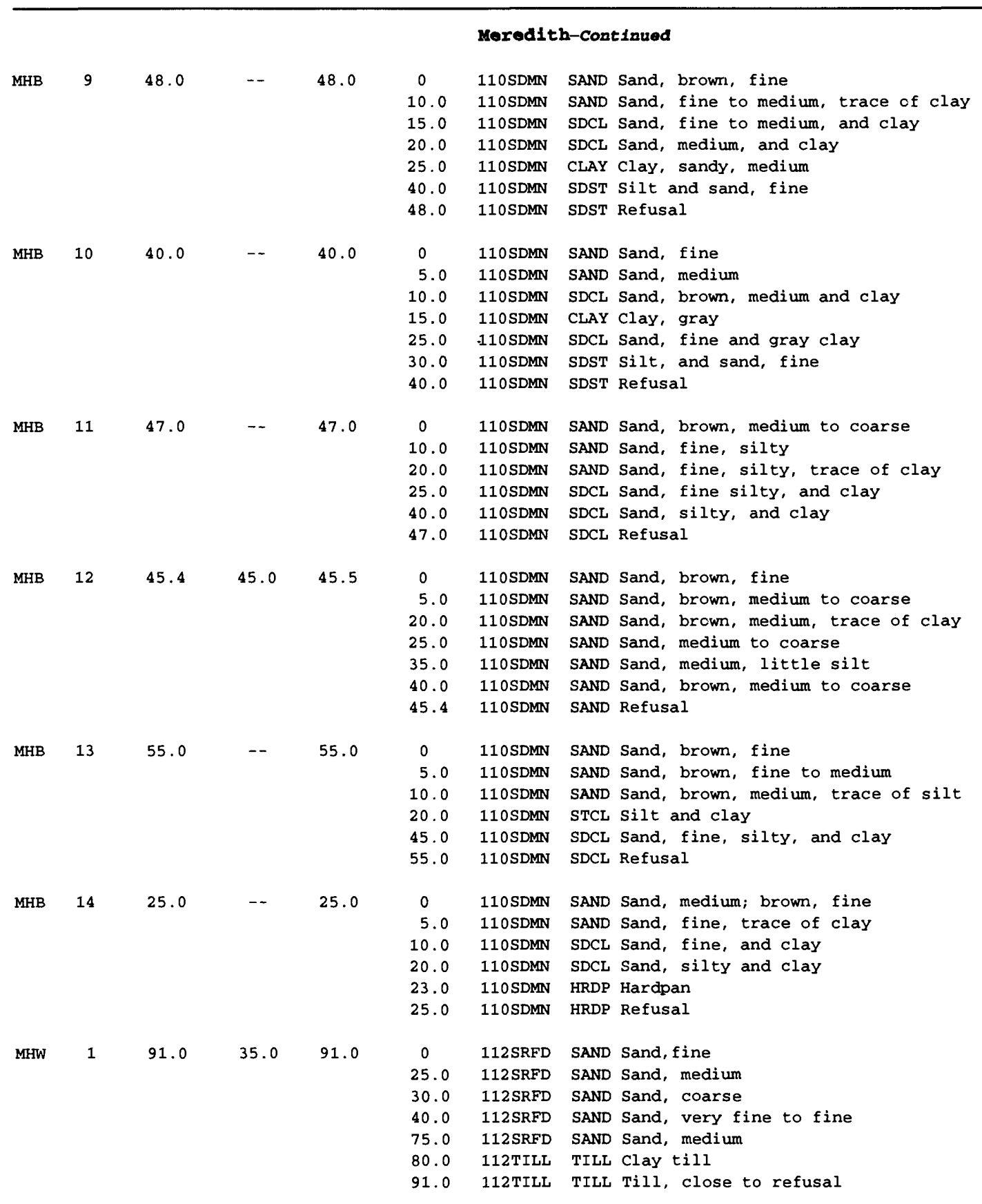


Table B-1. Stratigraphic logs of selected wells and borings in the Winnipesaukee River Basin, central New Hampshire-Continued

\begin{tabular}{|c|c|c|c|c|c|c|}
\hline $\begin{array}{l}\text { Local } \\
\text { site } \\
\text { number }\end{array}$ & $\begin{array}{l}\text { Depth } \\
\text { drilled } \\
\text { (feet) }\end{array}$ & $\begin{array}{c}\text { Depth } \\
\text { of } \\
\text { weil } \\
\text { (feet) }\end{array}$ & $\begin{array}{l}\text { Depth } \\
\text { to } \\
\text { refusal } \\
\text { (feet) }\end{array}$ & $\begin{array}{c}\text { Depth } \\
\text { to } \\
\text { top } \\
\text { (feet) }\end{array}$ & $\begin{array}{l}\text { Aquifer } \\
\text { code }\end{array}$ & $\begin{array}{c}\text { Lithologic description } \\
\text { of } \\
\text { material }\end{array}$ \\
\hline
\end{tabular}

\section{BELKNAP COUNTY}

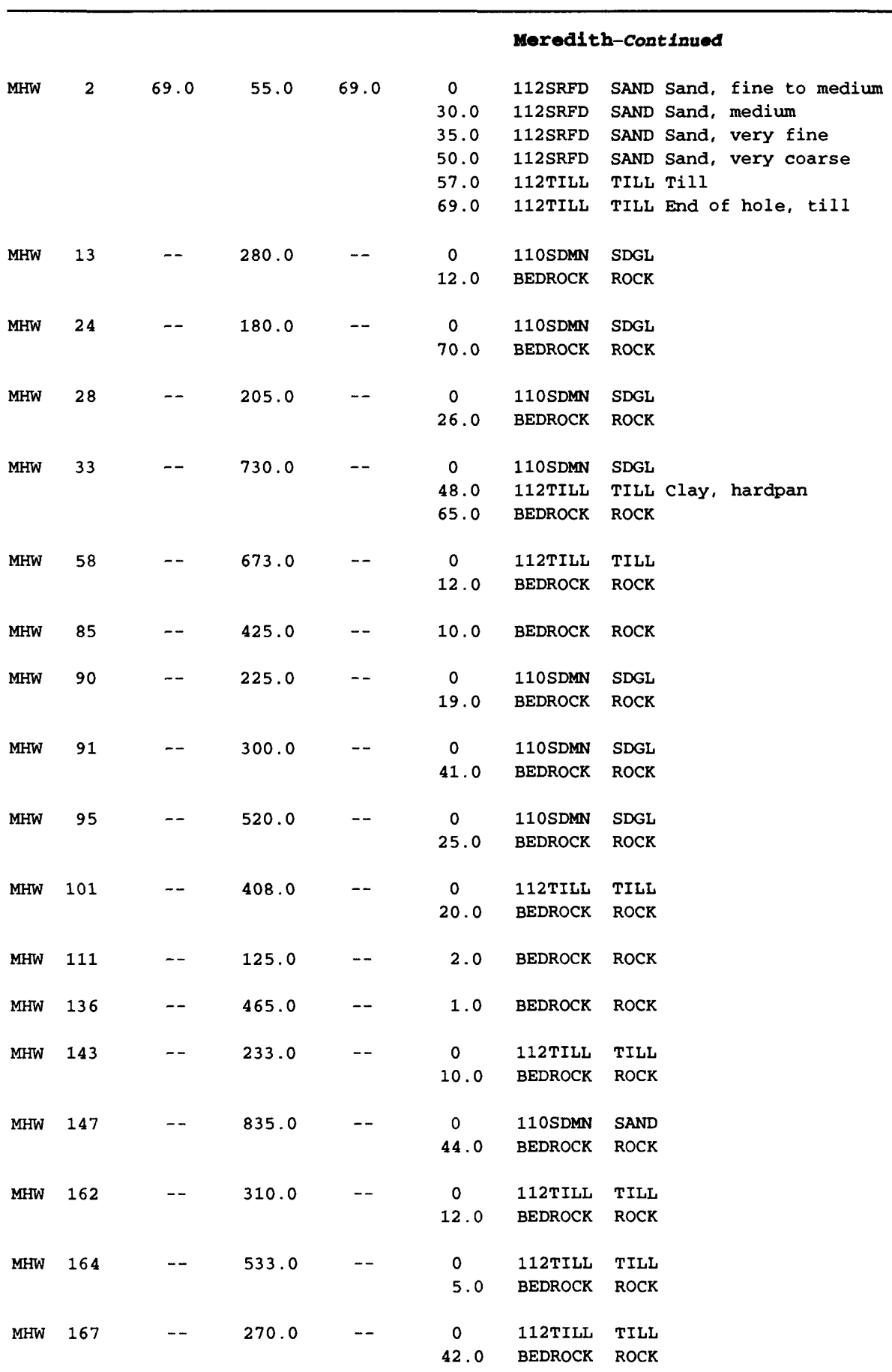


Table B-1. Stratigraphic logs of selected wells and borings in the Winnipesaukee River Basin, central New Hampshire-Continued

\begin{tabular}{|c|c|c|c|c|c|c|}
\hline $\begin{array}{l}\text { Local } \\
\text { site } \\
\text { number }\end{array}$ & $\begin{array}{l}\text { Depth } \\
\text { drilled } \\
\text { (feet) }\end{array}$ & $\begin{array}{l}\text { Depth } \\
\text { of } \\
\text { well } \\
\text { (feet) }\end{array}$ & $\begin{array}{l}\text { Depth } \\
\text { to } \\
\text { refusal } \\
\text { (feet) }\end{array}$ & $\begin{array}{l}\text { Depth } \\
\text { to } \\
\text { top } \\
\text { (feet) }\end{array}$ & $\begin{array}{c}\text { Aquifer } \\
\text { code }\end{array}$ & $\begin{array}{c}\text { Lithologic description } \\
\text { of } \\
\text { material }\end{array}$ \\
\hline
\end{tabular}

\section{BELKNAP COUNTY}

\begin{tabular}{|c|c|c|c|c|c|c|c|}
\hline \multirow[b]{2}{*}{ MHW } & \multirow[b]{2}{*}{185} & \multirow[b]{2}{*}{--} & \multirow[b]{2}{*}{300.0} & \multirow[b]{2}{*}{--} & \multirow[b]{2}{*}{$\begin{array}{c}0 \\
43.0\end{array}$} & \multicolumn{2}{|c|}{ Meredith-Continued } \\
\hline & & & & & & $\begin{array}{l}110 \text { SDMN } \\
\text { BEDROCK }\end{array}$ & $\begin{array}{l}\text { CLAY } \\
\text { ROCK }\end{array}$ \\
\hline MHW & 203 & -- & 277.0 & -- & $\begin{array}{c}0 \\
44.0\end{array}$ & $\begin{array}{l}110 \text { SDMN } \\
\text { BEDROCK }\end{array}$ & $\begin{array}{l}\text { SDCL } \\
\text { ROCK }\end{array}$ \\
\hline MHW & 212 & -- & 205.0 & -- & $\begin{array}{l}0 \\
9.0\end{array}$ & $\begin{array}{l}112 \text { TILL } \\
\text { BEDROCK }\end{array}$ & $\begin{array}{l}\text { TILL Gravel, hardpan } \\
\text { ROCK }\end{array}$ \\
\hline MHW & 216 & -- & 305.0 & -- & $\begin{array}{c}0 \\
10.0\end{array}$ & $\begin{array}{l}110 \text { SDMN } \\
\text { BEDROCK }\end{array}$ & $\begin{array}{l}\text { CLAY } \\
\text { ROCK }\end{array}$ \\
\hline MHW & 223 & -- & 805.0 & -- & $\begin{array}{l}0 \\
67.0\end{array}$ & $\begin{array}{l}110 \text { SDMN } \\
\text { BEDROCK }\end{array}$ & $\begin{array}{l}\text { OTHR } \\
\text { ROCK }\end{array}$ \\
\hline MHW & 236 & -- & 255.0 & -- & $\begin{array}{c}0 \\
10.0\end{array}$ & $\begin{array}{l}110 S D M N \\
\text { BEDROCK }\end{array}$ & $\begin{array}{l}\text { CLAY } \\
\text { ROCK }\end{array}$ \\
\hline MHW & 237 & -- & 280.0 & -- & $\begin{array}{c}0 \\
10.0\end{array}$ & $\begin{array}{l}110 \text { SDMN } \\
\text { BEDROCK }\end{array}$ & $\begin{array}{l}\text { CLAY } \\
\text { ROCK }\end{array}$ \\
\hline MHW & 242 & -- & 400.0 & -- & $\begin{array}{c}0 \\
12.0\end{array}$ & $\begin{array}{l}\text { 110SDMN } \\
\text { BEDROCK }\end{array}$ & $\begin{array}{l}\text { SAND } \\
\text { ROCK }\end{array}$ \\
\hline MHW & 258 & -- & 210.0 & -- & $\begin{array}{c}0 \\
30.0\end{array}$ & $\begin{array}{l}\text { 112TILL } \\
\text { BEDROCK }\end{array}$ & $\begin{array}{l}\text { TILL } \\
\text { ROCK }\end{array}$ \\
\hline MHW & 262 & -- & 250.0 & -- & $\begin{array}{c}0 \\
47.0\end{array}$ & $\begin{array}{l}110 S D M N \\
\text { BEDROCK }\end{array}$ & $\begin{array}{l}\text { SDGL } \\
\text { ROCK }\end{array}$ \\
\hline & & & & & & New & Hampton \\
\hline NHW & 33 & 275.0 & 275.0 & -- & $\begin{array}{c}0 \\
40.0\end{array}$ & $\begin{array}{l}\text { 112SRFD } \\
\text { BEDROCK }\end{array}$ & $\begin{array}{l}\text { SAND } \\
\text { ROCK End of hole at } 275 \text { feet }\end{array}$ \\
\hline NHW & 34 & 252.0 & 252.0 & -- & $\begin{array}{c}0 \\
15.0\end{array}$ & $\begin{array}{l}\text { 112SRFD } \\
\text { BEDROCK }\end{array}$ & $\begin{array}{l}\text { SAND Sand } \\
\text { ROCK End of hole at } 252 \text { feet }\end{array}$ \\
\hline & & & & & & San & bornton \\
\hline $\mathrm{SCB}$ & 3 & 119.0 & -- & 119.0 & $\begin{array}{r}0 \\
86.0 \\
119.0\end{array}$ & $\begin{array}{l}\text { 112LCSR } \\
112 \text { SRFD } \\
\text { BEDROCK }\end{array}$ & $\begin{array}{l}\text { SAND Sand, fine } \\
\text { GRVL Gravel } \\
\text { ROCK Refusal; boulders or bedrock }\end{array}$ \\
\hline SCW & 45 & -- & 140.0 & -- & 60.0 & BEDROCK & \\
\hline SCW & 49 & -- & 200.0 & -- & 30.0 & BEDROCK & \\
\hline SCW & 69 & -- & 225.0 & -- & 25.0 & BEDROCK & ROCK \\
\hline SCW & 81 & -- & 250.0 & -- & $\begin{array}{c}0 \\
10.0\end{array}$ & $\begin{array}{l}\text { 112TILL } \\
\text { BEDROCK }\end{array}$ & $\begin{array}{l}\text { TILL } \\
\text { ROCK }\end{array}$ \\
\hline SCW & 88 & -- & 135.0 & -- & $\begin{array}{c}0 \\
17.0 \\
56.0\end{array}$ & $\begin{array}{l}112 T I L L \\
110 \text { SDMN } \\
\text { BEDROCK }\end{array}$ & $\begin{array}{l}\text { TILL } \\
\text { CLAY } \\
\text { ROCK }\end{array}$ \\
\hline
\end{tabular}


Table B-1. Stratigraphic logs of selected wells and borings in the Winnipesaukee River Basin, central New Hampshire-Continued

\begin{tabular}{|c|c|c|c|c|c|c|}
\hline $\begin{array}{l}\text { Local } \\
\text { site } \\
\text { number }\end{array}$ & $\begin{array}{l}\text { Depth } \\
\text { drilled } \\
\text { (feet) }\end{array}$ & $\begin{array}{l}\text { Depth } \\
\text { of } \\
\text { well } \\
\text { (feet) }\end{array}$ & $\begin{array}{l}\text { Depth } \\
\text { to } \\
\text { refusal } \\
\text { (feet) }\end{array}$ & $\begin{array}{l}\text { Depth } \\
\text { to } \\
\text { top } \\
\text { (feet) }\end{array}$ & $\begin{array}{l}\text { Aquifer } \\
\text { code }\end{array}$ & $\begin{array}{c}\text { Lithologic description } \\
\text { of } \\
\text { material }\end{array}$ \\
\hline
\end{tabular}

\section{BELKNAP COUNTY}

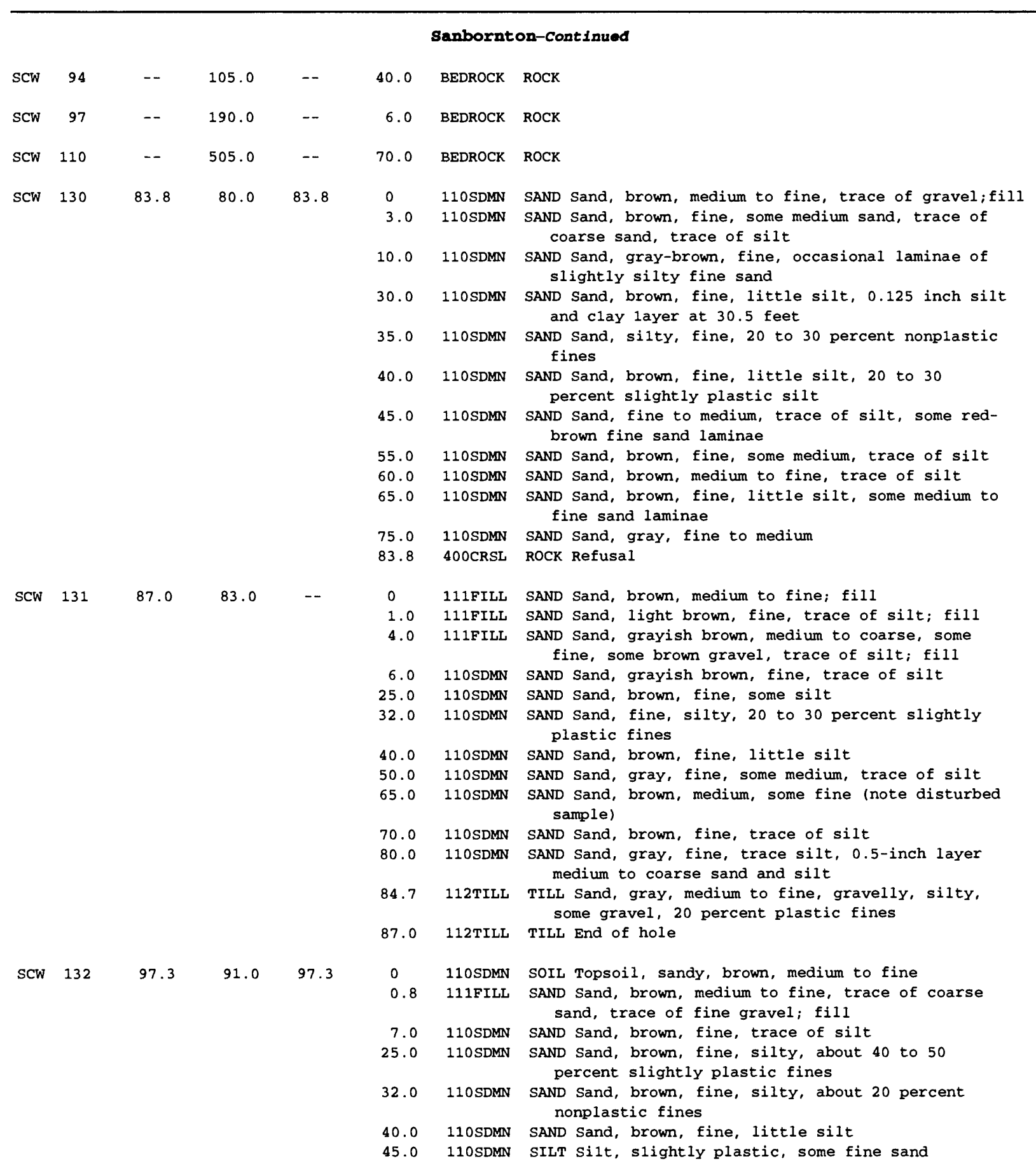


Table B-1. Stratigraphic logs of selected wells and borings in the Winnipesaukee River Basin, central New Hampshire-Continued

\begin{tabular}{|c|c|c|c|c|c|c|}
\hline $\begin{array}{l}\text { Local } \\
\text { site } \\
\text { number }\end{array}$ & $\begin{array}{l}\text { Depth } \\
\text { drilled } \\
\text { (feet) }\end{array}$ & $\begin{array}{l}\text { Depth } \\
\text { of } \\
\text { well } \\
\text { (feet) }\end{array}$ & $\begin{array}{l}\text { Depth } \\
\text { to } \\
\text { refusal } \\
\text { (feet) }\end{array}$ & $\begin{array}{l}\text { Depth } \\
\text { to } \\
\text { top } \\
\text { (feet) }\end{array}$ & $\begin{array}{l}\text { Aquifer } \\
\text { code }\end{array}$ & $\begin{array}{c}\text { Lithologic description } \\
\text { of } \\
\text { material }\end{array}$ \\
\hline
\end{tabular}

BELKNAP COUNTY

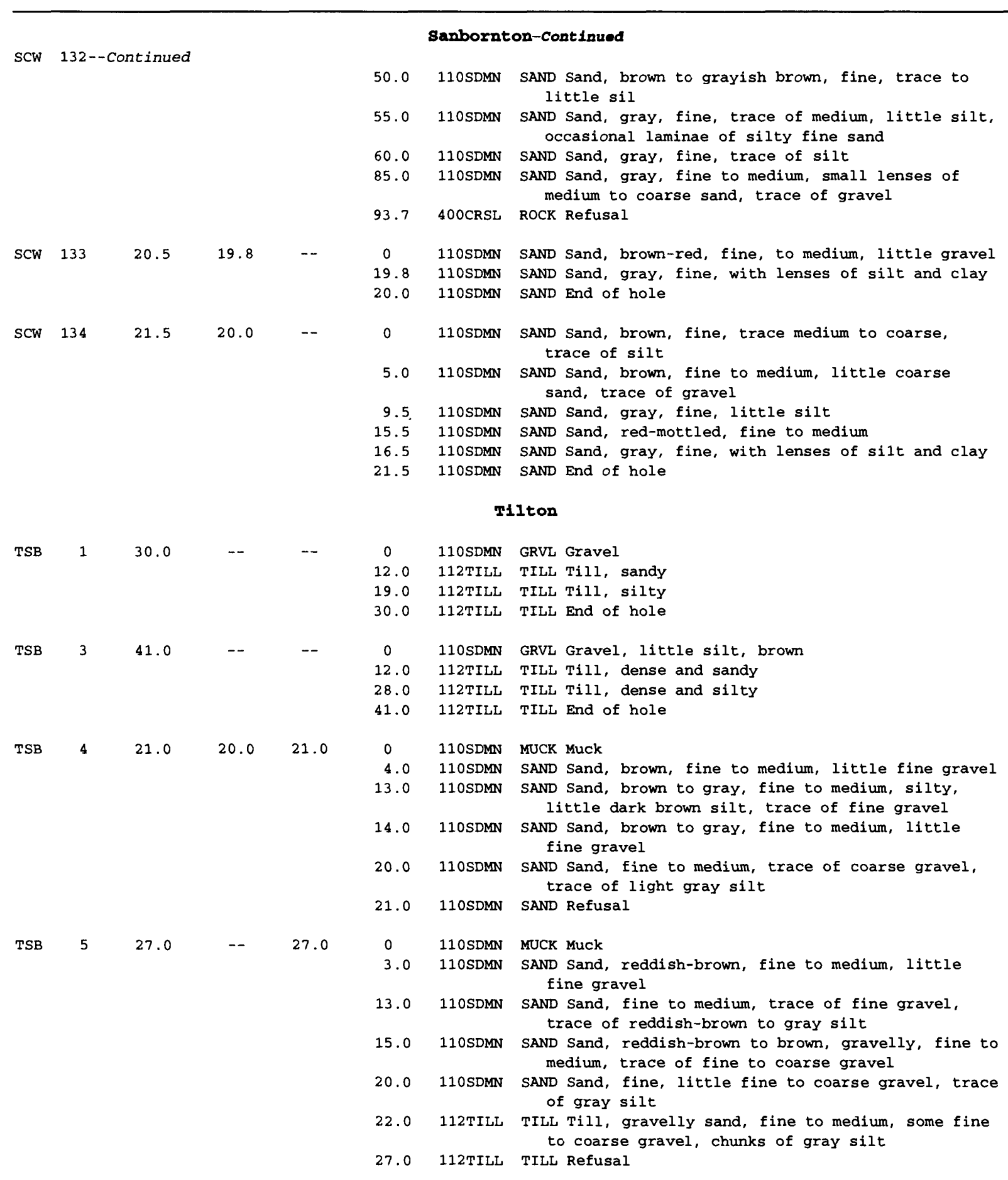


Table B-1. Stratigraphic logs of selected wells and borings in the Winnipesaukee River Basin, central New Hampshire-Continued

\begin{tabular}{|c|c|c|c|c|c|c|}
\hline $\begin{array}{l}\text { Local } \\
\text { site } \\
\text { number }\end{array}$ & $\begin{array}{l}\text { Depth } \\
\text { drilled } \\
\text { (feet) }\end{array}$ & $\begin{array}{l}\text { Depth } \\
\text { of } \\
\text { well } \\
\text { (feet) }\end{array}$ & $\begin{array}{l}\text { Depth } \\
\text { to } \\
\text { refusal } \\
\text { (feet) }\end{array}$ & $\begin{array}{l}\text { Depth } \\
\text { to } \\
\text { top } \\
\text { (feet) }\end{array}$ & $\begin{array}{l}\text { Aquifer } \\
\text { code }\end{array}$ & $\begin{array}{c}\text { Lithologic description } \\
\text { of } \\
\text { material }\end{array}$ \\
\hline
\end{tabular}

\section{BELKNAP COUNTY}

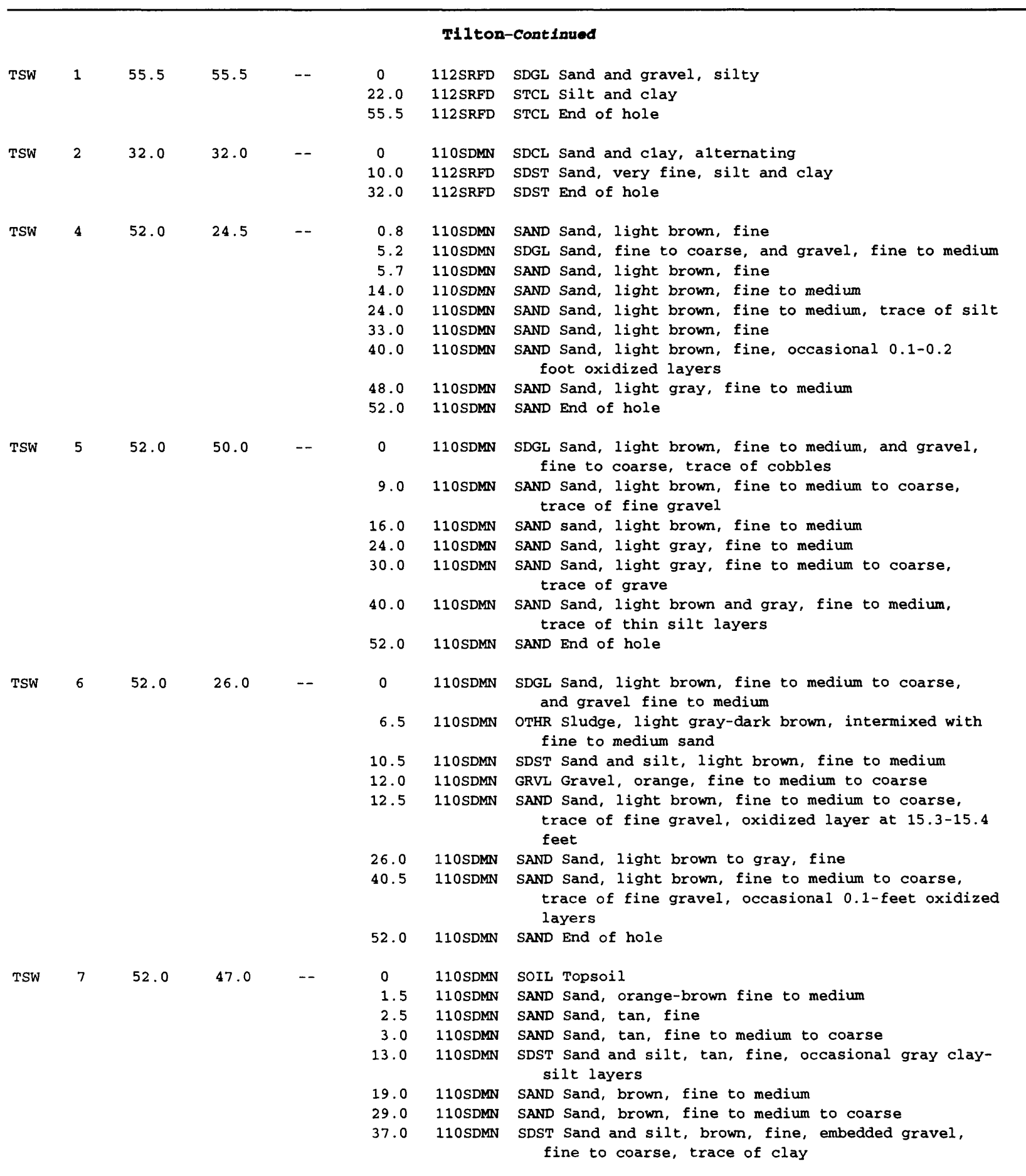


Table B-1. Stratigraphic logs of selected wells and borings in the Winnipesaukee River Basin, central New Hampshire-Continued

\begin{tabular}{|c|c|c|c|c|c|c|}
\hline $\begin{array}{l}\text { Local } \\
\text { site } \\
\text { number }\end{array}$ & $\begin{array}{l}\text { Depth } \\
\text { drilled } \\
\text { (feet) }\end{array}$ & $\begin{array}{l}\text { Depth } \\
\text { of } \\
\text { well } \\
\text { (feet) }\end{array}$ & $\begin{array}{l}\text { Depth } \\
\text { to } \\
\text { refusal } \\
\text { (feet) }\end{array}$ & $\begin{array}{l}\text { Depth } \\
\text { to } \\
\text { top } \\
\text { (feet) }\end{array}$ & $\begin{array}{l}\text { Aquifer } \\
\text { code }\end{array}$ & $\begin{array}{c}\text { Lithologic description } \\
\text { of } \\
\text { material }\end{array}$ \\
\hline
\end{tabular}

\section{BELKNAP COUNTY}

\begin{tabular}{|c|c|c|c|c|c|c|c|}
\hline \multirow{4}{*}{ TSW } & \multicolumn{7}{|c|}{ Tilton-Continued } \\
\hline & \multicolumn{4}{|c|}{ 7--Continued } & \multirow{3}{*}{$\begin{array}{l}41.0 \\
52.0\end{array}$} & \multirow{3}{*}{$\begin{array}{l}11.0 \text { SDMN } \\
110 \text { SDMN }\end{array}$} & \multirow{3}{*}{$\begin{array}{l}\text { GRVL Gravel, fine to coarse, poorly sorted, trace of } \\
\text { fine sand } \\
\text { GRVL End of hole }\end{array}$} \\
\hline & & & & & & & \\
\hline & & & & & & & \\
\hline \multirow[t]{9}{*}{ TSW } & 8 & 52.0 & 30.0 & -- & 0 & 110 SDMN & SOIL Topsoil \\
\hline & & & & & 0.8 & 110 SDMN & SAND Sand, brown, medium to coarse \\
\hline & & & & & 5.0 & $11.0 \mathrm{SDMN}$ & $\begin{array}{l}\text { SAND Sand, light brown, fine to medium, with brown } \\
\text { mottling }\end{array}$ \\
\hline & & & & & 15.0 & 110 SDMN & $\begin{array}{l}\text { SAND Sand, light brown, fine, occasional micaceous } \\
\text { laminae }\end{array}$ \\
\hline & & & & & 20.0 & 110 SDMN & $\begin{array}{l}\text { SAND Sand, brown, fine, trace of silt, some clay } \\
\text { pockets } 0.125 \text {-inch thick }\end{array}$ \\
\hline & & & & & 25.0 & 110 SDMN & SAND Sand, brown-tan, fine, occasional orange mottles \\
\hline & & & & & 34.0 & 110 SDMN & SILT silt, gray, clayey, trace of fine sand \\
\hline & & & & & 42.0 & 110 SDMN & CLAY Clay, gray \\
\hline & & & & & 52.0 & 110 SDMN & CLAY End of hole \\
\hline \multirow[t]{13}{*}{ TSW } & 9 & 52.0 & 31.0 & -- & 0 & 110 SDMN & SOIL TOpsoil \\
\hline & & & & & 0.8 & 110 SDMN & $\begin{array}{l}\text { SAND Sand, brown, medium to coarse, trace of fine } \\
\text { gravel }\end{array}$ \\
\hline & & & & & 10.0 & 110 SDMN & SAND Sand, tan, fine to coarse \\
\hline & & & & & 11.0 & 110 SDMN & SAND Sand, tan, fine \\
\hline & & & & & 15.0 & 110SDMN & SAND Sand, brown, fine to medium \\
\hline & & & & & 20.0 & 110 SDMN & SAND Sand, tan, fine \\
\hline & & & & & 25.0 & 110 SDMN & $\begin{array}{l}\text { SAND Sand, tan, fine, frequent micaceous Iaminae } \\
\text { interbedded }\end{array}$ \\
\hline & & & & & 30.0 & 110 SDMN & $\begin{array}{l}\text { SAND Sand, brown, fine, little silt, frequent } \\
\text { micaceous laminae interbedded }\end{array}$ \\
\hline & & & & & 32.0 & 110 SDMN & $\begin{array}{l}\text { SAND Sand, brown, fine, trace of silt, occasional } \\
0.125 \text {-inch clay lenses }\end{array}$ \\
\hline & & & & & 35.0 & 110 SDMN & CLAY Clay, gray, silty, layered \\
\hline & & & & & 45.0 & 110 SDMN & $\begin{array}{l}\text { SILT silt, gray, clayey, frequent pockets of silty } \\
\text { clay }\end{array}$ \\
\hline & & & & & 50.0 & 110 SDMN & SILT silt, gray, trace of fine sand \\
\hline & & & & & 52.0 & 110 SDMN & SILT End of hole \\
\hline \multirow[t]{11}{*}{ TSW } & 10 & 49.0 & 13.0 & -- & 0 & $110 \mathrm{SDMN}$ & SOIL Topsoil \\
\hline & & & & & 0.8 & 110 SDMN & $\begin{array}{l}\text { SDGL Sand, light brown, fine to medium to coarse, } \\
\text { and gravel, fine to medium }\end{array}$ \\
\hline & & & & & 3.0 & $110 \mathrm{SDMN}$ & $\begin{array}{l}\text { SAND sand, light brown, medium to coarse, trace of } \\
\text { fine gravel }\end{array}$ \\
\hline & & & & & 8.5 & 110 SDMN & SAND Sand, orange-brown, fine to medium \\
\hline & & & & & 14.0 & $110 S D M N$ & $\begin{array}{l}\text { SDST sand, light brown, fine, and silt, with } \\
\text { occasional } 0.0625 \text {-inch oxidized layers }\end{array}$ \\
\hline & & & & & 19.0 & $110 \mathrm{SDMN}$ & $\begin{array}{l}\text { SILT silt, light brown, little fine sand, occasional } \\
0.25 \text {-inch clay layers }\end{array}$ \\
\hline & & & & & 26.0 & 110 SDMN & SDST Sand, gray, fine, and silt \\
\hline & & & & & 28.5 & 110 SDMN & $\begin{array}{l}\text { SAND Sand, gray-purple, fine to medium, trace of } \\
\text { fine to medium gravel, with little to some silt }\end{array}$ \\
\hline & & & & & 38.0 & 110 SDMN & $\begin{array}{l}\text { SAND Sand, light gray, fine to medium, little } \\
\text { embedded fine to coarse gravel, trace of silt }\end{array}$ \\
\hline & & & & & 45.0 & 110 SDMN & $\begin{array}{l}\text { SILT silt, gray, little fine sand, little embedded } \\
\text { gravel, fine to medium, trace of clay }\end{array}$ \\
\hline & & & & & 49.0 & 110 SDMN & SILT End of hole \\
\hline
\end{tabular}


Table B-1. Stratigraphic logs of selected wells and borings in the Winnipesaukee River Basin, central New Hampshire-Continued

\begin{tabular}{|c|c|c|c|c|c|c|}
\hline $\begin{array}{l}\text { Local } \\
\text { site } \\
\text { number }\end{array}$ & $\begin{array}{l}\text { Depth } \\
\text { drilled } \\
\text { (feet) }\end{array}$ & $\begin{array}{l}\text { Depth } \\
\text { of } \\
\text { well } \\
\text { (feet) }\end{array}$ & $\begin{array}{l}\text { Depth } \\
\text { to } \\
\text { refusal } \\
\text { (feet) }\end{array}$ & $\begin{array}{l}\text { Depth } \\
\text { to } \\
\text { top } \\
\text { (feet) }\end{array}$ & $\begin{array}{l}\text { Aquifer } \\
\text { code }\end{array}$ & $\begin{array}{c}\text { Lithologic description } \\
\text { of } \\
\text { material }\end{array}$ \\
\hline
\end{tabular}

\section{BELKNAP COUNTY}

\begin{tabular}{|c|c|c|c|c|c|c|c|}
\hline & & & & & & Tilton & -Continued \\
\hline TSW & 11 & 28.0 & 26.0 & -- & $\begin{array}{r}5 \\
5.0 \\
8.0 \\
20.0 \\
25.0 \\
28.0\end{array}$ & $\begin{array}{l}110 \text { SDMN } \\
110 \text { SDMN } \\
110 \text { SDMN } \\
110 \text { SDMN } \\
110 \text { SDMN } \\
110 \text { SDMN }\end{array}$ & $\begin{array}{l}\text { SDGL Sand and gravel, brown, fine to coarse } \\
\text { SAND Sand, brown, medium to coarse, some gravel } \\
\text { SAND Sand, brown, medium } \\
\text { SAND Sand, dark brown, medium, trace of fine sand } \\
\text { SAND Sand, brown to gray, medium } \\
\text { SAND End of hole }\end{array}$ \\
\hline $\mathrm{TSW}$ & 12 & 31.5 & 30.0 & -- & $\begin{array}{l}0 \\
10.0 \\
14.0 \\
20.0 \\
31.5\end{array}$ & $\begin{array}{l}110 \text { SDMN } \\
110 \text { SDMN } \\
110 \text { SDMN } \\
110 \text { SDMN } \\
110 \text { SDMN }\end{array}$ & $\begin{array}{l}\text { SDGL Sand and gravel, brown, fine to coarse } \\
\text { SDGL Sand and gravel, brown, medium to coarse } \\
\text { SAND Sand, brown, fine to coarse } \\
\text { SAND Sand, tan to brown, fine to coarse } \\
\text { SAND End of hole }\end{array}$ \\
\hline TSW & 13 & 81.5 & 75.0 & -- & $\begin{array}{r}0 \\
3.5 \\
10.0 \\
15.0 \\
20.0 \\
25.0 \\
40.0 \\
45.0 \\
55.0 \\
65.0 \\
75.0 \\
81.5\end{array}$ & $\begin{array}{l}110 \mathrm{SDMN} \\
110 \mathrm{SDMN} \\
110 \mathrm{SDMN} \\
110 \mathrm{SDMN} \\
110 \mathrm{SDMN} \\
110 \mathrm{SDMN} \\
110 \mathrm{SDMN} \\
110 \mathrm{SDMN} \\
110 \mathrm{SDMN} \\
110 \mathrm{SDMN} \\
110 \mathrm{SDMN} \\
110 \mathrm{SDMN}\end{array}$ & $\begin{array}{l}\text { SDGL Sand and gravel, brown, fine to coarse, trace } \\
\text { of silt } \\
\text { SAND Sand, brown, medium } \\
\text { SAND Sand, brown, medium, trace of gravel } \\
\text { SAND Sand, brown, medium to coarse, trace of gravel } \\
\text { SAND Sand, brown, fine to medium } \\
\text { SAND Sand, brown-gray, fine to medium } \\
\text { SAND Sand, brown-gray, fine, trace of medium } \\
\text { SAND Sand, brown to brown-gray, fine to medium } \\
\text { SAND Sand, brown-gray to gray, fine } \\
\text { SAND Sand, gray, fine to very fine } \\
\text { SILT Silt, gray, trace of fine sand } \\
\text { SILT End of hole }\end{array}$ \\
\hline TSW & 14 & 32.0 & 30.5 & -- & $\begin{array}{r}0 \\
3.5 \\
15.0 \\
20.0 \\
30.0 \\
32.0\end{array}$ & $\begin{array}{l}110 \text { SDMN } \\
110 \text { SDMN } \\
110 \text { SDMN } \\
110 \text { SDMN } \\
110 \text { SDMN } \\
110 S D M N\end{array}$ & $\begin{array}{l}\text { SDGL Sand and gravel, brown, fine to coarse, trace } \\
\text { of silt } \\
\text { SAND Sand, brown, medium } \\
\text { SAND Sand, brown, medium, trace of gravel } \\
\text { SAND Sand, brown, medium } \\
\text { SAND Sand, brown-gray, fine } \\
\text { SAND End of hole }\end{array}$ \\
\hline TSW & 15 & 16.5 & 14.5 & -- & $\begin{array}{r}0 \\
9.5 \\
14.5 \\
16.5\end{array}$ & $\begin{array}{l}110 \text { SDMN } \\
110 \text { SDMN } \\
110 \text { SDMN } \\
110 \text { SDMN }\end{array}$ & $\begin{array}{l}\text { SAND Sand, yellow-brown, fine to medium, trace of } \\
\text { silt } \\
\text { SAND Sand, brown-red, fine to coarse, trace of gravel } \\
\text { SAND Sand, gray, fine, little silt } \\
\text { SAND End of hole }\end{array}$ \\
\hline $\mathrm{TSW}$ & 16 & 16.5 & 15.0 & -- & $\begin{array}{l}0 \\
5.0 \\
10.0 \\
16.5\end{array}$ & $\begin{array}{l}110 \text { SDMN } \\
110 \text { SDMN } \\
110 \text { SDMN } \\
110 \text { SDMN }\end{array}$ & $\begin{array}{l}\text { SAND Sand, fine to medium, brown, well graded; some } \\
\text { fine gravel } \\
\text { SDGL Sand, fine to medium, brown, well graded; some } \\
\text { fine gravel } \\
\text { SAND Sand, fine to coarse, brown, well graded; some } \\
\text { fine gravel } \\
\text { SAND End of hole }\end{array}$ \\
\hline TSW & 17 & 16.5 & 15.0 & -- & $\begin{array}{r}0 \\
5.0 \\
10.0 \\
14.0 \\
16.5\end{array}$ & $\begin{array}{l}110 \text { SDMN } \\
110 \text { SDMN } \\
110 \text { SDMN } \\
110 \text { SDMN } \\
110 \text { SDMN }\end{array}$ & $\begin{array}{l}\text { SAND Sand, fine to coarse, red brown, well graded; } \\
\text { little fine gravel } \\
\text { SAND Sand, fine to medium, brown; some fine gravel } \\
\text { CLAY Clay, black, organic; some silt; trace of fine } \\
\text { sand } \\
\text { SAND Sand, fine to medium, well graded; little fine } \\
\text { gravel; trace of silt, gray } \\
\text { SAND End of hole }\end{array}$ \\
\hline
\end{tabular}


Table B-1. Stratigraphic logs of selected wells and borings in the Winnipesaukee River Basin, central New Hampshire-Continued

\begin{tabular}{|c|c|c|c|c|c|c|}
\hline $\begin{array}{l}\text { Local } \\
\text { site } \\
\text { number }\end{array}$ & $\begin{array}{l}\text { Depth } \\
\text { drilled } \\
\text { (feet) }\end{array}$ & $\begin{array}{l}\text { Depth } \\
\text { of } \\
\text { well } \\
\text { (feet) }\end{array}$ & $\begin{array}{l}\text { Depth } \\
\text { to } \\
\text { refusal } \\
\text { (feet) }\end{array}$ & $\begin{array}{l}\text { Depth } \\
\text { to } \\
\text { top } \\
\text { (feet) }\end{array}$ & $\begin{array}{l}\text { Aquifer } \\
\text { code }\end{array}$ & $\begin{array}{c}\text { Lithologic description } \\
\text { of } \\
\text { material }\end{array}$ \\
\hline
\end{tabular}

\section{BELKNAP COUNTY}

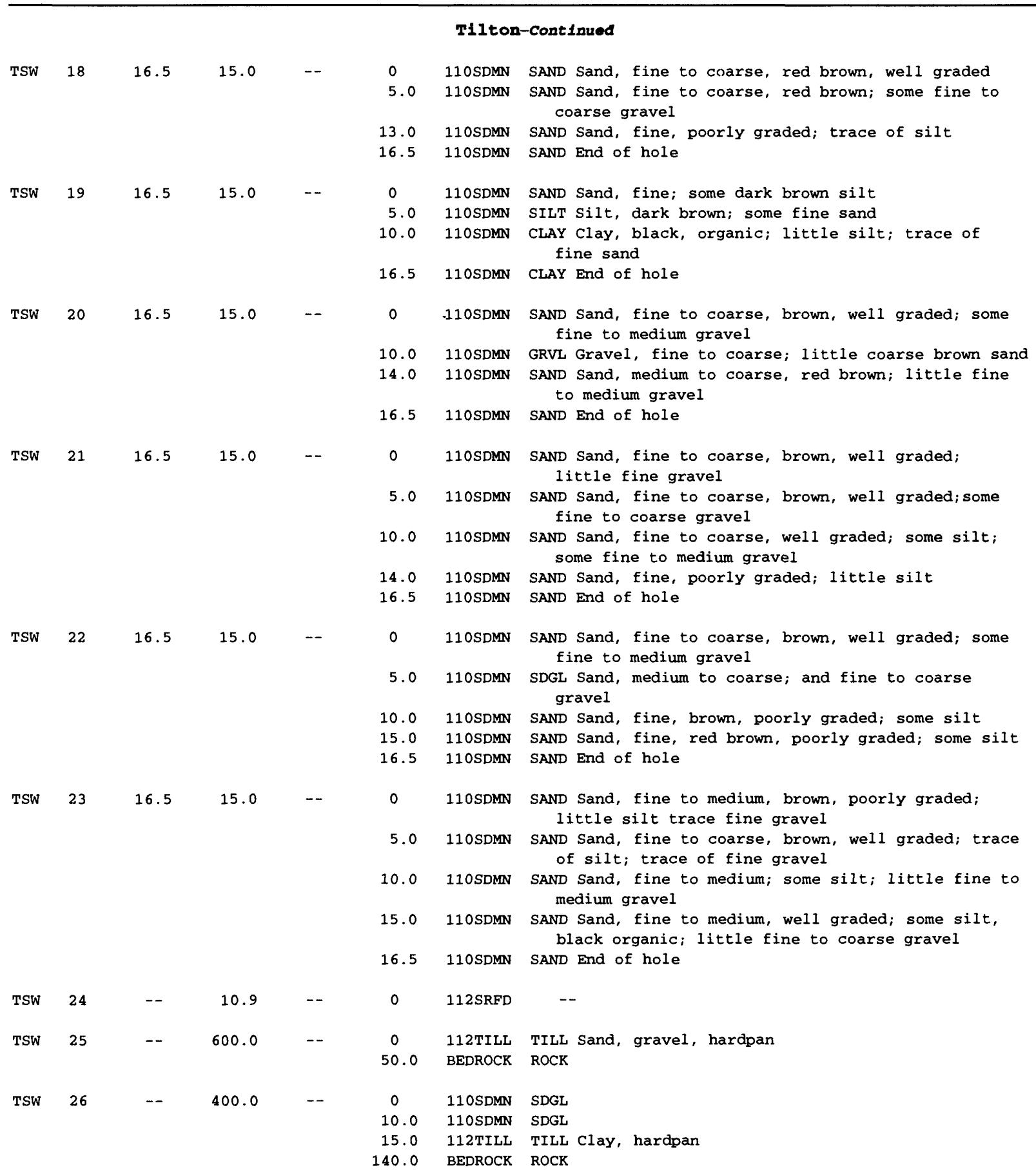


Table B-1. Stratigraphic logs of selected wells and borings in the Winnipesaukee River Basin, central New Hampshire-Continued

\begin{tabular}{|c|c|c|c|c|c|c|}
\hline $\begin{array}{l}\text { Local } \\
\text { site } \\
\text { number }\end{array}$ & $\begin{array}{l}\text { Depth } \\
\text { drilled } \\
\text { (feet) }\end{array}$ & $\begin{array}{l}\text { Depth } \\
\text { of } \\
\text { well } \\
\text { (feet) }\end{array}$ & $\begin{array}{l}\text { Depth } \\
\text { to } \\
\text { refusal } \\
\text { (feet) }\end{array}$ & $\begin{array}{l}\text { Depth } \\
\text { to } \\
\text { top } \\
\text { (feet) }\end{array}$ & $\begin{array}{l}\text { Aquifer } \\
\text { code }\end{array}$ & $\begin{array}{c}\text { Lithologic description } \\
\text { of } \\
\text { materlal }\end{array}$ \\
\hline
\end{tabular}

\section{BELKNAP COUNTY}

\begin{tabular}{|c|c|c|c|c|c|c|c|}
\hline & & & & & & Tilton & -continued \\
\hline TSW & 28 & -- & 280.0 & -- & $\begin{array}{c}0 \\
136.0\end{array}$ & $\begin{array}{l}\text { 112TILL } \\
\text { BEDROCK }\end{array}$ & $\begin{array}{l}\text { TILL } \\
\text { ROCK }\end{array}$ \\
\hline TSW & 33 & -- & 16.0 & -- & $\begin{array}{c}0 \\
5.0 \\
10.0\end{array}$ & $\begin{array}{l}110 \text { SDMN } \\
110 \text { SDMN } \\
110 \text { SDMN }\end{array}$ & $\begin{array}{l}\text { SAND } \\
\text { SDGL } \\
\text { CLAY }\end{array}$ \\
\hline TSW & 34 & -- & 310.0 & -- & $\begin{array}{c}0 \\
85.0\end{array}$ & $\begin{array}{l}\text { 110SDMN } \\
\text { BEDROCK }\end{array}$ & $\begin{array}{l}\text { SAND } \\
\text { ROCK }\end{array}$ \\
\hline TSW & 35 & -- & 280.0 & -- & $\begin{array}{c}0 \\
40.0\end{array}$ & $\begin{array}{l}110 \text { SDMN } \\
\text { BEDROCK }\end{array}$ & $\begin{array}{l}\text { SAND } \\
\text { ROCK }\end{array}$ \\
\hline TSW & 36 & -- & 310.0 & -- & $\begin{array}{c}0 \\
72.0\end{array}$ & $\begin{array}{l}\text { I1OSDMN } \\
\text { BEDROCK }\end{array}$ & $\begin{array}{l}\text { SAND } \\
\text { ROCK }\end{array}$ \\
\hline TSW & 40 & -- & 300.0 & -- & $\begin{array}{c}0 \\
67.0\end{array}$ & $\begin{array}{l}\text { 112TILL } \\
\text { BEDROCK }\end{array}$ & $\begin{array}{l}\text { TILL Gravel, clay, hardpan } \\
\text { ROCK }\end{array}$ \\
\hline TSW & 41 & -- & 230.0 & -- & $\begin{array}{c}0 \\
80.0\end{array}$ & $\begin{array}{l}110 \text { SDMN } \\
\text { BEDROCK }\end{array}$ & $\begin{array}{l}\text { SAND } \\
\text { ROCK }\end{array}$ \\
\hline TSW & 42 & -- & 430.0 & -- & $\begin{array}{c}0 \\
90.0\end{array}$ & $\begin{array}{l}110 \text { SDMN } \\
\text { BEDROCK }\end{array}$ & $\begin{array}{l}\text { SAND } \\
\text { ROCK }\end{array}$ \\
\hline TSW & 43 & -- & 400.0 & -- & 132.0 & BEDROCK & ROCK \\
\hline TSW & 44 & -- & 410.0 & -- & $\begin{array}{c}0 \\
80.0\end{array}$ & $\begin{array}{l}110 S D M N \\
\text { BEDROCK }\end{array}$ & $\begin{array}{l}\text { SAND } \\
\text { ROCK }\end{array}$ \\
\hline TSW & 45 & -- & 310.0 & -- & $\begin{array}{c}0 \\
80.0\end{array}$ & $\begin{array}{l}110 \text { SDMN } \\
\text { BEDROCK }\end{array}$ & $\begin{array}{l}\text { SAND } \\
\text { ROCK }\end{array}$ \\
\hline TSW & 49 & -- & 725.0 & -- & 90.0 & BEDROCK & ROCK \\
\hline TSW & 50 & -- & 365.0 & -- & 140.0 & BEDROCK & ROCK \\
\hline TSW & 52 & -- & 305.0 & -- & 130.0 & BEDROCK & ROCK \\
\hline TSW & 55 & -- & 202.0 & -- & $\begin{array}{c}0 \\
111.0\end{array}$ & $\begin{array}{l}110 \text { SDMN } \\
\text { BEDROCK }\end{array}$ & $\begin{array}{l}\text { SDGL } \\
\text { ROCK }\end{array}$ \\
\hline TSW & 57 & -- & 555.0 & -- & $\begin{array}{r}0 \\
37.0 \\
88.0 \\
93.0 \\
104.0\end{array}$ & $\begin{array}{l}110 \text { SDMN } \\
110 \text { SDMN } \\
110 \text { SDMN } \\
110 \text { SDMN } \\
\text { BEDROCK }\end{array}$ & $\begin{array}{l}\text { SGVC } \\
\text { SGVC } \\
\text { SGVC } \\
\text { SGVC } \\
\text { ROCK }\end{array}$ \\
\hline TSW & 58 & -- & 605.0 & -- & $\begin{array}{r}0 \\
39.0 \\
91.0 \\
100.0\end{array}$ & $\begin{array}{l}110 \text { SDMN } \\
110 \text { SDMN } \\
110 \text { SDMN } \\
\text { BEDROCK }\end{array}$ & $\begin{array}{l}\text { SGVC } \\
\text { SDGL } \\
\text { CLAY } \\
\text { ROCK }\end{array}$ \\
\hline TSW & 59 & -- & 355.0 & -- & $\begin{array}{c}0 \\
37.0 \\
84.0 \\
90.0\end{array}$ & $\begin{array}{l}110 \text { SDMN } \\
110 \text { SDMN } \\
110 \text { SDMN } \\
\text { BEDROCK }\end{array}$ & $\begin{array}{l}\text { SGVC } \\
\text { SGVC } \\
\text { CLAY } \\
\text { ROCK }\end{array}$ \\
\hline
\end{tabular}


Table B-1. Stratigraphic logs of selected wells and borings in the Winnipesaukee River Basin, central New Hampshire-Continued

\begin{tabular}{|c|c|c|c|c|c|c|}
\hline $\begin{array}{l}\text { Local } \\
\text { site } \\
\text { number }\end{array}$ & $\begin{array}{l}\text { Depth } \\
\text { drilled } \\
\text { (feet) }\end{array}$ & $\begin{array}{l}\text { Depth } \\
\text { of } \\
\text { well } \\
\text { (feet) }\end{array}$ & $\begin{array}{l}\text { Depth } \\
\text { to } \\
\text { refusal } \\
\text { (feet) }\end{array}$ & $\begin{array}{l}\text { Depth } \\
\text { to } \\
\text { top } \\
\text { (feet) }\end{array}$ & $\begin{array}{l}\text { Aquifer } \\
\text { code }\end{array}$ & $\begin{array}{c}\text { Lithologic description } \\
\text { of } \\
\text { material }\end{array}$ \\
\hline
\end{tabular}

BELKNAP COUNTY

\begin{tabular}{|c|c|c|c|c|c|c|c|}
\hline & & & & & & Tilton & -continued \\
\hline TSW & 60 & -- & 405.0 & -- & $\begin{array}{c}0 \\
39.0 \\
81.0 \\
93.0\end{array}$ & $\begin{array}{l}110 \text { SDMN } \\
110 \text { SDMN } \\
110 \text { SDMN } \\
\text { BEDROCK }\end{array}$ & $\begin{array}{l}\text { SGVC } \\
\text { SGVC } \\
\text { CLAY } \\
\text { ROCK }\end{array}$ \\
\hline TSW & 61 & -- & 57.0 & -- & $\begin{array}{c}0 \\
49.0\end{array}$ & $\begin{array}{l}110 \mathrm{SDMN} \\
110 \mathrm{SDMN}\end{array}$ & $\begin{array}{l}\text { SGVC } \\
\text { SDGL }\end{array}$ \\
\hline TSW & 65 & -- & 303.0 & -- & $\begin{array}{c}0 \\
135.0\end{array}$ & $\begin{array}{l}\text { 110SDMN } \\
\text { BEDROCK }\end{array}$ & $\begin{array}{l}\text { SDCL } \\
\text { ROCK }\end{array}$ \\
\hline TSW & 67 & -- & 280.0 & -- & $\begin{array}{c}0 \\
135.0\end{array}$ & $\begin{array}{l}\text { 112TILL } \\
\text { BEDROCK }\end{array}$ & $\begin{array}{l}\text { TILL Clay, hardpan } \\
\text { ROCK }\end{array}$ \\
\hline TSW & 69 & -- & 77.0 & -- & $\begin{array}{c}0 \\
60.2\end{array}$ & $\begin{array}{l}\text { 112TILL } \\
\text { BEDROCK }\end{array}$ & $\begin{array}{l}\text { TILL } \\
\text { ROCK }\end{array}$ \\
\hline TSW & 80 & 340.0 & 340.0 & -- & $\begin{array}{r}0 \\
15.0 \\
112.0\end{array}$ & $\begin{array}{l}\text { 112SRFD } \\
\text { 112LCSR } \\
\text { BEDROCK }\end{array}$ & $\begin{array}{l}\text { GRVL Gravel } \\
\text { SDCL Sand, very fine, silt and clay } \\
\text { ROCK Bedrock }\end{array}$ \\
\hline
\end{tabular}

\section{CARROLL COUNTY}

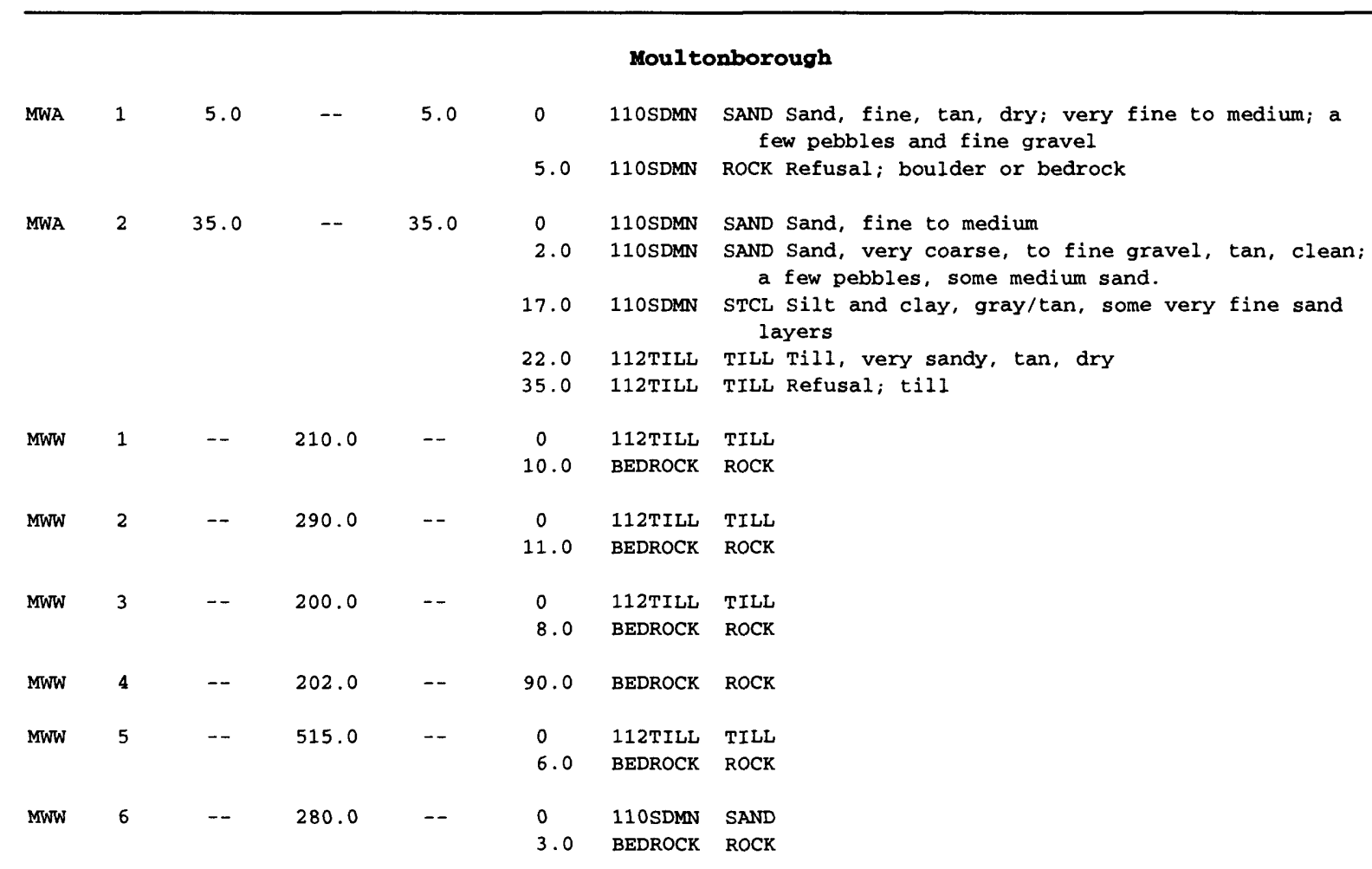


Table B-1. Stratigraphic logs of selected wells and borings in the Winnipesaukee River Basin, central New Hampshire-Continued

\begin{tabular}{|c|c|c|c|c|c|c|}
\hline $\begin{array}{l}\text { Local } \\
\text { slte } \\
\text { number }\end{array}$ & $\begin{array}{l}\text { Depth } \\
\text { drilled } \\
\text { (feet) }\end{array}$ & $\begin{array}{l}\text { Depth } \\
\text { of } \\
\text { well } \\
\text { (feet) }\end{array}$ & $\begin{array}{l}\text { Depth } \\
\text { to } \\
\text { refusal } \\
\text { (feet) }\end{array}$ & $\begin{array}{l}\text { Depth } \\
\text { to } \\
\text { top } \\
\text { (feet) }\end{array}$ & $\begin{array}{l}\text { Aquifer } \\
\text { code }\end{array}$ & $\begin{array}{c}\text { Lithologic descriptlon } \\
\text { of } \\
\text { material }\end{array}$ \\
\hline
\end{tabular}

\section{CARROLL COUNTY}

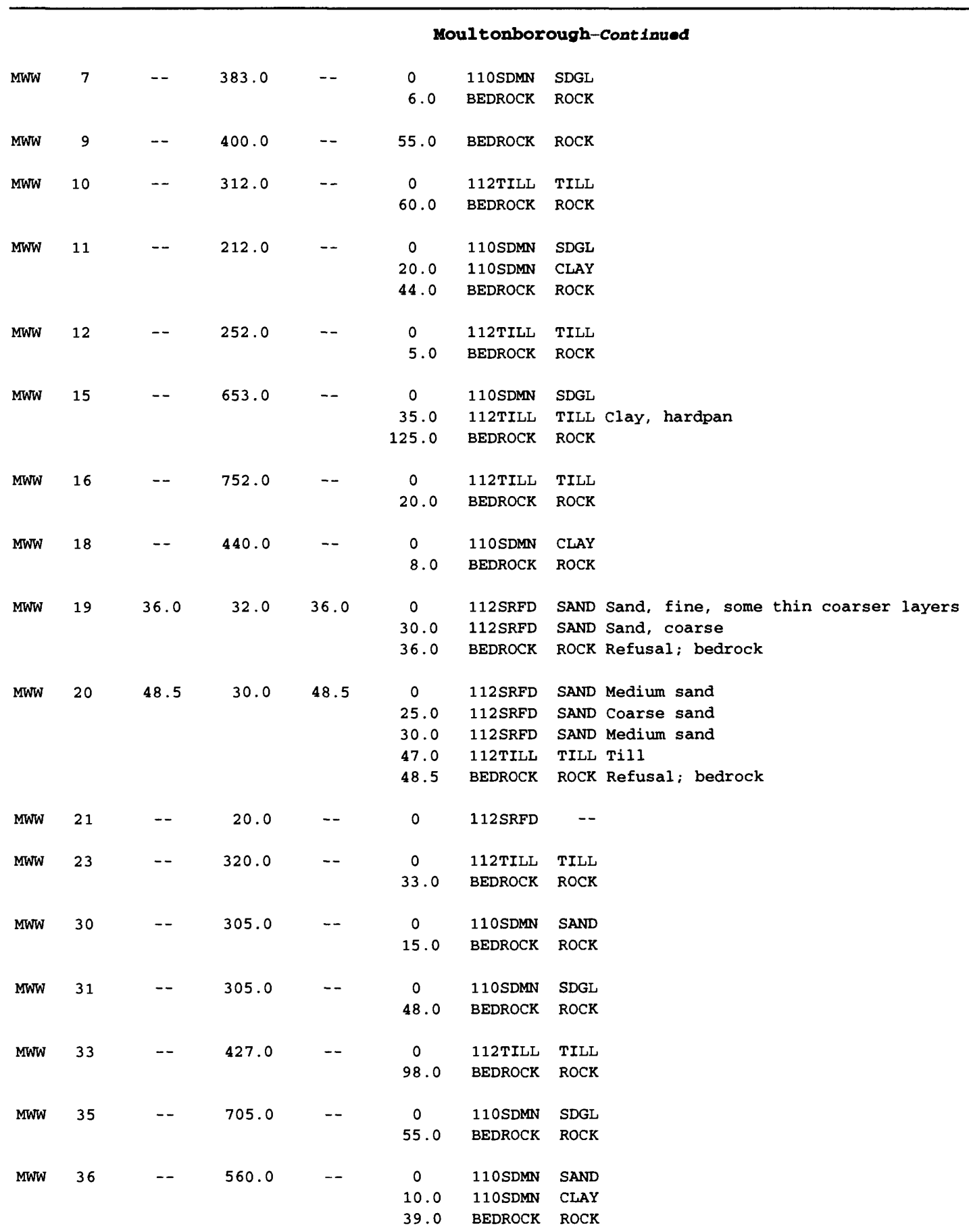


Table B-1. Stratigraphic logs of selected wells and borings in the Winnipesaukee River Basin, central New Hampshire-Continued

\begin{tabular}{ccccccc}
\hline $\begin{array}{c}\text { Local } \\
\text { site } \\
\text { number }\end{array}$ & $\begin{array}{c}\text { Depth } \\
\text { drilled } \\
\text { (feet) }\end{array}$ & $\begin{array}{c}\text { Depth } \\
\text { of } \\
\text { well } \\
\text { (feet) }\end{array}$ & $\begin{array}{c}\text { Depth } \\
\text { to } \\
\text { refusal } \\
\text { (feet) }\end{array}$ & $\begin{array}{c}\text { Depth } \\
\text { to } \\
\text { top } \\
\text { (feet) }\end{array}$ & $\begin{array}{c}\text { Aquifer } \\
\text { code }\end{array}$ & $\begin{array}{c}\text { Lithologic description } \\
\text { of } \\
\text { material }\end{array}$ \\
\hline & & & & CARROLL COUNTY & \\
\hline
\end{tabular}

\begin{tabular}{|c|c|c|c|c|c|c|c|}
\hline \multirow{3}{*}{ MWW } & \multirow{3}{*}{52} & \multirow{3}{*}{--} & \multirow{3}{*}{455.0} & \multirow{3}{*}{--} & \multicolumn{3}{|c|}{ Moultonborough-Continued } \\
\hline & & & & & 0 & 110 SDMN & SDGL \\
\hline & & & & & 30.0 & BEDROCK & ROCK \\
\hline \multirow[t]{3}{*}{ MWW } & 53 & -- & 230.0 & -- & 0 & 110 SDMN & SDGL \\
\hline & & & & & 12.0 & 112TILL & TILL Clay, hardpan \\
\hline & & & & & 28.0 & BEDROCK & ROCK \\
\hline \multirow[t]{3}{*}{ MWW } & 54 & -- & 106.0 & -- & 0 & 112TILL & TILL \\
\hline & & & & & 7.0 & 110SDMN & CLAY \\
\hline & & & & & 23.0 & BEDROCK & ROCK \\
\hline \multirow[t]{2}{*}{ MWW } & 55 & -- & 450.0 & -- & 0 & 110 SDMN & SDGL \\
\hline & & & & & 65.0 & BEDROCK & ROCK \\
\hline \multirow[t]{2}{*}{ MWW } & 64 & -- & 330.0 & -- & 0 & $110 \mathrm{SDMN}$ & SDGL \\
\hline & & & & & 30.0 & BEDROCK & ROCK \\
\hline \multirow[t]{2}{*}{ MWW } & 66 & -- & 410.0 & -- & 0 & 112TILL & TILL \\
\hline & & & & & 6.0 & BEDROCK & ROCK \\
\hline \multirow[t]{2}{*}{ MWW } & 68 & -- & 253.0 & -- & 0 & 112TILL & TILL \\
\hline & & & & & 10.0 & BEDROCK & ROCK \\
\hline \multirow[t]{2}{*}{ MWW } & 70 & -- & 330.0 & -- & 0 & $110 \mathrm{SDMN}$ & SAND \\
\hline & & & & & 10.0 & BEDROCK & ROCK \\
\hline \multirow[t]{2}{*}{ MWW } & 71 & -- & 172.0 & -- & 0 & $110 \mathrm{SDMN}$ & SAND \\
\hline & & & & & 7.0 & BEDROCK & ROCK \\
\hline \multirow[t]{2}{*}{ MWW } & 72 & -- & 550.0 & -- & 0 & $110 \mathrm{SDMN}$ & SDGL \\
\hline & & & & & 120.0 & BEDROCK & ROCK \\
\hline \multirow[t]{2}{*}{ MWW } & 81 & -- & 233.0 & -- & 0 & 112 TILL & TILL \\
\hline & & & & & 5.0 & BEDROCK & ROCK \\
\hline \multirow[t]{2}{*}{ MWW } & 84 & -- & 713.0 & -- & 0 & $112 \mathrm{TILL}$ & TILL \\
\hline & & & & & 3.0 & BEDROCK & ROCK \\
\hline \multirow[t]{2}{*}{ MWW } & 88 & -- & 565.0 & -- & 0 & 112TILL & TILL \\
\hline & & & & & 70.0 & BEDROCK & ROCK \\
\hline \multirow[t]{2}{*}{ MWW } & 96 & -- & 290.0 & -- & 0 & 112TILL & TILL \\
\hline & & & & & 6.0 & BEDROCK & $\mathrm{ROCK}$ \\
\hline \multirow[t]{2}{*}{ MWW } & 101 & -- & 400.0 & -- & 0 & $112 \mathrm{TILL}$ & TILL Clay, hardpan \\
\hline & & & & & 60.0 & BEDROCK & ROCK \\
\hline \multirow[t]{2}{*}{ MWW } & 103 & -- & 275.0 & -- & 0 & $110 \mathrm{SDMN}$ & SAND \\
\hline & & & & & 18.0 & BEDROCK & ROCK \\
\hline \multirow[t]{2}{*}{ MWW } & 106 & -- & 550.0 & -- & 0 & $110 \mathrm{SDMN}$ & SAND \\
\hline & & & & & 11.0 & BEDROCK & ROCK \\
\hline \multirow[t]{2}{*}{ MWW } & 111 & -- & 325.0 & -- & 0 & $110 \mathrm{SDMN}$ & SDGL \\
\hline & & & & & 50.0 & BEDROCK & ROCK \\
\hline
\end{tabular}


Table B-1. Stratigraphic logs of selected wells and borings in the Winnipesaukee River Basin, central New Hampshire-Continued

\begin{tabular}{|c|c|c|c|c|c|c|}
\hline $\begin{array}{l}\text { Local } \\
\text { site } \\
\text { number }\end{array}$ & $\begin{array}{l}\text { Depth } \\
\text { drilled } \\
\text { (feet) }\end{array}$ & $\begin{array}{c}\text { Depth } \\
\text { of } \\
\text { well } \\
\text { (feet) }\end{array}$ & $\begin{array}{l}\text { Depth } \\
\text { to } \\
\text { refusal } \\
\text { (feet) }\end{array}$ & $\begin{array}{l}\text { Depth } \\
\text { to } \\
\text { top } \\
\text { (feet) }\end{array}$ & $\begin{array}{l}\text { Aquifer } \\
\text { code }\end{array}$ & $\begin{array}{c}\text { Lithologic description } \\
\text { of } \\
\text { material }\end{array}$ \\
\hline
\end{tabular}

\section{CARROLL COUNTY}

\begin{tabular}{|c|c|c|c|c|c|c|c|}
\hline \multicolumn{8}{|c|}{ Moultonborough-Continued } \\
\hline MWW & 114 & -- & 140.0 & -- & $\begin{array}{c}0 \\
11.0\end{array}$ & $\begin{array}{l}112 \text { TILL } \\
\text { BEDROCK }\end{array}$ & $\begin{array}{l}\text { TILL } \\
\text { ROCK }\end{array}$ \\
\hline MWW & 116 & -- & 210.0 & -- & $\begin{array}{l}0 \\
4.0\end{array}$ & $\begin{array}{l}110 \text { SDMN } \\
\text { BEDROCK }\end{array}$ & $\begin{array}{l}\text { SAND } \\
\text { ROCK }\end{array}$ \\
\hline MWW & 120 & -- & 270.0 & -- & $\begin{array}{c}0 \\
18.0\end{array}$ & $\begin{array}{l}112 \text { TILL } \\
\text { BEDROCK }\end{array}$ & $\begin{array}{l}\text { TILL } \\
\text { ROCK }\end{array}$ \\
\hline MWW & 132 & -- & 272.0 & -- & $\begin{array}{l}0 \\
5.0\end{array}$ & $\begin{array}{l}112 \text { TILL } \\
\text { BEDROCK }\end{array}$ & $\begin{array}{l}\text { TILL } \\
\text { ROCK }\end{array}$ \\
\hline MWW & 153 & -- & 522.0 & -- & $\begin{array}{c}0 \\
60.0\end{array}$ & $\begin{array}{l}\text { 112TILL } \\
\text { BEDROCK }\end{array}$ & $\begin{array}{l}\text { TILL Clay, hardpan } \\
\text { ROCK }\end{array}$ \\
\hline MWW & 155 & -- & 330.0 & -- & $\begin{array}{l}0 \\
6.0\end{array}$ & $\begin{array}{l}112 \text { TILL } \\
\text { BEDROCK }\end{array}$ & $\begin{array}{l}\text { TILL } \\
\text { ROCK }\end{array}$ \\
\hline MWW & 165 & -- & 623.0 & -- & $\begin{array}{c}0 \\
50.0 \\
90.0\end{array}$ & $\begin{array}{l}112 \text { TILL } \\
110 \text { SDMN } \\
\text { BEDROCK }\end{array}$ & $\begin{array}{l}\text { TILL } \\
\text { CLAY } \\
\text { ROCK }\end{array}$ \\
\hline MWW & 171 & $-\cdots$ & 462.0 & -- & $\begin{array}{c}0 \\
28.0\end{array}$ & $\begin{array}{l}110 \text { SDMN } \\
\text { BEDROCK }\end{array}$ & $\begin{array}{l}\text { CLAY } \\
\text { ROCK }\end{array}$ \\
\hline MWW & 177 & -- & 273.0 & -- & $\begin{array}{c}0 \\
15.0\end{array}$ & $\begin{array}{l}\text { 112TILL } \\
\text { BEDROCK }\end{array}$ & $\begin{array}{l}\text { TILL } \\
\text { ROCK }\end{array}$ \\
\hline MWW & 179 & -- & 353.0 & -- & $\begin{array}{c}0 \\
82.0\end{array}$ & $\begin{array}{l}112 T I L L \\
\text { BEDROCK }\end{array}$ & $\begin{array}{l}\text { TILL Clay, hardpan } \\
\text { ROCK }\end{array}$ \\
\hline MWW & 180 & -- & 277.0 & -- & $\begin{array}{c}0 \\
20.0\end{array}$ & $\begin{array}{l}110 \text { SDMN } \\
\text { BEDROCK }\end{array}$ & $\begin{array}{l}\text { SDCL } \\
\text { ROCK }\end{array}$ \\
\hline MWW & 181 & -- & 333.0 & -- & $\begin{array}{c}0 \\
15.0\end{array}$ & $\begin{array}{l}110 \text { SDMN } \\
\text { BEDROCK }\end{array}$ & $\begin{array}{l}\text { SAND } \\
\text { ROCK }\end{array}$ \\
\hline MWW & 183 & -- & 272.0 & -- & $\begin{array}{l}0 \\
79.0\end{array}$ & $\begin{array}{l}110 S D M N \\
\text { BEDROCK }\end{array}$ & $\begin{array}{l}\text { SDGL } \\
\text { ROCK }\end{array}$ \\
\hline MWW & 187 & -- & 550.0 & -- & $\begin{array}{c}0 \\
25.0\end{array}$ & $\begin{array}{l}110 \text { SDMN } \\
\text { BEDROCK }\end{array}$ & $\begin{array}{l}\text { SDCL } \\
\text { ROCK }\end{array}$ \\
\hline MWW & 194 & -- & 874.0 & -- & $\begin{array}{c}0 \\
22.0\end{array}$ & $\begin{array}{l}112 \text { TILL } \\
\text { BEDROCK }\end{array}$ & $\begin{array}{l}\text { TILL Gravel, hardpan } \\
\text { ROCK }\end{array}$ \\
\hline MWW & 197 & -- & 1600.0 & -- & $\begin{array}{c}0 \\
40.0\end{array}$ & $\begin{array}{l}112 T I L L \\
\text { BEDROCK }\end{array}$ & $\begin{array}{l}\text { TILL Gravel, hardpan } \\
\text { ROCK }\end{array}$ \\
\hline MWW & 198 & -- & 613.0 & -- & $\begin{array}{l}0 \\
6.0\end{array}$ & $\begin{array}{l}112 \text { TILL } \\
\text { BEDROCK }\end{array}$ & $\begin{array}{l}\text { TILL } \\
\text { ROCK }\end{array}$ \\
\hline MWW & 199 & -- & 1110.0 & -- & $\begin{array}{l}0 \\
15.0\end{array}$ & $\begin{array}{l}\text { 112TILL } \\
\text { BEDROCK }\end{array}$ & $\begin{array}{l}\text { TILL } \\
\text { ROCK }\end{array}$ \\
\hline MWW & 201 & -- & 350.0 & -- & $\begin{array}{c}0 \\
12.0\end{array}$ & $\begin{array}{l}\text { 11OSDMN } \\
\text { BEDROCK }\end{array}$ & $\begin{array}{l}\text { SAND } \\
\text { ROCK }\end{array}$ \\
\hline
\end{tabular}


Table B-1. Stratigraphic logs of selected wells and borings in the Winnipesaukee River Basin, central New Hampshire-Continued

\begin{tabular}{|c|c|c|c|c|c|c|c|}
\hline \multicolumn{2}{|c|}{$\begin{array}{l}\text { Local } \\
\text { site } \\
\text { number }\end{array}$} & \multirow[t]{2}{*}{$\begin{array}{l}\text { Depth } \\
\text { drilled } \\
\text { (feet) }\end{array}$} & \multirow[t]{2}{*}{$\begin{array}{l}\text { Depth } \\
\text { of } \\
\text { well } \\
\text { (feet) }\end{array}$} & \multirow[t]{2}{*}{$\begin{array}{l}\text { Depth } \\
\text { to } \\
\text { refusal } \\
\text { (feet) }\end{array}$} & \multirow[t]{2}{*}{$\begin{array}{l}\text { Depth } \\
\text { to } \\
\text { top } \\
\text { (feet) }\end{array}$} & \multicolumn{2}{|r|}{$\begin{array}{c}\text { Lithologic description } \\
\text { of } \\
\text { material }\end{array}$} \\
\hline \multicolumn{4}{|c|}{ CARROLL COUNTY } & & & & \\
\hline \multicolumn{8}{|c|}{ Moultonborough-Continued } \\
\hline MWW & 203 & -- & 453.0 & -- & $\begin{array}{c}0 \\
12.0\end{array}$ & $\begin{array}{l}\text { 112TILL } \\
\text { BEDROCK }\end{array}$ & $\begin{array}{l}\text { TILL } \\
\text { ROCK }\end{array}$ \\
\hline MWW & 206 & -- & 600.0 & -- & $\begin{array}{c}0 \\
42.0\end{array}$ & $\begin{array}{l}110 \text { SDMN } \\
\text { BEDROCK }\end{array}$ & $\begin{array}{l}\text { SAND } \\
\text { ROCK }\end{array}$ \\
\hline MWW & 207 & -- & 250.0 & -- & $\begin{array}{c}0 \\
20.0\end{array}$ & $\begin{array}{l}\text { 112TILL } \\
\text { BEDROCK }\end{array}$ & $\begin{array}{l}\text { TILL } \\
\text { ROCK }\end{array}$ \\
\hline MWW & 210 & -- & 350.0 & -- & $\begin{array}{c}0 \\
50.0\end{array}$ & $\begin{array}{l}\text { 112TILL } \\
\text { BEDROCK }\end{array}$ & $\begin{array}{l}\text { TILL } \\
\text { ROCK }\end{array}$ \\
\hline MWW & 214 & -- & 360.0 & -- & $\begin{array}{l}0 \\
6.0\end{array}$ & $\begin{array}{l}\text { 112TILL } \\
\text { BEDROCK }\end{array}$ & $\begin{array}{l}\text { TILL } \\
\text { ROCK }\end{array}$ \\
\hline MWW & 217 & -- & 980.0 & -- & $\begin{array}{l}0 \\
9.0\end{array}$ & $\begin{array}{l}110 \text { SDMN } \\
\text { BEDROCK }\end{array}$ & $\begin{array}{l}\text { SAND } \\
\text { ROCK }\end{array}$ \\
\hline MWW & 218 & -- & 760.0 & -- & $\begin{array}{l}0 \\
9.0\end{array}$ & $\begin{array}{l}110 \text { SDMN } \\
\text { BEDROCK }\end{array}$ & $\begin{array}{l}\text { SAND } \\
\text { ROCK }\end{array}$ \\
\hline MWW & 219 & -- & 980.0 & -- & $\begin{array}{l}0 \\
6.0\end{array}$ & $\begin{array}{l}110 \text { SDMN } \\
\text { BEDROCK }\end{array}$ & $\begin{array}{l}\text { SAND } \\
\text { ROCK }\end{array}$ \\
\hline MWW & 220 & -- & 855.0 & -- & $\begin{array}{c}0 \\
150.0\end{array}$ & $\begin{array}{l}\text { 110SDMN } \\
\text { BEDROCK }\end{array}$ & $\begin{array}{l}\text { OTHR } \\
\text { ROCK }\end{array}$ \\
\hline MWW & 221 & -- & 305.0 & -- & $\begin{array}{l}0 \\
14.0\end{array}$ & $\begin{array}{l}\text { 11OSDMN } \\
\text { BEDROCK }\end{array}$ & $\begin{array}{l}\text { SAND } \\
\text { ROCK }\end{array}$ \\
\hline MWW & 222 & -- & 305.0 & -- & $\begin{array}{c}0 \\
85.0\end{array}$ & $\begin{array}{l}\text { 112TILL } \\
\text { BEDROCK }\end{array}$ & $\begin{array}{l}\text { TILL Sand, hardpan } \\
\text { ROCK }\end{array}$ \\
\hline MWW & 225 & -- & 730.0 & -- & $\begin{array}{c}0 \\
20.0 \\
70.0\end{array}$ & $\begin{array}{l}\text { 11OSDMN } \\
\text { 112TILL } \\
\text { BEDROCK }\end{array}$ & $\begin{array}{l}\text { SDGL } \\
\text { TILL Clay, hardpan } \\
\text { ROCK }\end{array}$ \\
\hline MWW & 227 & -- & 428.0 & -- & $\begin{array}{l}0 \\
16.0\end{array}$ & $\begin{array}{l}110 \text { SDMN } \\
\text { BEDROCK }\end{array}$ & $\begin{array}{l}\text { CLAY } \\
\text { ROCK }\end{array}$ \\
\hline MWW & 228 & -- & 578.0 & -- & $\begin{array}{c}0 \\
43.0\end{array}$ & $\begin{array}{l}110 \text { SDMN } \\
\text { BEDROCK }\end{array}$ & $\begin{array}{l}\text { SAND } \\
\text { ROCK }\end{array}$ \\
\hline MWW & 232 & -- & 118.0 & -- & $\begin{array}{l}0 \\
5.0\end{array}$ & $\begin{array}{l}110 \text { SDMN } \\
\text { BEDROCK }\end{array}$ & $\begin{array}{l}\text { SAND } \\
\text { ROCK }\end{array}$ \\
\hline MWW & 234 & -- & 464.0 & -- & $\begin{array}{c}0 \\
25.0\end{array}$ & $\begin{array}{l}\text { 112TILL } \\
\text { BEDROCK }\end{array}$ & $\begin{array}{l}\text { TILL } \\
\text { ROCK }\end{array}$ \\
\hline MWW & 238 & -- & 305.0 & -- & $\begin{array}{l}0 \\
10.0\end{array}$ & $\begin{array}{l}\text { 110SDMN } \\
\text { BEDROCK }\end{array}$ & $\begin{array}{l}\text { SDCL } \\
\text { ROCK }\end{array}$ \\
\hline MWW & 257 & -- & 680.0 & -- & $\begin{array}{c}0 \\
20.0\end{array}$ & $\begin{array}{l}\text { 112TILL } \\
\text { BEDROCK }\end{array}$ & $\begin{array}{l}\text { TILL Sand, gravel, hardpan } \\
\text { ROCK }\end{array}$ \\
\hline MWW & 258 & -- & 155.0 & -- & $\begin{array}{l}0 \\
6.0\end{array}$ & $\begin{array}{l}110 \text { SDMN } \\
\text { BEDROCK }\end{array}$ & $\begin{array}{l}\text { SDCL } \\
\text { ROCK }\end{array}$ \\
\hline
\end{tabular}


Table B-1. Stratigraphic logs of selected wells and borings in the Winnipesaukee River Basin, central New Hampshire-Continued

\begin{tabular}{|c|c|c|c|c|c|c|}
\hline $\begin{array}{l}\text { Local } \\
\text { site } \\
\text { number }\end{array}$ & $\begin{array}{l}\text { Depth } \\
\text { drilled } \\
\text { (feet) }\end{array}$ & $\begin{array}{l}\text { Depth } \\
\text { of } \\
\text { well } \\
\text { (feet) }\end{array}$ & $\begin{array}{l}\text { Depth } \\
\text { to } \\
\text { refusal } \\
\text { (feet) }\end{array}$ & $\begin{array}{l}\text { Depth } \\
\text { to } \\
\text { top } \\
\text { (feet) }\end{array}$ & $\begin{array}{l}\text { Aquifer } \\
\text { code }\end{array}$ & $\begin{array}{c}\text { Lithologic description } \\
\text { of } \\
\text { material }\end{array}$ \\
\hline
\end{tabular}

\section{CARROLL COUNTY}

\begin{tabular}{|c|c|c|c|c|c|c|c|}
\hline \multirow[b]{2}{*}{ MWW } & \multirow[b]{2}{*}{265} & \multirow[b]{2}{*}{-} & \multirow[b]{2}{*}{130.0} & \multicolumn{4}{|c|}{ Moultonborough-continued } \\
\hline & & & & -- & $\begin{array}{c}0 \\
10.0\end{array}$ & $\begin{array}{l}110 \text { SDMN } \\
\text { BEDROCK }\end{array}$ & $\begin{array}{l}\text { SDGL } \\
\text { ROCK }\end{array}$ \\
\hline MWW & 275 & -- & 782.0 & -- & $\begin{array}{c}0 \\
67.0\end{array}$ & $\begin{array}{l}110 \text { SDMN } \\
\text { BEDROCK }\end{array}$ & $\begin{array}{l}\text { SAND } \\
\text { ROCK }\end{array}$ \\
\hline MWW & 287 & - & 815.0 & -- & $\begin{array}{c}0 \\
27.0\end{array}$ & $\begin{array}{l}110 \text { SDMN } \\
\text { BEDROCK }\end{array}$ & $\begin{array}{l}\text { SDGL } \\
\text { ROCK }\end{array}$ \\
\hline MWW & 295 & - & 680.0 & -- & $\begin{array}{c}0 \\
22.0\end{array}$ & $\begin{array}{l}110 \text { SDMN } \\
\text { BEDROCK }\end{array}$ & $\begin{array}{l}\text { SAND } \\
\text { ROCK }\end{array}$ \\
\hline MWW & 301 & - & 200.0 & -- & $\begin{array}{l}0 \\
8.0\end{array}$ & $\begin{array}{l}112 \mathrm{TILL} \\
\text { BEDROCK }\end{array}$ & $\begin{array}{l}\text { TILL } \\
\text { ROCK }\end{array}$ \\
\hline MWW & 303 & -- & 540.0 & -- & $\begin{array}{c}0 \\
15.0\end{array}$ & $\begin{array}{l}110 \text { SDMN } \\
\text { BEDROCK }\end{array}$ & $\begin{array}{l}\text { SDCL } \\
\text { ROCK }\end{array}$ \\
\hline MWW & 304 & -- & 18.0 & -- & $\begin{array}{l}0 \\
6.0 \\
8.0\end{array}$ & $\begin{array}{l}110 \text { SDMN } \\
110 \text { SDMN } \\
110 \text { SDMN }\end{array}$ & $\begin{array}{l}\text { SDGL } \\
\text { CLAY } \\
\text { SDGL }\end{array}$ \\
\hline MWW & 307 & -- & 420.0 & -- & $\begin{array}{l}15.0 \\
17.0\end{array}$ & $\begin{array}{l}112 \text { TILL } \\
\text { BEDROCK }\end{array}$ & $\begin{array}{l}\text { TILL } \\
\text { ROCK }\end{array}$ \\
\hline MWW & 309 & -- & 640.0 & -- & $\begin{array}{c}0 \\
13.0\end{array}$ & $\begin{array}{l}110 \text { SDMN } \\
\text { BEDROCK }\end{array}$ & $\begin{array}{l}\text { SDCL } \\
\text { ROCK }\end{array}$ \\
\hline MWW & 310 & -- & 420.0 & -- & $\begin{array}{c}0 \\
60.0\end{array}$ & $\begin{array}{l}110 \text { SDMN } \\
\text { BEDROCK }\end{array}$ & $\begin{array}{l}\text { SGVC } \\
\text { ROCK }\end{array}$ \\
\hline MWW & 316 & -- & 205.0 & -- & $\begin{array}{c}0 \\
10.0\end{array}$ & $\begin{array}{l}112 \text { TILL } \\
\text { BEDROCK }\end{array}$ & $\begin{array}{l}\text { TILL Sand, gravel, hardpan } \\
\text { ROCK }\end{array}$ \\
\hline MWW & 321 & -- & 310.0 & -- & $\begin{array}{c}0 \\
12.0\end{array}$ & $\begin{array}{l}112 \text { TILL } \\
\text { BEDROCK }\end{array}$ & $\begin{array}{l}\text { TILL } \\
\text { ROCK }\end{array}$ \\
\hline MWW & 324 & -- & 661.0 & -- & $\begin{array}{c}0 \\
25.0\end{array}$ & $\begin{array}{l}110 \text { SDMN } \\
\text { BEDROCK }\end{array}$ & $\begin{array}{l}\text { SDGL } \\
\text { ROCK }\end{array}$ \\
\hline MWW & 326 & -- & 230.0 & -- & $\begin{array}{c}0 \\
22.0\end{array}$ & $\begin{array}{l}\text { 112TILL } \\
\text { BEDROCK }\end{array}$ & $\begin{array}{l}\text { TILL } \\
\text { ROCK }\end{array}$ \\
\hline MWW & 330 & -- & 255.0 & -- & 4.0 & BEDROCK & ROCK \\
\hline MWW & 331 & -- & 430.0 & -- & $\begin{array}{c}0 \\
20.0\end{array}$ & $\begin{array}{l}110 S D M N \\
\text { BEDROCK }\end{array}$ & $\begin{array}{l}\text { CLAY } \\
\text { ROCK }\end{array}$ \\
\hline MWW & 332 & -- & 655.0 & -- & $\begin{array}{l}0 \\
4.0\end{array}$ & $\begin{array}{l}110 \text { SDMN } \\
\text { BEDROCK }\end{array}$ & $\begin{array}{l}\text { CLAY } \\
\text { ROCK }\end{array}$ \\
\hline MWW & 334 & -- & 530.0 & -- & $\begin{array}{c}0 \\
86.0\end{array}$ & $\begin{array}{l}\text { 112TILL } \\
\text { BEDROCK }\end{array}$ & $\begin{array}{l}\text { TILL Sand, hardpan } \\
\text { ROCK }\end{array}$ \\
\hline MWW & 335 & - & 405.0 & -- & $\begin{array}{c}0 \\
20.0\end{array}$ & $\begin{array}{l}112 \text { TILL } \\
\text { BEDROCK }\end{array}$ & $\begin{array}{l}\text { TILL } \\
\text { ROCK }\end{array}$ \\
\hline
\end{tabular}


Table B-1. Stratigraphic logs of selected wells and borings in the Winnipesaukee River Basin, central New Hampshire-Continued

\begin{tabular}{|c|c|c|c|c|c|c|}
\hline $\begin{array}{l}\text { Local } \\
\text { site } \\
\text { number }\end{array}$ & $\begin{array}{l}\text { Depth } \\
\text { drilled } \\
\text { (feet) }\end{array}$ & $\begin{array}{l}\text { Depth } \\
\text { of } \\
\text { well } \\
\text { (feet) }\end{array}$ & $\begin{array}{l}\text { Depth } \\
\text { to } \\
\text { refusal } \\
\text { (feet) }\end{array}$ & $\begin{array}{l}\text { Depth } \\
\text { to } \\
\text { top } \\
\text { (feet) }\end{array}$ & $\begin{array}{l}\text { Aquifer } \\
\text { code }\end{array}$ & $\begin{array}{c}\text { Lithologic description } \\
\text { of } \\
\text { material }\end{array}$ \\
\hline
\end{tabular}

CARROLL COUNTY

\begin{tabular}{|c|c|c|c|c|c|c|c|}
\hline \multirow[b]{2}{*}{ MWW } & \multirow[b]{2}{*}{339} & \multirow[b]{2}{*}{--} & \multirow[b]{2}{*}{405.0} & \multirow[b]{2}{*}{--} & \multicolumn{3}{|c|}{ Moultonborough-Continued } \\
\hline & & & & & $\begin{array}{l}0 \\
60.0\end{array}$ & $\begin{array}{l}\text { 112TILL } \\
\text { BEDROCK }\end{array}$ & $\begin{array}{l}\text { TILL Clay, hardpan } \\
\text { ROCK }\end{array}$ \\
\hline MWW & 340 & -- & 355.0 & -- & $\begin{array}{c}0 \\
38.0\end{array}$ & $\begin{array}{l}\text { 110SDMN } \\
\text { BEDROCK }\end{array}$ & $\begin{array}{l}\text { SDGL } \\
\text { ROCK }\end{array}$ \\
\hline MWW & 343 & -- & 805.0 & -- & $\begin{array}{c}0 \\
16.0\end{array}$ & $\begin{array}{l}\text { 110SDMN } \\
\text { BEDROCK }\end{array}$ & $\begin{array}{l}\text { SAND } \\
\text { ROCK }\end{array}$ \\
\hline MWW & 355 & -- & 750.0 & -- & $\begin{array}{c}0 \\
20.0\end{array}$ & $\begin{array}{l}\text { 112TILL } \\
\text { BEDROCK }\end{array}$ & $\begin{array}{l}\text { TILL } \\
\text { ROCK }\end{array}$ \\
\hline & & & & & & sax & dwich \\
\hline SEW & 10 & -- & 475.0 & -- & $\begin{array}{c}0 \\
11.0\end{array}$ & $\begin{array}{l}110 \text { SDMN } \\
\text { BEDROCK }\end{array}$ & $\begin{array}{l}\text { SDGL } \\
\text { ROCK }\end{array}$ \\
\hline SEW & 15 & -- & 300.0 & -- & 31.0 & BEDROCK & ROCK \\
\hline SEW & 21 & -- & 225.0 & -- & $\begin{array}{c}0 \\
25.0\end{array}$ & $\begin{array}{l}\text { 112TILL } \\
\text { BEDROCK }\end{array}$ & $\begin{array}{l}\text { TILL } \\
\text { ROCK }\end{array}$ \\
\hline SEW & 31 & -- & 18.0 & -- & $\begin{array}{l}0 \\
3.0\end{array}$ & $\begin{array}{l}110 \text { SDMN } \\
112 \text { TILL }\end{array}$ & $\begin{array}{l}\text { SDGL } \\
\text { TILL Grave1, hardpan }\end{array}$ \\
\hline SEW & 49 & -- & 242.0 & -- & $\begin{array}{l}0 \\
8.0\end{array}$ & $\begin{array}{l}112 \text { TILL } \\
\text { BEDROCK }\end{array}$ & $\begin{array}{l}\text { TILL } \\
\text { ROCK }\end{array}$ \\
\hline SEW & 50 & -- & 230.0 & -- & $\begin{array}{l}0 \\
60.0\end{array}$ & $\begin{array}{l}\text { 112TILL } \\
\text { BEDROCK }\end{array}$ & $\begin{array}{l}\text { TILL } \\
\text { ROCK }\end{array}$ \\
\hline SEW & 53 & -- & 363.0 & -- & $\begin{array}{l}0 \\
2.0 \\
5.0\end{array}$ & $\begin{array}{l}\text { 11OSDMN } \\
112 \text { TILL } \\
\text { BEDROCK }\end{array}$ & $\begin{array}{l}\text { SDGL } \\
\text { TILL } \\
\text { ROCK }\end{array}$ \\
\hline SEW & 60 & -- & 593.0 & -- & $\begin{array}{c}0 \\
21.0\end{array}$ & $\begin{array}{l}\text { 112TILL } \\
\text { BEDROCK }\end{array}$ & $\begin{array}{l}\text { TILL } \\
\text { ROCK }\end{array}$ \\
\hline SEW & 61 & -- & 333.0 & -- & $\begin{array}{c}0 \\
20.0\end{array}$ & $\begin{array}{l}112 \text { TILL } \\
\text { BEDROCK }\end{array}$ & $\begin{array}{l}\text { TILL } \\
\text { ROCK }\end{array}$ \\
\hline SEW & 105 & -- & 320.0 & -- & $\begin{array}{c}0 \\
23.0\end{array}$ & $\begin{array}{l}112 \text { TILL } \\
\text { BEDROCK }\end{array}$ & $\begin{array}{l}\text { TILL } \\
\text { ROCK }\end{array}$ \\
\hline SEW & 108 & -- & 977.0 & -- & $\begin{array}{c}0 \\
15.0\end{array}$ & $\begin{array}{l}\text { 112TILL } \\
\text { BEDROCK }\end{array}$ & $\begin{array}{l}\text { TILL } \\
\text { ROCK }\end{array}$ \\
\hline SEW & 150 & -- & 100.0 & -- & $\begin{array}{c}0 \\
5.0 \\
23.0\end{array}$ & $\begin{array}{l}\text { 110SDMN } \\
112 \text { TILL } \\
\text { BEDROCK }\end{array}$ & $\begin{array}{l}\text { SAND } \\
\text { TILL } \\
\text { ROCK }\end{array}$ \\
\hline SEW & 151 & -- & 205.0 & -- & $\begin{array}{c}0 \\
130.0\end{array}$ & $\begin{array}{l}\text { 110SDMN } \\
\text { BEDROCK }\end{array}$ & $\begin{array}{l}\text { CLAY } \\
\text { ROCK }\end{array}$ \\
\hline
\end{tabular}


Table B-1. Stratigraphic logs of selected wells and borings in the Winnipesaukee River Basin, central New Hampshire-Continued

\begin{tabular}{|c|c|c|c|c|c|c|}
\hline $\begin{array}{l}\text { Local } \\
\text { site } \\
\text { number }\end{array}$ & $\begin{array}{l}\text { Depth } \\
\text { drilled } \\
\text { (feet) }\end{array}$ & $\begin{array}{l}\text { Depth } \\
\text { of } \\
\text { well } \\
\text { (feet) }\end{array}$ & $\begin{array}{l}\text { Depth } \\
\text { to } \\
\text { refusal } \\
\text { (feet) }\end{array}$ & $\begin{array}{l}\text { Depth } \\
\text { to } \\
\text { top } \\
\text { (feet) }\end{array}$ & $\begin{array}{l}\text { Aquifer } \\
\text { code }\end{array}$ & $\begin{array}{c}\text { Lithologlc description } \\
\text { of } \\
\text { materiai }\end{array}$ \\
\hline
\end{tabular}

\section{CARROLL COUNTY}

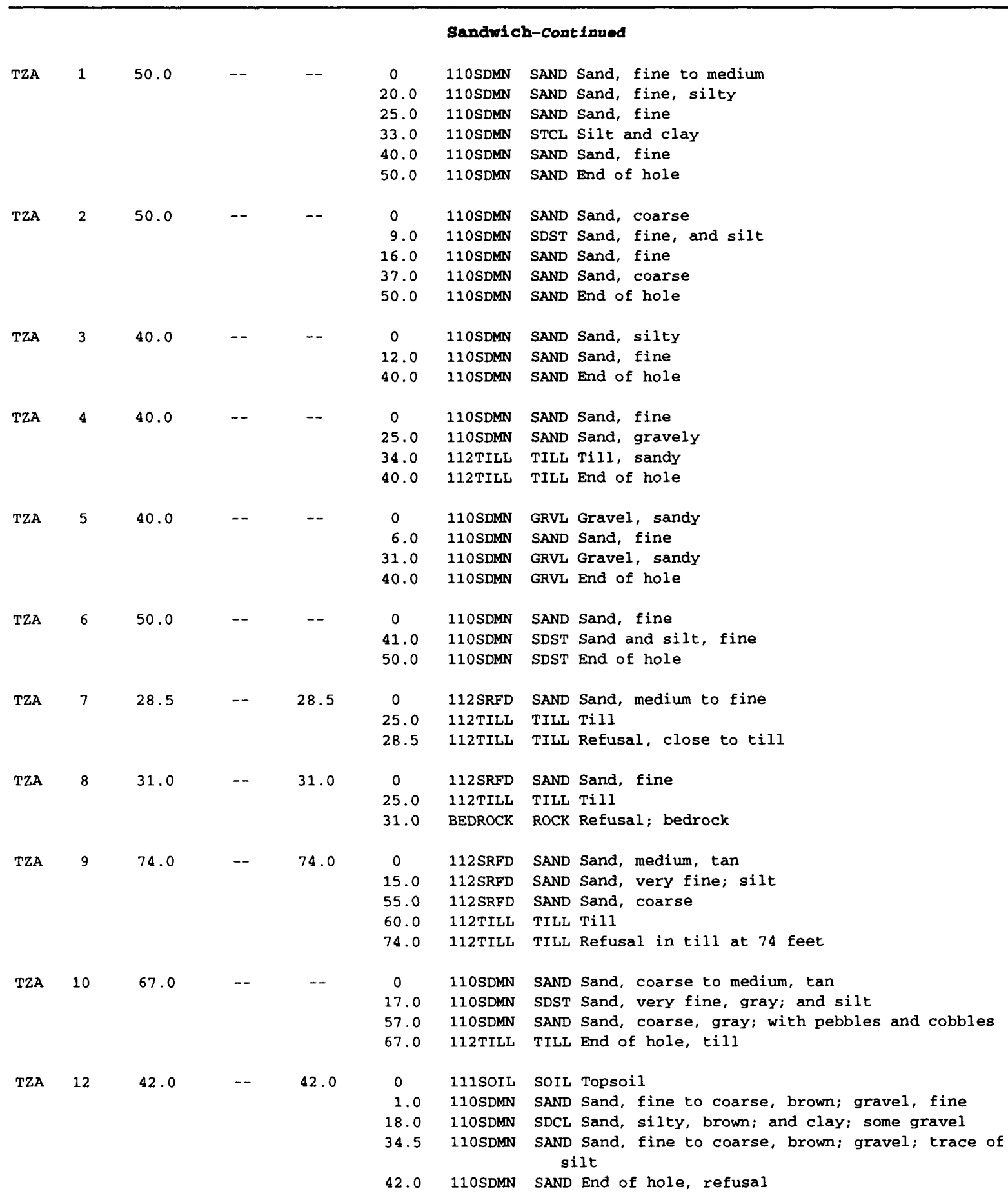


Table B-1. Stratigraphic logs of selected wells and borings in the Winnipesaukee River Basin, central New Hampshire-Continued

\begin{tabular}{|c|c|c|c|c|c|c|}
\hline $\begin{array}{l}\text { Local } \\
\text { site } \\
\text { number }\end{array}$ & $\begin{array}{l}\text { Depth } \\
\text { drilled } \\
\text { (feet) }\end{array}$ & $\begin{array}{l}\text { Depth } \\
\text { of } \\
\text { well } \\
\text { (feet) }\end{array}$ & $\begin{array}{l}\text { Depth } \\
\text { to } \\
\text { refusal } \\
\text { (feet) }\end{array}$ & $\begin{array}{l}\text { Depth } \\
\text { to } \\
\text { top } \\
\text { (feet) }\end{array}$ & $\begin{array}{l}\text { Aquifer } \\
\text { code }\end{array}$ & $\begin{array}{c}\text { Lithologic description } \\
\text { of } \\
\text { material }\end{array}$ \\
\hline
\end{tabular}

\section{CARROLL COUNTY}

\begin{tabular}{|c|c|c|c|c|c|c|c|}
\hline \multirow[b]{2}{*}{ TZA } & \multicolumn{7}{|c|}{ Sandwich-continued } \\
\hline & 13 & 23.0 & -- & 23.0 & $\begin{array}{l}0 \\
16.0 \\
23.0\end{array}$ & $\begin{array}{l}110 \text { SDMN } \\
110 \text { SDMN } \\
110 \text { SDMN }\end{array}$ & $\begin{array}{l}\text { SDGL Sand, fine to coarse, brown; gravel, fine } \\
\text { SAND Sand, brown; and clay, gray; some gravel } \\
\text { SAND End of hole, refusal }\end{array}$ \\
\hline \multicolumn{8}{|c|}{ Tuftonboro } \\
\hline \multirow[t]{7}{*}{ TZA } & 14 & 54.0 & -- & 54.0 & 0 & 111SOIL & SOIL Topsoil \\
\hline & & & & & 1.0 & 110 SDMN & $\begin{array}{l}\text { SAND Sand, fine to medium, red-brown; some coarse } \\
\text { sand; some gravel }\end{array}$ \\
\hline & & & & & 11.0 & 110SDMN & SAND Sand, fine, gray; some coarse sand \\
\hline & & & & & 23.0 & $110 \mathrm{SDMN}$ & SDCL Sand, silty, brown; and clay \\
\hline & & & & & 35.0 & 110 SDMN & $\begin{array}{l}\text { SAND Sand, fine, brown; some medium to coarse sand; } \\
\text { silt }\end{array}$ \\
\hline & & & & & 50.0 & 110 SDMN & SAND Sand, fine to coarse; gravel; silt \\
\hline & & & & & 54.0 & 110 SDMN & SAND End of hole, refusal \\
\hline \multirow[t]{5}{*}{ TZA } & 15 & 39.0 & -- & 39.0 & 0 & 110 SDMN & SAND Sand, fine, light tan \\
\hline & & & & & 17.0 & 110 SDMN & $\begin{array}{l}\text { SAND Sand, fine; with } 3 \text {-inch coarse layer and } 5 \text {-inch } \\
\text { medium layer }\end{array}$ \\
\hline & & & & & 19.0 & 112TILL & TILL Till, clay/silt, blue-gray to tan \\
\hline & & & & & 29.0 & 112 TILL & TILL Till coarse, sandy, with pebbles \\
\hline & & & & & 39.0 & 112 TILL & TILL Refusal; till \\
\hline \multirow[t]{8}{*}{ TZA } & 16 & 89.0 & -- & -- & 0 & 110SDMN & SAND Sand, medium to coarse, light brown \\
\hline & & & & & 17.0 & 110 SDMN & SAND Sand, fine to coarse, gray-tan \\
\hline & & & & & 29.0 & 110SDMN & $\begin{array}{l}\text { SDST Sand, fine; some } 0.25 \text {-inch silt layers } \\
\text { throughout }\end{array}$ \\
\hline & & & & & 39.0 & 110 SDMN & $\begin{array}{l}\text { SAND Sand, fine to med; some } 0.125 \text {-inch lenses } \\
\text { biotite and very fine sand }\end{array}$ \\
\hline & & & & & 49.0 & 110 SDMN & SAND Sand, very fine to fine, light gray-tan, compact \\
\hline & & & & & 59.0 & 110 SDMN & $\begin{array}{l}\text { SDST Sand, very fine to med; some } 0.25 \text {-inch silt } \\
\text { layers }\end{array}$ \\
\hline & & & & & 69.0 & 110 SDMN & SAND Sand, medium \\
\hline & & & & & 89.0 & 110 SDMN & SAND End of hole, drill rig broken \\
\hline \multirow[t]{3}{*}{ TZA } & 17 & 37.0 & -- & 37.0 & 0 & 110 SDMN & SAND Sand, medium, finer with depth \\
\hline & & & & & 20.0 & 112TILL & TILL Till, very sandy \\
\hline & & & & & 37.0 & BEDROCK & ROCK Bedrock \\
\hline \multirow[t]{2}{*}{ TZA } & 18 & 19.0 & -- & 19.0 & 0 & 112SRFD & SAND Sand, medium to fine, some silt \\
\hline & & & & & $\begin{array}{l}16.0 \\
19.0\end{array}$ & $\begin{array}{l}112 \text { TILL } \\
\text { BEDROCK }\end{array}$ & $\begin{array}{l}\text { TILL Till, refus } \\
\text { ROCK }\end{array}$ \\
\hline \multirow[t]{6}{*}{ TZW } & 1 & 101.0 & 100.0 & -- & 0 & $110 \mathrm{SDMN}$ & $\begin{array}{l}\text { SDGL Sand, brown, and gravel, fine to medium, trace } \\
\text { of cobbles }\end{array}$ \\
\hline & & & & & 8.0 & $110 \mathrm{SDMN}$ & $\begin{array}{l}\text { SAND Sand, light brown-white, medium coarse, trace } \\
\text { of fine gravel }\end{array}$ \\
\hline & & & & & 20.0 & 110SDMN & $\begin{array}{l}\text { SAND Sand, light brown-white, fine to medium, trace } \\
\text { of fine to medium gravel }\end{array}$ \\
\hline & & & & & 40.0 & 110 SDMN & SAND Sand, light brown-white, fine to medium \\
\hline & & & & & 70.0 & $110 \mathrm{SDMN}$ & $\begin{array}{l}\text { SAND Sand, light brown-white, fine to medium, trace } \\
\text { of fine gravel }\end{array}$ \\
\hline & & & & & 101.0 & 110 SDMN & SAND End of hole \\
\hline TZW & 2 & 35.0 & 23.0 & 35.0 & 0 & $110 \mathrm{SDMN}$ & $\begin{array}{l}\text { SAND Sand, coarse to very coarse, fine sand layer at } \\
30 \text { feet }\end{array}$ \\
\hline
\end{tabular}


Table B-1. Stratigraphic logs of selected wells and borings in the Winnipesaukee River Basin, central New Hampshire-Continued

\begin{tabular}{|c|c|c|c|c|c|c|c|}
\hline \multicolumn{2}{|c|}{$\begin{array}{l}\text { Locai } \\
\text { site } \\
\text { number }\end{array}$} & \multirow[t]{2}{*}{$\begin{array}{l}\text { Depth } \\
\text { driilied } \\
\text { (feet) }\end{array}$} & \multirow[t]{2}{*}{$\begin{array}{l}\text { Depth } \\
\text { of } \\
\text { weii } \\
\text { (feet) }\end{array}$} & \multirow[t]{2}{*}{$\begin{array}{l}\text { Depth } \\
\text { to } \\
\text { refusai } \\
\text { (feet) }\end{array}$} & \multirow[t]{2}{*}{$\begin{array}{l}\text { Depth } \\
\text { to } \\
\text { top } \\
\text { (feet) }\end{array}$} & \multicolumn{2}{|r|}{$\begin{array}{c}\text { Lithoiogic description } \\
\text { of } \\
\text { materiai }\end{array}$} \\
\hline \multicolumn{4}{|c|}{ CARROLL COUNTY } & & & & \\
\hline \multicolumn{8}{|c|}{ Tuftonboro-Continued } \\
\hline \multirow[t]{3}{*}{ TZW } & \multirow{3}{*}{\multicolumn{2}{|c|}{$2--$ Continued }} & & & & & \\
\hline & & & & & 34.0 & 112TILL & TILL Till \\
\hline & & & & & 35.0 & BEDROCK & ROCK Bedrock \\
\hline \multirow[t]{6}{*}{ TZW } & 3 & 108.0 & 51.0 & 108.0 & 0 & $110 \mathrm{SDMN}$ & SAND Sand, medium, tan; some fine and coarse \\
\hline & & & & & 37.0 & $110 \mathrm{SDMN}$ & SAND Sand, coarse; some medium and very coarse \\
\hline & & & & & 67.0 & $110 \mathrm{SDMN}$ & SAND Sand, medium to fine \\
\hline & & & & & 77.0 & 110 SDMN & SAND Sand, coarse \\
\hline & & & & & 87.0 & $110 \mathrm{SDMN}$ & SAND Sand, fine to medium \\
\hline & & & & & 108.0 & $110 S D M N$ & SAND Refusal \\
\hline \multirow[t]{3}{*}{ TZW } & 8 & 23.0 & 20.0 & 23.0 & 0 & 110 SDMN & SAND Sand, medium to fine, tan; some pebbles \\
\hline & & & & & 17.0 & $110 \mathrm{SDMN}$ & SAND Sand, coarse, brown \\
\hline & & & & & 23.0 & BEDROCK & ROCK Refusal; boulder or bedrock \\
\hline \multirow[t]{6}{*}{ TZW } & 9 & 35.0 & 27.0 & 35.0 & 0 & $110 S D M N$ & SAND Sand, fine, dark brown \\
\hline & & & & & 17.0 & 110 SDMN & $\begin{array}{l}\text { SAND Sand, very fine, grading into cobbles with } \\
\text { coarse sand, top } 1 / 2 \text { inch: gray silty clay }\end{array}$ \\
\hline & & & & & 18.0 & $110 S D M N$ & $\begin{array}{l}\text { SAND Sand, very coarse; some pebbles; some coarse } \\
\text { sand }\end{array}$ \\
\hline & & & & & 28.0 & 110 SDMN & CLAY Clay, silty, tan-gray \\
\hline & & & & & 28.5 & 112TILL & TILL Till, sandy, with silt and clay, very compact \\
\hline & & & & & 35.0 & 112 TILL & ROCK Refusal; bedrock or boulder \\
\hline \multirow[t]{4}{*}{ TZW } & 11 & -- & 378.0 & -- & 0 & 110 SDMN & SAND \\
\hline & & & & & 34.0 & BEDROCK & ROCK \\
\hline & & & & & -- & $110 \mathrm{SDMN}$ & SAND \\
\hline & & & & & 34.0 & BEDROCK & ROCK \\
\hline \multirow[t]{2}{*}{ TZW } & 16 & -- & 227.0 & -- & 0 & $110 \mathrm{SDMN}$ & SDCL \\
\hline & & & & & 170.0 & BEDROCK & ROCK \\
\hline \multirow[t]{4}{*}{ TZW } & 18 & -- & 220.0 & -- & 0 & $110 \mathrm{SDMN}$ & SAND \\
\hline & & & & & 10.0 & 112TILL & TILL \\
\hline & & & & & 35.0 & $110 \mathrm{SDMN}$ & SAND \\
\hline & & & & & 50.0 & BEDROCK & ROCK \\
\hline \multirow[t]{2}{*}{ TZW } & 26 & -- & 300.0 & -- & 0 & $110 \mathrm{SDMN}$ & SDGL \\
\hline & & & & & 32.0 & BEDROCK & ROCK \\
\hline \multirow[t]{3}{*}{ TZW } & 27 & -- & 224.0 & -- & 0 & $110 \mathrm{SDMN}$ & SAND \\
\hline & & & & & 40.0 & $110 \mathrm{SDMN}$ & SDGL \\
\hline & & & & & 70.0 & BEDROCK & ROCK \\
\hline \multirow[t]{2}{*}{ TZW } & 29 & -- & 302.0 & -- & 0 & 112TILL & TILL \\
\hline & & & & & 34.0 & BEDROCK & $\mathrm{ROCK}$ \\
\hline \multirow[t]{2}{*}{ TZW } & 35 & -- & 330.0 & -- & 0 & $110 \mathrm{SDMN}$ & SDGL \\
\hline & & & & & 100.0 & BEDROCK & ROCK \\
\hline \multirow[t]{2}{*}{ TZW } & 39 & -- & 602.0 & -- & 0 & I12TILL & TrLL Clay, hardpan \\
\hline & & & & & 232.0 & BEDROCK & ROCK \\
\hline \multirow[t]{2}{*}{ TZW } & 43 & -- & 656.0 & -- & 0 & 110 SDMN & SAND \\
\hline & & & & & 25.0 & BEDROCK & ROCK \\
\hline
\end{tabular}


Table B-1. Stratigraphic logs of selected wells and borings in the Winnipesaukee River Basin, central New Hampshire-Continued

\begin{tabular}{|c|c|c|c|c|c|c|c|}
\hline \multicolumn{2}{|c|}{$\begin{array}{l}\text { Local } \\
\text { site } \\
\text { number }\end{array}$} & \multirow[t]{2}{*}{$\begin{array}{l}\text { Depth } \\
\text { drilled } \\
\text { (feet) }\end{array}$} & \multirow[t]{2}{*}{$\begin{array}{l}\text { Depth } \\
\text { of } \\
\text { well } \\
\text { (feet) }\end{array}$} & \multirow[t]{2}{*}{$\begin{array}{l}\text { Depth } \\
\text { to } \\
\text { refusal } \\
\text { (feet) }\end{array}$} & \multirow[t]{2}{*}{$\begin{array}{l}\text { Depth } \\
\text { to } \\
\text { top } \\
\text { (feet) }\end{array}$} & \multicolumn{2}{|r|}{$\begin{array}{c}\text { Lithologic description } \\
\text { of } \\
\text { material }\end{array}$} \\
\hline \multicolumn{4}{|c|}{ CARROLL COUNTY } & & & & \\
\hline \multicolumn{8}{|c|}{ Tuftonboro-Continued } \\
\hline TZW & 44 & -- & 517.0 & -- & $\begin{array}{l}0 \\
5.0\end{array}$ & $\begin{array}{l}\text { 112TILL } \\
\text { BEDROCK }\end{array}$ & $\begin{array}{l}\text { TILL } \\
\text { ROCK }\end{array}$ \\
\hline TZW & 47 & -- & 282.0 & -- & $\begin{array}{l}0 \\
16.0\end{array}$ & $\begin{array}{l}\text { 112TILL } \\
\text { BEDROCK }\end{array}$ & $\begin{array}{l}\text { TILL } \\
\text { ROCK }\end{array}$ \\
\hline TZW & 48 & - & 302.0 & -- & $\begin{array}{l}0 \\
85.0\end{array}$ & $\begin{array}{l}\text { 11OSDMN } \\
\text { BEDROCK }\end{array}$ & $\begin{array}{l}\text { SDCL } \\
\text { ROCK }\end{array}$ \\
\hline TZW & 63 & -- & 561.0 & -- & $\begin{array}{c}0 \\
15.0\end{array}$ & $\begin{array}{l}110 \text { SDMN } \\
\text { BEDROCK }\end{array}$ & $\begin{array}{l}\text { SAND } \\
\text { ROCK }\end{array}$ \\
\hline TZW & 71 & -- & 482.0 & - & $\begin{array}{l}0 \\
65.0\end{array}$ & $\begin{array}{l}\text { 112TILL } \\
\text { BEDROCK }\end{array}$ & $\begin{array}{l}\text { TILL } \\
\text { ROCK }\end{array}$ \\
\hline TZW & 88 & - & 305.0 & -- & $\begin{array}{l}0 \\
18.0\end{array}$ & $\begin{array}{l}110 \text { SDMN } \\
\text { BEDROCK }\end{array}$ & $\begin{array}{l}\text { SDGL } \\
\text { ROCK }\end{array}$ \\
\hline TZW & 95 & - & 202.0 & -- & $\begin{array}{l}0 \\
60.0\end{array}$ & $\begin{array}{l}110 \text { SDMN } \\
\text { BEDROCK }\end{array}$ & $\begin{array}{l}\text { SDCL } \\
\text { ROCK }\end{array}$ \\
\hline TZW & 99 & -- & 552.0 & -- & $\begin{array}{c}0 \\
180.0\end{array}$ & $\begin{array}{l}110 \mathrm{SDMN} \\
\text { BEDROCK }\end{array}$ & $\begin{array}{l}\text { CLAY } \\
\text { ROCK }\end{array}$ \\
\hline TZW & 102 & -- & 242.0 & -- & $\begin{array}{c}0 \\
20.0\end{array}$ & $\begin{array}{l}\text { 112TILL } \\
\text { BEDROCK }\end{array}$ & $\begin{array}{l}\text { TILL } \\
\text { ROCK }\end{array}$ \\
\hline TZW & 104 & -- & 162.0 & -- & $\begin{array}{c}0 \\
77.0\end{array}$ & $\begin{array}{l}110 \text { SDMN } \\
\text { BEDROCK }\end{array}$ & $\begin{array}{l}\text { CLAY } \\
\text { ROCK }\end{array}$ \\
\hline TZW & 107 & -- & 206.0 & -- & $\begin{array}{l}0 \\
18.0\end{array}$ & $\begin{array}{l}\text { 112TILL } \\
\text { BEDROCK }\end{array}$ & $\begin{array}{l}\text { TILL } \\
\text { ROCK }\end{array}$ \\
\hline TZW & 108 & -- & 650.0 & -- & $\begin{array}{c}0 \\
20.0\end{array}$ & $\begin{array}{l}110 \text { SDMN } \\
\text { BEDROCK }\end{array}$ & $\begin{array}{l}\text { SDGL } \\
\text { ROCK }\end{array}$ \\
\hline TZW & 109 & -- & 600.0 & -- & $\begin{array}{c}0 \\
20.0\end{array}$ & $\begin{array}{l}110 \text { SDMN } \\
\text { BEDROCK }\end{array}$ & $\begin{array}{l}\text { SAND } \\
\text { ROCK }\end{array}$ \\
\hline TZW & 111 & -- & 39.0 & - & $\begin{array}{l}0 \\
12.0\end{array}$ & $\begin{array}{l}110 \mathrm{SDMN} \\
110 \mathrm{SDMN}\end{array}$ & $\begin{array}{l}\text { SDGL } \\
\text { SAND }\end{array}$ \\
\hline TZW & 114 & -- & 293.0 & -- & $\begin{array}{l}0 \\
60.0\end{array}$ & $\begin{array}{l}\text { 112TILL } \\
\text { BEDROCK }\end{array}$ & $\begin{array}{l}\text { TILL Sand, hardpan } \\
\text { ROCK }\end{array}$ \\
\hline TZW & 116 & -- & 482.0 & -- & $\begin{array}{l}0 \\
8.0\end{array}$ & $\begin{array}{l}110 \text { SDMN } \\
\text { BEDROCK }\end{array}$ & $\begin{array}{l}\text { CLAY } \\
\text { ROCK }\end{array}$ \\
\hline TZW & 128 & -- & 302.0 & -- & $\begin{array}{c}0 \\
35.0 \\
63.0\end{array}$ & $\begin{array}{l}\text { 112TILL } \\
\text { 110SDMN } \\
\text { BEDROCK }\end{array}$ & $\begin{array}{l}\text { TILL Clay, hardpan } \\
\text { CLAY } \\
\text { ROCK }\end{array}$ \\
\hline TZW & 130 & -- & 423.0 & -- & $\begin{array}{c}0 \\
50.0\end{array}$ & $\begin{array}{l}\text { 112TILL } \\
\text { BEDROCK }\end{array}$ & $\begin{array}{l}\text { TILL } \\
\text { ROCK }\end{array}$ \\
\hline
\end{tabular}


Table B-1. Stratigraphic logs of selected wells and borings in the Winnipesaukee River Basin, central New Hampshire-Continued

\begin{tabular}{|c|c|c|c|c|c|c|}
\hline $\begin{array}{l}\text { Local } \\
\text { site } \\
\text { number }\end{array}$ & $\begin{array}{l}\text { Depth } \\
\text { drilled } \\
\text { (feet) }\end{array}$ & $\begin{array}{l}\text { Depth } \\
\text { of } \\
\text { well } \\
\text { (feet) }\end{array}$ & $\begin{array}{l}\text { Depth } \\
\text { to } \\
\text { refusal } \\
\text { (feet) }\end{array}$ & $\begin{array}{l}\text { Depth } \\
\text { to } \\
\text { top } \\
\text { (feet) }\end{array}$ & $\begin{array}{c}\text { Aquifer } \\
\text { code }\end{array}$ & $\begin{array}{c}\text { Lithologic description } \\
\text { of } \\
\text { material }\end{array}$ \\
\hline
\end{tabular}

\section{CARROLL COUNTY}

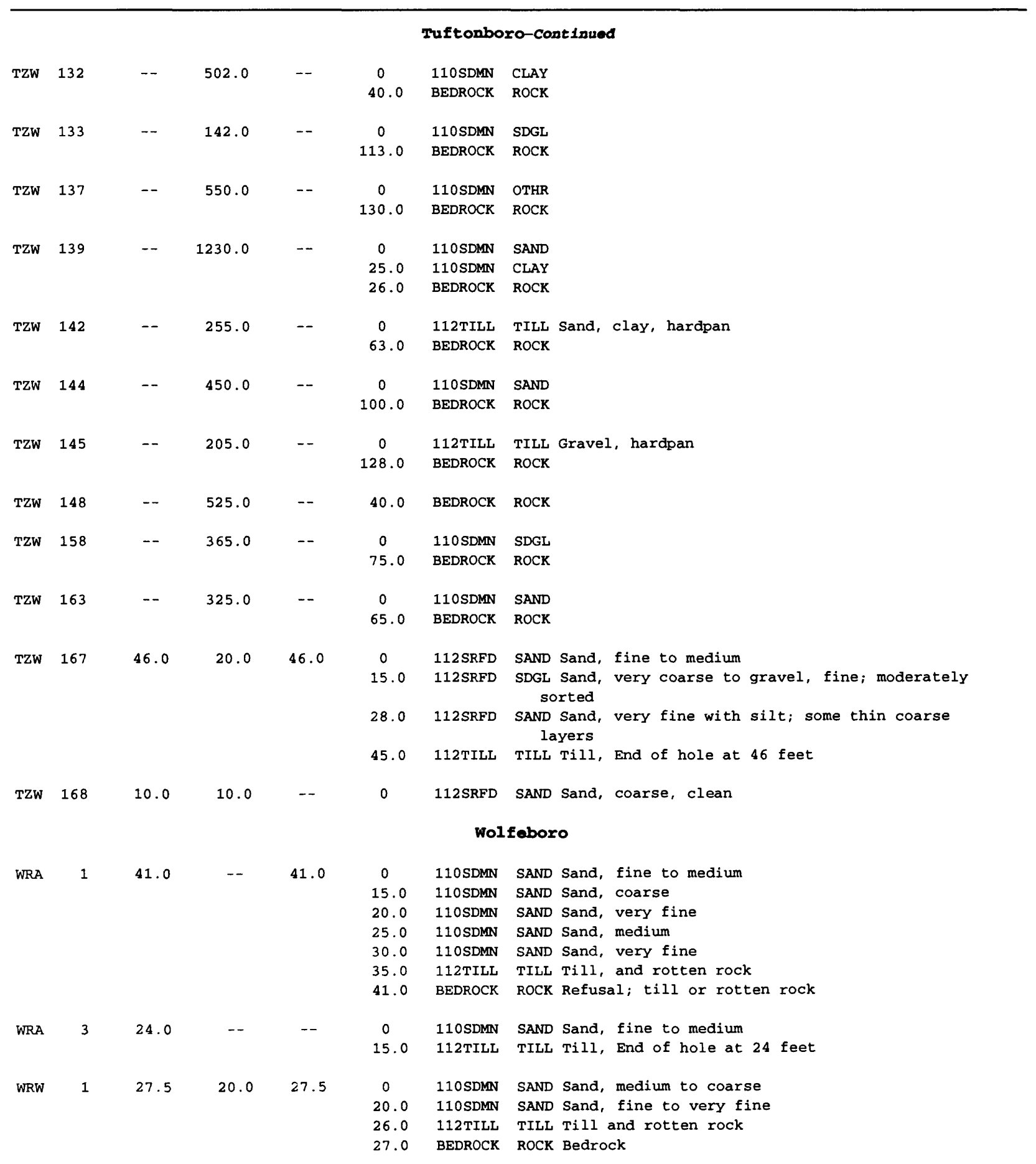


Table B-1. Stratigraphic logs of selected wells and borings in the Winnipesaukee River Basin, central New Hampshire-Continued

\begin{tabular}{|c|c|c|c|c|c|c|}
\hline $\begin{array}{l}\text { Local } \\
\text { site } \\
\text { number }\end{array}$ & $\begin{array}{l}\text { Depth } \\
\text { drilled } \\
\text { (feet) }\end{array}$ & $\begin{array}{l}\text { Depth } \\
\text { of } \\
\text { well } \\
\text { (feet) }\end{array}$ & $\begin{array}{l}\text { Depth } \\
\text { to } \\
\text { refusal } \\
\text { (feet) }\end{array}$ & $\begin{array}{l}\text { Depth } \\
\text { to } \\
\text { top } \\
\text { (feet) }\end{array}$ & $\begin{array}{c}\text { Aquifer } \\
\text { code }\end{array}$ & $\begin{array}{c}\text { Lithologic description } \\
\text { of } \\
\text { material }\end{array}$ \\
\hline
\end{tabular}

\section{CARROLL COUNTY}

\begin{tabular}{|c|c|c|c|c|c|c|c|c|}
\hline & & & & & & Wolfebox & ro-Continued & • \\
\hline WRW & 3 & -- & 115.0 & -- & $\begin{array}{l}0 \\
15.0\end{array}$ & $\begin{array}{l}\text { 112TILL } \\
\text { BEDROCK }\end{array}$ & $\begin{array}{l}\text { TILL } \\
\text { ROCK }\end{array}$ & \\
\hline WRW & 4 & -- & 125.0 & -- & $\begin{array}{l}0 \\
5.0\end{array}$ & $\begin{array}{l}\text { 112TILL } \\
\text { BEDROCK }\end{array}$ & $\begin{array}{l}\text { TILL } \\
\text { ROCK }\end{array}$ & \\
\hline WRW & 6 & -- & 503.0 & -- & $\begin{array}{l}0 \\
35.0\end{array}$ & $\begin{array}{l}\text { 110SDMN } \\
\text { BEDROCK }\end{array}$ & $\begin{array}{l}\text { SGVC } \\
\text { ROCK }\end{array}$ & \\
\hline WRW & 11 & -- & 421.0 & -- & $\begin{array}{c}0 \\
20.0\end{array}$ & $\begin{array}{l}\text { 11OSDMN } \\
\text { BEDROCK }\end{array}$ & $\begin{array}{l}\text { SDCL } \\
\text { ROCK }\end{array}$ & \\
\hline WRW & 12 & -- & 500.0 & -- & $\begin{array}{l}0 \\
80.0\end{array}$ & $\begin{array}{l}\text { 110SDMN } \\
\text { BEDROCK }\end{array}$ & $\begin{array}{l}\text { SAND } \\
\text { ROCK }\end{array}$ & \\
\hline WRW & 19 & -- & 363.0 & -- & $\begin{array}{l}0 \\
90.0\end{array}$ & $\begin{array}{l}\text { 11OSDMN } \\
\text { BEDROCK }\end{array}$ & $\begin{array}{l}\text { SAND } \\
\text { ROCK }\end{array}$ & \\
\hline WRW & 20 & -- & 203.0 & -- & $\begin{array}{l}0 \\
31.0\end{array}$ & $\begin{array}{l}\text { I1OSDMN } \\
\text { BEDROCK }\end{array}$ & $\begin{array}{l}\text { SDCL } \\
\text { ROCK }\end{array}$ & \\
\hline WRW & 29 & -- & 547.0 & -- & $\begin{array}{l}0 \\
20.0\end{array}$ & $\begin{array}{l}\text { 112TILL } \\
\text { BEDROCK }\end{array}$ & $\begin{array}{l}\text { TILL } \\
\text { ROCK }\end{array}$ & \\
\hline WRW & 32 & -- & 283.0 & -- & $\begin{array}{l}0 \\
20.0\end{array}$ & $\begin{array}{l}\text { 112TILL } \\
\text { BEDROCK }\end{array}$ & $\begin{array}{l}\text { TILL } \\
\text { ROCK }\end{array}$ & \\
\hline WRW & 33 & - & 260.0 & -- & $\begin{array}{l}0 \\
12.0\end{array}$ & $\begin{array}{l}\text { 110SDMN } \\
\text { BEDROCK }\end{array}$ & $\begin{array}{l}\text { SDGL } \\
\text { ROCK }\end{array}$ & \\
\hline WRW & 34 & -- & 302.0 & -- & $\begin{array}{l}0 \\
60.0\end{array}$ & $\begin{array}{l}\text { 110SDMN } \\
\text { BEDROCK }\end{array}$ & $\begin{array}{l}\text { SDCL } \\
\text { ROCK }\end{array}$ & \\
\hline WRW & 37 & -- & 402.0 & -- & $\begin{array}{l}0 \\
95.0\end{array}$ & $\begin{array}{l}\text { 110SDMN } \\
\text { BEDROCK }\end{array}$ & $\begin{array}{l}\text { SDGL } \\
\text { ROCK }\end{array}$ & \\
\hline WRW & 43 & -- & 482.0 & -- & $\begin{array}{l}0 \\
15.0\end{array}$ & $\begin{array}{l}\text { 112TILL } \\
\text { BEDROCK }\end{array}$ & $\begin{array}{l}\text { TILL Sand, gravel, hardpan } \\
\text { ROCK }\end{array}$ & \\
\hline WRW & 44 & -- & 162.0 & -- & $\begin{array}{l}0 \\
37.0\end{array}$ & $\begin{array}{l}\text { 110SDMN } \\
\text { BEDROCK }\end{array}$ & $\begin{array}{l}\text { SDGL } \\
\text { ROCK }\end{array}$ & \\
\hline WRW & 45 & -- & 363.0 & -- & $\begin{array}{c}0 \\
75.0\end{array}$ & $\begin{array}{l}\text { 112TILL } \\
\text { BEDROCK }\end{array}$ & $\begin{array}{l}\text { TILL } \\
\text { ROCK }\end{array}$ & \\
\hline WRW & 59 & -- & 1000.0 & -- & 10.0 & BEDROCK & ROCK & \\
\hline WRW & 71 & -- & 400.0 & -- & $\begin{array}{r}0 \\
6.0 \\
90.0\end{array}$ & $\begin{array}{l}\text { 110SDMN } \\
112 T I L L \\
\text { BEDROCK }\end{array}$ & $\begin{array}{l}\text { SAND } \\
\text { TILL Clay, hardpan } \\
\text { ROCK }\end{array}$ & \\
\hline WRW & 72 & -- & 500.0 & -- & $\begin{array}{l}0 \\
6.0 \\
95.0\end{array}$ & $\begin{array}{l}\text { 11OSDMN } \\
\text { 112TILL } \\
\text { BEDROCK }\end{array}$ & $\begin{array}{l}\text { SAND } \\
\text { TILL Clay, hardpan } \\
\text { ROCK }\end{array}$ & \\
\hline
\end{tabular}


Table B-1. Stratigraphic logs of selected wells and borings in the Winnipesaukee River Basin, central New Hampshire-Continued

\begin{tabular}{|c|c|c|c|c|c|c|}
\hline $\begin{array}{l}\text { Local } \\
\text { site } \\
\text { number }\end{array}$ & $\begin{array}{l}\text { Depth } \\
\text { drilled } \\
\text { (feet) }\end{array}$ & $\begin{array}{c}\text { Depth } \\
\text { of } \\
\text { well } \\
\text { (feet) }\end{array}$ & $\begin{array}{l}\text { Depth } \\
\text { to } \\
\text { refusal } \\
\text { (feet) }\end{array}$ & $\begin{array}{l}\text { Depth } \\
\text { to } \\
\text { top } \\
\text { (feet) }\end{array}$ & $\begin{array}{l}\text { Aquifer } \\
\text { code }\end{array}$ & $\begin{array}{c}\text { Lithologic description } \\
\text { of } \\
\text { material }\end{array}$ \\
\hline
\end{tabular}

\section{CARROLL COUNTY}

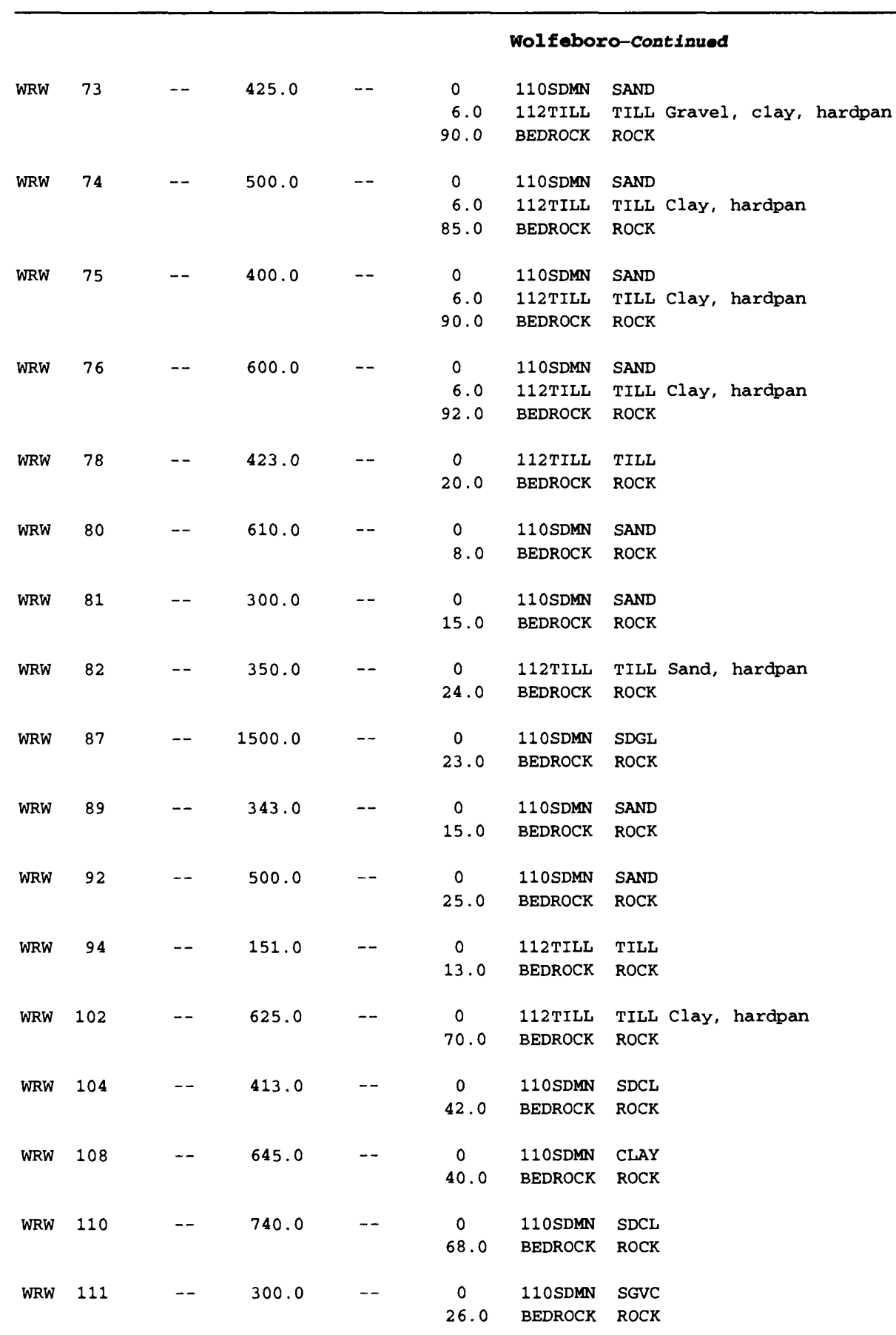


Table B-1. Stratigraphic logs of selected wells and borings in the Winnipesaukee River Basin, central New Hampshire-Continued

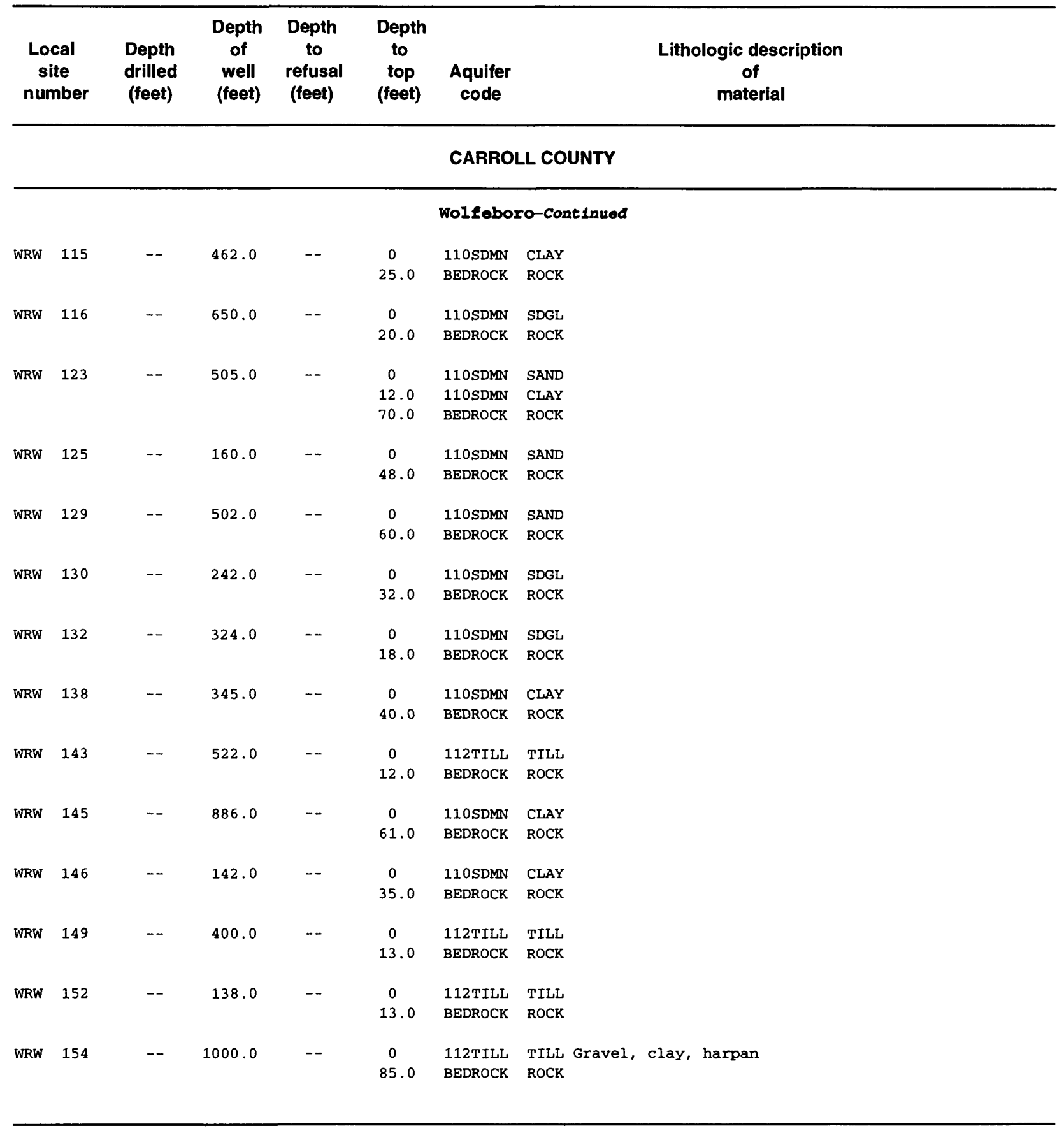

\section{MERRIMACK COUNTY}

\section{Franklin}

$\begin{array}{lccrrrrl}\text { FKW } & 7 & -- & 131.0 & - & 75.0 & \text { BEDROCK } & \\ & & & & & & & \\ \text { FKW } & 78 & 38.0 & -- & 38.0 & 0 & 110 \text { SDMN } & \text { SDMN Muck } \\ & & & & & 2.0 & 110 \text { SDMN } & \text { SDST Sand, fine, silty } \\ & & & & & 5.0 & 112 \text { TILL } & \text { TILL Till } \\ & & & & & 38.0 & \text { BEDROCK } & \text { ROCK Bedrock }\end{array}$


Table B-1. Stratigraphic logs of selected wells and borings in the Winnipesaukee River Basin, central New Hampshire-Continued

\begin{tabular}{|c|c|c|c|c|c|c|}
\hline $\begin{array}{l}\text { Local } \\
\text { site } \\
\text { number }\end{array}$ & $\begin{array}{l}\text { Depth } \\
\text { drilled } \\
\text { (feet) }\end{array}$ & $\begin{array}{l}\text { Depth } \\
\text { of } \\
\text { well } \\
\text { (feet) }\end{array}$ & $\begin{array}{l}\text { Depth } \\
\text { to } \\
\text { refusal } \\
\text { (feet) }\end{array}$ & $\begin{array}{l}\text { Depth } \\
\text { to } \\
\text { top } \\
\text { (feet) }\end{array}$ & $\begin{array}{l}\text { Aquifer } \\
\text { code }\end{array}$ & $\begin{array}{c}\text { Lithologic description } \\
\text { of } \\
\text { material }\end{array}$ \\
\hline
\end{tabular}

\section{MERAIMACK COUNTY}

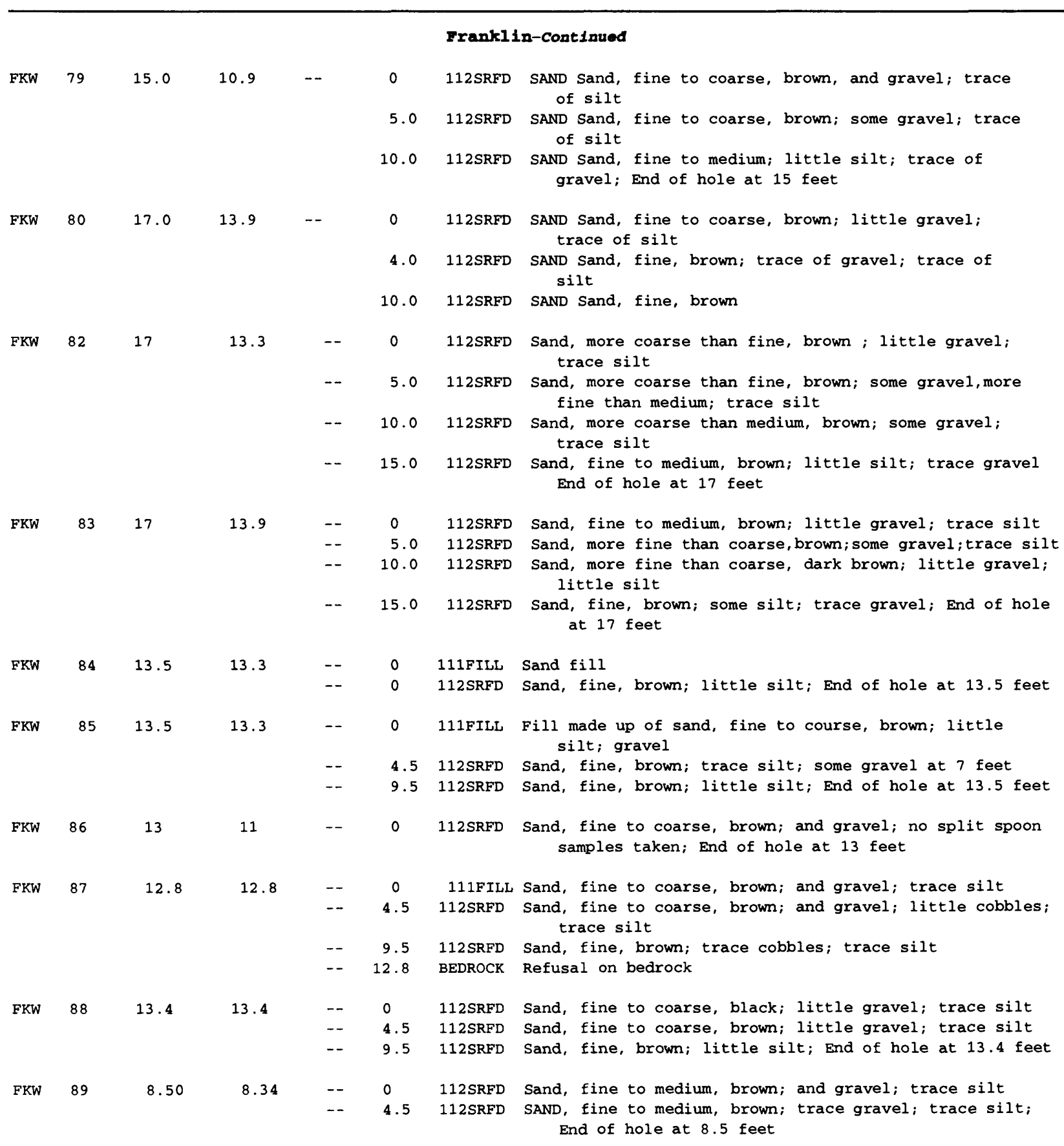


Table B-1. Stratigraphic logs of selected wells and borings in the Winnipesaukee River Basin, central New Hampshire-Continued

\begin{tabular}{|c|c|c|c|c|c|c|c|}
\hline \multicolumn{2}{|c|}{$\begin{array}{l}\text { Local } \\
\text { site } \\
\text { number }\end{array}$} & \multirow[t]{2}{*}{$\begin{array}{l}\text { Depth } \\
\text { drilled } \\
\text { (feet) }\end{array}$} & \multirow[t]{2}{*}{$\begin{array}{l}\text { Depth } \\
\text { of } \\
\text { well } \\
\text { (feet) }\end{array}$} & \multirow[t]{2}{*}{$\begin{array}{l}\text { Depth } \\
\text { to } \\
\text { refusal } \\
\text { (feet) }\end{array}$} & \multirow[t]{2}{*}{$\begin{array}{l}\text { Depth } \\
\text { to } \\
\text { top } \\
\text { (feet) }\end{array}$} & \multicolumn{2}{|r|}{$\begin{array}{l}\text { Lithologic description } \\
\text { of } \\
\text { material }\end{array}$} \\
\hline \multicolumn{4}{|c|}{ MERRIMACK COUNTY } & & & & \\
\hline \multicolumn{8}{|c|}{ Franklin-Continued } \\
\hline \multirow[t]{2}{*}{ FKW } & 90 & 15.5 & 14.1 & -- & $\begin{array}{l}0 \\
3.5 \\
9.5\end{array}$ & $\begin{array}{l}111 \text { FILL } \\
112 \text { SRFD } \\
112 \text { SRFD }\end{array}$ & $\begin{array}{l}\text { Sand, fine to coarse, brown; trace gravel; trace silt } \\
\text { Sand, fine to coarse, brown; and gravel; trace silt } \\
\text { Sand, more fine than medium, brown; little silt; trace } \\
\text { gravel }\end{array}$ \\
\hline & & & & -- & 14.5 & 112SRFD & $\begin{array}{l}\text { Sand, fine to coarse, brown; little silty clay; trace } \\
\text { gravel; refusal at } 15.5 \text { feet }\end{array}$ \\
\hline \multirow[t]{2}{*}{ FKW } & 91 & 16.5 & 14.5 & -- & 0 & 111FILL & $\begin{array}{l}\text { Fill made up of sand, fine to coarse, brown; gravel, } \\
\text { fine to coarse; 1ittle pebbles to cobbles; trace silt }\end{array}$ \\
\hline & & & & -- & $\begin{array}{l}9.5 \\
16\end{array}$ & $\begin{array}{l}112 \text { SRFD } \\
112 \text { SRFD }\end{array}$ & $\begin{array}{l}\text { Sand, fine; gray; trace gravel; trace silt } \\
\text { Sand, more fine than medium, brown; little gravel; trace } \\
\text { silt; End of hole at } 16.5 \text { feet }\end{array}$ \\
\hline \multirow[t]{3}{*}{ FKW } & 97 & 16.5 & 14.6 & -- & 0 & 111FILL & Sand fill \\
\hline & & & & -- & 4.5 & 112SRFD & Sand, fine, brown; trace gravel; trace silt \\
\hline & & & & -- & 9.5 & 112TILL & $\begin{array}{l}\text { Sandy till, compactness increases with depth; End of } \\
\text { hole at } 16.5 \text { feet }\end{array}$ \\
\hline \multirow[t]{3}{*}{ FKW } & 98 & 18.5 & 18.5 & -- & 0 & 111FILL & Sandy fill \\
\hline & & & & -- & 9.5 & 112SRFD & Sand, fine to coarse, gray; some gravel; little silt \\
\hline & & & & -- & 14.5 & 112 SRFD & $\begin{array}{l}\text { Sand, fine, orange brown; trace silt; End of hole at } \\
18.5 \text { feet }\end{array}$ \\
\hline FKW & 99 & 18 & 18 & -- & 0 & 110 SDMN & No samples taken; End of hole at 18 feet \\
\hline \multirow[t]{3}{*}{ FKW } & 100 & 17 & 17 & -- & 0 & 111FILL & Sandy fill \\
\hline & & & & -- & 9.5 & 112SRFD & Sand, fine, gray; trace silt \\
\hline & & & & -- & 14.5 & 112SRFD & $\begin{array}{l}\text { Sand, fine to coarse, orange; and gravel; trace silt; } \\
\text { End of hole at } 17 \text { feet }\end{array}$ \\
\hline \multirow[t]{3}{*}{ FKW } & 101 & 17 & 15.8 & -- & 0 & 111FILL & Sandy fill; including ash slag \\
\hline & & & & -- & 9.5 & 112SRFD & Sand, fine to coarse, brown; some gravel; trace silt \\
\hline & & & & -- & 14.5 & 112TILL & Sand, fine to gravel, trace silt; End of hole at 17 feet \\
\hline \multirow[t]{5}{*}{ FKW } & 102 & 18.8 & 16.7 & -- & 0 & 111FILL & Sandy fill \\
\hline & & & & -- & -- & 110SDMN 1 & No sample taken between 2 feet and 9.5 feet \\
\hline & & & & -- & 9.5 & 112SRFD & Sand, fine to coarse, brown; some gravel; trace silt \\
\hline & & & & -- & 14.5 & 112SRFD & Sand, medium, brown; little gravel; trace silt \\
\hline & & & & -- & 15.5 & 112SRFD & Sand, fine, brown; End of hole at 18.8 feet \\
\hline FKW & 103 & 16 & 15.1 & -- & -- & -- & - \\
\hline \multicolumn{8}{|c|}{ Northfield } \\
\hline \multirow[t]{5}{*}{$\mathrm{NRB}$} & 1 & 50 & -- & -- & 0 & 110 SDMN & Sand and silt \\
\hline & & & & -- & 4.0 & 110SDMN & Sand, coarse \\
\hline & & & & -- & 28.0 & 110 SDMN & Sand, fine and silt \\
\hline & & & & -- & 41.0 & 110 SDMN & Sand, fine \\
\hline & & & & -- & 50.0 & 110 SDMN & End of hole \\
\hline \multirow[t]{3}{*}{ NRB } & 26 & 36 & -- & -- & 0 & $110 \mathrm{SDMN}$ & Sand, fine to coarse \\
\hline & & & & -- & 9.0 & 112TILL & Till, silty \\
\hline & & & & -- & 36.0 & 112TILL & End of hole \\
\hline \multirow[t]{3}{*}{ NRB } & 27 & 49 & -- & -- & 0 & 110SDMN & Sand, gravelly \\
\hline & & & & -- & 11.0 & 110 SDMN & Sand, silty \\
\hline & & & & -- & 20.0 & $110 \mathrm{SDMN}$ & Silt and clay \\
\hline
\end{tabular}


Table B-1. Stratigraphic logs of selected wells and borings in the Winnipesaukee River Basin, central New Hampshire-Continued

\begin{tabular}{|c|c|c|c|c|c|c|}
\hline $\begin{array}{l}\text { Local } \\
\text { site } \\
\text { number }\end{array}$ & $\begin{array}{l}\text { Depth } \\
\text { drilled } \\
\text { (feet) }\end{array}$ & $\begin{array}{l}\text { Depth } \\
\text { of } \\
\text { well } \\
\text { (feet) }\end{array}$ & $\begin{array}{l}\text { Depth } \\
\text { to } \\
\text { refusal } \\
\text { (feet) }\end{array}$ & $\begin{array}{l}\text { Depth } \\
\text { to } \\
\text { top } \\
\text { (feet) }\end{array}$ & $\begin{array}{l}\text { Aquifer } \\
\text { code }\end{array}$ & $\begin{array}{c}\text { Lithologic description } \\
\text { of } \\
\text { material }\end{array}$ \\
\hline
\end{tabular}

MERRIMACK COUNTY

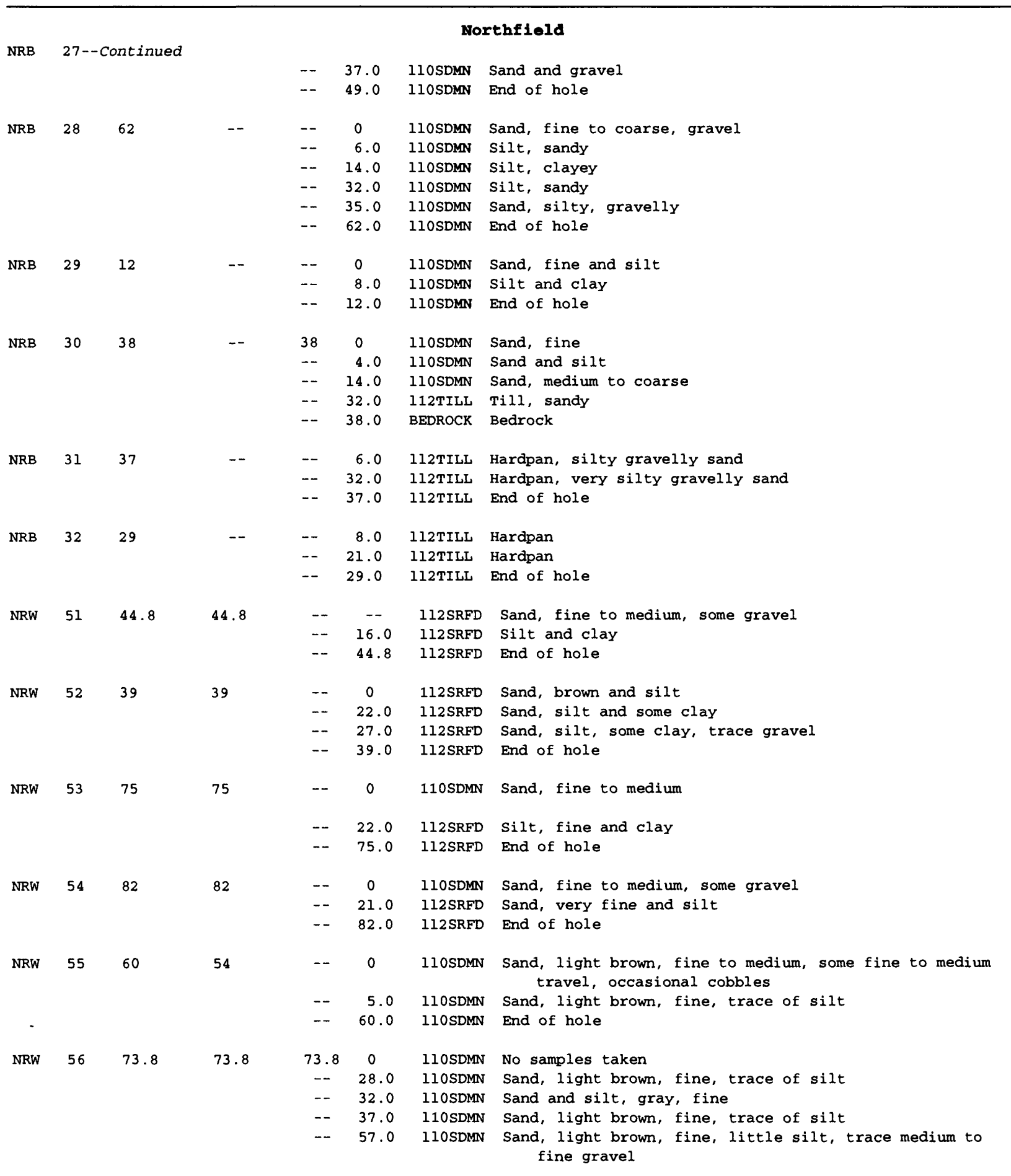


Table B-1. Stratigraphic logs of selected wells and borings in the Winnipesaukee River Basin, central New Hampshire-Continued

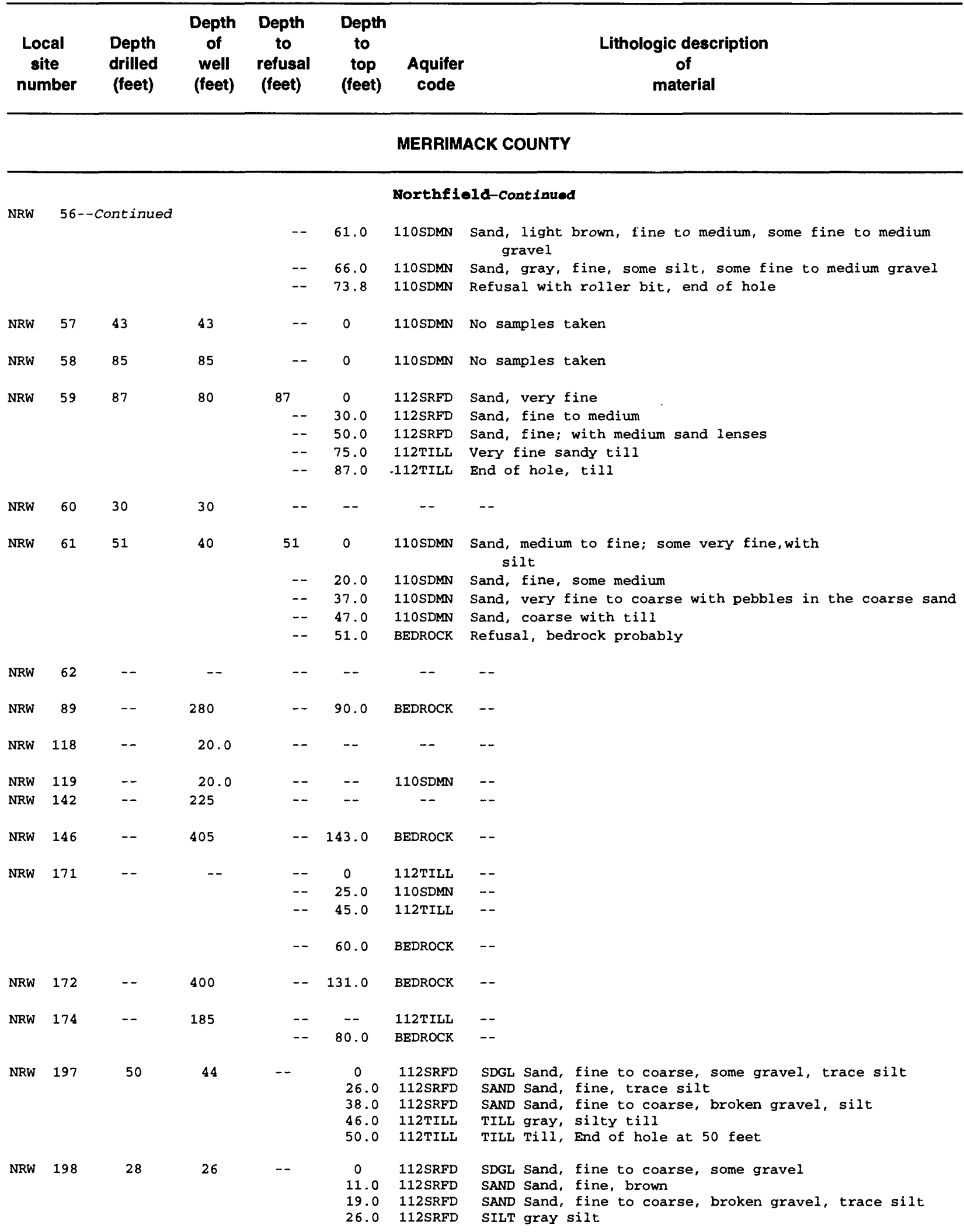


Table B-1. Stratigraphic logs of selected wells and borings in the Winnipesaukee River Basin, central New Hampshire-Continued

\begin{tabular}{|c|c|c|c|c|c|c|}
\hline $\begin{array}{l}\text { Local } \\
\text { site } \\
\text { number }\end{array}$ & $\begin{array}{l}\text { Depth } \\
\text { drilled } \\
\text { (feet) }\end{array}$ & $\begin{array}{l}\text { Depth } \\
\text { of } \\
\text { well } \\
\text { (feet) }\end{array}$ & $\begin{array}{l}\text { Depth } \\
\text { to } \\
\text { refusal } \\
\text { (feet) }\end{array}$ & $\begin{array}{l}\text { Depth } \\
\text { to } \\
\text { top } \\
\text { (feet) }\end{array}$ & $\begin{array}{l}\text { Aquifer } \\
\text { code }\end{array}$ & $\begin{array}{c}\text { Lithologic description } \\
\text { of } \\
\text { material }\end{array}$ \\
\hline
\end{tabular}

MERRIMACK COUNTY

\begin{tabular}{|c|c|c|c|c|c|c|c|}
\hline & \multicolumn{7}{|c|}{ Northfield-Continued } \\
\hline NRW & 199 & 70 & 67 & -- & $\begin{array}{l}0 \\
20.0 \\
40.0 \\
44.0 \\
67.0\end{array}$ & $\begin{array}{l}112 \text { SRFD } \\
112 \text { SRFD } \\
112 \text { SRFD } \\
112 \text { SRFD } \\
112 \text { SRFD }\end{array}$ & $\begin{array}{l}\text { SAND Sand, medium to coarse } \\
\text { SAND Sand, fine to medium } \\
\text { SAND Sand, fine to medium, some coarse } \\
\text { SDGL Sand, fine to coarse, some gravel } \\
\text { SILT Silt }\end{array}$ \\
\hline NRW & 200 & 76 & 76 & -- & $\begin{array}{l}0 \\
24.0 \\
31.0 \\
40.0 \\
51.0 \\
58.0 \\
60.0 \\
76.0\end{array}$ & $\begin{array}{l}112 \text { SRFD } \\
112 \text { SRFD } \\
112 \text { SRFD } \\
112 \text { SRFD } \\
112 \text { SRFD } \\
112 \text { SRFD } \\
112 \text { SRFD } \\
112 \text { SRFD }\end{array}$ & $\begin{array}{l}\text { SAND Sand, fine, some medium, trace silt } \\
\text { SAND Sand, fine to medium } \\
\text { SAND Sand, fine to coarse; some gravel } \\
\text { SAND Sand, fine to coarse } \\
\text { SDGL Sand, fine to coarse; some gravel } \\
\text {-- } \\
\text { SDGL Sand, medium to coarse; some broken gravel } \\
\text { SDGL Sand, fine to coarse, some gravel; silt }\end{array}$ \\
\hline NRW & 201 & 77 & 69 & -- & $\begin{array}{l}0 \\
16.0 \\
27.0 \\
36.0 \\
38.0 \\
43.0 \\
69.0\end{array}$ & $\begin{array}{l}112 \text { SRFD } \\
112 \text { SRFD } \\
112 \text { SRFD } \\
112 \text { SRFD } \\
112 \text { SRFD } \\
112 \text { SRFD } \\
112 \text { SRFD }\end{array}$ & $\begin{array}{l}\text { SAND Sand, fine to medium, some coarse } \\
\text { SAND Sand, fine to medium, trace silt } \\
\text { SDST Sand, fine, silt } \\
\text { CLAY Clay, gray } \\
\text { SAND Sand, fine, some medium } \\
\text { SDGL Sand, fine to coarse; gravel } \\
\text { SAND Sand, fine to coarse; some gravel, silt }\end{array}$ \\
\hline NRW & 202 & 77 & 68 & -- & $\begin{array}{l}0 \\
20.0 \\
46.0 \\
75.0\end{array}$ & $\begin{array}{l}112 \text { SRFD } \\
112 \text { SRFD } \\
112 \text { SRFD } \\
112 \text { SRFD }\end{array}$ & $\begin{array}{l}\text { SDGL Sand, fine to coarse; gravel } \\
\text { SAND Sand, fine to medium; some coarse } \\
\text { SDGL Sand, fine; some medium to coarse; broken gravel } \\
\text { SAND Sand, fine; some medium to coarse; gravel silt }\end{array}$ \\
\hline NRW & 203 & 67 & 63 & -- & $\begin{array}{l}0 \\
30.0 \\
38.0 \\
44.0 \\
54.0\end{array}$ & $\begin{array}{l}112 \text { SRFD } \\
112 \text { SRFD } \\
112 \text { SRFD } \\
112 \text { SRFD } \\
112 \text { SRFD }\end{array}$ & $\begin{array}{l}\text { SDGL Sand, fine to coarse; gravel } \\
\text { SAND Sand, fine to medium, some coarse } \\
\text { SDGL Sand, fine to coarse; gravel } \\
\text { SAND Sand, fine to coarse } \\
\text { SDGL Sand, fine to coarse, gravel, silt }\end{array}$ \\
\hline NRW & 204 & 69 & 69 & -- & $\begin{array}{l}0 \\
20.0 \\
30.0 \\
50.0 \\
55.0 \\
60.0\end{array}$ & $\begin{array}{l}112 \text { SRFD } \\
112 \text { SRFD } \\
112 \text { SRFD } \\
112 \text { SRFD } \\
112 \text { SRFD } \\
112 \text { SRFD }\end{array}$ & $\begin{array}{l}\text { SAND Sand, fine to medium } \\
\text { SDGL Sand, fine to mdium; gravel, medium to coarse } \\
\text { SAND Sand, fine to medium, with mica } \\
\text { SAND Sand, fine to Coarse } \\
\text { SAND Sand, fine to medium } \\
\text { SDGL Sand, fine to medium; gravel, cobbles }\end{array}$ \\
\hline NRW & 205 & 69 & 69 & -- & $\begin{array}{l}0 \\
30.0 \\
44.0 \\
55.0 \\
60.0 \\
66.0 \\
67.0\end{array}$ & $\begin{array}{l}112 \text { SRFD } \\
112 \text { SRFD } \\
112 \text { SRFD } \\
112 \text { SRFD } \\
112 \text { SRFD } \\
112 \text { SRFD } \\
112 \text { SRFD }\end{array}$ & $\begin{array}{l}\text { SAND Sand, fine to coarse } \\
\text { SAND Sand, fine; trace silt and clay } \\
\text { SDGL Sand, gravel, cobbles } \\
\text { SDGL Sand and gravel, fine to coarse } \\
\text { SAND Sand, fine to coarse } \\
\text { SAND Sand, fine to coarse, with mica } \\
\text { SDGL Sand, fine to coarse; gravel, cobbles }\end{array}$ \\
\hline
\end{tabular}

STRAFFORD COUNTY

Middleton

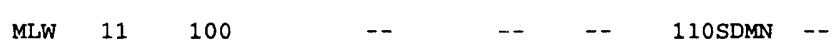

$9.0 \quad$ BEDROCK BEDROCK 
Table B-1. Stratigraphic logs of selected wells and borings in the Winnipesaukee River Basin, central New Hampshire-Continued

\begin{tabular}{|c|c|c|c|c|c|c|}
\hline $\begin{array}{l}\text { Local } \\
\text { site } \\
\text { number }\end{array}$ & $\begin{array}{l}\text { Depth } \\
\text { drilled } \\
\text { (feet) }\end{array}$ & $\begin{array}{l}\text { Depth } \\
\text { of } \\
\text { well } \\
\text { (feet) }\end{array}$ & $\begin{array}{l}\text { Depth } \\
\text { to } \\
\text { refusal } \\
\text { (feet) }\end{array}$ & $\begin{array}{l}\text { Depth } \\
\text { to } \\
\text { top } \\
\text { (feet) }\end{array}$ & $\begin{array}{l}\text { Aquifer } \\
\text { code }\end{array}$ & $\begin{array}{c}\text { Lithologic description } \\
\text { of } \\
\text { material }\end{array}$ \\
\hline
\end{tabular}

STRAFFORD COUNTY

\begin{tabular}{|c|c|c|c|c|c|c|c|}
\hline & & & & & & New & Durham \\
\hline NFA & 1 & 20 & -- & 20 & 0 & 112SRFD & Sand, medium to coarse, refusal at 20 feet \\
\hline NFA & 2 & 16.5 & -- & $\begin{array}{c}16.5 \\
-- \\
--\end{array}$ & $\begin{array}{r}0 \\
7.0 \\
15.0\end{array}$ & $\begin{array}{l}111 \mathrm{ALVM} \\
112 \text { SRFD } \\
112 \text { TILL }\end{array}$ & $\begin{array}{l}\text { Muck } \\
\text { Sand, trace silt, some gravel } \\
\text { Till }\end{array}$ \\
\hline NFB & 3 & 15.9 & - & $\begin{array}{c}15.9 \\
-- \\
--\end{array}$ & $\begin{array}{r}0 \\
8.0 \\
14.9\end{array}$ & $\begin{array}{l}120 \text { SDMS } \\
112 \text { ICCC } \\
112 \text { TILL }\end{array}$ & $\begin{array}{l}-- \\
\text { Sand, Medium to coarse; Gravel } \\
\text { Refusal at } 15.9 \text { feet }\end{array}$ \\
\hline NFB & 26 & 17 & -- & $\begin{array}{l}-- \\
-- \\
-- \\
--\end{array}$ & $\begin{array}{r}0 \\
7.0 \\
15.0 \\
17.0\end{array}$ & $\begin{array}{l}110 \text { SDMN } \\
110 \text { SDMN } \\
112 \text { TILL } \\
112 \text { TILL }\end{array}$ & $\begin{array}{l}\text { Muck } \\
\text { Sand, medium to coarse } \\
\text { Hardpan, sandy } \\
\text { End of hole }\end{array}$ \\
\hline NFB & 27 & 13 & -- & $\begin{array}{l}13 \\
-- \\
--\end{array}$ & $\begin{array}{r}0 \\
7.0 \\
13.0\end{array}$ & $\begin{array}{l}110 \text { SDMN } \\
110 \text { SDMN } \\
\text { BEDROCK }\end{array}$ & $\begin{array}{l}\text { Sand, fine to medium } \\
\text { Sand and gravel } \\
\text { Bedrock }\end{array}$ \\
\hline NFW & 1 & 158 & 158 & $\begin{array}{l}-- \\
--\end{array}$ & $\begin{array}{l}0 \\
96.0\end{array}$ & $\begin{array}{l}\text { 112SRFD } \\
\text { BEDROCK }\end{array}$ & Drilled into rock \\
\hline NFW & 2 & 14 & 14 & -- & - & 1120TSH & -- \\
\hline NFW & 3 & 6.5 & 6.5 & -- & - & $11220 \mathrm{CL}$ & -- \\
\hline NFW & 4 & 17.1 & 17.1 & -- & -- & $1120 \mathrm{TSH}$ & -- \\
\hline NFW & 5 & 11.4 & 11.4 & -- & 1.0 & $112 \mathrm{OTSH}$ & -- \\
\hline NFW & 6 & 12.2 & 12.2 & -- & - & 1120TSH & -- \\
\hline NFW & 7 & 30 & 30 & -- & - & $112 \mathrm{OTSH}$ & -- \\
\hline NFW & 8 & 7.7 & 7.7 & -- & - & 1120TSH & -- \\
\hline NFW & 16 & 11.9 & 11.9 & -- & -- & 1120TSH & -- \\
\hline NFW & 19 & 23.5 & 23.5 & -- & -- & 1120TSH & -- \\
\hline NFW & 21 & 15 & 15 & -- & $\begin{array}{l}0 \\
3.0\end{array}$ & $\begin{array}{l}\text { 1120TSH } \\
1120 \mathrm{TSH}\end{array}$ & -- \\
\hline NFW & 27 & 22 & 22 & -- & - & 1120TSH & - \\
\hline NFW & 28 & -- & -- & -- & -- & -- & -- \\
\hline NFW & 29 & 13.9 & 13.9 & -- & -- & $1120 \mathrm{TSH}$ & -- \\
\hline NFW & 30 & 13.2 & 13.2 & -- & - & $1120 \mathrm{TSH}$ & -- \\
\hline NFW & 53 & 68 & 60 & $\begin{array}{l}68 \\
-- \\
-- \\
-- \\
-- \\
--\end{array}$ & $\begin{array}{r}0 \\
12.0 \\
32.0 \\
42.0 \\
47.0 \\
57.0\end{array}$ & $\begin{array}{l}112 \text { SRFD } \\
112 \text { SRFD } \\
112 \text { SRFD } \\
112 \text { SRFD } \\
112 \text { SRFD } \\
112 \text { SRFD }\end{array}$ & $\begin{array}{l}\text { Sand, coarse to gravel, cobbles } \\
\text { Sand, coarse, little gravel } \\
\text { Sand, coarse } \\
\text { Sand, fine to medium, mostly medium } \\
\text { Sand, fine to fine gravel, mostly coarse } \\
\text { Sand, fine to coarse, refusal at } 68.0 \text { feet }\end{array}$ \\
\hline
\end{tabular}


Table B-1. Stratigraphic logs of selected wells and borings in the Winnipesaukee River Basin, central New Hampshire-Continued

\begin{tabular}{|c|c|c|c|c|c|c|}
\hline $\begin{array}{l}\text { Local } \\
\text { site } \\
\text { number }\end{array}$ & $\begin{array}{l}\text { Depth } \\
\text { drilled } \\
\text { (feet) }\end{array}$ & $\begin{array}{l}\text { Depth } \\
\text { of } \\
\text { well } \\
\text { (feet) }\end{array}$ & $\begin{array}{l}\text { Depth } \\
\text { to } \\
\text { refusal } \\
\text { (feet) }\end{array}$ & $\begin{array}{l}\text { Depth } \\
\text { to } \\
\text { top } \\
\text { (feet) }\end{array}$ & $\begin{array}{l}\text { Aquifer } \\
\text { code }\end{array}$ & $\begin{array}{c}\text { Lithologic description } \\
\text { of } \\
\text { material }\end{array}$ \\
\hline
\end{tabular}

\section{STRAFFORD COUNTY}

\begin{tabular}{|c|c|c|c|c|c|c|c|}
\hline \multirow[b]{2}{*}{ NFW } & \multirow[b]{2}{*}{54} & \multirow[b]{2}{*}{81} & \multirow[b]{2}{*}{23} & \multirow[b]{2}{*}{$\begin{array}{l}81 \\
-- \\
-- \\
--\end{array}$} & \multirow[b]{2}{*}{$\begin{array}{l}0 \\
27.0 \\
33.0 \\
44.0 \\
81.0\end{array}$} & \multicolumn{2}{|c|}{ New Durham-Continued } \\
\hline & & & & & & $\begin{array}{l}112 \text { SRFD } \\
112 \text { SRFD } \\
112 \text { SRFD } \\
112 \text { SRFD } \\
\text { BEDROCK }\end{array}$ & $\begin{array}{l}\text { Sand, medium, some coarse Sand } \\
\text { Sand, medium } \\
\text { Sand, fine, some coarse Sand } \\
\text { Sand, very fine, some silt } \\
\text { Schist and other rock, refusal at } 81.0 \text { feet }\end{array}$ \\
\hline NFW & 55 & 49 & 46 & -- & $\begin{array}{c}0 \\
17.0\end{array}$ & $\begin{array}{l}112 \text { SRFD } \\
112 \text { MRIN }\end{array}$ & $\begin{array}{l}\text { Sand, very fine to medium, mostly medium } \\
\text { Sand, very fine to fine, end of hole at } 49 \text { feet }\end{array}$ \\
\hline NFW & 56 & 66 & 23 & -- & $\begin{array}{l}0 \\
21.0 \\
36.0 \\
58.0\end{array}$ & $\begin{array}{l}112 \text { SRFD } \\
112 \text { SRFD } \\
112 \text { SRFD } \\
112 \text { SRFD }\end{array}$ & $\begin{array}{l}\text { Sand, very fine to fine, mostly fine } \\
\text { Sand, very fine to medium, mostly fine } \\
\text { Sand, very fine to fine, mostly very fine } \\
\text { Sand, very fine, some silt, end of hole at } 66.0 \text { feet }\end{array}$ \\
\hline NFW & 59 & 50 & -- & -- & -- & -- & -- \\
\hline NFW & 61 & 105 & -- & -- & 10.0 & $\begin{array}{l}110 \text { SDMN } \\
\text { BEDROCK }\end{array}$ & $\begin{array}{l}\text { Sand and gravel } \\
\text { Bedrock }\end{array}$ \\
\hline NFW & 62 & 353 & -- & -- & 87.0 & $\begin{array}{l}110 \text { SDMN } \\
\text { BEDROCK }\end{array}$ & $\begin{array}{l}\text { Sand, gravel, and Clay } \\
\text { Bedrock }\end{array}$ \\
\hline NFW & 63 & 265 & -- & -- & 35.0 & $\begin{array}{l}\text { 112TILL } \\
\text { BEDROCK }\end{array}$ & $\begin{array}{l}\text { Till } \\
\text { Bedrock }\end{array}$ \\
\hline NFW & 67 & 162 & -- & - & 73.0 & $\begin{array}{l}110 \text { SDMN } \\
\text { BEDROCK }\end{array}$ & $\begin{array}{l}\text { Sand and gravel } \\
\text { Bedrock }\end{array}$ \\
\hline NFW & 69 & 200 & -- & -- & 42.0 & $\begin{array}{l}\text { 110SDMN } \\
\text { BEDROCK }\end{array}$ & $\begin{array}{l}\text { Sand and gravel } \\
\text { Bedrock }\end{array}$ \\
\hline NFW & 71 & 99 & -- & -- & 12.0 & $\begin{array}{l}\text { 112TILL } \\
\text { BEDROCK }\end{array}$ & $\begin{array}{l}\text { Till } \\
\text { Bedrock }\end{array}$ \\
\hline NFW & 72 & 150 & -- & -- & 53.0 & $\begin{array}{l}\text { 110SDMN } \\
\text { BEDROCK }\end{array}$ & $\begin{array}{l}\text { Sand and gravel } \\
\text { Bedrock }\end{array}$ \\
\hline NFW & 76 & 140 & -- & -- & 15.0 & $\begin{array}{l}110 S D M N \\
\text { BEDROCK }\end{array}$ & $\begin{array}{l}\text { Sand and gravel } \\
\text { Bedrock }\end{array}$ \\
\hline NFW & 77 & 262 & -- & -- & 11.0 & $\begin{array}{l}110 \text { SDMN } \\
\text { BEDROCK }\end{array}$ & $\begin{array}{l}\text { Sand and gravel } \\
\text { Bedrock }\end{array}$ \\
\hline NFW & 80 & 230 & -- & -- & 22.0 & $\begin{array}{l}110 S D M N \\
\text { BEDROCK }\end{array}$ & $\begin{array}{l}\text { Sand } \\
\text { Bedrock }\end{array}$ \\
\hline NFW & 81 & 186 & -- & -- & 18.0 & $\begin{array}{l}112 \text { TILL } \\
\text { BEDROCK }\end{array}$ & $\begin{array}{l}\text { Till } \\
\text { Bedrock }\end{array}$ \\
\hline NFW & 86 & -- & 15.5 & -- & -- & -- & -- \\
\hline NFW & 87 & -- & 10.2 & -- & -- & -- & -- \\
\hline
\end{tabular}




\section{APPENDIX C. Geohydrologic sections interpreted from seismic-refraction data, central New Hampshire}




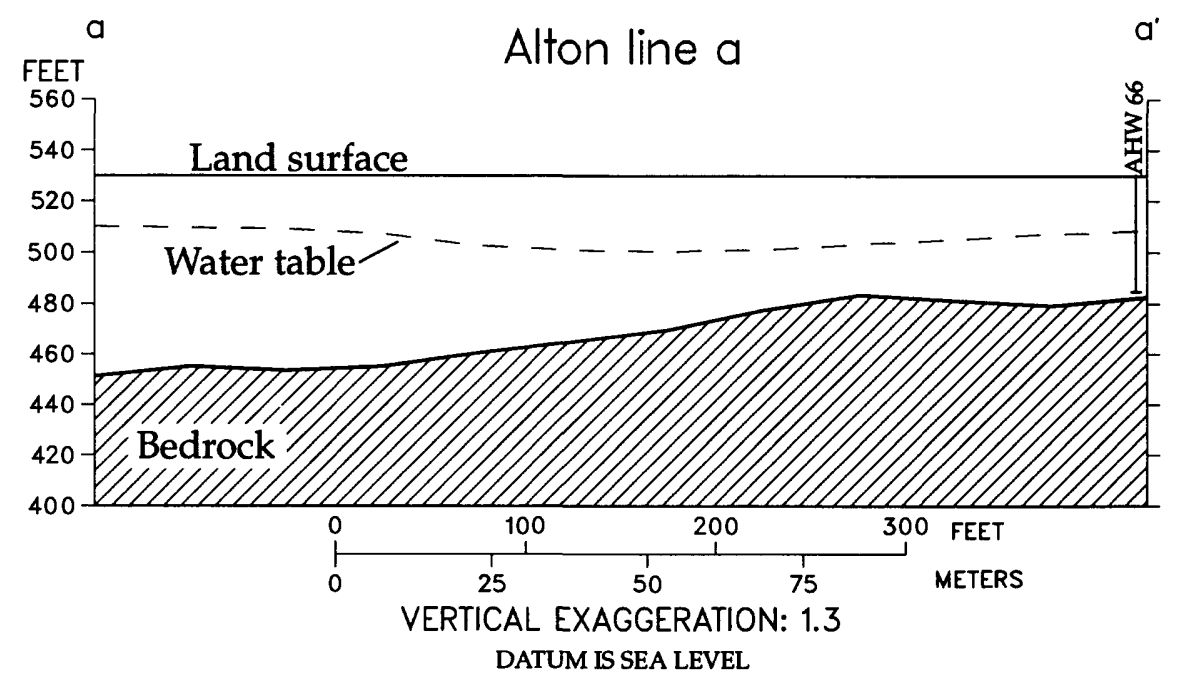

METERS
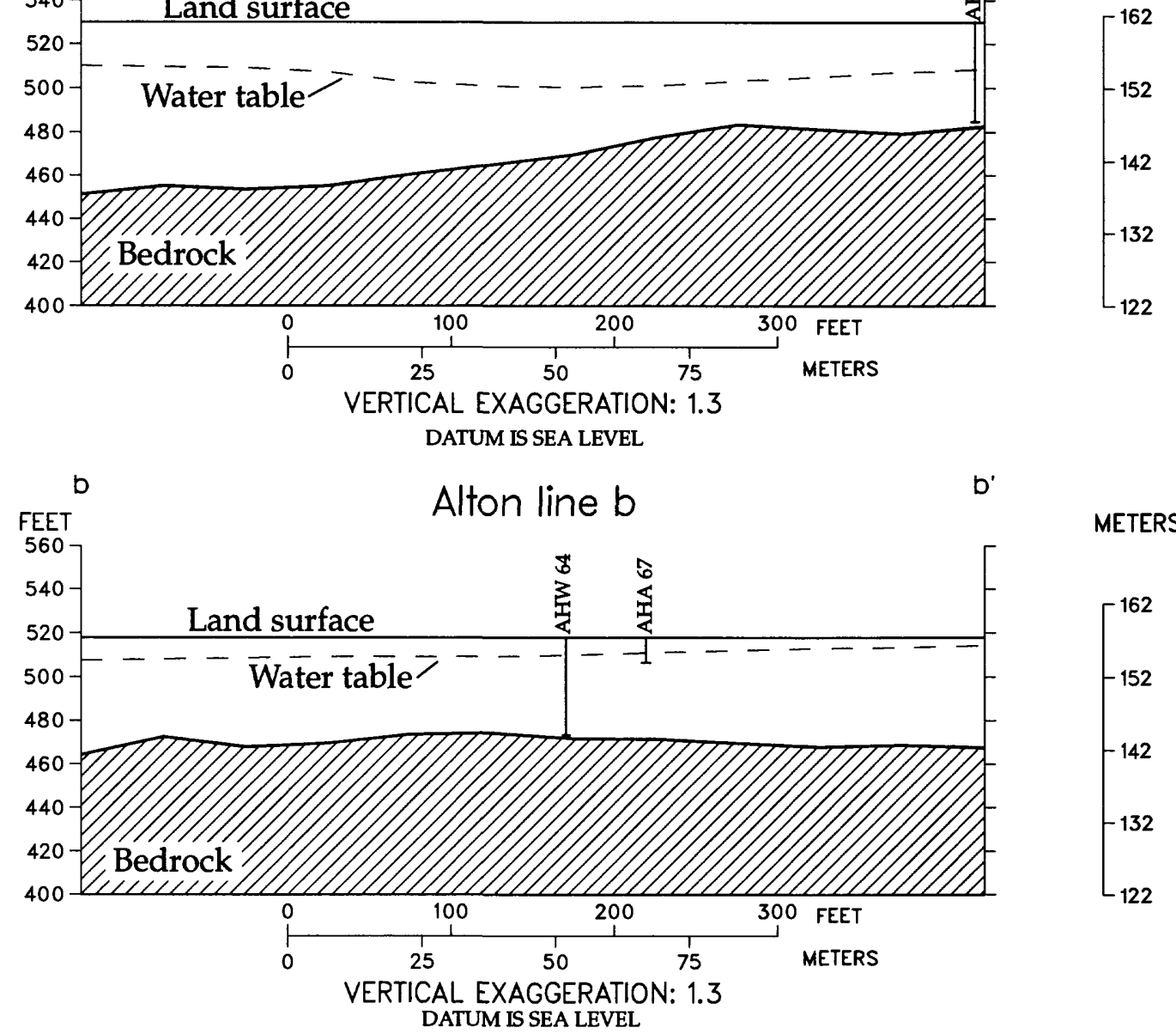

METERS

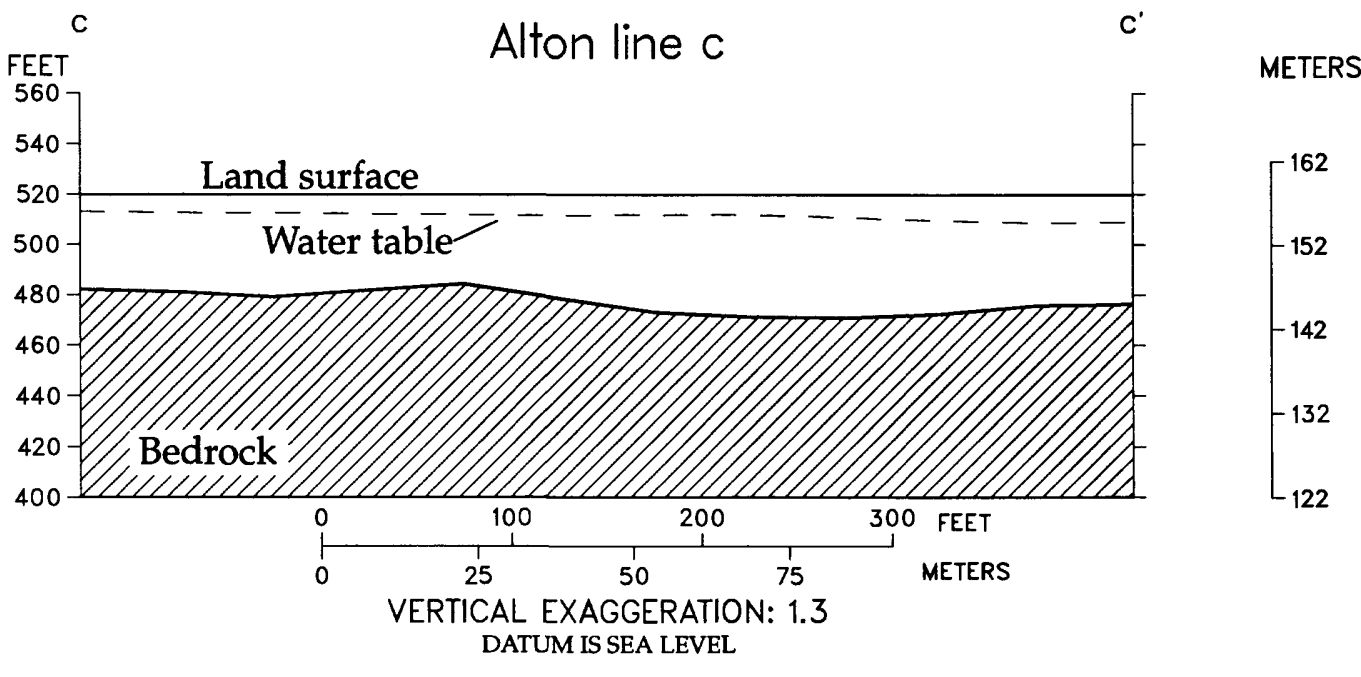

Figure $\mathrm{Cl}$. Geohydrologic sections interpreted from seismic-refraction data for Alton lines $a-a^{\prime}, b-b^{\prime}$, and $c-c^{\prime}$ (locations shown on plate 2). 


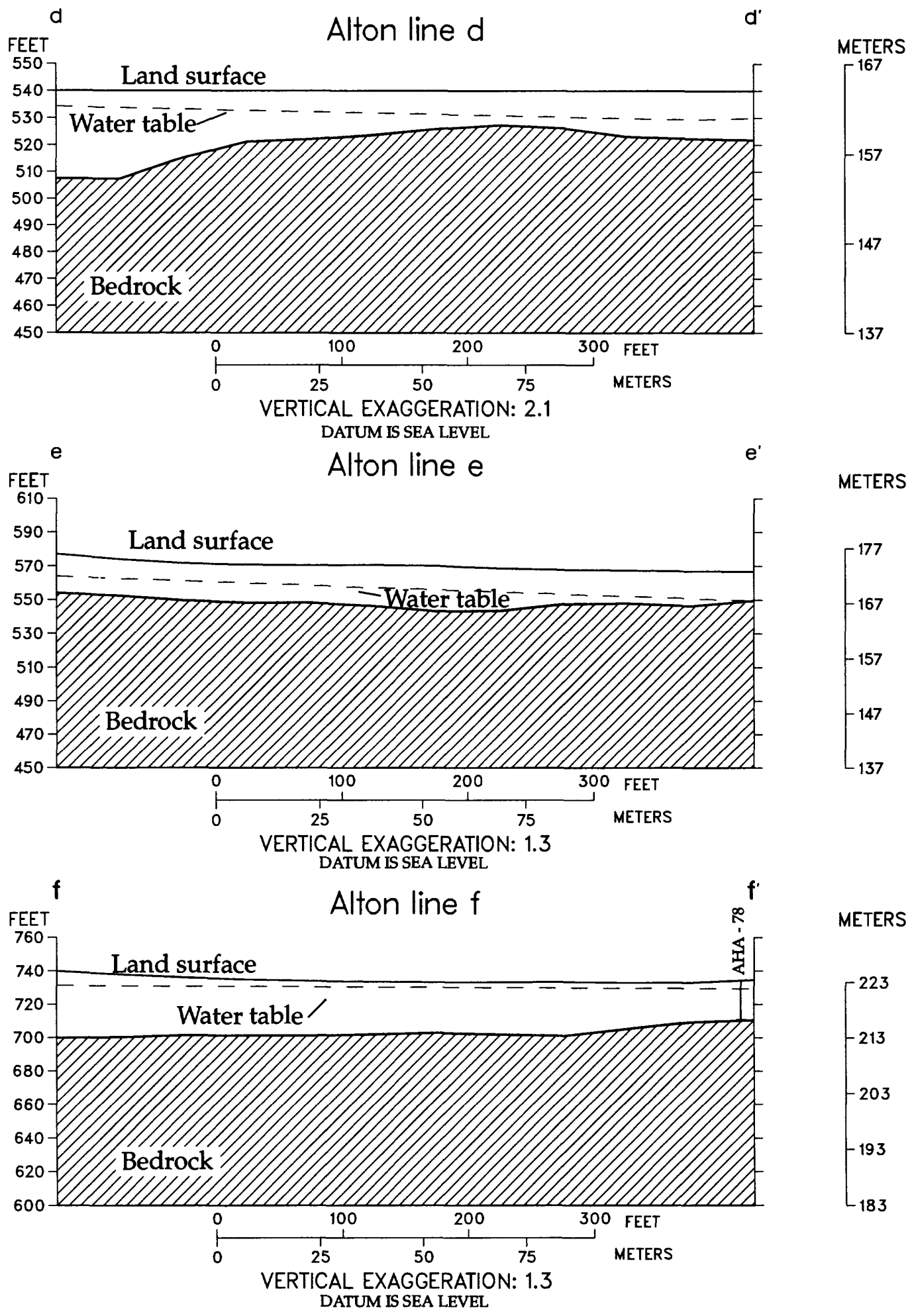

Figure C2. Geohydrologic sections interpreted from seismic-refraction data for Alton lines $d-d^{\prime}, e-e^{\prime}$, and f-f' (locations shown on plate 2). 

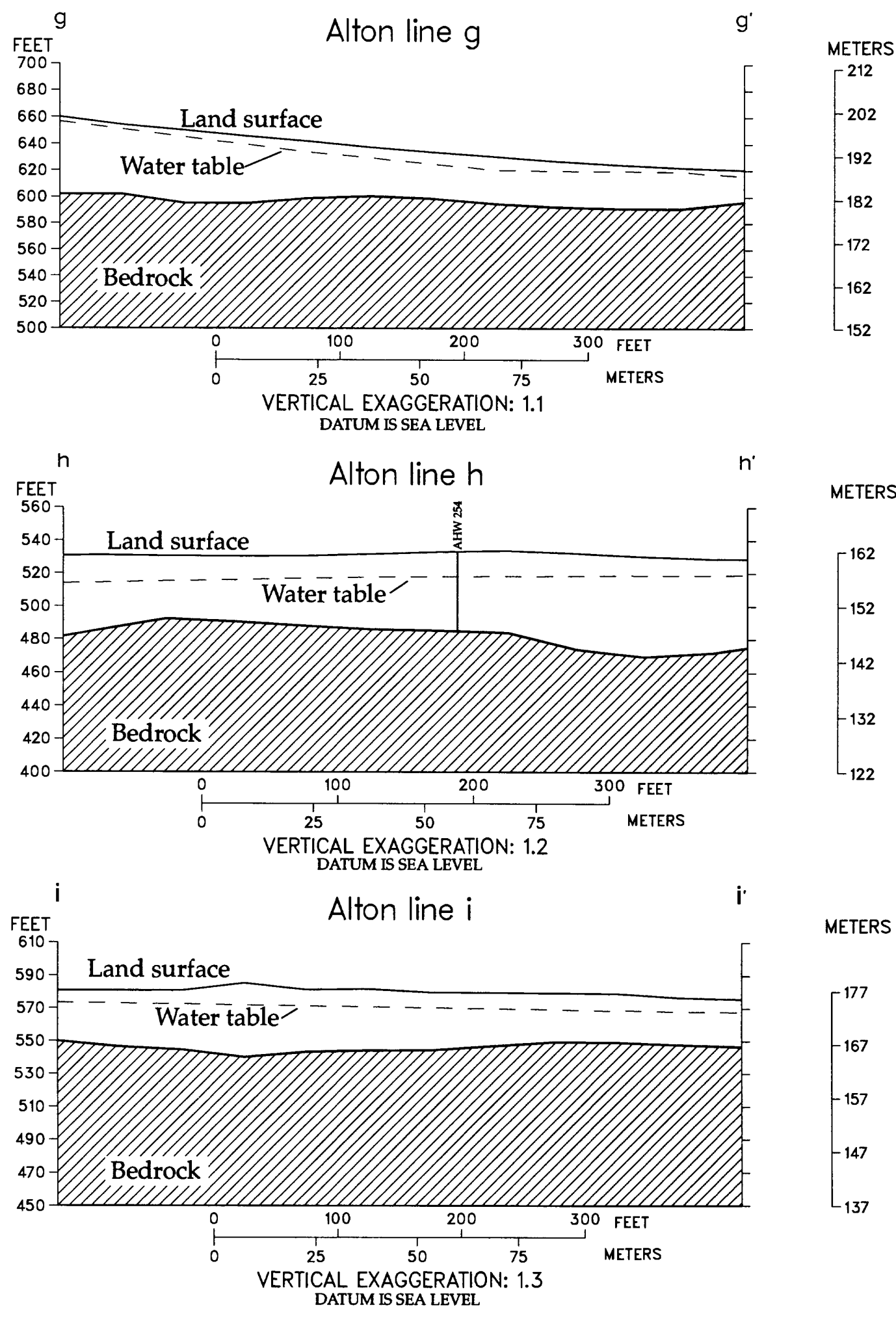

Figure C3. Geohydrologic sections interpreted from seismic-refraction data for Alton lines $g-g^{\prime}, h^{-} h^{\prime}$, and $i^{-} i^{\prime}$ (locations shown on plate 2). 

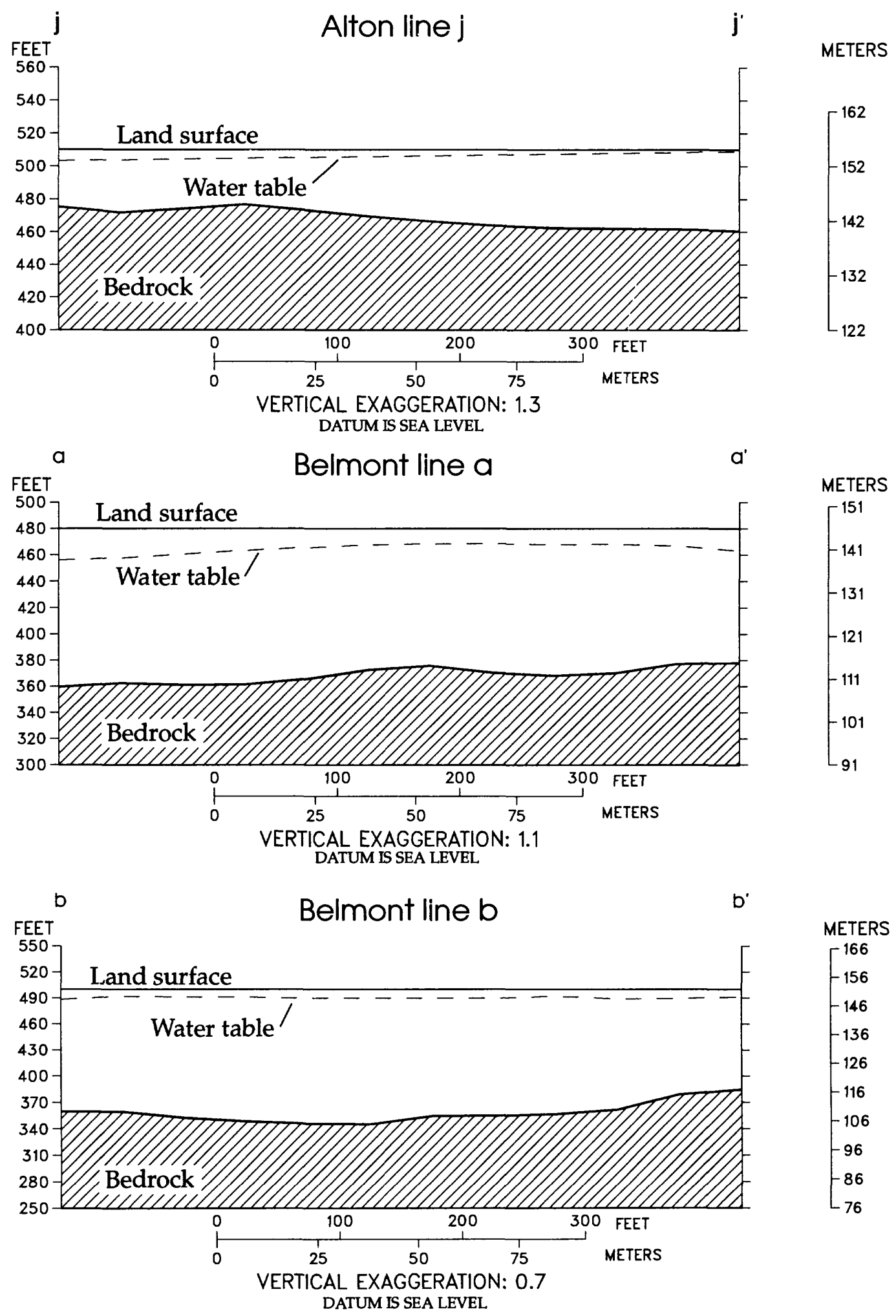

Figure C4. Geohydrologic sections interpreted from seismic-refraction data for Alton lines j-j', (location shown on plate 2) and Belmont lines a-a' and b-b' (locations shown on plate 1). 

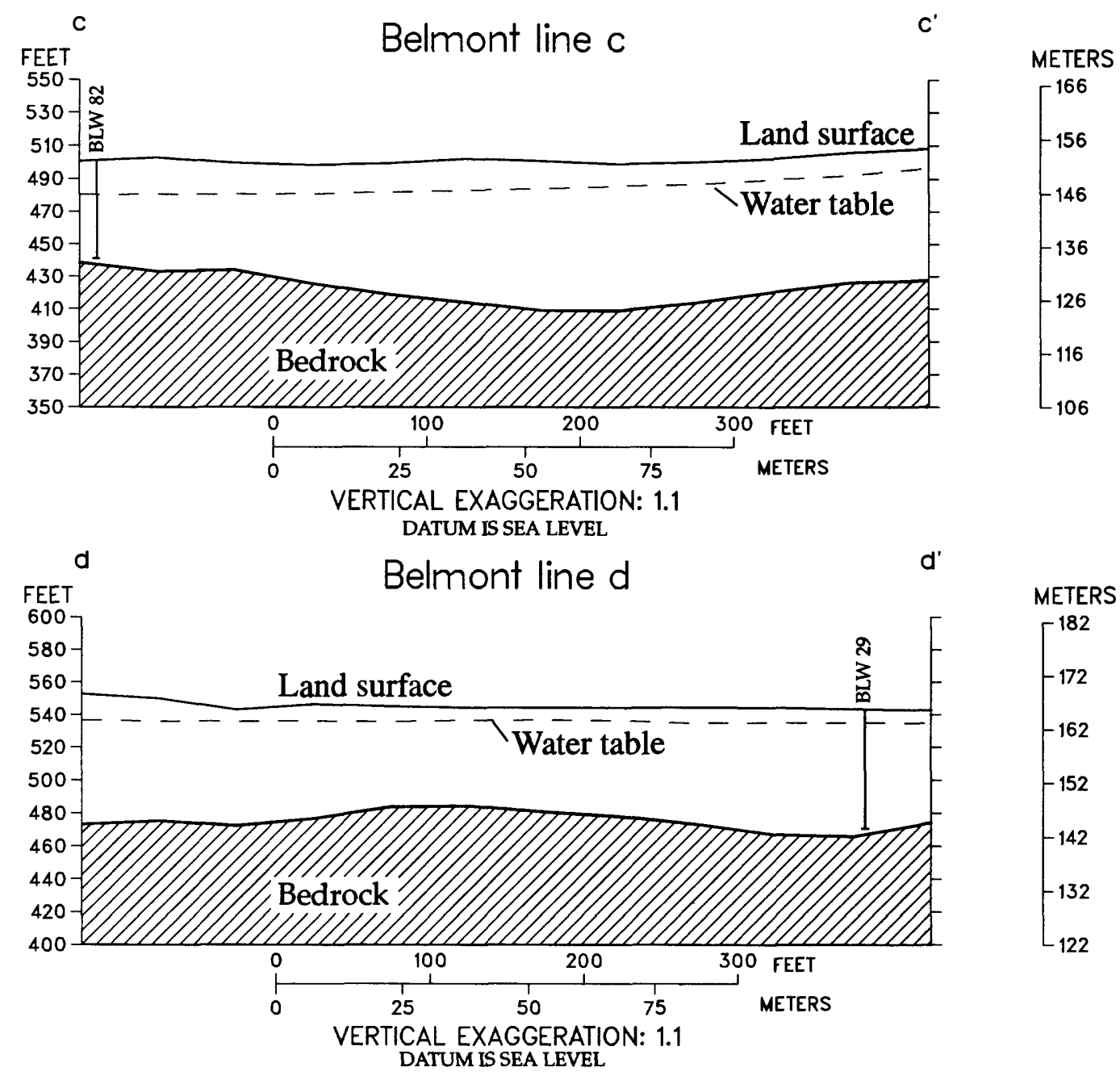

METERS

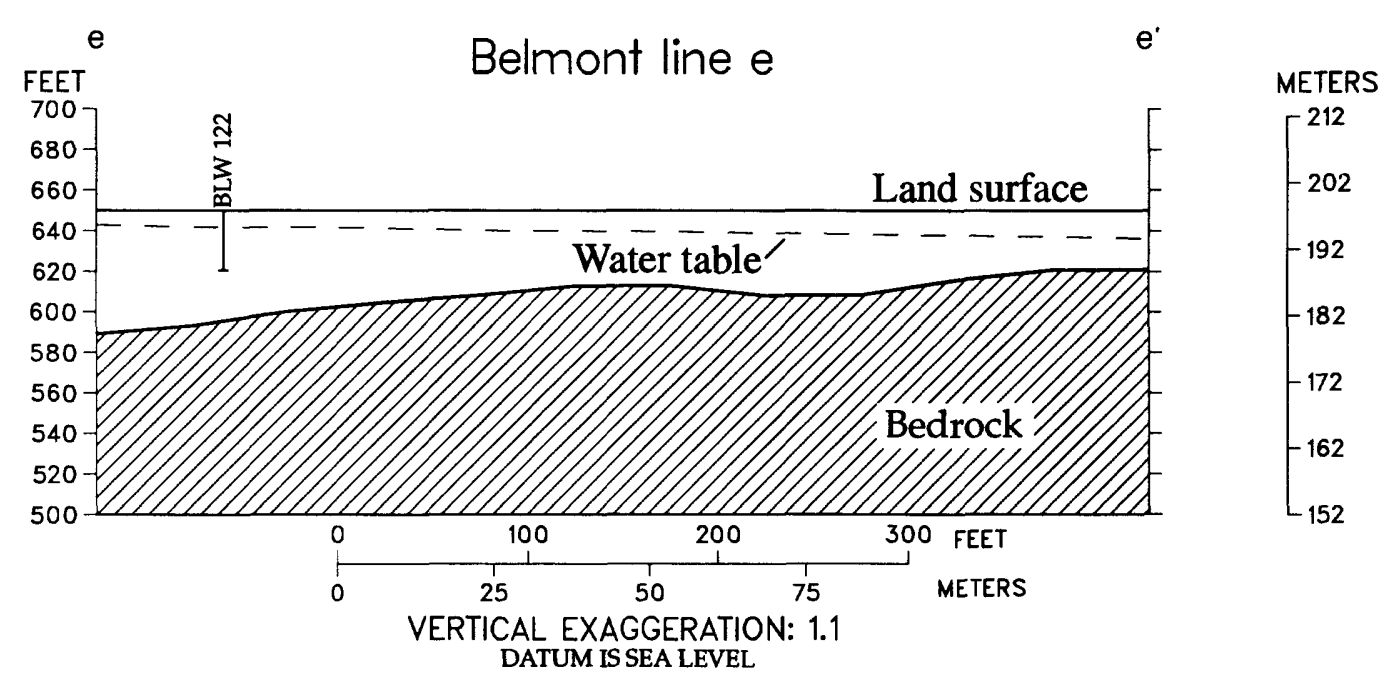

Figure C5. Geohydrologic sections interpreted from seismic-refraction data for Belmont lines $c-c^{\prime}, d-d^{\prime}$, and e-e' (locations shown on plate 1). 


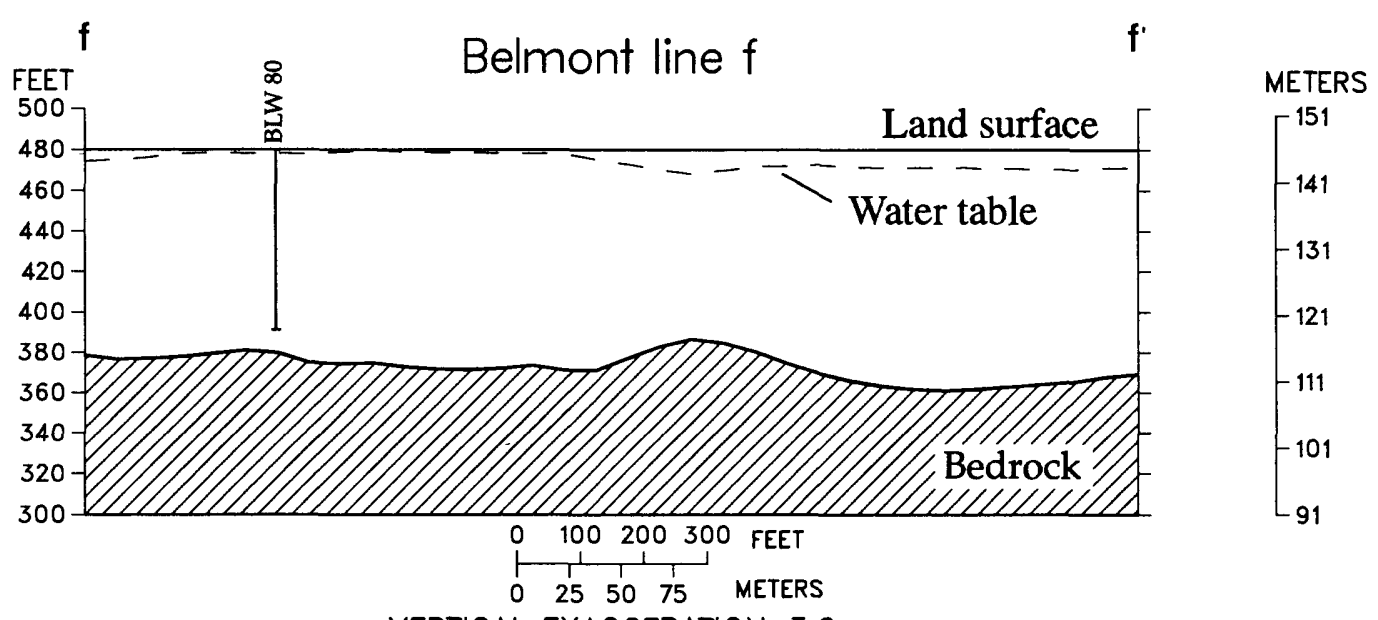

VERTICAL EXAGGERATION: 3.2

DATUM IS SEA LEVEL
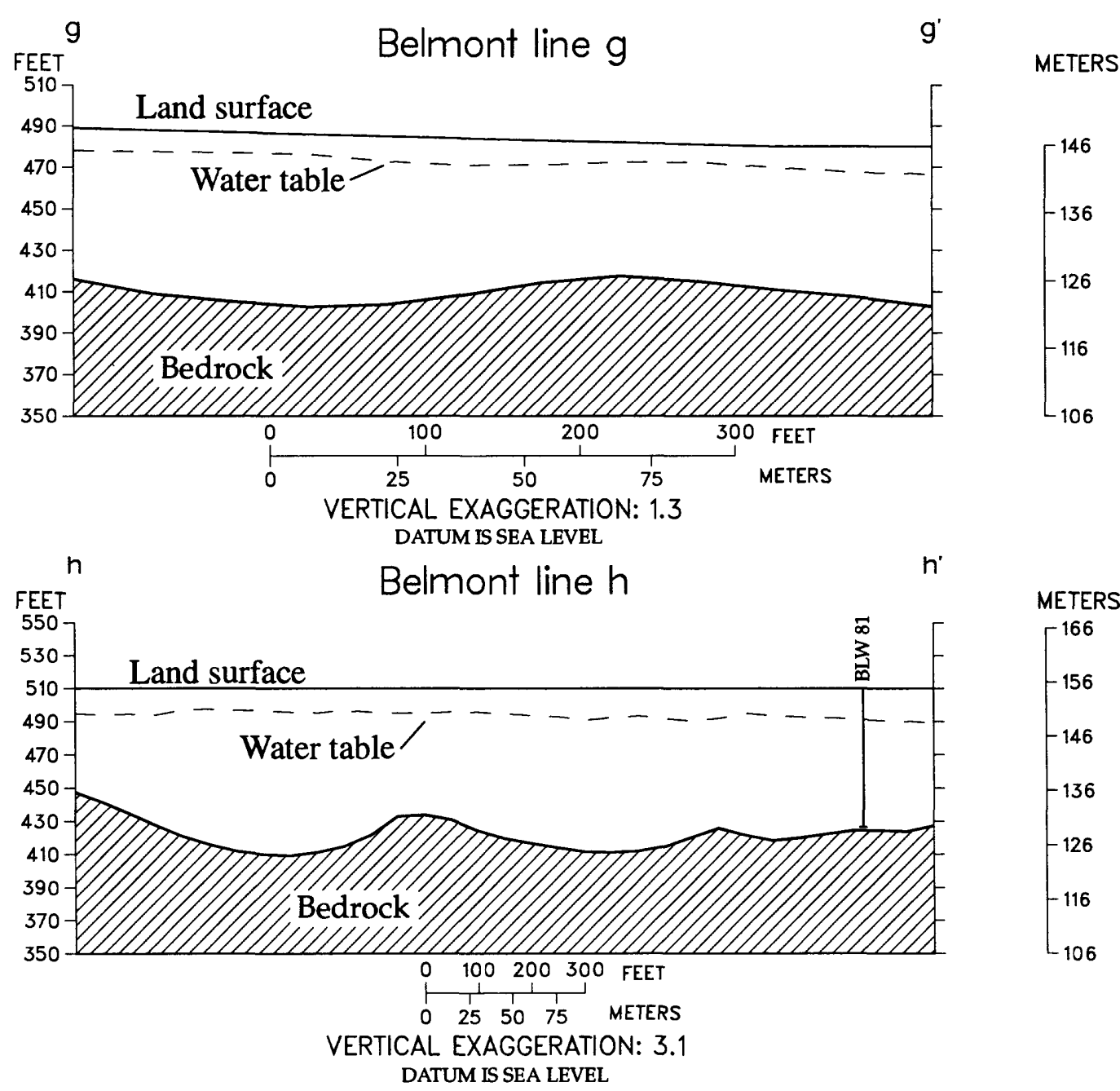

Figure C6. Geohydrologic sections interpreted from seismic-refraction data for Belmont lines $f-f^{\prime}, g-g^{\prime}$, and $h-h^{\prime}$ (locations shown on plate 1) 

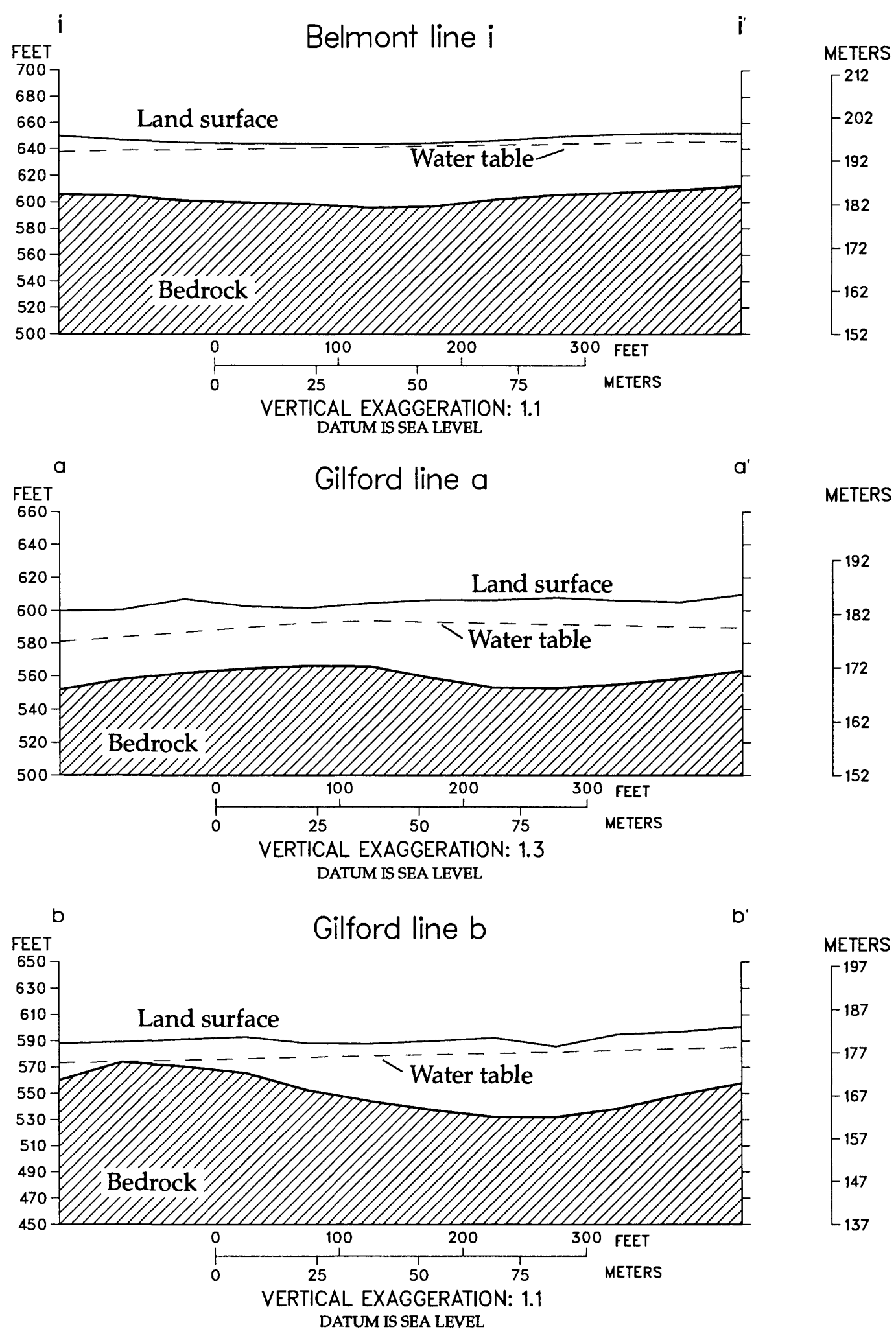

Figure C7. Geohydrologic sections interpreted from seismic-refraction data for Belmont line i-i' (locations shown on plate 1) and Gilford lines $a-a^{\prime}$ and b-b' (locations shown on plate 1). 

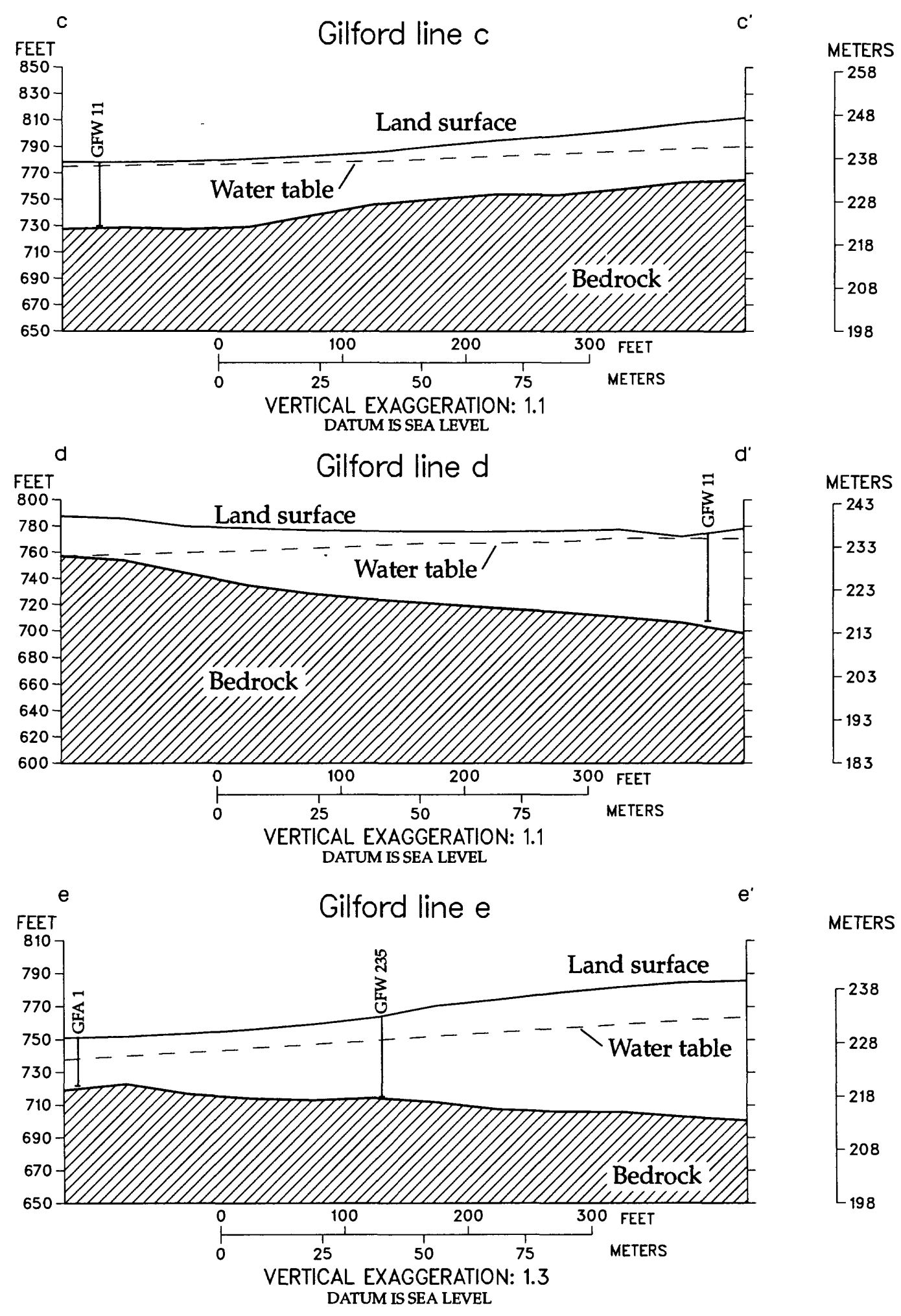

Figure C8. Geohydrologic sections interpeted from seismic-refraction data for Gilford lines $c-c^{\prime}, d-d$ ', and e-e' (locations shown on plate I). 

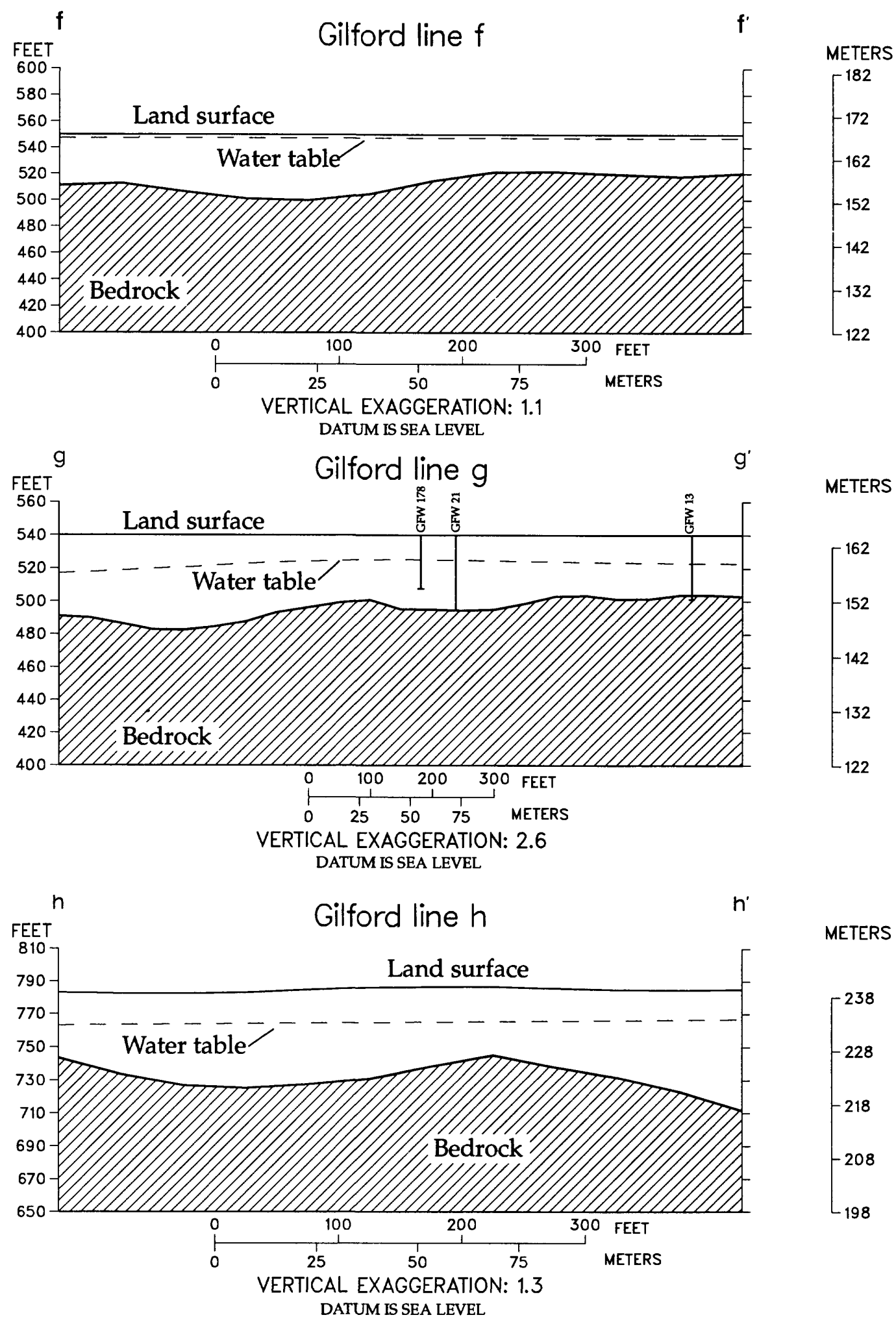

Figure C9. Geohydrologic sections interpreted from seismic-refraction data for Gllford lines f-f' (plate 3), g-g', h-h' (locations shown on plate 1). 

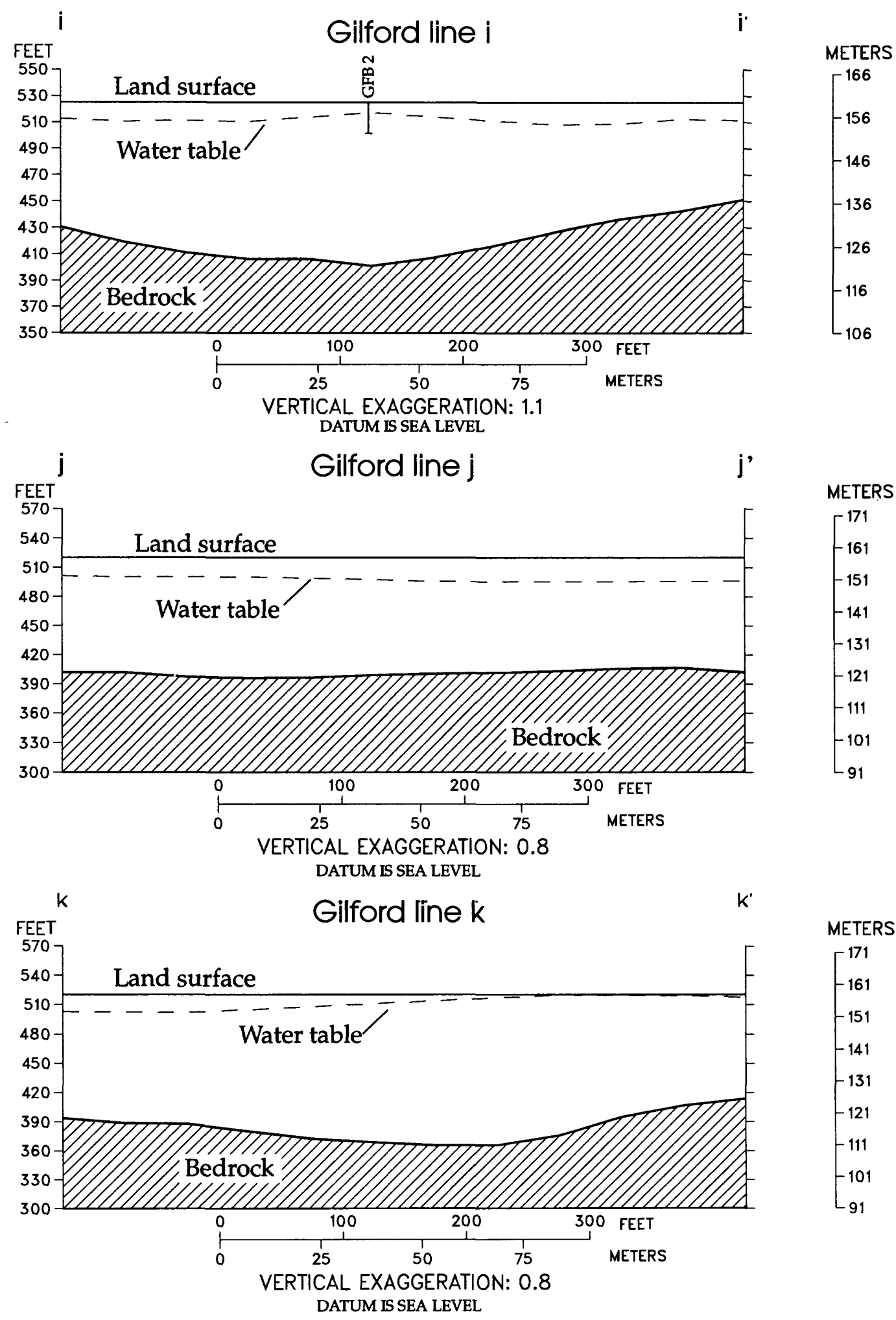

Figure C10. Geohydrologic sections interpreted from seismic-refraction data for

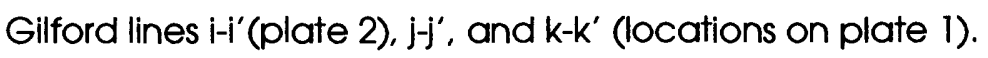



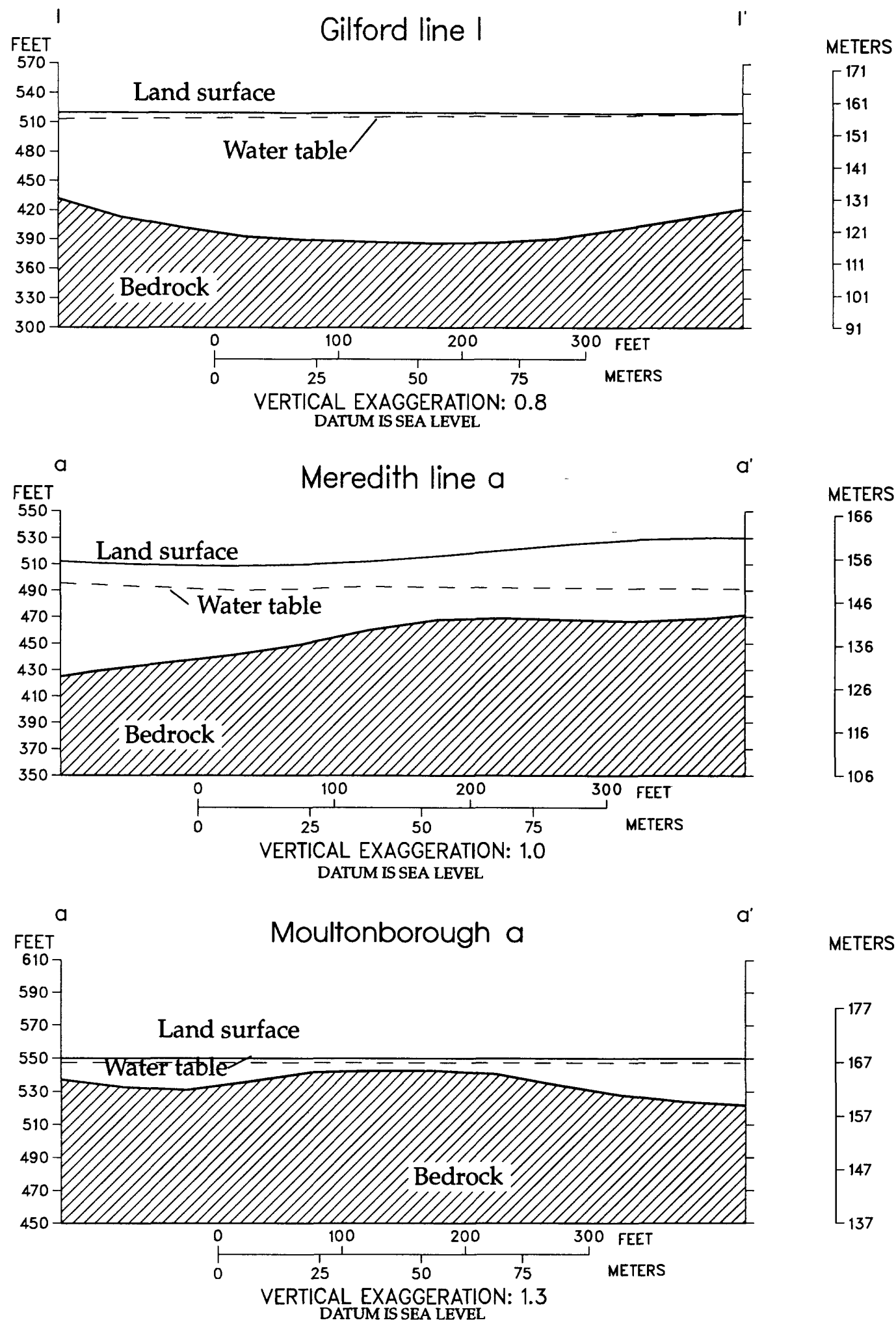

Figure C11. Geohydrologic sections interpreted from seismic-refraction for Gilford line $\mathrm{H}^{\prime}$ (location shown on plate 1); Meredith line a-a' (location shown on plate 3), and Moultonborough line a-a' (location shown on plate 3 ). 


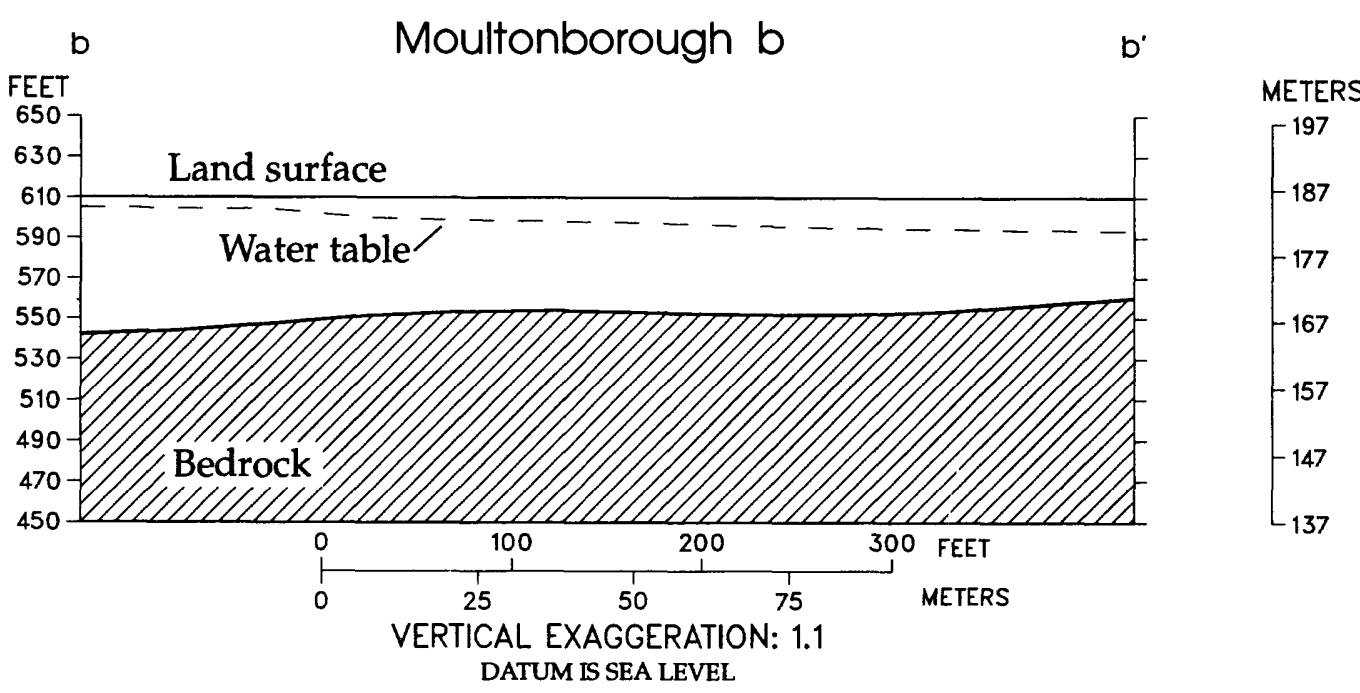

C

$c^{\prime}$
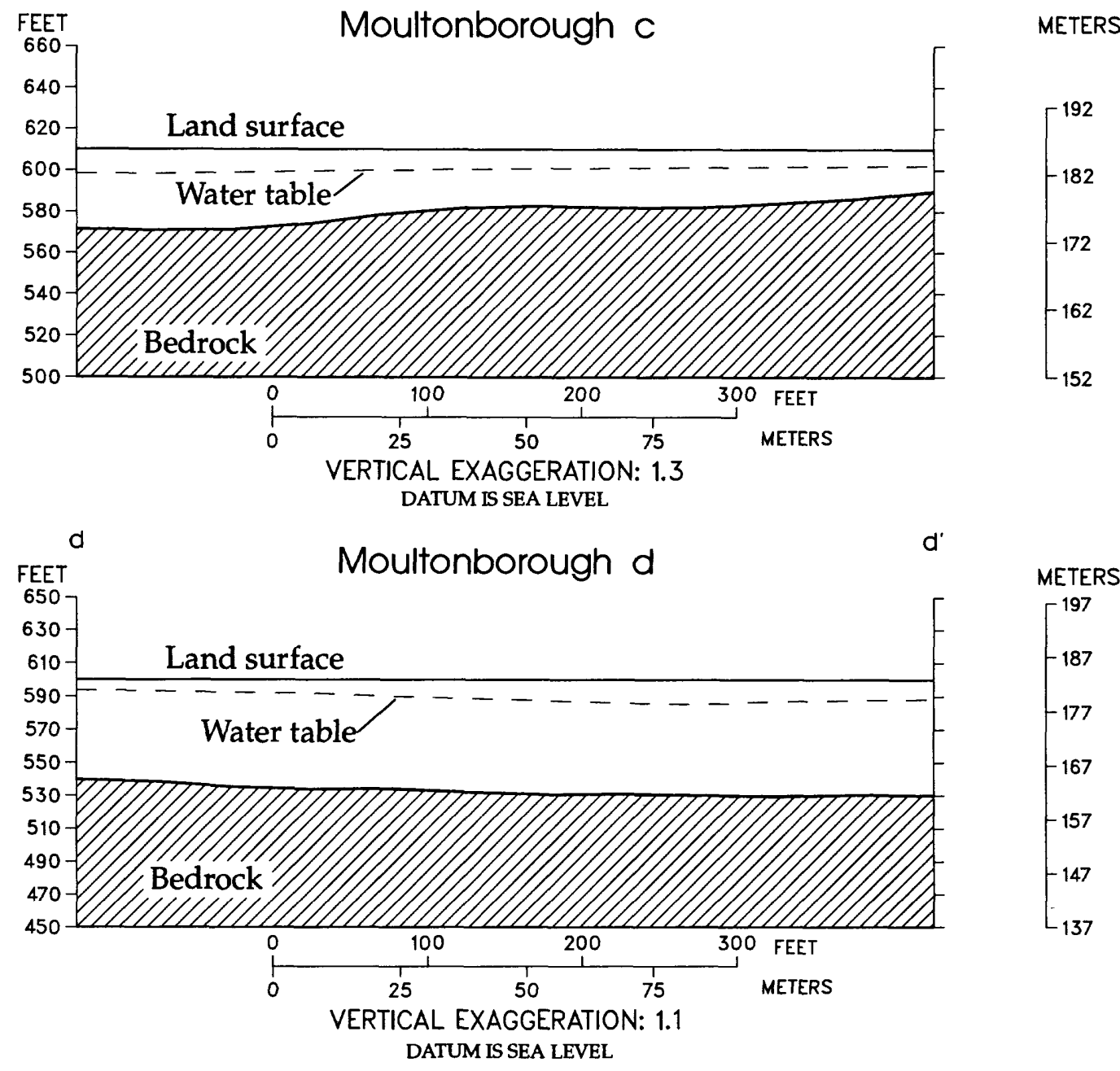

Figure C12. Geohydrologic sections interpreted from seismic-refraction data for Moultonborough lines b-b', c-c', and d-d' (locations shown on plate 4). 


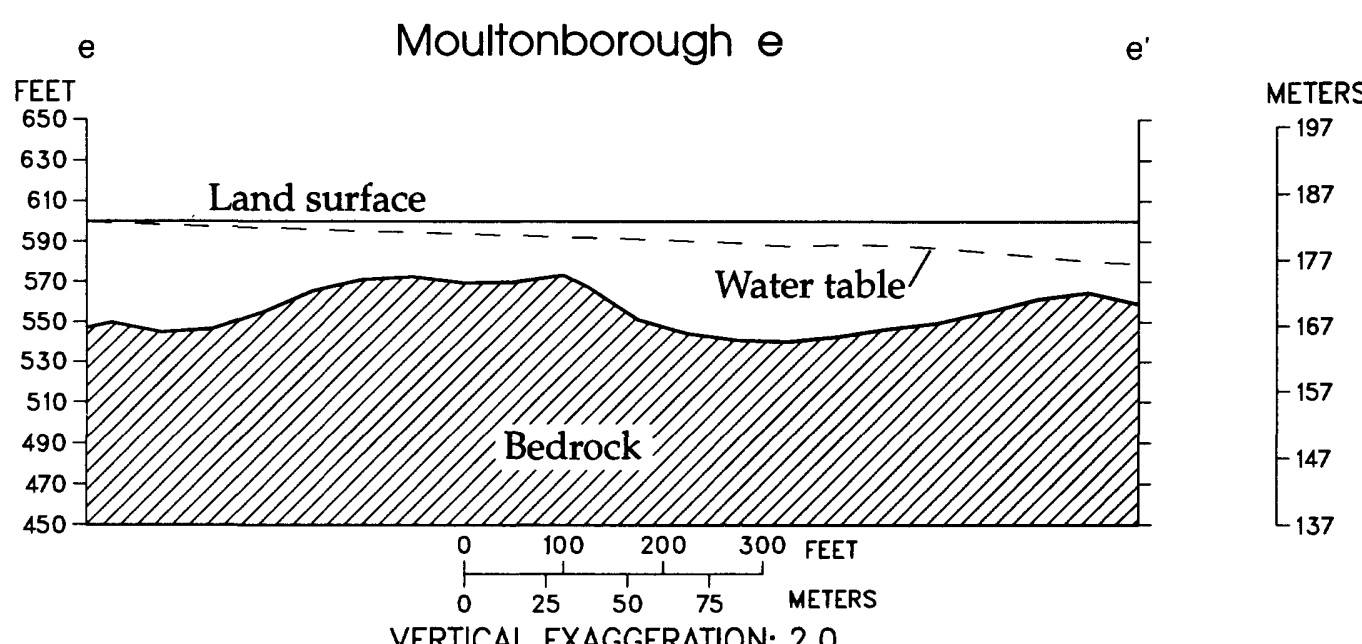

VERTICAL EXAGGERATION: 2.0 DATUM IS SEA LEVEL
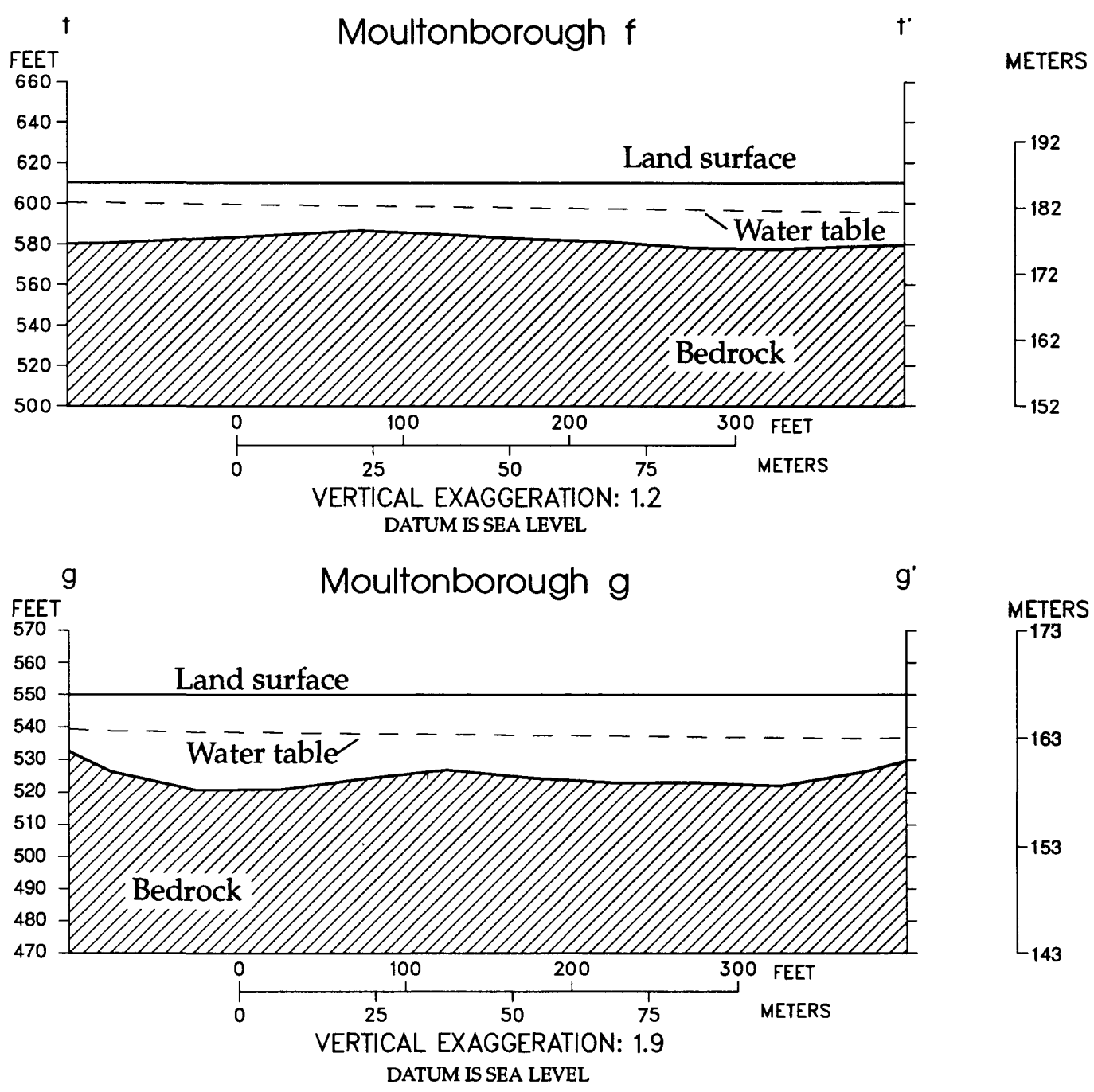

Figure C13. Geohydrologic sections interpreted from seismic-refraction data for Moultonborough lines e-e', f-f', and g-g' (locations shown on plate 3 ). 

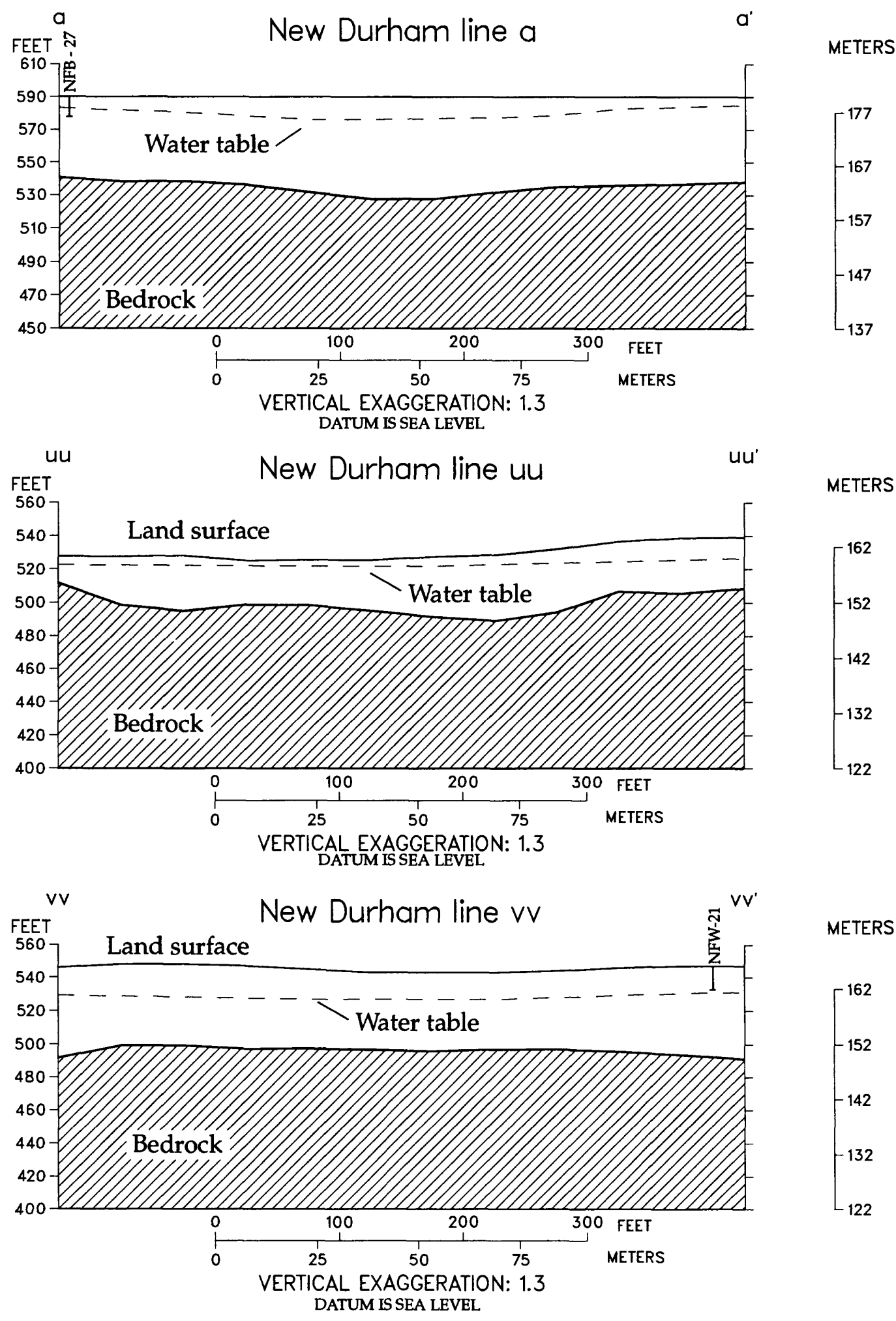

Figure C14. Geohydrologic sections interpreted from seismic-refraction data for New Durham lines a-a', uu-uu', and w-w' (modified from Mack and Lawlor, 1992; locations shown on plate 2). 

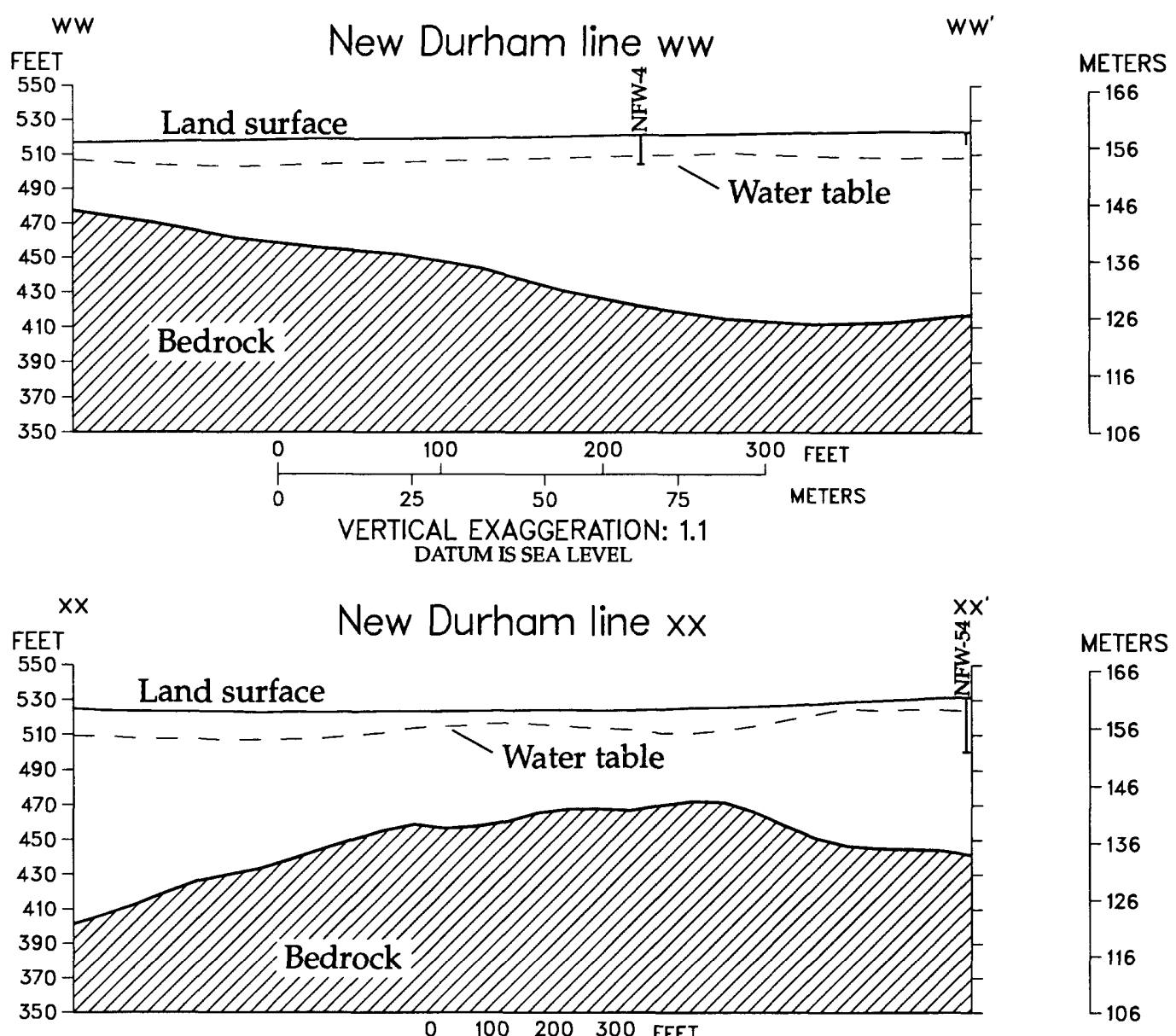

VERTICAL EXAGGERATION: 2.8

DATUM IS SEA LEVEL

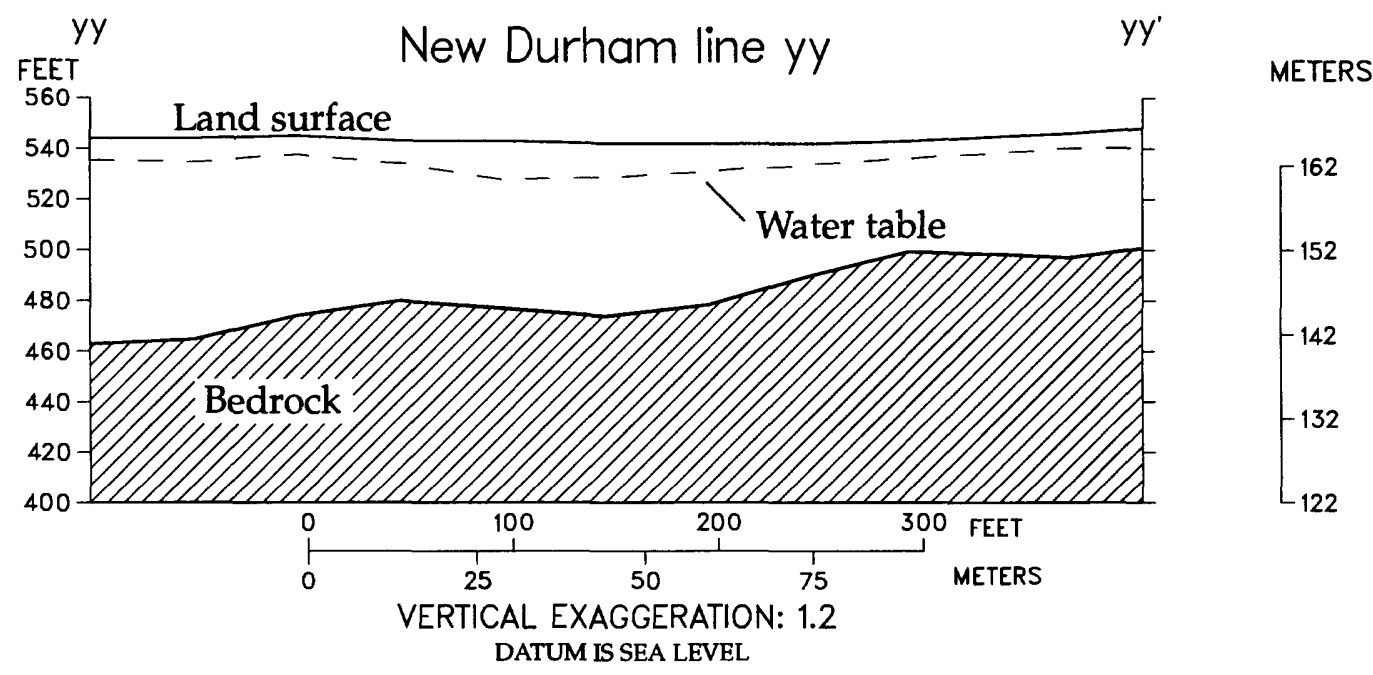

Figure C15. Geohydrologic sections interpreted from seismic-refraction data for New Durham lines ww-ww', $x x-x x^{\prime}$, and $y y-y y^{\prime}$ (modified from Mack and Lawlor, 1992; locations shown on plate 2). 

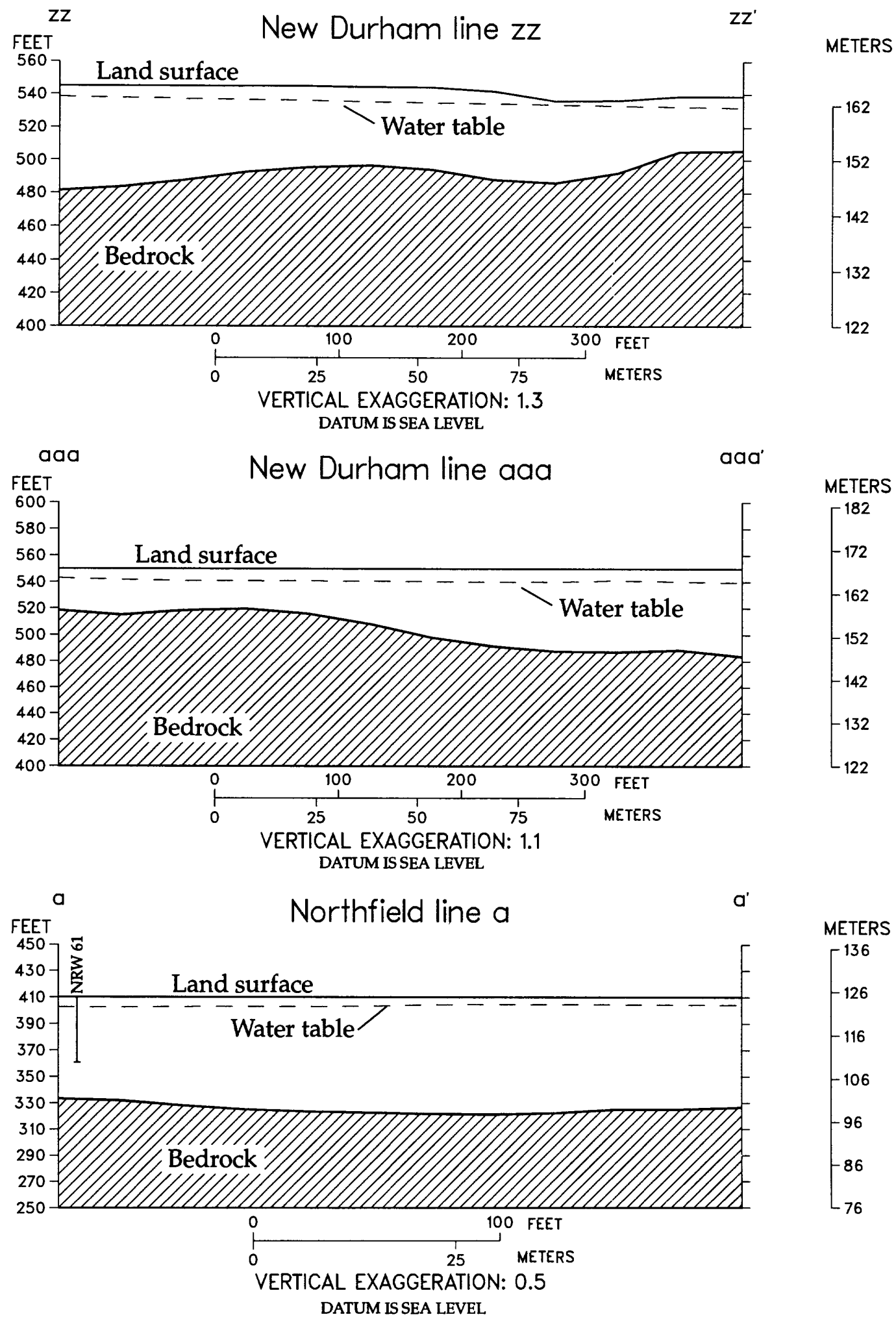

Figure C16. Geohydrologic sections interpreted from seismic-refraction data for New Durham lines zz-zz' and aaa-aaa' (modified from Mack and Lawlor, 1992; locations shown on plate 2), and Northfield line a-a' (location shown on plate 1). 

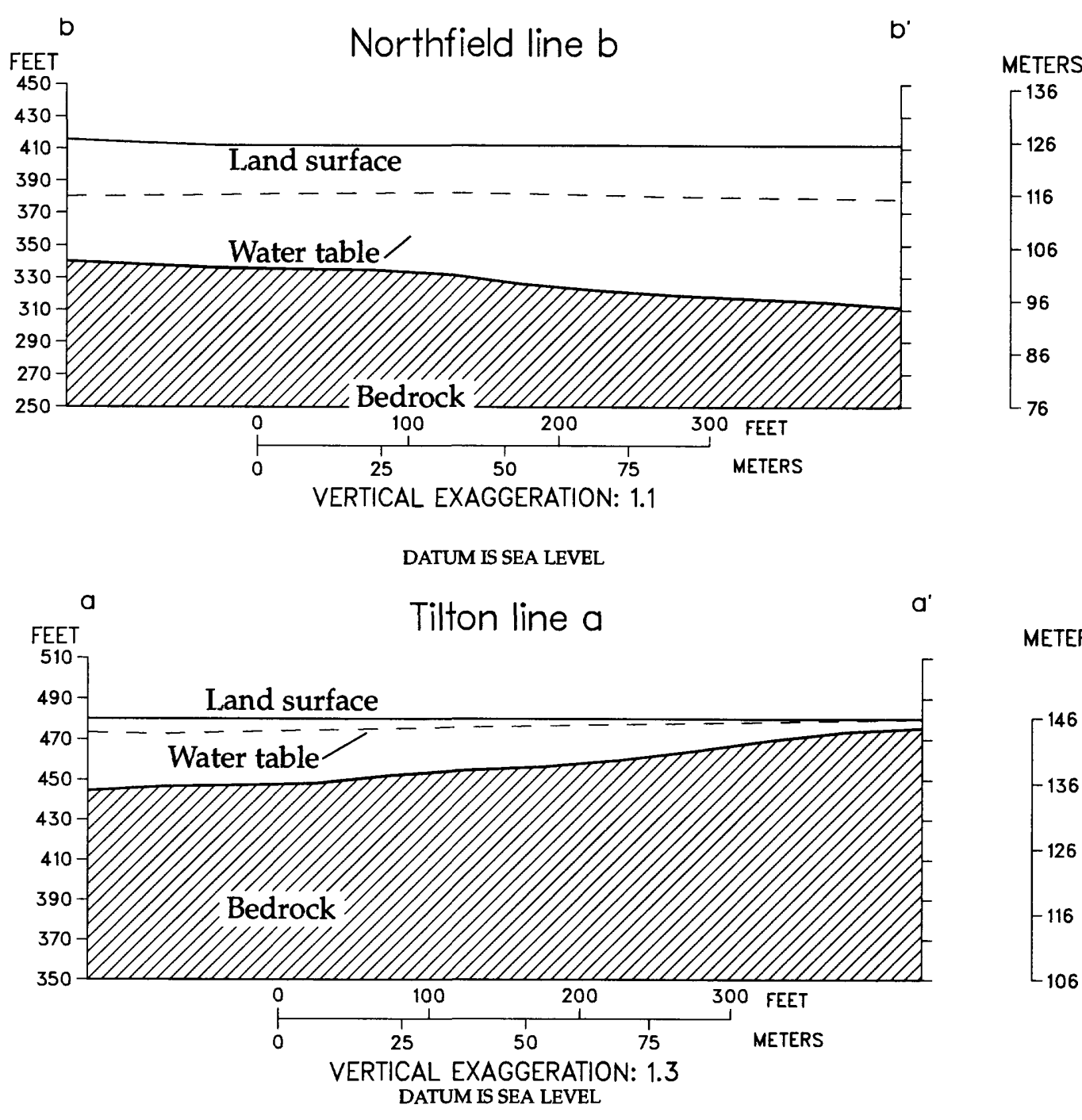

METERS

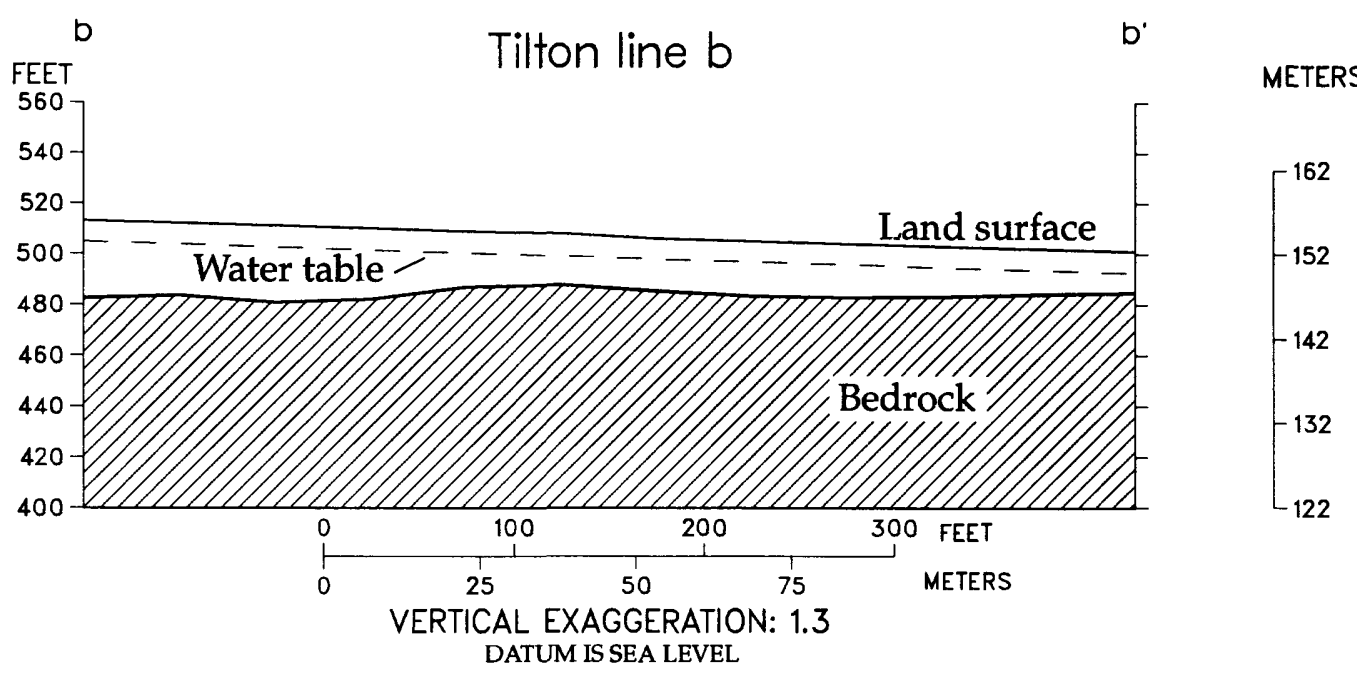

Figure C17. Geohydrologic sections interpreted from seismic-refraction data for Northfield line $b-b^{\prime}$, and Tilton lines $a-a^{\prime}$ and $b-b^{\prime}$ (locations shown on plate 1). 

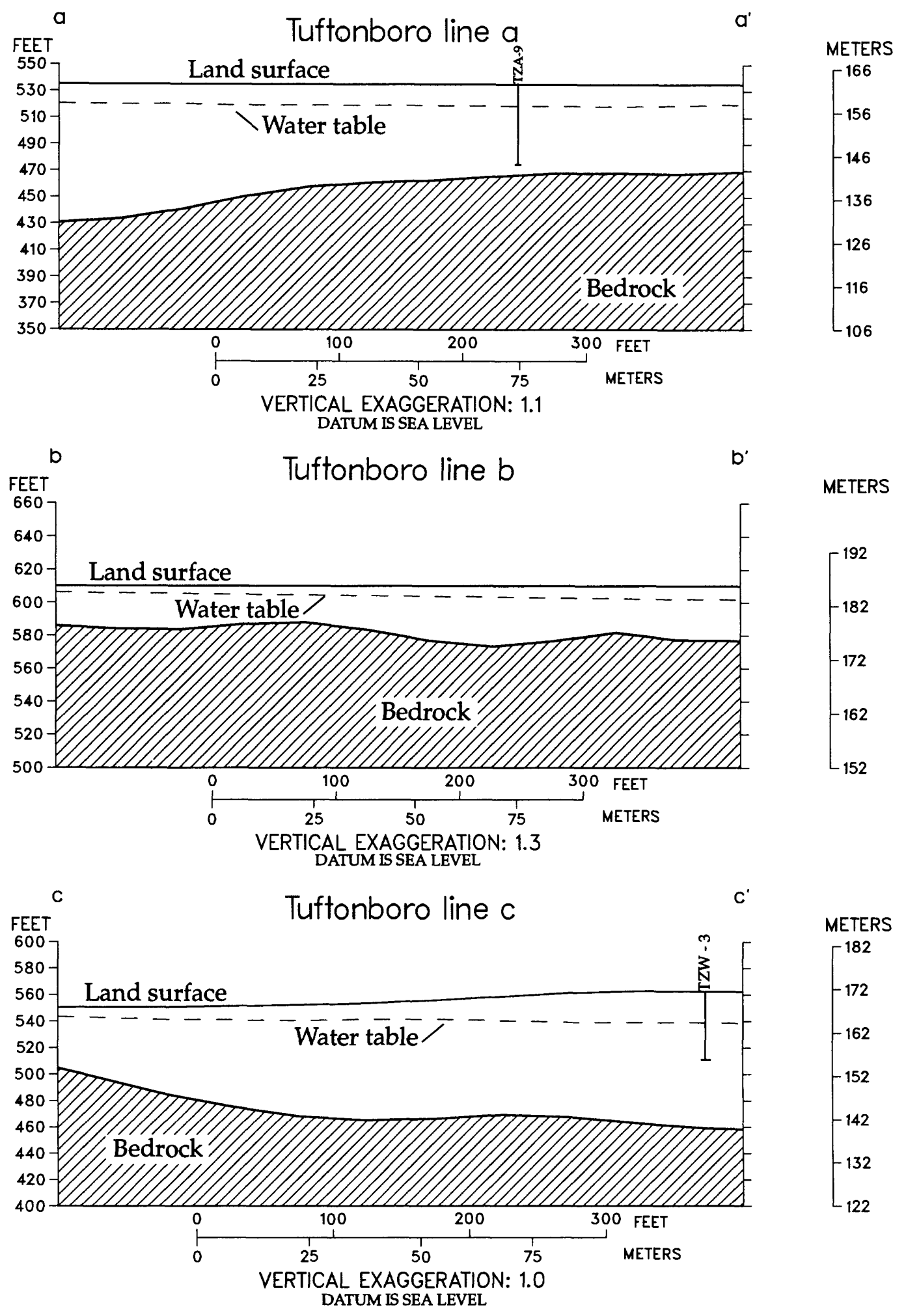

Figure C18. Geohydrologic sectlons interpreted from selsmic-refraction data for Tuftonboro lines $a-a^{\prime}, b_{-} b^{\prime}$, and c-c' (locations shown on plate 4). 


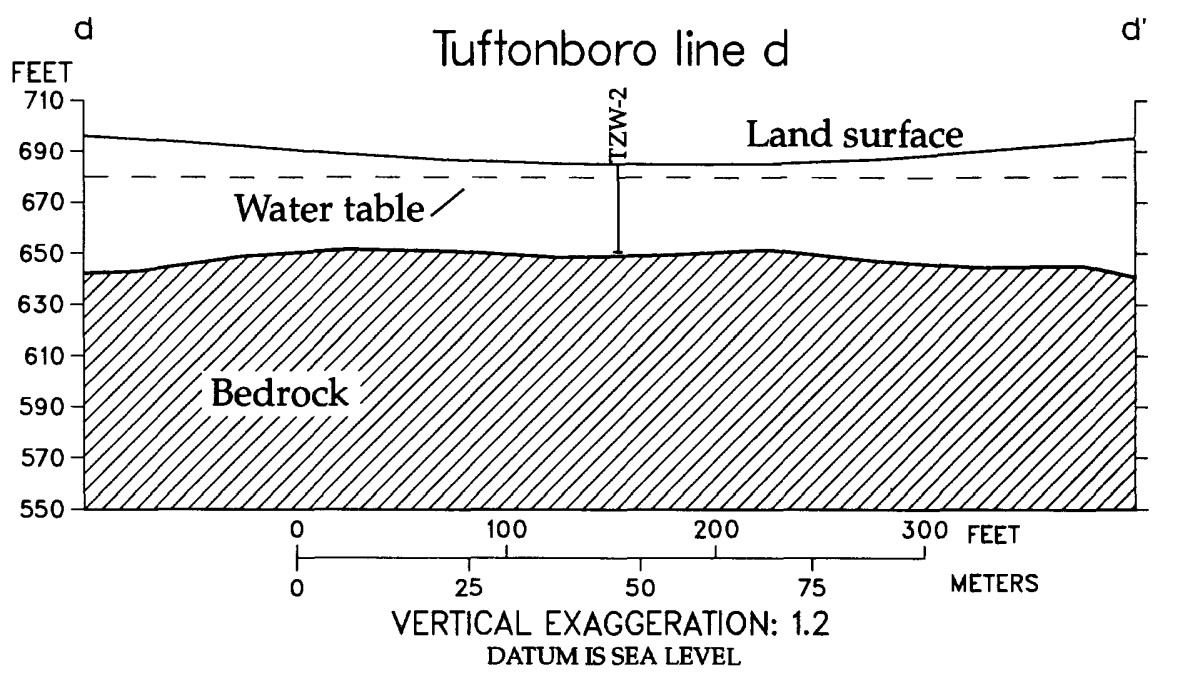

METERS

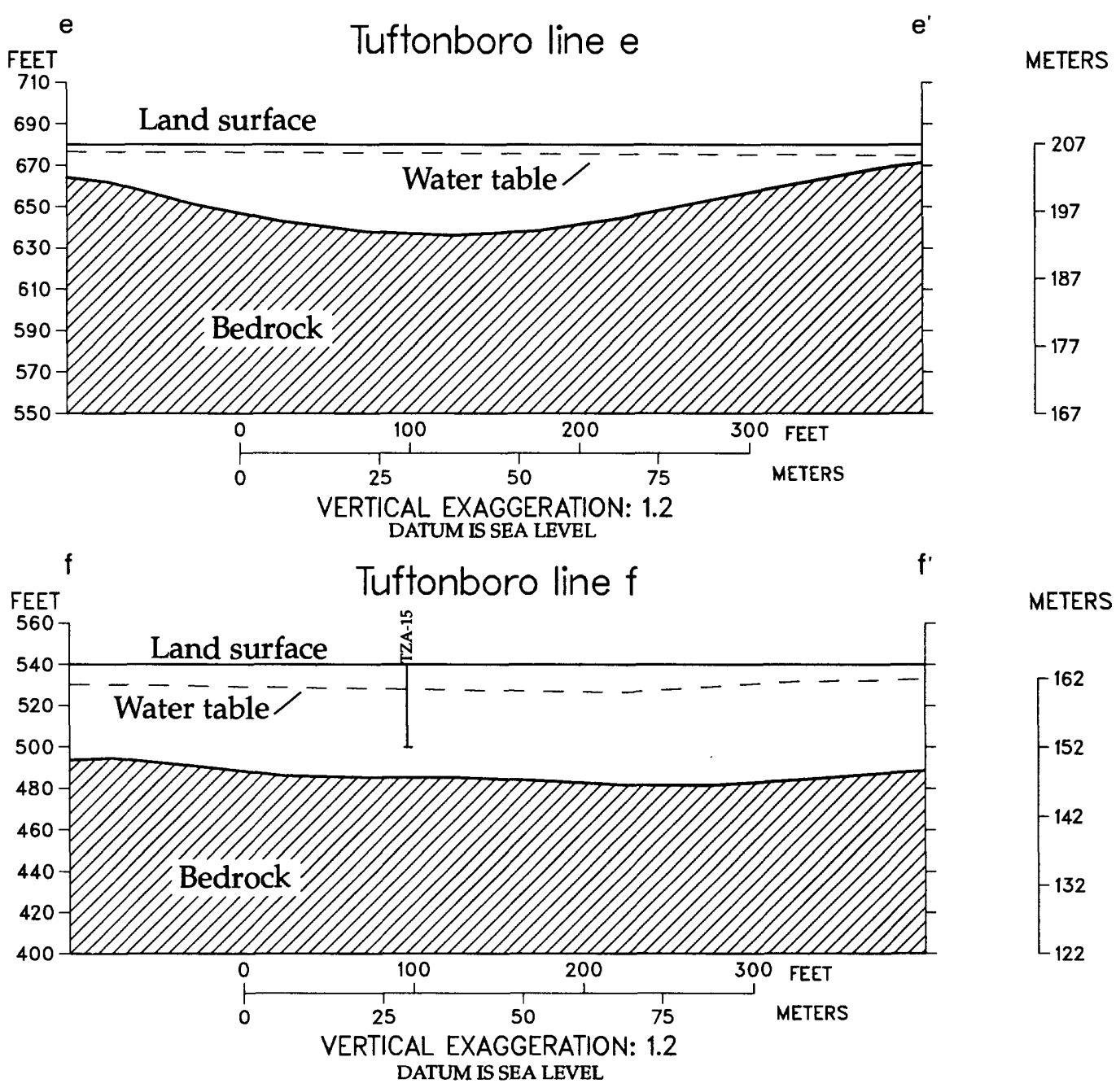

Figure C19. Geohydrologic sections interpreted from seismic-refraction data for Tuftonboro lines $d-d^{\prime}, e_{-} e^{\prime}$, and f-f' (locations shown on plate 4). 

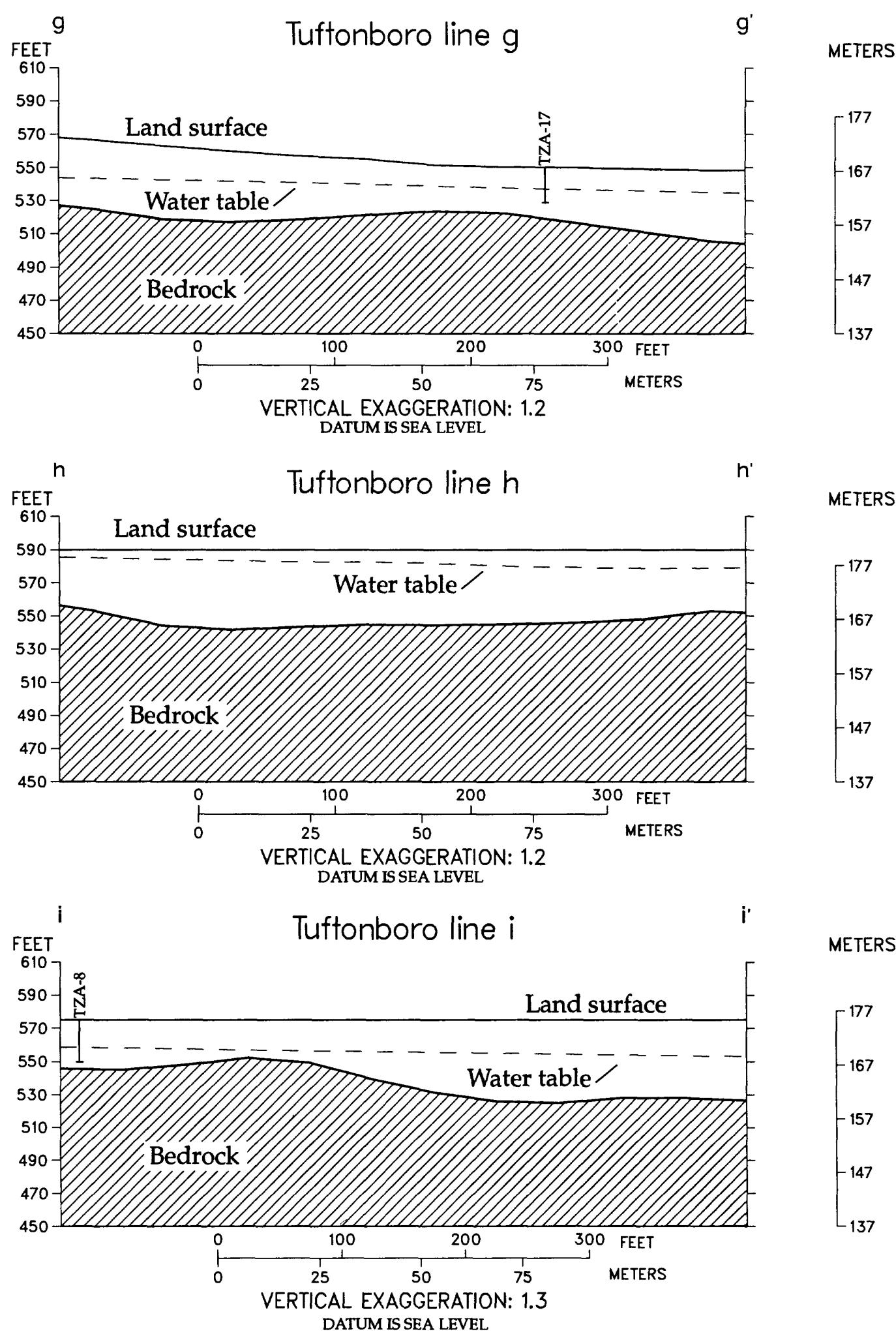

Figure C20. Geohydrologic sections interpreted from seismic-refraction data for Tuftonboro lines $\mathrm{g}-\mathrm{g}^{\prime}, \mathrm{h}-\mathrm{h}^{\prime}$, and $\mathrm{i}^{-} \mathrm{i}^{\prime}$ (locations shown on plate 4). 

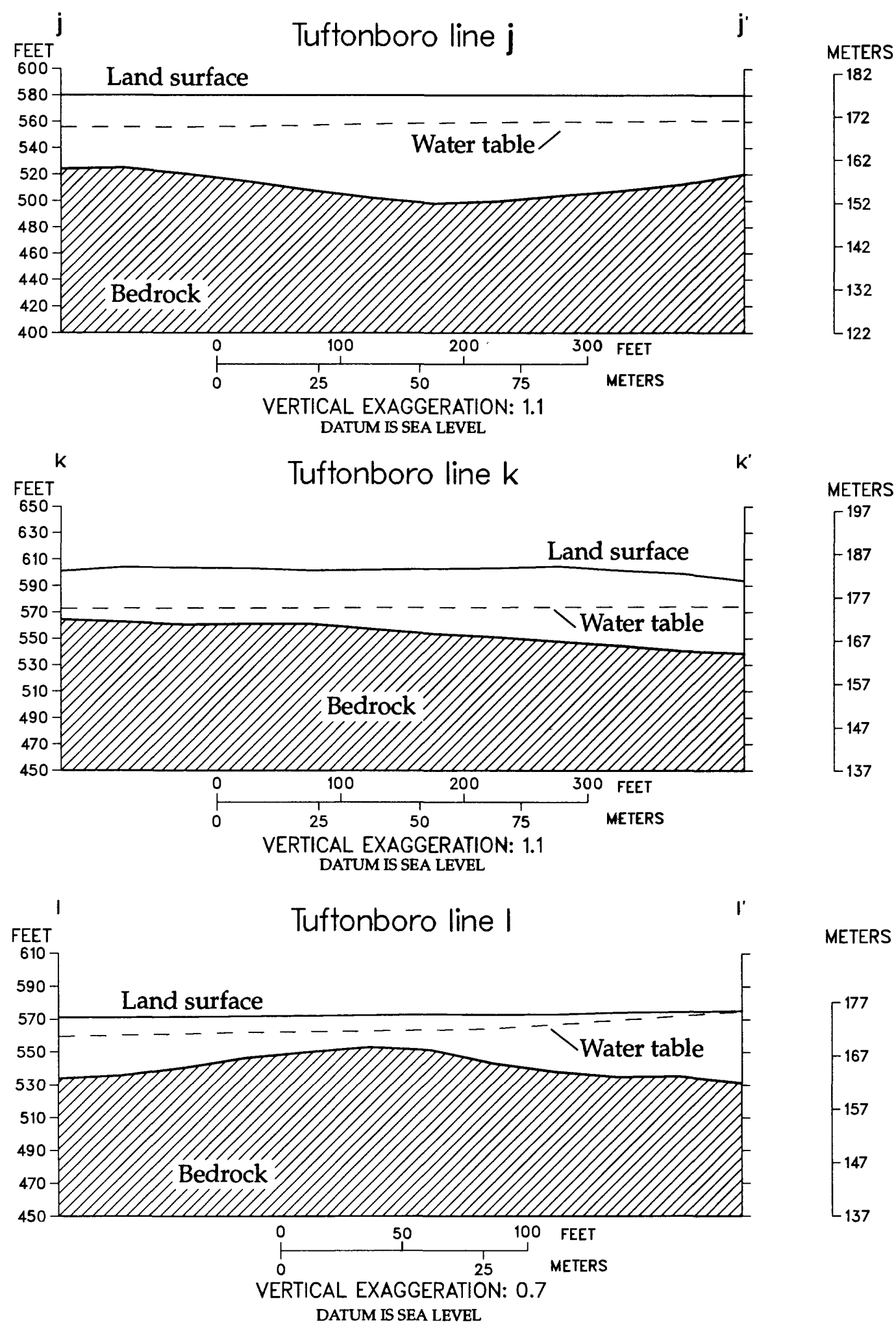

Figure C21. Geohydrologic sections interpreted from seismic-refraction data for Tuftonboro lines j-j', k-k', and I-l' (locations shown on plate 4). 

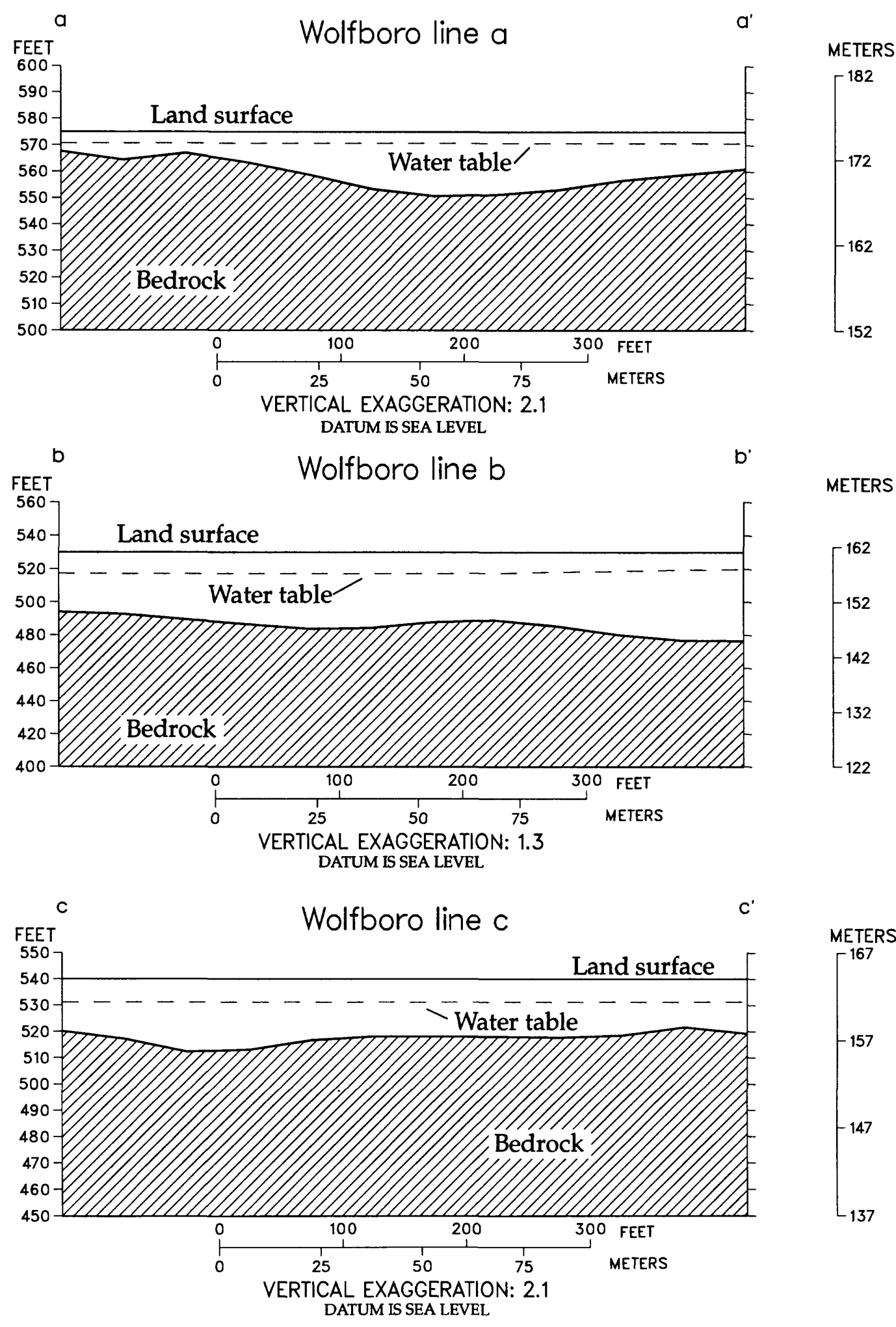

Figure C22. Geohydrologic sections interpreted from seismic-refraction data for Wolfeboro lines $a-a^{\prime}, b_{-} b^{\prime}$, and $c-c^{\prime}$ (locations shown on plate 4). 


\section{APPENDIX D. Low streamflow measurements at miscellaneous sites in central New Hampshire}


Table D-1. Low streamflow measurements at miscellaneous sites in central New Hampshire $\left[\mathrm{mi}^{2}\right.$, square mile; $\mathrm{ft}^{3} / \mathrm{s}$, cubic foot per second; lat, latitude; long, longitude; $\mathrm{ft}$, foot]

\begin{tabular}{|c|c|c|c|c|c|c|}
\hline \multirow{2}{*}{$\begin{array}{l}\text { Mea- } \\
\text { sure- } \\
\text { ment } \\
\text { number }\end{array}$} & \multirow[b]{2}{*}{ Stream } & \multirow[b]{2}{*}{ Tributary to } & \multirow[b]{2}{*}{ Location } & \multirow[b]{2}{*}{$\begin{array}{l}\text { Drainage } \\
\text { area } \\
\left(\mathrm{mi}^{2}\right)\end{array}$} & \multicolumn{2}{|c|}{ Measurements } \\
\hline & & & & & Date & $\begin{array}{l}\text { Dis- } \\
\text { charge } \\
\left(\mathrm{ft}^{3} / \mathrm{s}\right)\end{array}$ \\
\hline \multicolumn{7}{|c|}{ MERRIMACK RIVER BASIN } \\
\hline 1 & $\begin{array}{l}\text { Merrimeeting } \\
\text { River }\end{array}$ & $\begin{array}{c}\text { Lake Winni- } \\
\text { pesaukee }\end{array}$ & $\begin{array}{l}\text { Lat } 43^{\circ} 26^{\prime} 15^{\prime \prime} \text {, long } 71^{\circ} 10^{\prime} 21^{\prime \prime} \text {, Belknap County, } \\
\text { Hydrologic Unit } 01070002,200 \mathrm{ft} \text { downstream from } \\
\text { dam on Main Street in New Durham, } 150 \mathrm{ft} \text { upstream } \\
\text { of main branch. }\end{array}$ & 17.4 & $7-3-91$ & 8.6 \\
\hline 2 & Coffin Brook & $\begin{array}{l}\text { Merrimeeting } \\
\text { River }\end{array}$ & $\begin{array}{l}\text { Lat } 43^{\circ} 25^{\prime} 01^{\prime \prime} \text {, long } 71^{\circ} 13^{\prime} 03^{\prime \prime}, \text { Belknap County, } \\
\text { Hydrologic Unit } 01070002,3,500 \mathrm{ft} \text { west of } \\
\text { Stockbridge Corners off Route } 28,50 \mathrm{ft} \text { upstream at } \\
\text { old mill site. }\end{array}$ & 6.06 & $7-3-91$ & .35 \\
\hline 3 & $\begin{array}{l}\text { Unnamed } \\
\text { Tributary }\end{array}$ & $\begin{array}{l}\text { Merrimeeting } \\
\text { River }\end{array}$ & $\begin{array}{l}\text { Lat } 43^{\circ} 25^{\prime} 15^{\prime \prime} \text {, long } 71^{\circ} 10^{\prime} 33^{\prime \prime} \text {, Belknap County, } \\
\text { Hydrologic Unit } 01070002 \text {, upstream side of culvert at } \\
\text { Stockbridge Road } 8,000 \mathrm{ft} \text { east of Stockbridge Road } \\
\text { on Route } 11 \text { in New Durham. }\end{array}$ & .54 & $7-3-91$ & 0 \\
\hline 4 & $\begin{array}{l}\text { Unnamed } \\
\text { Tributary }\end{array}$ & $\begin{array}{l}\text { Merrimeeting } \\
\text { River }\end{array}$ & $\begin{array}{l}\text { Lat } 43^{\circ} 27^{\prime} 23^{\prime \prime} \text {, long } 71^{\circ} 12^{\prime} 58^{\prime \prime}, \text { Belknap County, } \\
\text { Hydrologic Unit } 01070002,1,200 \mathrm{ft} \text { from Alton at } \\
\text { culvert under Route } 28,6,000 \mathrm{ft} \text { south of Alton Bay. }\end{array}$ & .32 & $7-3-91$ & 0 \\
\hline 5 & $\begin{array}{l}\text { Unnamed } \\
\text { Tributary }\end{array}$ & $\begin{array}{l}\text { Merrimeeting } \\
\text { River }\end{array}$ & $\begin{array}{l}\text { Lat } 43^{\circ} 27^{\prime} 34^{\prime \prime} \text {, long } 71^{\circ} 13^{\prime} 10^{\prime \prime} \text {, Belknap County, } \\
\text { Hydrologic Unit } 01070002 \text {, at culvert under Route } 28 \text {, } \\
\text { upstream side, } 2,000 \mathrm{ft} \text { from Alton and } 4,600 \mathrm{ft} \text { from } \\
\text { Alton Bay. }\end{array}$ & .31 & $7-3-91$ & 0 \\
\hline 6 & $\begin{array}{l}\text { Unnamed } \\
\text { Tributary }\end{array}$ & $\begin{array}{l}\text { Merrimeeting } \\
\text { River }\end{array}$ & $\begin{array}{l}\text { Lat } 43^{\circ} 27^{\prime} 11^{\prime \prime} \text {, long } 71^{\circ} 13^{\prime} 48^{\prime \prime} \text {, Belknap County, } \\
\text { Hydrologic Unit } 01070002 \text {, at culvert, down-stream } \\
\text { side of Route } 140,3,000 \mathrm{ft} \text { west from Alton and } 6,000 \\
\mathrm{ft} \text { south of Alton Bay. }\end{array}$ & 1.02 & $7-3-91$ & .06 \\
\hline 7 & $\begin{array}{l}\text { Nineteen } \\
\text { Mile } \\
\text { Brook }\end{array}$ & $\begin{array}{l}\text { Lake } \\
\text { Winni- } \\
\text { pesaukee }\end{array}$ & $\begin{array}{l}\text { Lat } 43^{\circ} 38^{\prime} 00^{\prime \prime} \text {, long } 71^{\circ} 14 ' 42^{\prime \prime} \text {, Carroll County, } \\
\text { Hydrologic Unit } 01070002 \text {, downstream side of } \\
\text { culvert under Route } 109 \mathrm{~A}, 7,500 \mathrm{ft} \text { from Center } \\
\text { Tuftonboro. }\end{array}$ & 2.09 & $7-3-91$ & .54 \\
\hline 8 & $\begin{array}{c}\text { Whitten } \\
\text { Brook }\end{array}$ & $\begin{array}{l}\text { Nineteen } \\
\text { Mile } \\
\text { Brook }\end{array}$ & $\begin{array}{l}\text { Lat } 43^{\circ} 38^{\prime} 17^{\prime \prime} \text {, long } 71^{\circ} 14 ' 43^{\prime \prime} \text {, Carroll County, } \\
\text { Hydrologic Unit } 01070002,50 \mathrm{ft} \text { downstream from } \\
\text { culvert under Route } 109 \mathrm{~A} 5,500 \mathrm{ft} \text { from Center } \\
\text { Tuftonboro. }\end{array}$ & 1.71 & $7-3-91$ & .28 \\
\hline 9 & $\begin{array}{r}\text { Melvin } \\
\text { River }\end{array}$ & $\begin{array}{l}\text { Lake Winni- } \\
\text { pesaukee }\end{array}$ & $\begin{array}{l}\text { Lat } 43^{\circ} 42^{\prime} 40^{\prime \prime}, \text { long } 71^{\circ} 17 ' 34^{\prime \prime} \text {, Carroll County, } \\
\text { Hydrologic Unit } 01070002,10 \mathrm{ft} \text { downstream from } \\
\text { bridge at Route } 171,9,000 \mathrm{ft} \text { north of Melvin Village. }\end{array}$ & 2.05 & $7-3-91$ & .24 \\
\hline 10 & $\begin{array}{r}\text { Melvin } \\
\text { River }\end{array}$ & $\begin{array}{l}\text { Lake Winni- } \\
\text { pesaukee }\end{array}$ & $\begin{array}{l}\text { Lat } 43^{\circ} 41^{\prime} 50^{\prime \prime} \text {, long } 71^{\circ} 17 ' 54^{\prime \prime} \text {, Carroll County, } \\
\text { Hydrologic Unit } 01070002 \text {, at downstream side of } \\
\text { bridge on New Road, } 4,000 \mathrm{ft} \text { north of Melvin Village. }\end{array}$ & 10.9 & $7-3-91$ & 1.4 \\
\hline
\end{tabular}


Table D-1. Low streamflow measurements at miscellaneous sites in central New Hampshire-Continued

\begin{tabular}{|c|c|c|c|c|c|c|}
\hline \multirow{2}{*}{$\begin{array}{l}\text { Mea- } \\
\text { sure- } \\
\text { ment } \\
\text { number }\end{array}$} & \multirow[b]{2}{*}{ Stream } & \multirow[b]{2}{*}{ Tributary to } & \multirow[b]{2}{*}{ Location } & \multirow{2}{*}{$\begin{array}{c}\text { Drainage } \\
\text { area } \\
\left(\mathrm{mi}^{2}\right)\end{array}$} & \multicolumn{2}{|c|}{ Measurements } \\
\hline & & & & & Date & $\begin{array}{l}\text { Dis- } \\
\text { charge } \\
\left(\mathrm{ft}^{3} / \mathrm{s}\right)\end{array}$ \\
\hline \multicolumn{7}{|c|}{ MERRIMACK RIVER BASIN } \\
\hline 11 & $\begin{array}{r}\text { Melvin } \\
\text { River }\end{array}$ & $\begin{array}{c}\text { Lake Winni- } \\
\text { pesaukee }\end{array}$ & $\begin{array}{l}\text { Lat } 43^{\circ} 41^{\prime} 44^{\prime \prime} \text {, long } 71^{\circ} 17^{\prime} 07^{\prime \prime} \text {, Carroll County, } \\
\text { Hydrologic Unit } 01070002,50 \mathrm{ft} \text { downstream from } \\
\text { bridge on Sodom Road, } 6,000 \mathrm{ft} \text { east of Melvin } \\
\text { Village. }\end{array}$ & 11.5 & $7-3-91$ & 1.0 \\
\hline 12 & $\begin{array}{r}\text { Melvin } \\
\text { River }\end{array}$ & $\begin{array}{c}\text { Lake Winni- } \\
\text { pesaukee }\end{array}$ & $\begin{array}{l}\text { Lat } 43^{\circ} 41^{\prime} 37^{\prime \prime}, \text { long } 71^{\circ} 18 ' 26^{\prime \prime}, \text { Carroll County, } \\
\text { Hydrologic Unit } 01070002,2,000 \mathrm{ft} \text { from Melvin } \\
\text { Village, } 50 \mathrm{ft} \text { upstream from bridge of Country Road, } \\
2,500 \mathrm{ft} \text { from intersection with Route } 109 .\end{array}$ & 13.8 & $7-3-91$ & 1.9 \\
\hline 13 & $\begin{array}{c}\text { Shannon } \\
\text { Brook }\end{array}$ & $\begin{array}{c}\text { Lake Winni- } \\
\text { pesaukee }\end{array}$ & $\begin{array}{l}\text { Lat } 43^{\circ} 43^{\prime} 14^{\prime \prime} \text {, long } 71^{\circ} 19^{\prime} 21^{\prime \prime} \text {, Carroll County, } \\
\text { Hydrologic Unit } 01070002 \text {, at upstream side of bridge } \\
\text { at Route } 171,1,300 \mathrm{ft} \text { from Melvin Village, } 500 \mathrm{ft} \\
\text { from intersection with Route } 109 .\end{array}$ & 3.39 & $7-3-91$ & .58 \\
\hline 14 & $\begin{array}{c}\text { Shannon } \\
\text { Brook }\end{array}$ & $\begin{array}{c}\text { Lake Winni- } \\
\text { pesaukee }\end{array}$ & $\begin{array}{l}\text { Lat } 43^{\circ} 43^{\prime} 01^{\prime \prime} \text {, long } 71^{\circ} 19^{\prime} 28^{\prime \prime}, \text { Carroll County, } \\
\text { Hydrologic Unit } 01070002,1,100 \mathrm{ft} \text { north of Melvin } \\
\text { Village, } 3 \mathrm{ft} \text { down-stream from culvert on Severence } \\
\text { Road. }\end{array}$ & .16 & $7-3-91$ & .01 \\
\hline 15 & $\begin{array}{c}\text { Shannon } \\
\text { Brook }\end{array}$ & $\begin{array}{c}\text { Lake Winni- } \\
\text { pesaukee }\end{array}$ & $\begin{array}{l}\text { Lat } 43^{\circ} 43^{\prime} 49^{\prime \prime}, \text { long } 71^{\circ} 21^{\prime} 29^{\prime \prime} \text {, Carroll County, } \\
\text { Hydrologic Unit } 01070002,5 \mathrm{ft} \text { downstream from } \\
\text { bridge at Route } 109,4,000 \mathrm{ft} \text { south of intersection with } \\
\text { Route } 171,5,000 \mathrm{ft} \text { from outlet into Lake Winni- } \\
\text { pesaukee. }\end{array}$ & 3.62 & $7-3-91$ & .32 \\
\hline 16 & $\begin{array}{c}\text { Halfway } \\
\text { Brook }\end{array}$ & $\begin{array}{l}\text { Lake Winni- } \\
\text { pesaukee }\end{array}$ & $\begin{array}{l}\text { Lat } 43^{\circ} 45^{\prime} 30^{\prime \prime}, \text { long } 71^{\circ} 21^{\prime} 47^{\prime \prime} \text {, Carroll County, } \\
\text { Hydrologic Unit } 01070002,20 \mathrm{ft} \text { downstream from } \\
\text { wooden bridge, } 4,000 \mathrm{ft} \text { from Route } 109,3,000 \mathrm{ft} \text { from } \\
\text { inter-section of Routes } 109 \text { and } 25 .\end{array}$ & 1.39 & $7-3-91$ & .47 \\
\hline 17 & $\begin{array}{c}\text { Halfway } \\
\text { Brook }\end{array}$ & $\begin{array}{c}\text { Lake Winni- } \\
\text { pesaukee }\end{array}$ & $\begin{array}{l}\text { Lat } 43^{\circ} 45^{\prime} 18^{\prime \prime} \text {, long } 71^{\circ} 22^{\prime} 34^{\prime \prime}, \text { Belknap County, } \\
\text { Hydrologic Unit } 01070002,25 \mathrm{ft} \text { upstream from } \\
\text { culvert under Route } 109,4,000 \mathrm{ft} \text { from intersection of } \\
\text { Route } 109 \text { and } 25,3,000 \mathrm{ft} \text { from Moultonboro Center. }\end{array}$ & 1.49 & $7-3-91$ & .30 \\
\hline 18 & $\begin{array}{c}\text { Halfway } \\
\text { Brook }\end{array}$ & $\begin{array}{c}\text { Lake Winni- } \\
\text { pesaukee }\end{array}$ & $\begin{array}{l}\text { Lat } 43^{\circ} 44^{\prime} 30^{\prime \prime} \text {, long } 71^{\circ} 23^{\prime} 13^{\prime \prime} \text {, Carroll County, } \\
\text { Hydrologic Unit } 01070002,30 \mathrm{ft} \text { down-stream from } \\
\text { culvert under Lees Mill Road, } 2,800 \mathrm{ft} \text { from Route } \\
109,5,000 \mathrm{ft} \text { from intersection of Routes } 109 \text { and } 125 .\end{array}$ & 5.28 & $7-3-91$ & .22 \\
\hline 19 & $\begin{array}{c}\text { Gunstock } \\
\text { Brook }\end{array}$ & $\begin{array}{c}\text { Lake Winni- } \\
\text { pesaukee }\end{array}$ & $\begin{array}{l}\text { Lat } 43^{\circ} 31^{\prime} 45^{\prime \prime} \text {, long } 71^{\circ} 24^{\prime} 16^{\prime \prime}, \text { Belknap County, } \\
\text { Hydrologic Unit } 01070002,30 \mathrm{ft} \text { below bridge at } \\
\text { downstream side of Hoyt Road, } 6,500 \mathrm{ft} \text { from Gilford } \\
\text { Village and 2,500 ft from Belknap Mountain Road. }\end{array}$ & 3.83 & $7-3-91$ & .78 \\
\hline
\end{tabular}


Table D-1. Low streamflow measurements at miscellaneous sites in central New Hampshire--Continued

\begin{tabular}{|c|c|c|c|c|c|c|}
\hline \multirow{2}{*}{$\begin{array}{l}\text { Mea- } \\
\text { sure- } \\
\text { ment } \\
\text { number }\end{array}$} & \multirow[b]{2}{*}{ Stream } & \multirow[b]{2}{*}{ Tributary to } & \multirow[b]{2}{*}{ Location } & \multirow{2}{*}{$\begin{array}{l}\text { Drainage } \\
\text { area } \\
\left(\mathrm{mi}^{2}\right)\end{array}$} & \multicolumn{2}{|c|}{ Measurements } \\
\hline & & & & & Date & $\begin{array}{l}\text { Dis- } \\
\text { charge } \\
\left(\mathrm{ft}^{3} / \mathrm{s}\right)\end{array}$ \\
\hline \multicolumn{7}{|c|}{ MERRIMACK RIVER BASIN } \\
\hline 20 & $\begin{array}{l}\text { Gunstock } \\
\text { Brook }\end{array}$ & $\begin{array}{c}\text { Lake Winni- } \\
\text { pesaukee }\end{array}$ & $\begin{array}{l}\text { Lat } 43^{\circ} 33^{\prime} 00^{\prime \prime} \text {, long } 71^{\circ} 24^{\prime} 15^{\prime \prime}, \text { Belknap County, } \\
\text { Hydrologic Unit } 01070002,1,200 \mathrm{ft} \text { from intersection } \\
\text { of Belknap Mountain Road and Route 11B. }\end{array}$ & 5.84 & $7-3-91$ & 0.94 \\
\hline 21 & $\begin{array}{c}\text { Gunstock } \\
\text { Brook }\end{array}$ & $\begin{array}{c}\text { Lake Winni- } \\
\text { pesaukee }\end{array}$ & $\begin{array}{l}\text { Lat } 43^{\circ} 33^{\prime} 58^{\prime \prime} \text {, long } 71^{\circ} 23^{\prime} 58^{\prime \prime}, \text { Belknap County, } \\
\text { Hydrologic Unit } 01070002,60 \mathrm{ft} \text { upstream from } \\
\text { bridge at Henderson Road, } 500 \mathrm{ft} \text { west of Route } 11 \mathrm{~B} \text {. }\end{array}$ & 8.26 & $7-3-91$ & 1.26 \\
\hline 22 & $\begin{array}{c}\text { Gunstock } \\
\text { Brook }\end{array}$ & $\begin{array}{c}\text { Lake Winni- } \\
\text { pesaukee }\end{array}$ & $\begin{array}{l}\text { Lat } 43^{\circ} 34^{\prime} 28^{\prime \prime} \text {, long } 71^{\circ} 24^{\prime} 10^{\prime \prime} \text {, Belknap County, } \\
\text { Hydrologic Unit } 01070002,40 \mathrm{ft} \text { down-stream from } \\
\text { bridge at Old Lake-shore Road, } 300 \mathrm{ft} \text { from inter- } \\
\text { section of Route } 11 \mathrm{~B}, 1,000 \mathrm{ft} \text { from Gilford Village. }\end{array}$ & 8.74 & $7-3-91$ & 1.13 \\
\hline 23 & $\begin{array}{c}\text { Hawkins } \\
\text { Brook }\end{array}$ & $\begin{array}{c}\text { Lake Winni- } \\
\text { pesaukee }\end{array}$ & $\begin{array}{l}\text { Lat } 43^{\circ} 40^{\prime} 09^{\prime \prime} \text {, long } 71^{\circ} 30^{\prime} 16^{\prime \prime} \text {, Belknap County, } \\
\text { Hydrologic Unit } 01070002 \text {, downstream side of } \\
\text { culvert, on Transfer Station Road, } 4,500 \mathrm{ft} \text { north of } \\
\text { Meredith. }\end{array}$ & 2.20 & $7-3-91$ & .14 \\
\hline 24 & $\begin{array}{c}\text { Hawkins } \\
\text { Brook }\end{array}$ & $\begin{array}{l}\text { Lake Winni- } \\
\text { pesaukee }\end{array}$ & $\begin{array}{l}\text { Lat } 43^{\circ} 39^{\prime} 56^{\prime \prime} \text {, long } 71^{\circ} 29^{\prime} 54^{\prime \prime}, \text { Belknap County, } \\
\text { Hydrologic Unit } 01070002,40 \mathrm{ft} \text { upstream from } \\
\text { culvert under road to Town Highway Department, } \\
\text { through Town Park, } 1,000 \mathrm{ft} \text { east of Route } 3,3,000 \mathrm{ft} \\
\text { north of Meredith. }\end{array}$ & 2.54 & $7-3-91$ & .51 \\
\hline 25 & $\begin{array}{l}\text { Jewett } \\
\text { Brook }\end{array}$ & $\begin{array}{l}\text { Lake } \\
\text { Winnisquam }\end{array}$ & $\begin{array}{l}\text { Lat } 43^{\circ} 31 \text { '54", long } 71^{\circ} 27^{\prime} 37^{\prime \prime}, \text { Belknap County, } \\
\text { Hydrologic Unit } 01070002,25 \mathrm{ft} \text { downstream from } \\
\text { bridge at High St., } 5,000 \mathrm{ft} \text { from intersection with } \\
\text { Route } 11 \mathrm{~A}, 4,500 \mathrm{ft} \text { from intersection with Route } 11 \\
\text { bypass. }\end{array}$ & 5.26 & $7-3-91$ & .49 \\
\hline 26 & $\begin{array}{r}\text { Durkee } \\
\text { Brook }\end{array}$ & $\begin{array}{l}\text { Lake } \\
\text { Winnisquam }\end{array}$ & $\begin{array}{l}\text { Lat } 43^{\circ} 30^{\prime} 56^{\prime \prime} \text {, long } 71^{\circ} 27^{\prime} 34^{\prime \prime}, \text { Belknap County, } \\
\text { Hydrologic Unit } 01070002,20 \mathrm{ft} \text { upstream from } \\
\text { bridge on connector between Routes } 106 \text { and } 107 \text {, } \\
1,300 \mathrm{ft} \text { from Route } 11 \text { bypass, } 4,500 \mathrm{ft} \text { from Laconia. }\end{array}$ & 1.96 & $7-3-91$ & .80 \\
\hline 27 & $\begin{array}{c}\text { Wickwas } \\
\text { Outlet }\end{array}$ & $\begin{array}{c}\text { Lake Winni- } \\
\text { pesaukee }\end{array}$ & $\begin{array}{l}\text { Lat } 43^{\circ} 36^{\prime} 50^{\prime \prime} \text {, long } 71^{\circ} 32^{\prime} 01^{\prime \prime} \text {, Belknap County, } \\
\text { Hydrologic Unit } 01070002,40 \mathrm{ft} \text { upstream from } \\
\text { bridge on Meredith Center Road, } 6,000 \mathrm{ft} \text { from } \\
\text { intersection of Route } 104,1,000 \mathrm{ft} \text { west of Meredith } \\
\text { Center. }\end{array}$ & 12.0 & $7-3-91$ & .29 \\
\hline 28 & $\begin{array}{l}\text { Durgin } \\
\text { Brook }\end{array}$ & $\begin{array}{l}\text { Lake } \\
\text { Winnisquam }\end{array}$ & $\begin{array}{l}\text { Lat } 43^{\circ} 29^{\prime} 29^{\prime \prime} \text {, long } 71^{\circ} 30^{\prime} 09^{\prime \prime} \text {, Belknap County, } \\
\text { Hydrologic Unit } 01070002,300 \mathrm{ft} \text { upstream from } \\
\text { bridge at Bean Hill Road, } 500 \mathrm{ft} \text { from intersection with } \\
\text { Route } 3,2,000 \mathrm{ft} \text { north of bridge over Winnisquam } \\
\text { Lake. }\end{array}$ & 3.84 & $7-2-91$ & 0 \\
\hline
\end{tabular}


Table D-1. Low streamflow measurements at miscellaneous sites in central New Hampshire--Continued

\begin{tabular}{|c|c|c|c|c|c|c|}
\hline \multirow{2}{*}{$\begin{array}{l}\text { Mea- } \\
\text { sure- } \\
\text { ment } \\
\text { number }\end{array}$} & \multirow[b]{2}{*}{ Stream } & \multirow[b]{2}{*}{ Tributary to } & \multirow[b]{2}{*}{ Location } & \multirow[b]{2}{*}{$\begin{array}{l}\text { Drainage } \\
\text { area } \\
\left(\mathrm{mi}^{2}\right)\end{array}$} & \multicolumn{2}{|c|}{ Measurements } \\
\hline & & & & & Date & $\begin{array}{l}\text { Dis- } \\
\text { charge } \\
\left(\mathrm{ft}^{3} / \mathrm{s}\right)\end{array}$ \\
\hline \multicolumn{7}{|c|}{ MERRIMACK RIVER BASIN } \\
\hline 29 & $\begin{array}{l}\text { Unnamed } \\
\text { Tributary }\end{array}$ & $\begin{array}{l}\text { Lake } \\
\text { Winnisquam }\end{array}$ & $\begin{array}{l}\text { Lat } 43^{\circ} 28^{\prime} 25^{\prime \prime}, \text { long } 71^{\circ} 30^{\prime} 48^{\prime \prime}, \text { Belknap County, } \\
\text { Hydrologic Unit } 01070002 \text {, downstream side of } \\
\text { culvert at Union Road, } 6,500 \mathrm{ft} \text { east of Lochmere. }\end{array}$ & .39 & $7-2-91$ & 0.04 \\
\hline 30 & $\begin{array}{l}\text { Windy Hill } \\
\text { Brook }\end{array}$ & $\begin{array}{l}\text { Silver } \\
\text { Lake }\end{array}$ & $\begin{array}{l}\text { Lat } 43^{\circ} 28^{\prime} 26^{\prime \prime}, \text { long } 71^{\circ} 32^{\prime} 38^{\prime \prime}, \text { Belknap County, } \\
\text { Hydrologic Unit } 01070002 \text {, at upstream side of culvert } \\
\text { at Route } 11 \text { in Lochmere, } 2,500 \mathrm{ft} \text { from East Tilton, } \\
1,000 \mathrm{ft} \text { from intersection of Route } 11 \text { and I-93. }\end{array}$ & 1.87 & $7-3-91$ & 0 \\
\hline 31 & $\begin{array}{l}\text { Tioga } \\
\text { River }\end{array}$ & $\begin{array}{l}\text { Winnipesaukee } \\
\text { River }\end{array}$ & $\begin{array}{l}\text { Lat } 43^{\circ} 27^{\prime} 04^{\prime \prime} \text {, long } 71^{\circ} 28^{\prime} 13^{\prime \prime}, \text { Belknap County, } \\
\text { Hydrologic Unit } 01070002,4,500 \mathrm{ft} \text { from Belmont, } \\
300 \mathrm{ft} \text { downstream from Badger Pond, } 100 \mathrm{ft} \text { upstream } \\
\text { from Route } 106 .\end{array}$ & 14.7 & $7-3-91$ & 1.1 \\
\hline 32 & $\begin{array}{l}\text { Pumping } \\
\text { Station }\end{array}$ & $\begin{array}{l}\text { Tioga } \\
\text { River }\end{array}$ & $\begin{array}{l}\text { Lat } 43^{\circ} 25^{\prime} 47^{\prime \prime} \text {, long } 71^{\circ} 28^{\prime} 43^{\prime \prime} \text {, Belknap County, } \\
\text { Hydrologic Unit } 01070002,300 \mathrm{ft} \text { downstream from } \\
\text { culverts at Wareing Road, } 5,000 \mathrm{ft} \text { south of Belmont. }\end{array}$ & 2.35 & $7-3-91$ & .80 \\
\hline 33 & $\begin{array}{l}\text { Unnamed } \\
\text { Tributary }\end{array}$ & $\begin{array}{l}\text { Tioga } \\
\text { River }\end{array}$ & $\begin{array}{l}\text { Lat } 43^{\circ} 26^{\prime} 36^{\prime \prime}, \text { long } 71^{\circ} 29^{\prime} 43^{\prime \prime}, \text { Belknap County, } \\
\text { Hydrologic Unit } 01070002,3,500 \mathrm{ft} \text { west of Belmont } \\
\text { at confluence with Tioga River. }\end{array}$ & 1.03 & $7-3-91$ & 0 \\
\hline 34 & $\begin{array}{l}\text { Tioga } \\
\text { River }\end{array}$ & $\begin{array}{l}\text { Winnipesaukee } \\
\text { River }\end{array}$ & $\begin{array}{l}\text { Lat } 43^{\circ} 26^{\prime} 40^{\prime \prime} \text {, long } 71^{\circ} 29^{\prime} 46^{\prime \prime}, \text { Belknap County, } \\
\text { Hydrologic Unit } 01070002,3,500 \mathrm{ft} \text { from Belmont } \\
\text { downstream from confluence with Unnamed } \\
\text { Tributary. }\end{array}$ & 18.7 & $7-3-91$ & 3.9 \\
\hline 35 & $\begin{array}{l}\text { Tioga } \\
\text { River }\end{array}$ & $\begin{array}{l}\text { Winnipesaukee } \\
\text { River }\end{array}$ & $\begin{array}{l}\text { Lat } 43^{\circ} 26^{\prime} 33^{\prime \prime} \text {, long } 71^{\circ} 31^{\prime} 06^{\prime \prime}, \text { Belknap County, } \\
\text { Hydrologic Unit } 01070002 \text {, at downstream edge of } \\
\text { bridge abutment on South Road, } 9,000 \mathrm{ft} \text { from } \\
\text { Belmont, } 1,200 \mathrm{ft} \text { from intersection with Route } 140 \text {. }\end{array}$ & 26.85 & $7-3-91$ & 5.58 \\
\hline 36 & $\begin{array}{l}\text { Gulf } \\
\text { Brook }\end{array}$ & $\begin{array}{l}\text { Winnipesaukee } \\
\text { River }\end{array}$ & $\begin{array}{l}\text { Lat } 43^{\circ} 27^{\prime} 19^{\prime \prime} \text {, long } 71^{\circ} 33^{\prime} 51^{\prime \prime}, \text { Belknap County, } \\
\text { Hydrologic Unit } 01070002,10 \mathrm{ft} \text { upstream from old } \\
\text { railroad trestle bridge on Pike Industries property, } 500 \\
\text { ft downstream from Route } 11,1,500 \mathrm{ft} \text { from } \\
\text { intersection with I-93. }\end{array}$ & 5.52 & $7-2-91$ & .28 \\
\hline 37 & $\begin{array}{l}\text { Williams } \\
\text { Brook }\end{array}$ & $\begin{array}{l}\text { Winnipesaukee } \\
\text { River }\end{array}$ & $\begin{array}{l}\text { Lat } 43^{\circ} 25^{\prime} 58^{\prime \prime} \text {, long } 71^{\circ} 366^{\prime} 05^{\prime \prime} \text {, Belknap County, } \\
\text { Hydrologic Unit } 01070002,10 \mathrm{ft} \text { downstream from } \\
\text { bridge at Sargent Road, } 4,000 \mathrm{ft} \text { from Northfield, } \\
2,500 \mathrm{ft} \text { from intersection with Route } 132 \text {. }\end{array}$ & 7.62 & $7-3-91$ & .66 \\
\hline
\end{tabular}




\section{APPENDIX E. Monthly water levels at selected wells, central New Hampshire}



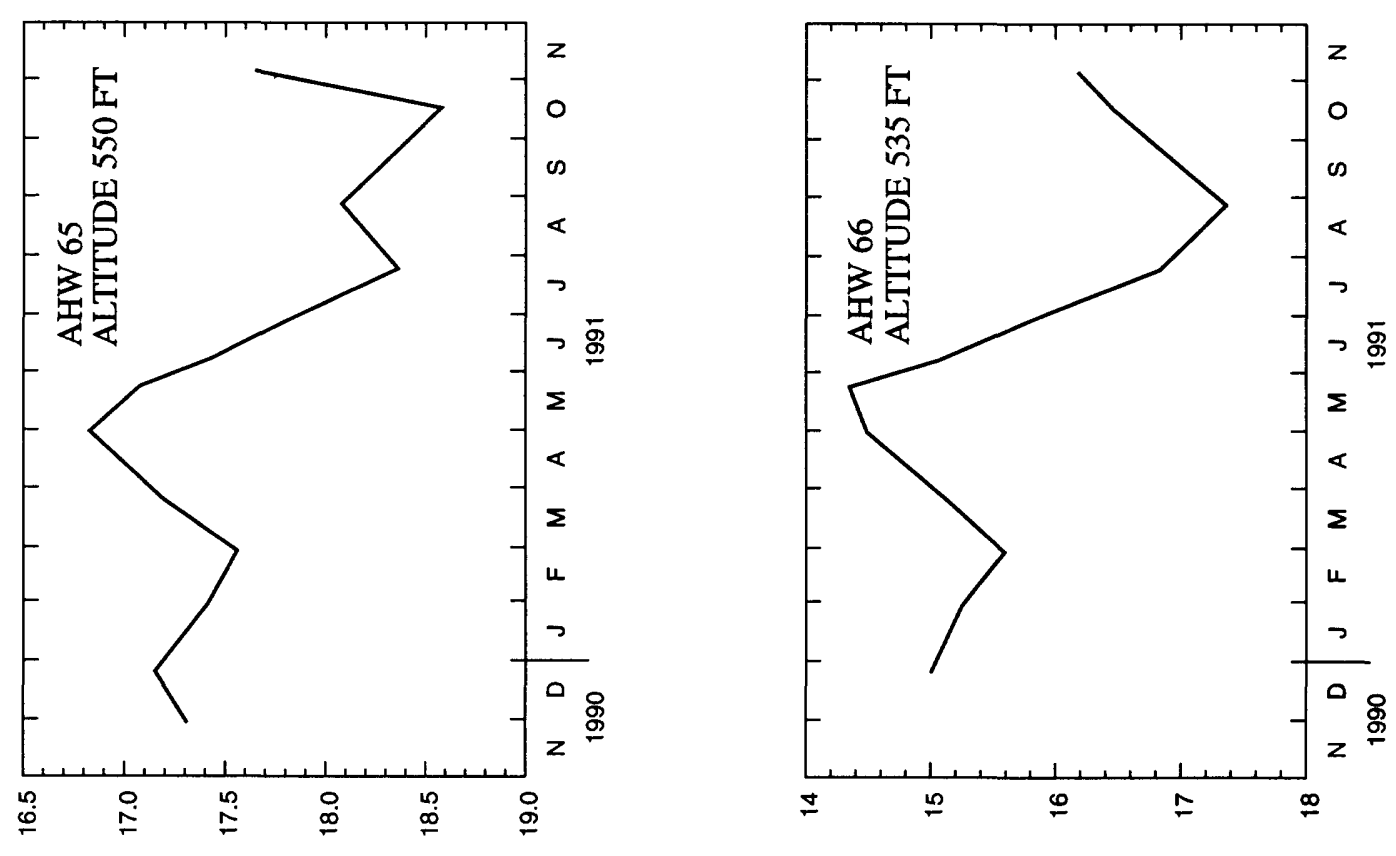

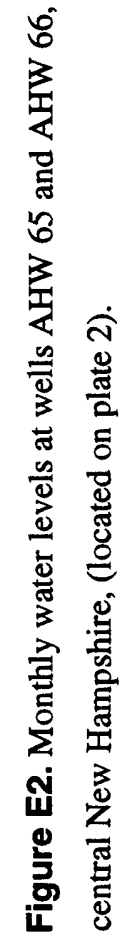
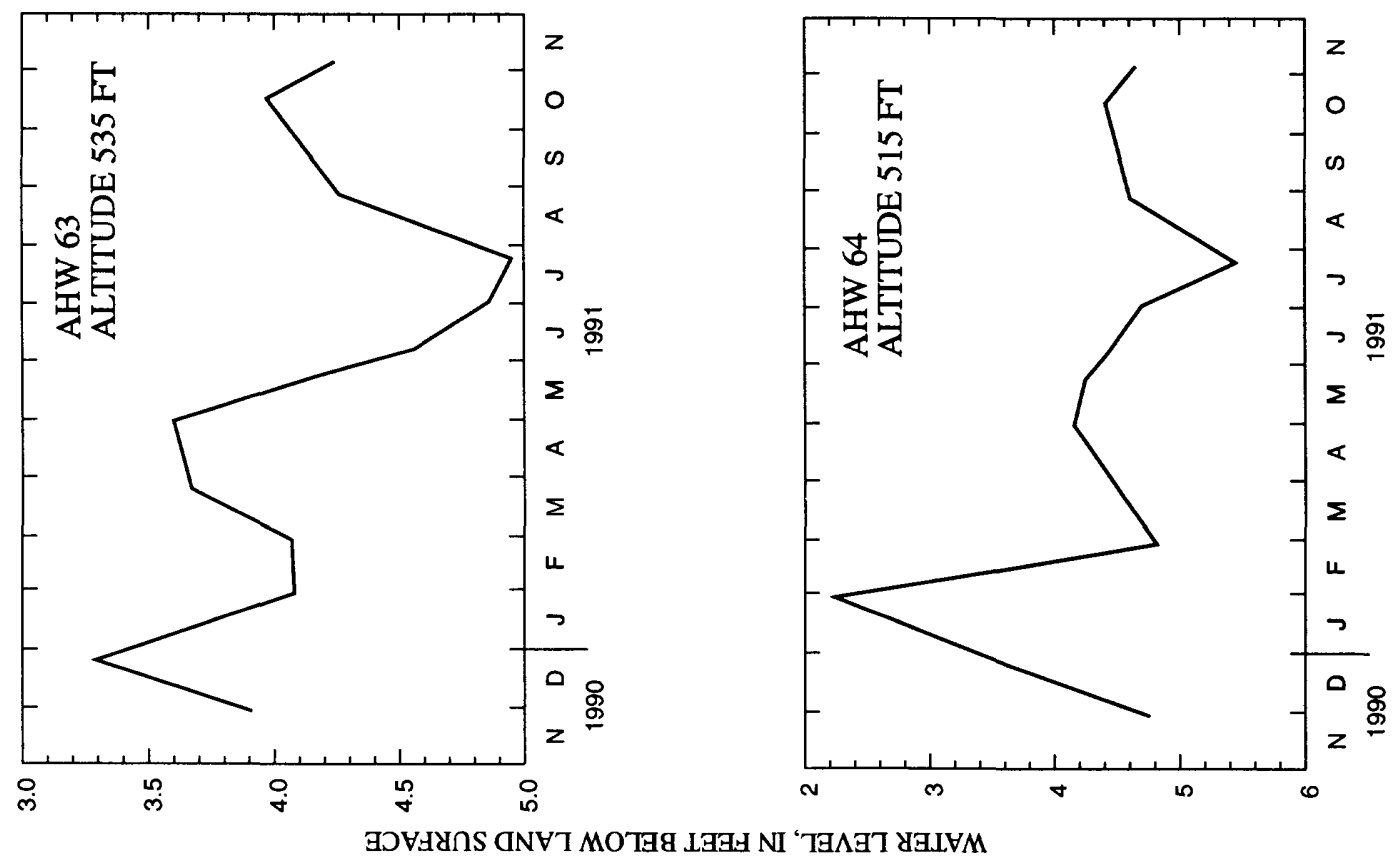

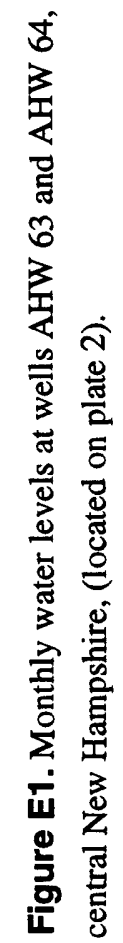



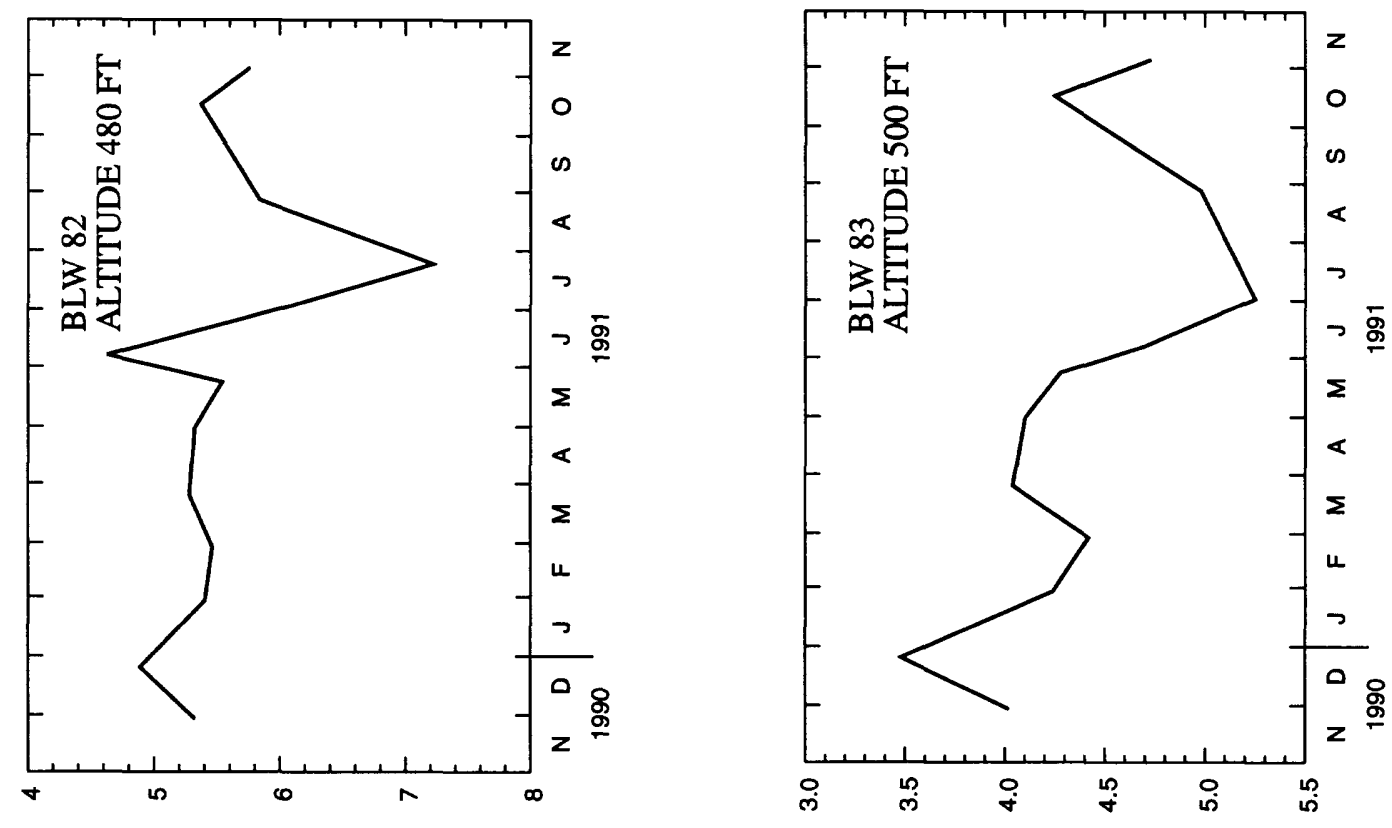

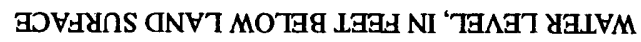

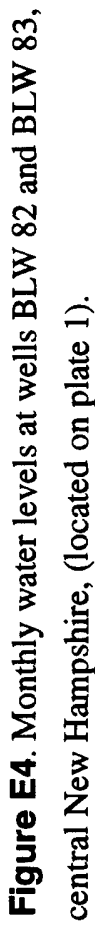
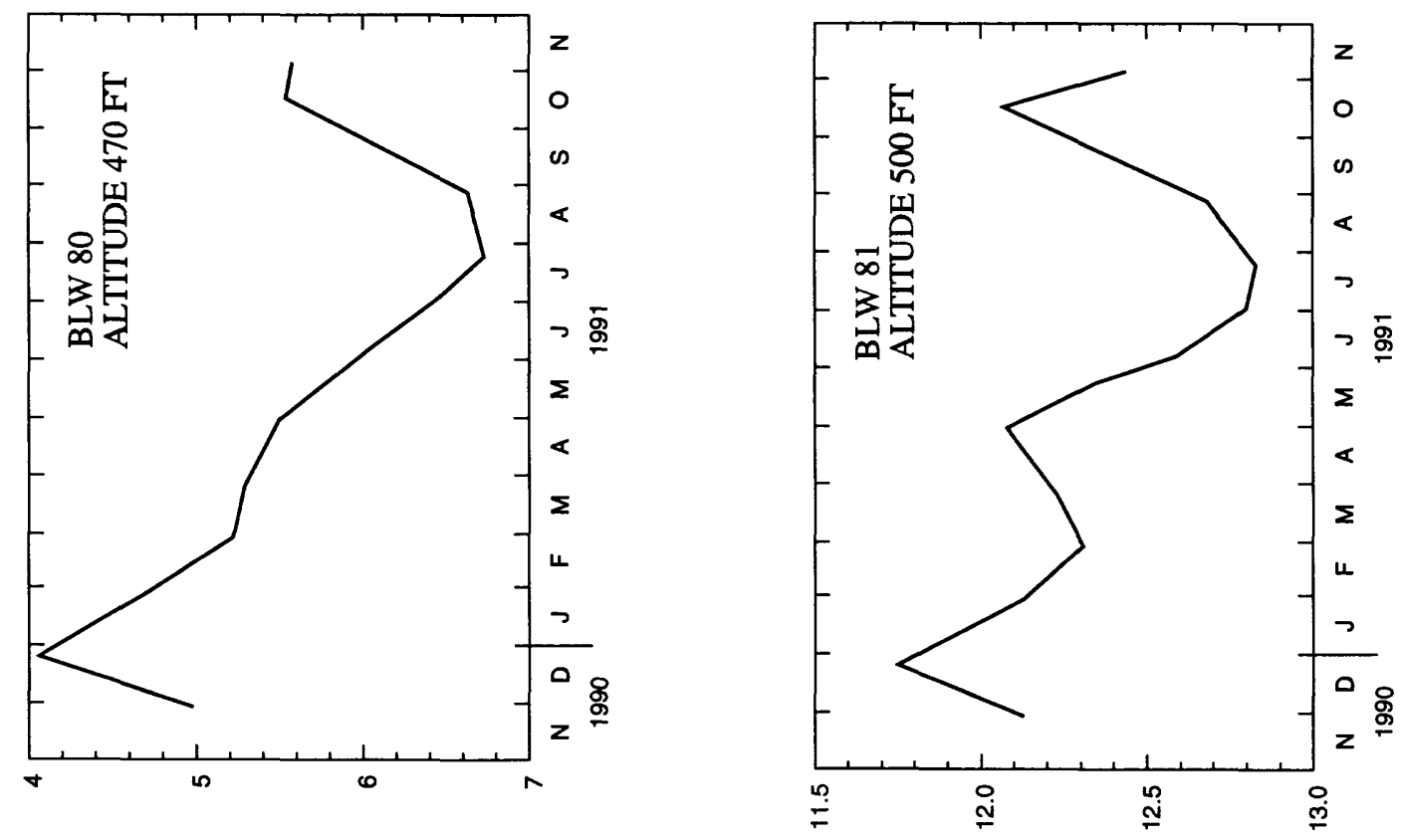

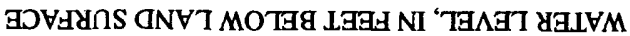

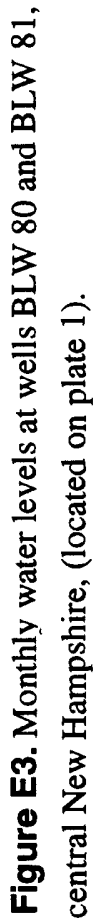



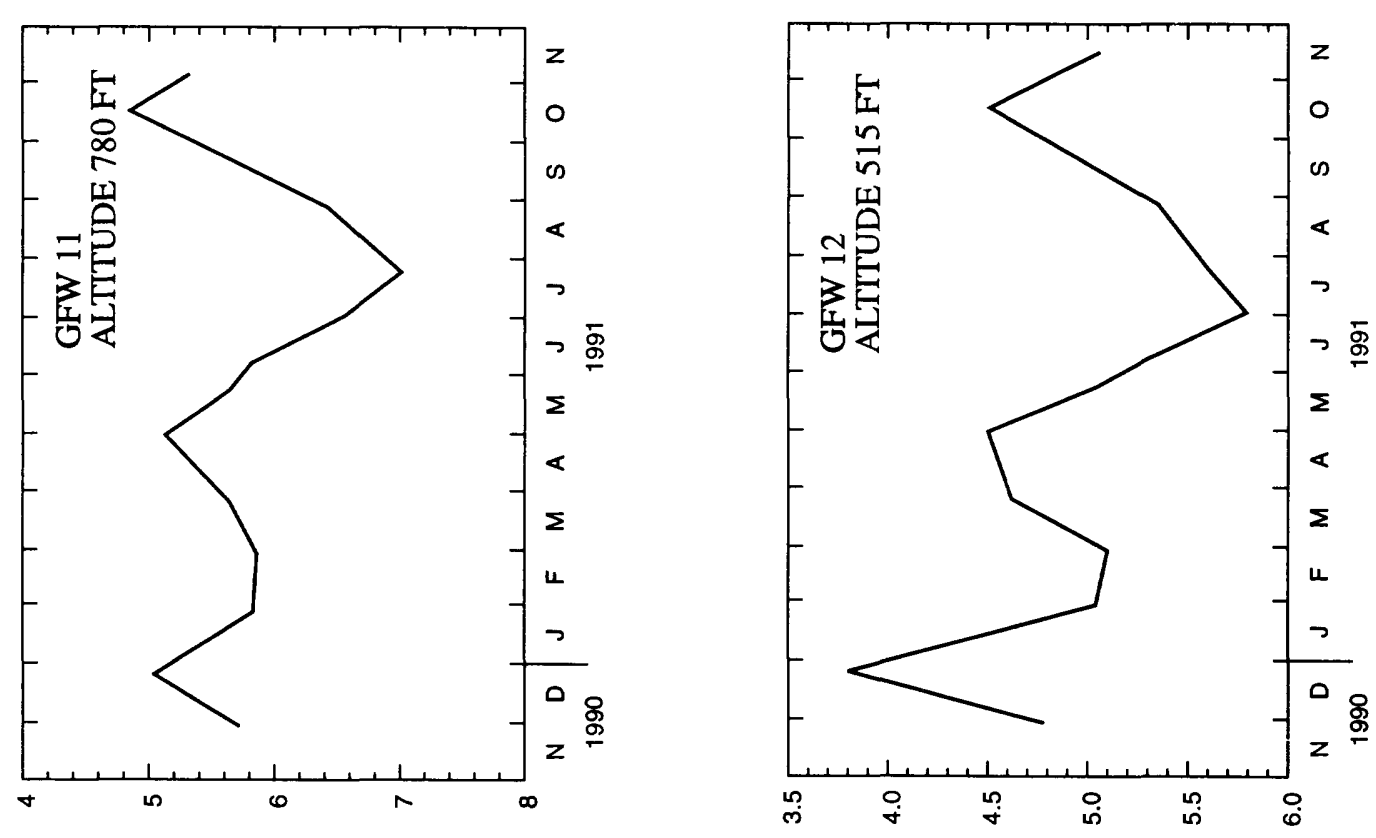

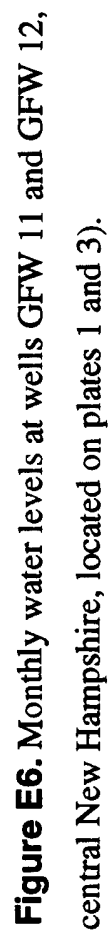

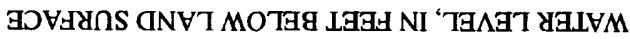
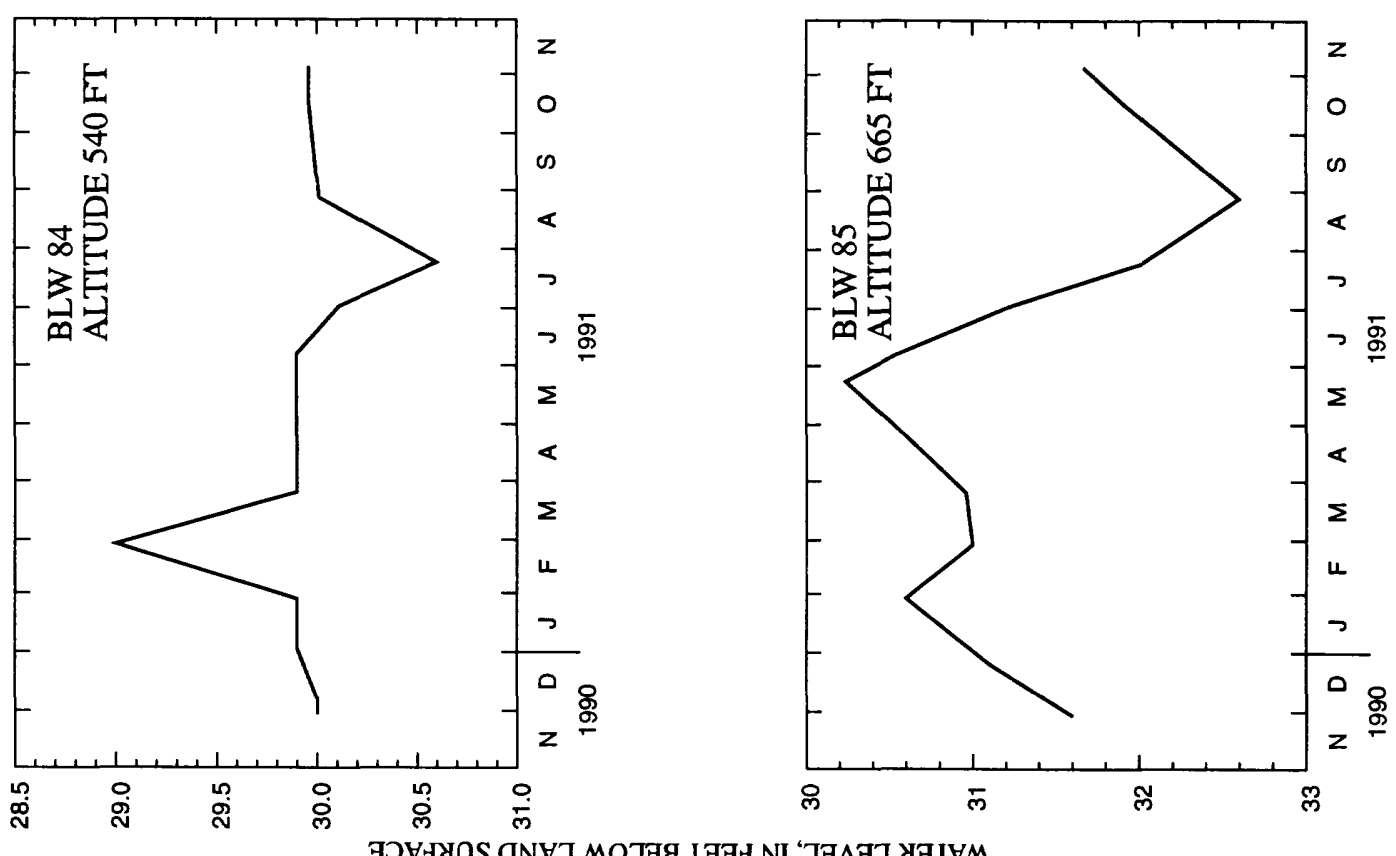

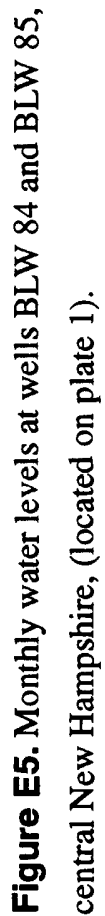



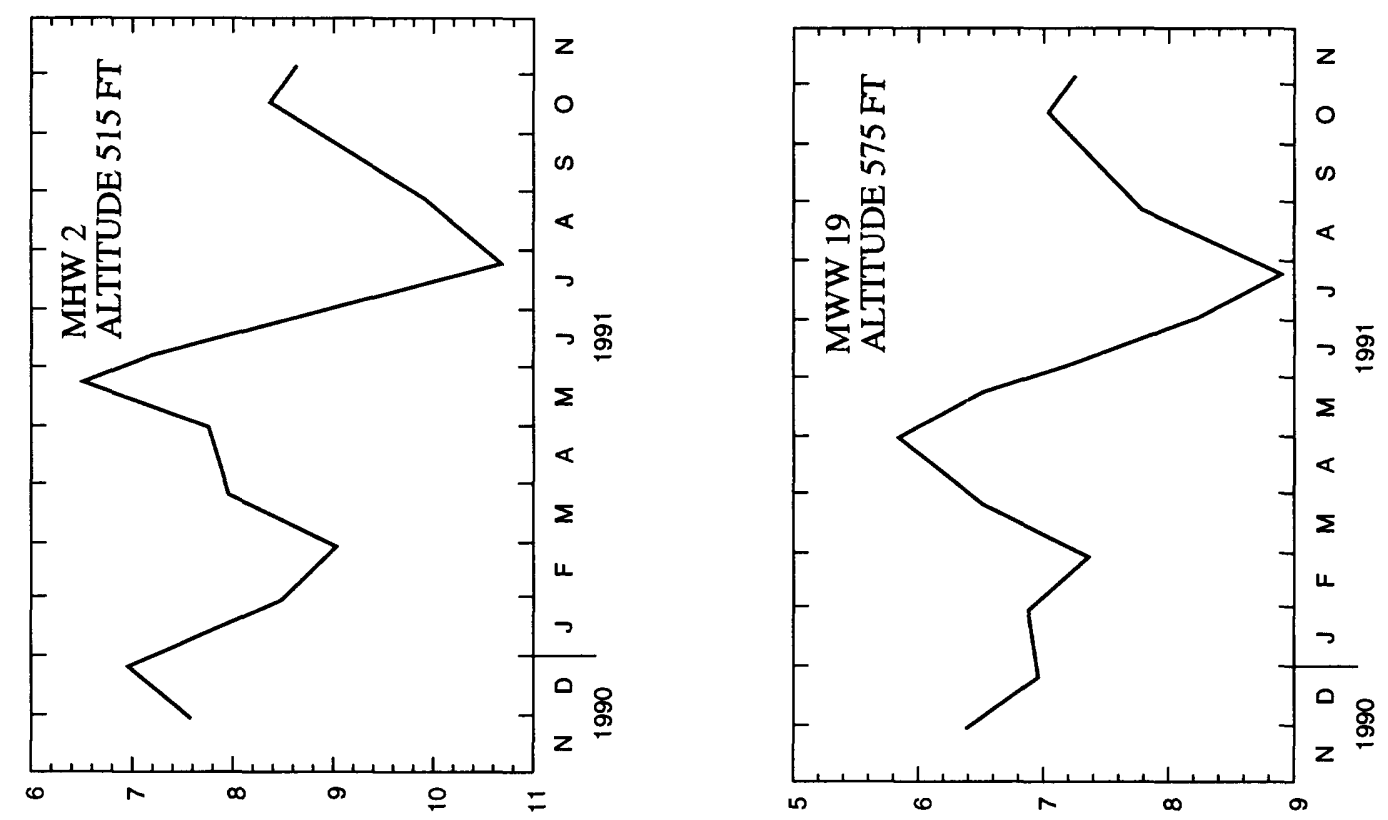

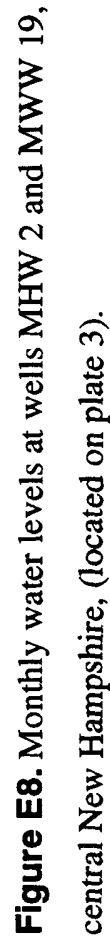

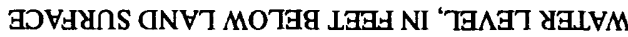
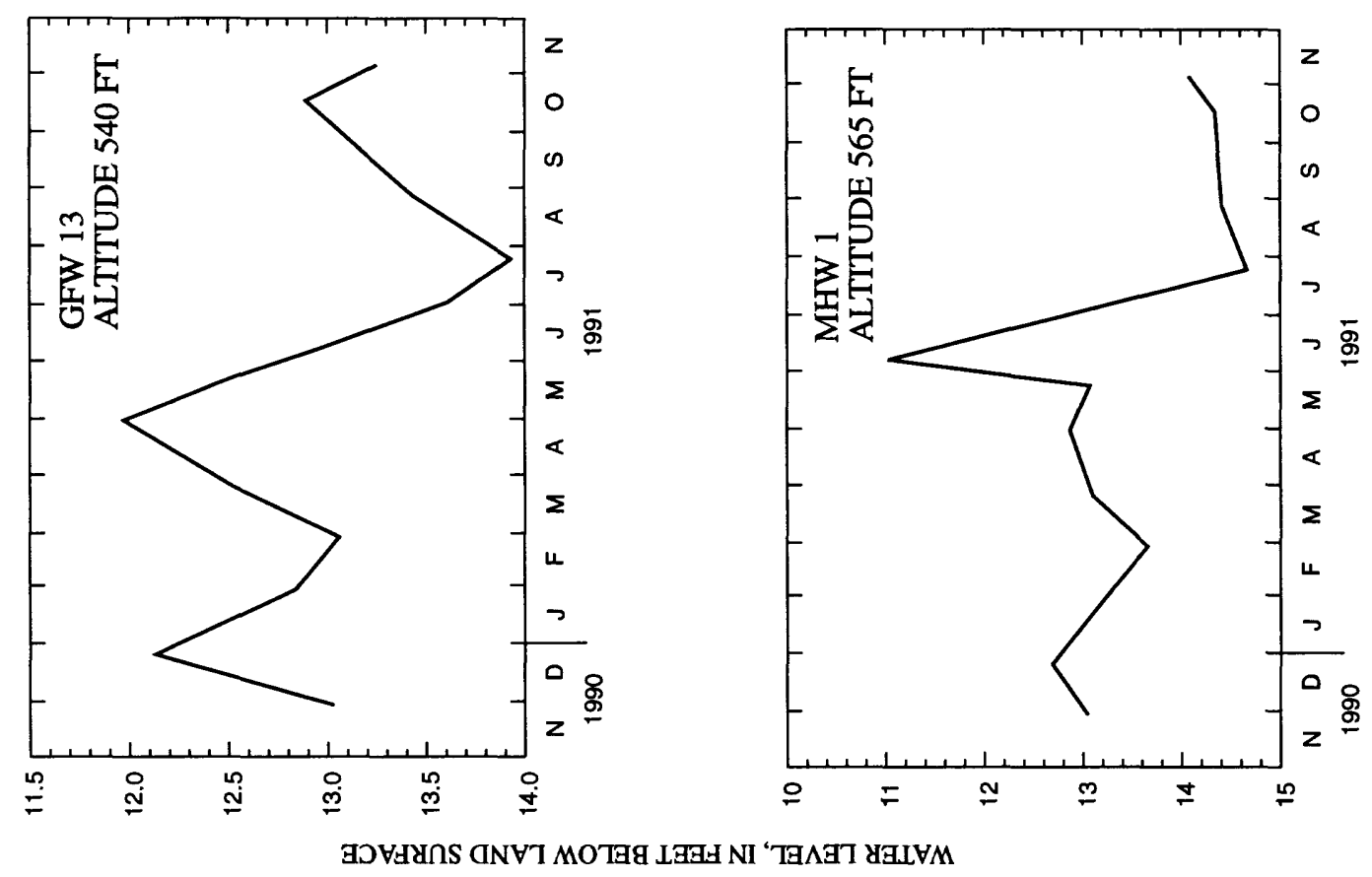

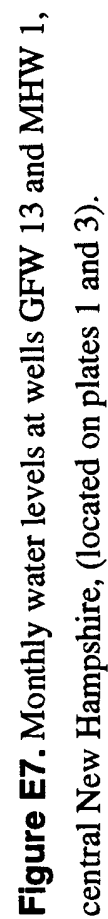

